\title{
Screening Analysis for EPACT-Covered Commercial HVAC and Water-Heating Equipment
}
S. Somasundaram
D. L. Hadley
P. R. Armstrong
S. Katipamula ${ }^{(a)}$
D. B. Belzer
D. L. Smith
S. C. Gaines
D. W. Winiarski

April 2000

Prepared for

the U.S. Department of Energy

under Contract DE-AC06-76RLO 1830

Pacific Northwest National Laboratory

Richland, Washington 99352

(a) Enron Energy Services, Houston, Texas 


\section{DISCLAIMER}

This report was prepared as an account of work sponsored by an agency of the United States Government. Neither the United States Government nor any agency thereof, nor any of their employees, make any warranty, express or implied, or assumes any legal liability or responsibility for the accuracy, completeness, or usefulness of any information, apparatus, product, or process disclosed, or represents that its use would not infringe privately owned rights. Reference herein to any specific commercial product, process, or service by trade name, trademark, manufacturer, or otherwise does not necessarily constitute or imply its endorsement, recommendation, or favoring by the United States Government or any agency thereof. The views and opinions of authors expressed herein do not necessarily state or reflect those of the United States Government or any agency thereof. 


\section{DISCLAIMER}

Portions of this document may be illegible in electronic image products. Images are produced from the best available original document. 


\section{Summary}

The Energy Policy and Conservation Act (EPCA) (P.L. 94-163), as amended by the Energy Policy Act of 1992 (EPACT) (P.L. 102-486), establishes a role for the U.S. Department of Energy (DOE) to regulate efficiency levels of certain categories of commercial heating, cooling, and water-heating equipment. Initial minimum efficiency levels for products falling under these equipment categories were established in EPACT, based on the requirements contained in ASHRAE/IES Standard 90.1-1989 (ASHRAE 1989). EPCA ${ }^{(a)}$ requirements state that, if the American Society of Heating, Refrigerating and Air-Conditioning Engineers, Inc. (ASHRAE) amends efficiency levels prescribed in Standard 90.1-1989, then DOE must establish an amended uniform national manufacturing standard at the minimum level specified in amended Standard 90.1. However, DOE can establish higher efficiency levels if it can show through clear and convincing evidence that a higher efficiency level, that is technologically feasible and economically justified, would produce significant additional energy savings.

On October 29, 1999, ASHRAE approved the amended Standard $90.1,{ }^{(b)}$ which increases the minimum efficiency levels for some of the commercial heating, cooling, and water-heating equipment covered by EPCA 92. DOE asked Pacific Northwest National Laboratory (PNNL) ${ }^{(c)}$ to conduct a screening analysis to determine the energy-savings potential of the efficiency levels listed in Standard 90.1-1999. The analysis estimates the annual national energy consumption and the potential for energy savings that would result if the EPACT-covered products were required to meet these efficiency levels. The analysis also estimates additional energy-savings potential for the EPACT-covered products if they were to exceed the efficiency levels prescribed in Standard 90.1-1999. In addition, a simple life-cycle cost (LCC) analysis was performed for some alternative efficiency levels. This paper will describe the methodology, data assumptions, and results of the analysis.

The magnitude of HVAC and SWH loads imposed on equipment depends on the building's physical and operational characteristics and prevailing climatic conditions. To address this variation in energy use, coil loads for 7 representative building types at 11 climate locations were estimated based on a wholebuilding simulation. For each equipment category, the energy usage.of a given piece of equipment was estimated based on a characteristic equipment size for each combination of representative building type and climate location. The unit energy use was estimated using a full-load equivalent operating hour (FLEOH) approach and adjusted for each nominal equipment efficiency level.

The national energy impacts of higher efficiency equipment were estimated by mapping climate locations onto regions and estimating the fraction of each year's national equipment shipments (by product category) within market segments, as defined by a representative building type within a particular

(a) EPCA, as amended by EPACT, will be referred to as "EPCA 92."

(b) The commercial HVAC equipment efficiencies contained in ASHRAE/IESNA Standard 90.1-1999 will become effective on October 29, 2001, two years after final ASHRAE Board approval of the Standard.

(c) Pacific Northwest National Laboratory is operated by Battelle for the U.S. Department of Energy. 
U.S. region. National energy consumption for each equipment category was then estimated at each efficiency level by multiplying the annual unit energy use in each market segment with the annual shipments expected for that market segment.

The LCC analysis was conducted at the market segment level with region-specific energy prices, providing insight on the distribution of LCC cost savings across the building population. National net present value (NPV) was calculated as a summary metric of the total national economic impact due to any chosen level of efficiency standard.

Table S.1 provides the results of the analysis. The baseline energy consumption, the energy savings, the NPV, and the carbon reductions were all summed up across the different capacities for each equipment category analyzed. 
Table S.1. Aggregated Energy Savings and NPV for Efficiency Levels with Maximum NPV

\begin{tabular}{|c|c|c|c|c|c|c|c|c|}
\hline \multirow[b]{2}{*}{ Product } & \multicolumn{3}{|c|}{ Efficiency Level } & \multicolumn{2}{|c|}{ Energy Savings (TBtu) } & \multicolumn{2}{|c|}{ Carbon Reduction (MMtons) } & \multirow[b]{2}{*}{$\begin{array}{c}\text { NPV }^{(2)} \\
\text { (mill. 98\$) }\end{array}$} \\
\hline & EPCA & \begin{tabular}{|l|}
$90.1-$ \\
1999
\end{tabular} & $\begin{array}{c}\text { Max } \\
\text { NPV }^{(a)}\end{array}$ & $\begin{array}{c}90.1 \text { Over } \\
\text { EPCA }\end{array}$ & $\begin{array}{c}\text { Max NPV }^{(\mathrm{g})} \\
\text { Over } 90.1\end{array}$ & $\begin{array}{l}\text { 90.1 Over } \\
\text { EPCA }\end{array}$ & $\begin{array}{c}\text { Max NPV (a) }^{(1)} \text { Over } 90.1\end{array}$ & \\
\hline Central Air-Source AC (135 to $240 \mathrm{kBtu} / \mathrm{h})$ & 8.5 & 9.7 & 10.4 & 899.4 & 428.8 & 13.2 & 6.3 & 417.9 \\
\hline Central Air-Source HP (135 to $240 \mathrm{kBtu} / \mathrm{h})$ & 8.5 & 9.3 & 10.4 & 27.9 & 31.4 & 0.4 & 0.5 & 3.2 \\
\hline Central Water-Cooled AC (135 to $240 \mathrm{kBtu} / \mathrm{h})$ & 9.6 & 11.0 & 11.5 & 8.5 & 2.5 & 0.1 & 0.0 & 3.0 \\
\hline Central Air-Source $\Lambda C(65$ to $135 \mathrm{kBtu} / \mathrm{h})$ & 8.9 & 10.3 & 10.3 & 1197.9 & 0.0 & 17.6 & 0.0 & 0.0 \\
\hline Central Air-Source HP (65 to $135 \mathrm{kBtu} / \mathrm{h})$ & 8.9 & 10.1 & 10.1 & 107.9 & 0.0 & 1.6 & 0.0 & 0.0 \\
\hline Central Water-Source HP (65 to $135 \mathrm{kBtu} / \mathrm{h})$ & 10.5 & 12.0 & 12.0 & 32.0 & 0.0 & 0.5 & 0.0 & 0.0 \\
\hline Central Water Cooled AC (65 to $135 \mathrm{kBtu} / \mathrm{h})$ & 10.5 & 11.5 & 12.4 & 3.6 & 2.7 & 0.1 & 0.1 & 0.8 \\
\hline Packaged Terminal Air Conditioners & 8.5 & 8.8 & 10.5 & 67.5 & 311.7 & 1.0 & 4.6 & 274.7 \\
\hline Packaged Terminal Heat Pumps & 8.2 & 8.4 & 9.9 & 38.7 & 249.0 & 0.6 & 3.7 & 241.9 \\
\hline 3-Phase, Single-Package Air-Source AC $(<65 \mathrm{kBtu} / \mathrm{h})$ & 9.7 & 9.7 & 12.0 & 0.0 & 1412.7 & 0.0 & 20.8 & 897.7 \\
\hline 3-Phase, Split-System Air-Source AC (<65 kBtu/h) & 10.0 & 10.0 & 11.0 & 0.0 & 278.6 & 0.0 & 4.1 & 109.1 \\
\hline 3-Phase, Single-Package Air-Source HP $(<65 \mathrm{kBtu} / \mathrm{h})$ & 9.7 & 9.7 & 12.0 & 0.0 & 183.6 & 0.0 & 2.7 & 91.3 \\
\hline 3-Phase, Split-System Air Source HP ( $<65 \mathrm{kBtu} / \mathrm{h})$ & 10 & 10.0 & 12.0 & 0.0 & 66.4 & 0.0 & 1.0 & 47.0 \\
\hline Central Water-Cooled AC $(<65 \mathrm{kBtu} / \mathrm{h})$ & 9.3 & 12.1 & 12.1 & 6.6 & 0.0 & 0.1 & 0.0 & 0.0 \\
\hline Central Water-Source HP (17 to $65 \mathrm{kBtu} / \mathrm{h})$ & 9.3 & 12.0 & 12.5 & 471.6 & 65.0 & 6.9 & 1.0 & 23.0 \\
\hline Central Water-Source HP $(<17 \mathrm{kBtu} / \mathrm{h})$ & 9.3 & 11.2 & 11.2 & 56.5 & 0.0 & 0.8 & 0.0 & 0.0 \\
\hline Large Gas-Fired Hot Water Boilers $(>2,500 \mathrm{kBtu} / \mathrm{h})$ & $80 \%$ & $80 \%$ & $88 \%$ & & & & & \\
\hline Large Gas-Fired Steam Boilers $(>2,500 \mathrm{kBtu} / \mathrm{h})$ & $80 \%(b)$ & $80 \%$ (v) & $82 \%^{(\mathrm{c})}$ & 0.0 & 79.0 & 0.0 & 1.0 & 86.6 \\
\hline Small Gas-Fired Boilers $(<2,500 \mathrm{kBtu} / \mathrm{h})$ & $80 \%$ & $75 \%$ & $78.7 \%^{(0)}$ & 63.9 & 200.0 & 0.8 & 2.6 & 146.0 \\
\hline Gas-Fired Warm-Air Furnaces & $80 \%(0)$ & $80 \%$ & $80 \%{ }^{(\mathrm{c})}$ & $\overline{478.4}$ & 0.0 & $6.3^{\sigma}$ & 0.0 & 0.0 \\
\hline Gas Storage Water Heaters $(>155 \mathrm{kBtu} / \mathrm{h})$ & $78 \%$ & $80.4 \%$ (c) & $80.4 \%(c)$ & 53.9 & 0.0 & 0.8 & 0.0 & 0.0 \\
\hline Gas Storage Water Heaters $(<155 \mathrm{kBtu} / \mathrm{h})$ & $78 \%(c)$ & $80 \%$ (c) & $80 \%^{(\mathrm{c})}$ & 12.5 & 0.0 & 0.2 & 0.0 & 0.0 \\
\hline Electric Water Heaters & $\begin{array}{c}\text { See } \\
\text { Note } \\
\text { (d) }\end{array}$ & $\begin{array}{c}\text { See } \\
\text { Note }\end{array}$ & $\begin{array}{c}\text { See } \\
\text { Note }^{(n)}\end{array}$ & -7.2 & 5.3 & -0.1 & 0.1 & 1.1 \\
\hline Tankless Instantaneous Water Heaters & $80 \%$ & $80 \%(c)$ & $81.5 \%(\mathrm{c})$ & 0.0 & 102.0 & 0.0 & 1.5 & 45.3 \\
\hline Instantaneous Water Henters with Tanks & $77 \%(\mathrm{~d})$ & $80 \%$ & $80 \%(\mathrm{c})$ & 6.9 & 0.0 & 0.1 & 0.0 & 0.0 \\
\hline $\begin{array}{l}\text { (a) NPV = national net present value. } \\
\text { (b) Combustion efficiency (\%). } \\
\text { (c) Thermal efficiency }(\%) \text {. } \\
\text { (d) Savings due to tighter jacket loss requirement. } \\
\text { (d) } 30+27 / \mathrm{V}(\% / \mathrm{h}) \mathrm{V}=\mathrm{Measured} \text { storage volume in ga } \\
\text { (e) } 20+35 \mathrm{Sqrt}(\mathrm{V})(\mathrm{Btu} / \mathrm{h}) \mathrm{V}=\mathrm{Rated} \text { volume in gallons. } \\
\text { (f) } 1.73 \mathrm{~V}+\mathbf{1 5 5}(\mathrm{Btu} / \mathrm{h}) \mathrm{V}=\mathrm{Rated} \text { volume in gallons. }\end{array}$ & & & & & & & & \\
\hline
\end{tabular}




\section{Contents}

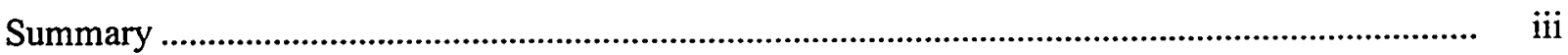

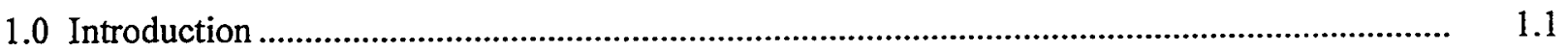

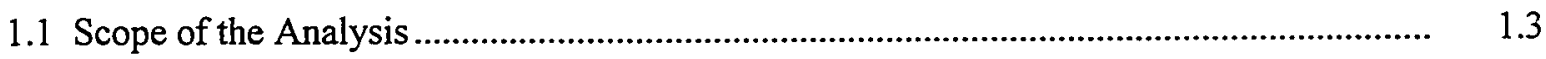

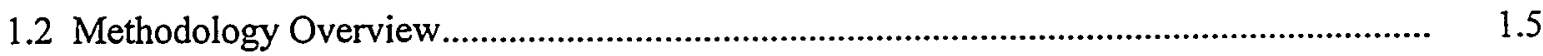

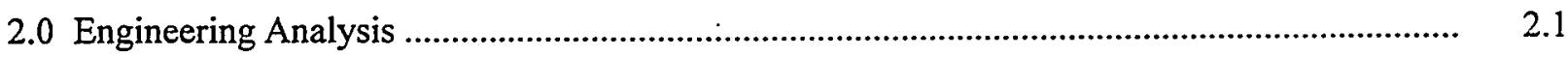

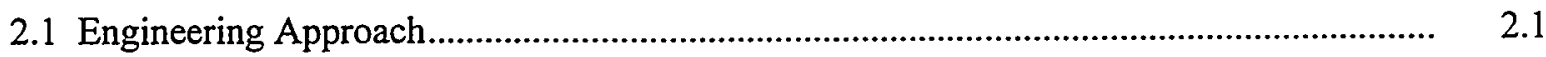

2.2 Annual Building and Equipment Space-Heating and -Cooling Loads............................. 2.3

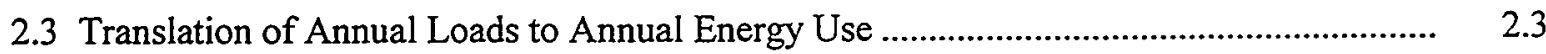

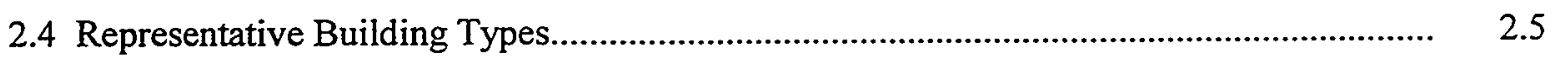

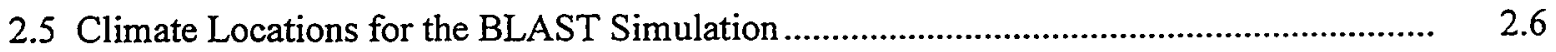

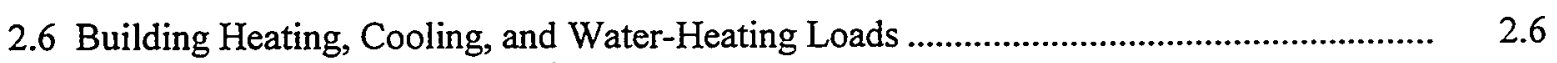

2.6.1 Building Space-Heating and Space-Cooling Loads ............................................... 2.7

2.6.2 SWH Loads and Equipment Sizing................................................................... 2.8

2.7 Mapping EPCA Equipment Categories to ASHRAE/Industry Equipment Categories....... $\quad 2.8$

2.8 Lifetime, Shipment, Baseline Cost, and Relative Cost Data ......................................... 2.10

2.8.1 Distribution Chain and Pricing for HVAC/SWH Equipment................................... 2.10

2.8.2 Efficiency and Cost Data - Cooling Equipment .................................................. $\quad 2.12$

2.8.3 Efficiency and Cost Data - Packaged Boilers ...................................................... 2.18

2.8.4 Efficiency and Cost Data - Warm-Air Furnaces.................................................. 2.21

2.8.5 Efficiency and Cost Data - Service Water Heaters ............................................... 2.26

3.0 Energy Savings and Economic Impact Analysis ............................................................ 3.1

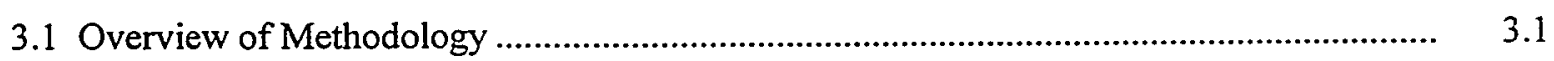


3.2 Data and Key Assumptions ................................................................................... 3.2

3.2.1 Energy Prices............................................................................................... 3.3

3.2.2 Energy Conversion Factors ..................................................................................... 3.4

3.2.3 Discount Rate .......................................................................................... 3.5

3.2.4 Shipment Forecasts......................................................................................... 3.5

3.2.5 Equipment Price Markups ...................................................................................... 3.5

3.3 National Energy Consumption and Energy Savings ...................................................... 3.5

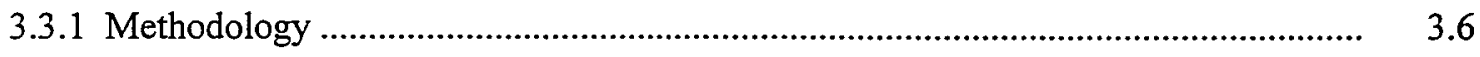

3.3.2 Energy Savings Results .................................................................................. 3.7 .

3.3.3 Estimates of National NPV .............................................................................. . $\quad 3.10$

3.4 Life-Cycle Cost Analysis .................................................................................... 3.13

3.4.1 Market Segment to National Average Results ………………………………….... 3.14

3.4.2 Methodology Used to Compute National NPV ………......................................... 3.18

3.5 Reductions in Environmental Emissions ...................................................................... 3.19

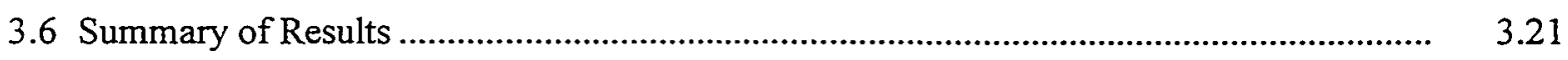

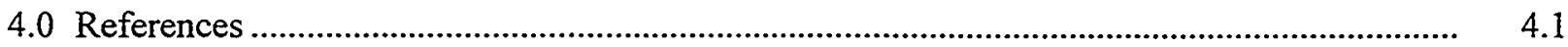

Appendix A - Engineering Data …………………………................................................... A.1

Appendix B - Aggregation Methodology Used to Estimate National Results ................................ B. B.1

Appendix C - Screening Analysis Spreadsheet: User's Guide and Model Documentation ............. C.1

Appendix D - Summary Results for all Products Analyzed .......................................................... D. D.1 


\section{Figures}

2.1 Proposed Process for Estimating the Weighted FLEOH by Building Type and Climate Location.

2.2 U.S. Map Showing 11 Climate Locations and Corresponding Climate Regions, and 9 Census Divisions.

2.3 Equipment Distribution Chain.

3.1 Overview of the Energy Savings and Economic Analysis Methodology.

\section{Tables}

S.1 Aggregated Energy Savings and NPV for Efficiency Levels with Maximum NPV .............. v

1.1 Commercial Equipment Product Categories: Air Conditioners and Heat Pumps .................. 1.2

1.2 Commercial Equipment Product Categories: Furnaces, Boilers, and Storage Water Heaters

1.3 Characteristics of Certain Products Analyzed in Screening Analysis

1.4 Characteristics of Certain Products Not Analyzed in Screening Analysis

2.1 Energy Consumption by Principal Building Activity

2.2 Building Service Water Heater Load Parameters by Building Type

2.3 Cooling Equipment Annual Shipment Data Used in the Screening Analysis

2.4 Cooling Equipment Baseline Cost Data

2.5 1999 Contractor Cost Data for Cooling Products by Efficiency Level

2.6 Estimated Annual Shipments for Gas-Fired Boilers Used in the Analysis......

2.7 Boiler Baseline Cost Data.

2.8 Gas-Fired Boiler Efficiencies Analyzed 
2.9 Cost Estimates for Gas-Fired Boilers

2.10 ARI 1998 Statistical Profile for Year Round Units.

2.11 Standard 90.1 Furnace Design Options

2.12 Relative Cost and Efficiency Data for Furnace Screening Analysis

2.13 Contractor Costs for Furnace Efficiency Levels Analyzed

2.14 Total Gas and Electric Commercial Water Heater Shipments.

2.15 Commercial Water Heater Shipment Proportions and Estimated Shipments.

2.16 Baseline Gas Storage Water Heater Costs.

2.17 Baseline Gas Instantaneous and Electric Water Heater Costs.

2.18 Water Heater Efficiency Levels and Contractor Costs Used in Screening Analysis

3.1 Electricity and Gas Prices Used for Screening Analysis

3.2 National Baseline Energy Consumption and Energy Savings - Space-Cooling Equipment...

3.3 National Baseline Energy Consumption and Energy Savings - Space-Heating Equipment...

3.4 National Baseline Energy Consumption and Energy Savings - Water-Heating Equipment...

3.5 NPV for Efficiency Levels Exceeding Standard 90.1-1999 - Space-Cooling Equipment......

3.6 NPV for Efficiency Levels Exceeding Standard 90.1-1999 - Space-Heating Equipment ......

3.7 NPV for Efficiency Levels Exceeding Standard 90.1-1999 - Water-Heating Equipment......

3.8 Market Segment Weighted LCC for All Efficiency Levels - Space-Cooling Equipment ......

3.9 Market Segment Weighted LCC for All Efficiency Levels - Space-Heating Equipment.......

3.10 Market Segment Weighted LCC for All Efficiency Levels - Water-Heating Equipment .......

3.11 Energy Savings and Carbon Reductions from Adopting Standard 90.1-1999 and from Maximum NP. 


\subsection{Introduction}

The Energy Policy and Conservation Act (EPCA) (P.L. 94-163) as amended by the Energy Policy Act of 1992 (EPACT) (P.L. 102-486), establishes a role for the U.S. Department of Energy (DOE) to regulate efficiency levels of certain categories of commercial heating, cooling, and water-heating equipment. Initial minimum efficiency levels for products falling under these equipment categories were established in EPACT (Tables 1.1 and 1.2), based on the requirements contained in ASHRAE/IES Standard 90.1-1989 (ASHRAE 1989). EPCA ${ }^{(a)}$ requirements state that, if the American Society of Heating, Refrigerating and Air-Conditioning Engineers, Inc. (ASHRAE) amends efficiency levels prescribed in Standard 90.1-1989, then DOE must establish an amended uniform national manufacturing standard at the minimum level specified in amended Standard 90.1. However, DOE can establish higher efficiency levels if it can show through clear and convincing evidence that a higher efficiency level, that is technologically feasible and economically justified, would produce significant additional energy savings.

On October 29, 1999, ASHRAE approved the amended Standard $90.1,{ }^{(b)}$ which increases the minimum efficiency levels for some of the commercial heating, cooling, and water-heating equipment covered by EPCA 92. DOE asked Pacific Northwest National Laboratory (PNNL) ${ }^{(c)}$ to conduct has conducted a screening analysis to determine the energy-savings potential of the efficiency levels listed in Standard 90.1-1999. The analysis estimates the annual national energy consumption and the potential for energy savings that would result if the EPACT-covered products were required to meet these efficiency levels. The analysis also estimates additional energy-savings potential for the EPACT-covered products if they were to exceed the efficiency levels prescribed in Standard 90.1-1999. In addition, a simple lifecycle cost (LCC) analysis was performed for some alternative efficiency levels. This report describes the methodology, data assumptions, and results of the analysis.

Section 2.0 includes a detailed description of the engineering approach used in the analysis, including the data and cost versus efficiency curves. The methodology used for national energy-savings impacts, LCC, and national economic impacts is described in Section 3.0. The energy savings, LCC, and net present value (NPV) results for the various cooling, heating, and water-heating products are also presented in Section 3.0. Section 4.0 is a list of references cited in this report. The details of the building characteristics data used in the BLAST simulations (Building Loads and System Thermodynamics) and for the water-heating analysis for each of the representative building types is presented in Appendix A. Appendix $B$ describes the methodology used to aggregate the engineering results for specific locations

(a) In this document, EPCA, as amended by EPACT, is often referred to as "EPCA 92."

(b) On June 24, 1999, ASHRAE's Board of Directors provisionally approved revisions to ASHRAE/IES Standard 90.1, subject to a formal appeal process. Four appeals were filed, and an Appeals Hearing was held on October 9, 1999. The Appeals Panel recommended that the appeals be dismissed, and the ASHRAE Board approved the Appeals Panel report in a special meeting on October 29, 1999, thus concluding ASHRAE's process for amending the standard. The commercial HVAC equipment efficiencies contained in ASHRAE/IESNA Standard 90.1-1999 will become effective on October 29, 2001, two years after final ASHRAE approval.

(c) Pacific Northwest National Laboratory is operated by Battelle for the U.S. Department of Energy. 
Table 1.1. Commercial Equipment Product Categories: Air Conditioners (AC) and Heat Pumps (HP) (EPCA [as amended] Section 342 (a) (1), (2), and (3))

\begin{tabular}{|c|c|c|c|c|c|}
\hline \multirow{2}{*}{$\begin{array}{c}\text { Equipment } \\
\text { Category }\end{array}$} & \multirow{2}{*}{$\begin{array}{l}\text { Equipment } \\
\text { Subcategory }\end{array}$} & \multirow[b]{2}{*}{ EPCA Section } & \multirow{2}{*}{$\begin{array}{c}\text { EPCA } \\
\text { Date }\end{array}$} & \multicolumn{2}{|c|}{ Efficiency Levels } \\
\hline & & & & EPCA 92 & 90.1-1999 \\
\hline \multirow[t]{5}{*}{$\begin{array}{l}\text { Small Commercial } \\
\text { Packaged Air- } \\
\text { Conditioning and } \\
\text { Heating Equipment }\end{array}$} & $\begin{array}{l}\mathrm{AC} / \mathrm{HP}<65 \mathrm{kBtu} / \mathrm{h} \\
\text { Air-Cooled 3-Phase, } \\
\text { Central-Split System }\end{array}$ & $\begin{array}{l}\text { Cooling Eff. } \\
342(a)(1)(A) \\
\text { Heating Eff. } \\
342(a)(1)(D)\end{array}$ & $1 / 1 / 94$ & $\begin{array}{l}\text { SEER } 10.0 \\
\text { HSPF } 6.8\end{array}$ & $\begin{array}{l}\text { SEER } 10.0 \\
\text { HSPF } 6.8\end{array}$ \\
\hline & $\begin{array}{l}\mathrm{AC} / \mathrm{HP}<65 \mathrm{kBtu} / \mathrm{h} \\
\text { Air-Cooled 3-Phase, } \\
\text { Central-Single Package }\end{array}$ & $\begin{array}{l}\text { Cooling Eff. } \\
342(a)(1)(B) \\
\text { Heating Eff. } \\
342(a)(1)(E)\end{array}$ & $1 / 1 / 94$ & $\begin{array}{l}\text { SEER } 9.7 \\
\text { HSPF } 6.6\end{array}$ & $\begin{array}{l}\text { SEER } 9.7 \\
\text { HSPF } 6.6\end{array}$ \\
\hline & $\begin{array}{l}\mathrm{AC} / \mathrm{HP} \text { 65-135 kBtu/h } \\
\text { Air-Cooled Central }\end{array}$ & $\begin{array}{l}\text { Cooling Eff. } \\
342(a)(1)(C) \\
\text { Heating Eff. } \\
342(a)(1)(F)\end{array}$ & $1 / 1 / 94$ & $\begin{array}{l}\text { EER } 8.9 \\
\text { COP } 3.0\end{array}$ & $\begin{array}{l}\text { EER } 10.3 \\
\text { COP } 3.2\end{array}$ \\
\hline & $\begin{array}{l}\text { AC/HP }<65 \mathrm{kBtu} / \mathrm{h} \\
\text { Water-Cooled } \\
\text { Evap. Cooled } \\
\text { Water-Source Central }\end{array}$ & $\begin{array}{l}\text { Cooling Eff. } \\
342(a)(1)(G) \\
\text { Heating Eff. } \\
\text { Water-Source only } \\
342(a)(1)(I)\end{array}$ & $1 / 1 / 94$ & $\begin{array}{l}\text { EER } 9.3 \\
\text { COP } 3.8\end{array}$ & $\begin{array}{l}\text { EER } 12.1 \\
\text { COP } 4.2\end{array}$ \\
\hline & $\begin{array}{l}\text { AC/HP } 65-135 \mathrm{kBtu} / \mathrm{h} \\
\text { Water-Cooled } \\
\text { Evap. Cooled } \\
\text { Water-Source Central }\end{array}$ & $\begin{array}{l}\text { Cooling Eff. } \\
342(\mathrm{a})(1)(\mathrm{H}) \\
\text { Heating Eff. } \\
\text { Water-Source only } \\
342(\mathrm{a})(1)(\mathrm{I})\end{array}$ & $1 / 1 / 94$ & \begin{tabular}{|l} 
EER 10.5 \\
COP 3.8
\end{tabular} & $\begin{array}{l}\text { EER } 11.5 \\
\text { COP } 4.2\end{array}$ \\
\hline \multirow[t]{2}{*}{$\begin{array}{l}\text { Large Commercial } \\
\text { Packaged Air- } \\
\text { Conditioning and } \\
\text { Heating Equipment }\end{array}$} & $\begin{array}{l}\mathrm{AC} / \mathrm{HP} 135-240 \mathrm{kBtu} / \mathrm{h} \\
\text { Air-Cooled Central }\end{array}$ & $\begin{array}{l}\text { Cooling Eff. } \\
342(\mathrm{a})(2)(\mathrm{A}) \\
\text { Heating Eff. } \\
342(\mathrm{a})(2)(\mathrm{B})\end{array}$ & $1 / 1 / 95$ & $\begin{array}{l}\text { EER } 8.5 \\
\text { COP } 2.9\end{array}$ & $\begin{array}{l}\text { EER } 9.7 \\
\text { COP } 3.1\end{array}$ \\
\hline & $\begin{array}{l}\text { AC/HP } 135-240 \mathrm{kBtu} / \mathrm{h} \\
\text { Water-Cooled } \\
\text { Evap. Cooled Central }\end{array}$ & $\begin{array}{l}\text { Cooling Eff. } \\
342(\mathrm{a})(2)(\mathrm{A}) \\
\text { No Heating Eff. } \\
\text { Requirement } \\
\end{array}$ & $1 / 1 / 95$ & EER 9.6 & EER 11.0 \\
\hline $\begin{array}{l}\text { Packaged Terminal } \\
\text { Air Conditioners and } \\
\text { Heat Pumps }\end{array}$ & $\begin{array}{l}\text { PTAC/PTHP } \\
\text { Air-Cooled }\end{array}$ & $\begin{array}{l}\text { Cooling Eff. } \\
342(a)(3)(A) \\
\text { Heating Eff. } \\
342(a)(3)(B)\end{array}$ & $1 / 1 / 94$ & $\begin{array}{l}\text { EER and COP } \\
\text { vary by capacity }\end{array}$ & $\begin{array}{l}\text { EER and COP } \\
\text { vary by capacity } \\
\text { (different } \\
\text { formulas) }\end{array}$ \\
\hline
\end{tabular}

(cities) to a national level. Appendix $C$ contains instructions on how to use the analysis spreadsheet developed for the screening analysis. Appendix $\mathrm{D}$ lists one-page summary results for all the products (cooling, heating, and water heating) analyzed in the screening analysis. 
Table 1.2. Commercial Equipment Product Categories: Furnaces, Boilers, and Storage Water Heaters (EPCA [as amended] Section 342 (a) (4), and (5))

\begin{tabular}{|c|c|c|c|c|c|}
\hline \multirow{2}{*}{$\begin{array}{l}\text { Equipment } \\
\text { Category }\end{array}$} & \multirow{2}{*}{$\begin{array}{l}\text { Equipment } \\
\text { Subcategory }\end{array}$} & \multirow[b]{2}{*}{ EPCA Section } & \multirow{2}{*}{$\begin{array}{l}\text { EPCA } \\
\text { Date }\end{array}$} & \multicolumn{2}{|c|}{$\begin{array}{l}\text { Efficiency Levels } \\
\end{array}$} \\
\hline & & & & EPCA 92 & 90.1-1999 \\
\hline \multirow{2}{*}{$\begin{array}{l}\text { Warm-Air } \\
\text { Furnaces }\end{array}$} & $>225 \mathrm{kBtu} / \mathrm{h}$ & Gas Fired Eff. & $1 / 1 / 94$ & Thermal Efficiency & Thermal Efficiency \\
\hline & $\begin{array}{l}\text { Gas-Fired } \\
\text { Oil-Fired }\end{array}$ & $\begin{array}{l}342(a)(4)(A) \\
\text { Oil Fired Eff. } \\
342(a)(4)(A)\end{array}$ & & $80 \%$ Gas $\quad 81 \%$ Oil & $80 \%$ Gas $81 \%$ Oil \\
\hline \multirow[t]{2}{*}{ Package Boilers } & $>300 \mathrm{kBtu} / \mathrm{h}$ & Gas Fired Eff. & $1 / 1 / 94$ & Combustion Efficiency & Combustion Efficiency \\
\hline & $\begin{array}{l}\text { Gas-Fired Oil- } \\
\text { Fired }\end{array}$ & $\begin{array}{l}342(a)(4)(C) \\
\text { Oil Fired Eff. } \\
342(a)(4)(D)\end{array}$ & & $80 \%$ Gas $\quad 83 \%$ Oil & $80 \%$ Gas $83 \%$ Oil \\
\hline \multirow[t]{3}{*}{$\begin{array}{l}\text { Storage Water } \\
\text { Heaters }\end{array}$} & Electric & $\begin{array}{l}\text { Standby Loss } \\
342(a)(5)(A)\end{array}$ & $1 / 1 / 94$ & $0.3+27 / \mathrm{Va}$ & $20+35 \sqrt{V}$ \\
\hline & $\begin{array}{l}\leq 155 \mathrm{kBtu} / \mathrm{h} \\
\text { and } \mathrm{V} \leq 140 \text { gal }\end{array}$ & $\begin{array}{l}\text { Thermal Eff. and } \\
\text { Standby Loss } \\
342(\mathrm{a})(5)(\mathrm{B})\end{array}$ & $1 / 1 / 94$ & $\begin{array}{l}\text { Thermal Eff. } 78 \% \\
\text { Standby Loss Varies } \\
\text { by Volume }\end{array}$ & $\begin{array}{l}\text { Thermal Eff. } 80 \% \\
\text { Standby Loss Varies by } \\
\text { Volume }\end{array}$ \\
\hline & $\begin{array}{l}>155 \mathrm{kBtu} / \mathrm{h} \\
\text { and } V \leq 140 \text { gal }\end{array}$ & $\begin{array}{l}\text { Thermal Eff. and } \\
\text { Standby Loss } \\
342(a)(5)(C)\end{array}$ & $1 / 1 / 94$ & $\begin{array}{l}\text { Thermal Eff. } 78 \% \\
\text { Standby Loss Varies } \\
\text { by Volume }\end{array}$ & $\begin{array}{l}\text { Thermal Eff. } 80 \% \\
\text { Standby Loss Varies by } \\
\text { Volume }\end{array}$ \\
\hline \multirow[t]{2}{*}{$\begin{array}{l}\text { Instantaneous } \\
\text { Water Heaters }\end{array}$} & \begin{tabular}{|l|}
$\mathrm{V}<10$ gal \\
Instantaneous
\end{tabular} & $\begin{array}{l}\text { Thermal Eff. } \\
\text { 342(a)(5)(D) }\end{array}$ & $1 / 1 / 94$ & Thermal Eff. $80 \%$ & Thermal Eff. $80 \%$ \\
\hline & $\begin{array}{l}10 \text { gal }<\mathrm{V} \\
<140 \text { gal } \\
\text { Instantaneous }\end{array}$ & $\begin{array}{l}\text { Thermal Eff. and } \\
\text { Standby Loss } \\
342(a)(5)(E)\end{array}$ & $1 / 1 / 94$ & $\begin{array}{l}\text { Thermal Eff. } 77 \% \\
\text { Standby Loss Varies } \\
\text { by Volume }\end{array}$ & $\begin{array}{l}\text { Thermal Eff. } 80 \% \\
\text { Standby Loss Varies by } \\
\text { Volume }\end{array}$ \\
\hline \multirow[t]{2}{*}{ Storage Tanks } & $\begin{array}{l}\mathrm{V}>140 \text { gal } \\
\text { Unfired }\end{array}$ & $\begin{array}{l}\text { Heat Loss } \\
342(a)(5)(F)\end{array}$ & $1 / 1 / 94$ & Heat Loss $6.5 \mathrm{Btu} / \mathrm{h} \cdot \mathrm{ft}^{2}$ & Heat Loss $6.5 \mathrm{Btu} / \mathrm{h} \cdot \mathrm{ft}^{2}$ \\
\hline & $\begin{array}{l}\text { Storage Water } \\
\text { Heaters and } \\
\text { Storage Tanks } \\
>140 \text { gal }\end{array}$ & $\begin{array}{l}\text { Prescriptive } \\
342(a)(5)(G)\end{array}$ & $1 / 1 / 94$ & $\mathrm{R}-12.5, \mathrm{IID}$ & R-12.5, IID \\
\hline
\end{tabular}

\subsection{Scope of the Analysis}

The screening analysis examined the efficiency levels specified in EPCA and Standard 90.1-1999 for the EPACT-covered equipment, as well as more efficient levels, including those associated with the most efficient products available in the market. For each level above the EPCA standard, the following were estimated:

1. the incremental national energy and carbon emission savings that would result from a standard set at that level

2. the NPV that would result from a standard set at that level, as compared with the corresponding Standard 90.1-1999 and EPCA standards. 
Table 1.3. Characteristics of Certain Products Analyzed in Screening Analysis

\begin{tabular}{|c|c|c|}
\hline Equipment Type & Size Category & $\begin{array}{c}\text { Performance } \\
\text { Characteristic Analyzed }\end{array}$ \\
\hline 3-Phase, Single-Package, Air-Source AC & \multirow{4}{*}{$<65 \mathrm{kBtu} / \mathrm{h}$} & \\
\hline 3-Phase, Split-System, Air-Source AC & & \\
\hline 3-Phase, Single-Package, Air-Source HP & & \begin{tabular}{|c|c|c|} 
cooling performance only \\
\end{tabular} \\
\hline 3-Phase, Split-System, Air-Source HP & & cooling performance only \\
\hline Central Air-Source AC & \multirow{4}{*}{$\geq 65 \mathrm{kBtu} / \mathrm{h}$ and $<135 \mathrm{kBtu} / \mathrm{h}$} & \\
\hline Central Air-Source HP & & cooling performance only \\
\hline Central Water-Source HP & & \begin{tabular}{|c|c|} 
cooling performance only \\
\end{tabular} \\
\hline Central Water-Cooled AC & & \\
\hline Central Air-Source AC & \multirow{3}{*}{$\geq 135 \mathrm{kBtu} / \mathrm{h}$ and $<240 \mathrm{kBtu} / \mathrm{h}$} & \\
\hline Central Air-Source HP & & cooling performance only \\
\hline Central Water-Cooled AC & & \\
\hline Central Water-Cooled AC & $<65 \mathrm{kBtu} / \mathrm{h}$ & \\
\hline Central Water-Source HP & $<17 \mathrm{kBtu} / \mathrm{h}$ & cooling performance only \\
\hline Central Water-Source HP & $\geq 17 \mathrm{kBtu} / \mathrm{h}$ and $<65 \mathrm{kBtu} / \mathrm{h}$ & cooling performance only \\
\hline Packaged Terminal Air Conditioners (PTACs) & & \\
\hline Packaged Terminal Heat Pumps (PTHPs) & & cooling performance only \\
\hline Small Gas-Fired Steam Boilers & $<2,500 \mathrm{kBtu} / \mathrm{h}$ & \\
\hline Large Gas-Fired Steam Boilers & $>2,500 \mathrm{kBtu} / \mathrm{h}$ & \\
\hline Large Gas-Fired Hot Water Boilers & $>2,500 \mathrm{kBtu} / \mathrm{h}$ & \\
\hline Gas-Fired Warm-Air Furnaces & $>225 \mathrm{kBtu} / \mathrm{h}$ & \\
\hline Gas Storage Water Heaters & $>155 \mathrm{kBtu} / \mathrm{h}$ & \\
\hline Gas Storage Water Heaters & $\leq 155 \mathrm{kBtu} / \mathrm{h}$ & \\
\hline Electric Water Heaters & $>12 \mathrm{~kW}$ & \\
\hline Gas-Fired Tankless Instantaneous Water Heaters & & \\
\hline Gas-Fired Instantaneous Water Heaters with Tanks & & \\
\hline
\end{tabular}

Table 1.4. Characteristics of Certain Products Not Analyzed in Screening Analysis

\begin{tabular}{|l|l|l|}
\hline \multicolumn{1}{|c|}{ Equipment Type } & \multicolumn{1}{|c|}{ Size Category } & $\begin{array}{c}\text { Performance Characteristic } \\
\text { Not Analyzed }\end{array}$ \\
\hline 3-Phase, Single-Package Air-Source HP & $<65 \mathrm{kBtu} / \mathrm{h}$ & heating performance \\
\cline { 3 - 3 } 3-Phase, Split-System Air-Source HP & \multicolumn{1}{|c|}{ heating performance } \\
\hline Central Air-Source HP & $\geq 135 \mathrm{kBtu} / \mathrm{h}$ and $<240 \mathrm{kBtu} / \mathrm{h}$ & heating performance \\
\hline Central Air-Source HP & $\geq 65 \mathrm{kBtu} / \mathrm{h}$ and $<135 \mathrm{kBtu} / \mathrm{h}$ & heating performance \\
\hline Central Water-Source HP & $<135 \mathrm{kBtu} / \mathrm{h}$ & heating performance \\
\hline Packaged Terminal HP & & heating performance \\
\hline Water-Source HP & $\geq 135 \mathrm{kBtu} / \mathrm{h}$ and $<240 \mathrm{kBtu} / \mathrm{h}$ & \\
\hline Evaporatively Cooled Products & & \\
\hline Oil-Fired Warm-Air Furnaces & $>225 \mathrm{kBtu} / \mathrm{h}$ & \\
\hline Oil-Fired Storage Water Heaters & $\leq 155 \mathrm{kBtu} / \mathrm{h}$ & \\
\hline Oil-Fired Storage Water Heaters & $>155 \mathrm{kBtu} / \mathrm{h}$ & \\
\hline $\begin{array}{l}\text { Oil-Fired Instantaneous Water Heaters with } \\
\text { Tanks }\end{array}$ & & steam and hot water \\
\hline Oil-Fired Small Boilers & $<2,500 \mathrm{kBtu} / \mathrm{h}$ & \\
\hline Oil-Fired Large Boilers & $>2,500 \mathrm{kBtu} / \mathrm{h}$ & \\
\hline Tankless Oil-Fired Instantaneous Water Heaters & & \\
\hline
\end{tabular}


These products were excluded because of insufficient data describing baseline energy consumption and cost-efficiency relationships, a small market for the products or lack of product shipment data, or, for heating performance of air-source heat pumps, absence of a suitable methodology to discriminate their heating function from that of supplemental heat sources with which they are often used.

\subsection{Methodology Overview}

This section provides an overview of the methodology used for the screening analysis (with additional details provided in subsequent sections), which was divided into five steps:

1. Engineering Analysis

2. National Energy Impacts

3. National Economic Impacts

4. Life-Cycle Cost (LCC) Analysis

5. National Emissions Reductions

The energy end-uses for the various cooling, heating, and water-heating equipment categories at several different efficiency levels were estimated using a full-load equivalent operating hour (FLEOH) approach. The details of the engineering analysis are provided in Section 2.0.

The magnitude of heating, ventilating, and air-conditioning (HVAC) and service water-heating (SWH) loads imposed on equipment depends on the physical and operational characteristics of the building in which the equipment is used, as well as the prevailing climatic conditions. To capture this variation of equipment energy use, coil loads for 7 representative building types at 11 climate locations were estimated, based on a whole-building simulation. Details of this process are presented in Section 2.0. The mapping of the building loads to normalized equipment loads (for a particular equipment size) using a FLEOH approach is also addressed.

For each equipment category, the energy usage of a given piece of equipment was estimated based on a characteristic equipment size for each combination of representative building type and climate location. The unit energy use was estimated using FLEOH and adjusted for each nominal equipment efficiency level being considered.

The national energy impacts of higher efficiency equipment were estimated by 1) mapping climate locations onto regions and 2) estimating the fraction of each year's national equipment shipments (by product category) within market segments, as defined by a representative building type within a particular region of the United States. Because detailed statistical information related to where and in what types of buildings the equipment is currently being installed is generally unavailable, an allocation process was developed. The estimated allocation of national shipments to market segments was primarily based on information from the Commercial Building Energy Consumption Survey (CBECS) (EIA 1992, 1995) related to floor space and saturations of generic equipment types for each market segment. National energy consumption for each equipment category was then estimated at each efficiency level by multiplying the annual unit energy use in each market segment with the annual shipments expected for that market segment. 
The LCC analysis was conducted at the market segment level with region-specific energy prices; and thus provides some insight on the distribution of LCC cost savings across the building population.

National NPV was calculated as a summary metric of the total national economic impact due to any chosen level of efficiency standard. This metric combines the influence of the LCC savings per unit, as well as the projected volume of shipments in each equipment category. This process is explained in more detail in Section 3.0, as well as the national emissions reductions that can be achieved by adopting higher efficiency level. 


\subsection{Engineering Analysis}

This section describes the engineering approach used in the screening analysis. A discussion on how the space-heating, space-cooling, and water-heating loads were generated is presented. The method for selecting representative building types and climate locations used for the analysis and the basis for their selection are then described, followed by the approach used to estimate the equipment loads and annual energy use. Finally, the cost data, including the first cost and equipment cost versus efficiency for each of the products analyzed and the sources of the information, are provided.

\subsection{Engineering Approach}

The annual load and energy use for the various EPACT-covered heating, cooling, and water-heating products at different efficiency levels were estimated for the analysis using a FLEOH approach. The FLEOH is effectively the number of hours that a system would have to run at full capacity to serve a total load equal to the annual load on the equipment. FLEOH is calculated as:

$$
\text { FLEOH }=\frac{\text { Annual Load }}{\text { Equipment Capacity }}
$$

FLEOH is strictly defined as being related to the equipment capacity, not the peak load on the system. Because FLEOH is used to generate annual heating and cooling loads irrespective of equipment size, an assumption is required on how the equipment is typically sized that must be used consistently. For this analysis, the assumption was that the equipment is sized based on the design-day peak equipment load with no explicit oversizing:

$$
\text { Equipment Capacity }=\text { Design Day Peak Load }
$$

Substituting Equation (2.1) into Equation (2.2) yields:

$$
\text { FLEOH }=\frac{\text { Annual Load }}{\text { Design Day Peak Load }}
$$

The FLEOH for a piece of equipment is a function of the relative annual load to the peak building load. In general, this ratio will vary depending on building construction, building internal loads, building schedules, and orientation and exposure of the zone that the equipment serves. It was assumed that for any given building type, the internal-load characteristics and building schedules are constant across the building.

The FLEOH represents a simplified approach for estimating energy use. The efficiency level analysis is based on the rated efficiency at the rated conditions [e.g., the energy efficiency ratio (EER) rating for commercial packaged cooling equipment] as a proxy for equipment efficiency. For example, 
improvements in rated EER can come from several design modifications, including more efficient compressor designs, better heat transfer characteristics of the coils, improved refrigerants, or reduced fan energy requirements. The EER may not reflect efficiency improvements from some design options or control strategies used to enhance the part-load or off-design performance, such as a multiple-compressor system designed to improve part-load performance.

The design changes that enhance full-load performance will generally improve part-load efficiency; thus, improvements in full-load efficiency ratings can be used in estimating a minimum improvement in average annual efficiency for a product.

Three general caveats should be noted with regard to the FLEOH approach. First, the approach does not directly address the off-design performance. Second, accuracy decreases when assessing equipment energy uses that do not scale with the load on the equipment; e.g., the supply fan energy use in packaged cooling equipment, or the standby loss inherent in a water heater or a boiler. Third, the approach does not address cycling losses in equipment.

For cooling equipment, the condenser performance (COP) generally increases at off-design performance. However, this fact is mitigated by the cycling losses that tend to occur in actual use and by the fact the fan energy use is relatively constant.

A review of package system annual average EER data from simulations of actual cooling systems by Barwig et al. (1996) showed no consistent pattern as to whether the annual efficiency of packaged airconditioning equipment in a typical building application was over- or under-represented. Annual average EER variations of $-14 \%$ to $+12 \%$ of the nominal EER rating were seen across the building types and locations modeled.

For boilers and furnaces, the FLEOH approach may somewhat underestimate the annual energy used in the equipment. For furnaces, the effect is small because the losses during the off-cycle periods are small, and much of the heat remaining in the heat exchanger during the off-cycle will be picked up in the building air stream, at least during periods of occupancy.

For boilers, the total annual standby loss is largely a function of the period available for operation (hot standby period). Because this is an operation issue and is not specific to equipment design and climate location, the standby loss cannot be accurately captured in a simplified analysis. For this analysis, the boiler FLEOHs are adjusted by calculating a standby loss factor to account for the standby losses (as described in Appendix A).

The analysis of SWH equipment was similar to the boiler analysis. The total standby loss of energy for SWH equipment is a function of the standby loss rating for the equipment being examined, as well as the number of hours the system is on standby (generally 8760 hours minus actual firing hours). Unlike the boiler analysis, where the FLEOHs were adjusted to reflect standby losses, the standby losses for water heaters were explicitly specified. 


\subsection{Annual Building and Equipment Space-Heating and -Cooling Loads}

The first step in the process to create the building-level weighted FLEOH was to use a generic threestory, 15-zone prototype building, with characteristics that represent a particular building type to estimate the coil loads. The generic building coil loads are estimated for each building type and at each climate location. In addition to the variation in building characteristics, the use of airside economizers and setback (setup) schedules can significantly affect the space loads. To account for these variations, four sets of the generic building coil loads were estimated: 1) with economizer and setbacks; 2) with economizer and without setbacks; 3) without economizer with setbacks; and 4) without economizers and setbacks. The generic coil loads for each simulation (308 total runs, corresponding to 7 building types, 11 climate locations, and 4 combinations) were scaled to represent an average building (see Appendix A for details of the building size and shape selections). The four sets of FLEOH for the cooling products and two sets of FLEOH for the heating products (economizer runs do not apply to heating products) are tabulated in Appendix A, as well as the weights associated with the fraction of the buildings having economizers and setbacks/setups. These weights were derived from the CBECS (EIA 1995a).

From the scaled results, FLEOH were generated for heating and cooling equipment for each representative building. Because multiple building zones exist in the scaled building, the FLEOHs from each zone are weighted by the design loads in the zone to determine an average weighted FLEOH for that building. The weights account for higher influence by zones having larger peak loads and a corresponding larger number of units serving the zone. This aggregation results in a single FLEOH for a particular building type and climate location. FLEOH are calculated for each class of equipment (heating and cooling) and for each representative building type and climate location simulated. The process for estimating the weighted FLEOH by building type and climate location is illustrated in Figure 2.1 .

The annual load on HVAC or SWH equipment can be estimated by multiplying the FLEOH for that representative building type, equipment use (heating, cooling or water heating), and climate, by the output capacity (i.e., $\mathrm{kBtu} / \mathrm{h}$ ) of the equipment. For this analysis, the assumption was that the equipment is sized to meet the design-day peak load, consistent with the chosen sizing algorithm.

\subsection{Translation of Annual Loads to Annual Energy Use}

Equipment efficiency is used to translate annual equipment loads to energy use as shown in Equation (2.4). For simplicity, the equipment efficiency rating was used in the analysis seasonal energy efficiency ratio (SEER)/EER for cooling equipment, thermal efficiency for heating and water-heating equipment) because it is readily available for comparison across equipment categories; hence, for commercial cooling equipment:

$$
\text { Annual Energy Use }=\frac{\text { FLEOH } x \text { Equipment Capacity }}{\text { Efficiency }}
$$




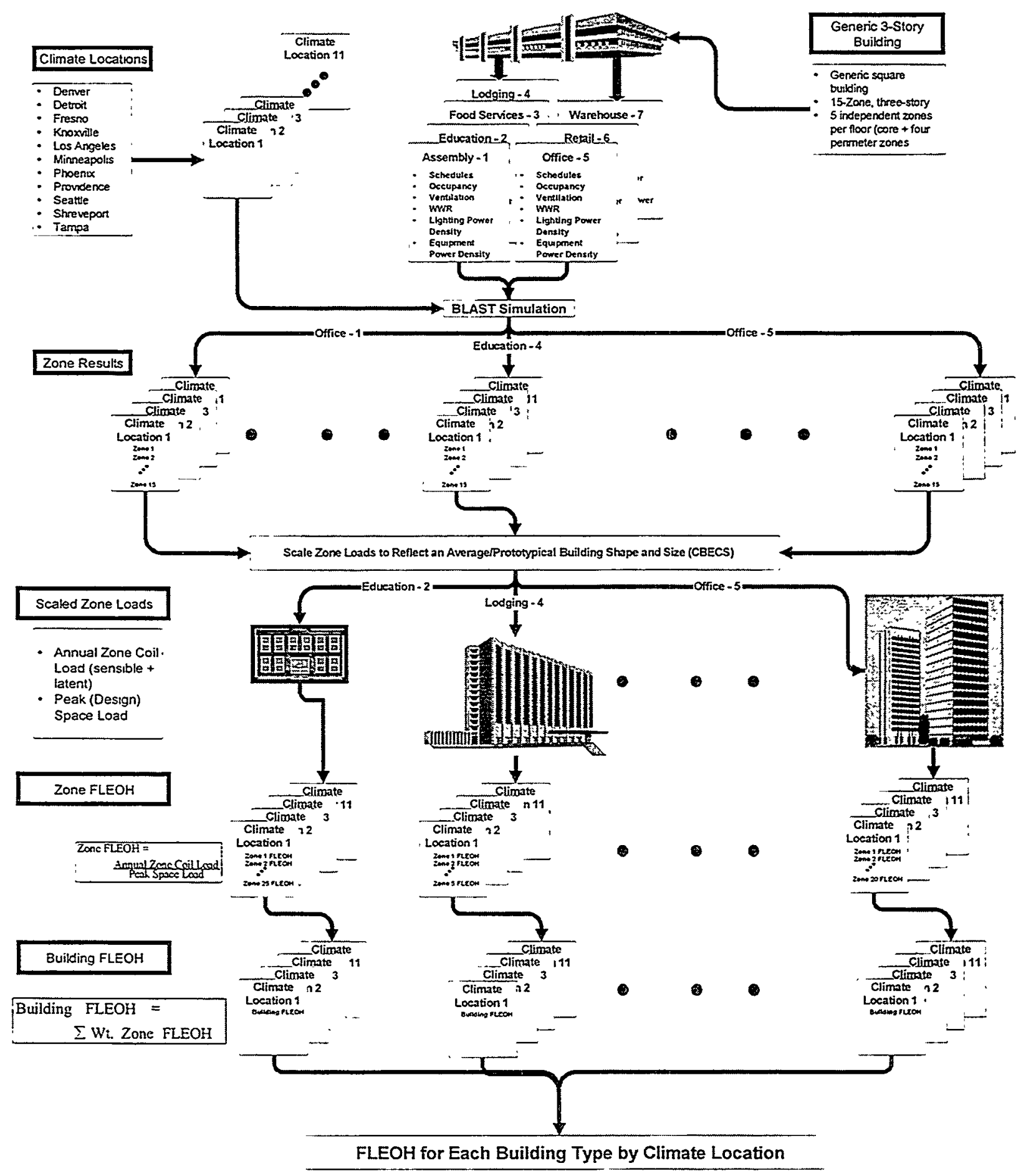

Figure 2.1. Proposed Process for Estimating the Weighted FLEOH by Building Type and Climate Location 
For packaged boilers and water-heating equipment, the FLEOH were adjusted to account for jacket losses and standby losses, respectively. Therefore, the calculated annual energy use is the gross consumption, including any losses associated with the products.

\subsection{Representative Building Types}

Because the scope of the analysis was to screen the products showing significant additional energy savings over the Standard 90.1-1999 efficiency levels, the building types to be used in the analysis were selected to account for at least $75 \%$ of the total commercial building energy consumption.

Based on the annual energy use of principal building types from the CBECS (EIA 1995), a ranking of the building types was developed as shown in Table 2.1. Seven of the top eight building types (in terms of the magnitude of annual energy use) were used in a previous analysis of efficiency levels for selected commercial equipment (Barwig et al. 1996). The 7 building types also represent $78.4 \%$ of the cumulative total energy consumption of all commercial buildings. Because they account for more than three-quarters of the total commercial building energy consumption, the 7 building types were selected as the representative building types that were simulated using the BLAST software for the present analysis (BLAST 1991).

Although the health care building type accounts for a significant fraction (10\%) of the total commercial building energy use, it was not chosen for this analysis because comprehensive and accurate building characteristics were not available. However, the outpatient care/doctor's office segment of the health care building type was accounted for by using the office building model to represent space-cooling, space-heating, and water-heating loads. This addition brought the percentage of the energy consumption captured in the screening analysis up to over $80 \%$.

Table 2.1. Energy Consumption by Principal Building Activity

\begin{tabular}{|l|c|c|c|}
\hline Principal Building Activity & $\begin{array}{c}\text { Annual Energy Use } \\
\text { (trillion Btu) }\end{array}$ & Percent of Total & $\begin{array}{c}\text { Cumulative } \\
\text { Percent }\end{array}$ \\
\hline Office & $\mathbf{1 , 0 1 9}$ & $\mathbf{1 9 . 1}$ & $\mathbf{1 9 . 1}$ \\
\hline Mercantile and Service & $\mathbf{9 7 3}$ & $\mathbf{1 8 . 3}$ & $\mathbf{3 7 . 4}$ \\
\hline Education & $\mathbf{6 1 4}$ & $\mathbf{1 1 . 5}$ & $\mathbf{4 9 . 0}$ \\
\hline Health Care & 561 & 10.5 & 59.5 \\
\hline Lodging & $\mathbf{4 6 1}$ & $\mathbf{8 . 7}$ & $\mathbf{6 8 . 2}$ \\
\hline Public Assembly & $\mathbf{4 4 9}$ & $\mathbf{8 . 4}$ & 76.6 \\
\hline Food Service & $\mathbf{3 3 2}$ & $\mathbf{6 . 2}$ & $\mathbf{8 2 . 8}$ \\
\hline Warehouse and Storage & $\mathbf{3 2 5}$ & $\mathbf{6 . 1}$ & $\mathbf{8 8 . 9}$ \\
\hline Other & 173 & 3.3 & 92.2 \\
\hline Food Sales & 137 & 2.6 & 94.8 \\
\hline Public Order and Safety & 124 & 2.3 & 97.1 \\
\hline Religious Worship & 104 & 2.0 & 99.0 \\
\hline Vacant & 51 & 1.0 & 100.0 \\
\hline \multicolumn{1}{|c|}{ Total } & 100.0 & \\
\hline Source: CBECS (EIA 1995). & 5,323 & & \\
\hline The building activities in bold were used in the screening analysis. & \\
\hline
\end{tabular}




\subsection{Climate Locations for the BLAST Simulation}

The national climate variations for the BLAST simulation were represented by the same 11 climate locations used in the Standard 90.1-1999 analysis, as well as the earlier equipment standards analysis (Barwig et al. 1996). The 11 climate locations are Providence, Rhode Island; Detroit, Michigan; Minneapolis, Minnesota; Knoxville, Tennessee; Shreveport, Louisiana; Tampa, Florida; ${ }^{(a)}$ Denver, Colorado; Phoenix, Arizona; Seattle, Washington; Fresno, California; and Los Angeles, California.

Climate locations (see Figure 2.2) were selected to represent their influence on energy use in commercial buildings. The selection process used climate-based criteria to determine the most representative climates. Work performed in developing Standard 90.1-1989 identified 11 climate-based criteria that were determined to have significant influence on energy use in commercial buildings (ASHRAE 1989). Further details on the selection criteria can be found in Appendix D of Barwig et al. (1996).

\subsection{Building Heating, Cooling, and Water-Heating Loads}

For heating and cooling equipment, the annual energy use is a function of the heating or cooling loads the equipment must meet. For a single equipment application, these loads can vary by hour of the day,

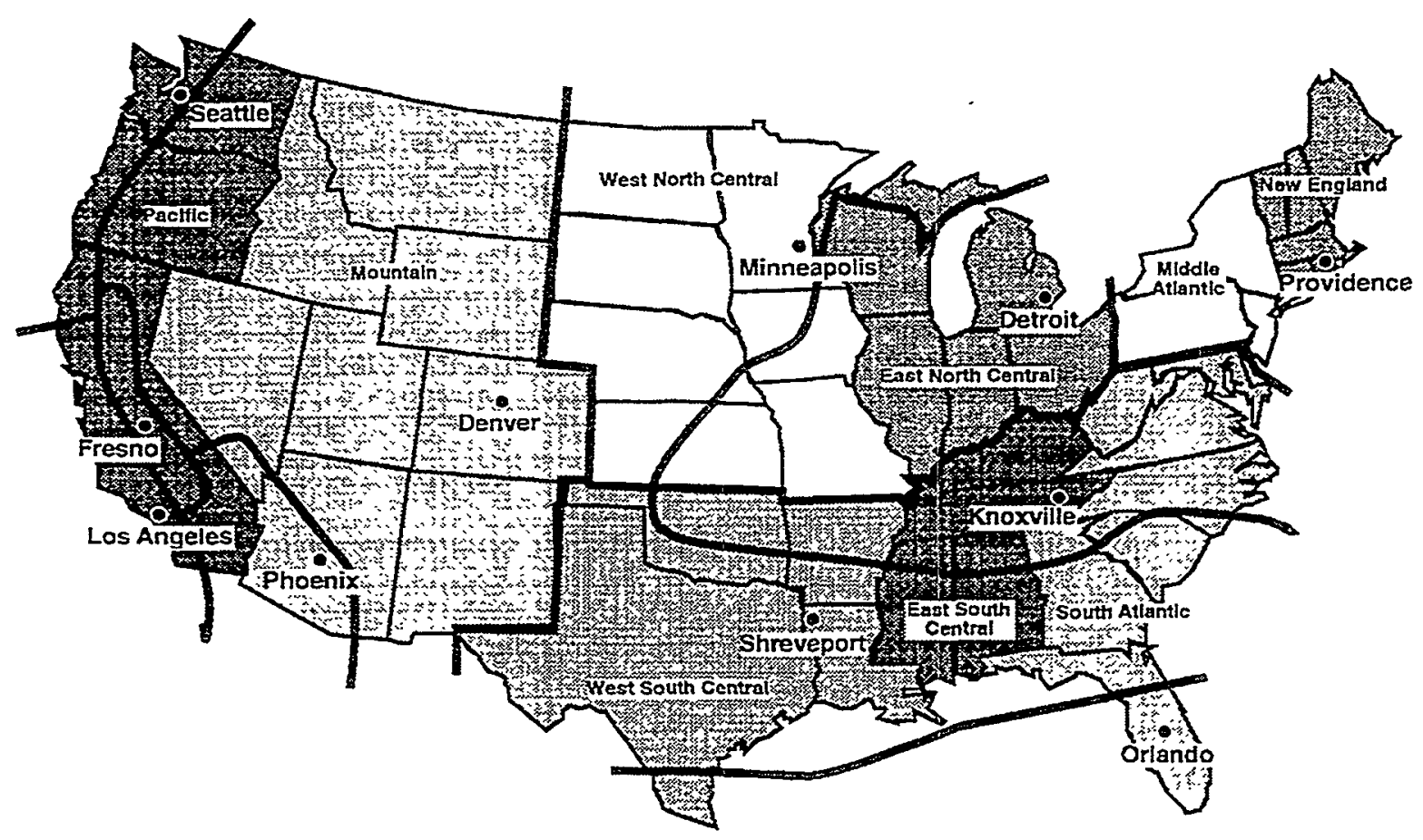

Figure 2.2. U.S. Map Showing 11 Climate Locations (cities) and Corresponding Climate Regions (dark boundaries), and 9 Census Divisions (shaded area)

(a) We replaced Orlando, Florida with Tampa, Florida because TMY2 weather data used for this analysis were not available for Orlando. 
day of the week, and time of the year. The variations are driven by factors such as the type of building in which the equipment is installed; the activities and internal loads (lighting, occupant, and receptacle loads) in the building; and the buildings' internal and external environmental conditions, ventilation rates, and HVAC control strategy. Building type is a convenient descriptor for categorizing the nature of loads the HVAC equipment must meet. For water-heating equipment, annual energy consumption depends on the demand for hot water. This demand can be also be linked to building type by the activities that create the demand.

\subsubsection{Building Space-Heating and Space-Cooling Loads}

The BLAST detailed hourly simulation program was used to calculate the building (zone) loads (BLAST 1991). Modeling the commercial buildings using the BLAST simulation tool required several important input assumptions about the buildings' internal loads; key envelope characteristics; occupancy/ activity characteristics; ventilation rates and strategies; equipment control schedules; and HVAC. Most of these inputs are based on the review of CBECS data (EIA 1992, 1995), and utility metering studies of real buildings. Appendix A provides a detailed discussion of building load data that were used in estimating the loads for the representative buildings types selected for the screening analysis.

This screening analysis used a generic three-story, 15-zone prototype building to estimate the coil loads for all building types. Because of the extreme diversity in building size, shape, and other characteristics, even within a particular building-type category, it is difficult to identify a single prototype building that adequately represents the stock of buildings being analyzed. Any specific building plan selected to represent an office building, for example, will have features that are not appropriate to apply to all office buildings; e.g., the interdependence of a building's aspect ratio (length versus width) and window orientation. Few buildings are exactly square or have the same amount of glass on each face. To address this issue and others, including the economy of BLAST input file development and maintenance, a single generic building prototype for all building types was used.

The generic prototype ${ }^{(a)}$ was a square, 15 -zone, three-story building with five independent controlled zones on each floor-a single "core" zone and four "perimeter" zones facing each of the four cardinal directions. For each building type actually modeled (e.g., office buildings), the internal loads, load and operation schedules, and building envelope were modified to represent the particular characteristics of the building type. The coil loads from BLAST are used as generic estimates of loads in the zones (core versus perimeter, ground versus roof) of the different building types.

The generic zone coil load estimates for various building types and climate locations were scaled to represent the coil loads for an average building of that type. The details of the scaling process are described in the Appendix B of Barwig et al. (1996). The representative building size and shape (or average building) for each building type were developed based on CBECS data (EIA 1992, 1995). The details are provided in Appendix $A$ of this report.

(a) Justification for using a three-story, 15-zone building and scaling loads from the generic building to a specific building type is described in Barwig et al. (1996); additional details on the 15-zone building prototype are also described in Friedrich and Messinger (1995). 


\subsubsection{SWH Loads and Equipment Sizing}

\subsubsection{Loads}

Average and peak hourly loads are based on data provided in Chapter 45, Table 7, of the ASHRAE Handbook of HVAC Applications (ASHRAE 1995). However, the loads are given in terms of service units, which were converted to loads per sq $\mathrm{ft}$ for this analysis. These conversions were developed for each building type (see Appendix A, Section A.11).

\subsubsection{Sizing}

Knowing the peak hourly load is not sufficient to properly size water-heating equipment. The volume-to-recovery ratio for most commercial storage water heaters is considerably less than one hour, and commercial buildings with built-up systems often provide storage much greater than one hour. Chapter 45 of ASHRAE (1995) provides curves that characterize the trade-off between water heater recovery capacity and usable storage capacity for each building type. For this analysis, the ASHRAE curves were normalized by expressing storage capacity in terms of storage time rather than storage volume. With the normalized curves, presented in Appendix A, Section A.11, the ratio of a given water heater's peak-load capacity to steady-state capacity in a given application can be obtained from the water heater's storage time:

$$
\text { Storage Time (hours) }=\frac{\text { Storage Volume }}{\text { Recovery Capacity }}
$$

where storage volume is the actual storage volume in gallons and recovery capacity is the rated recovery capacity in gallons per hour.

The analysis was further simplified by finding the slope and intercept for each sizing curve in the small region (Storage Time $<1$ hour) where all EPACT-covered equipment lies. The slopes and intercepts, and service unit conversions from Appendix A; the average and peak hourly loads from Chapter 45 of ASHRAE (1995), Table 7; and other essential parameters (sources noted) are summarized by building type in Table 2.2 .

\subsection{Mapping EPCA Equipment Categories to ASHRAE/Industry Equipment Categories}

EPCA, Section 342, as modified by EPACT, includes minimum-efficiency standards for small and large commercial packaged air-conditioning and heating equipment, packaged terminal air conditioners and heat pumps, warm-air furnaces, packaged boilers, storage water heaters, instantaneous water heaters, and unfired hot water storage tanks. Each of these general classes of equipment is broken down by size and design into categories, for each of which a minimum efficiency standard is prescribed in EPCA. Most of these original categories are from Standard 90.1-1989. 
Table 2.2. Building Service Water Heater Load Parameters by Building Type

\begin{tabular}{|c|c|c|c|c|c|c|c|c|}
\hline & Assembly & Education & Restaurant & Lodging & Office & Retail & Warehouse & Source \\
\hline $\begin{array}{l}\text { Average } \\
\text { Loads } \\
\text { (gph/su) } \\
\end{array}$ & 0.042 & 0.050 & 0.100 & 0.583 & 0.042 & 0.042 & 0.042 & ASHRAE 1995 \\
\hline $\begin{array}{l}\text { Peak Load } \\
(\mathrm{gph} / \mathrm{su})\end{array}$ & 0.4 & 0.8 & 1.5 & 5 & 0.4 & 0.4 & 0.4 & ASHRAE 1995 \\
\hline Service Unit & Occupant & Student & Meal & Room & Occupant & Occupant & Occupant & ASHRAE 1995 \\
\hline $\begin{array}{l}\text { Occupancy } \\
\text { (people/ } \\
1,000 \mathrm{ft}^{2} \text { ) }\end{array}$ & 16 & 10.7 & 11 & 3.3 & 3.3 & 2.2 & 0.3 & $\begin{array}{l}\text { Barwig et al. } \\
1996\end{array}$ \\
\hline $\begin{array}{l}\text { Service Unit } \\
\left(\mathrm{su} / 1,000 \mathrm{ft}^{2}\right) \\
\text { Density } \\
\end{array}$ & 16 & 10 & 19 & 3.3 & 3.3 & 2.2 & 0.3 & $\begin{array}{l}\text { Appendix A, } \\
\text { Section A.11 }\end{array}$ \\
\hline $\begin{array}{l}\text { Average } \\
\text { Load }(\mathrm{agph} / \\
\left.1,000 \mathrm{ft}^{2}\right)\end{array}$ & 0.67 & 0.50 & 1.90 & 1.93 & 0.14 & 0.09 & 0.013 & Calculated \\
\hline $\begin{array}{l}\text { Peak Load } \\
(\mathrm{xgph} / \\
\left.1,000 \mathrm{ft}^{2}\right)\end{array}$ & 6.40 & 8.00 & 28.50 & 16.50 & 1.32 & 0.88 & 0.120 & Calculated \\
\hline Slope & -2.5 & -6.7 & -3.3 & -2.7 & -2.5 & -2.5 & -2.5 & $\begin{array}{l}\text { Appendix A, } \\
\text { Section A.11 }\end{array}$ \\
\hline $\begin{array}{l}\text { Intercept } \\
\text { (xgph/agph) }\end{array}$ & 9.6 & 18.2 & 15.0 & 8.3 & 9.6 & 9.6 & 9.6 & $\begin{array}{l}\text { Appendix A, } \\
\text { Section A.11 }\end{array}$ \\
\hline Set Point $\left({ }^{\circ} \mathbf{F}\right)$ & 120 & 120 & 160 & 140 & 120 & 120 & 140 & $\begin{array}{l}\text { Barwig et al. } \\
1996\end{array}$ \\
\hline Set Point $\left({ }^{\circ} \mathrm{F}\right)$ & 120 & 120 & 140 & 120 & 120 & 120 & 120 & ASHRAE 1995 \\
\hline $\begin{array}{l}\text { Operation } \\
\text { (day/yr) }\end{array}$ & 365.25 & 205 & 365.25 & 365.25 & 365.25 & 365.25 & 365.25 & ASHRAE 1995 \\
\hline
\end{tabular}

To update the EPCA 92 minimum-efficiency requirements to be based on those in Standard 90.11999 , and to obtain cost data for the appropriate equipment categories, the Standard 90.1-1999 equipment categories were mapped to those in EPCA. Generally, a one-to-one correspondence existed between the categories in Standard 90.1-1999 and EPCA. However, in the following instances, EPCA does not delineate categories of equipment in the same manner as Standard 90.1-1999:

1. where Standard 90.1-1999 splits the EPCA size category into multiple-size categories such as the EPCA category for water-source heat pumps $<65 \mathrm{kBtu} / \mathrm{h}$

2. where EPCA provides a single efficiency level for "water-cooled, evaporatively cooled, and watersource central air conditioners and central air-conditioning heat pumps;" in each of several size categories identified. Standard 90.1-1999 provides a separate standard for three product categories: water-cooled air conditioners, evaporatively cooled air conditioners, and water-source heat pumps.

3. where Standard 90.1-1999 has broken both the PTAC and PTHP categories into "new construction" and replacement market categories 
4. where EPCA has two boiler categories-one for natural gas and one for oil-Standard 90.1-1999 has broken these two boiler categories into several separate categories based on size range ( 300 to $<2,500 \mathrm{kBtu} / \mathrm{h}$ and $>2,500 \mathrm{kBtu} / \mathrm{h}$ ), fuel type (gas-fired, oil-fired, oil-fired [residual]), and either hot water or steam output.

\subsection{Lifetime, Shipment, Baseline Cost, and Relative Cost Data}

This section presents the engineering data that were gathered and used for the screening analysis.

\subsubsection{Distribution Chain and Pricing for HVAC/SWH Equipment}

To understand cost information on HVAC and SWH equipment, we had to know the distribution chain and the point in the chain from which a cost was collected. Original equipment manufacturers (OEMs) have design, development, materials, labor, and overhead costs to produce mechanical equipment. Based on these costs and other factors, they determine selling prices for various markets and circumstances. As a product moves through distributors, agents, and dealers/contractors, expenses and margins are added to the selling price. For any group of costs, we must know the source of each cost and its level within the distribution chain (see Figure 2.3).

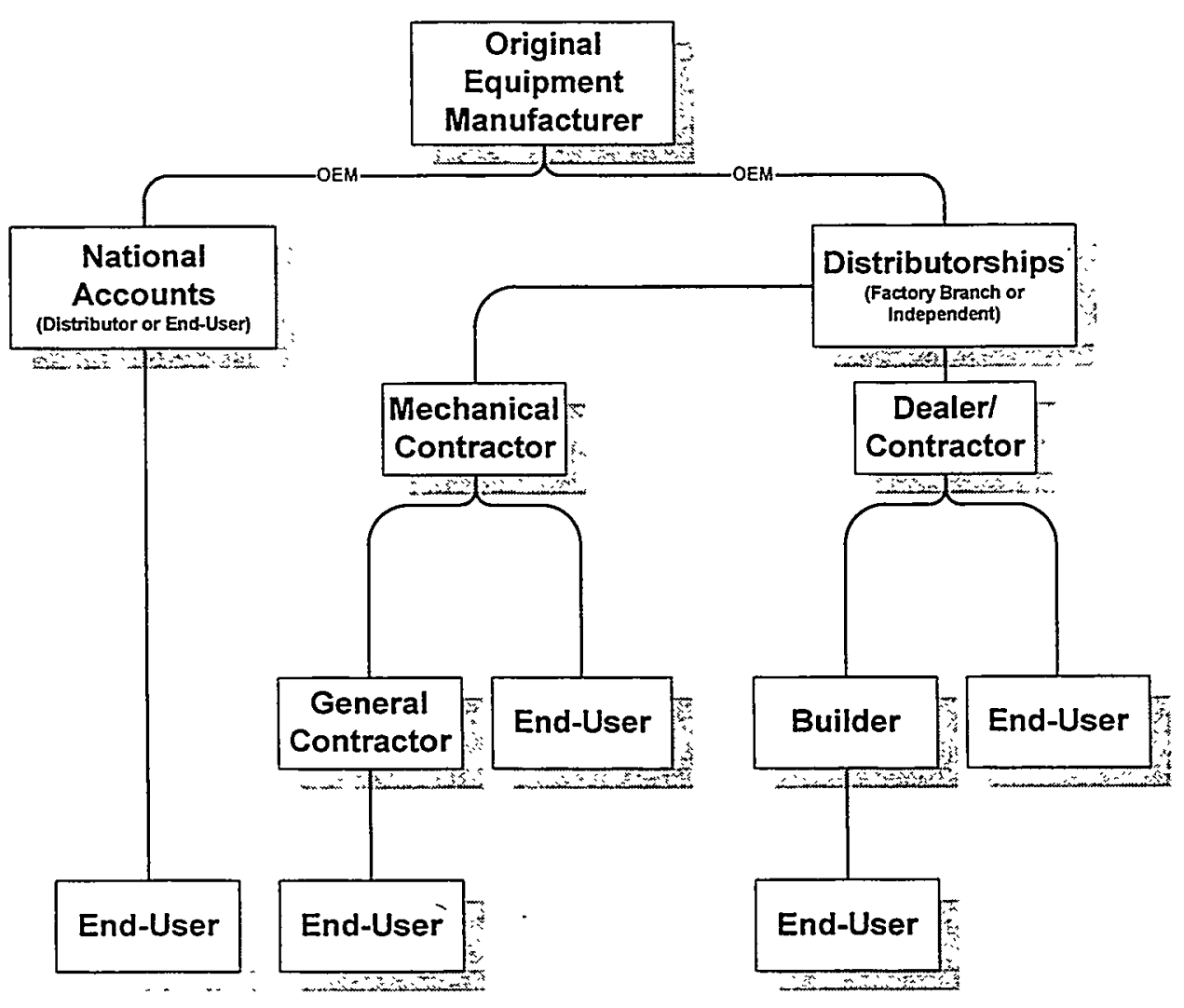

Figure 2.3. Equipment Distribution Chain 
While the structure of the distribution chain may vary among manufacturers, several basic levels can be identified. OEMs traditionally market their products in two ways-through national accounts and distribution systems. National accounts may be end-users or function as secondary distribution systems. Distribution systems may be multiple combinations of factory-owned distribution branches, independently owned distributorships, and manufacturer's agents.

Factory-owned distribution branches and independently owned distributorships usually operate within designated or franchised territories. Regardless of whether the distributorship is factory-or independently owned, it represents the OEM in the area and is responsible for delivering the market share considered appropriate by the OEM.

Manufacturer's agents function similar to independent distributorships. They are the OEM's distribution representatives within a franchised sales territory responsible for delivering market share. Agents do not customarily stock products but rather arrange product shipments from the OEM.

National accounts are usually high-volume purchasers developed and serviced by the OEM at the national level. They tend to cut across sales territory lines and are usually excluded from franchised distribution agreements. Products are shipped directly from factories to clients at either individual job sites or warehousing facilities. Some national accounts are end-users while others resell the product for installation. Manufactured and modular home producers are traditional national account markets because the ultimate destination of the OEM's product may cross sales territory lines.

Distribution systems primarily serve two groups of contractors-heating and air-conditioning or plumbing dealers/contractors and mechanical contractors. The heating and air-conditioning or plumbing dealer/contractor traditionally purchases mechanical equipment from the distributorship and contracts with end-users to provide and install the equipment. The dealer/contractor is usually a local company that sells and services one or two equipment brands. In exchange for loyalty to a distributor's brand, the company may be given a somewhat exclusive right to market that brand in a given area. When quoting equipment and installation costs, the contract price is usually presented as one figure and does not separate equipment from other costs. Issues such as system design, installation, start-up, and warranty make the sale of "equipment only" impractical and unlikely.

Mechanical contractors generally bid to general contractors on construction projects designed by architects and engineers. The bid must be based on specified or listed equipment approved as equivalent for each job. The distributorship or manufacturer's agent furnishes quotes on the specified equipment (or approved alternatives) for each construction project to all mechanical contractors planning to bid on the project and for other equipment upon request. The mechanical contractor exhibits no brand loyalty and has no protected sales territory. Equipment sales to mechanical contractors are from the distributorship or manufacturer's agent and do not go through the dealer/contractor. The mechanical contractor's bid is incorporated into the general contractor's bid and increased by some percentage as a part of the general contractor's fee for managing the project. The cost of the equipment is not separated from other costs. For design-build and other negotiated work, the mechanical contractor may contract directly with the enduser. Even in these situations, the contract price seldom separates equipment from other costs. 


\subsubsection{Efficiency and Cost Data - Cooling Equipment}

This section presents the lifetime, shipments, baseline cost, and relative cost for higher efficiency levels for the cooling equipment.

\subsubsection{Service Life}

Estimates of service life for equipment are based on data in ASHRAE (1995). A 15-year service life was used for all air-cooled products. A 19-year service life was used for all evaporatively cooled and water-cooled products.

\subsubsection{Shipment Data and Characteristic Equipment Size}

In 1994, during the development of Standard 90.1-1999, the Air-Conditioning and Refrigeration Institute (ARI) provided annual shipment data ${ }^{(a)}$ on most of the cooling equipment categories covered in this analysis. In November 1999, ARI provided updated 1999 shipment estimates for most of the cooling product categories in the screening analysis. ${ }^{(b)}$ In addition, ARI updated a list of characteristic equipment sizes for each product category to best reflect current industry standards. Table 2.3 shows the 1999 shipment data provided by $\mathrm{ARI}^{(\mathrm{b})}$ and representative equipment sizes used in the screening analysis.

In the 1999 data, ARI recommended that the PTAC and PTHP equipment categories be broken into four capacity ranges. It is necessary to examine multiple capacities for PTAC and PTHP equipment because both the existing EPCA and Standard 90.1-1999 efficiency requirements are stated as a function of cooling capacity.

Separate shipment estimates for evaporatively cooled air-conditioning equipment were not available because ARI statistics combine the shipments of evaporatively cooled products with water-cooled air conditioners. ARI believes that over $90 \%$ of these combined evaporative and water-cooled shipments are water-cooled products.

Shipment estimates for the following five additional categories of equipment were not provided:

1. 3-phase, single-package air conditioners $<65 \mathrm{kBtu} / \mathrm{h}$

2. 3-phase, split-system air conditioners $<65 \mathrm{kBtu} / \mathrm{h}$

3. 3-phase, single-package heat pumps $<65 \mathrm{kBtu} / \mathrm{h}$

(a) ARI provided 1994 shipment data to the ASHRAE Mechanical Subcommittee during Standard 90.1-1999 development.

(b) 1999 commercial cooling equipment shipment data and supporting letter provided by ARI to DOE, December 1, 1999. 
Table 2.3. Cooling Equipment Annual Shipment Data Used in the Screening Analysis

\begin{tabular}{|c|c|c|c|}
\hline Category Description & $\begin{array}{c}\text { Characteristic } \\
\text { Capacity } \\
(\mathrm{kBtu} / \mathrm{h})\end{array}$ & $\begin{array}{l}\text { Estimated } \\
\text { Shipments }\end{array}$ & Source \\
\hline 3-Phase, Single-Package, Air-Source AC, $<65 \mathrm{kBtu} / \mathrm{h}$ & 60 & 213,728 & ADL, PNNL \\
\hline 3-Phase, Single-Package, Air-Source HP, $<65 \mathrm{kBtu} / \mathrm{h}$ & 60 & 27,773 & ADL, PNNL \\
\hline 3-Phase, Split, Air-Source AC, $<65 \mathrm{kBtw} / \mathrm{h}$ & 60 & 91,598 & ADL, PNNL \\
\hline 3-Phase, Split, Air-Source HP, <65 kBtu/h & 60 & 11,903 & ADL, PNNL \\
\hline Central, Air-Source AC, $\geq 65$ and $<135 \mathrm{kBtu} / \mathrm{h}$ & 90 & 165,000 & ARI 1999 \\
\hline Central, Air-Source HP, $\geq 65$ and $<135 \mathrm{kBtu} / \mathrm{h}$ & 90 & 17,000 & ARI 1999 \\
\hline Central, Water-Cooled $\mathrm{AC},<65 \mathrm{kBtu} / \mathrm{h}$ & 60 & 700 & ARI 1999 \\
\hline Central, Evaporatively Cooled AC, $<65 \mathrm{kBtu} / \mathrm{h}$ & 36 & N/A & ARI 1999 \\
\hline Central, Water-Source HP, $<17 \mathrm{kBtu} / \mathrm{h}$ & $\begin{array}{c}12 \text { (or pick a } \\
\text { reasonable size) }\end{array}$ & 41,000 & ARI 1999 \\
\hline Central, Water-Source $\mathrm{HP},>17$ and $<65 \mathrm{kBtu} / \mathrm{h}$ & 36 & 86,000 & ARI 1999 \\
\hline Central, Water-Cooled $\mathrm{AC}, \geq 65$ and $<135 \mathrm{kBtu} / \mathrm{h}$ & 90 & 800 & ARI 1999 \\
\hline Central, Evaporatively Cooled $\mathrm{AC}, \geq 65$ and $<135 \mathrm{kBtu} / \mathrm{h}$ & 90 & \multicolumn{2}{|c|}{$\begin{array}{c}\text { Included with water-cooled for } \\
\text { same size category }\end{array}$} \\
\hline Central, Water-Source HP, $\geq 65$ and $<135 \mathrm{kBtu} / \mathrm{h}$ & 90 & 5,000 & ARI 1999 \\
\hline Central, Air-Source AC, $\geq 135$ and $<240 \mathrm{kBtu} / \mathrm{h}$ & 180 & 65,000 & ARI 1999 \\
\hline Central, Air-Source HP, $\geq 135$ and $<240 \mathrm{kBtu} / \mathrm{h}$ & 180 & 2,900 & ARI 1999 \\
\hline Central, Water-Cooled AC, $\geq 135$ and $<240 \mathrm{kBtu} / \mathrm{h}$ & 180 & 600 & ARI 1999 \\
\hline Central, Evaporatively Cooled $\mathrm{AC}, \geq 135$ and $<240 \mathrm{kBtu} / \mathrm{h}$ & 180 & \multicolumn{2}{|c|}{$\begin{array}{l}\text { Included with water-cooled for } \\
\text { same size category }\end{array}$} \\
\hline Central, Water-Source HP, $\geq 135$ and $<240 \mathrm{kBtu} / \mathrm{h}$ & 180 & \multicolumn{2}{|c|}{ Not Available } \\
\hline Package Terminal $\mathrm{AC},<7 \mathrm{kBtu} / \mathrm{h}$ & 7 & 18,000 & ARI 1999 \\
\hline Package Terminal AC, 7-10 kBtu/h & 9 & 93,000 & ARI 1999 \\
\hline Package Terminal AC, 10-13 kBtu/h & 12 & 97,000 & ARI 1999 \\
\hline Package Terminal $\mathrm{AC},>13 \mathrm{kBtu} / \mathrm{h}$ & 14 & 44,000 & ARI 1999 \\
\hline Package Terminal HP, $<7 \mathrm{kBtu} / \mathrm{h}$ & 7 & 16,000 & ÁRI 1999 \\
\hline Package Terminal HP, 7-10 kBtu $/ \mathrm{h}$ & 9 & 89,000 & ARI 1999 \\
\hline Package Terminal HP, $10-13 \mathrm{kBtu} / \mathrm{h}$ & 12 & 74,000 & ARI 1999 \\
\hline Package Terminal HP, $>13 \mathrm{kBtu} / \mathrm{h}$ & 14 & 37,000 & ARI 1999 \\
\hline
\end{tabular}

4. 3-phase, split-system heat pumps $<65 \mathrm{kBtu} / \mathrm{h}$

5. water-source heat pumps $>135 \mathrm{kBtu} / \mathrm{h}$ cooling capacity.

\subsubsection{3-Phase, $<65 \mathrm{kBtu} / \mathrm{h}$ Unitary Cooling Equipment Shipment Estimates}

According to the Copeland Corporation, unitary residential shipments (condensing units) were roughly $5,639,000 .^{\text {(a) }}$ Shipments of commercial 3-phase equipment were 625,000 units, for a total of $6,264,000$ units shipped (ARI 1998b). ARI reports shipments by equipment capacity so that out of the

(a) Data provided by Mark Kendal of Arthur D. Little (ADL) in email communication on December 1999. Original data published in Air Conditioning, Heating and Refrigeration News, December 14, 1998. 
total ARI shipment, 280,134 units were listed as $\geq 65 \mathrm{kBtu} / \mathrm{h}$ in capacity. It is assumed that virtually all of the units $>65 \mathrm{kBtu} / \mathrm{h}$ use 3-phase motors. If we use the Copeland estimate of 625,000 3-phase condensing units and subtract the 280,134 unitary equipment shipments $>65 \mathrm{kBtu} / \mathrm{h}$ capacity, we arrive at 344,860 3-phase units $<65 \mathrm{kBtu} / \mathrm{h}$ capacity.

It was necessary to develop the shipments of single package versus split systems for both air conditioner and heat pump units. ADL suggests that in 1994, single-package equipment made up approximately $14 \%$ of all 3-phase and single-phase unitary shipments $<65 \mathrm{kBtu} / \mathrm{h}$. However, information from commercial contractors suggests that a much larger fraction (probably the majority) of the commercial systems in this size range is single-package rooftops as opposed to split systems. For this analysis, it was assumed that $70 \%$ of the 3 -phase systems in this size range are single-package equipment.

\subsubsection{Baseline Cost Data}

Baseline costs for cooling equipment were developed based on data collected through mechanical contractors and equipment distributors in $1999^{(a)}$. Collected cost data represented the minimum efficiency products available from a given distributor. The number of data points collected varied from 1 to 7 for each product analyzed. When more than three data points were collected, the high- and low-cost data points were removed and the remaining cost data were averaged to reduce the effects of high- and lowcost outliers. In addition, the rated efficiency (EER or SEER) data were collected for as many of the equipment categories as available.

In all cases, the average EER was higher than the minimum specified by EPCA 92. Thus, the average of the cost and efficiency data are referred to as the market baseline cost and efficiency. When possible, the available relative cost versus efficiency data for each product were used to back out the cost for an EPCA 92 baseline product from the market baseline cost and efficiency data. This was done using relative cost versus efficiency curves discussed in the following section.

Table 2.4 shows the number of data points collected; the high, low, and average cost without highand low-cost outliers; and the corresponding average efficiency figure for each product. The relative cost for the higher efficiency level (EER), as compared with the EPCA 92 baseline, is also shown, as well as the final estimate for the baseline EPCA 92 contractor cost.

\subsubsection{Relative Cost for Higher Efficiency Levels}

In 1994, ARI provided the ASHRAE Standing Standards Project Committee 90.1 (SSPC 90.1) with relative cost versus efficiency curves for product efficiencies above the EPCA 92 baseline. These curves were based on data collected by member industries and represented costs for which $90 \%$ of the industries surveyed believed they could manufacture the equipment (relative to EPCA 92 baseline efficiency level). The data were collected in this manner to preserve sensitive cost information among manufacturers.

(a) Baseline commercial equipment cost data collected by a) DuPont Dobbs Engineers, LLC, in 1999 under contract to DOE, and b) Pacific Northwest National Laboratory Staff. 
Table 2.4. Cooling Equipment Baseline Cost Data

\begin{tabular}{|c|c|c|c|c|c|c|c|c|c|}
\hline \multirow[b]{2}{*}{ Product } & \multirow{2}{*}{$\begin{array}{c}1994 \\
\text { Estimated } \\
\text { Cost for } \\
\text { ASHRAE } \\
\text { Analysis (\$) }\end{array}$} & \multicolumn{8}{|c|}{1999 Cost Data } \\
\hline & & $\begin{array}{l}\text { No. of } \\
\text { Data } \\
\text { Points }\end{array}$ & $\left|\begin{array}{r}\text { High } \\
\text { Cost }(S)\end{array}\right|$ & $\mid \begin{array}{c}\text { Low } \\
\text { Cost }(S)\end{array}$ & $\begin{array}{l}\text { Average } \\
\text { Cost (S) }\end{array}$ & $\begin{array}{l}\text { Average } \\
\text { EER }^{(2)}\end{array}$ & $\begin{array}{l}\text { Relative } \\
\text { Cost }^{(b)}\end{array}$ & $\begin{array}{c}\text { Relative Cost } \\
\text { Curve }\end{array}$ & $\begin{array}{c}\text { EPCA } \\
\text { Baseline } \\
\text { Contractor } \\
\text { Cost (\$) }\end{array}$ \\
\hline $\begin{array}{l}\text { 3-Phase Single-Package, Air- } \\
\text { Source } A C,<65 \mathrm{kBtu} / \mathrm{h}\end{array}$ & $\mathrm{N} / \mathrm{A}$ & 7 & 3,760 & 1,770 & 2,234 & 10.04 & 1.05 & $\begin{array}{l}\text { ARI Data for } \\
\text { CAC Rule }\end{array}$ & 2,128 \\
\hline $\begin{array}{l}\text { 3-Phase Single-Package, Air- } \\
\text { Source HP, }<65 \mathrm{kBtu} / \mathrm{h}\end{array}$ & N/A & 6 & 4,640 & 2,100 & 2,613 & 10.07 & 1.04 & $\begin{array}{l}\text { ARI Data for } \\
\text { CAC Rule }\end{array}$ & 2,513 \\
\hline $\begin{array}{l}\text { 3-Phase Split, Air-Source AC, } \\
<65 \mathrm{kBtu} / \mathrm{h}\end{array}$ & N/A & 4 & 2,800 & 1,750 & 2,200 & 10.15 & 1.015 & $\begin{array}{l}\text { ARI Data for } \\
\text { CAC Rule }\end{array}$ & 2,167 \\
\hline $\begin{array}{l}\text { 3-Phase Split, Air-Source HP, } \\
<65 \mathrm{kBtu} / \mathrm{h}\end{array}$ & $\mathrm{N} / \mathrm{A}$ & 5 & 3,280 & 2,080 & 2,395 & 11.20 & 1.128 & $\begin{array}{l}\text { ARI Data for } \\
\text { CAC Rule }\end{array}$ & 2,123 \\
\hline $\begin{array}{l}\text { Central, Air-Source AC, } \geq 65 \\
\text { and }<135 \mathrm{kBtu} / \mathrm{h}\end{array}$ & 3,452 & 7 & 7,196 & 2,587 & 3,613 & 9.70 & 1.131 & $\mathrm{UACl}$ & 3,194 \\
\hline $\begin{array}{l}\text { Central, Air-Source HP, } \geq 65 \\
\text { and }<135 \mathrm{kBtw} / \mathrm{h}\end{array}$ & 3,636 & 6 & 8,560 & 3,200 & 4,115 & 8.93 & 1.006 & UHP1 & 4,090 \\
\hline $\begin{array}{l}\text { Central, Water-Cooled } \mathrm{AC} \text {, } \\
<65 \mathrm{kBtu} / \mathrm{h}\end{array}$ & 2,550 & 4 & 4,000 & 2,650 & 3,536 & 12.00 & 1.305 & UAC5 & 2,709 \\
\hline $\begin{array}{l}\text { Central, Water-Source HP, } \\
<17 \mathrm{kBtw} / \mathrm{h}\end{array}$ & N/A & 5 & 835 & 632 & 700 & 11.03 & 1.141 & UHP3 & 613 \\
\hline $\begin{array}{l}\text { Central, Water-Source HP, } \\
>17 \text { and }<65 \mathrm{kBtu} / \mathrm{h}\end{array}$ & 1,655 & 5 & 1,200 & 960 & 1,127 & 12.20 & 1.31 & UHP3 & 860 \\
\hline $\begin{array}{l}\text { Central, Water-Cooled AC, } \\
265 \text { and }<135 \mathrm{kBtu} / \mathrm{h}\end{array}$ & 5,468 & 5 & 6,800 & 3,000 & 4,141 & 13.07 & 1.424 & UAC6 & 2,908 \\
\hline $\begin{array}{l}\text { Central, Evaporatively }{ }^{(c)} \\
\text { Cooled } \mathrm{AC}, \geq 65 \text { and } \\
<135 \mathrm{kBtw} / \mathrm{h}\end{array}$ & N/A & 1 & 3,475 & 3,475 & 3,475 & 13.70 & 1.558 & & 2,230 \\
\hline $\begin{array}{l}\text { Central, Water-Source HP, } \\
265 \text { and }<135 \mathrm{kBtu} / \mathrm{h}\end{array}$ & $\mathrm{N} / \mathrm{A}$ & 6 & 4,490 & 3,200 & 3,557 & 12.07 & 1.285 & UHP3 & 2,768 \\
\hline $\begin{array}{l}\text { Central, Air-Source AC, } \geq 135 \\
\text { and }<240 \mathrm{kBtu} / \mathrm{h}\end{array}$ & 5,967 & 6 & 9,560 & 5,163 & 7,273 & 9.20 & 1.07 & UHP1 & 6,797 \\
\hline $\begin{array}{l}\text { Central, Air-Source HP, } \geq 135 \\
\text { and }<240 \mathrm{kBtu} / \mathrm{h}\end{array}$ & 7,911 & 5 & 11,520 & 6,644 & 9,526 & 9.48 & 1.14 & UHP21 & 8,356 \\
\hline $\begin{array}{l}\text { Central, Water-Cooled } \mathrm{AC}, \\
\geq 135 \text { and }<240 \mathrm{kBtu} / \mathrm{h}\end{array}$ & 11,079 & 5 & 9,600 & 5,800 & 7,830 & 12.33 & 1.15 & UAC4 & 6,808 \\
\hline $\begin{array}{l}\text { Central, Evaporatively }{ }^{(c)} \\
\text { Cooled } \mathrm{AC}, \geq 135 \text { and } \\
240 \mathrm{kBtu} / \mathrm{h}\end{array}$ & 11,079 & 2 & 6,400 & 5,800 & NA & NA & NA & UAC4 & NA \\
\hline $\begin{array}{l}\text { Central, Water-Source }{ }^{\mathrm{d})} \mathrm{HP}, \\
\geq 135 \text { and }<240 \mathrm{kBtu} / \mathrm{h}\end{array}$ & $\mathrm{N} / \mathrm{A}$ & 7 & 9,078 & 5,800 & 7,372 & NA & NA & NA & NA \\
\hline $\begin{array}{l}\text { Package Terminal AC, } \\
<7 \mathrm{kBtu} / \mathrm{h}\end{array}$ & N/A & 5 & 748 & 640 & 710 & 11.45 & 1.214 & $\mathrm{NA}$ & 585 \\
\hline $\begin{array}{l}\text { Package Terminal AC, } \\
7-10 \mathrm{kBtw} / \mathrm{h}\end{array}$ & 808 & 6 & 774 & 660 & 726 & 10.62 & 1.134 & ptl & 640 \\
\hline $\begin{array}{l}\text { Package Terminal AC, } \\
10-13 \mathrm{kBtu} / \mathrm{h}\end{array}$ & 834 & 6 & 800 & 680 & 753 & 10.62 & 1.334 & $\mathrm{pt} 2$ & 564 \\
\hline $\begin{array}{l}\text { Package Terminal AC, } \\
>13 \mathrm{kBtw} / \mathrm{h}\end{array}$ & 891 & 6 & 840 & 720 & 802 & 9.36 & 1.119 & pt3 & 716 \\
\hline $\begin{array}{l}\text { Package Terminal HP, } \\
<7 \mathrm{kBtu} / \mathrm{h}\end{array}$ & N/A & 5 & 832 & 710 & 781 & 11.53 & 1.204 & NA & 649 \\
\hline $\begin{array}{l}\text { Package Terminal HP, } \\
7-10 \mathrm{kBtu} / \mathrm{h}\end{array}$ & 905 & 6 & 1,054 & 730 & 817 & 10.84 & 1.157 & $\mathrm{pt4}$ & 706 \\
\hline $\begin{array}{l}\text { Package Terminal HP, } \\
10-13 \mathrm{kBtu} / \mathrm{h}\end{array}$ & 936 & 6 & 1,076 & 760 & 842 & 10.36 & 1.344 & pt5 & 626 \\
\hline $\begin{array}{l}\text { Package Terminal HP, } \\
>13 \mathrm{kBtw} / \mathrm{h}\end{array}$ & 1,009 & 6 & 1,160 & 780 & 886 & 9.20 & 1.159 & pt6 & 764 \\
\hline $\begin{array}{l}\text { (a) After removing high- an } \\
\text { (b) Relative cost estimate of } \\
\text { (c) Evaporatively cooled pro } \\
\text { (d) Water-source heat pump }\end{array}$ & $\begin{array}{l}\text { ducts were } n \\
>135 \mathrm{kBtu} / \mathrm{h}\end{array}$ & alyzed & $\begin{array}{l}\text { A baselir } \\
\text { lependen } \\
\text { yzed. }\end{array}$ & y from & ter-cọole & roducts. & & & \\
\hline
\end{tabular}


Updated relative cost curves based on the average relative cost figures provided by manufacturers, were unavailable for the present analysis. Thus, the 1994 relative cost curves, in conjunction with the baseline costs discussed previously, were used as the basis for developing costs for higher efficiency equipment, except for the 3-phase, $<65 \mathrm{kBtu} / \mathrm{h}$ single-package and split-unitary systems. For this equipment, relative cost curves were based on ARI data for single-phase, single-package, and split-system air conditioners and heat pumps.

For PTHP and PTAC products, the 1994 ARI relative cost versus efficiency curves were for three equipment capacities $-9,12$, and $14 \mathrm{kBtu} / \mathrm{h}$. Relative costs for efficiency levels for the $<7 \mathrm{kBtu} / \mathrm{h}$ categories were determined from an average relative-cost increase for the other three size categories for the same relative increase in efficiency.

\subsubsection{Relative Cost Versus Efficiency Data for Control Water-Source Heat Pumps}

For central water-source heat pumps $\geq 65 \mathrm{kBtu} / \mathrm{h}$ and $<135 \mathrm{kBtu} / \mathrm{h}$, the relative cost versus efficiency data for the $<65 \mathrm{kBtu} / \mathrm{h}$ water-source heat pump was used.

\subsubsection{Product Efficiencies Analyzed}

The range of efficiencies available on the market were determined by reviewing several data sources, including the California Energy Commission Cooling Equipment Database (CEC 1999) and the ARI unitary and applied equipment databases (ARI 1998a). From this list of available products, a highest efficiency level was chosen to represent the highest efficiency products available on the market. The highest efficiency level was not always the highest single point available on the market because, in some cases, efficiency level may be available only for a single capacity in an otherwise wide-capacity range. More often, the high-efficiency product analyzed represented the upper $5 \%$ of efficiencies available for that product category and size range.

The analysis also required several intermediate efficiency levels between the EPCA 92 baseline and the highest efficiency level analyzed level. No single method was used to choose these data points for all cooling products. However, intermediate efficiency levels were based on several sources, including

- Standard 90.1-1999 Tier 2 efficiency levels

- recommended 2005 efficiency levels provided as comment to Standard 90.1-1999 by the ASHRAE 90.1-1999 upgrade committee

- the end points of the ARI relative cost curves, which should represent high-efficiency levels that could be met by $90 \%$ of equipment manufacturers.

In other instances, points were chosen only to provide a range of possible efficiency levels for the analysis based on the available data (e.g., single package and split systems $<65 \mathrm{kBtu} / \mathrm{h}$ capacity). For some products, the endpoints of the ARI relative cost curves or the recommended Tier 2 efficiency levels exceeded the efficiencies available on the market, and these points became new highest-efficiency levels 
for the screening analysis. For the PTHP and PTAC categories, Standard 90.1-1999 provides a required efficiency for new construction and a lower required efficiency requirement for replacement market. A maximum of six efficiency levels were analyzed for any given product.

Costs for each of the chosen efficiency levels were generated using the EPCA baseline cost estimates and the relative cost versus efficiency curves. Table 2.5 shows the estimated contractor cost for each efficiency level used in the cooling equipment analysis.

Table 2.5. 1999 Contractor Cost Data for Cooling Products by Efficiency Level

\begin{tabular}{|c|c|c|c|c|c|c|c|c|c|c|c|c|c|}
\hline \multirow[b]{2}{*}{ Product Description } & \multirow[b]{2}{*}{$\begin{array}{c}\text { Capacity } \\
\text { Analyzed } \\
(\mathrm{kBtu} / \mathrm{h})\end{array}$} & \multicolumn{2}{|c|}{$\begin{array}{c}\text { Level 1 } \\
\text { (EPCA 92) }\end{array}$} & \multicolumn{2}{|c|}{ Level 2} & \multicolumn{2}{|c|}{ Level 3} & \multicolumn{2}{|c|}{ Level 4} & \multicolumn{2}{|c|}{ Level 5} & \multicolumn{2}{|c|}{ Level 6} \\
\hline & & $\begin{array}{c}\text { SEER } \\
\text { EER }\end{array}$ & $\begin{array}{l}\text { Cost } \\
\text { (S) }\end{array}$ & EER & $\begin{array}{l}\text { Cost } \\
\text { (\$) }\end{array}$ & EER & $\begin{array}{l}\text { Cost } \\
\text { (\$) }\end{array}$ & EER & $\begin{array}{l}\text { Cost } \\
(\$)\end{array}$ & EER & $\begin{array}{c}\text { Cost } \\
(\mathbf{S})\end{array}$ & EER & $\begin{array}{l}\text { Cost } \\
(\mathbf{S})\end{array}$ \\
\hline $\begin{array}{l}\text { 3-Phase Single-Package, Air- } \\
\text { Source } A C,<65 \mathrm{kBtw} / \mathrm{h}^{(a)}\end{array}$ & 60 & 9.7 & 2128 & 9.7 & 2128 & 11.0 & 2532 & 12.0 & 2766 & 13.0 & 3468 & 15.0 & 4745 \\
\hline $\begin{array}{l}\text { 3-Phase Single-Package, Air- } \\
\text { Source HP, }<65 \mathrm{kBtu} / \mathrm{h}^{(3)}\end{array}$ & 60 & 9.7 & 2513 & 9.7 & 2513 & 11.0 & 2865 & 12.0 & 3216 & 13.0 & 4021 & 15.0 & 5353 \\
\hline $\begin{array}{l}\text { 3-Phase Split, Air-Source AC, } \\
<65 \mathrm{kBtu} / \mathrm{h}^{(\mathrm{a})}\end{array}$ & 60 & 10.0 & 2167 & 10.0 & 2167 & 11.0 & 2514 & 12.0 & 2947 & 13.0 & 3533 & 15.0 & 5201 \\
\hline $\begin{array}{l}\text { 3-Phase Split, Air-Source HP, } \\
<65 \mathrm{kBtw} / \mathrm{h}^{(\mathrm{s})}\end{array}$ & 60 & $10.0^{2}$ & 2123 & 10.0 & 2123 & 11.0 & 2335 & 12.0 & 2632 & 13.0 & 3057 & 15.0 & 4437 \\
\hline $\begin{array}{l}\text { Central, Air-Source AC, } \\
\geq 65 \text { and }<135 \mathrm{kBtu} / \mathrm{h}\end{array}$ & 90 & 8.9 & 3194 & 10.3 & 3932 & 10.5 & 4101 & 10.8 & 4392 & 11.0 & $46 \overline{48}$ & 12.5 & 8823 \\
\hline $\begin{array}{l}\text { Central, Air-Source HP, } \\
\geq 65 \text { and }<135 \mathrm{kBtu} / \mathrm{h}\end{array}$ & 90 & 8.9 & 4090 & 10.1 & 4957 & 10.5 & 5485 & 10.6 & 5636 & 11.0 & 6524 & 11.7 & 9219 \\
\hline $\begin{array}{l}\text { Central, Water-Cooled AC, } \\
<65 \mathrm{kBtu} / \mathrm{h}\end{array}$ & 60 & 9.3 & 2709 & 12.1 & 3573 & 12.5 & 3752 & 13.1 & 4080 & 14.0 & 4798 & 12.5 & 3752 \\
\hline $\begin{array}{l}\text { Central, Water-Source HP, } \\
<17 \mathrm{kBtu} / \mathrm{h}\end{array}$ & 12 & 9.3 & 614 & 11.2 & 711 & 12.5 & 843 & 13.1 & 946 & 14.0 & 1165 & 15.8 & $\overline{N A}$ \\
\hline $\begin{array}{l}\text { Central, Water-Source HP, } \\
>17 \text { and }<65 \mathrm{kBtu} / \mathrm{h}\end{array}$ & 36 & 9.3 & 861 & 12.0 & 1094 & 12.5 & 1182 & 13.1 & 1327 & 14.0 & 1634 & 15.2 & $\overline{\mathrm{NA}}$ \\
\hline $\begin{array}{l}\text { Central, Water-Cooled } \mathrm{AC} \text {, } \\
\geq 65 \text { and }<135 \mathrm{kBtu} / \mathrm{h}\end{array}$ & 90 & 10.5 & 2908 & 11.5 & 3347 & 12.0 & 3562 & 12.4 & 3760 & 14.0 & 4714 & $\overline{\mathrm{NA}}$ & NA \\
\hline $\begin{array}{l}\text { Central, Water-Source HP, } \\
\geq 65 \text { and }<135 \mathrm{kBtu} / \mathrm{h}\end{array}$ & 90 & 10.5 & 2768 & 12.0 & 3239 & 12.5 & 3502 & 13.0 & 3848 & 14.0 & 4839 & NA & $\overline{\mathrm{NA}}$ \\
\hline $\begin{array}{l}\text { Central, Air-Source AC, } \\
\geq 135 \text { and }<240 \mathrm{kBtu} / \mathrm{h}\end{array}$ & 180 & 8.5 & 6797 & 9.7 & 7613 & 10.2 & 7885 & 10.4 & 8089 & 10.8 & $\overline{\mathrm{NA}}$ & 11.5 & $\overline{N A}$ \\
\hline $\begin{array}{l}\text { Central, Air-Source HP, } \\
2135 \text { and } \angle 240 \mathrm{kBtu} / \mathrm{h}\end{array}$ & 180 & 8.5 & 8356 & $\overline{9.3}$ & 9259 & 9.8 & 9919 & 10.4 & 10713 & 10.8 & $\overline{\mathrm{NA}}$ & 10.5 & NA \\
\hline $\begin{array}{l}\text { Central, Water-Cooled AC, } \\
\geq 135 \text { and }<240 \mathrm{kBtu} / \mathrm{h}\end{array}$ & 180 & 9.6 & 6808 & 11.0 & 7830 & 11.1 & 7830 & 11.2 & 7945 & 11.3 & 7993 & 11.5 & 8081 \\
\hline $\begin{array}{l}\text { Package Terminal AC, } \\
<7 \mathrm{kBtu} / \mathrm{h}\end{array}$ & 6 & 8.88 & 585 & 9.41 & 597 & 11.01 & 686 & 11.24 & 713 & 0.00 & 776 & 11.60 & $\overline{N A}$ \\
\hline $\begin{array}{l}\text { Package Terminal AC, } \\
7-10 \mathrm{kBtu} / \mathrm{h}\end{array}$ & 8.5 & 8.56 & 640 & 8.98 & 656 & 10.58 & 725 & 10.83 & 741 & $\overline{\mathrm{NA}}$ & $\overline{\mathrm{NA}}$ & 11.50 & 831 \\
\hline $\begin{array}{l}\text { Package Terminal } A C \text {, } \\
10-13 \mathrm{kBtu} / \mathrm{h}\end{array}$ & 11.5 & 8.08 & 564 & 8.34 & 582 & 9.94 & 703 & 10.20 & 725 & 10.50 & 753 & 10.70 & $\overline{\mathrm{NA}}$ \\
\hline $\begin{array}{l}\text { Package Terminal AC, } \\
>13 \mathrm{kBtu} / \mathrm{h}\end{array}$ & 14 & 7.76 & 716. & 7.92 & 721 & 9.52 & 819 & 9.79 & 871 & 10.00 & 967 & 10.00 & 967 \\
\hline $\begin{array}{l}\text { Package Terminal HP, } \\
<7 \mathrm{kBtu} / \mathrm{h}\end{array}$ & 6 & 8.88 & 649 & 9.31 & 658 & 10.81 & 745 & 11.04 & 776 & 0.00 & 865 & 11.60 & $\overline{N A}$ \\
\hline $\begin{array}{l}\text { Package Terminal HP, } \\
7-10 \mathrm{kBtu} / \mathrm{h}\end{array}$ & 8.5 & 8.56 & 706 & 8.88 & 727 & 10.38 & 791 & 10.63 & 802 & 11.40 & 882 & 11.50 & $\overline{\mathrm{NA}}$ \\
\hline $\begin{array}{l}\text { Package Terminal HP, } \\
10-13 \mathrm{kBtu} / \mathrm{h}\end{array}$ & 11.5 & 8.08 & 626 & 8.24 & 631 & 9.74 & 719 & 10.00 & 762 & 10.50 & 877 & 10.70 & $\overline{\mathrm{NA}}$ \\
\hline $\begin{array}{l}\text { Package Terminal HP, } \\
>13 \mathrm{kBtw} / \mathrm{h}\end{array}$ & 14 & 7.76 & 764 & 7.82 & 766 & 9.32 & 899 & 9.59 & 943 & NA & NA & 10.00 & 1032 \\
\hline
\end{tabular}




\subsubsection{Efficiency and Cost Data - Packaged Boilers}

This section presents the lifetime, shipments, baseline cost, and relative cost for higher efficiency data for packaged boilers based on 1999 estimates.

\subsubsection{Service Life}

Estimates of service life for equipment are based on data in ASHRAE (1995). A 30-year service life was used for all boilers.

\subsubsection{Shipment Data and Characteristic Equipment Size}

Boilers represent a large and diverse category of heating equipment, both in terms of the range of sizes available, fuel types used, output (steam or hot water), or designs. During the development of Standard 90.1-1999, steam and hot water boilers were analyzed separately (since the performance and sometimes design varies with the type of output), using four different sizes of gas-fired packaged boilers. Oil-fired boilers were not explicitly analyzed but were assumed to have thermal and combustion efficiencies three percentage points higher than that finally established for gas-fired boilers. These same four sizes were used for the screening analysis as well.

In November 1999, the Gas Appliance Manufacturers' Association (GAMA) provided historical shipment estimates for gas-fired and oil-fired package boilers by fuel type. ${ }^{(a)}$ The data provided was insufficient to establish shipments for commercial boilers by size and fuel type as needed for the screening analysis. Shipments by size and fuel type were based on data provided by the Hydronics Institute in 1996, which included shipments for 1994 and projected shipments to 2000 (b) $^{\text {(b) }}$ The projected shipments suggested a $45 \%$ growth in boiler shipments between 1994 and 2000 . The historical data provided by GAMA in 1999 did not suggest any growth trend in total boiler shipments over the period from 1989 to 1998 . Thus, the commercial shipments in 1994 were assumed to be an acceptable estimate for future annual shipments.

The Hydronics Institute data were by size category and fuel, as well as by hot water and steam output for cast iron construction. For steel boiler construction, steam, or hot water output were not indicated so shipments of steel boilers were split between gas and oil categories.

The size categories in the Hydronics Institute data do not align with those specified for the screening analysis. Shipments in several of the Hydronics Institute size categories were split according to the fraction of the category range that belonged within the size ranges used in the screening analysis. The resulting shipment estimates for gas-fired boilers are shown in Table 2.6.

(a) Gas-fired space conditioning and service water heating equipment shipment data and supporting letter provided to Cyrus Nasseri of DOE, December 7, 1999.

(b) Detailed boiler shipment data provided in a fax from the Hydronics Institute to Pacific Northwest National Laboratory, 1996. 
Table 2.6. Estimated.Annual Shipments for Gas-Fired Boilers Used in the Analysis

\begin{tabular}{|l|c|c|c|}
\hline & & \multicolumn{2}{c|}{ Estimated Shipments } \\
\cline { 3 - 4 } \multicolumn{1}{|c|}{ Product Description } & Typical Capacity $(\mathrm{kBtu} / \mathrm{h})$ & Gas-Fired & Oil-Fired \\
\hline Hot Water Boilers, 300-400 kBtu/h & 400 & 2,821 & 2,389 \\
\hline Hot Water Boilers, $400-1,000 \mathrm{kBtu} / \mathrm{h}$ & 800 & 3,077 & 2,641 \\
\hline Hot Water Boilers, $1,000-2,500 \mathrm{kBtu} / \mathrm{h}$ & 1,500 & 540 & 1,337 \\
\hline Hot Water Boilers, $2,500+\mathrm{kBtu} / \mathrm{h}$ & 3,000 & 178 & 627 \\
\hline Steam Boilers, 300-400 kBtu/h & 400 & 1,268 & 987 \\
\hline Steam Boilers, $400-1,000 \mathrm{kBtu} / \mathrm{h}$ & 800 & 1,731 & 1,213 \\
\hline Steam Boilers, $1,000-2,500 \mathrm{kBtu} / \mathrm{h}$ & 1,500 & 424 & 850 \\
\hline Steam Boilers, $2,500+\mathrm{kBtu} / \mathrm{h}$ & 3,000 & 135 & 374 \\
\hline
\end{tabular}

\subsubsection{Baseline Cost Data}

Baseline costs for boilers were developed from data provided primarily by mechanical contractors or equipment distributors. The data identified boiler costs by characteristic boiler size, hot water or steam output, and gas or oil fuel input. The number of data points available varied from 3 to 7 for each product analyzed. When more than three data points were available, the high- and low-cost data points were removed from the set and the remaining cost data were averaged to reduce the effects of high- and lowcost outliers.

In all cases, the average combustion efficiency was higher than the minimum specified by EPCA. Thus, the average of the cost and efficiency data are referred to as the market baseline cost and efficiency. When possible, available relative cost versus efficiency data for each product were used to back out the cost for an EPCA baseline product from the market baseline cost and efficiency data. The relative cost versus efficiency data used was based on combustion efficiency relative cost curves supplied by GAMA in 1994 to the SSPC. When the efficiency for a particular product was not provided, $80 \%$ combustion efficiency was assumed. Note that the averaged market combustion efficiency was generally close to the EPCA baseline (within two percentage points in all but one instance), and the impact on the final cost estimate was a $5 \%$ to $13.5 \%$ reduction in cost from the market baseline to the EPCA baseline, depending on product. Table 2.7 shows the baseline cost data for boilers.

\subsubsection{Relative Cost for Higher Efficiency Levels}

In 1994, GAMA provided tables to the ASHRAE Mechanical Subcommittee during Standard 90.11999 development showing relative costs for specific combustion efficiency and thermal efficiency improvements above the efficiency levels required by Standard 90.1-1989 (same as the EPCA levels). These data were developed based on GAMA surveys of member industries and represented the average manufacturer cost increases needed to reach specific efficiency levels. In some instances, the given efficiency.level represented a range of efficiencies that could be achieved at essentially the same relative cost. The SSPC 90.1 performed its analysis using thermal efficiency as the metric of choice and thus recommended thermal efficiency as the metric for the Standard 90.1-1999 requirements covering all boiler sizes except for. boiler capacities $>2,500 \mathrm{kBtu} / \mathrm{h}$. Because thermal efficiency can be directly 
Table 2.7. Boiler Baseline Cost Data

\begin{tabular}{|c|c|c|c|c|c|c|}
\hline Product & $\begin{array}{c}1994 \\
\text { Estimated } \\
\text { Cost for } \\
\text { ASHRAE } \\
\text { Analysis (\$) }\end{array}$ & $\begin{array}{l}\text { No. of } \\
\text { Data } \\
\text { Points }\end{array}$ & $\begin{array}{l}\text { Average } \\
\text { Cost }^{(2)}(\$)\end{array}$ & $\begin{array}{c}\text { Average } \\
\text { Comb } \\
\text { EFF } \\
(\%)\end{array}$ & $\begin{array}{c}\text { Relative } \\
\text { Cost }{ }^{(b)} \\
(\%)\end{array}$ & $\begin{array}{c}\text { EPCA } \\
\text { Baseline } \\
\text { Contractor } \\
\text { Cost (\$) }\end{array}$ \\
\hline Package Boilers, Gas-Fired, 400, HW & 5,015 & 7 & 4,389 & 80.7 & 111 & 3,972 \\
\hline Package Boilers, Gas-Fired, $800, \mathrm{HW}$ & 6,621 & 7 & 6,220 & 80.7 & 111 & 5,629 \\
\hline Package Boilers, Gas-Fired, 1,500, HW & 9,258 & 7 & 9,649 & 80.9 & 114 & 8,501 \\
\hline Package Boilers, Gas-Fired, 3,000, HW & 14,969 & 7 & 15,161 & 81.4 & 110 & 13,733 \\
\hline Package Boilers, Gas-Fired, 400, Steam & 5,015 & 4 & 5,460 & 80.0 & 100 & 5,460 \\
\hline Package Boilers, Gas-Fired, 800, Steam & 6,621 & 4 & 7,248 & 80.0 & 100 & 7,248 \\
\hline Package Boilers, Gas-Fired, 1,500, Steam & 9,258 & 5 & 13,813 & 81.0 & 110 & 12,580 \\
\hline Package Boilers, Gas-Fired, 3,000, Steam & 14,969 & 5 & 18,746 & 82.0 & 104 & 18,025 \\
\hline
\end{tabular}

correlated with energy use, the screening analysis also uses thermal efficiency as the metric for efficiency improvements. For boilers $>2,500-\mathrm{kBtu} / \mathrm{h}$ input rating, the Standard 90.1-1999 efficiency level is a combustion efficiency rating primarily because of difficulties in testing the thermal efficiency of larger boilers.

In 1994, GAMA provided relative cost versus efficiency data to the SSPC 90.1. Applying these relative cost data to the baseline costs results in costs that do not reflect current prices for high-efficiency equipment. $^{\text {(a) }}$ Therefore, using boiler cost data from Freeman (1995), a functional relationship was developed between the contractor cost data and boiler performance characteristics as shown below:

$$
\text { Contractor Cost }(\$ 96)=3.23 \times \text { input }+2.64 \times(E c)^{2}+1,009 \times \text { burner }-15,755
$$

where input $=$ the gas fuel input in $\mathrm{kBtu} / \mathrm{h}$

$E_{c}=$ rated combustion efficiency as a two-digit integer $\left(80=80 \% \mathrm{E}_{c}\right)$

burner $=$ a bimodal variable to represent the presence of a power burner (burner $=1)$ or atmospheric burner (burner $=0$ ).

Equation (2.6) was used to generate the relative cost for targeted efficiency levels above the EPCA minimum for hot water boilers with capacities up to $2,500 \mathrm{kBtu} / \mathrm{h}$. Power burners were assumed for boiler efficiencies greater than $82 \%$, which was characteristic of the collected data. The data used to generate Equation (2.6) incorporated few boilers above 2,500 kBtu/h. For boilers greater than $2,500 \mathrm{kBtu} / \mathrm{h}$, estimates of cost for higher efficiency levels were based on data supplied by an industry consultant. $^{(\mathrm{b})}$

(a) Personal communications with Dirk Granberg; Chris Jostel of Mechanical Sales Inc., in 1999.

(b) Personal communications with Dirk Granberg in 1999. 
Equation (2.6) provides the relative cost as a function of input rating. However, a contractor purchases a boiler based on output capacity to ensure it can meet the building load. Output capacity is a function of the input rating as well as the thermal efficiency. Using a higher efficiency allows the input rating to be reduced, reducing the boiler cost as calculated by the equation.

For low-pressure steam boilers, where the boiler design may be essentially the same as that for a hot water boiler except for controls, the combustion efficiency is somewhat lower due to the change in temperature of the working fluid from $180^{\circ} \mathrm{F}$ to $212^{\circ} \mathrm{F}(0$ psig steam $)$ as specified in the proposed test procedure). The gap between the combustion and thermal efficiency is also larger for steam boilers due to the higher operating temperature increasing the shell losses from a steam boiler. The effect or shell losses depends on boiler volume, boiler input rating, and insulation level. Relative cost curves for steam boilers were also developed assuming a typical $2 \%$ point difference between hot water and steam thermal efficiencies for the two smaller size categories ( $400-800 \mathrm{kBtu} / \mathrm{h}$ boilers) analyzed, and a $1 \%$ point difference for the next-larger $(1,500 \mathrm{Btu} / \mathrm{h})$ size category. For the largest size category, costs were based directly on relative cost estimates supplied by consultants. ${ }^{\text {(a) }}$

Relative cost versus efficiency data for oil-fired boilers were not collected during the analysis, nor were these data provided for the analysis of these products during the development of Standard 90.1-1999. Data provided by industry consultant $t^{(a)}$ and other manufacturer's representatives indicate that a combustion efficiency of $83 \%$ to $84 \%$ is typically the maximum for oil-fired designs due to difficulties in designing for condensation in oil-fired equipment and associated flue systems.

\subsubsection{Efficiency Levels Analyzed}

An EPCA minimum, a Standard 90.1-1999 minimum, and the highest thermal efficiency level were used for all gas-fired boilers. The combustion efficiency specified in EPCA was translated to thermal efficiency based on the information provided by GAMA, which is $75 \%$ thermal efficiency for hot water boilers and $72 \%$ thermal efficiency for steam boilers. The highest thermal efficiencies analyzed were $88 \%$ for hot water boilers and between $81 \%$ and $82 \%$ for steam boilers, depending on size and available data. Efficiency levels between the EPCA minimum and the highest efficiency levels were used based on the availability of data points from the GAMA relative cost data. Table 2.8 shows the efficiency levels analyzed and the corresponding relative costs above the EPCA minimum. Table 2.9 shows cost estimates for boilers at each efficiency level that were obtained by applying the relative costs (from Table 2.8) to the first-cost data.

\subsubsection{Efficiency and Cost Data - Warm-Air Furnaces}

This section presents the lifetime, shipments, baseline cost, and relative cost for higher efficiency levels for warm-air furnaces.

(a) Provided by Dirk Granberg in December 1999. 
Table 2.8. Gas-Fired Boiler Efficiencies Analyzed (with relative cost above baseline)

\begin{tabular}{|c|c|c|c|c|c|c|c|c|c|c|c|c|c|}
\hline \multirow[b]{2}{*}{ Product Description } & \multirow[b]{2}{*}{$\begin{array}{c}\text { Typical } \\
\text { Capacity } \\
(\mathrm{kBtu} / \mathrm{h})\end{array}$} & \multicolumn{2}{|c|}{ Level 1 (EPCA 92) } & \multicolumn{2}{|c|}{ Lcvel 2 (90.1-1999) } & \multicolumn{2}{|c|}{ Level 3} & \multicolumn{2}{|c|}{ Level 4} & \multicolumn{2}{|c|}{ Level 5} & \multicolumn{2}{|c|}{ Level 6} \\
\hline & & $\begin{array}{c}\text { Thermal } \\
\text { Efficiency } \\
(\%)\end{array}$ & $\begin{array}{l}\text { Relative } \\
\text { Cost }(\%)\end{array}$ & \begin{tabular}{c|} 
Thermal \\
Efficiency \\
$(\%)$ \\
\end{tabular} & $\begin{array}{l}\text { Relative } \\
\text { Cost (\%) }\end{array}$ & $\begin{array}{l}\text { Thermal } \\
\text { Efficiency } \\
(\%)\end{array}$ & $\begin{array}{c}\text { Relative } \\
\text { Cost } \\
(\%)\end{array}$ & $\begin{array}{c}\text { Thermal } \\
\text { Efficiency } \\
(\%)\end{array}$ & $\begin{array}{c}\text { Relative } \\
\text { Cost } \\
(\%)\end{array}$ & $\begin{array}{c}\text { Thermal } \\
\text { Efficiency } \\
(\%)\end{array}$ & $\begin{array}{c}\text { Relative } \\
\text { Cost } \\
(\%)\end{array}$ & $\begin{array}{l}\text { Thermal } \\
\text { Efficiency } \\
(\%)\end{array}$ & $\begin{array}{c}\text { Relative } \\
\text { Cost } \\
(\%)\end{array}$ \\
\hline $\begin{array}{l}\text { Hot Water Boilers, } 300-400 \mathrm{kBtu} / \mathrm{h} \\
\text { output }\end{array}$ & 400 & 75 & 100 & 75 & 100 & 78 & 115 & 79 & 132 & 81 & 209 & 88 & 318 \\
\hline $\begin{array}{l}\text { Ilot Water Boilers, } 400-1,000 \mathrm{kBtu} / \mathrm{h} \\
\text { output }\end{array}$ & 800 & 75 & 100 & 75 & 100 & 76 & 110 & 78 & 120 & 79 & 158 & 88 & 237 \\
\hline $\begin{array}{l}\text { Iot Water Boilers, } 1,000- \\
2500 \mathrm{kBtu} / \mathrm{h} \text { output }\end{array}$ & 1,500 & 75 & 100 & 75 & 100 & 77 & 105 & 78 & 111 & 79 & 134 & 88 & 180 \\
\hline $\begin{array}{l}\text { Hot Water Boilers, } 2,500+\mathrm{kBtw} / \mathrm{h} \\
\text { output }\end{array}$ & 3,000 & 75 & 100 & 72 & 100 & 78 & 110 & 79 & 120 & 80 & 122 & 88 & 160 \\
\hline $\begin{array}{l}\text { Steam Boilers, } 300-400 \mathrm{kBtu} / \mathrm{h} \\
\text { output }\end{array}$ & 400 & 72 & 100 & 75 & 110 & 76 & 115 & 77 & 132 & 79 & 209 & 82 & 244 \\
\hline $\begin{array}{l}\text { Steam Boilers, } 400-1,000 \mathrm{kBtu} / \mathrm{h} \\
\text { output }\end{array}$ & 800 & 72 & 100 & 75 & 115 & 76 & 120 & 78 & 158 & 79 & 163 & 82 & 225 \\
\hline $\begin{array}{l}\text { Steam Boilers, } 1,000-2,500 \mathrm{kBtu} / \mathrm{h} \\
\text { output }\end{array}$ & 1,500 & 72 & 100 & 75 & 105 & 77 & 123 & 78 & 134 & 79 & 141 & 81 & 152 \\
\hline Stean Boilers, $2,500+k B t u / h$ output & 3,000 & 72 & 100 & 72 & 100 & 78 & 130 & 79 & 135 & 80 & 138 & 82 & 156 \\
\hline
\end{tabular}

Table 2.9. Cost Estimates for Gas-Fired Boilers

\begin{tabular}{|c|c|c|c|c|c|c|c|c|c|c|c|c|c|}
\hline \multirow[b]{2}{*}{ Product Description } & \multirow[b]{2}{*}{$\begin{array}{c}\text { Typical } \\
\text { Capacity } \\
(\text { kBtu/h) }\end{array}$} & \multicolumn{2}{|c|}{ Level 1 (EPCA 92) } & \multicolumn{2}{|c|}{ Level 2 (90.1-1999) } & \multicolumn{2}{|c|}{ Level 3} & \multicolumn{2}{|c|}{ Level 4} & \multicolumn{2}{|c|}{ Level 5} & \multicolumn{2}{|c|}{$\begin{array}{l}\text { Level } 6 \text { (highest } \\
\text { efficiency level) }\end{array}$} \\
\hline & & $\begin{array}{l}\text { Thermal } \\
\text { Efficiency } \\
(\%)\end{array}$ & Cost (\$) & $\begin{array}{c}\text { Thermal } \\
\text { Efficienc } \\
\text { y }(\%)\end{array}$ & Cost (\$) & \begin{tabular}{|c|} 
Thermal \\
Efficiency \\
$(\%)$
\end{tabular} & Cost (\$) & \begin{tabular}{c|} 
Thermal \\
Efficiency \\
$(\%)$
\end{tabular} & Cost (\$) & $\begin{array}{c}\text { Thermal } \\
\text { Efficiency } \\
(\%)\end{array}$ & Cost (\$) & \begin{tabular}{c|} 
Thermal \\
Efficiency \\
$(\%)$
\end{tabular} & Cost (\$) \\
\hline $\begin{array}{l}\text { Hot Water Boilers, } 300-400 \mathrm{kBtu} / \mathrm{h} \\
\text { output }\end{array}$ & 400 & 75 & 3,972 & 75 & 3,972 & 78 & 4,585 & 79 & 5,262 & 81 & 8,291 & 88 & 12,636 \\
\hline $\begin{array}{l}\text { Hot Water Boilers, } 400-1,000 \mathrm{kBtu} / \mathrm{h} \\
\text { output }\end{array}$ & 800 & 75 & 5,629 & 75 & 5,629 & 76 & 6,220 & 78 & 6,772 & 79 & 8,908 & 88 & 13,360 \\
\hline $\begin{array}{l}\text { Hot Water Boilers, } 1,000- \\
2,500 \mathrm{kBtu} / \mathrm{h} \text { output }\end{array}$ & 1,500 & 75 & 8,502 & 75 & 8,502 & 77 & 8,927 & 78 & 9,452 & 79 & 11,420 & 88 & 15,293 \\
\hline $\begin{array}{l}\text { Ilot Water Boilers, } 2,500+k B t u / h \\
\text { output }\end{array}$ & 3,000 & 75 & 13,733 & 75 & 13,733 & 78 & 15,107 & 79 & 16,480 & 80 & 16,755 & 88 & 21,973 \\
\hline $\begin{array}{l}\text { Steam Boilers, } 300-400 \mathrm{kBtu} / \mathrm{h} \\
\text { output }\end{array}$ & 400 & 72 & 5,460 & 75 & 6,006 & 76 & 6,279 & 77 & 7,207 & 79 & 11,411 & 82 & 13,322 \\
\hline $\begin{array}{l}\text { Steam Boilers, } 400-1,000 \mathrm{kBtu} / \mathrm{h} \\
\text { output }\end{array}$ & 800 & 72 & 7,248 & 75 & 8,335 & 76 & 8,698 & 78 & 11,452 & 79 & 11,814 & 82 & 16,308 \\
\hline $\begin{array}{l}\text { Steam Boilers, } 1,000-2,500 \mathrm{kBtu} / \mathrm{h} \\
\text { output }\end{array}$ & 1,500 & 72 & 12,580 & 75 & 13,209 & 77 & 15,443 & 78 & 16,899 & 79 & 17,704 & 81 & 19,136 \\
\hline Steam Boilers, $2,500+\mathrm{kBtu} / \mathrm{h}$ output & 3,000 & 72 & 18,026 & 72 & 18,026 & 78 & 23,433 & 79 & 24,335 & 80 & 24,875 & 82 & 28,120 \\
\hline
\end{tabular}




\subsubsection{Service Life}

Most commercial furnaces covered under EPCA are installed as an integral part of a combined packaged cooling and heating unit, typically rooftop mounted. A 15-year service life was used for all furnaces based on equipment life data published in the ASHRAE (1995) for packaged cooling equipment. Life expectancies for stand-alone furnaces are expected to be slightly longer based on the same data source.

\subsubsection{Shipment Data and Characteristic Equipment Size}

Total annual shipments of commercial furnaces are estimated to be 181,384 , based on 1994 GAMA data showing shipments of 164,300 commercial furnaces adjusted for a $15 \%$ increase in total furnace shipments (residential and commercial) between 1994 and $1998 .^{(a)}$

Two furnace sizes were analyzed in the screening analysis -250 and $400 \mathrm{kBtu} / \mathrm{h}$. These two sizes were chosen based on the availability of relative cost versus efficiency data supplied by GAMA during the development of Standard 90.1-1999. In addition, the relative cost versus efficiency data supplied by GAMA suggested strong differences between the 250 - and $400-\mathrm{kBtu} / \mathrm{h}$ furnace costs relative to baseline efficiency models.

Shipment weights for furnaces were estimated based on the fraction of total unitary equipment shipments having furnaces corresponding to the $250-\mathrm{kBtu} / \mathrm{h}$ category or to the larger $400-\mathrm{kBtu} / \mathrm{h}$ furnace design. It was assumed that larger furnaces would have relative costs versus efficiency profiles similar to those for the 400-kBtu/h category. The 1998 ARI statistical releases (ARI 1998b) provide the following equipment shipment data as shown in Table 2.10.

All of the 135- through $184.9-\mathrm{kBtu} / \mathrm{h}$ cooling equipment and $50 \%$ of the 185 - through $249.9-\mathrm{kBtu} / \mathrm{h}$ cooling equipment were assumed to use furnaces around the $250-\mathrm{kBtu} / \mathrm{h}$ size. The remainder of the cooling equipment was assumed to use furnaces at or around the $400-\mathrm{kBtu} / \mathrm{h}$ sizes. Thus, the relative weights applied to these two furnace categories are $61 \%$ for $250-\mathrm{kBtu} / \mathrm{h}$ and $39 \%$ for $400-\mathrm{kBtu} / \mathrm{h}$ and above furnaces. The estimated annual shipment was 110,644 small furnaces (represented by the $250-\mathrm{kBtu} / \mathrm{h}$ size) and 70,740 large furnaces (represented by the $400-\mathrm{kBtu} / \mathrm{h}$ size).

\subsubsection{Baseline Cost Data}

The Standard 90.1-1999 furnace analysis was based on cost data provided by GAMA in 1994 to the SSPC 90.1. The data were provided as a multiplier on the entire cost of a package heating and cooling system. An assumption was made that the $250-\mathrm{kBtu} / \mathrm{h}$ capacity furnace was appropriately sized to a 10 -ton system and a $400-\mathrm{kBtu} / \mathrm{h}$ furnace was appropriately sized to a 15 -ton cooling system. The screening analysis used the relative cost information for higher efficiency furnaces that was tied to the * total package system price.

(a) Gas-fired space conditioning and service water heating equipment shipment data and supporting letter provided to Cyrus Nasseri of DOE, December 7, 1999. 
Table 2.10. ARI 1998 Statistical Profile for Year Round Units

\begin{tabular}{|c|c|}
\hline $\begin{array}{c}\text { Cooling Capacity } \\
(\mathbf{k B t u} / \mathbf{h})\end{array}$ & 1998 Shipments \\
\hline $135-184.9$ & 46,030 \\
\hline $185-249.9$ & 22,224 \\
\hline $250-319.9$ & 10,788 \\
\hline $320-379.9$ & 4,207 \\
\hline $380-539.9$ & 4,013 \\
\hline $540-639.9$ & 2,292 \\
\hline 640 \& Over & 4,377 \\
\hline
\end{tabular}

In 1994, the ASHRAE 90.1 mechanical subcommittee assumed the $250-\mathrm{kBtu} / \mathrm{h}$ capacity furnaces would be used on a 10 -ton system, and a $400-\mathrm{kBtu} / \mathrm{h}$ furnace would be used on a 15 -ton system. A review of available products from Carrier, Trane, and Bryant suggested this match was uncommon (Barwig et al. 1996). Furnaces are typically available in both low-heat and high-heat configurations for most commercial packaged equipment. A more typical matching for the high-heat configuration would be to use a $250-\mathrm{kBtu} / \mathrm{h}$ furnace on a 10 - to 12.5 -ton system, and a $400-\mathrm{kBtu} / \mathrm{h}$ furnace would be considered the high-heat option for a 15- to 20-ton system and the low-heat option on a 25-ton airconditioning system. For any piece of equipment, the low-heat furnace options are typically about twothirds the input rate of the high-input furnaces, and may actually represent the more commonly purchased option. Using the combination analyzed by the SSPC 90.1 minimized the cost increases for higher efficiency furnaces; therefore, the same combination $(250 \mathrm{kBtu} / \mathrm{h}$ to 10 -ton and $400 \mathrm{kBtu} / \mathrm{h}$ to 15 -ton) was also used for the present analysis.

The base cost data for packaged systems with furnaces was based on 1994 data used by the Standard 90.1 Mechanical Subcommittee in the furnace analysis. These furnace costs provided to the subcommittee included a $25 \%$ markup. For this analysis, these costs were brought forward to 1999 using a $2 \%$ per year gross domestic product inflator. After removing the $25 \%$ markup, the first costs used in the screening analysis were $\$ 4,602$ for a $250-\mathrm{kBtu} / \mathrm{h}$ furnace combined with a 10 -ton packaged cooling system, and $\$ 6,349$ for a $400-\mathrm{kBtu} / \mathrm{h}$ furnace on a 15 -ton packaged cooling system.

\subsubsection{Relative Cost for Higher Efficiency Levels}

The relative cost versus design options data provided to the Standard 90.1-1999 committee included costs for reducing casing losses, as well as adopting power burners and Intermittent Ignition Devices (IIDs) in furnaces. Twelve separate design options were considered (as shown in Table 2.11). Because the basic EPCA 92 specifies only a combustion efficiency rating of $80 \%$, Case 2 (as shown in Table 2.11) was used as the EPCA 92 baseline. This baseline furnace has a casing loss of $1.5 \%$ based on rated test conditions. The test condition casing loss was then multiplied by a factor of 3.3 to represent losses in outdoor conditions ( 10 CFR Part 430 Subpart B, Appendix N). Table 2.11 shows the relative cost and thermal efficiency data for each design option. 
Table 2.11. Standard 90.1 Furnace Design Options

\begin{tabular}{|c|c|c|c|c|c|}
\hline \multirow[b]{2}{*}{ Furnace Designs } & \multicolumn{2}{|c|}{$\begin{array}{c}\text { Costs Relative To EPCA } \\
\text { Baseline }\end{array}$} & \multirow{2}{*}{$\begin{array}{c}\text { Combustion } \\
\text { Efficiency } \\
(\%)\end{array}$} & \multirow{2}{*}{$\begin{array}{l}\text { Casing Loss } \\
(\%)\end{array}$} & \multirow{2}{*}{$\begin{array}{c}\text { Thermal } \\
\text { Efficiency } \\
(\%)\end{array}$} \\
\hline & $250 \mathrm{kBtu} / \mathrm{h}$ & $400 \mathrm{kBtu} / \mathrm{h}$ & & & \\
\hline $\begin{array}{l}\text { Case } 1, \text { Atmospheric Burner, Ec }=78 \% \text {, } \\
600-\text { Btu/h Pilot, } 1.5 \% \text { Casing Loss }\end{array}$ & 1.000 & 1.000 & 78 & 1.50 & 73.05 \\
\hline $\begin{array}{l}\text { Case 2, Atmospheric Burner, Ec }=80 \% \text {, IID, } \\
1.5 \% \text { Casing Loss }\end{array}$ & 1.015 & 1.015 & 80 . & 1.50 & 75.05 \\
\hline $\begin{array}{l}\text { Case 3, Atmospheric Burner, Vent Cap, } \\
\mathrm{Ec}=80 \% \text {, IID, } 1.5 \% \text { Casing Loss }\end{array}$ & 1.035 & 1.035 & 80 & 1.50 & 75.05 \\
\hline $\begin{array}{l}\text { Case } 4 \text {, Power Burner, Ec }=80 \%, \text { IID, } 1.5 \% \\
\text { Casing Loss }\end{array}$ & 1.060 & 1.060 & 80 & 1.50 & 75.05 \\
\hline $\begin{array}{l}\text { Case 5, Power Burner, Ec }=82 \%, \text { IID, } 1.5 \% \\
\text { Casing Loss }\end{array}$ & 1.070 & 1.060 & 82 & 1.50 & 77.05 \\
\hline $\begin{array}{l}\text { Case 6, Power Burner, Ec }=88 \%, \text { IID }, 1.5 \% \\
\text { Casing Loss }\end{array}$ & 1.500 & 1.510 & 88 & 1.50 & 83.05 \\
\hline $\begin{array}{l}\text { Case 7, Atmospheric Burner, } \mathrm{Ec}=78 \% \text {, } \\
600-\mathrm{Btu} / \mathrm{h} \text { Pilot, } 0.75 \% \text { Casing Loss }\end{array}$ & 1.050 & 1.010 & 78 & 0.75 & 75.53 \\
\hline $\begin{array}{l}\text { Case } 8 \text {, Atmospheric Burner, Ec }=80 \% \text {, IID, } \\
0.75 \% \text { Casing Loss }\end{array}$ & 1.065 & 1.025 & 80 & 0.75 & 77.53 \\
\hline $\begin{array}{l}\text { Case } 9 \text {, Atmospheric Burner, Vent Cap, } \\
\mathrm{Ec}=80 \% \text {, IID, } 0.75 \% \text { Casing Loss }\end{array}$ & 1.085 & 1.045 & 80 & 0.75 & 77.53 \\
\hline $\begin{array}{l}\text { Case } 10 \text {, Power Burner, Ec }=80 \% \text {, IID, } \\
0.75 \% \text { Casing Loss }\end{array}$ & 1.110 & 1.070 & 80 & 0.75 & 77.53 \\
\hline $\begin{array}{l}\text { Case } 11 \text {, Power Burner, Ec }=82 \% \text {, IID, } \\
0.75 \% \text { Casing Loss }\end{array}$ & 1.120 & 1.070 & 82 & 0.75 & 79.53 \\
\hline $\begin{array}{l}\text { Case } 12, \text { Power Furnace, Ec }=88 \% \text {, IID, } \\
0.75 \% \text { Casing Loss }\end{array}$ & 1.550 & 1.520 & 88 & 0.75 & 85.53 \\
\hline
\end{tabular}

The lowest-cost product suggested by GAMA was Case 1 , which, at $78 \%$ efficiency, is not allowed under EPCA. The next lowest-cost product was for Case 2, which is assumed to represent the EPCA baseline rooftop furnace product ( $1.5 \%$ casing loss, atmospheric burner, IID, $80 \%$ combustion efficiency). In addition to the EPCA baseline product features, the Standard 90.1-1999 efficiency level has mandated a $0.75 \%$ casing loss, represented by Case 8 .

The next higher combustion efficiency level $(82 \%)$ is met by applying a power burner to Case 8 , represented by Case 11 .

The highest efficiency level analyzed corresponds to Case 12, a condensing furnace. However, no condensing rooftop furnaces were found from available literature.

Because a large number of existing furnace products have combustion efficiency levels near $81 \%$, an $81 \%$ efficiency level was added (for the analysis) at $50 \%$ of the cost to reach the $82 \%$ level. Table 2.12 shows costs normalized to the EPCA baseline (Case 2).

Incorporating the first-cost information and the relative costs for higher efficiency levels results in the cost estimates for each efficiency level shown in Table 2.13. 
Table 2.12. Relative Cost and Efficiency Data for Furnace Screening Analysis

\begin{tabular}{|c|c|c|c|c|c|}
\hline \multirow[b]{2}{*}{ Furnace Designs } & \multicolumn{2}{|c|}{$\begin{array}{l}\text { Costs Relative to } \\
\text { EPCA Baseline }\end{array}$} & \multirow{2}{*}{$\begin{array}{l}\text { Combustion } \\
\text { Efficiency } \\
(\%)\end{array}$} & \multirow{2}{*}{$\begin{array}{l}\text { Casing } \\
\text { Loss } \\
(\%)\end{array}$} & \multirow{2}{*}{$\begin{array}{c}\text { Thermal } \\
\text { Efficiency } \\
(\%)\end{array}$} \\
\hline & $250 \mathrm{kBtu} / \mathrm{h}$ & $400 \mathrm{kBtu} / \mathrm{h}$ & & & \\
\hline $\begin{array}{l}\text { Case 2, Atmospheric Burner, } \\
\text { Ecomb }=80 \% \text {, IID, } 1.5 \% \text { Casing Loss }\end{array}$ & 1.000 & 1.000 & 80 & 1.50 & 75.05 \\
\hline $\begin{array}{l}\text { Case 8, Atmospheric Burner, Ec }= \\
80 \%, \text { IID }, 0.75 \% \text { Casing Loss }\end{array}$ & 1.049 & 1.010 & 80 & 0.75 & 77.53 \\
\hline $\begin{array}{l}\text { Case } 11, \text { Power Burner, Ec }=81 \% \text {, } \\
\text { IID, } 0.75 \% \text { Casing Loss }\end{array}$ & 1.044 & 1.020 & 81 & 0.75 & 78.53 \\
\hline $\begin{array}{l}\text { Case } 11, \text { Power Burner, } \mathrm{Ec}=82 \% \text {, } \\
\text { IID, } 0.75 \% \text { Casing Loss }\end{array}$ & 1.103 & 1.054 & 82 & 0.75 & 79.53 \\
\hline $\begin{array}{l}\text { Case } 12, \text { Power Furnace, } E c=88 \% \text {, } \\
\text { IID, } 0.75 \% \text { Casing Loss }\end{array}$ & 1.527 & 1.498 & 88 & 0.75 & 85.53 \\
\hline
\end{tabular}

Table 2.13. Contractor Costs for Furnace Efficiency Levels Analyzed

\begin{tabular}{|c|c|c|c|c|c|c|c|c|c|c|c|c|}
\hline \multirow[b]{2}{*}{$\begin{array}{l}\text { Gas-Furnace } \\
\text { Product }\end{array}$} & \multicolumn{2}{|c|}{$\begin{array}{c}\text { Level 1 } \\
\text { (EPCA 92) }\end{array}$} & \multicolumn{2}{|c|}{$\begin{array}{c}\text { Level 2 } \\
(90.1-1999)\end{array}$} & \multicolumn{2}{|c|}{ Level 3} & \multicolumn{2}{|c|}{ Level 4} & \multicolumn{2}{|c|}{ Level 5} & \multicolumn{2}{|c|}{ Level 6} \\
\hline & $\begin{array}{c}\text { Thermal } \\
\text { Efficiency } \\
(\%) \\
\end{array}$ & $\begin{array}{l}\text { Cost } \\
(\mathbf{S})\end{array}$ & $\begin{array}{c}\text { Thermal } \\
\text { Efficiency } \\
(\%)\end{array}$ & $\begin{array}{c}\text { Cost } \\
(\$)\end{array}$ & $\begin{array}{c}\text { Thermal } \\
\text { Efficiency } \\
(\%)\end{array}$ & $\begin{array}{c}\text { Cost } \\
(\$)\end{array}$ & $\begin{array}{c}\text { Thermal } \\
\text { Efficiency } \\
(\%)\end{array}$ & $\begin{array}{c}\text { Cost } \\
(\$)\end{array}$ & $\begin{array}{c}\text { Thermal } \\
\text { Efficiency } \\
(\%)\end{array}$ & $\begin{array}{c}\text { Cost } \\
(\$)\end{array}$ & \begin{tabular}{|c|} 
Thermal \\
Efficiency \\
$(\%)$
\end{tabular} & $\operatorname{Cost}(\$)$ \\
\hline $\begin{array}{l}\text { Warm-Air } \\
\text { Fumaces, Gas- } \\
\text { Fired, } 250 \mathrm{kBtu} / \mathrm{h}\end{array}$ & 75.1 & 4,602 & 77.5 & 4,827 & 78.5 & 4,952 & 79.5 & 5,076 & 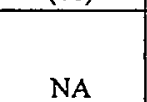 & NA & 85.5 & 7,027 \\
\hline $\begin{array}{l}\text { Warm-Air } \\
\text { Furnaces, Gas- } \\
\text { Fired, } 400 \mathrm{kBtu} / \mathrm{h}\end{array}$ & 75.1 & 6,349 & 77.5 & 6,412 & 78.5 & 6,552 & 79.5 & 6,692 & $\mathrm{NA}$ & NA & 85.5 & 9,511 \\
\hline
\end{tabular}

\subsubsection{Efficiency and Cost Data - Service Water Heaters}

This section presents the lifetime, shipments, baseline cost, and relative cost for higher efficiency levels for service water heaters.

\subsubsection{Service Life}

Commercial storage water heaters covered under EPCA were analyzed assuming a 7-year service life and a 15-year life for instantaneous water heaters, based on data developed in the SSPC 90.1 analysis.

\subsubsection{Shipment Data and Characteristic Equipment Size}

GAMA provided annual shipments of gas commercial water heaters and electric commercial water heaters from 1989 to 1998 . $^{\text {(a) }}$ GAMA data breaking down the shipments into product categories were not available. In addition, the gas water heater shipments did not include copper tube or coil-type water heaters. The GAMA data through 1996 separates residential from commercial (EPACT-covered) water

(a) Gas-fired space conditioning and service water heating equipment shipment data and supporting letter provided to Cyrus Nasseri of DOE, December 7, 1999. 
heaters. However, the data beginning in 1997 separates residential and commercial water heater shipments, based on the manufacturer's marketing of the product, which modifies the shipment data for both gas-fired and electric products.

For this analysis, the shipments over the 5-year period from 1992 to 1996 were averaged to provide an estimate for total shipments of gas storage and electric commercial water heaters. The resulting estimated shipments are 107,646 units per year for commercial gas water heaters and 23,387 for electric water heaters (see Table 2.14). GAMA does not track shipments of oil water heaters at either the residential or the commercial level.

Table 2.14. Total Gas and Electric Commercial Water Heater Shipments

\begin{tabular}{|c|c|c|c|c|c|c|c|c|c|c|c|}
\hline Year & 1989 & 1990 & 1991 & 1992 & 1993 & 1994 & 1995 & 1996 & $1997^{(2 \mathrm{~d})}$ & $1998^{(2, b)}$ & 5-yr avg. ${ }^{(\mathrm{c})}$ \\
\hline Gas Water Heaters & 106,401 & 98,872 & 91,143 & 103,386 & 118,923 & 91,027 & 96,913 & 127,978 & 96,501 & 94,577 & 107,646 \\
\hline $\begin{array}{l}\text { Electric Water } \\
\text { Heaters }\end{array}$ & 19,768 & 20,121 & 19,768 & 22,646 & 21,142 & 22,288 & 23,905 & 26,954 & 30,339 & 35,586 & 23,387 \\
\hline $\begin{array}{l}\text { (a) Does not includ } \\
\text { (b) Definitions for } \\
\text { (c) Represents data }\end{array}$ & $\begin{array}{l}\text { coppert } \\
\text { identia }\end{array}$ & $\begin{array}{l}\text { e or coi } \\
\text { ind com } \\
\text { through }\end{array}$ & $\begin{array}{l}\text { l-type cc } \\
\text { mercial } \\
1996 .\end{array}$ & of & . & see t & & & & & \\
\hline
\end{tabular}

Estimates were made of the relative proportions of commercial water heater shipments in 10 product categories. These estimates were primarily based on data from an industry consultant ${ }^{(\mathrm{a})}$ and are shown in Table 2.15. These estimates, in conjunction with GAMA shipment data, were used to develop shipments data for the current analysis. It was assumed that shipments of commercial electric water heaters are correctly represented by the GAMA data. It was assumed that the GAMA data for gas water heaters essentially represented all shipments of gas storage water heaters, as well as instantaneous water heaters $\geq 10$-gal capacity. Hence, the total GAMA shipments were allocated to these four categories in the proportions indicated in Table 2.15. Shipments for the remaining < 10 -gal instantaneous gas water heaters were assumed to be in the relative proportion to gas storage water heater shipments shown in Table 2.15. Estimated annual shipments for all gas and electric water heater categories are shown in the rightmost column of Table 2.15. ADL has estimated shipments of commercial oil-fired water heaters at less than 1,000 units annually. ${ }^{(b)}$ Because of the low volume of shipments and uncertainty in the number of shipments, no further analysis of oil-fired water heaters was done.

\subsubsection{Baseline Cost Data and Characteristic Sizes}

Characteristic sizes for gas storage and instantaneous water heaters were based on sizes and input ratings used in the Standard 90.1-1999 analysis for each category of commercial gas water heaters listed under EPCA. Two sizes of tankless instantaneous water heaters (400 and 1,000 kBtu/h) and a single size

(a) Personal communication with Max Minnear on January 8, 2000 regarding annual water heater shipments by model category.

(b) Personal communication with Ed Barbour from ADL in November 1999. 
Table 2.15. Commercial Water Heater Shipment Proportions and Estimated Shipments

\begin{tabular}{|c|c|c|c|c|c|c|c|c|}
\hline \multirow[b]{2}{*}{ Type } & \multirow[b]{2}{*}{ Fuel } & \multirow[b]{2}{*}{$\begin{array}{l}\text { Input Rating } \\
(\mathrm{kBtu} / \mathrm{h})\end{array}$} & \multirow{2}{*}{$\begin{array}{c}\text { Volume } \\
\text { Rating } \\
\text { (gal) }\end{array}$} & \multicolumn{4}{|c|}{$\begin{array}{c}\text { Original Estimated } \\
\text { Proportion of Shipment }\end{array}$} & \multirow{2}{*}{$\begin{array}{c}\text { Final } \\
\text { Estimated } \\
\text { Annual } \\
\text { Shipments }\end{array}$} \\
\hline & & & & \multicolumn{3}{|c|}{$\begin{array}{c}\text { Individual Elements } \\
(\%)\end{array}$} & $\begin{array}{l}\text { Total } \\
(\%)\end{array}$ & \\
\hline Storage & Electric & All & None & 100 & 20 & \multirow[b]{4}{*}{75} & 15.00 & $23,387^{\text {(a) }}$ \\
\hline Storage & Gas & $>75, \leq 155$ & None & 20 & \multirow[b]{3}{*}{75} & & 11.25 & 21,083 \\
\hline Storage & Gas & $>155, \leq 250$ & None & 40 & & & 22.50 & 42,166 \\
\hline Storage & Gas & $>250$ & None & 40 & & & 22.50 & 42,166 \\
\hline Instantaneous & Gas & $>210$ & $<10$ & 95 & \multirow[b]{2}{*}{95} & \multirow[b]{2}{*}{25} & 22.56 & 42,279 \\
\hline Instantaneous & Gas & $>210$ & $\geq 10$ & 5 & & & 1.19 & 2,230 \\
\hline $\begin{array}{l}\text { (a) Refiects s } \\
\text { estimates. } \\
\text { (b) Totals app }\end{array}$ & lied GAM & actual shipr & $\begin{array}{l}\text { ater heate } \\
\text { its. }\end{array}$ & & & & ent $\mathrm{tr}$ & \\
\hline
\end{tabular}

instantaneous, integral tank water heater design were analyzed $(500 \mathrm{kBtu} / \mathrm{h}, 100 \mathrm{gal})$. A single size commercial electric storage water heater with a 120 -gal storage volume and $30-\mathrm{kW}$ input rate was chosen for the analysis.

Baseline cost data for storage water heaters were developed based on contractor cost data collected by industry consultants in 1999. (a) Cost data for instantaneous water heaters was based on data collected in 1995 (Freeman 1995), which was used to develop equations relating contractor cost to water heater input capacity and combustion efficiency. For tankless water heaters, this equation simplifies to

$$
\operatorname{COST}=2.35 \times \text { INPUT }-7,872 \times \mathrm{Ec}+49.5 \times \mathrm{Ec}^{2}+314,743
$$

where $\operatorname{COST}=$ the contractor cost in $1996 \$$

INPUT $=$ the input rating in $\mathrm{kBtu} / \mathrm{h}$

$E_{c}=$ the combustion efficiency.

For instantaneous water heaters with integral tank, the difference between a high-input storage water heater and the instantaneous water heater with tank is somewhat irrelevant and immaterial in terms of design, with units falling just above and just below the 4,000-Btu/h.gal threshold level. Equation (2.8) gives the cost for a water heater with integral tank above $155 \mathrm{kBtu} / \mathrm{h}$ and between 10 - and 140 -gal capacity, regardless of whether the water heater is classified as an instantaneous design or a storage water heater under EPCA.

$$
\operatorname{COST}=5.80 \times \text { INPUT }+129 \times \text { WARRANTY }+486 \times \text { TANK }+910 \times \text { BURNER }+468
$$

(a) Baseline commercial equipment cost data collected by DuPont Dobbs Engineers, LLC, in 1999. 
where COST $=$ the contractor cost in $1996 \$$

INPUT $=$ the input rating in $\mathrm{kBtu} / \mathrm{h}$

WARRANTY $=$ the length of the warranty in years

TANK $=$ an indicator of tank construction (ASME tank $=1$, else 0 )

BURNER = an indicator of type of burner (power burner $=1$, atmospheric $=0$ ).

For the screening analysis, a 3-year warranty was assumed. For these high-input instantaneous water heater designs, a power burner and ASME-rated tank were assumed.

In all cases, costs for gas instantaneous water heaters calculated using Equations (2.7) and (2.8) were adjusted to 1999 costs using a 2\% GDP inflator. The 1999 cost estimates for the products analyzed are shown in Table 2.16.

Table 2.16. Baseline Gas Storage Water Heater Costs

\begin{tabular}{|c|c|c|c|c|c|c|c|}
\hline $\begin{array}{c}\text { Equipment } \\
\text { Category }\end{array}$ & $\begin{array}{c}\text { Input } \\
\text { Category } \\
\text { (kBtu/h) }\end{array}$ & $\begin{array}{l}\text { Size } \\
\text { Category } \\
\text { (gal) }\end{array}$ & $\begin{array}{c}\text { Typical } \\
\text { Volume } \\
\text { (gal) }\end{array}$ & $\begin{array}{c}\text { Typical } \\
\text { Input } \\
\text { Rating } \\
\text { (kBtu/h) }\end{array}$ & $\begin{array}{c}\text { ASHRAE } \\
\text { Cost } \\
\text { (1994\$) }\end{array}$ & $\begin{array}{l}\text { No. Data } \\
\text { Points } \\
\text { Collected } \\
(1999)\end{array}$ & $\begin{array}{c}\text { Average } \\
\text { Cost w/o } \\
\text { Hi and Lo } \\
(1999 \$)\end{array}$ \\
\hline $\begin{array}{l}\text { Gas-Fired Storage } \\
\text { Water Heaters }\end{array}$ & $>75, \leq 155$ & Any & 75 & 120 & 3,665 & 3 & 1,775 \\
\hline \multirow{2}{*}{$\begin{array}{l}\text { Gas-Fired Storage } \\
\text { Water Heaters }\end{array}$} & \multirow[b]{2}{*}{$>155$} & \multirow[b]{2}{*}{ Any } & 100 & 199 & 4,291 & 4 & 2,213 \\
\hline & & & 100 & 360 & 5,720 & 4 & 3,784 \\
\hline \multirow[b]{4}{*}{ Storage Tanks } & \multirow[b]{4}{*}{ N/A } & $\mathrm{V}<140 \mathrm{gal}$ & 120 & \multirow[b]{4}{*}{ N/A } & 1,980 & 4 & 1,609 \\
\hline & & & 200 & & 3,294 & 3 & 2,375 \\
\hline & & & 500 & & 8,274 & 3 & 5,022 \\
\hline & & $V \geq 140$ gal & 1,000 & & 13,550 & 3 & 8,900 \\
\hline
\end{tabular}

Costs for the baseline electric storage water heater were estimated using data collected by Freeman (1995). These data are very extensive for electric water heaters, representing approximately 1,000 records for electric storage water heaters from nine companies, with tank volumes from 50 to $1,000 \mathrm{gal}$ and input ratings from 13.5 to $480 \mathrm{~kW}$. Three separate cost models were developed from the data, representing costs for common tank volumes of 50, 80, and 120 gal. Each cost model was a function of the type of thermostat used (surface or immersion), tank construction (ASME or standard), warranty, and one of three input rating classes. The cost model for a 120-gal electric water heater is shown as:

$$
\operatorname{COST}=877+485 \times \text { THERM }+371 \times \text { TANK }+162 \times \text { WARRANTY }+392 \times C 2+1002 \times C 3
$$

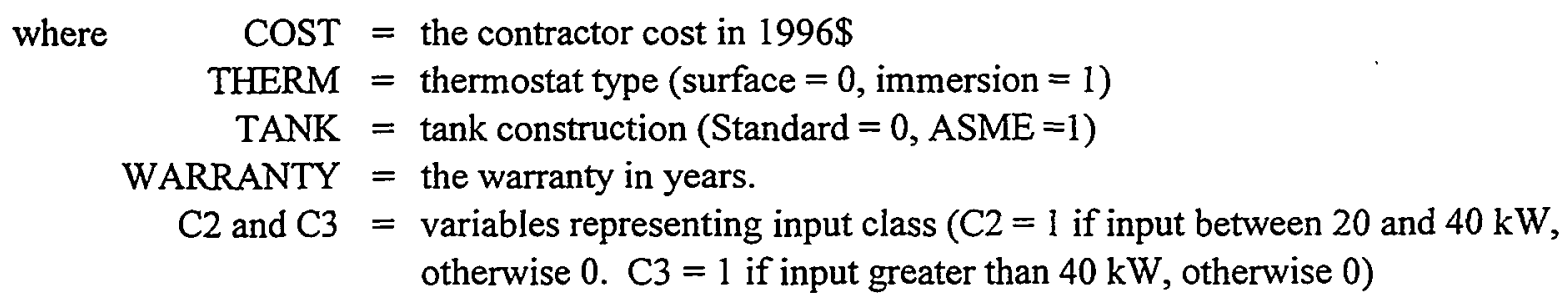


For the design analyzed, a surface-mount thermostat with a standard-tank construction, a 3-year warranty, and a $30-\mathrm{kW}$ element was chosen to represent the baseline model.

Table 2.17 provides the costs used in the Standard 90.1-1999 analysis for instantaneous water heater products, as well as the estimated cost based on the data collected in 1999 that were used in the screening analysis.

Table 2.17. Baseline Gas Instantaneous and Electric Water Heater Costs

\begin{tabular}{|l|c|c|c|c|c|c|}
\hline \multicolumn{1}{|c|}{$\begin{array}{c}\text { Input } \\
\text { Equipment Category }\end{array}$} & $\begin{array}{c}\text { Category } \\
\text { (kBtu/h) }\end{array}$ & $\begin{array}{c}\text { Size } \\
\text { Category } \\
\text { (gal) }\end{array}$ & $\begin{array}{c}\text { Typical } \\
\text { Volume } \\
\text { (gal) }\end{array}$ & $\begin{array}{c}\text { Typical Input } \\
\text { Rating }\end{array}$ & $\begin{array}{c}\text { ASHRAE } \\
\text { Cost } \\
(\mathbf{1 9 9 4 \$ )}\end{array}$ & $\begin{array}{c}\text { Estimated } \\
\text { Cost } \\
(\mathbf{1 9 9 9} \text { ) }\end{array}$ \\
\hline $\begin{array}{l}\text { Gas-Fired Instantaneous Water } \\
\text { Heaters - Tankless }\end{array}$ & $>200$ & $\mathrm{~V}<10$ & N/A & $400 \mathrm{kBtu} / \mathrm{h}$ & 3,477 & 2,794 \\
\cline { 4 - 7 } & & N/A & $1,000 \mathrm{kBtu} / \mathrm{h}$ & 5,460 & 4,294 \\
\hline $\begin{array}{l}\text { Gas-Fired Instantaneous Water } \\
\text { Heaters - Integral Tank }\end{array}$ & $>200$ & $\mathrm{~V} \geq 10$ & 100 & $500 \mathrm{kBtu} / \mathrm{h}$ & 8,824 & 5,466 \\
\hline Electric Water Heaters & N/A & $\mathrm{V} \geq 100$ & 120 & $30 \mathrm{~kW}$ & NA & 1862 \\
\hline
\end{tabular}

\subsubsection{Costs for Higher Efficiency Levels}

Storage Water Heaters - Five combinations of thermal efficiency and standby loss levels were analyzed for gas storage water heaters. These levels represented:

1. EPCA baseline

2. Standard 90.1-1999 requirements for thermal efficiency and standby loss

3. $82 \%$ thermal efficiency with Standard $90.1-1999$ standby loss levels

4. $82 \%$ thermal efficiency with Standard 90.1-1999 standby loss levels reduced by an additional inch of insulation on the tank

5. a high-efficiency ( $86 \%$ thermal) water heater with approximately two-thirds of the standby loss of the EPCA baseline

6. $94 \%$ thermal efficiency, fully condensing commercial water heater with two-thirds of the standby loss of the EPCA baseline.

Relative costs above the EPCA 92 baseline were established for levels 2 through 6 above as follows: cost information for changes in efficiencies from $78 \%$ to $82 \%$ were based on regressions of product cost and efficiency outlined in Freeman (1995) for the $<155 \mathrm{kBtu} / \mathrm{h}$ gas storage water heater category and brought up to present value using a $2 \%$ cost inflator. For storage water heaters $>155 \mathrm{kBtu} / \mathrm{h}$, cost increases were scaled by input rate. Note that the resulting cost increase in all three cases was consistently below the GAMA relative cost data provided for the Standard 90.1-1999 analysis. 
Typical commercial gas water heaters use 2 in. of insulation. ${ }^{(a)}$ An estimate of standby loss reduction by adding 1 in. of insulation (R-7.5) was made for a 100-gal tank. No corresponding improvement in efficiency was assumed because the thermal efficiency standard is separately regulated in both ASHRAE and EPCA requirements. Manufacturer costs were estimated to increase $\$ 20$ for the 100 -gal water heaters examined based on data supplied by industry consultants. ${ }^{\text {(a) }}$ The manufacturing cost for adding 1 in. of insulation to the 75 -gal water heater design was $\$ 17.17$, based on the relative area to be covered on the top and sides of two typical water heater designs (each with tank height of 55 in., and either 20 or 23 in. in diameter for 75- and 100-gal water heaters, respectively). A $60 \%$ markup from manufacturing to contractor costs was assumed.

An $86 \%$ thermal efficiency rating (partial condensing) with approximately two-thirds of the EPCA 92 standby loss was also analyzed based on GAMA relative cost data provided for the Standard 90.1 analysis.

Finally, the fully condensing water heater (highest efficiency level) design was analyzed, assuming a first-cost at $200 \%$ of the last noncondensing water heater design ( $82 \%$ efficiency, 3 in. of insulation).

\subsubsection{Instantaneous Water Heaters}

Five levels of thermal efficiency were examined for the gas-fired instantaneous water heaters with $<10$-gal storage capacity. Estimates for the higher efficiency costs were obtained from Freeman (1995). The costs estimated for a baseline in this report are similar to those used in the Standard 90.1 analysis. The relative cost increases for higher efficiency levels are typically less than those supplied by GAMA to ASHRAE for the $83 \%$ and $86 \%$ efficiency levels analyzed. A fully condensing thermal efficiency level of $94 \%$ was assumed to cost $200 \%$ of the cost of the $83 \%$ (noncondensing) level.

Six combinations of thermal efficiency and standby loss requirements were examined for instantaneous gas-fired water heaters with volume $>10$ gal. These cost estimates were based on the same data as for the storage water heaters.

\subsubsection{Electric Water Heaters}

Only one size of an electric storage water heater was examined ( $18 \mathrm{~kW}, 120 \mathrm{gal})$. Information from industry consultant ${ }^{(2)}$, as well as a review of the products in the commercial equipment cost survey (Freeman 1995), suggested that most electric water heaters have 3 in. of insulation and standby loss levels below those required by EPCA 92 . Some products may meet the EPCA requirements with 2 to 2.5 in. of insulation. For this analysis, we have assumed that the baseline model would have 3 in. of insulation.

Standard 90.1-1999 allows an increase in standby loss, which occurs across all sizes of electric water heaters. An analysis was done to estimate the impact of going from the EPCA levels to the requirements

(a) Personal communication with Max Minnear in 1999. 
in Standard 90.1-1999. No requirement exists under EPCA for a minimum thermal efficiency of electric water heaters; however, to be consistent with the other water heater analysis, we estimated the thermal efficiency as:

$$
\text { Thermal Efficiency }=1-\text { Standby loss/input rating }
$$

where standby loss is the allowed standby loss requirement in Standard 90.1-1999 and input is based on the $30 \mathrm{~kW}$ assumed for this water heater design. Both variables were converted to consistent heat units $(\mathrm{Btu} / \mathrm{h}$ ) for use in Equation (2.9), assuming a 100\% conversion of electrical power input to heat.

For the screening analysis, 2 in. of foam insulation was assumed to meet the Standard 90.1-1999 standby loss level. The standby loss impact of an additional inch of insulation (R-7.5) on the tank walls and roof (estimated at $35.6 \mathrm{ft}^{2}$ for the 120 -gal electric water heater design analyzed) was calculated. The difference between hot water and ambient air temperature was assumed to be $70^{\circ} \mathrm{F}$ for the above calculation.

The cost to add this third inch of insulation was estimated assuming a manufacturing cost increase of approximately $\$ 23$, based on a $\$ 20$ manufacturer's cost increase for a 100 -gal tank. ${ }^{(a)}$ A further $60 \%$ markup was used to go from manufacturer's cost increase to a contractor cost increase of $\$ 37$. No further reduction in standby loss requirement was analyzed for electric water heater designs.

No relative cost information was collected for commercial oil-fired water heaters in the screening analysis. Because of the low volume of shipments and lack of cost data for higher efficiency levels, no further analysis of oil-fired water heaters was attempted in the screening analysis.

Table 2.18 outlines the water heater thermal efficiency levels, standby loss requirements, and associated product cost. Efficiency levels corresponding to Test Level 2 for instantaneous gas water heaters (<10-gal capacity) and Test Levels 2, 3, and 4 for electric water heaters were not developed for the screening analysis and hence are marked "NA" in Table 2.18.

(a) Personal communication with Max Minnear in 1999. 
Table 2.18. Water Heater Efficiency Levels and Contractor Costs Used in Screening Analysis

\begin{tabular}{|c|c|c|c|c|c|c|c|c|c|c|c|c|c|c|c|c|c|c|}
\hline \multirow[b]{2}{*}{ Product } & \multicolumn{3}{|c|}{ EPCA 1992} & \multicolumn{3}{|c|}{ Standard 90.1-1999 } & \multicolumn{3}{|c|}{ Test Level 1} & \multicolumn{3}{|c|}{ Test Level 2} & \multicolumn{3}{|c|}{ Test Level 3} & \multicolumn{3}{|c|}{ Test Level 4} \\
\hline & $\begin{array}{l}\text { Eff. } \\
\left(E_{t}\right) \\
(\%)\end{array}$ & \begin{tabular}{|c|} 
Standby \\
Loss \\
(Btu/h)
\end{tabular} & \begin{tabular}{|c|} 
First \\
Cost \\
$(\$)$ \\
\end{tabular} & $\begin{array}{l}\text { Eff. } \\
\left(\mathbf{E}_{\mathrm{t}}\right) \\
(\%)\end{array}$ & \begin{tabular}{|c|} 
Standby \\
Loss \\
$($ Btu $/ \mathrm{h})$
\end{tabular} & \begin{tabular}{c|} 
First \\
Cost \\
$(\$)$ \\
\end{tabular} & $\begin{array}{l}\text { Eff. } \\
\left(E_{4}\right) \\
(\%)\end{array}$ & $\begin{array}{c}\text { Standby } \\
\text { Loss } \\
(B t u / h)\end{array}$ & \begin{tabular}{c|} 
First \\
Cost (\$)
\end{tabular} & $\begin{array}{l}\text { Eff. } \\
\left(\mathbf{E}_{t}\right) \\
(\%)\end{array}$ & $\begin{array}{c}\text { Standby } \\
\text { Loss } \\
(\text { Btu/h) } \\
\end{array}$ & $\begin{array}{c}\text { First } \\
\text { Cost } \\
(\$)\end{array}$ & $\begin{array}{l}\text { Eff. } \\
\left(E_{t}\right) \\
(\%) \\
\end{array}$ & $\begin{array}{c}\text { Standby } \\
\text { Loss } \\
\text { (Btu/h) }\end{array}$ & $\begin{array}{c}\text { First } \\
\text { Cost } \\
(\$) \\
\end{array}$ & $\begin{array}{l}\text { Eff. } \\
\left(E_{t}\right) \\
(\%)\end{array}$ & $\begin{array}{c}\text { Standby } \\
\text { Loss } \\
\text { (Btu/h) }\end{array}$ & \begin{tabular}{|c|} 
First \\
Cost \\
$(\$)$ \\
\end{tabular} \\
\hline $\begin{array}{l}\text { Storage Water Heater, Gas- } \\
\text { Fired, } 120 \mathrm{kBtu} / \mathrm{h}\end{array}$ & 78 & 1,193 & 1,775 & 80 & 1,103 & 1,822 & 82 & 1,103 & 1,869 & 82 & 1,053 & 1,897 & 86 & 804 & 2,787 & 94 & 804 & 3,739 \\
\hline $\begin{array}{l}\text { Storage Water Heater, Gas- } \\
\text { Fired, } 199 \mathrm{kBtu} / \mathrm{h}\end{array}$ & 78 & 1,262 & 2,213 & 80 & 1,349 & 2,291 & 82 & 1,349 & 2,369 & 82 & 1,291 & 2,401 & $86^{\circ}$ & 934 & 3,696 & 94 & 934 & 4,739 \\
\hline $\begin{array}{l}\text { Storage Water Heater, Gas- } \\
\text { Fired, } 360 \mathrm{kBtw} / \mathrm{h}\end{array}$ & 78 & 1,262 & 3,784 & 80 & 1,550 & 3,924 & 82 & 1,550 & 4,067 & 82 & 1,492 & 4,099 & 86 & 934 & 6,319 & 94 & 934 & 8,134 \\
\hline $\begin{array}{l}\text { Instantaneous Water Heater, } \\
\text { Gas-Fired, } 400 \mathrm{kBtu} / \mathrm{h}\end{array}$ & 80 & NA & 2,794 & 80 & NA & 2,794 & 83 & NA & 3,420 & NA & NA & NA & 86 & NA & 4,991 & 94 & NA & 6,839 \\
\hline $\begin{array}{l}\text { Instantaneous Water Heater, } \\
\text { Gas-Fired, } 1,000 \mathrm{kBtu} / \mathrm{h}\end{array}$ & 80 & NA & 4,294 & 80 & $\mathrm{NA}$ & 4,294 & 83 & NA & 4,920 & NA & NA & NA & 86 & $\mathrm{NA}$ & 6,491 & 94 & NA & 9,839 \\
\hline $\begin{array}{l}\text { Instantaneous Water Heater, } \\
\text { Gas-Fired, with integral tank, } \\
500 \mathrm{kBtu} / \mathrm{h}\end{array}$ & 77 & 1,649 & 5,466 & 80 & 1,725 & 5,747 & 82 & 1,725 & 6,027 & 82 & 1,667 & 6,059 & 86 & 1,110 & 9,730 & 94 & 1,110 & 12,055 \\
\hline Electric (120 gal) & 99.4 & 343 & 1,862 & 99.3 & 403 & 1,862 & 99.4 & 348 & 1,900 & NA & NA & NA & NA & NA & NA & NA & NA & NA \\
\hline
\end{tabular}




\subsection{Energy Savings and Economic Impact Analysis}

This section describes the methodology and key data inputs to estimate energy savings and economic impacts of alternative efficiency levels for products addressed in the screening analysis. Section 3.1 provides an overview of the energy savings and economic analysis methodology. Section 3.2 discusses the key data sources and assumptions used in the economic analysis-energy prices, the conversion of delivered to primary energy, the discount rate, the shipment projections, and product cost markups. The methodology and the resulting estimates of national energy savings and national net present value are included in Section 3.3. Section 3.4 presents the detailed methodology used to generate life-cycle cost (LCC) estimates by building type and region and to aggregate them to national impacts. Section 3.5 discusses the expected reduction in carbon emissions associated with the national energy savings. Finally, Section 3.6 presents the aggregated summary results for national energy savings, carbon emission savings, and NPV for all products considered in the screening analysis. A one-page summary of the energy and economic results for each product is provided. A more detailed discussion of the results for selected products using this one-page summary is contained in Appendix C (Section C.4).

\subsection{Overview of Methodology}

Figure 3.1 presents an overview of the energy savings and economic impacts analysis conducted as part of the screening analysis. The figure is divided into three columns. The leftmost column shows the inputs from the engineering analysis. The center column shows the key inputs and outputs that are estimated for each of the 77 market segments (product of 7 building types and 11 subcensus divisions) that were used in the overall analysis. The rightmost column shows the aggregation of both energy savings and economic results to national values.

With respect to the engineering analysis, the top left box shows the estimated FLEOH (generated for each of the market segments) that serve as the primary input to estimating unit energy consumption. Of course, the unit consumption also depends upon the capacity of the equipment and the efficiency level. To estimate national energy consumption, unit energy consumption was multiplied by an estimate of product shipments to each market segment and then summed to a national total. Lacking direct information on regional shipments of equipment, the approach in the screening analysis was to use information on the distribution of commercial building floor space and the percentage of floor space served by generic types of equipment to generate estimates of distributions of shipments by market segment. These distributions were applied to projections of total national shipments to yield projections of shipments by market segment. (The methodology and data sources to generate these distributions are described in Appendix B.) National energy savings estimates were calculated as the difference in national energy consumption between two assumed levels (a baseline standard and a potentially higher standard) of energy efficiency for the product being analyzed. 


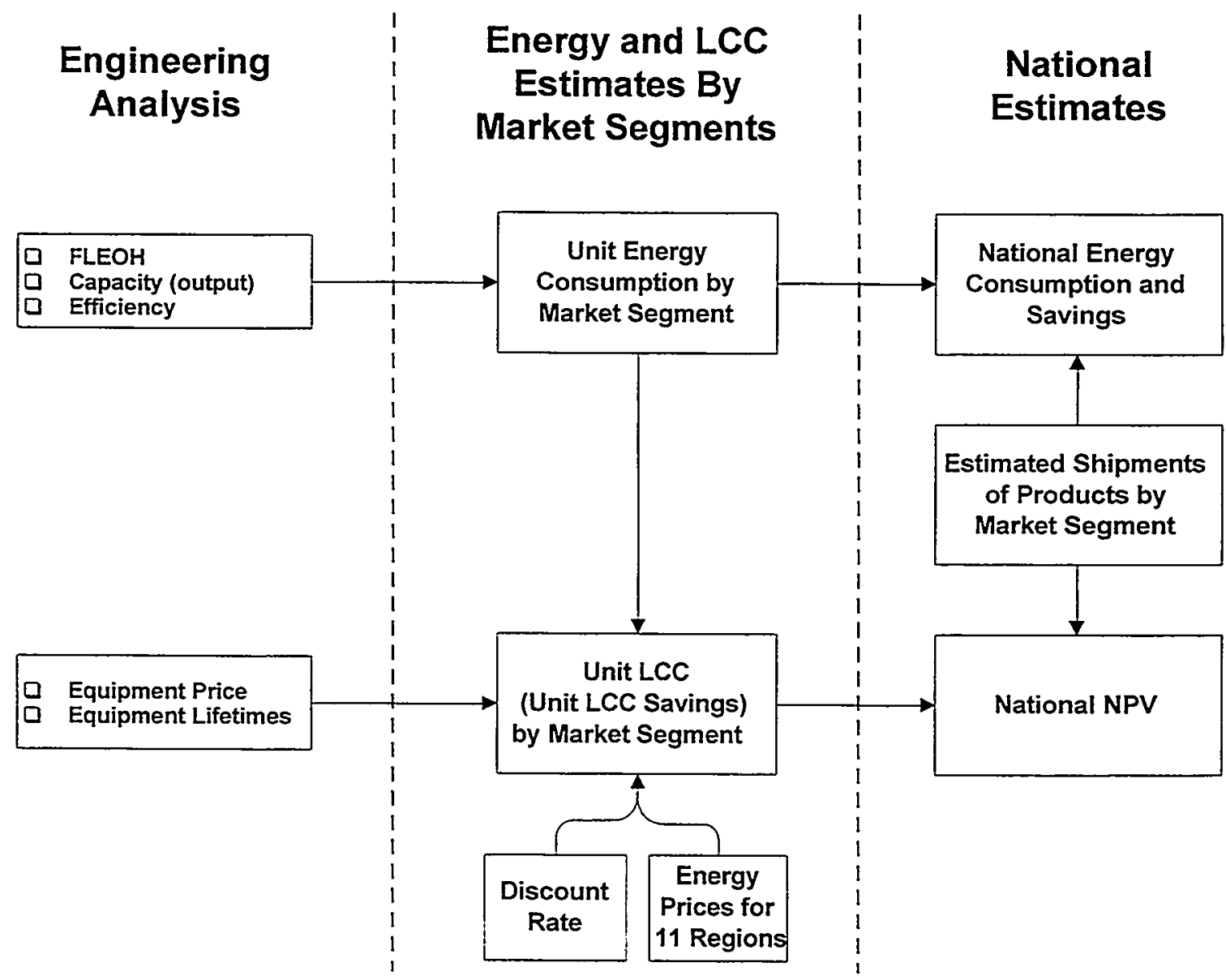

Figure 3.1. Overview of the Energy Savings and Economic Analysis Methodology

The LCC analysis was also conducted at the market segment level. Among other inputs, for a single unit of equipment, the LCC analysis requires estimates of the price (first cost) of the equipment as well as annual energy consumption. The equipment price information and estimated lifetime of the equipment are also inputs to the analysis. Unit energy consumption feeds directly into the LCC analysis as shown in the middle column. The two boxes at the bottom of the middle column illustrate the two remaining inputs to generate LCC-discount rate and energy prices. Energy prices were determined for the subcensus divisions (modified census divisions) used in the market segment analysis, and were assumed constant for all representative building types within a given division.

National NPV was based upon an aggregation of the LCC estimates for each market segment, again using the estimated distribution of shipments by market segment.

\subsection{Data and Key Assumptions}

LCC measures are functions of the unit energy consumption, equipment prices, energy prices, and the discount rate. The approach for determining the unit energy consumption and equipment prices is 
discussed in Section 2.0. This section documents the approach used to generate energy prices for the economic analysis, as well as the discount rate chosen. In addition, conversion factors are needed to convert delivered energy to a primary basis.

\subsubsection{Energy Prices}

The Energy Information Administration (EIA) Annual Energy Outlook (AEO) provided the projected energy prices used in the screening analysis (EIA 1999b). The AEO projects energy prices by census division for all major fuels for each sector (residential, commercial, industrial, and transportation). The AEO extends to only 2020, whereas the screening analysis used a time horizon extending to 2030 . The energy prices beyond 2020 were fixed at the AEO 2020 levels.

As described in Appendix B, the Mountain and Pacific census divisions were split into "north" and "south" regions. The projected energy prices for these subcensus divisions were estimated using adjustment factors applied to the AEO energy price projections. This process is explained in Appendix B.

We had to consider how to account for the (electricity) demand charges that may affect the economics of higher-efficiency cooling equipment. A priori, the impact of demand charges is expected to result in a marginal price of electricity that exceeds the average price because the contribution of lower cooling energy consumption is expected to have a greater proportional effect on peak load than on the total energy consumption. A rough analysis of the effect of demand charges on the marginal electricity price showed that adding perhaps 1 to 1.5 cents per $\mathrm{kWh}$ to the average electricity price would adequately account for this effect. ${ }^{(a)}$

For the screening analysis, a somewhat higher price for electricity (for cooling) was used to adequately reflect the national benefits of reducing peak summer electricity demand. In part, to give additional weight to the presence of buildings with relatively higher summer electric peak loads, electricity prices in the screening analysis were uniformly adjusted upward by $5 \%$. Table 3.1 shows the final sets of regional energy prices for selected years, including the electricity price adjustment used in the screening analysis.

Toward the end of the analysis, a quick assessment of the electricity price was done using Ernest Orlando Lawrence Berkley National Laboratory's (LBNL) existing database of utility rate structures. The initial assessment was that, averaged across 30 utilities representing $26 \%$ of all commercial customers nationwide, the effective marginal price that would be appropriate for reductions in cooling energy consumption was higher ( $3 \%$ to $4 \%$ ) than the average price, just slightly less than the $5 \%$ adjustment used in the screening analysis.

(a) Memorandum from Steven Nadel and Keith Emerson to the SSPC 90.1 HVAC panel dated March 7, 1994, regarding demand charges for cooling equipment. 
Table 3.1. Electricity and Gas Prices Used for Screening Analysis

\begin{tabular}{|l|lllll|}
\hline \multicolumn{1}{|c|}{ Region } & \multicolumn{5}{|c|}{ Electricity } \\
\multicolumn{1}{|c}{ (cents per kWh) } \\
\hline Northeast & $\mathbf{2 0 0 0}$ & $\mathbf{2 0 0 5}$ & $\mathbf{2 0 1 0}$ & $\mathbf{2 0 2 0}$ & $\mathbf{2 0 3 0}$ \\
Mid-Atlantic & 9.8 & 9.3 & 8.3 & 7.9 & 7.9 \\
East North Central & 9.8 & 8.4 & 7.9 & 7.8 & 7.8 \\
West North Central & 7.4 & 6.6 & 6.2 & 6.0 & 6.0 \\
South Atlantic & 6.9 & 6.4 & 6.4 & 6.1 & 6.1 \\
East South Central & 6.7 & 6.2 & 6.2 & 6.0 & 6.0 \\
West South Central & 6.7 & 6.3 & 6.2 & 6.1 & 6.1 \\
Mountain North & 6.9 & 6.5 & 6.4 & 6.3 & 6.3 \\
Mountain South & 6.2 & 6.1 & 6.1 & 5.8 & 5.8 \\
Pacific North & 7.8 & 7.6 & 7.6 & 7.3 & 7.3 \\
Pacific South & 5.0 & 4.5 & 4.4 & 4.3 & 4.3 \\
U.S. Average & 9.5 & 8.5 & 8.3 & 8.2 & 8.2 \\
\hline & 7.6 & 6.9 & 6.7 & 6.5 & 6.5 \\
\hline \multicolumn{1}{|c}{ Region } & $\mathbf{5 0 0 0}$ & $\mathbf{2 0 0 5}$ & $\mathbf{2 0 1 0}$ & $\mathbf{2 0 2 0}$ & $\mathbf{2 0 3 0}$ \\
\hline Northeast & 7.08 & 7.02 & 6.93 & 6.71 & 6.71 \\
Mid-Atlantic & 5.30 & 5.34 & 5.39 & 5.39 & 5.39 \\
East North Central & 5.37 & 5.35 & 5.36 & 5.35 & 5.35 \\
West North Central & 4.96 & 5.04 & 5.03 & 5.03 & 5.03 \\
South Atlantic & 6.45 & 6.21 & 6.19 & 6.09 & 6.09 \\
East South Central & 5.81 & 5.68 & 5.76 & 5.82 & 5.82 \\
West South Central & 4.84 & 4.76 & 4.87 & 5.01 & 5.01 \\
Mountain North & 4.63 & 4.95 & 5.24 & 5.26 & 5.26 \\
Mountain South & 4.63 & 4.95 & 5.24 & 5.26 & 5.26 \\
Pacific North & 5.79 & 5.97 & 6.00 & 5.69 & 5.69 \\
Pacific South & 5.79 & 5.97 & 6.00 & 5.69 & 5.69 \\
U.S. Average & 5.47 & 5.48 & 5.53 & 5.50 & 5.50 \\
\hline
\end{tabular}

\subsubsection{Energy Conversion Factors}

The final national estimates of energy savings for the screening analysis are defined on a primary energy basis and, thus, include generation and transmission losses in addition to the energy delivered to the building. For electricity, the conversion from delivered to primary energy is based on the commercial-sector projections of delivered electricity and electricity losses from the AEO 2000. Table 2 from the AEO 2000 provides delivered electricity and associated losses for 1998, 2005, 2010, 2015, and 2020 (EIA 1999a, Reference Case, Table 2, p. 118). The ratios of [(delivered + losses)/(delivered)] were calculated for these years and then interpolated for the intervening years. The resulting conversion factors were then used to convert the annual electricity consumption estimates for the various efficiency levels to primary energy (trillion Btu or TBtu) estimates. 
Some losses are also incurred in the transmission and distribution of natural gas (e.g., natural gas used to power pumps along gas pipelines). The screening analysis used the estimate of $11 \%$ losses (as used in the residential water heater analysis).

\subsubsection{Discount Rate}

For the calculations of LCC and NPV, the preliminary screening analysis used a constant 7\% (real) discount rate. This value has been used in prior DOE analyses of residential appliances to generate estimates of national NPV from more stringent equipment efficiency standards. This particular value is motivated by the recommendation of the Office of Management and Budget (OMB) in Circular A-94, (OMB 1992). Circular A-94 indicates that this value corresponds to the approximate marginal pretax rate of return on the average investment in the private sector in recent years.

\subsubsection{Shipment Forecasts}

Section 2.0 describes the data sources and assumptions to estimate total shipments of each product for a recent year, nominally chosen as 1999 . The estimates of national energy savings and carbon emissions through 2030 depend upon the differences in unit energy savings from higher efficiency as well as the projected total shipments over the time frame. A constant $1 \%$ growth rate was applied to the estimate of 1999 shipments to generate the projected levels of shipments over the analysis period. The $1 \%$ growth rate was motivated by the AEO 2000 (EIA 1999a) projection of the growth rate in total commercial building floor space between 1998 and 2020 of $0.9 \%$ per year. The use of a common growth rate for all products results in comparisons of potential energy savings that reflect only the economics of higher efficiency levels and the current shipments.

\subsubsection{Equipment Price Markups}

The development of contractor costs for all equipment analyzed in the screening analysis was discussed in detail in Section 2.0. As discussed in Section 2.8.1, the equipment cost is generally marked up as part of the contractor's final price to the builder owner. Following the assumptions in related work (Barwig et al. 1996; data used during Standard 90.1-1999 development), a 25\% markup factor was applied to contractor costs for all equipment.

\subsection{National Energy Consumption and Energy Savings}

As stated above, the energy consumption and energy savings are based on the estimates of FLEOH generated in the engineering analysis and on the aggregation procedures described in Section 2.0. The economic analysis focuses on an LCC approach, which yields some insight into the distribution of cost savings by market segment, as well as measures of aggregate economic benefit to the nation. This section lays out the method to compute the energy savings and economic benefit measures. 


\subsubsection{Methodology}

The engineering analysis yields an estimate of the FLEOH for each market segment. With the estimate of FLEOH, annual energy consumption for a unit of equipment in each market segment can be expressed by Equation (2.4). Total consumption in each market segment is based on unit annual energy consumption multiplied by projected shipments to that segment. The estimates of shipments to the market segments are based on a projected distribution by market segment applied to total national shipments (a single value for each year). ${ }^{(a)}$ Using the letter (k) to designate the level of efficiency, national energy consumption is calculated by summing the estimated consumption for all market segments, as in

$$
\begin{aligned}
& \text { National Energy Consumption }(k)= \\
& \frac{\left(\sum_{i}^{7} \sum_{j}^{11} \mathrm{MS}_{i, j} \times \text { Shipments } x \text { Rated Capacity } x \text { FLEOH }_{i, j}\right)}{\text { Rated Efficiency } y_{k}}
\end{aligned}
$$

where $\quad \mathrm{MS}_{\mathrm{i}, \mathrm{j}}=$ share of national shipments installed in market segment $\mathrm{i}, \mathrm{j}$

$i=$ building type

$\mathrm{j}=$ subcensus division

Shipments $=$ total units shipped, nationally.

Because of the linearity of the entire process, the value of national energy consumption from Equation (3.1) is identical to the value calculated from a national average FLEOH (FLEOH US ) and total national shipments. ${ }^{(b)}$ This alternative formulation is shown as:

$$
\text { National Energy Consumption }(\mathrm{k})=\frac{\left(\text { Shipments } \times \text { Rated Capacity } \times \text { FLEOH }_{\text {US }}\right)}{\text { Rated Efficiency }}
$$

For water heaters, the existence of standby losses complicates the expression in Equation (3.1) [or (3.2)] to some degree. Standby losses are expressed in British thermal units per hour (Btu/h) and thus the annual consumption is expressed as the product of the number of hours the water heater is not firing $(8760-$ FLEOH) times the standby loss per hour. Thus, national energy consumption for water heaters is calculated as:

$$
\begin{aligned}
& \text { National Energy Consumption }(\mathrm{k})= \\
& \text { Shipments } x\left(\frac{\left(\text { Rated Capacity } \times \text { FLEOH }_{\text {US }}\right)}{\text { Rated Efficiency }}+(8760-\text { FLEOH }) \times \text { Standby loss }\right)
\end{aligned}
$$

(a) The definitions of the market segments and methodology to project shipments to each market segment are discussed in Appendix B.

(b) The derivation of FLEOH US $_{\text {is }}$ iscribed at the end of Appendix B. 
By convention, for the baseline efficiency, $k$ is assigned a value of 0 . With this notation, energy savings for any selected efficiency level higher than the baseline is given by:

$$
\begin{aligned}
& \text { National Energy Savings }(k)= \\
& \text { National Energy Consumption(0) - National Energy Consumption(k) }
\end{aligned}
$$

While shipments in Equations (3.1) through (3.3) can be either annual or cumulative, to estimate national energy savings in any future year, we must account for the influence of equipment turnover. Assuming that all units are replaced at the end of their assumed lifetime, total national energy consumption is the sum of the previous $\mathrm{N}$ years of shipments (yielding the currently installed stock) times the unit energy consumption. The annual savings in any year is the difference in the energy consumption of the stock evaluated at the two efficiency levels.

\subsubsection{Energy Savings Results}

The national energy savings estimates for all of the efficiency levels analyzed in the screening analysis are presented in Tables 3.2 through 3.4. Table 3.2 shows the estimates for the 22 cooling products analyzed. The first two columns show the baseline energy consumption and EER for each cooling product, based upon the efficiency level specified in EPCA 92. Baseline energy consumption is defined as the cumulative energy consumption of all products in that size category sold between 2004 and 2030. The top three products in terms of overall energy consumption are the 3-phase single-package air conditioner $(<65 \mathrm{kBtu} / \mathrm{h})$, the central air source air conditioner $(\geq 65 \mathrm{kBtu} / \mathrm{h}$ and $<135 \mathrm{kBtu} / \mathrm{h}$ ), and the central air source air conditioner $(\geq 135 \mathrm{kBtu} / \mathrm{h}$ and $<240 \mathrm{kBtu} / \mathrm{h})$.

The 3-phase unitary and HP equipment are available up to a SEER of 15. At these efficiency levels, the potential savings through 2030 would exceed four quads of primary energy.

For the small central air source AC unit ( $\geq 65 \mathrm{kBtu}$ and $\leq 135 \mathrm{kBtu})$, the adoption of Standard 90.11999 is expected to achieve about 0.9 quads ( $900 \mathrm{TBtu}$ ) of savings over the 2004 to 2030 time frame. This level of energy savings results from an increase in EER from 8.5 to 9.7. For an efficiency of 11.5 EER, the additional energy savings potential is nearly one quad.

The energy savings potentials for heating products are shown in Table 3.3. In terms of total energy consumption, the category is dominated by gas-fired furnaces (as part of packaged space-conditioning equipment). Baseline energy consumption for the two size categories of furnaces over the 2004 to 2030 period is nearly 16 quads, while consumption for all of the boiler classes is less than 5 quads. All of the efficiency metrics are in terms of thermal efficiency. Thermal efficiency generally ranges from 3-to-5 percentage points less than the combustion efficiency levels for these products.

Table 3.4 shows the national energy savings potential for the commercial water-heating equipment considered in the analysis. To maintain simplicity in the table, only the thermal efficiency requirement of the storage water heaters is shown in the table. In some cases, two levels of energy savings are shown for the same thermal efficiency; this result arises from different standby loss requirements. 
Table 3.2. National Baseline Energy Consumption and Energy Savings - Space-Cooling Equipment

\begin{tabular}{|c|c|c|c|c|c|c|c|c|c|c|c|c|}
\hline \multirow[b]{2}{*}{ Product } & \multicolumn{2}{|c|}{ EPCA 1992} & \multicolumn{2}{|c|}{$\begin{array}{l}\text { Standard } 90.1-1999 \\
\text { Relative to EPCA } 92 \\
\end{array}$} & \multicolumn{2}{|c|}{\begin{tabular}{|c|} 
Efficiency Level 1 \\
Relative to 90.1-1999 \\
\end{tabular}} & \multicolumn{2}{|c|}{$\begin{array}{c}\text { Efficiency Level } 2 \\
\text { Relative to } 90.1-1999 \\
\end{array}$} & \multicolumn{2}{|c|}{\begin{tabular}{|c|} 
Efficiency Level 3 \\
Relative to $90.1-1999$
\end{tabular}} & \multicolumn{2}{|c|}{$\begin{array}{c}\text { Efficiency Level } 4 \\
\text { Relative to } 90.1-1999\end{array}$} \\
\hline & $\begin{array}{c}2004-2030 \\
\text { Bascline } \\
\text { Consumption } \\
\text { (TBtu) } \\
\end{array}$ & EER & EER & $\begin{array}{l}\text { Encrgy } \\
\text { Savings } \\
\text { (TBtu) }\end{array}$ & EER & $\begin{array}{c}\text { Energy } \\
\text { Savings } \\
\text { (TBtu) } \\
\end{array}$ & EER & $\begin{array}{l}\text { Energy } \\
\text { Savings } \\
\text { (TBtu) }\end{array}$ & EER & $\begin{array}{l}\text { Energy } \\
\text { Savings } \\
\text { (TBtu) } \\
\end{array}$ & EER & $\begin{array}{c}\text { Encrgy } \\
\text { Savings } \\
\text { (TBtu) }\end{array}$ \\
\hline 3-Phase, Single-Packaged, Air-Source AC, $<65 \mathrm{kBtu} / \mathrm{h}$ & 7,371 & 9.7 & 9.7 & 0.0 & 11.0 & 871.1 & 12.0 & 1412.7 & 13.0 & 1871.0 & 15.0 & 2604.3 \\
\hline 3-Phase, Single-Packaged, Air-Source HP, $<65 \mathrm{kBtu} / \mathrm{h}$ & 958 & 9.7 & 9.7 & 0.0 & 11.0 & 113.2 & 12.0 & 183.6 & 13.0 & 243.1 & 15.0 & 338.4 \\
\hline 3-Phase, Split, Air-Source AC, $<65 \mathrm{kBtu} / \mathrm{h}$ & 3,064 & 10.0 & 10.0 & 0.0 & 11.0 & 278.6 & 12.0 & 510.7 & 13.0 & 707.1 & 15.0 & 1021.4 \\
\hline 3-Phase, Split, Air-Source HP, $<65 \mathrm{kBtu} / \mathrm{h}$ & 398 & 10.0 & 10.0 & 0.0 & 11.0 & 36.2 & 12.0 & 66.4 & 13.0 & 91.9 & 15.0 & 132.7 \\
\hline Central, Air-Source $A C, \geq 65$ and $<135 \mathrm{kBtu} / \mathrm{h}$ & 8,813 & 8.9 & 10.3 & 1197.9 & 10.5 & 145.0 & 10.8 & 352.5 & 11.0 & 484.6 & 12.5 & 1340.2 \\
\hline Central, Air-Source HP, $\geq 65$ and $<135 \mathrm{kBtu} / \mathrm{h}$ & 908 & 8.9 & 10.1 & 107.9 & 10.5 & 30.5 & 10.6 & 37.7 & 11.0 & 65.5 & 11.7 & 109.4 \\
\hline Central, Water-Cooled $\mathrm{AC},<65 \mathrm{kBtu} / \mathrm{h}$ & 28 & 9.3 & 12.1 & 6.6 & 12.5 & 0.7 & 13.1 & 1.7 & 14.0 & 3.0 & 12.5 & 0.7 \\
\hline Central, Water-Source HP, $<17 \mathrm{kBtu} / \mathrm{h}$ & 333 & 9.3 & 11.2 & 56.5 & 12.5 & 28.8 & 13.1 & 40.1 & 14.0 & 55.3 & 15.8 & 80.5 \\
\hline Central, Water-Source HP, $>17$ and $<65 \mathrm{kBtu} / \mathrm{h}$ & 2,096 & 9.3 & 12.0 & 471.6 & 12.5 & 65.0 & 13.1 & 136.4 & 14.0 & 232.1 & 15.2 & 342.0 \\
\hline Central, Water-Cooled AC, $\geq 65$ and $<135 \mathrm{kBtu} / \mathrm{h}$ & 41 & 10.5 & 11.5 & 3.6 & 12.0 & 1.6 & 12.4 & 2.7 & 14.0 & 6.7 & NA & NA \\
\hline Central, Water-Source HP, 265 and $<135 \mathrm{kBtu} / \mathrm{h}$ & 256 & 10.5 & 12.0 & 32.0 & 12.5 & 8.9 & 13.0 & 17.2 & 14.0 & 32.0 & NA & NA \\
\hline Central, Air-Source AC, $\geq 135$ and $<240 \mathrm{kBtu} / \mathrm{h}$ & 7,270 & 8.5 & 9.7 & 899.4 & 10.2 & 312.3 & 10.4 & 428.8 & 10.8 & 648.9 & 11.5 & 997.2 \\
\hline Central, Air-Source HP, $\geq 135$ and $<240 \mathrm{kBtu} / \mathrm{h}$ & 324 & 8.5 & 9.3 & 27.9 & 9.8 & 15.1 & 10.4 & 31.4 & 10.8 & 41.2 & 10.5 & 33.9 \\
\hline Central, Water-Cooled $A C, \geq 135$ and $<240 \mathrm{kBtu} / \mathrm{h}$ & 67 & 9.6 & 11.0 & 8.5 & 11.1 & 0.5 & 11.2 & 1.0 & 11.3 & 1.6 & 11.5 & 2.5 \\
\hline Packaged Terminal AC, $<7 \mathrm{kBtu} / \mathrm{h}$ & 75 & 8.9 & 9.4 & 4.2 & 11.0 & 10.2 & 11.2 & 11.5 & 0.0 & NA & 11.6 & 13.3 \\
\hline Packaged Terminal $\mathrm{AC}, 7-10 \mathrm{kBtu} / \mathrm{h}$ & 567 & 8.6 & 9.0 & 26.7 & 10.6 & 81.7 & 10.8 & 92.1 & 11.5 & 118.3 & 11.5 & 118.3 \\
\hline Packaged Terminal AC, $10-13 \mathrm{kBtu} / \mathrm{h}$ & 848 & 8.1 & 8.3 & 26.8 & 9.9 & 132.1 & 10.2 & 149.7 & 10.5 & 168.6 & 10.7 & 180.8 \\
\hline Packaged Terminal $\Lambda \mathrm{C},>13 \mathrm{kBtu} / \mathrm{h}$ & 488 & 7.8 & 7.9 & 9.7 & 9.5 & 80.3 & 9.8 & 91.3 & 10.0 & 99.5 & 10.0 & 99.5 \\
\hline Packaged Terminal HP, $<7 \mathrm{kBtu} / \mathrm{h}$ & 66 & 8.9 & 9.3 & 3.1 & 10.8 & 8.8 & 11.0 & 10.0 & 0.0 & NA & 11.6 & 12.5 \\
\hline Packaged Terminal HP, 7-10 kBtu/h & 543 & 8.6 & 8.9 & 19.7 & 10.4 & 75.6 & 10.6 & 85.9 & 11.4 & 115.5 & 11.5 & 119.0 \\
\hline Packaged Terminal HP, $10-13 \mathrm{kBtu} / \mathrm{h}$ & 647 & 8.1 & 8.2 & 12.9 & 9.7 & 97.6 & 10.0 & 111.5 & 10.5 & 136.2 & 10.7 & 145.5 \\
\hline Packaged Terminal HP, $>13 \mathrm{kBtu} / \mathrm{h}$ & 410 & 7.8 & 7.8 & 3.0 & 9.3 & 65.5 & 9.6 & 75.1 & 10.0 & 88.8 & 10.0 & 88.8 \\
\hline
\end{tabular}


Tạble 3.3. National Baseline Energy Consumption and Energy Savings - Space-Heating Equipment

\begin{tabular}{|c|c|c|c|c|c|c|c|c|c|c|c|c|}
\hline \multirow[b]{2}{*}{$\begin{array}{r}\text { Product } \\
\end{array}$} & \multicolumn{2}{|c|}{ EPCA 1992} & \multicolumn{2}{|c|}{$\begin{array}{l}\text { Standard } 90.1-1999 \\
\text { Relative to EPCA } 92 \\
\end{array}$} & \multicolumn{2}{|c|}{$\begin{array}{c}\text { Efficiency Level 1 } \\
\text { Relative to 90.1-1999 }\end{array}$} & \multicolumn{2}{|c|}{$\begin{array}{c}\text { Efficiency Level } 2 \\
\text { Relative to 90.1-1999 } \\
\end{array}$} & \multicolumn{2}{|c|}{\begin{tabular}{|c|} 
Efficiency Level 3 \\
Relative to 90.1-1999 \\
\end{tabular}} & \multicolumn{2}{|c|}{$\begin{array}{l}\text { Efficiency Level } 4 \\
\text { Relative to 90.1-1999 }\end{array}$} \\
\hline & \begin{tabular}{|c|}
$2004-2030$ \\
Baseline \\
Consumption \\
(TBtu)
\end{tabular} & $\begin{array}{c}\text { Thermal } \\
\text { Efficiency } \\
(\%)\end{array}$ & $\begin{array}{c}\text { Thermal } \\
\text { Efriciency } \\
(\%)\end{array}$ & $\begin{array}{l}\text { Energy } \\
\text { Savings } \\
\text { (TBtu) } \\
\end{array}$ & $\begin{array}{c}\text { Thermal } \\
\text { Erficiency } \\
(\%)\end{array}$ & $\begin{array}{l}\text { Energy } \\
\text { Savings } \\
\text { (TBtu) }\end{array}$ & $\begin{array}{c}\text { Thermal } \\
\text { Efficiency } \\
(\%)\end{array}$ & $\begin{array}{l}\text { Energy } \\
\text { Savings } \\
\text { (TBtu) } \\
\end{array}$ & $\begin{array}{c}\text { Thermal } \\
\text { Efficiency } \\
(\%) \\
\end{array}$ & $\begin{array}{c}\text { Energy } \\
\text { Savings } \\
\text { (TBtu) } \\
\end{array}$ & $\begin{array}{c}\text { Thermal } \\
\text { Efriciency } \\
(\%)\end{array}$ & $\begin{array}{l}\text { Energy } \\
\text { Savings } \\
\text { (TBtu) } \\
\end{array}$ \\
\hline Packaged Boilers, Gas-Fired, $400 \mathrm{kBtu} / \mathrm{h}, \mathrm{HW}$ & 684 & 75.0 & 75.0 & 0.0 & 78.0 & 26.3 & 79.0 & 34.7 & 81.0 & 50.7 & 88.0 & 101.1 \\
\hline Packaged Boilcrs, Gas-Fired, $800 \mathrm{kBtu} / \mathrm{h}, \mathrm{HW}$ & 1,493 & 75.0 & 75.0 & 0.0 & 76.0 & 19.6 & 78.0 & 57.4 & 79.0 & 75.6 & 88.0 & 220.5 \\
\hline Packaged Boilers, Gas-Fired, $1,500 \mathrm{kBtu} / \mathrm{h}, \mathrm{HW}$ & 491 & 75.0 & 75.0 & 0.0 & 77.0 & 12.8 & 78.0 & 18.9 & 79.0 & 24.9 & 88.0 & 72.6 \\
\hline Packaged Boilcrs, Gas-Fired, $3,000 \mathrm{kBtu} / \mathrm{h}, \mathrm{HW}$ & 324 & 75.0 & 75.0 & 0.0 & 78.0 & 12.5 & 79.0 & 16.4 & 80.0 & 20.2 & 88.0 & 47.8 \\
\hline Packaged Boilers, Gas-Fired, $400 \mathrm{kBtu} / \mathrm{h}$, Steam & 320 & 72.0 & 75.0 & 12.8 & 76.0 & 4.0 & 77.0 & 8.0 & 79.0 & 15.6 & 82.0 & 26.3 \\
\hline Packaged Boilers, Gas-Fired, $800 \mathrm{kBlu} / \mathrm{h}$, Steam & 875 & 72.0 & 75.0 & 35.0 & 76.0 & 11.1 & 78.0 & 32.3 & 79.0 & 42.5 & 82.0 & 71.7 \\
\hline $\begin{array}{l}\text { Packaged Boilers, Gas-Fired, } 1,500 \mathrm{kBtu} / \mathrm{h}, \\
\text { Steam }\end{array}$ & 402 & 72.0 & 75.0 & 16.1 & 77.0 & 10.0 & 78.0 & 14.8 & 79.0 & 19.5 & 81.0 & 28.6 \\
\hline $\begin{array}{l}\text { Packaged Boilers, Gas-Fired, 3,000 kBtu/h, } \\
\text { Steam }\end{array}$ & 256 & 72.0 & 72.0 & 0.0 & 78.0 & 19.7 & 79.0 & 22.7 & 80.0 & 25.6 & 82.0 & 31.2 \\
\hline Warm-Air Furnaces, Gas-Fired, $250 \mathrm{kBtu} / \mathrm{h}$ & 7,392 & 75.1 & 77.5 & 236.5 & 78.5 & 91.1 & 79.5 & 180.0 & 0.0 & $\mathrm{~N} \Lambda$ & 85.5 & 669.3 \\
\hline Warm-Air Furnaces, Gas-Fired, $400 \mathrm{kBtu} / \mathrm{h}$ & 7,562 & 75.1 & 77.5 & 241.9 & 78.5 & 93.2 & 79.5 & 184.1 & 0.0 & $\overline{N A}$ & 85.5 & 684.7 \\
\hline
\end{tabular}

Table 3.4. National Baseline Energy Consumption and Energy Savings - Water-Heating Equipment

\begin{tabular}{|c|c|c|c|c|c|c|c|c|c|c|c|c|}
\hline \multirow[b]{2}{*}{ Product } & \multicolumn{2}{|c|}{ EPCA 1992} & \multicolumn{2}{|c|}{$\begin{array}{l}\text { Standard } 90.1-1999 \\
\text { Relative to EPCA } 92\end{array}$} & \multicolumn{2}{|c|}{$\begin{array}{l}\text { Efficiency Level I } \\
\text { Relative to 90.1.1999 }\end{array}$} & \multicolumn{2}{|c|}{$\begin{array}{c}\text { Efficiency Level } 2 \\
\text { Relative to 90.1-1999 }\end{array}$} & \multicolumn{2}{|c|}{$\begin{array}{c}\text { Efficiency Level } 3 \\
\text { Relative to } 90.1-1999\end{array}$} & \multicolumn{2}{|c|}{$\begin{array}{c}\text { Efficiency Level } 4 \\
\text { Relative to 90.1-1999 }\end{array}$} \\
\hline & \begin{tabular}{|c|}
$2004-2030$ \\
Baseline \\
Consumption \\
(TBtu)
\end{tabular} & $\begin{array}{l}\text { Thermal } \\
\text { Efficiency } \\
(\%)\end{array}$ & $\begin{array}{c}\text { Thermal } \\
\text { Efficiency } \\
(\%)\end{array}$ & $\begin{array}{l}\text { Energy } \\
\text { Savings } \\
\text { (TBtu) }\end{array}$ & $\begin{array}{c}\text { Thermal } \\
\text { Efficiency } \\
\text { (\%) }\end{array}$ & $\begin{array}{l}\text { Energy } \\
\text { Savings } \\
\text { (TBtu) }\end{array}$ & $\begin{array}{c}\text { Thermal } \\
\text { Efficiency } \\
(\%)\end{array}$ & $\begin{array}{l}\text { Energy } \\
\text { Savings } \\
\text { (TBtu) }\end{array}$ & $\begin{array}{c}\text { Thermal } \\
\text { Efficiency } \\
(\%)\end{array}$ & $\begin{array}{l}\text { Energy } \\
\text { Savings } \\
\text { (TBtu) }\end{array}$ & $\begin{array}{c}\text { Thermal } \\
\text { Efficiency } \\
(\%)\end{array}$ & $\begin{array}{l}\text { Energy } \\
\text { Savings } \\
\text { (TBtu) }\end{array}$ \\
\hline Storage Water Heater, Gas-Fired, $120 \mathrm{kBtu} / \mathrm{h}$ & 408 & 78.0 & 80.0 & 12.5 & 82.0 & 8.6 & 82.0 & 10.5 & 86.0 & 35.9 & 94.0 & 63.9 \\
\hline Storage Water Heater, Gas-Fired, $199 \mathrm{kBtu} / \mathrm{h}$ & 1,282 & 78.0 & 80.0 & 23.2 & 82.0 & 28.2 & 82.0 & 32.6 & 86.0 & 111.8 & 94.0 & 203.5 \\
\hline Storage Water Heater, Gas-Fired, $360 \mathrm{kBtu} / \mathrm{h}$ & 2,188 & 78.0 & 80.0 & 30.7 & 82.0 & 49.8 & 82.0 & 54.1 & 86.0 & 188.6 & 94.0 & 350.2 \\
\hline $\begin{array}{l}\text { Instantaneous Water Heater, Gas-Fired, } \\
400 \mathrm{kBtu} / \mathrm{h}\end{array}$ & 2,822 & 80.0 & 80.0 & 0.0 & 83.0 & 40.8 & NA & $\mathrm{NA}$ & 86.0 & 78.7 & 94.0 & 168.1 \\
\hline $\begin{array}{l}\text { Instantaneous Water Heater, Gas-Fired, } \\
1,000 \mathrm{kBtu} / \mathrm{h}\end{array}$ & 2,822 & 80.0 & 80.0 & 0.0 & 83.0 & 102.0 & NA & NA & 86.0 & 196.9 & 94.0 & 420.2 \\
\hline $\begin{array}{l}\text { Instantaneous Tank Type, Water Heater, Gas- } \\
\text { Fired, } 500 \mathrm{kBtu} / \mathrm{h}\end{array}$ & 155 & 77.0 & 80.0 & 5.3 & 82.0 & 3.5 & 82.0 & 3.7 & 86.0 & 12.4 & 94.0 & 23.8 \\
\hline Electric (120 gal) & 738 & 99.4 & 99.3 & -7.2 & 99.4 & 6.6 & NA & NA & 0.0 & NA & $\mathrm{NA}$ & NA \\
\hline
\end{tabular}


For gas-fired storage water heaters, the estimated total energy savings from adopting Standard 90.11999 is about 125 TBtu. With fully condensing units at $94 \%$ efficiency, the savings would climb to over 500 TBtu (or over one-half quad).

Based on the available information, the estimated consumption of instantaneous-type water heaters is significant in the commercial sector. At the baseline level of efficiency, these units may consume over $50 \%$ of the total natural gas used for water heating in the commercial sector. Because ASHRAE did not address these products in Standard 90.1-1999, the energy savings in the first set of columns is zero. As with storage water heaters, the selection of condensing technology for these products $(94 \%$ thermal efficiency) would yield over one-half quad of energy savings.

One size of electric water heater was also analyzed. As discussed in Section 2.0, the Standard 90.11999 appears to have relaxed the standby loss requirements for electric water heaters. This factor leads to a calculated increase in energy use (negative energy savings) of a little more than 7 TBtu as shown in Table 3.4.

\subsubsection{Estimates of National NPV}

National NPV provides an aggregate measure of the discounted total dollar savings to the nation from the use of higher-efficiency equipment. For the screening analysis, the national NPV is based on the sum of the discounted LCC savings for all 77 market segments discussed in Section 3.1. The final expression for calculating NPV is shown in Equation 3.13 (Section 3.4.2).

Tables 3.5 through 3.7 provide a summary of the national NPV for up to four efficiency levels beyond those in the Standard 90.1-1999.

Table 3.5 shows the NPV for cooling products. The first row of the table presents the results for 3-phase single package cooling equipment. The "Efficiency Level 2" has the maximum NPV [897.7 million (1998) dollars] of the four efficiency levels considered in the screening analysis.

The higher efficiency levels for this product, at EERs of 13 and 15 show negative NPV values. In these instances, the discounted energy cost savings from higher efficiency levels are insufficient to offset the increase in first cost of the equipment. As is shown in the subsequent section, these results reflect the underlying life-cycle costs that tend to increase for higher levels of efficiency. For some products, [(e.g., central air source $A C(\geq 65 \mathrm{kBtu} / \mathrm{h}$ and $<135 \mathrm{kBtu} / \mathrm{h})]$ all efficiency levels beyond the Standard 90.1-1999 have a negative NPV.

Other cooling products with relatively high values of NPV for efficiency levels beyond Standard 90.1-1999 levels include large central air-source AC equipment ( $\geq 135 \mathrm{kBtu} / \mathrm{h}$ and $<240 \mathrm{kBtu} / \mathrm{h}$ ) and several of the packaged terminal $\mathrm{AC}$ and $\mathrm{HP}$ equipment. 
Table 3.5. NPV for Efficiency Levels Exceeding Standard 90.1-1999 - Space-Cooling Equipment

\begin{tabular}{|c|c|c|c|c|c|c|c|c|c|}
\hline \multirow[b]{2}{*}{ Product } & \multirow{2}{*}{\begin{tabular}{|c|} 
ASHRAE \\
$90.1-1999$ \\
EER \\
\end{tabular}} & \multicolumn{2}{|c|}{\begin{tabular}{|c|} 
Efficiency Level 1 \\
Relative to $90.1-1999$ \\
\end{tabular}} & \multicolumn{2}{|c|}{$\begin{array}{c}\text { Efficiency Level } 3 \\
\text { Relative to } 90.1-1999 \\
\end{array}$} & \multicolumn{2}{|c|}{$\begin{array}{l}\text { Efficiency Level } 3 \\
\text { Relative to } 90.1-1999\end{array}$} & \multicolumn{2}{|c|}{$\begin{array}{l}\text { Efficiency Level } 4 \\
\text { Relative to } 90.1-1999\end{array}$} \\
\hline & & EER & $\begin{array}{c}\text { NPV } \\
\text { (mill.98\$) }\end{array}$ & EER & $\begin{array}{c}\text { NPV } \\
\text { (mill.98\$) }\end{array}$ & EER & $\begin{array}{c}\text { NPV } \\
\text { (mill.98\$) }\end{array}$ & EER & $\begin{array}{c}\text { NPV } \\
\text { (mill.98\$) }\end{array}$ \\
\hline 3-Phase, Single-Packaged, Air-Source AC, $<65 \mathrm{kBtu} / \mathrm{h}$ & 9.7 & 11.0 & $\$ 521.6$ & 12.0 & $\$ 897.7$ & 13.0 & $-\$ 290.6$ & 15.0 & $-\$ 2,649.5$ \\
\hline 3-Phase, Single-Packaged, Air-Source HP, $<65 \mathrm{kBtu} / \mathrm{h}$ & 9.7 & 11.0 & $\$ 88.2$ & 12.0 & $\$ 91.3$ & 13.0 & $-\$ 102.7$ & 15.0 & $-\$ 430.6$ \\
\hline 3-Phase, Split, Air-Source AC, $<65 \mathrm{kBtu} / \mathrm{h}$ & 10.0 & 11.0 & $\$ 109.1$ & 12.0 & $\$ 14.9$ & 13.0 & $-\$ 344.4$ & 15.0 & $-\$ 1,857.4$ \\
\hline 3-Phase, Split, Air-Source HP, $<65 \mathrm{kBtu} / \mathrm{h}$ & 10.0 & 11.0 & $\$ 36.5$ & 12.0 & $\$ 47.0$ & 13.0 & $\$ 27.0$ & 15.0 & $-\$ 121.5$ \\
\hline Central, Air-Source $A C, \geq 65$ and $<135 \mathrm{kBtu} / \mathrm{h}$ & 10.3 & 10.5 & $-\$ 102.9$ & 10.8 & $-\$ 362.0$ & 11.0 & $-\$ 689.6$ & 12.5 & $-\$ 8,623.1$ \\
\hline Central, Air-Source HP, $\geq 65$ and $<135 \mathrm{kBtu} / \mathrm{h}$ & 10.1 & 10.5 & $-\$ 65.0$ & 10.6 & $-\$ 86.5$ & 11.0 & $-\$ 242.5$ & 11.7 & $-\$ 795.9$ \\
\hline Central, Water-Cooled AC, $<65 \mathrm{kBtu} / \mathrm{h}$ & 12.1 & 12.5 & $-\$ 0.4$ & 13.1 & $-\$ 1.6$ & 14.0 & $-\$ 6.1$ & 12.5 & $-\$ 0.4$ \\
\hline Central, Water-Source HP, $<17 \mathrm{kBtu} / \mathrm{h}$ & 11.2 & 12.5 & $-\$ 18.3$ & 13.1 & $-\$ 54.7$ & 14.0 & $-\$ 149.9$ & 15.8 & NA \\
\hline Central, Water-Source HP, $>17$ and $<65 \mathrm{kBtu} / \mathrm{h}$ & 12.0 & 12.5 & $\$ 23.0$ & 13.1 & $-\$ 8.4$ & 14.0 & $-\$ 186.9$ & 15.2 & NA \\
\hline Central, Water-Cooled $A C, \geq 65$ and $<135 \mathrm{kBtu} / \mathrm{h}$ & 11.5 & 12.0 & $\$ 0.7$ & 12.4 & $\$ 0.8$ & 14.0 & $-\$ 2.0$ & 0.0 & NA \\
\hline Central, Water-Source HP, $\geq 65$ and $<135 \mathrm{kBtu} / \mathrm{h}$ & 12.0 & 12.5 & $-\$ 0.6$ & 13.0 & $-\$ 8.3$ & 14.0 & $-\$ 48.2$ & 0.0 & NA \\
\hline Central, Air-Source AC, $\geq 135$ and $<240 \mathrm{kBtu} / \mathrm{h}$ & 9.7 & 10.2 & $\$ 372.2$ & 10.4 & $\$ 417.9$ & 10.8 & NA & 11.5 & NA \\
\hline Central, Air-Source HP, $\geq 135$ and $<240 \mathrm{kBtu} / \mathrm{h}$ & 9.3 & 9.8 & $\$ 3.2$ & 10.4 & $\$ 3.2$ & 10.8 & NA & 10.5 & NA \\
\hline Central, Water-Cooled $\mathrm{AC}, \geq 135$ and $<240 \mathrm{kBtu} / \mathrm{h}$ & 11.0 & 11.1 & $\$ 1.1$ & 11.2 & $\$ 1.1$ & 11.3 & $\$ 1.7$ & 11.5 & $\$ 3.0$ \\
\hline Packaged Terminal AC, $<7 \mathrm{kBtu} / \mathrm{h}$ & 9.4 & 11.0 & $-\$ 2.2$ & 11.2 & $-\$ 6.4$ & 0.0 & NA & 11.6 & NA \\
\hline Packaged Terminal $A C, 7-10 \mathrm{kBtu} / \mathrm{h}$ & 9.0 & 10.6 & $\$ 72.2$ & 10.8 & $\$ 72.0$ & 11.5 & $\$ 7.4$ & 11.5 & $\$ 7.4$ \\
\hline Packaged Terminal AC, $10-13 \mathrm{kBtu} / \mathrm{h}$ & 8.3 & 9.9 & $\$ 97.6$ & 10.2 & $\$ 103.4$ & 10.5 & $\$ 102.7$ & 10.7 & NA \\
\hline Packaged Terminal AC, $>13 \mathrm{kBtu} / \mathrm{h}$ & 7.9 & 9.5 & $\$ 99.1$ & 9.8 & $\$ 88.6$ & 10.0 & $\$ 45.8$ & 10.0 & $\$ 45.8$ \\
\hline Packaged Terminal HP, $<7 \mathrm{kBtu} / \mathrm{h}$ & 9.3 & 10.8 & $-\$ 2.1$ & 11.0 & $-\$ 6.7$ & 0.0 & NA & 11.6 & NA \\
\hline Packaged Terminal HP, 7-10 kBtu/h & 8.9 & 10.4 & $\$ 70.1$ & 10.6 & $\$ 77.4$ & 11.4 & $\$ 36.0$ & 11.5 & NA \\
\hline Packaged Terminal LP, $10-13 \mathrm{kBtu} / \mathrm{h}$ & 8.2 & 9.7 & $\$ 103.0$ & 10.0 & $\$ 85.9$ & 10.5 & $\$ 16.2$ & 10.7 & NA \\
\hline Packaged Terminal HP, $>13 \mathrm{kBtu} / \mathrm{h}$ & 7.8 & 9.3 & $\$ 61.6$ & 9.6 & $\$ 57.8$ & 10.0 & $\$ 39.0$ & 10.0 & $\$ 39.0$ \\
\hline
\end{tabular}


Table 3.6. NPV for Efficiency Levels Exceeding Standard 90.1-1999 - Space-Heating Equipment

\begin{tabular}{|c|c|c|c|c|c|c|c|c|c|}
\hline \multirow[b]{2}{*}{ Products } & \multirow{2}{*}{\begin{tabular}{c|} 
ASHIRAE \\
$90.1-1999$ \\
Thermal \\
Efficiency \\
$(\%)$ \\
\end{tabular}} & \multicolumn{2}{|c|}{$\begin{array}{c}\text { Efficiency Level } 2 \\
\text { Relative to 90.1-1999 }\end{array}$} & \multicolumn{2}{|c|}{$\begin{array}{l}\text { Efficiency Level } 2 \\
\text { Relative to 90.1-1999 }\end{array}$} & \multicolumn{2}{|c|}{$\begin{array}{c}\text { Efficiency Level } 3 \\
\text { Relative to } 90.1-1999\end{array}$} & \multicolumn{2}{|c|}{$\begin{array}{c}\text { Efficiency Level } 4 \\
\text { Relative to } 90.1-1999\end{array}$} \\
\hline & & \begin{tabular}{|c|} 
Thermal \\
Efficiency \\
$(\%)$
\end{tabular} & $\begin{array}{c}\text { NPV } \\
\text { (mill. 98\$) }\end{array}$ & $\begin{array}{c}\text { Thermal } \\
\text { Efficiency } \\
(\%)\end{array}$ & $\begin{array}{c}\text { NPV } \\
\text { (mill. 98\$) }\end{array}$ & $\begin{array}{c}\text { Thermal } \\
\text { Efficiency } \\
(\%)\end{array}$ & $\begin{array}{c}\text { NPV } \\
\text { (mill. 98\$) }\end{array}$ & $\begin{array}{c}\text { Thermal } \\
\text { Efficiency } \\
(\%)\end{array}$ & $\begin{array}{c}\text { NPV } \\
\text { (mill. 98\$) }\end{array}$ \\
\hline Packaged Boilers, Gas-Fired, $400 \mathrm{kBtu} / \mathrm{h}$, IIW & 75.0 & 78.0 & $\$ 17.9$ & 79.0 & $\$ 4.5$ & 81.0 & $-\$ 89.4$ & 88.0 & $-\$ 180.2$ \\
\hline Packaged Boilers, Gas-Fired, $800 \mathrm{kBtu} / \mathrm{h}$, IIW & 75.0 & 76.0 & $\$ 5.9$ & 78.0 & $\$ 42.5$ & 79.0 & $-\$ 20.3$ & 88.0 & $\$ 19.6$ \\
\hline Packaged Boilers, Gas-Fired, 1,500 kBtu/h, HW & 75.0 & 77.0 & $\$ 17.2$ & 78.0 & $\$ 23.0$ & 79.0 & $\$ 17.7$ & 88.0 & $\$ 64.6$ \\
\hline Packaged Boilers, Gas-Fired, 3,000 kBtu/h, HW & 75.0 & 78.0 & $\$ 16.5$ & 79.0 & $\$ 19.3$ & 80.0 & $\$ 24.8$ & 88.0 & $\$ 55.9$ \\
\hline Packaged Boilers, Gas-Fired, 400 kBtu/h, Steam & 75.0 & 76.0 & $\$ 1.6$ & 77.0 & $-\$ 8.5$ & 79.0 & $-\$ 70.9$ & 82.0 & $-\$ 87.8$ \\
\hline Packaged Boilers, Gas-Fired, 800 kBtu/h, Steam & 75.0 & 76.0 & $\$ 8.9$ & 78.0 & $-\$ 23.8$ & 79.0 & $-\$ 16.3$ & 82.0 & $-\$ 78.5$ \\
\hline Packaged Boilers, Gas-Fired, 1,500 kBtu/h, Steam & 75.0 & 77.0 & $\$ 2.8$ & 78.0 & $\$ 1.8$ & 79.0 & $\$ 4.5$ & 81.0 & $\$ 10.5$ \\
\hline Packaged Boilers, Gas-Fired, 3,000 kBtu/h, Stcam & 72.0 & 78.0 & $\$ 21.2$ & 79.0 & $\$ 24.3$ & 80.0 & $\$ 27.9$ & 82.0 & $\$ 30.8$ \\
\hline Warm-Air Furnaces, Gas-Fired, $250 \mathrm{kBtu} / \mathrm{h}$ & 77.5 & 78.5 & $-\$ 120.5$ & 79.5 & $-\$ 244.3$ & 0.0 & $\mathrm{NA}$ & 85.5 & $-\$ 3,511.5$ \\
\hline Warm-Air Furnaces, Gas-Fired, $400 \mathrm{kBtu} / \mathrm{h}$ & 77.5 & 78.5 & $-\$ 68.9$ & 79.5 & $-\$ 141.3$ & 0.0 & NA & 85.5 & $-\$ 3,549.1$ \\
\hline
\end{tabular}

Table 3.7. NPV for Efficiency Levels Exceeding Standard 90.1-1999 - Water-Heating Equipment

\begin{tabular}{|c|c|c|c|c|c|c|c|c|c|}
\hline Product & $\begin{array}{c}\text { Standard } \\
90.1-1999 \\
\text { Thermal } \\
\text { Efficiency } \\
(\%)\end{array}$ & \multicolumn{2}{|c|}{$\begin{array}{l}\text { Efficiency Level 1 } \\
\text { Relative to 90.1-1999 }\end{array}$} & \multicolumn{2}{|c|}{$\begin{array}{c}\text { Efficiency Level } 2 \\
\text { Relative to } 90.1-1999\end{array}$} & \multicolumn{2}{|c|}{$\begin{array}{l}\text { Efficiency Level } 3 \\
\text { Relative to 90.1-1999 }\end{array}$} & \multicolumn{2}{|c|}{$\begin{array}{c}\text { Efficiency Level } 4 \\
\text { Relative to } 90.1-1999\end{array}$} \\
\hline Storage Water Heater, Gas-Fired, $120 \mathrm{kBtu} / \mathrm{h}$ & 80.0 & 82.0 & $-\$ 0.7$ & 82.0 & $-\$ 6.0$ & 86.0 & $-\$ 229.3$ & 94.0 & $-\$ 466.6$ \\
\hline Storage Water Heater, Gas-Fired, $199 \mathrm{kBtu} / \mathrm{h}$ & 80.0 & 82.0 & $-\$ 2.9$ & 82.0 & $-\$ 15.2$ & 86.0 & $-\$ 656.4$ & 94.0 & $-\$ 1,130.0$ \\
\hline $\begin{array}{l}\text { Instantancous Water Heater, Gas-Fired, } \\
1,000 \mathrm{kBtu} / \mathrm{h}\end{array}$ & 80.0 & 83.0 & $\$ 45.3$ & NA & NA & 86.0 & $-\$ 79.6$ & 94.0 & $-\$ 314.4$ \\
\hline $\begin{array}{l}\text { Instantaneous Tank Type, Water Heater, Gas- } \\
\text { Fired, } 500 \mathrm{kBtu} / \mathrm{h}\end{array}$ & 80.0 & 82.0 & $-\$ 3.4$ & 82.0 & $-\$ 4.0$ & 86.0 & $-\$ 105.0$ & 94.0 & $-\$ 160.1$ \\
\hline Electric (120 gal) & 99.3 & 99.4 & $\$ 1.1$ & 0.0 & $\mathrm{~N} \Lambda$ & 0.0 & NA & 0.0 & NA \\
\hline
\end{tabular}


The national NPV results for heating equipment are shown in Table 3.6. The highest levels of NPV are estimated for the highest efficiency levels for largest two size categories of hot water boilers. Total potential cost savings to the nation is in excess of $\$ 100$ million if these efficiency levels were chosen as compared to Standard 90.1-1999 levels.

Table 3.7 displays the results of the NPV calculations for water heaters. The estimate of national NPV is significantly positive for only one product-the larger-sized instantaneous water heater.

\subsection{Life-Cycle Cost Analysis}

LCC is a measure of the total cost of a unit of equipment over its lifetime, including the initial purchase price of the equipment and the annual operating expenses. Future operating expenses are discounted to the time of equipment purchase and summed over its expected lifetime. LCC is defined as

$$
\mathrm{LCC}=\mathrm{EQPCOST}+\sum_{\mathrm{t}=1}^{N} \frac{\mathrm{OPCOST}(\mathrm{t})}{(1+\mathrm{r})^{\mathrm{t}}}
$$

where $\mathrm{EQPCOST}=$ equipment cost (purchase price)

$\mathrm{OPCOST}=$ annual operating expense

$\mathrm{R}=$ discount rate (real)

$\mathrm{N}=$ expected equipment lifetime (years).

LCC provides a method to evaluate the trade-off between the purchase price and the operating expenses of a particular type of equipment. Alternative measures of this trade-off include payback period and internal rate of return.

The annual operating expense in Equation (3.5) is generally broken into two overall categories: 1) maintenance and repair costs and 2) energy costs. For the present screening analysis, maintenance costs are assumed to remain constant across various equipment efficiencies. This assumption leads to the result that any net change in LCC depends solely on the change in the purchase cost offset by the change in (discounted) energy costs.

Based on the information in Section 3.1.1 on energy savings, annual unit energy cost can be expressed as ${ }^{(a)}$

$$
\text { Annual Unit Energy Cost }=\frac{\text { Rated Capacity } \times \text { FLEOH } \times \text { PFUEL }}{\text { Rated Efficiency }}
$$

where PFUEL $=$ price of the relevant energy source $(\$ / \mathrm{kWh}, \$ /$ therm, etc. $)$.

(a) The equations that follow relate to the cooling and heating products. The equations for water heaters would include a term to represent the standby losses, analogous to Equation (3.2). 
In the present analysis, we account for changes in future fuel price, as reflected in the projections in the Annual Energy Outlook 2000 (EIA 1999a). For a given efficiency level, Rated Efficiency, equipment lifetime $N$, and discount rate $\mathrm{r}$, we can then combine Equations (3.5) and (3.6) to yield a general expression for LCC as

$$
\operatorname{LCC}(\mathrm{k})=\mathrm{EQPCOS} T+\sum_{\mathrm{t}=1}^{\mathrm{N}} \frac{\text { Rated Capacity } \times \text { FLEOH } \times \text { PFUEL } \mathrm{t}}{(1+\mathrm{r})^{\mathrm{t}} \times \text { Rated Efficiency } \mathrm{k}}
$$

where $\mathrm{t}=0$ denotes the time the equipment is installed.

LCC savings per unit of equipment is computed as the difference in the LCC between two efficiency levels. Consistent with the discussion above, the efficiency level index (k) is assigned a value of 0 for the baseline standard. The LCC savings associated with a more stringent standard with an enhanced efficiency level is

$$
\mathrm{LCC}(\mathrm{k}) \text { savings }=\mathrm{LCC}(0)-\mathrm{LCC}(\mathrm{k})
$$

\subsubsection{Market Segment to National Average Results}

The development of a national measure of NPV follows the same procedure used to estimate national energy consumption and savings, namely an aggregation of results from the individual market segments. In this case, $\mathrm{LCC}$ is calculated for each building type $\mathrm{i}$ and subcensus division $\mathrm{j}$ as

$$
\operatorname{LCC}(\mathrm{k})_{\mathrm{i}, \mathrm{j}}=\mathrm{EQPCOST}+\sum_{\mathrm{t}=1}^{\mathrm{N}} \frac{\text { Rated Capacity } \times \text { FLEOH }_{\mathrm{i}, \mathrm{j}} \times \text { PFUEL } \mathrm{j}, \mathrm{t}^{\mathrm{s}}}{(1+\mathrm{r})^{\mathfrak{t}} \times \text { Rated Efficiency } \mathrm{k}_{\mathrm{k}}}
$$

Note that region-specific fuel prices are used in determining LCC for each market segment.

A national average unit LCC can then be calculated as an appropriately weighted average of the LCC results for the market segments. This aggregation is represented formally as:

$$
\operatorname{LCC}(\mathrm{k})_{\mathrm{US}}=\sum_{\mathrm{i}}^{7} \sum_{j}^{11} \mathrm{MS}_{\mathrm{i}, \mathrm{j}} \times \operatorname{LCC}(\mathrm{k})_{\mathrm{i}, \mathrm{j}}
$$

In contrast, an alternative summary measure of the average cost effectiveness of a particular efficiency level relative to baseline efficiency is the change in LCC for a unit operated at the national average number of operating hours (FLEOHus) with the national average price of energy (PFUELUs). Using the notation in Equation (3.9), the expression for LCC at the national level for efficiency level $\mathrm{k}$ is

$$
\mathrm{LCC}(\mathrm{k})_{\mathrm{US}}^{\prime}=\mathrm{EQPCOST}+\sum_{i=1}^{N} \frac{\text { Rated Capacity } \mathrm{FLEOH}_{\mathrm{US}} \times \text { PFUEL }_{\mathrm{US} . \mathrm{t}}}{(1+\mathrm{r})^{\mathrm{t}} \times \text { Rated Efficiency }_{\mathrm{k}}}
$$


In general, the existence of interactions between the FLEOH and energy prices by market segment will lead to results from Equation (3.11) differing from those generated by Equation (3.9). Thus, the same congruity of results between the approaches is not achieved for the LCC calculation as it is for national energy consumption [i.e., using Equations (3.1) and (3.2)].

The market segment approach implemented in the screening analysis provides some ability to identify and estimate the percentage of the building population (or, more specifically, final purchasers of the commercial equipment under consideration) that is likely to experience reductions in LCC from a higher level of efficiency and equipment cost. The segmentation approach is intended to capture some of the key variables influencing the distribution of the LCC savings but does not try to reflect all of the factors that may contribute to the variability. ${ }^{(a)}$

Based on the weighting specification in Equation (3.10), Tables 3.8 through 3.10 present the LCC estimates for each efficiency level, beginning with the EPCA 92 level. The use of projected energy prices in the screening analysis implies that the LCC for each market segment will differ to a small degree for each year of the analysis period, 2004-2030. In the LCC tables, the LCC estimates assume the equipment is purchased in 2010. The annual energy costs thus are based on the energy prices projected for 2010 and extending though the expected life of the equipment [see Equation (3.7)].

Table 3.8 shows the LCC estimates for the 22 cooling products analyzed. Considerable variation in the magnitude of the LCC across the products exists, reflecting the size and associated first cost of the equipment. At the EPCA 92 efficiency level, a packaged terminal AC unit has an estimated LCC of $\$ 1,377$, while the LCC for a large central AC unit is over $\$ 30,000$.

For the first product in the table-3-phase single-package $\mathrm{AC}$ equipment, the LCC declines from $\$ 8,524$ for an EER of 9.7 to $\$ 8,198$ for an EER of 12.0. The nature of the cost-efficiency relationship suggests that LCC would rise for higher efficiency levels. At an EER of 15 , the analysis suggests that the LCC would be about $\$ 1,500$ higher than at the minimum point.

Table 3.9 shows the LCC at each efficiency level for the 10 heating products in the analysis. The magnitude of the LCCs, especially for boilers, are considerably greater than for the cooling products. For the largest class of boilers, the sum of the first cost and discounted energy costs over the assumed 30-year life of the equipment is approximately $\$ 400,000$. For these large boilers, the cost savings to an individual consumer can be considerable.

(a) Some simple measures associated with the distribution of LCC savings by efficiency level are generated in the screening analysis spreadsheet and are discussed in Appendix C. 
Table 3.8. Market Segment Weighted LCC for All Efficiency Levels - Space-Cooling Equipment

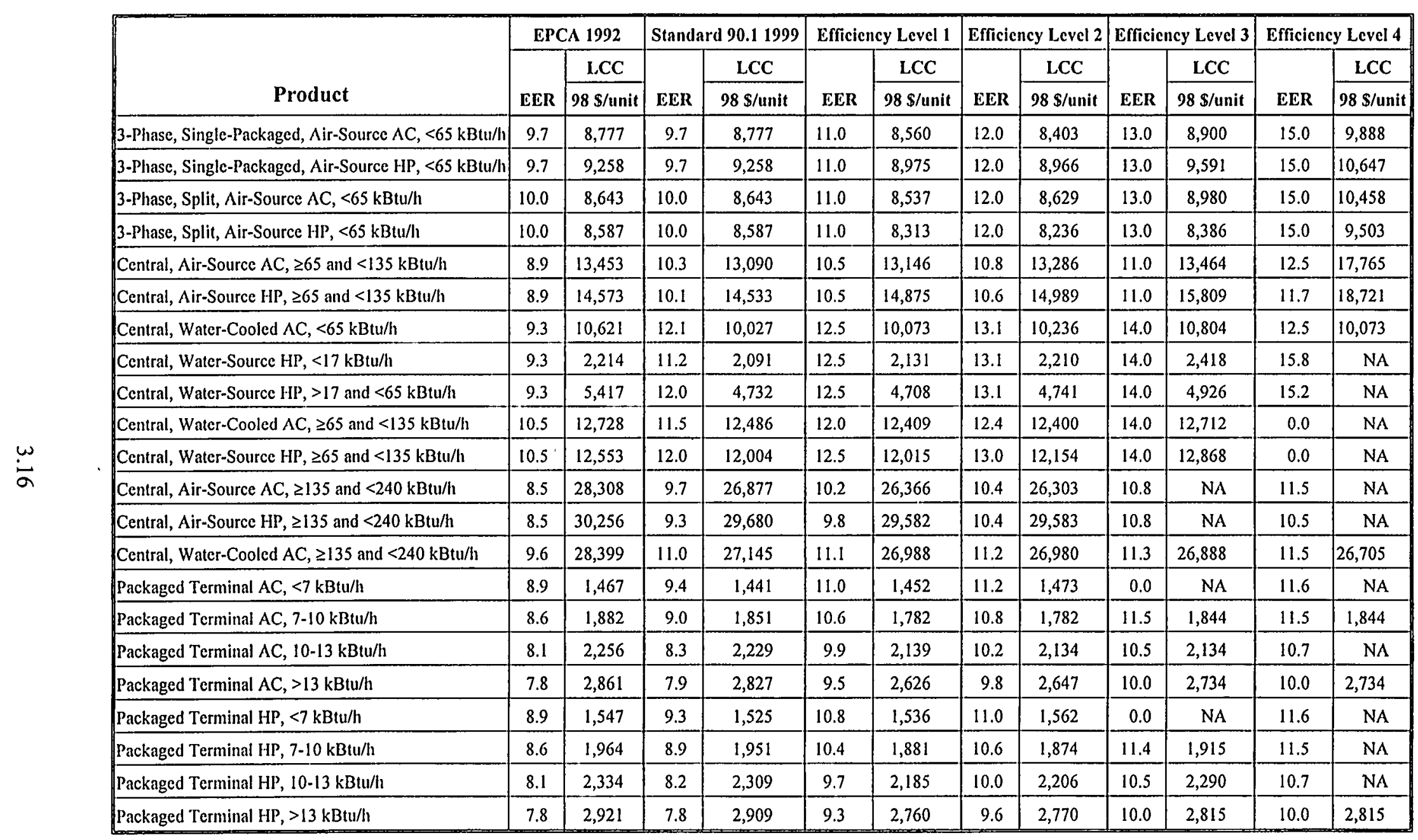


Table 3.9. Market Segment Weighted LCC for All Efficiency Levels - Space-Heating Equipment

\begin{tabular}{|c|c|c|c|c|c|c|c|c|c|c|c|c|}
\hline \multirow[b]{2}{*}{ Product } & \multicolumn{2}{|c|}{ EPCA 1992} & \multicolumn{2}{|c|}{ Standard 90.11999} & \multicolumn{2}{|c|}{ Efficiency Level 1} & \multicolumn{2}{|c|}{ Efficiency Level 2} & \multicolumn{2}{|c|}{ Efficiency Level 3} & \multicolumn{2}{|c|}{ Efficiency Level 4} \\
\hline & $\begin{array}{c}\text { Thermal } \\
\text { Efinciency } \\
(\%)\end{array}$ & $\begin{array}{c}\text { LCC } \\
98 \text { s/unit } \\
\end{array}$ & \begin{tabular}{|c|}
$\begin{array}{c}\text { Thermal } \\
\text { Efficiency } \\
(\%)\end{array}$ \\
\end{tabular} & $\begin{array}{c}\text { LCC } \\
98 \text { S/unit } \\
\end{array}$ & \begin{tabular}{|c|} 
Thermal \\
Efficiency \\
$(\%)$
\end{tabular} & $\begin{array}{c}\text { LCC } \\
98 \text { \$/unit }\end{array}$ & \begin{tabular}{|c|} 
Thermal \\
Efficiency \\
$(\%)$
\end{tabular} & $\begin{array}{c}\text { LCC } \\
98 \text { \$/unit }\end{array}$ & \begin{tabular}{|c|}
$\begin{array}{c}\text { Thermal } \\
\text { Efficiency } \\
(\%)\end{array}$ \\
\end{tabular} & $\begin{array}{c}\text { LCC } \\
98 \text { s/unit } \\
\end{array}$ & \begin{tabular}{|c|} 
Thermal \\
Efficiency \\
$(\%)$
\end{tabular} & $\begin{array}{c}\text { LCC } \\
98 \text { s/unit } \\
\end{array}$ \\
\hline Packaged Boilers, Gas-Fired, $400 \mathrm{kBtu} / \mathrm{h}, \mathrm{HW}$ & 75.0 & 39,588 & 75.0 & 39,588 & 78.0 & 39,022 & 79.0 & 39,447 & 81.0 & 42,422 & 88.0 & 45,303 \\
\hline Packaged Boilers, Gas-Fired, $800 \mathrm{kBtw} / \mathrm{h}, \mathrm{HW}$ & 75.0 & 76,282 & 75.0 & 76,282 & 76.0 & 76,109 & 78.0 & 75,047 & 79.0 & 76,873 & 88.0 & 75,716 \\
\hline Packaged Boilers, Gas-Fired, 1,500 kBtu/h, HW & 75.0 & 140,462 & 75.0 & 140,462 & 77.0 & 137,621 & 78.0 & 136,656 & 79.0 & 137,536 & 88.0 & 129,770 \\
\hline Packaged Boilers, Gas-Fired, 3,000 kBtu/h, HW & 75.0 & 276,835 & 75.0 & 276,835 & 78.0 & 268,564 & 79.0 & 267,120 & 80.0 & 264,382 & 88.0 & 248,775 \\
\hline Packaged Boilers, Gas-Fired, $400 \mathrm{kBtu} / \mathrm{h}$, Steam & 72.0 & 42,890 & 75.0 & 42,130 & 76.0 & 42,016 & 77.0 & 42,732 & 79.0 & 47,134 & 82.0 & 48,320 \\
\hline Packaged Boilers, Gas-Fired, $800 \mathrm{kBtu} / \mathrm{h}$, Steam & 72.0 & 81,190 & 75.0 & 79,664 & 76.0 & 79,206 & 78.0 & 80,896 & 79.0 & 80,507 & 82.0 & 83,719 \\
\hline Packaged Boilers, Gas-Fired, $1,500 \mathrm{kBtu} / \mathrm{h}$, Stcam & 72.0 & 150,969 & 75.0 & 146,346 & 77.0 & 145,765 & 78.0 & 145,964 & 79.0 & 145,391 & 81.0 & 144,137 \\
\hline Packaged Boilers, Gas-Fired, $3,000 \mathrm{kBtu} / \mathrm{h}$, Stcam & 72.0 & 293,020 & 72.0 & 293,020 & 78.0 & 278,973 & 79.0 & 276,939 & 80.0 & 274,533 & 82.0 & 272,651 \\
\hline Warm-Air Furnaces, Gas-Fired, $250 \mathrm{kBtu} / \mathrm{h}$ & 75.1 & 16,311 & 77.5 & 16,404 & 78.5 & 16,501 & 79.5 & 16,602 & 0.0 & NA & 85.5 & 19,242 \\
\hline Warm-Air Furnaces, Gas-Fired, $400 \mathrm{kBtu} / \mathrm{h}$ & 75.1 & 25,737 & 77.5 & 25,409 & 78.5 & 25,496 & 79.5 & 25,588 & 0.0 & NA & 85.5 & 29,896 \\
\hline
\end{tabular}

Table 3.10. Market Segment Weighted LCC for All Efficiency Levels - Water-Heating Equipment

\begin{tabular}{|c|c|c|c|c|c|c|c|c|c|c|c|c|}
\hline \multirow[b]{2}{*}{ Product } & \multicolumn{2}{|c|}{ EPCA 1992} & \multicolumn{2}{|c|}{ Standard 90.1 1999} & \multicolumn{2}{|c|}{ Efficiency Level 1} & \multicolumn{2}{|c|}{ Efficiency Level 2} & \multicolumn{2}{|c|}{ Efficiency Level 3} & \multicolumn{2}{|c|}{ Efficiency Level 4} \\
\hline & $\begin{array}{l}\text { Thermal } \\
\text { Efficicncy } \\
(\%)\end{array}$ & $\begin{array}{c}\text { LCC } \\
98 \$ \text { /unit }\end{array}$ & $\begin{array}{c}\text { Thermal } \\
\text { Efficiency } \\
(\%)\end{array}$ & $\begin{array}{c}\text { LCC } \\
98 \$ / \text { unit } \\
\end{array}$ & $\begin{array}{c}\text { Thermal } \\
\text { Efficiency } \\
(\%)\end{array}$ & $\begin{array}{c}\text { LCC } \\
98 \text { \$/unit }\end{array}$ & $\begin{array}{c}\text { Thermal } \\
\text { Efficiency } \\
(\%)\end{array}$ & $\begin{array}{c}\text { LCC } \\
98 \text { \$/unit }\end{array}$ & $\begin{array}{l}\text { Thermal } \\
\text { Efficiency } \\
(\%)\end{array}$ & $\begin{array}{c}\text { LCC } \\
98 \$ / \text { unit } \\
\end{array}$ & $\begin{array}{c}\text { Thermal } \\
\text { Efficicncy } \\
(\%)\end{array}$ & $\begin{array}{c}\text { LCC } \\
98 \text { \$/unit }\end{array}$ \\
\hline Storage Water Heater, Gas-Fired, $120 \mathrm{kBtu} / \mathrm{h}$ & 78.0 & 4,881 & 80.0 & 4,858 & 82.0 & 4,861 & 82.0 & 4,883 & 86.0 & 5,831 & 94.0 & 6,837 \\
\hline Storage Water Heater, Gas-Fired, $199 \mathrm{kBtu} / \mathrm{h}$ & 78.0 & 6,954 & 80.0 & 6,975 & 82.0 & 6,981 & 82.0 & 7,007 & 86.0 & 8,366 & 94.0 & 9,370 \\
\hline Storage Water Heater, Gas-Fired, $360 \mathrm{kBtu} / \mathrm{h}$ & 78.0 & 11,879 & 80.0 & 11,954 & 82.0 & 11,969 & 82.0 & 11,995 & 86.0 & 14,332 & 94.0 & 16,072 \\
\hline $\begin{array}{l}\text { Instantaneous Water Heater, Gas-Fired, } \\
400 \mathrm{kBtu} / \mathrm{h}\end{array}$ & 80.0 & 15,857 & 80.0 & 15,857 & 83.0 & 16,192 & NA & NA & 86.0 & 17,741 & 94.0 & 19,072 \\
\hline $\begin{array}{l}\text { Instantancous Water Heater, Gas-Fired, } \\
1,000 \mathrm{kBtu} / \mathrm{h}\end{array}$ & 80.0 & 36,280 & 80.0 & 36,280 & 83.0 & 35,945 & $\mathrm{NA}$ & NA & 86.0 & 36,869 & 94.0 & 38,607 \\
\hline $\begin{array}{l}\text { Instantaneous Tank Type, Water Heater, Gas- } \\
\text { Fired, } 500 \mathrm{kBtu} / \mathrm{h}\end{array}$ & 77.0 & 16,433 & 80.0 & 16,457 & 82.0 & 16,592 & 82.0 & 16,618 & 86.0 & 20,668 & 94.0 & 22,874 \\
\hline Electric (120 gal) & 99.4 & 8,001 & 99.3 & 8,056 & 99.4 & 8,052 & 0.0 & $\mathrm{NA}$ & 0.0 & NA & 0.0 & NA \\
\hline
\end{tabular}


For the large boiler $(>3,000 \mathrm{kBtu} / \mathrm{h}$ ), the cost saving from going to a condensing model (at $88 \%$ thermal efficiency) is nearly $\$ 50,000$ compared with the current standard (both EPCA 92 and 90.1-1999) of $75 \%{ }^{(\mathrm{a})}$.

The LCC by efficiency level for water-heating equipment is shown in Table 3.10. The shorter lifetimes of the storage water heaters - compared with the instantaneous type-are reflected in smaller LCCs. Except for the large instantaneous water heater (the fifth product listed in Table 3.10), the minimum LCC is generally at the Standard 90.1-1999 level.

\subsubsection{Methodology Used to Compute National NPV}

The discussion on Equations (3.7) through (3.11) focuses exclusively on the LCC and LCC savings for a single unit of equipment. Of course, the potential national economic benefits of setting an efficiency standard for any specific product depends on both the unit LCC savings and the size of the market (total shipments) for that product.

Following the approach in previous analyses of national equipment efficiency standards, a convenient summary metric of the benefits is the national NPV of the cost savings. For the screening analysis, the method used to compute this metric first involved estimating the present value of the total LCC savings associated with each year's shipments. ${ }^{(b)}$

At the efficiency level $k$, the national LCC savings (NLCCS) from total shipments in year " $y$ " meeting the standard can be expressed as

$$
\operatorname{NLCCS}(y, k)=\operatorname{Shipments}(y) \times \sum_{i}^{7} \sum_{j}^{11} \operatorname{MS}_{i, j} \times\left[\left(\operatorname{LCC}(y, 0)_{i, j}-\operatorname{LCC}(y, k)_{i, j}\right]\right.
$$

Note that in Equation (3.12) the expressions for LCC include the year y as an argument, recognizing that the LCC may vary for each year depending on the levels of energy prices. For the screening analysis,

(a) In all LCC discussions, an "individual" user represents the average consumer across the market segments. Depending on climate and energy prices, some consumers would experience greater savings and others would have smaller savings.

(b) This analysis assumes a common discount rate that is used in the LCC calculations and in the NPV calculation. With this assumption, the LCC savings and NPV would be the same for units shipped in the "present" year and where the energy cost savings is discounted to this year. The "net" in the NPV compares the present value of the purchase price offset by the present (i.e., discounted) value of the energy savings. When applied to vintages of equipment shipments over a period of future years, the NPV calculation recognizes that national economic benefits in these more distant future years are not as valuable as near-term benefits. 
the national NPV is evaluated for the year 2000 using a time horizon that extends to 2030 (c) $^{(2)}$ National NPV is thus based on discounting the national LCC savings associated with each year's shipments back to the "present" year 2000 and summing the results. Thus, we have

$$
\text { National NPV }(k)=\sum_{y=2000}^{2030} \frac{N L C C S(y, k)}{(1+r)^{y-2000}}
$$

\subsection{Reductions in Environmental Emissions}

The reductions in energy consumption from the use of more energy-efficient commercial equipment help to lower the nation's total environmental emissions associated with the burning of fossil fuels. Two categories of emissions were considered in the screening analysis: 1) carbon (as part of $\mathrm{CO}_{2}$ released in combustion process) and 2) nitrous oxides $\left(\mathrm{NO}_{\mathrm{x}}\right)$. The results in Table 3.11 show the estimated reductions in carbon emissions for all products in the screening analysis. More detailed results including the NOx emission estimates, are shown in Appendices C and D. The factors to convert electricity and natural gas savings to reductions in these emissions were extracted from a table used by the DOE Office of Energy Efficiency and Renewable Energy (EERE) in its assessment of various DOE energy conservation programs (DOE 1999). The values in the EERE table are derived from conversion factors developed by EIA. EIA, however, provides emissions factors only for primary fuels and not for electricity. EERE has subsequently developed emissions factors for electricity that reflect a projection of fuels that would likely be impacted due to marginal reductions in electricity consumption.

In Table 3.11, the energy savings from adopting the Standard 90.1-1999 efficiency level, as well as a higher efficiency level (corresponding to maximum national NPV), were translated into estimates of millions of metric tons (MMtons) of carbon emissions reductions. The total carbon emissions reduction from the adoption of Standard 90.1-1999 is estimated to be about 52 MMtons. An additional 51 MMtons could be reduced by moving to the efficiency level with maximum NPV. The Annual Energy Outlook 2000 (EIA 1999a) projects carbon emissions through 2020 for each major end use sector (residential, commercial, industrial, transportation) consistent with their energy consumption projections. Based on extrapolating the AEO projections to 2030 by using the 2015-2020 annual growth rate, the cumulative commercial-sector carbon emissions between 2004 and 2030 are estimated to be about 8,100 MMtons.

(c) We should point out that this method takes what might be termed an "accrual" approach to computing the NPV as compared to a "cash flow" approach. In the method here-using LCC savings - the ultimate economic benefit (energy cost savings) is assigned to the year in which in the investment (incremental equipment cost) is made. This approach has the advantage that the LCC savings associated with any year's shipments can be readily rolled up to a national measure, regardless of the particular time horizon chosen. In a cash flow approach, for short time horizons, the NPV can be negative since the energy savings associated with a particular vintage of equipment may not have fully offset the incremental cost of the equipment. If these time horizon considerations are eliminated-in part by choosing a sufficiently long period to evaluate the NPV-the two approaches will yield equivalent results. 
Table 3.11. Energy Savings and Carbon Reductions from Adopting Standard 90.1-1999 and from Maximum NPV

\begin{tabular}{|c|c|c|c|c|c|c|}
\hline \multirow[b]{2}{*}{ Product } & \multicolumn{3}{|c|}{ Standard 90.11999} & \multicolumn{3}{|c|}{ Efficiency with Maximum NPV } \\
\hline & $\begin{array}{c}\text { EER/ } \\
\text { Thermal } \\
\text { Efficiency } \\
(\%)\end{array}$ & $\begin{array}{l}\text { Energy Savings } \\
\text { (TBtu) }\end{array}$ & $\begin{array}{c}\text { Carbon } \\
\text { Reduction } \\
\text { (MMtons) }\end{array}$ & $\begin{array}{c}\text { EER } \\
\text { Thermal } \\
\text { Efficiency } \\
(\%)\end{array}$ & $\begin{array}{c}\text { Additional } \\
\text { Energy } \\
\text { Savings } \\
\text { (TBtu) } \\
\end{array}$ & $\begin{array}{l}\text { Additional } \\
\text { Carbon } \\
\text { Reduction } \\
\text { (MMtons) }\end{array}$ \\
\hline \multicolumn{7}{|l|}{ Cooling Equipment } \\
\hline 3-Phase, Single-Packaged, Air-Source AC, $<65 \mathrm{kBtu} / \mathrm{h}$ & 9.7 & 0.0 & 0.0 & 12.0 & $1,412.7$ & 20.8 \\
\hline 3-Phase, Single-Packaged, Air-Source HP, $<65 \mathrm{kBtu} / \mathrm{h}$ & 9.7 & 0.0 & 0.0 & 12.0 & 183.6 & 2.7 \\
\hline 3-Phase, Split, Air-Source AC, $<65 \mathrm{kBtu} / \mathrm{h}$ & 10.0 & 0.0 & 0.0 & 11.0 & 278.6 & 4.1 \\
\hline 3-Phase, Split, Air-Source HP, $<65 \mathrm{kBtu} / \mathrm{h}$ & 10.0 & 0.0 & 0.0 & 12.0 & 66.4 & 1.0 \\
\hline Central, Air-Source $\mathrm{AC}, \geq 65$ and $<135 \mathrm{kBtu} / \mathrm{h}$ & 10.3 & 1197.9 & 17.6 & 10.3 & 0.0 & 0.0 \\
\hline Central, Air-Source HP, $\geq 65$ and $<135 \mathrm{kBtu} / \mathrm{h}$ & 10.1 & 107.9 & 1.6 & 10.1 & 0.0 & 0.0 \\
\hline Central, Water-Cooled AC, $<65 \mathrm{kBtu} / \mathrm{h}$ & 12.1 & 6.6 & 0.1 & 12.1 & 0.0 & 0.0 \\
\hline Central, Water-Source HP, $<17 \mathrm{kBtu} / \mathrm{h}$ & 11.2 & 56.5 & 0.8 & 11.2 & 0.0 & 0.0 \\
\hline Central, Water-Source HP, $>17$ and $<65 \mathrm{kBtu} / \mathrm{h}$ & 12.0 & 471.6 & 6.9 & 12.5 & 65.0 & 1.0 \\
\hline Central, Water-Cooled $\mathrm{AC}, \geq 65$ and $<135 \mathrm{kBtw} / \mathrm{h}$ & 11.5 & 3.6 & 0.1 & 12.4 & 2.7 & 0.0 \\
\hline Central, Water-Source HP, $\geq 65$ and $<135 \mathrm{kBtu} / \mathrm{h}$ & 12.0 & 32.0 & 0.5 & 12.0 & 0.0 & 0.0 \\
\hline Central, Air-Source $A C, \geq 135$ and $<240 \mathrm{kBtu} / \mathrm{h}$ & 9.7 & 899.4 & 13.2 & 10.4 & 428.8 & 6.3 \\
\hline Central, Air-Source HP, $\geq 135$ and $<240 \mathrm{kBtu} / \mathrm{h}$ & 9.3 & 27.9 & 0.4 & 10.4 & 31.4 & 0.5 \\
\hline Central, Water-Cooled $A C, \geq 135$ and $<240 \mathrm{kBtu} / \mathrm{h}$ & 11.0 & 8.5 & 0.1 & 11.5 & 2.5 & 0.0 \\
\hline Packaged Terminal AC, $<7 \mathrm{kBtu} / \mathrm{h}$ & 9.4 & 4.2 & 0.1 & 9.4 & 0.0 & 0.0 \\
\hline Packaged Terminal AC, 7-10 kBtu/h & 9.0 & 26.7 & 0.4 & 10.6 & 81.7 & 1.2 \\
\hline Packaged Terminal AC, $10-13 \mathrm{kBtu} / \mathrm{h}$ & 8.3 & 26.8 & 0.4 & 10.2 & 149.7 & 2.2 \\
\hline Packaged Terminal AC, $>13 \mathrm{kBtw} / \mathrm{h}$ & 7.9 & 9.7 & 0.1 & 9.5 & 80.3 & 1.2 \\
\hline Packaged Terminal HP, $<7 \mathrm{kBtw} / \mathrm{h}$ & 9.3 & 3.1 & 0.0 & 9.3 & 0.0 & 0.0 \\
\hline Packaged Terminal HP, 7-10 kBtu/h & 8.9 & 19.7 & 0.3 & 10.6 & 85.9 & 1.3 \\
\hline Packaged Terminal HP, $10-13 \mathrm{kBtu} / \mathrm{h}$ & 8.2 & 12.9 & 0.2 & 9.7 & 97.6 & 1.4 \\
\hline Packaged Terminal HP, $>13 \mathrm{kBtu} / \mathrm{h}$ & 7.8 & 3.0 & 0.0 & 9.3 & 65.5 & 1.0 \\
\hline \multicolumn{7}{|l|}{ Heating Equipment } \\
\hline Packaged Boilers, Gas-Fired, $400 \mathrm{kBtu} / \mathrm{h}, \mathrm{HW}$ & 75.0 & 0.0 & 0.0 & 78.0 & 26.3 & 0.3 \\
\hline Packaged Boilers, Gas-Fired, $800 \mathrm{kBtu} / \mathrm{h}$, HW & 75.0 & 0.0 & 0.0 & 78.0 & 57.4 & 0.8 \\
\hline Packaged Boilers, Gas-Fired, 1,500 kBtu/h, HW & 75.0 & 0.0 & 0.0 & 88.0 & 72.6 & 0.9 \\
\hline Packaged Boilers, Gas-Fired, 3,000 kBtu/h, HW & 75.0 & 0.0 & 0.0 & 88.0 & 47.8 & 0.6 \\
\hline Packaged Boilers, Gas-Fired, $400 \mathrm{kBtu} / \mathrm{h}$, Steam & 75.0 & 12.8 & 0.2 & 76.0 & 4.0 & 0.1 \\
\hline Packaged Boilers, Gas-Fired, $800 \mathrm{kBtu} / \mathrm{h}$, Steam & 75.0 & 35.0 & 0.5 & 76.0 & 11.1 & 0.1 \\
\hline Packaged Boilers, Gas-Fired, $1,500 \mathrm{kBtu} / \mathrm{h}$, Steam & 75.0 & 16.1 & 0.2 & 81.0 & 28.6 & 0.4 \\
\hline Packaged Boilers, Gas-Fired, 3,000 kBtu/h, Steam & 72.0 & 0.0 & 0.0 & 82.0 & 31.2 & 0.4 \\
\hline Warm-Air Furnaces, Gas-Fired, $250 \mathrm{kBtu} / \mathrm{h}$ & 77.5 & 236.5 & 3.1 & 77.5 & 0.0 & 0.0 \\
\hline Warm-Air Furnaces, Gas-Fired, $400 \mathrm{kBtu} / \mathrm{h}$ & 77.5 & 241.9 & 3.2 & 77.5 & 0.0 & 0.0 \\
\hline
\end{tabular}


Table 3.11. (contd)

\begin{tabular}{|c|c|c|c|c|c|c|}
\hline \multirow[b]{2}{*}{ Product } & \multicolumn{3}{|c|}{ Standard 90.1 1999} & \multicolumn{3}{|c|}{ Efficiency with Maximum NPV } \\
\hline & $\begin{array}{c}\text { EER } \\
\text { Thermal } \\
\text { Efficiency } \\
(\%)\end{array}$ & $\begin{array}{c}\text { Energy Savings } \\
\text { (TBtu) }\end{array}$ & $\begin{array}{l}\text { Carbon } \\
\text { Reduction } \\
\text { (MMtons) }\end{array}$ & $\begin{array}{c}\text { EER/ } \\
\text { Thermal } \\
\text { Efficiency } \\
(\%)\end{array}$ & $\begin{array}{l}\text { Additional } \\
\text { Energy } \\
\text { Savings } \\
\text { (TBtu) } \\
\end{array}$ & $\begin{array}{l}\text { Additional } \\
\text { Carbon } \\
\text { Reduction } \\
\text { (MMtons) }\end{array}$ \\
\hline \multicolumn{7}{|l|}{ Water Heating Equipment } \\
\hline Storage Water Heater, Gas-Fired, $120 \mathrm{kBtu} / \mathrm{h}$ & 80.0 & 12.5 & 0.2 & 80.0 & 0.0 & 0.0 \\
\hline Storage Water Heater, Gas-Fired, $199 \mathrm{kBtu} / \mathrm{h}$ & 80.0 & 23.2 & 0.3 & 80.0 & 0.0 & 0.0 \\
\hline Storage Water Heater, Gas-Fired, $360 \mathrm{kBtu} / \mathrm{h}$ & 80.0 & 30.7 & 0.5 & 80.0 & 0.0 & 0.0 \\
\hline Instantaneous Water Heater, Gas-Fired, $400 \mathrm{kBtu} / \mathrm{h}$ & 80.0 & 0.0 & 0.0 & 80.0 & 0.0 & 0.0 \\
\hline Instantaneous Water Heater, Gas-Fired, $1,000 \mathrm{kBtu} / \mathrm{h}$ & 80.0 & 0.0 & 0.0 & 83.0 & 102.0 & 1.5 \\
\hline $\begin{array}{l}\text { Instantaneous Tank Type, Water Heater, Gas-Fired, } \\
500 \mathrm{kBtu} / \mathrm{h}\end{array}$ & 80.0 & 5.3 & 0.1 & 80.0 & 0.0 & 0.0 \\
\hline Electric (120 gal) & 99.3 & -7.2 & -0.1 & 99.4 & 6.6 & 0.1 \\
\hline Total & & & 52.2 & & & 50.8 \\
\hline
\end{tabular}

\subsection{Summary of Results}

Several of the product categories were analyzed at different representative sizes; e.g., the screening analysis included six different sizes of packaged gas-fired boilers with capacities $<2,500 \mathrm{kBtu} / \mathrm{h}$. Because the EPCA 1992 level and the Standard 90.1-1999 level are for a single category of gas-fired boilers with capacities $<2,500 \mathrm{kBtu} / \mathrm{h}$, the results presented in Table 3.3 were aggregated.

This aggregation was done for the following product categories:

- packaged terminal air conditioners

- packaged terminal heat pumps

- large gas-fired hot water boilers $(>2,500 \mathrm{kBtu} / \mathrm{h})$

- large gas-fired steam boilers $(>2,500 \mathrm{kBtu} / \mathrm{h})$

- small gas-fired boilers $(<2,500 \mathrm{kBtu} / \mathrm{h})$

- gas storage water heaters $(>155 \mathrm{kBtu} / \mathrm{h})$

- gas storage water heaters $(<155 \mathrm{kBtu} / \mathrm{h})$

- instantaneous water heaters with tanks. 
The efficiency levels were aggregated across the different capacities of equipment analyzed using the baseline energy consumption as relative weights. The baseline energy consumption, the energy savings, the NPV, and the carbon reductions were all summed up across the different capacities of the particular equipment category. The aggregated results are presented in Table 3.12. 
Table 3.12. Aggregated Energy Savings and NPV for Efficiency Levels with Maximum NPV

\begin{tabular}{|c|c|c|c|c|c|c|c|c|}
\hline \multirow[b]{2}{*}{ Product } & \multicolumn{3}{|c|}{ Efficiency Level } & \multicolumn{2}{|c|}{ Energy Savings (TBtu) } & \multicolumn{2}{|c|}{ Carbon Reduction (MMtons) } & \multirow[b]{2}{*}{$\begin{array}{c}\mathrm{NPV}^{(\boldsymbol{( a )}} \\
\text { (mill. 98\$) }\end{array}$} \\
\hline & EPCA & \begin{tabular}{|l|}
$90.1-$ \\
1999
\end{tabular} & $\begin{array}{c}\overline{M a x} \\
\text { NPV }^{(a)}\end{array}$ & $\begin{array}{c}90.1 \text { Over } \\
\text { EPCA }\end{array}$ & $\begin{array}{c}\text { Max NPV } \overline{P V}^{(a)} \\
\text { Over } 90.1\end{array}$ & $\begin{array}{c}\text { 90.1 Over } \\
\text { EPCA }\end{array}$ & $\begin{array}{c}\text { Max NPV(a) } \\
\text { Over } 90.1\end{array}$ & \\
\hline Central Air-Source AC (135 to $240 \mathrm{kBtu} / \mathrm{h})$ & 8.5 & 9.7 & 10.4 & 899.4 & 428.8 & 13.2 & 6.3 & 417.9 \\
\hline Central Air-Source HP (135 to $240 \mathrm{kBtu} / \mathrm{h})$ & 8.5 & 9.3 & 10.4 & 27.9 & 31.4 & 0.4 & 0.5 & 3.2 \\
\hline Central Water-Cooled AC (135 to $240 \mathrm{kBtu} / \mathrm{h})$ & 9.6 & 11.0 & 11.5 & 8.5 & 2.5 & 0.1 & 0.0 & 3.0 \\
\hline Central Air-Source AC (65 to $135 \mathrm{kBtu} / \mathrm{h})$ & 8.9 & 10.3 & 10.3 & 1197.9 & 0.0 & 17.6 & 0.0 & 0.0 \\
\hline Central Air-Source HP (65 to $135 \mathrm{kBtu} / \mathrm{h})$ & 8.9 & 10.1 & 10.1 & 107.9 & 0.0 & 1.6 & 0.0 & 0.0 \\
\hline Central Water-Source HP (65 to $135 \mathrm{kBtu} / \mathrm{h})$ & 10.5 & 12.0 & 12.0 & 32.0 & 0.0 & 0.5 & 0.0 & 0.0 \\
\hline Central Water Cooled AC (65 to $135 \mathrm{kBtu} / \mathrm{h})$ & 10.5 & 11.5 & 12.4 & 3.6 & 2.7 & 0.1 & 0.1 & 0.8 \\
\hline Packaged Terminal Air Conditioners & 8.5 & 8.8 & 10.5 & 67.5 & 311.7 & 1.0 & 4.6 & 274.7 \\
\hline Packaged Terminal Heat Pumps & 8.2 & 8.4 & 9.9 & 38.7 & 249.0 & 0.6 & 3.7 & 241.9 \\
\hline 3-Phase, Single-Package Air-Source AC ( $<65 \mathrm{kBtu} / \mathrm{h})$ & 9.7 & 9.7 & 12.0 & 0.0 & 1412.7 & 0.0 & 20.8 & 897.7 \\
\hline 3-Phase, Split-System Air-Source AC (<65 kBtu/h) & 10.0 & 10.0 & 11.0 & 0.0 & 278.6 & 0.0 & 4.1 & 109.1 \\
\hline 3-Phase, Single-Package Air-Source HP (<65 kBtu/h) & 9.7 & 9.7 & 12.0 & 0.0 & 183.6 & 0.0 & 2.7 & 91.3 \\
\hline 3-Phase, Split-System Air Source HP (<65 kBtu/h) & 10 & 10.0 & 12.0 & 0.0 & 66.4 & 0.0 & 1.0 & 47.0 \\
\hline Central Water-Cooled AC $(<65 \mathrm{kBtu} / \mathrm{h})$ & 9.3 & 12.1 & 12.1 & 6.6 & 0.0 & 0.1 & 0.0 & 0.0 \\
\hline Central Water-Source HP (17 to $65 \mathrm{kBtu} / \mathrm{h})$ & 9.3 & 12.0 & 12.5 & 471.6 & 65.0 & 6.9 & 1.0 & 23.0 \\
\hline Central Water-Source HP $(<17 \mathrm{kBtu} / \mathrm{h})$ & 9.3 & 11.2 & 11.2 & 56.5 & 0.0 & 0.8 & 0.0 & 0.0 \\
\hline Large Gas-Fired Hot Water Boilers $(>2,500 \mathrm{kBtu} / \mathrm{h})$ & $80 \%$ & $80 \%$ & $88 \% \%^{(0)}$ & & & & & \\
\hline Large Gas-Fired Steam Boilers $(>2,500 \mathrm{kBtu} / \mathrm{h})$ & $80 \%$ (b) & $80 \% \%^{(\text {b) }}$ & $82 \%$ (c) & 0.0 & 79.0 & 0.0 & 1.0 & 86.6 \\
\hline Small Gas-Fired Boilers $(<2,500 \mathrm{kBtu} / \mathrm{h}$ & $80 \%$ (v) & $75 \%$ (c) & $78.7 \%$ (c) & 63.9 & 200.0 & 0.8 & 2.6 & 146.0 \\
\hline Gas-Fired Warm-Air Furnaces & $80 \%$ (c) & $80 \%$ (c) & $80 \%(c)$ & 478.4 & 0.0 & $6.3^{\sigma}$ & 0.0 & 0.0 \\
\hline Gas Storage Water Heaters $(>155 \mathrm{kBtu} / \mathrm{h})$ & $78 \% \%^{(\text {() }}$ & $80.4 \%{ }^{(\mathrm{CT})}$ & $80.4 \%$ & 53.9 & 0.0 & 0.8 & 0.0 & 0.0 \\
\hline Gas Storage Water Heaters $(<155 \mathrm{kBtu} / \mathrm{h})$ & $78 \% \%^{(0)}$ & $80 \%^{(\mathrm{c})}$ & $80 \%$ (c) & 12.5 & 0.0 & 0.2 & 0.0 & 0.0 \\
\hline Electric Water Heaters & $\begin{array}{l}\text { See } \\
\text { Note }^{(d)}\end{array}$ & \begin{tabular}{|l} 
See \\
Note \\
(c)
\end{tabular} & $\begin{array}{l}\text { See } \\
\text { Note }^{(\mathfrak{l})}\end{array}$ & -7.2 & 5.3 & -0.1 & 0.1 & 1.1 \\
\hline Tankless Instantaneous Water Heaters & $80 \%{ }^{\text {(a) }}$ & $80 \%{ }^{(\mathrm{c})}$ & $81.5 \%$ & 0.0 & 102.0 & 0.0 & 1.5 & 45.3 \\
\hline Instantaneous Water Heaters with Tanks & $77 \%$ (c) & $80 \%$ & $80 \%{ }^{(c)}$ & 6.9 & 0.0 & 0.1 & 0.0 & 0.0 \\
\hline \multicolumn{9}{|l|}{$\begin{array}{l}\text { (a) } \mathrm{NPV}=\text { national net present value. } \\
\text { (b) Combustion efficiency }(\%) \text {. } \\
\text { (c) Thermal efficiency }(\%) \text {. } \\
\text { (d) Savings due to tighter jacket loss requirement. } \\
\text { (d) } 30+27 / \mathrm{V}(\% / \mathrm{h}) \mathrm{V}=\text { Measured storage volume in gals. } \\
\text { (e) } 20+35 \mathrm{Sqrt}(\mathrm{V})(\mathrm{Btu} / \mathrm{h}) \mathrm{V}=\mathrm{Rated} \text { volume in gals. } \\
\text { (f) } 1.73 \mathrm{~V}+155(\mathrm{Btu} / \mathrm{h}) \mathrm{V}=\mathrm{Rated} \text { volume in gals. }\end{array}$} \\
\hline
\end{tabular}




\subsection{References}

10 CFR Part 430. Subpart B, Appendix N. 1998. "Energy Conservation Program for Consumer Products." U.S. Code of Federal Regulations.

Air-Conditioning and Refrigeration Institute (ARI). 1998a. Electronic Unitary Directory ARIEUD 98. ARI CD-ROM (I), Arlington, Virginia.

Air-Conditioning and Refrigeration Institute (ARI). 1998b. Statistical Releases, January 1998 December 1998. Available URL: http://www.ari.org

American Society of Heating, Refrigerating and Air-Conditioning Engineers, Inc. (ASHRAE). 1989. ASHRAE/IES Standard 90.1-1989, "Energy Efficient Design of New Buildings Except Low-Rise Residential Buildings." Atlanta, Georgia.

American Society of Heating, Refrigerating and Air-Conditioning Engineers, Inc. (ASHRAE). 1995. Handbook of HVAC Applications. Atlanta, Georgia.

Barwig, F. E., D. B. Elliott, S. L. Freeman, M. Friedrich, A. Y. Gu, D. L. Hadley, M. A. Halverson, R. E. Jarnagin, S. Katipamula, L. A. Klevgard, J. D. Miller, R. G. Pratt, J. S. Schliesing, S. A. Shankle, S. Somasundaram, G. P. Sullivan, Z. T. Taylor, and D. W. Winiarski. 1996. Preliminary Findings: Analysis of Commercial Space-Conditioning and Storage Water-Heating Equipment Efficiencies. PNNL-11191, Pacific Northwest National Laboratory, Richland, Washington.

BLAST Support Office (BLAST). 1991. Volume 1: BLAST User Manual. University of Illinois at Urbana-Champaign, Illinois.

California Energy Commission (CEC). 1999. Cooling Equipment Database. Available URL: http://www.energy.ca.gov/efficiency/appliances/index.html

Crawley, D. B., P. K. Riesen, and R. S. Briggs. 1989. Users Guide for ENVSTD Program Version 2.0 and LTGSTD Program Version 2.0. PNL-6839, Pacific Northwest Laboratory, Richland, Washington.

Energy Information Administration (EIA). 1992. 1992 Commercial Building Energy Consumption and Expenditures (CBECS), Public Use Data, Micro-data files on EIA website: ftp://ftp.eia.doe.gov/pub/consumption/commercial/micro.data/

Energy Information Administration (EIA). 1995. 1995 Commercial Building Energy Consumption and Expenditures (CBECS), Public Use Data, Micro-data files on EIA website: http://www.eia.doe.gov/emeu/cbecs/microdat.htmI

Energy Information Administration (EIA). 1999a. Annual Energy Outlook 2000. DOE/EIA-0383(2000), U.S. Government Printing Office, Washington, D.C. 
Energy Information Administration (EIA). 1999b. Supplement Tables for the Annual Energy Outlook 2000 on EIA website: http://www.eia.doe.gov/oief/aeo/supplement/index.html, Tables 11-20. U.S. Department of Energy, Washington, D.C.

Energy Policy Act of 1992 (EPACT). Public Law 102-486, 1096 Stat 2776.

Energy Policy and Conservation Act (EPCA). 42 USC 62901, et seq.

Freeman, S. L. 1995. Commercial Equipment Cost Database. PNL-10365, Pacific Northwest Laboratory, Richland, Washington.

Friedrich, M., and M. Messinger. 1995. "Method to Assess the Gross Annual Energy Saving Potential of Energy Conservation Technologies Used in Commercial Buildings." ASHRAE Transaction, 101(1):444453. American Society of Heating, Refrigerating and Air-Conditioning Engineers, Inc., Atlanta Georgia.

Office of Management and Budget (OMB). 1992. Guidelines and Discount Rates for Benefit-Cost Analyses of Federal Programs. OMB Circular A-94. Available URL:

http://www.whitehouse.gov/OMB/circulars/a094/a094.html

U.S. Department of Energy (DOE). 1999. GPRA Data Call, Fiscal Year 2001. U.S. Government Printing Office, Washington, D.C. 


\section{Appendix A}

\section{Engineering Data}




\section{Appendix A}

\section{Engineering Data}

\section{A.1 Introduction}

Modeling the commercial buildings and equipment using the Building Loads and Systems Thermodynamics (BLAST) simulation tool (BLAST 1991) required assumptions about the buildings' internal loads; key envelope characteristics; occupancy characteristics; ventilation rates; and heating, ventilating, and air-conditioning (HVAC) and service water-heating (SWH) equipment operation schedules. This appendix describes the building characteristics that were used in estimating the loads for the representative building types selected for the screening analysis.

For heating and cooling equipment, the annual energy use is a function of, among other things, the heating or cooling loads the equipment must meet. These loads can vary by hour of the day, day of the week, and time of the year. The variations are driven by factors such as the type of building in which the equipment is installed; the activities and internal loads (lighting, occupant, and receptacle loads) in the building; and the buildings' internal and external environmental conditions, ventilation rates, and HVAC control strategy. Consequently, building type is a convenient descriptor for categorizing the nature of loads the HVAC equipment must meet. For SWH equipment, annual energy consumption depends on the demand for hot water. This demand can be also be linked to building type by the activities that create the demand.

\section{A.2 Lighting and Plug Load Assumptions}

Lighting and plug loads represent a significant fraction of building internal loads for many representative building types. Typically, these loads are represented by a peak power density (in watts per square foot) and a profile that describes the hourly magnitude with respect to the peak. These profiles are typically "hat-shaped" with a "crown" representing the peak period and a "brim" representing the off-hours (base-load). In between the "crown" and "brim" is a transition period representing the period between when the light and plug loads first start to increase and when these loads are fully "on" during the "crown" period. The significant characteristics of the profile are the duration of the "crown," the duration of the transition period, and the relative magnitude of the off-hour "brim" with regard to the peak.

The peak load and profile are unique for each building, but much similarity exists for buildings of the same type and occupancy. While each building is unique, building performance researchers often choose a representative description of the lighting and plug loads for simulation purposes. In the energy efficiency standards arena, the American Society of Heating, Refrigeration and Air-Conditioning Engineers, Inc. (ASHRAE) Standing Standards Project Committee (SSPC) 90.1 has developed several 
typical profiles for use in their energy cost budget (ECB) compliance method, which estimates the annual energy consumption of a design building. These profiles, while not representative of any particular building, reflect the professional judgment of the members of the committee about the appearance of plug and light profiles for various building types. This judgment is influenced by another major source of information-metered data from individual buildings. These data are available from several sources and are usually collected by utilities or government agencies for use in energy conservation and demand-side management programs.

For the screening analysis, lighting and equipment load profiles were developed from the profiles recommended by ASHRAE for each of the building types considered. Where metered data were available, observed peak and base loads were used to scale the profiles to reflect loads observed in "real" buildings. In addition, adjustments were made as necessary to the duration of "on" periods to reflect typical occupancy patterns observed in the Commercial Building Energy Consumption Survey (CBECS) data (EIA 1992, 1995).

The lighting and plug load profiles in Standard 90.1-1989 (ASHRAE 1989a) were modified through ASHRAE's addenda process. ASHRAE's proposed Addendum 90.lj to Standard 90.1-1989 (referred to as "Addendum 90.1j" in this appendix) revises several simulation profiles by increasing the magnitude of off-hour loads. These load shapes were selected as the basis for the Phase-I analysis (Barwig et al. 1996), and therefore were selected for the screening analysis, as well for the seven representative building types.

ELCAP developed profiles for several commercial building types (Taylor and Pratt 1989; Taylor and Pratt 1990; Taylor 1992). Taylor and Pratt (1989) provide average profiles for several building types, Taylor (1992) provides more detailed average information for five building types, and Taylor and Pratt (1990) provide similar information for individual retail and office buildings. Kasmar (1992) provides useful profile information for several building types. Metering the DOE Headquarters Building by the Federal Energy Management Program (FEMP) provided plug and light profiles for this building as documented in Halverson et al. (1994).

\section{A.2.1 Lighting and Plug Load Schedules and Peak Intensities}

The ASHRAE profiles were modified for use in the screening analysis by scaling their base-to-peak load ratios to match observations in metered data available for many of the building types. Profiles used for buildings without sufficient available metered data were unmodified in terms of base and peak loads. Tables A.1 and A.2 show the peak- and base-load intensities used to normalize the ASHRAE profiles. Table A.3 shows the hourly lighting and plug load fractions for the commercial building types for weekdays, Saturdays, and Sundays/holidays. These fractions multiplied by the peak-load intensity give the actual load intensity for each hour.

\section{A.2.2 Lighting Densities}

The lighting peak power density for each representative building was estimated at the level the buildings would use in 2015. Base-load values for light and plug loads and peak-load values for plug loads were drawn from the metered data sources to refine values supplied by ASHRAE for use with their 
Table A.1. Lighting Load Intensities Used to Normalize the ASHRAE Hourly Profiles for the Screening Analysis

\begin{tabular}{|c|c|c|c|c|c|c|}
\hline \multirow[b]{3}{*}{ Building Type } & \multicolumn{6}{|c|}{ Lighting (W/ft $\left.{ }^{2}\right)$} \\
\hline & \multicolumn{2}{|c|}{ Weekday } & \multicolumn{2}{|c|}{ Saturday } & \multicolumn{2}{|c|}{ Sunday/Holiday } \\
\hline & Peak $^{(\text {a) }}$ & Base & Peak $^{(\mathrm{a})}$ & Base & Peak $^{(\mathrm{a})}$ & Base \\
\hline Assembly & 2.25 & 0.45 & 2.25 & 0.13 & 2.25 & 0.13 \\
\hline Education & 0.90 & 0.10 & 0.10 & 0.10 & 0.10 & 0.10 \\
\hline Food Service & 1.60 & 0.30 & 1.60 & 0.30 & 1.60 & 0.30 \\
\hline Lodging & 1.26 & 0.14 & 1.26 & 0.14 & 0.98 & 0.14 \\
\hline Office & 1.47 & 0.26 & 0.68 & 0.26 & 0.26 & 0.26 \\
\hline Retail & 1.50 & 0.27 & 1.35 & 0.27 & 0.90 & 0.27 \\
\hline Warehouse & 0.60 & 0.10 & 0.10 & 0.10 & 0.10 & 0.10 \\
\hline \multicolumn{7}{|c|}{$\begin{array}{l}\text { (a) The peak lighting loads used for the actual simulation were based on } \\
\text { estimated peak design lighting intensity levels that would be } \\
\text { expected for } 2015 \text {. }\end{array}$} \\
\hline
\end{tabular}

Table A.2. Plug Load Intensities Used to Normalize the ASHRAE Hourly Profiles and BLAST Simulations for the Screening Analysis

\begin{tabular}{|l|c|c|c|c|c|c|}
\hline \multirow{2}{*}{ Building Type } & \multicolumn{6}{|c|}{ Plug Loads $\left(\mathrm{W} / \mathrm{ft}^{2}\right)$} \\
\cline { 2 - 7 } & \multicolumn{2}{|c|}{ Weekday } & \multicolumn{2}{c|}{ Saturday } & \multicolumn{2}{c|}{ Sunday/Holiday } \\
\cline { 2 - 7 } & Peak & Base & Peak & Base & Peak & Base \\
\hline Assembly & 0.19 & 0.10 & 0.13 & 0.10 & 0.16 & 0.10 \\
\hline Education & 0.48 & 0.01 & 0.01 & 0.01 & 0.01 & 0.01 \\
\hline Food Service & 1.20 & 0.50 & 1.20 & 0.50 & 1.20 & 0.50 \\
\hline Lodging & 0.23 & 0.10 & 0.18 & 0.10 & 0.20 & 0.11 \\
\hline Office & 0.64 & 0.30 & 0.45 & 0.30 & 0.30 & 0.30 \\
\hline Retail & 0.40 & 0.10 & 0.36 & 0.10 & 0.24 & 0.10 \\
\hline Warehouse & 0.15 & 0.10 & 0.10 & 0.10 & 0.10 & 0.10 \\
\hline
\end{tabular}

profiles. Metered data were available for five of the DOE commercial building types (education, food service, office, retail, and warehouse). For assembly and lodging building types, the peak and base loads for plugs, and base load for lights were the values provided by ASHRAE.

The year 2015 lighting power density estimates were derived using a combination of interior space type lighting models and estimated future lighting technology and application trends. This combination allows the estimates to be based on individual components of a lighting power density (design elements, technologies, application where known) rather than an escalation of any existing power density values. 
Table A.3. Lighting and Plug Load Schedules for BLAST Runs (fraction of weekday peak loads)

\begin{tabular}{|c|c|c|c|c|c|c|c|c|c|c|c|c|c|c|c|c|c|c|c|c|c|c|c|c|c|c|}
\hline $\begin{array}{l}\text { Building } \\
\text { Type }\end{array}$ & $\begin{array}{c}\text { Peak } \\
\text { Densities }\end{array}$ & $\begin{array}{l}\text { Day of } \\
\text { Week }\end{array}$ & 0 & 1 & 2 & 3 & 4 & 5 & 6 & 7 & 8 & 9 & 10 & 11 & 12 & 13 & 14 & 15 & 16 & 17 & 18 & 19 & 20 & 21 & 22 & 23 \\
\hline \multirow{6}{*}{ Assembly } & \multirow{3}{*}{\begin{tabular}{|l|} 
Lighting \\
1.59 \\
$\mathrm{~W} / \mathrm{n}^{2}$
\end{tabular}} & Weekday & $\mid 0.20$ & 0.20 & 0.20 & 0.20 & 0.20 & 0.20 & 0.63 & 0.63 & 0.63 & 1.00 & 1.00 & 1.00 & 1.00 & 1.00 & 1.00 & 1.00 & 1.00 & 1.00 & 1.00 & 1.00 & 1.00 & 1.00 & 0.47 & 0.20 \\
\hline & & \begin{tabular}{|l|} 
Sat. \\
\end{tabular} & 0.06 & 0.06 & 0.06 & 0.06 & 0.06 & 0 & 0.06 & $\overline{0.06}$ & 0.06 & 0.62 & $\overline{0.62}$ & 1.00 & 1.00 & 1.00 & 1.00 & 1.00 & 1.00 & 1.00 & 1.00 & 1.00 & 1.00 & 1.00 & $\mid 0.62$ & 0.06 \\
\hline & & Sun. & 0.06 & 0.06 & 0.06 & 0.06 & 0.06 & 0.06 & 0.06 & 0.06 & 0.06 & $\overline{0.49}$ & 0.49 & 0.49 & 1.00 & 1.00 & \begin{tabular}{|l|}
1.00 \\
\end{tabular} & 1.00 & 1.00 & 1.00 & 1.00 & 1.00 & 1.00 & 1.00 & $\overline{0.49}$ & $\overline{0.06}$ \\
\hline & \multirow{3}{*}{\begin{tabular}{|l|} 
Plugs \\
0.19 \\
$W / \Omega^{2}$
\end{tabular}} & Weckday & $\overline{0.53}$ & 0.53 & 0.53 & 0.53 & $\overline{0.53}$ & 0.53 & 0.78 & 0.78 & \begin{tabular}{|l|}
0.78 \\
\end{tabular} & 1.00 & 1.00 & 1.00 & 1.00 & 1.00 & $\begin{array}{ll}1.00 \\
\end{array}$ & 1.00 & 1.00 & 1.00 & 1.00 & 1.00 & $\overline{1.00}$ & 1.00 & $\overline{0.69}$ & $\overline{0.53}$ \\
\hline & & \begin{tabular}{|l|} 
Sat. \\
\end{tabular} & 0.53 & $\overline{0.53}$ & 0.53 & $\overline{0.53}$ & 0.53 & 0.53 & 0.53 & 0.53 & 0.53 & 0.53 & 0.61 & 0.67 & 0.67 & 0.67 & \begin{tabular}{|l|}
0.67 \\
\end{tabular} & $\overline{0.67}$ & 0.67 & 0.67 & 0.67 & 0.67 & 0.67 & 0.67 & $\overline{0.53}$ & $\overline{0.53}$ \\
\hline & & Sun. & $\overline{0.53}$ & $\overline{0.53}$ & 0.53 & $\overline{0.53}$ & $\overline{0.53}$ & $\overline{0.53}$ & 0.53 & 0.53 & 0.53 & $\overline{0.53}$ & 0.69 & $\overline{0.69}$ & 0.87 & 0.87 & \begin{tabular}{|l|}
0.87 \\
\end{tabular} & $\overline{0.87}$ & 0.87 & $\overline{0.87}$ & 0.87 & $\overline{0.87}$ & $\overline{0.87}$ & 0.87 & 0.53 & 0.53 \\
\hline \multirow{6}{*}{ Education } & \multirow{3}{*}{$\begin{array}{l}\text { Lighting } \\
1.45 \\
W / \pi^{2}\end{array}$} & Weekday & 0.11 & $\overline{0.11}$ & 0.11 & 0.11 & 0.11 & 0.11 & 0.11 & 0.38 & 0.90 & \begin{tabular}{|l|l|}
1.00 \\
\end{tabular} & 1.00 & 1.00 & 0.86 & 0.86 & 0.86 & $\overline{0.76}$ & 0.57 & 0.57 & 0.43 & $\overline{0.43}$ & $\overline{0.43}$ & 0.38 & 0.11 & 0.11 \\
\hline & & \begin{tabular}{|l|} 
Sat. \\
\end{tabular} & 0.11 & $\overline{0.11}$ & 0.11 & $\overline{0.11}$ & 0.11 & 0.11 & 0.11 & $\overline{0.11}$ & 0.11 & 0.11 & 0.11 & 0.11 & 0.11 & 0.11 & 0.11 & $\overline{0.11}$ & 0.11 & 0.11 & 0.11 & 0.11 & 0.11 & 0.11 & 0.11 & 0.11 \\
\hline & & Sun. & 0.11 & 0.11 & 0.11 & 0.11 & 0.11 & 0.11 & 0.11 & 0.11 & 0.11 & $\overline{0.11}$ & 0.11 & 0.11 & 0.11 & 0.11 & 0.11 & $\overline{0.11}$ & 0.11 & 0.11 & 0.11 & 0.11 & 0.11 & $\overline{0.11}$ & 0.11 & 0.11 \\
\hline & \multirow{3}{*}{$\begin{array}{l}\text { Plugs } \\
0.48 \\
\mathrm{~W} / \mathrm{f}^{2} \\
\end{array}$} & Weekday & 0.02 & 0.02 & 0.02 & 0.02 & 0.02 & 0.02 & 0.02 & $\overline{0.32}$ & $\overline{0.32}$ & $\overline{0.32}$ & 1.00 & 1.00 & 0.84 & $\overline{0.84}$ & 0.84 & $\overline{0.74}$ & 0.53 & 0.53 & 0.37 & 0.37 & 0.37 & $\overline{0.32}$ & 0.02 & 0.02 \\
\hline & & Sat. & 0.02 & $\overline{0.02}$ & 0.02 & 0.02 & 0.02 & $\overline{0.02}$ & $\mid \overline{0.02}$ & 0.02 & 0.02 & $\overline{0.02}$ & $\overline{0.02}$ & $\overline{0.02}$ & 0.02 & 0.02 & \begin{tabular}{|l|l}
0.02 \\
\end{tabular} & $\overline{0.02}$ & 0.02 & $\overline{0.02}$ & 0.02 & 0.02 & 0.02 & 0.02 & 0.02 & 0.02 \\
\hline & & Sun. & $\overline{0.02}$ & $\overline{0.02}$ & $\overline{0.02}$ & $\overline{0.02}$ & $\overline{0.02}$ & $\overline{0.02}$ & $\overline{0.02}$ & 0.02 & $\overline{0.02}$ & 0.02 & $\overline{0.02}$ & 0.02 & 0.02 & 0.02 & \begin{tabular}{|l|}
0.02 \\
\end{tabular} & $\overline{0.02}$ & $\overline{0.02}$ & 0.02 & $\overline{0.02}$ & 0.02 & 0.02 & 0.02 & 0.02 & 0.02 \\
\hline \multirow{6}{*}{ Food Service } & \multirow{3}{*}{\begin{tabular}{|l|} 
Lighting \\
1.75 \\
$W / \mathrm{f}^{2}$ \\
\end{tabular}} & Weekday & 0.43 & 0.28 & 0.19 & \begin{tabular}{|l|}
0.19 \\
\end{tabular} & 0.19 & 0.33 & 0.52 & 0.52 & 0.71 & \begin{tabular}{|l|}
0.71 \\
\end{tabular} & 1.00 & 1.00 & 1.00 & 1.00 & \begin{tabular}{|l|l|}
1.00 \\
\end{tabular} & 1.00 & 1.00 & 1.00 & 1.00 & 1.00 & 0.90 & 0.90 & 0.71 & 0.62 \\
\hline & & Sat. & 0.43 & $\overline{0.28}$ & 0.19 & 0.19 & 0.19 & 0.19 & 0.33 & 0.43 & 0.71 & 0.71 & 0.90 & 0.90 & 0.90 & 0.90 & 0.90 & 0.90 & 0.90 & 1.00 & 1.00 & 1.00 & 1.00 & 0.81 & 0.71 & $\overline{0.62}$ \\
\hline & & Sun. & $\overline{0.43}$ & $\overline{0.28}$ & 0.19 & 0.19 & 0.19 & 0.19 & $\overline{0.33}$ & $\overline{0.43}$ & 0.71 & \begin{tabular}{|l|l|}
0.71 \\
\end{tabular} & 0.90 & 0.90 & $\overline{0.90}$ & 0.90 & \begin{tabular}{|l|l}
0.90 \\
\end{tabular} & $\overline{0.90}$ & $\overline{0.90}$ & 1.00 & 1.00 & 1.00 & 1.00 & $\overline{0.81}$ & 0.71 & 0.62 \\
\hline & \multirow{3}{*}{$\begin{array}{l}\text { Plugs } \\
1.2 \\
\mathrm{~W} / \mathrm{n}^{2}\end{array}$} & Weekday & 0.59 & 0.49 & 0.42 & 0.42 & 0.42 & 0.52 & 0.66 & 0.66 & 0.79 & 0.79 & 1.00 & 1.00 & \begin{tabular}{|l|}
1.00 \\
\end{tabular} & 1.00 & 1.00 & 1.00 & 1.00 & 1.00 & 1.00 & 1.00 & $\overline{0.93}$ & 0.93 & 0.79 & $\overline{0.73}$ \\
\hline & & \begin{tabular}{|l|} 
Sat. \\
\end{tabular} & 0.59 & 0.49 & 0.42 & 0.42 & 0.42 & 0.42 & 0.52 & 0.59 & 0.79 & 0.79 & $\mid 0.93$ & $\mid 0.93$ & 0.93 & 0.93 & 0.93 & $\overline{0.93}$ & 0.93 & 1.00 & 1.00 & 1.00 & 1.00 & 0.86 & 0.79 & 0.73 \\
\hline & & Sun. & $\overline{0.59}$ & $\overline{0.49}$ & $\overline{0.42}$ & $\overline{0.42}$ & 0.42 & 0.42 & 0.52 & 0.59 & $\overline{0.79}$ & 0.79 & \begin{tabular}{|l|l|}
0.93 \\
\end{tabular} & $\overline{0.93}$ & 0.93 & 0.93 & 0.93 & 0.93 & $\overline{0.93}$ & 1.00 & 1.00 & 1.00 & 1.00 & 0.86 & 0.79 & $\overline{0.73}$ \\
\hline \multirow{6}{*}{ Lodging } & \multirow{3}{*}{\begin{tabular}{|l|} 
Lighting \\
1.54 \\
$\mathrm{~W} / \mathrm{ft}^{2}$
\end{tabular}} & Weekday & 0.22 & 0.17 & 0.11 & 0.11 & 0.11 & $\sqrt{0.22}$ & $\overline{0.44}$ & 0.56 & 0.44 & 0.44 & \begin{tabular}{|l|}
0.28 \\
\end{tabular} & $\overline{0.28}$ & $\overline{0.28}$ & 0.28 & 0.28 & 0.28 & 0.28 & 0.28 & 0.67 & $\mid 0.89$ & 1.00 & $\overline{0.89}$ & 0.67 & $\overline{0.33}$ \\
\hline & & Sat. & 0.26 & 0.26 & 0.11 & 0.11 & 0.11 & 0.11 & $\overline{0.41}$ & 0.41 & 0.56 & 0.56 & 0.41 & 0.33 & 0.33 & 0.33 & $\overline{0.33}$ & 0.33 & 0.33 & 0.33 & 0.85 & 1.00 & 1.00 & 1.00 & 0.85 & 0.41 \\
\hline & & Sun. & 0.22 & $\overline{0.22}$ & 0.11 & 0.11 & 0.11 & 0.11 & 0.22 & $\overline{0.33}$ & $\overline{0.33}$ & 0.22 & 0.22 & 0.22 & 0.22 & 0.11 & 0.11 & 0.11 & 0.11 & 0.11 & 0.44 & 0.07 & 0.78 & 0.56 & 0.44 & 0.22 \\
\hline & \multirow{3}{*}{\begin{tabular}{|l} 
Plugs \\
0.23 \\
$W / \mathrm{ft}^{2}$
\end{tabular}} & Weekday & 0.51 & 0.48 & 0.44 & 0.44 & 0.44 & 0.51 & 0.65 & 0.72 & 0.65 & $\overline{0.65}$ & $\overline{0.55}$ & $\overline{0.55}$ & $\overline{0.55}$ & 0.55 & $\overline{0.55}$ & 0.55 & $\overline{0.55}$ & 0.55 & $\mid 0.79$ & 0.93 & 1.00 & $\overline{0.93}$ & 0.79 & $\overline{0.58}$ \\
\hline & & \begin{tabular}{|l} 
Sat. \\
\end{tabular} & 0.50 & 0.50 & 0.44 & 0.44 & 0.44 & 0.44 & 0.56 & 0.56 & 0.61 & $\overline{0.61}$ & 0.56 & 0.53 & 0.53 & 0.53 & $\overline{0.53}$ & $\overline{0.53}$ & 0.53 & 0.53 & 0.72 & 0.78 & 0.78 & 0.78 & 0.72 & 0.56 \\
\hline & & Sun. & 0.56 & 0.56 & 0.49 & $\overline{0.49}$ & $\overline{0.49}$ & $\overline{0.49}$ & 0.56 & $\overline{0.62}$ & \begin{tabular}{|l|}
0.62 \\
\end{tabular} & 0.56 & 0.56 & 0.56 & 0.56 & $\overline{0.49}$ & \begin{tabular}{|l|}
0.49 \\
\end{tabular} & 0.49 & \begin{tabular}{|l|l|}
0.49 \\
\end{tabular} & $\overline{0.49}$ & $\overline{0.69}$ & $\overline{0.82}$ & 0.89 & 0.76 & $\overline{0.69}$ & 0.56 \\
\hline \multirow{6}{*}{ Office } & \multirow{3}{*}{$\begin{array}{l}\text { Lighting } \\
1.32 \\
W / \mathrm{n}^{2}\end{array}$} & Weekday & 0.18 & 0.18 & 0.18 & 0.18 & 0.18 & $\overline{0.23}$ & 0.23 & $\overline{0.42}$ & 1.00 & 1.00 & 1.00 & 1.00 & 0.90 & 1.00 & 1.00 & 1.00 & 1.00 & 0.61 & 0.42 & 0.42 & 0.32 & $\overline{0.32}$ & 0.23 & 0.18 \\
\hline & & Sat. & 0.18 & 0.18 & 0.18 & \begin{tabular}{|l|l|}
0.18 \\
\end{tabular} & 0.18 & 0.18 & 0.23 & 0.23 & 0.46 & 0.46 & $\overline{0.46}$ & 0.46 & 0.46 & 0.46 & \begin{tabular}{|l|}
0.46 \\
\end{tabular} & 0.46 & \begin{tabular}{|l|l|}
0.46 \\
\end{tabular} & 0.18 & $\overline{0.18}$ & 0.18 & 0.18 & 0.18 & 0.18 & 0.18 \\
\hline & & Sun. & 0.18 & 0.18 & 0.18 & 0.18 & 0.18 & 0.18 & $\overline{0.18}$ & 0.18 & $\overline{0.18}$ & 0.18 & $\mid \overline{0.18}$ & $\mid \overline{0.18}$ & 0.18 & $\overline{0.18}$ & $\overline{0.18}$ & 0.18 & $\overline{0.18}$ & 0.18 & \begin{tabular}{|l|} 
\\
\end{tabular} & 0.18 & \begin{tabular}{|c|}
0.18 \\
\end{tabular} & 0.18 & 0.18 & 0.18 \\
\hline & \multirow{3}{*}{$\begin{array}{l}\text { Plugs } \\
0.64 \\
W / f^{2}\end{array}$} & Weekday & 0.47 & 0.47 & 0.47 & 0.47 & 0.47 & 0.50 & 0.50 & $\overline{0.63}$ & 1.00 & 1.00 & 1.00 & 1.00 & 0.94 & 1.00 & 1.00 & 1.00 & 1.00 & 0.75 & 0.63 & 0.63 & 0.56 & 0.56 & 0.50 & 0.47 \\
\hline & & Sat. & 0.47 & 0.47 & $\overline{0.47}$ & 0.47 & 0.47 & 0.47 & $\overline{0.52}$ & 0.52 & 0.70 & $\overline{0.70}$ & \begin{tabular}{|l|}
0.70 \\
\end{tabular} & 0.70 & \begin{tabular}{|l|}
0.70 \\
\end{tabular} & 0.70 & \begin{tabular}{|l|}
0.70 \\
\end{tabular} & 0.70 & \begin{tabular}{|l|l}
0.70 \\
\end{tabular} & 0.47 & 0.47 & 0.47 & 0.47 & 0.47 & 0.47 & 0.47 \\
\hline & & Sun. & \begin{tabular}{|l|l|}
0.47 \\
\end{tabular} & 0.47 & 0.47 & 0.47 & $\mid 0.47$ & $\overline{0.47}$ & $\overline{0.47}$ & 0.47 & $\overline{0.47}$ & 0.47 & \begin{tabular}{|l|}
0.47 \\
\end{tabular} & 0.47 & 0.47 & $\mid \overline{0.47}$ & \begin{tabular}{|l|}
0.47 \\
\end{tabular} & 0.47 & \begin{tabular}{|l|l|}
0.47 \\
\end{tabular} & 0.47 & 0.47 & 0.47 & $\mid 0.47$ & 0.47 & 0.47 & 0.47 \\
\hline
\end{tabular}




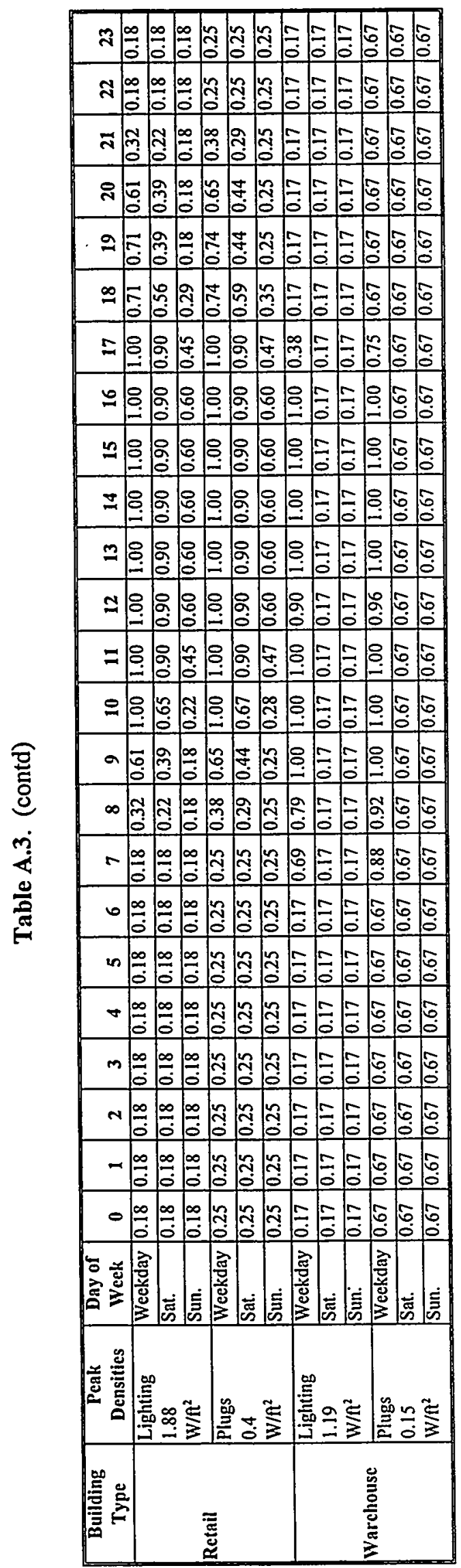


A major input in developing the 2015 estimates is the estimated market share of electronic versus magnetic fluorescent ballasts in 2015. This estimate was developed using the National Energy Savings model with 2027 base case (http://www.eren.doe.gov/buildings/codes standards/applbrf/ballast.html LBNL NESv_4). This ballast model, along with an internal Ernest Orlando Lawrence Berkley National Laboratory (LBNL) spreadsheet developed to supplement the NES, were used to run a consensus standards scenario to estimate magnetic ballast shipments. In the internal spreadsheet, the magnetic ballasts projected by the NES model for each year (which go to zero by a certain year under the standard) were added to the ballasts in the existing stock. This 2027 base scenario is assumed to cover renovated buildings whose magnetic ballasts are removed at the fixture turnover rate ( 16 years). In the internal spreadsheet, the magnetic ballasts projected by the NES model for each year (which go to zero by a certain year under the standard) were added to the ballasts in the existing stock. A new building growth rate of 1.07 percent was assumed (based on projected commercial and industrial historical and floor space (including federal buildings) from 1980 to 2030, based on data developed by building type by Regional Economic Research, Inc. (RER), San Diego, California. ${ }^{(a)}$

The results show (LBNL NESr-4) that by 2015 , the magnetic ballasts are likely to comprise $30 \%$ of the total ballast market under the anticipated standards ( 4690 in the 2027 base case). Fluorescent systems represent $77 \%$ of lit floor space according to the 1995 CBECS (EIA 1995). Thus, we concentrated on fluorescent technology to capture most changes.

The interior space type models used in this derivation are those developed for the Standard 90.1-1999 lighting standards. These models are considered by lighting design professionals and practitioners to represent good quality and innovative lighting design. These models do not represent the mix of existing building lighting designs. However, with the current interest in good quality design and human factor effects of the workplace environment, this kind of design will probably dominate much of the building stock by 2015 . By 2015 , a portion (estimated up to $16 \%$ ) of the building stock will consist of new buildings constructed with these design elements in mind. Further, a large portion of the existing building stock will also have been retrofit with partial or full redesign. This redesign would be caused primarily by the replacement of degraded 15+-year-old systems and building redesigns for other purposes such as new tenants and changing building space functions.

The Standard 90.1-1999 lighting standard models also include some specific characteristics considered appropriate for year 2015 estimation. These models incorporate the upper range of energyefficient equipment and ignore equipment that is generally on the trailing edge of the market as it is replaced with newer more efficient and upgraded versions. The models use the current leading edge T8 fluorescent technology as the basis for all linear fluorescent applications. The current trend in the development of smaller, cheaper, better CFL products will soon lead building lighting design and retrofit towards the application of CFLs in most previous incandescent applications. The models automatically incorporate compact fluorescent technology wherever it is possible to replace incandescent systems. The

(a) Technical Support Document: Energy Efficiency Standards for Consumer Products: Fluorescent Lamp Ballast Proposed Rule, January 2000. U.S. Department of Energy, http://www.eren.doe.gov/buildings/codes standards/applbrf/ballast.html. Appendix B, Table B.34. 
models also incorporate halogen (incandescent replacement) and small metal halide lamps (efficient for replacement in some fluorescent applications) where appropriate.

The impact of the controls was not considered. Because the installed wattage would not change, no data existed to support an estimate of the impact, and HVAC systems would likely be designed for the full lighting load (undimmed).

\section{Building Type: Assembly}

Discussion of Profile: Assembly includes museums, dance halls, auditoriums, gymnasiums, sports facilities, and churches. The typical assembly building lighting profile is hat-shaped. Peak lighting integrity in 2015 is estimated at $1.59 \mathrm{~W} / \mathrm{ft}^{2}$.

Metered data were not available for this building type.

\section{Building Type: Education}

Discussion of Profile: Education includes school buildings. The typical school building lighting profile is hat-shaped. Usually, the lights are either on or off in a school building. Note that school buildings include elementary schools that may be expected to operate from 8 a.m. to 5 p.m., secondary schools that may be expected to have significant extracurricular activities at night, and colleges and universities that may have evening classes. This building type is highly varied.

Measured peak load estimates range from $0.9 \mathrm{~W} / \mathrm{ft}^{2}$ to $2.3 \mathrm{~W} / \mathrm{ft}^{2}$, with most estimates falling between $1.4 \mathrm{~W} / \mathrm{ft}^{2}$ and $2.3 \mathrm{~W} / \mathrm{ft}^{2}$. Off-hour base-load estimates range from $0 \mathrm{~W} / \mathrm{ft}^{2}$ to $0.1 \mathrm{~W} / \mathrm{ft}^{2}$, with $0.1 \mathrm{~W} / \mathrm{ft}^{2}$ providing a representative average. The estimated peak lighting intensity in the year 2015 was $1.45 \mathrm{~W} / \mathrm{ft}^{2}$.

\section{Building Type: Food Service}

Discussion of Profile: The typical restaurant building lighting profile is hat-shaped, with all lights either on or off. The lights are on when food is being served. Obviously, a 24-hour restaurant will have a much different profile than a lunch counter that serves only breakfast and lunch.

Measured peak-load estimates range from $1.2 \mathrm{~W} / \mathrm{ft}^{2}$ to $2.0 \mathrm{~W} / \mathrm{ft}^{2}$. Off-hour base-load estimates range from $0.14 \mathrm{~W} / \mathrm{ft}^{2}$ to $0.8 \mathrm{~W} / \mathrm{ft}^{2}$. The estimated peak lighting intensity in the year 2015 was $1.75 \mathrm{~W} / \mathrm{ft}^{2}$.

\section{Building Type: Lodging}

Discussion of Profile: Lodging includes hotels, motels, resorts, barracks, and dormitories. A wide diversity of individual lighting systems are likely to exist, resulting in a low percentage of the total lights to be on at any one time, with some lights on all the time. More lights will be on in the evening, but lighting loads will occur all hours of the day, 7 days a week. The estimated peak lighting intensity in the year 2015 was $1.54 \mathrm{~W} / \mathrm{ft}^{2}$. 
Metered data were not available for this building type.

\section{Building Type: Office}

Discussion of Profile: The typical office building lighting profile is the classic hat shape, with a single-peak period occurring for most of the working day and a lower off-hour period. The peak period is typically 6 to 10 hours in duration. A transition period between the peak and off-hour period is typically 1 to 3 hours, depending on occupant behavior and lighting control schemes. Office buildings are typically active Monday through Friday, with minimal activity on Saturdays and even less on Sundays.

Measured peak working day estimates range from $0.7 \mathrm{~W} / \mathrm{ft}^{2}$ to $1.9 \mathrm{~W} / \mathrm{ft}^{2}$, with most of the estimates falling in the range of $1.3 \mathrm{~W} / \mathrm{ft}^{2}$ to $1.5 \mathrm{~W} / \mathrm{ft}^{2}$. The base off-hour load estimates range from $0 \mathrm{~W} / \mathrm{ft}^{2}$ to $0.6 \mathrm{~W} / \mathrm{ft}^{2}$, with most metered estimates being in the range of $0.2 \mathrm{~W} / \mathrm{ft}^{2}$ to $0.4 \mathrm{~W} / \mathrm{ft}^{2}$. The estimated peak lighting intensity in the year 2015 was $1.32 \mathrm{~W} / \mathrm{ft}^{2}$.

\section{Building Type: Retail}

Discussion of Profile: The typical retail building lighting profile is hat-shaped. Usually, the lights in a retail building are on if the business is open and off if the business is closed. The peak period is typically 10 hours in duration. Retail buildings are typically active all days of the week, with reduced hours on Sundays.

Peak lighting load estimates range from $1.1 \mathrm{~W} / \mathrm{ft}^{2}$ to $2.9 \mathrm{~W} / \mathrm{ft}^{2}$, with metered results tending to fall in the lower part of the range. Off-hour base-load estimates range from $0 \mathrm{~W} / \mathrm{ft}^{2}$ to $0.3 \mathrm{~W} / \mathrm{ft}^{2}$, with metered data indicating $0.1 \mathrm{~W} / \mathrm{ft}^{2}$ to $0.3 \mathrm{~W} / \mathrm{ft}^{2}$. The estimated peak lighting intensity in the year 2015 was $1.32 \mathrm{~W} / \mathrm{ft}^{2}$.

\section{Building Type: Warehouse}

Discussion of Profile: The typical warehouse building lighting profile is hat-shaped. Usually, the lights in a warehouse are on if the business is open and off if the business is closed. Weekends show minimal loads.

The peak load estimates range from $0.4 \mathrm{~W} / \mathrm{ft}^{2}$ to $0.7 \mathrm{~W} / \mathrm{ft}^{2}$ with most values falling near $0.6 \mathrm{~W} / \mathrm{ft}^{2}$. Off-hour base-load estimates range from $0 \mathrm{~W} / \mathrm{ft}^{2}$ to $0.2 \mathrm{~W} / \mathrm{ft}^{2}$, with $0.1 \mathrm{~W} / \mathrm{ft}^{2}$ representing a suitable average. The estimated peak lighting intensity in the year 2015 was $1.19 \mathrm{~W} / \mathrm{ft}^{2}$.

\section{A.2.3 Plug Loads}

\section{Building Type: Assembly}

Discussion of Profile: The typical assembly building plug load profile is hat-shaped.

Metered data were not available for this building type. The assumed peak and off-hour base loads for the screening analysis were $0.19 \mathrm{~W} / \mathrm{ft}^{2}$ and $0.01 \mathrm{~W} / \mathrm{ft}^{2}$, respectively. 


\section{Building Type: Education}

Discussion of Profile: The typical education building plug load profile is hat-shaped.

Because the sample size for metered data was very small; the proposed Standard 90.1-1999 profiles and associated peak and off-hour base loads were used for the screening analysis. The peak and off-hour base loads for the screening analysis were $0.475 \mathrm{~W} / \mathrm{ft}^{2}$ and $0.01 \mathrm{~W} / \mathrm{ft}^{2}$, respectively.

\section{Building Type: Food Service}

Discussion of Profile: The typical food service building plug load profile is hat-shaped. Obviously, a 24-hour restaurant will have a much different profile than a lunch counter that serves only breakfast and lunch.

The ASHRAE peak and off-hour base-load values were used for this screening analysis. The peak and off-hour base loads for the screening analysis were $1.2 \mathrm{~W} / \mathrm{ft}^{2}$ and $0.5 \mathrm{~W} / \mathrm{ft}^{2}$, respectively.

\section{Building Type: Lodging}

Discussion of Profile: Lodging includes hotels, motels, resorts, barracks, and dormitories.

Metered data were not available for this building type. The ASHRAE peak and off-hour base-load values were used for this screening analysis. The peak and off-hour base loads for the screening analysis were $0.225 \mathrm{~W} / \mathrm{ft}^{2}$ and $0.1 \mathrm{~W} / \mathrm{ft}^{2}$, respectively.

\section{Building Type: Office}

Discussion of Profile: The typical office building plug load profile is the classic hat-shape, with a single-peak period occurring for most of the working day and a lower off-hour period. The peak period is typically 6 to 10 hours. A transition period between the peak and off-hour period is typically 1 to 3 hours, depending on occupant behavior. Office buildings are typically active Monday through Friday, with minimal activity on Saturdays and even less on Sundays.

Peak-load estimates range from $0.2 \mathrm{~W} / \mathrm{ft}^{2}$ to $0.8 \mathrm{~W} / \mathrm{ft}^{2}$, with most falling in the range of $0.6 \mathrm{~W} / \mathrm{ft}^{2}$ to $0.8 \mathrm{~W} / \mathrm{ft}^{2}$. Off-hour base-load estimates range from $0 \mathrm{~W} / \mathrm{ft}^{2}$ to $0.4 \mathrm{~W} / \mathrm{ft}^{2}$, with many falling near $0.3 \mathrm{~W} / \mathrm{ft}^{2}$. The peak and off-hour base loads for the screening analysis were $0.64 \mathrm{~W} / \mathrm{ft}^{2}$ and $0.3 \mathrm{~W} / \mathrm{ft}^{2}$, respectively.

\section{Building Type: Retail}

Discussion of Profile: The typical retail building plug profile is hat-shaped.

Peak-load estimates range from $0.2 \mathrm{~W} / \mathrm{ft}^{2}$ to $0.6 \mathrm{~W} / \mathrm{ft}^{2}$. Off-hour base loads range from $0 \mathrm{~W} / \mathrm{ft}^{2}$ to $0.2 \mathrm{~W} / \mathrm{ft}^{2}$. The peak and off-hour base loads for the screening analysis were $0.4 \mathrm{~W} / \mathrm{ft}^{2}$ and $0.1 \mathrm{~W} / \mathrm{ft}^{2}$, respectively. 


\section{Building Type: Warehouse}

Discussion of Profile: The typical warehouse building plug load profile is hat-shaped.

Metered data indicate that relatively little difference exists between the peak and off-hour base plug loads in a warehouse, so the peak and off-hour base loads for the screening analysis were $0.15 \mathrm{~W} / \mathrm{ft}^{2}$ and $0.1 \mathrm{~W} / \mathrm{ft}^{2}$, respectively.

\section{A.3 Building HVAC Operation and Occupancy Assumptions}

\section{A.3.1 General Assumptions for Building Modeling}

The 1992 CBECS (EIA 1992) has a survey question that asks whether the building has extra heating and cooling hours ${ }^{\text {(a) }}$ (in addition to the normal operating hours of the building). The available responses are "yes," "no," or "inapplicable." Another question asks if there is a reduction in cooling off-hours, and a final question asks how many extra hours of heating and cooling are incurred beyond the (reported) operating hours. The average extra hours of operation per week (averaged by weighted square footage) were computed in the analysis.

Ventilation rates should be based on expected maximum occupancy (not the profile peak values used here) for internal load assumptions (ASHRAE 1989b).

Standard 90.1-1989 schedules and occupancy densities referred to in this appendix are from the proposed Addendum $90.1 \mathrm{j}$.

Tables A.4 and A.5 show the HVAC operation schedules and occupancy schedule for weekdays, weekends, and holidays, respectively, for each representative building type. These schedules and the source from which they were derived are described in the following section.

\section{A.3.2 Assembly Building Assumptions}

HVAC Operation Schedule - The CBECS (EIA 1992) reported 18 extra hours of HVAC operation per week, in addition to the normal operating hours of the building. However, only 10 extra hours were determined by adding 5 hours to the Saturday and Sunday occupancy schedules but none to the weekday occupancy schedule because 24 -hour operation on weekdays was assumed.

Saturday and Sunday Occupancy Schedule - Based on square footage (or weighted average), the building is typically closed on Saturday and Sunday. The second most prevalent schedule is open 24 hours. Other than 0 - or 24-hour operation, 12-hour operation was the most typical (based on the sample's sum of the square footage). Operating hours were assumed to be 11 a.m. to 11 p.m. ASHRAE

(a) The 1995 CBECS data did not have this information; therefore, 1992 CBECS data were used to extract the extra occupancy information (EIA 1992, 1995). 
Table A.4. HVAC Operation Schedules

\begin{tabular}{|c|c|c|c|}
\hline Building Type & Day of Week & Hour On & Hour Off \\
\hline \multirow{4}{*}{ Assembly } & Weekday & \multicolumn{2}{|c|}{---- On ---- } \\
\hline & Saturday & 0600 & 2300 \\
\hline & Sunday & 0600 & 2300 \\
\hline & Holiday & 0600 & 2300 \\
\hline \multirow{4}{*}{ Education } & Weekday & 0600 & 2300 \\
\hline & Saturday & 1000 & 1500 \\
\hline & Sunday & \multicolumn{2}{|c|}{----- Off ---- } \\
\hline & Holiday & \multicolumn{2}{|c|}{---- Off -..-- } \\
\hline \multirow{4}{*}{ Food Service } & Weekday & 0700 & 0300 \\
\hline & Saturday & 0700 & 0300 \\
\hline & Sunday & 0700 & 0300 \\
\hline & Holiday & 0700 & 0300 \\
\hline \multirow{4}{*}{ Lodging } & Weekday & \multicolumn{2}{|c|}{$-\cdots$ On --- } \\
\hline & Saturday & \multicolumn{2}{|c|}{---- On ---- } \\
\hline & Sunday & \multicolumn{2}{|c|}{---- On - -- } \\
\hline & Holiday & \multicolumn{2}{|c|}{$\cdots$ On - } \\
\hline \multirow{4}{*}{ Office } & Weekday & 0600 & 2300 \\
\hline & Saturday & 0900 & 1600 \\
\hline & Sunday & \multicolumn{2}{|c|}{--- Off --- } \\
\hline & Holiday & \multicolumn{2}{|c|}{-... Off --. } \\
\hline \multirow{4}{*}{ Retail } & Weekday & 0800 & 2300 \\
\hline & Saturday & 0800 & 2300 \\
\hline & Sunday & 1000 & 2000 \\
\hline & Holiday & 1000 & 2000 \\
\hline \multirow{4}{*}{ Warehouse } & Weekday & \multicolumn{2}{|c|}{$-\ldots$ On -.- } \\
\hline & Saturday & \multicolumn{2}{|c|}{---- Off ---- } \\
\hline & Sunday & \multicolumn{2}{|c|}{$-\cdots$ Off --- } \\
\hline & Holiday & \multicolumn{2}{|c|}{---- Off --- } \\
\hline
\end{tabular}

used noon to 10 p.m. full occupancy and 11 p.m. to 9 a.m. partial occupancy. The ASHRAE schedule was adjusted to have 12 hours of operation. Sunday was modeled the same as Saturday.

Weekday Occupancy Schedule - The CBECS (EIA 1992) reported 24-hour operation as the most prevalent schedule. Twenty-four hours were assumed using the ASHRAE occupancy shape for weekdays, but inflating the nighttime period occupancy to $10 \%$. The HVAC system was assumed to run 24 hours because the buildings were occupied for the whole period (although at reduced levels). 
Table A.5. Occupancy Schedules for BLAST Runs (fraction of weekday peak occupancy)

\begin{tabular}{|c|c|c|c|c|c|c|c|c|c|c|c|c|c|c|c|c|c|c|c|c|c|c|c|c|c|c|}
\hline Building Type & $\begin{array}{c}\text { Peak } \\
\text { Occupancy }\end{array}$ & $\begin{array}{l}\text { Day of } \\
\text { Weck }\end{array}$ & 0 & 1 & 2 & 3 & 4 & 5 & 6 & 7 & 8 & 9 & 10 & 11 & 12 & 13 & 14 & 15 & 16 & 17 & 18 & 19 & 20 & 21 & 22 & 23 \\
\hline \multirow{3}{*}{ Assembly } & \multirow{3}{*}{$\mid \begin{array}{l}0.016 \\
\text { people/ } \AA^{2}\end{array}$} & Weckday & 0.05 & 0.05 & 0.05 & 0.05 & 0.05 & 0.05 & 0.05 & $\overline{0.05}$ & 0.29 & 0.29 & 0.29 & \begin{tabular}{|l|}
1.00 \\
\end{tabular} & 1.00 & 1.00 & 1.00 & \begin{tabular}{|l|}
1.00 \\
\end{tabular} & 1.00 & 1.00 & 0.29 & 0.29 & 0.29 & \begin{tabular}{|l|}
0.29 \\
\end{tabular} & 0.17 & 0.05 \\
\hline & & Sat. & 10.00 & 0.00 & 0.00 & 0.00 & 0.00 & 0.00 & 0.00 & 0.00 & 0.00 & 0.00 & 0.25 & 0.75 & 0.75 & 0.75 & 0.75 . & 0.75 & 0.75 & 0.75 & 0.75 & 0.75 & 1.00 & 0.25 & 0.00 & $\overline{0.00}$ \\
\hline & & Sunt. & 10.00 & 0.00 & 0.00 & 0.00 & 0.00 & $\overline{0.00}$ & 0.00 & 0.00 & 0.00 & $\overline{0.00}$ & 0.13 & 0.13 & 0.13 & 0.88 & 0.88 & \begin{tabular}{|l|}
0.88 \\
\end{tabular} & 0.88 & 0.88 & 0.88 & 0.88 & $\overline{0.88}$ & 0.25 & 0.00 & $\overline{0.00}$ \\
\hline \multirow[t]{2}{*}{ Education } & \multirow{2}{*}{$\mid \begin{array}{l}0.0107 \\
\text { pcople/f } \mathbb{t}^{2}\end{array}$} & Sat. & 0.00 & 0.00 & 0.00 & 0.00 & 0.00 & 0.00 & 0.00 & 0.00 & 0.00 & 0.00 & 0.00 & 0.00 & 0.00 & 0.00 & 0.00 & 0.00 & 0.00 & 0.00 & 0.00 & 0.00 & 0.00 & 0.00 & 0.00 & $\overline{0.00}$ \\
\hline & & Sun. & 0.00 & 0.00 & 0.00 & 0.00 & 0.00 & 0.00 & \begin{tabular}{|l|}
0.00 \\
\end{tabular} & 0.00 & 0.00 & 0.00 & 0.00 & 0.00 & \begin{tabular}{|l|}
0.00 \\
\end{tabular} & 0.00 & 0.00 & 0.00 & 0.00 & 0.00 & 0.00 & $\overline{0.00}$ & 0.00 & $\overline{0.00}$ & 0.00 & 0.00 \\
\hline Food Service & $\mid \begin{array}{l}0.011 \\
\text { people/f } t^{2}\end{array}$ & Weekday & 0.11 & $\overline{0.02}$ & 0.00 & 0.00 & 0.00 & 0.00 & 0.02 & 0.02 & 0.05 & 0.05 & 0.22 & 0.54 & 0.86 & 0.76 & 0.43 & $\overline{0.22}$ & 0.27 & 0.54 & 0.86 & 0.86 & 0 & 0.54 & 0.38 & 0.22 \\
\hline \multirow{3}{*}{ Lodging } & \multirow{3}{*}{$\mid \begin{array}{l}0.0033 \\
\text { people/ } / \mathbf{f}^{2}\end{array}$} & Weekday & 1.00 & 1.00 & 1.00 & 1.00 & 1.00 & 1.00 & 0.77 & 0.43 & $\overline{0.43}$ & 0.20 & 0.20 & 0.20 & 0.20 & 0.20 & 0.20 & 0.31 & 0.54 & 0.54 & 0.54 & 0.77 & 0.77 & 0.89 & 1.00 & 1.00 \\
\hline & & Sat. & 1.00 & 1.00 & 1.00 & 1.00 & 1.00 & 1.00 & 0.77 & $\overline{0.53}$ & 0.53 & 0.30 & 0.30 & 0.30 & 0.30 & 0.30 & $\overline{0.30}$ & 0.30 & 0.30 & 0.53 & 0.65 & 0.65 & 0.65 & 0.77 & 0.77 & 0.77 \\
\hline & & Sun. & 0.77 & 0.77 & 0.77 & 0.77 & 0.77 & 0.77 & 0.77 & 0.77 & 0.54 & 0.54 & 0.54 & 0.31 & 0.31 & 0.20 & 0.20 & 0.20 & 0.31 & $\overline{0.43}$ & 0.43 & 0.66 & 0.66 & 0.88 & 0.88 & 0.88 \\
\hline \multirow{3}{*}{ Office } & \multirow{3}{*}{$\begin{array}{l}0.0033 \\
\text { people/f } \mathrm{f}^{2}\end{array}$} & Weckday & 0.00 & 0.00 & 0.00 & 0.00 & 0.00 & 0.00 & 0.11 & 0.21 & 1.00 & 1.00 & 1.00 & 1.00 & 0.53 & 1.00 & 1.00 & 1.00 & 1.00 & $\overline{0.32}$ & 0.11 & 0.11 & 0.11 & 0.11 & 0.05 & 0.05 \\
\hline & & Sat. & 0.00 & 0.00 & 0.00 & 0.00 & 0.00 & 0.00 & 0.11 & 0.11 & 0.11 & 0.11 & 0.11 & 0.11 & 0.11 & 0.11 & 0.11 & 0.11 & 0.11 & 0.05 & 0.05 & 0.00 & 0.00 & 0.00 & 0.00 & 0.00 \\
\hline & & Sun. & 0.00 & 0.00 & 0.00 & 0.00 & 0.00 & 0.00 & $\overline{0.05}$ & 0.05 & 0.05 & 0.05 & 0.05 & 0.05 & 0.05 & 0.05 & 0.05 & \begin{tabular}{|l|}
0.05 \\
\end{tabular} & 0.05 & 0.05 & 0.00 & 0.00 & 0.00 & 0.00 & 0.00 & $\overline{0.00}$ \\
\hline \multirow[t]{2}{*}{ Retail } & \multirow{2}{*}{$\mid \begin{array}{l}0.0022 \\
\text { people/ } / \mathbb{t}^{2}\end{array}$} & Sat. & 0.00 & 0.00 & 0.00 & 0.00 & 000 & 0.00 & 000 & 0.00 & 0.13 & 0.25 & 0.75 & 1.00 & 1.00 & 1.00 & 1.00 & 1.00 & 0.75 & 0.25 & 0.25 & 0.25 & 0.13 & 0.00 & $\overline{0.00}$ & $\overline{0.00}$ \\
\hline & & Sun. & 0.00 & 0.00 & 0.00 & 0.00 & $0 . \overline{00}$ & 0.00 & 0.00 & 0.00 & 0.00 & 0.00 & 0.13 & 0.25 & 0.50 & 0.50 & 0.50 & $\overline{0.50}$ & 0.50 & $\overline{0.25}$ & 0.13 & 0.00 & 0.00 & 0.00 & 0.00 & 0.00 \\
\hline \multirow{3}{*}{ Warehouse } & \multirow{3}{*}{$\begin{array}{l}0.0003 \\
\text { people/ftit }\end{array}$} & Weekday & 0.10 & 0.10 & 0.10 & 0.10 & 0.10 & 0.10 & 0.10 & 0.21 & 0.79 & 1.00 & 1.00 & 1.00 & $\overline{0.58}$ & 0.95 & 0.95 & $\overline{0.95}$ & 0.26 & $\overline{0.10}$ & 0.10 & 0.10 & 0.10 & 0.10 & 0.10 & 0.10 \\
\hline & & Sat. & 0.00 & 0.00 & 0.00 & 0.00 & 0.00 & 0.00 & 0.00 & 0.00 & 0.00 & 0.00 & 0.00 & 0.00 & 0.00 & 0.00 & 0.00 & $\overline{0.00}$ & $0.00 \square$ & 0.00 & 0.00 & 0.00 & 0.00 & 0.00 & 0.00 & 0.00 \\
\hline & & Sun. & 0.00 & 0.00 & 0.00 & 0.00 & 0.00 & 0.00 & 0.00 & 0.00 & 0.00 & 0.00 & 0.00 & 0.00 & 0.00 & 0.00 & 0.00 & 0.00 & 0.00 & 0.00 & 0.00 & 0.00 & 0.00 & 0.00 & 0.00 & 0.00 \\
\hline
\end{tabular}


Occupant Density - Assumptions were based on the proposed Addendum 90.1j data with maximum occupancy numbers from Standard 62-1989 (ASHRAE 1989b) and the Uniform Building Code (UBC) (ICBO 1994). For assembly, good data were lacking so the Standard 90.1-1989 data were normalized to $100 \%$ (ASHRAE's $80 \%$ peak were not used).

\section{A.3.3 Education Building Assumptions}

HVAC Operation Schedule - The.CBECS (EIA 1992) reported 20 extra hours of HVAC operation per week. Two hours were added before operation and 1 hour after operation, Monday through Friday. For Saturday, HVAC was assumed to be on for 5 hours [no occupancy is reported, but one person in the whole building on Saturday is too small to quantify; however, that person probably turns the HVAC system on (e.g., janitor, pastor)].

Saturday and Sunday Occupancy Schedule - CBECS (EIA 1992) and ELCAP both reported that most education buildings (by square feet and number of buildings) are closed on Saturday and Sunday. Addendum $90.1 \mathrm{j}$ showed they are open 5 hours on Saturday, which were eliminated.

Weekday Occupancy Schedule - CBECS (EIA 1992) reported that most education buildings are open from 7 a.m. to 10 p.m., with 7 a.m. to 4 p.m. close behind. ELCAP reported 8 a.m. to 10 p.m. and 7 a.m. to $4: 30 \mathrm{p} . \mathrm{m}$. as the most common open hours. Obviously, whether or not the education building is used at night is a factor (e.g., adult school, universities). The Addendum $90.1 \mathrm{j}$ schedule was used because it already showed the major load from 8 a.m. to 4 p.m., with another partial load in the evening and from 7 a.m. to 8 a.m.

Occupant Density - An assumption of $90 \mathrm{ft}^{2}$ per person average daily peak was used. Assumptions were based on ELCAP and CBECS (EIA 1992) data, with maximum occupancy numbers from Standard 62-1989 (ASHRAE 1989b) and the UBC (ICBO 1994). ELCAP reported the average peak as $120 \mathrm{ft}^{2}$ per person and CBECS reported $93 \mathrm{ft}^{2}$ per seat. The Addendum $90.1 \mathrm{j}$ schedule had a daily peak of $83.3 \mathrm{ft}^{2}$ per person.

\section{A.3.4 Food Service Building Assumptions}

HVAC Operation Schedule - CBECS (EIA 1992) reported 17 extra hours of HVAC operation per week. More extra hours were used because occupants are present (cooks, preps, cleaners) for many hours when the business is closed. The HVAC system remains on during all the hours the building is occupied.

Saturday Occupancy Schedule - CBECS (EIA 1992) reported that most food service buildings are open 12 to 14 hours on Saturday, typically from 11 a.m. to 1 a.m. ELCAP reported they are typically open from 9 a.m. to 2 a.m. Addendum $90.1 \mathrm{j}$ showed typical hours open from 10 a.m. to 2 a.m. The ASHRAE schedule was modified to open at the same time but close an hour early. Additional occupants were added before and after the business is open to account for prep work and cleanup ( $2 \%$ to $5 \%$ of occupants during closed hours). Sunday Occupancy Schedule - CBECS (EIA 1992) reported that most food service buildings are open 14 hours on Sunday, typically from 11 a.m. to 1 a.m. ELCAP reported they are typically open from 11 a.m. to 11 p.m. Addendum $90.1 \mathrm{j}$ showed typical hours open from 11 a.m. 
to 2 a.m. The ASHRAE schedule was modified to open at the same time but close an hour early, with additional occupants before and after the business is open to account for prep work and cleanup ( $2 \%$ to $5 \%$ of occupants during closed hours).

Weekday Occupancy Schedule - CBECS (EIA 1992) reported that most food service buildings are open 12 to 14 hours on weekdays, typically from 11 a.m. to 1 a.m. ELCAP reported they are typically open from 9 a.m. to midnight. Addendum $90.1 \mathrm{j}$ showed typical hours open from 10 a.m. to 2 a.m. The ASHRAE schedule was modified to open at the same time but close an hour early, with additional occupants before and after the business is open to account for prep work and cleanup ( $2 \%$ to $5 \%$ of occupants during closed hours).

Occupant Density - Assumptions were based on ELCAP and CBECS (EIA 1992) data, with maximum occupancy numbers from Standard 62-1989 (ASHRAE 1989b) and the UBC (ICBO 1994). ELCAP reported $110 \mathrm{ft}^{2}$ per person on weekdays and 75-95 $\mathrm{ft}^{2}$ per person on weekends. CBECS reported $42 \mathrm{ft}^{2}$ per seat ( $1 / 3$ of seats are empty at normal weekday peak). Addendum $90.1 \mathrm{j}$ showed $125 \mathrm{ft}^{2}$ per person.

\section{A.3.5 Lodging Building Assumptions}

HVAC Operation Schedule - CBECS (EIA 1992) reported three extra hours of HVAC operation per week, but because the buildings are occupied 24 hours a day, 7 days a week, this amount of time did not mean anything (no setback schedule).

Occupancy Schedule - CBECS (EIA 1992) reported 24-hour operation every day-the same as Standard 90.1-1989. The schedule remained identical to the proposed Addendum 90.1j.

Occupant Density - An assumption of $300 \mathrm{ft}^{2}$ per person was based on ELCAP and CBECS data, with maximum occupancy numbers from Standard 62-1989 (ASHRAE 1989b) and the UBC (ICBO 1994). ELCAP reported $300 \mathrm{ft}^{2}$ per person and CBECS reported $565 \mathrm{ft}^{2}$ per room (appx. 1.9 persons per room) for weekdays (peak). Addendum $90.1 \mathrm{j}$ had $278 \mathrm{ft}^{2}$ per person.

\section{A.3.6 Office Building Assumptions}

HVAC Operation Schedule - CBECS (EIA 1992) reported 30 extra hours of HVAC operation per week. To match the occupancy schedule, 7 hours/day, Monday through Friday, were added plus 7 hours on Saturday (again, the HVAC system is probably scheduled on Saturdays for the one or two people who come in even though the schedule says 0 occupants) (see Table A.6).

Saturday and Sunday Occupancy Schedule - CBECS (EIA 1992) and ELCAP reported that most buildings are closed on Saturday and Sunday. CBECS (EIA 1992) reported 20\% of office space open on Saturday from 8 a.m. to 1 p.m. The Addendum $90.1 \mathrm{j}$ schedule was used but matched to plug loads. Occupancy density on Saturday was dropped to only $10 \%$. 
Weekday Occupancy Schedule - CBECS (EIA 1992) and ELCAP both reported hours of operation as 8 a.m. to 6 p.m. The Addendum $90.1 \mathrm{j}$ schedule was used but matched to the plug schedule for ramps.

Occupant Density - Assumptions were based on ELCAP and CBECS (EIA 1992) data, with maximum occupancy numbers from Standard 62-1989 (ASHRAE 1989b) and the UBC (ICBO 1994). CBECS (EIA 1992) reported $760 \mathrm{ft}^{2}$ per person and ELCAP reported $875 \mathrm{ft}^{2}$ per person as the average daily peaks. Addendum 90.1 uses $290 \mathrm{ft}^{2}$ per person as the average daily peak. A typical office or cubicle space is about $15 \times 10 \mathrm{ft}$ and usually contains one to two people. Adding $3 \mathrm{ft}$ of hallway still equals less than $200 \mathrm{ft}^{2}$ per person. Adding restroom area, conference rooms, broom closets, and warehouse space may add another 50 to $100 \mathrm{ft}^{2}$ per person, which is still low compared to the numbers reported in CBECS (EIA 1992) and ELCAP. This low value may be because small office buildings generally hold multiple businesses, so the occupant density is much lower (e.g., real estate agencies, insurance offices, accountants). These buildings also have a lot more area that is not associated with office space (e.g., lobbies, wider hallways).

\section{A.3.7 Retail Building Assumptions}

HVAC Operation Schedule - CBECS (EIA 1992) reported 27 extra hours of HVAC operation per week. Three hours before and 1 hour after operating hours, 7 days a week, were added.

Saturday Occupancy Schedule - CBECS (EIA 1992) reported that most retail buildings are open from 10 a.m. to 9 p.m. on Saturday. The extremes of 24-hour operation and closed are tied for a close second. ELCAP reported typical retail hours from 9 a.m. to 6 p.m. on Saturday. The Addendum $90.1 \mathrm{j}$ schedule was used with a shorter schedule (deleted 8 a.m. and cut back percent occupancy at 9 a.m. and 10 a.m.).

Sunday Occupancy Schedule - CBECS (EIA 1992) and ELCAP both reported that most (CBECS $64 \%$ ) retail stores are closed on Sunday. On a square foot basis, most retail stores surveyed were open on Sunday from noon to 5 or 6 p.m. The Addendum $90.1 \mathrm{j}$ schedule was used with an hour deleted at 10 a.m. and a reduction in the number of occupants at 11 a.m.

Weekday Occupancy Schedule - CBECS (EIA 1992) reported that most retail stores are open from 10 a.m. to 9 p.m. on weekdays. ELCAP reported they are typically open from 9 a.m. to 9 p.m. The Addendum $90.1 \mathrm{j}$ schedule was used with occupancy deleted at $8 \mathrm{a} . \mathrm{m}$. and the number of occupants reduced at 9 a.m., 10 a.m., and 10 p.m.

Occupant Density - Assumptions were based on ELCAP and CBECS (EIA 1992) data, with maximum occupancy numbers from Standard 62-1989 (ASHRAE 1989b) and the UBC (ICBO 1994). ELCAP shows $450 \mathrm{ft}^{2}$ per person as the average daily peak on Monday through Saturday and $190 \mathrm{ft}^{2}$ per person as the average daily peak on Sunday. CBECS reports only employee density; thus, this data is inappropriate for occupant density. Addendum $90.1 \mathrm{j}$ shows $375 \mathrm{ft}^{2}$ per person as the average daily peak (Monday through Saturday). Note that ELCAP reported more occupants on Sunday than Monday through Saturday, but the Addendum 90.1j schedule has fewer occupants on Sunday than Monday through Saturday. 


\section{A.3.8 Warehouse Building Assumptions}

HVAC Operation Schedule - CBECS (EIA 1992) reported 18 extra hours of HVAC operation per week. No extra hours were added because the warehouse is assumed to be operating 24 hours per day, Monday through Friday, with no occupants on Saturday through Sunday.

Saturday and Sunday Occupancy Schedule - CBECS (EIA 1992) and ELCAP reported that most warehouse buildings are closed on Saturday and Sunday. Addendum $90.1 \mathrm{j}$ showed open hours on Saturday that were eliminated.

Weekday Occupancy Schedule - CBECS (EIA 1992) reported that most warehouses are open 24 hours, Monday through Friday. ELCAP reported they are typically open 8 a.m. to 5 p.m. Addendum $90.1 \mathrm{j}$ showed open hours from 7 a.m. to 5 p.m. This time span ( 7 a.m. to 5 p.m.) was left the same with an additional $5 \%$ occupancy added all night.

Occupant Density - An assumption of $3260 \mathrm{ft}^{2}$ per person was used. Assumptions were based on ELCAP and CBECS (EIA 1992) data, with maximum occupancy numbers from Standard 62-1989 (ASHRAE 1989b) and the UBC (ICBO 1994). ELCAP reported $1700 \mathrm{ft}^{2}$ per person and CBECS reported $4820 \mathrm{ft}^{2}$ per person. The average of the two surveys was used. Addendum $90.1 \mathrm{j}$ showed $16,667 \mathrm{ft}^{2}$ per person, which is extremely different from the survey results.

\section{A.4 Occupant Activity Levels}

For the BLAST loads calculations, the occupant activity level was assumed to be $425 \mathrm{Btu} / \mathrm{h}$ per person for all building types except food services and warehouses. For food services, the activity level was assumed to be $550 \mathrm{Btu} / \mathrm{h}$ per person. For warehouses, the activity level was $1,000 \mathrm{Btu} / \mathrm{h}$ per person. These values were derived from data in the ASHRAE 1993 Handbook: Fundamentals (ASHRAE 1993). The occupant activity levels were not varied with climate location.

\section{A.5 Outdoor-Air Ventilation}

The ventilation values for the outdoor-air requirement per person came from ASHRAE Standard 62-1989, Table A.2 (ASHRAE 1989b). Table A.6 summarizes the peak occupancy and the ventilation rates derived to meet the peak occupancy. BLAST simulations require that the ventilation requirement be provided as a fraction of the total supply airflow rate. Using the total building design supply airflow rate that was estimated by the BLAST simulation and the required ventilation flow that would satisfy peak occupancy, the fraction of the outdoor-air requirement was estimated for each climate location. The design supply airflow rate changes by zone and by climate location. To show the variation in outdoor-air percent change by location and building, the mean, minimum, and maximum outdoor-air percent for each of the seven representative building types are summarized in Table A.6. 
Table A.6. Ventilation Rates for BLAST Runs

\begin{tabular}{|c|c|c|c|c|c|c|}
\hline \multirow[b]{3}{*}{ Building Type } & & & \multirow{3}{*}{$\begin{array}{c}\begin{array}{c}\text { Outdoor-Air } \\
\text { Requirement }\end{array} \\
\text { (cfm/person) }\end{array}$} & \multicolumn{3}{|c|}{$\begin{array}{l}\text { Outdoor-Air } \\
\text { Requirement }\end{array}$} \\
\hline & \multicolumn{2}{|c|}{ Occupancy } & & Mean & Low & High \\
\hline & (ft/person) & (people/ft') & & $(\%)$ & $(\%)$ & $(\%)$ \\
\hline Assembly & 62.5 & 0.0160 & 15 & 53 & 46 & 59 \\
\hline Education & 90 & 0.0160 & 15 & 38 & 26 & 47 \\
\hline Food Service & 91 & 0.0111 & 20 & 38 & 34 & 42 \\
\hline Lodging & 300 & 0.0110 & 15 & 14 & 13 & 16 \\
\hline Office & 91 & 0.0033 & 20 & 17 & 14 & 20 \\
\hline Retail & 450 & 0.0110 & 15 & 8 & 6 & 9 \\
\hline Warehouse & 3,260 & 0.0022 & -- & 2 & 1 & 2 \\
\hline
\end{tabular}

\section{A.6 Windows}

The office, assembly, and food service building types have double-pane glazing with blinds $(R=1.45$, $\mathrm{SC}=0.58)$. Retail has single-pane glazing without blinds $(\mathrm{R}=0.50, \mathrm{SC}=0.95)$, and all other building types have single-pane with blinds $(\mathrm{R}=0.50, \mathrm{SC}=0.67)$. The assumptions for window variations by building type came from an analysis of CBECS data (EIA 1992). The thermal properties for single- and double-pane windows were obtained from the 1993 ASHRAE Handbook: Fundamentals, pages 27.36 and 27.6 (ASHRAE 1993).

CBECS (EIA 1992) data were used to calculate window-to-wall ratios (WWRs) for the buildings based on census region (DOC 1997). For the BLAST runs, these WWRs were expressed as a window height value. The calculation was based on a floor height of $13 \mathrm{ft}$ and a wall length of $100 \mathrm{ft}$ (for the generic prototype building). The window is $99 \mathrm{ft}$ in length, and the height is based on the WWR. The equation is

$$
\text { WHEIGHT }=13 \times 100 \times \frac{\text { WWR }}{99}
$$

Table A.7 lists the WWR assumptions for each building type and census region.

\section{A.7 Walls and Roofs/Ceilings}

CBECS (ELA 1992) data indicated that masonry walls and built-up roofs are the norms for the commercial building types considered (see Tables A.8 and A.9). The default insulation thickness corresponding to R-11 for all exterior walls and R- 13 for built-up roofs was assumed. A correction factor has been applied to the nominal $R$-values for the walls. This factor accounts for the reduction in thermal resistance caused by metal stud construction. The factor was determined to be 0.58 and thus the wall insulation $\mathrm{R}$-value is $6.41(11 \times 0.58)$. 
Table A.7. Window-to-Wall Ratios Assumed for Building Types in Each Census Region

\begin{tabular}{|l|c|c|c|c|}
\hline \multicolumn{1}{|c|}{ Building Type } & R1 & R2 & R3 & R4 \\
\hline Assembly & 0.20 & 0.10 & 0.10 & 0.10 \\
\hline Education & 0.40 & 0.20 & 0.10 & 0.10 \\
\hline Food Service & 0.20 & 0.10 & 0.10 & 0.20 \\
\hline Lodging & 0.20 & 0.20 & 0.20 & 0.20 \\
\hline Office & 0.20 & 0.10 & 0.10 & 0.20 \\
\hline Retail & 0.10 & 0.10 & 0.10 & 0.10 \\
\hline Warehouse & 0.10 & 0.10 & 0.10 & 0.10 \\
\hline R1 - Providence \\
R2 - Minnesota, Detroit \\
R3 - Knoxville, Shreveport, Orlando \\
R4 - Denver, Seattle, Los Angeles, Phoenix, Fresno. \\
\hline
\end{tabular}

Table A.8. Thermal Characteristics of Walls

Table A.9. Thermal Characteristics of Roofs

\begin{tabular}{|l|r|}
\hline Wall Insulation R-Value $\left(\mathrm{h} \cdot \mathrm{ft}^{2} /{ }^{\circ} \mathrm{F} \cdot \mathrm{Btu}\right)$ & 6.41 \\
\hline Total Wall R-Value $\left(\mathrm{h} \cdot \mathrm{ft}^{2} /{ }^{\circ} \mathrm{F} \cdot \mathrm{Btu}\right)$ & 7.42 \\
\hline Wall Mass $\left(\mathrm{lb} / \mathrm{ft}^{2}\right)$ & 47.94 \\
\hline
\end{tabular}

\begin{tabular}{|l|r|}
\hline Roof Insulation R-Value $\left(\mathrm{h} \cdot \mathrm{ft}^{2} /{ }^{\circ} \mathrm{F} \cdot \mathrm{Btu}\right)$ & 13.26 \\
\hline Total Roof R-Value $\left(\mathrm{h} \cdot \mathrm{ft}^{2} /{ }^{\circ} \mathrm{F} \cdot / \mathrm{Btu}\right)$ & 14.53 \\
\hline Roof Mass $\left(\mathrm{lb} / \mathrm{ft}^{2}\right)$ & 6.42 \\
\hline
\end{tabular}

The analysis assumed the wall construction to have an exterior surface with a 4 -in. brick facing (see Table A.8). The use of a more massive wall has a slight impact on reducing the building shell load through the opaque wall section.

\section{A.8 Infiltration}

Two infiltration schedules were used - one for interior and one for exterior for each building type. The interior schedules had zero outdoor air during periods when the building's HVAC system was scheduled to be off, which were applied to the core zones. The exterior schedules had an infiltration value of $49.4 \mathrm{cfm}$ (for the generic prototype with $1,500 \mathrm{ft}^{2}$ perimeter zones) when the HVAC system was off. This value was based on $0.038 \mathrm{cfm} / \mathrm{ft}^{2}$ in Standard 90.1-1989, Section 13.7.3.2 (ASHRAE 1989a).

\section{A.9 FLEOH and Weights Used for the Screening Analysis}

FLEOH for cooling and heating and for various combinations of BLAST runs are tabulated in this section (see Tables A.10-A.16). In addition to FLEOH, the weights used to aggregate various combinations of cooling and heating FLEOH are also tabulated. FLEOH for each combination are presented as a function of the 11 climate locations and 7 building types. 
Table A.10. Cooling FLEOH Without Economizer and Temperature Setback/Setup

\begin{tabular}{|l|c|c|c|c|l|l|c|}
\hline & Assembly & Education & Food Service & Lodging & Office & Retail & Warehouse \\
\hline Providence & 1066 & 873 & 1559 & 1210 & 1284 & 1410 & 1043 \\
\hline Detroit & 987 & 749 & 1455 & 1105 & 1199 & 1327 & 939 \\
\hline Minneapolis & 1080 & 828 & 1517 & 1183 & 1232 & 1284 & 1077 \\
\hline Knoxville & 1751 & 1304 & 2431 & 1917 & 1959 & 2176 & 1520 \\
\hline Shreveport & 2269 & 1699 & 2993 & 2492 & 2439 & 2721 & 1792 \\
\hline Orlando & 3184 & 2373 & 4062 & 3425 & 3259 & 3593 & 2370 \\
\hline Denver & 1197 & 906 & 1763 & 1434 & 1521 & 1568 & 1322 \\
\hline Phoenix & 2884 & 2314 & 3653 & 3238 & 3108 & 3500 & 2675 \\
\hline Seattle & 798 & 579 & 1437 & 925 & 1169 & 1320 & 1237 \\
\hline Fresno & 1926 & 1558 & 2646 & 2274 & 2277 & 2615 & 1848 \\
\hline Los Angeles & 1692 & 1224 & 2859 & 2013 & 2203 & 2554 & 1407 \\
\hline
\end{tabular}

Table A.11. Cooling FLEOH With Economizer and Temperature Setback/Setup

\begin{tabular}{|l|c|c|c|c|c|c|c|}
\hline & Assembly & Education & Food Service & Lodging & Office & Retail & Warehouse \\
\hline Providence & 876 & 611 & 1088 & 842 & 778 & 886 & 439 \\
\hline Detroit & 837 & 548 & 1043 & 765 & 739 & 834 & 407 \\
\hline Minneapolis & 929 & 630 & 1117 & 828 & 801 & 867 & 505 \\
\hline Knoxville & 1575 & 1059 & 1950 & 1560 & 1371 & 1523 & 1045 \\
\hline Shreveport & 2104 & 1403 & 2507 & 2162 & 1788 & 1966 & 1418 \\
\hline Orlando & 3016 & 1982 & 3499 & 3108 & 2493 & 2771 & 2040 \\
\hline Denver & 1011 & 701 & 1197 & 956 & 904 & 982 & 531 \\
\hline Phoenix & 2674 & 1864 & 3019 & 2763 & 2231 & 2456 & 2069 \\
\hline Seattle & 526 & 338 & 638 & 383 & 455 & 493 & 157 \\
\hline Fresno & 1685 & 1222 & 1976 & 1698 & 1504 & 1722 & 1199 \\
\hline Los Angeles & 1128 & 762 & 1502 & 898 & 1147 & 1314 & 322 \\
\hline
\end{tabular}

Table A.12. Cooling FLEOH With Economizer and Without Temperature Setback/Setup

\begin{tabular}{|l|c|c|c|c|c|c|c|}
\hline & Assembly & Education & Food Service & Lodging & Office & Retail & Warehouse \\
\hline Providence & 875 & 673 & 1114 & 842 & 868 & 939 & 537 \\
\hline Detroit & 832 & 596 & 1055 & 765 & 811 & 883 & 480 \\
\hline Minneapolis & 923 & 673 & 1136 & 828 & 873 & 901 & 627 \\
\hline Knoxville & 1581 & 1157 & 2018 & 1560 & 1570 & 1703 & 1082 \\
\hline Shreveport & 2111 & 1566 & 2604 & 2162 & 2083 & 2271 & 1486 \\
\hline Orlando & 3032 & 2240 & 3703 & 3108 & 2956 & 3236 & 2131 \\
\hline Denver & 999 & 722 & 1192 & 956 & 938 & 965 & 641 \\
\hline Phoenix & 2691 & 2104 & 3155 & 2763 & 2567 & 2822 & 2236 \\
\hline Seattle & 519 & 340 & 634 & 383 & 442 & 474 & 305 \\
\hline Fresno & 1671 & 1310 & 1997 & 1698 & 1667 & 1865 & 1261 \\
\hline Los Angeles & 1111 & 770 & 1484 & 898 & 1179 & 1372 & 514 \\
\hline
\end{tabular}


Table A.13. Cooling FLEOH Without Economizer and With Temperature Setback/Setup

\begin{tabular}{|l|c|c|c|c|l|l|c|}
\hline & Assembly & Education & Food Service & Lodging & Office & Retail & Warehouse \\
\hline Providence & 1059 & 773 & 1523 & 1210 & 1118 & 1297 & 952 \\
\hline Detroit & 983 & 676 & 1430 & 1105 & 1041 & 1216 & 862 \\
\hline Minneapolis & 1077 & 758 & 1488 & 1183 & 1081 & 1199 & 966 \\
\hline Knoxville & 1739 & 1173 & 2360 & 1917 & 1689 & 1941 & 1488 \\
\hline Shreveport & 2252 & 1504 & 2882 & 2492 & 2065 & 2360 & 1739 \\
\hline Orlando & 3157 & 2083 & 3832 & 3425 & 2724 & 3059 & 2291 \\
\hline Denver & 1193 & 829 & 1749 & 1434 & 1347 & 1468 & 1230 \\
\hline Phoenix & 2850 & 2001 & 3487 & 3238 & 2602 & 2903 & 2541 \\
\hline Seattle & 797 & 540 & 1435 & 925 & 1059 & 1293 & 1123 \\
\hline Fresno & 1914 & 1386 & 2572 & 2274 & 1971 & 2282 & 1816 \\
\hline Los Angeles & 1687 & 1139 & 2836 & 2013 & 1934 & 2359 & 1313 \\
\hline
\end{tabular}

Table A.14. Heating FLEOH With Temperature Setback/Setup

\begin{tabular}{|l|c|c|c|c|c|c|c|}
\hline & Assembly & Education & Food Service & Lodging & Office & Retail & Warehouse \\
\hline Providence & 1894 & 795 & 1388 & 1523 & 504 & 454 & 740 \\
\hline Detroit & 2037 & 901 & 1597 & 1683 & 615 & 540 & 894 \\
\hline Minneapolis & 1967 & 941 & 1564 & 1699 & 681 & 589 & 1125 \\
\hline Knoxville & 1483 & 634 & 1197 & 973 & 340 & 212 & 332 \\
\hline Shreveport & 1075 & 422 & 774 & 559 & 204 & 71 & 50 \\
\hline Orlando & 638 & 240 & 509 & 234 & 136 & 16 & 497 \\
\hline Denver & 1833 & 783 & 1282 & 1336 & 436 & 340 & 561 \\
\hline Phoenix & 966 & 317 & 722 & 349 & 176 & 16 & 22 \\
\hline Seattle & 2427 & 1070 & 1697 & 1784 & 583 & 370 & 743 \\
\hline Fresno & 1568 & 592 & 1057 & 779 & 257 & 98 & 54 \\
\hline Los Angeles & 1267 & 508 & 866 & 468 & 200 & 29 & 0 \\
\hline
\end{tabular}

Table A.15. Heating FLEOH Without Temperature Setback/Setup

\begin{tabular}{|l|c|c|c|c|c|c|c|}
\hline & Assembly & Education & Food Service & Lodging & Office & Retail & Warehouse \\
\hline Providence & 1927 & 1272 & 1269 & 1523 & 972 & 1207 & 1074 \\
\hline Detroit & 2067 & 1382 & 1458 & 1683 & 1143 & 1341 & 1216 \\
\hline Minneapolis & 1995 & 1386 & 1528 & 1699 & 1243 & 1417 & 1428 \\
\hline Knoxville & 1491 & 891 & 987 & 973 & 572 & 641 & 508 \\
\hline Shreveport & 1074 & 565 & 575 & 559 & 299 & 282 & 101 \\
\hline Orlando & 628 & 271 & 222 & 234 & 131 & 39 & 1318 \\
\hline Denver & 1855 & 1158 & 1173 & 1336 & 814 & 976 & 792 \\
\hline Phoenix & 961 & 370 & 398 & 349 & 188 & 95 & 77 \\
\hline Seattle & 2453 & 1599 & 1477 & 1784 & 1040 & 1148 & 1210 \\
\hline Fresno & 1567 & 783 & 782 & 779 & 390 & 390 & 140 \\
\hline Los Angeles & 1264 & 572 & 434 & 468 & 205 & 159 & 0 \\
\hline
\end{tabular}


The weights that are tabulated in this section were derived from the CBECS database (EIA 1995). There are four sets of weights for the cooling products (Tables A.16 through A.19) and only two sets of weights for the heating products (Tables A.20 and A.21).

Table A.16. Fraction of Building Stock Without Economizers and Setback/Setup - Cooling Analysis

\begin{tabular}{|l|l|c|l|c|c|c|c|}
\hline & Assembly & Education & $\begin{array}{c}\text { Food } \\
\text { Service }\end{array}$ & Lodging & Office & Retail & Warehouse \\
\hline New England & 0 & 0 & 0 & 0 & 0 & 0 & 0.227405 \\
\hline Middle Atlantic & 0 & 0 & 0 & 0 & 0 & 0 & 0.076886 \\
\hline East North Central & 0.005375 & 0 & 0 & 0 & 0 & 0.006694 & 0.258959 \\
\hline West North Central & 0.033255 & 0 & 0 & 0 & 0 & 0.007742 & 0.172003 \\
\hline South Atlantic & 0.08702 & 0 & 0 & 0 & 0 & 0.005462 & 0.193529 \\
\hline East South Central & 0 & 0 & 0 & 0 & 0 & 0.002834 & 0.363772 \\
\hline West South Central & 0.002634 & 0 & 0 & 0 & 0 & 0.011654 & 0.212309 \\
\hline Mountain North & 0 & 0 & 0 & 0 & 0 & 0.02884 & 0.126202 \\
\hline Mountain South & 0 & 0 & 0 & 0 & 0 & 0.02884 & 0.126202 \\
\hline Pacific North & 0.002397 & 0 & 0.113878 & 0 & 0 & 0.048839 & 0.025829 \\
\hline Pacific South & 0.002397 & 0 & 0.113878 & 0 & 0 & 0.048839 & 0.220804 \\
\hline
\end{tabular}

Table A.17. Fraction of Building Stock With Economizers and Without Setback/Setup - Cooling Analysis

\begin{tabular}{|l|l|l|l|l|l|l|c|}
\hline & Assembly & Education & $\begin{array}{c}\text { Food } \\
\text { Service }\end{array}$ & Lodging & \multicolumn{1}{|c|}{ Office } & \multicolumn{1}{|c|}{ Retail } & Warehouse \\
\hline New England & 0 & 0.04357 & 0 & 1 & 0.17546 & 0.039801 & 0.181893 \\
\hline Middle Atlantic & 0.397417 & 0.101377 & 0 & 0.915039 & 0.331983 & 0.155249 & 0.359142 \\
\hline East North Central & 0.195692 & 0.101478 & 0.160354 & 0.960406 & 0.26397 & 0.099795 & 0.236753 \\
\hline West North Central & 0.148188 & 0.009308 & 0.7787 & 0.97927 & 0.365021 & 0.237726 & 0.327376 \\
\hline South Atlantic & 0.290774 & 0.086204 & 0.259135 & 0.895641 & 0.23351 & 0.133141 & 0.162281 \\
\hline East South Central & 0.395539 & 0.075002 & 0.534163 & 0.915401 & 0.243597 & 0.229179 & 0.139533 \\
\hline West South Central & 0.187606 & 0.056535 & 0.027451 & 1 & 0.211972 & 0.158675 & 0.218878 \\
\hline Mountain North & 0.156179 & 0.078664 & 0 & 0.961944 & 0.1178 & 0.17659 & 0.050391 \\
\hline Mountain South & 0.156179 & 0.078664 & 0 & 0.961944 & 0.1178 & 0.17659 & 0.050391 \\
\hline Pacific North & 0.186046 & 0.064038 & 0.145197 & 0.900177 & 0.12675 & 0.089767 & 0.275024 \\
\hline Pacific South & 0.186046 & 0.064038 & 0.145197 & 0.900177 & 0.12675 & 0.089767 & 0.219979 \\
\hline
\end{tabular}


Table A.18. Fraction of Building Stock Without Economizers and With Setback/Setup - Cooling Analysis

\begin{tabular}{|l|c|c|c|c|c|c|c|}
\hline & Assembly & Education & $\begin{array}{c}\text { Food } \\
\text { Service }\end{array}$ & Lodging & Office & Retail & Warehouse \\
\hline New England & 0 & 0 & 0 & 0 & 0 & 0 & 0 \\
\hline Middle Atlantic & 0 & 0 & 0 & 0 & 0 & 0 & 0 \\
\hline East North Central & 0 & 0 & 0 & 0 & 0 & 0 & 0 \\
\hline West North Central & 0 & 0 & 0 & 0 & 0 & 0 & 0 \\
\hline South Atlantic & 0 & 0 & 0 & 0 & 0 & 0 & 0 \\
\hline East South Central & 0 & 0 & 0 & 0 & 0 & 0 & 0 \\
\hline West South Central & 0 & 0 & 0 & 0 & 0 & 0 & 0 \\
\hline Mountain North & 0 & 0 & 0 & 0 & 0 & 0 & 0 \\
\hline Mountain South & 0 & 0 & 0 & 0 & 0 & 0 & 0 \\
\hline Pacific North & 0 & 0 & 0 & 0 & 0 & 0 & 0 \\
\hline Pacific South & 0 & 0 & 0 & 0 & 0 & 0 & 0 \\
\hline
\end{tabular}

Table A.19. Fraction of Building Stock With Economizers and Setback/Setup - Cooling Analysis

\begin{tabular}{|l|l|l|l|l|l|l|l|}
\hline & Assembly & Education & $\begin{array}{c}\text { Food } \\
\text { Service }\end{array}$ & Lodging & \multicolumn{1}{|c|}{ Office } & \multicolumn{1}{|c|}{ Retail } & Warehouse \\
\hline New England & 1 & 0.95643 & 1 & 0 & 0.82454 & 0.960199 & 0.590702 \\
\hline Middle Atlantic & 0.602583 & 0.898623 & 1 & 0.084961 & 0.668017 & 0.844751 & 0.563972 \\
\hline East North Central & 0.798933 & 0.898522 & 0.839646 & 0.039594 & 0.73603 & 0.893511 & 0.504288 \\
\hline West North Central & 0.818556 & 0.990692 & 0.2213 & 0.02073 & 0.634979 & 0.754532 & 0.500621 \\
\hline South Atlantic & 0.622206 & 0.913796 & 0.740865 & 0.104359 & 0.76649 & 0.861397 & 0.64419 \\
\hline East South Central & 0.604461 & 0.924998 & 0.465837 & 0.084599 & 0.756403 & 0.767987 & 0.496694 \\
\hline West South Central & 0.80976 & 0.943465 & 0.972549 & 0 & 0.788028 & 0.829671 & 0.568813 \\
\hline Mountain North & 0.843821 & 0.921336 & 1 & 0.038056 & 0.8822 & 0.79457 & 0.823407 \\
\hline Mountain South & 0.843821 & 0.921336 & 1 & 0.038056 & 0.8822 & 0.79457 & 0.823407 \\
\hline Pacific North & 0.811558 & 0.935962 & 0.740925 & 0.099823 & 0.87325 & 0.861394 & 0.699147 \\
\hline Pacific South & 0.811558 & 0.935962 & 0.740925 & 0.099823 & 0.87325 & 0.861394 & 0.559217 \\
\hline
\end{tabular}


Table A.20. Fraction of Building Stock With Setback/Setup- Heating Products

\begin{tabular}{|l|l|l|l|l|l|l|l|}
\hline & Assembly & Education & \multicolumn{1}{|c|}{$\begin{array}{c}\text { Sood } \\
\text { Service }\end{array}$} & Lodging & \multicolumn{1}{|c|}{ Office } & \multicolumn{1}{|c|}{ Retail } & Warehouse \\
\hline New England & 0.899638 & 0.95643 & 1 & 0 & 0.801262 & 0.948773 & 0.552156 \\
\hline Middle Atlantic & 0.602583 & 0.886399 & 1 & 0.084961 & 0.636653 & 0.808539 & 0.557316 \\
\hline East North Central & 0.741131 & 0.869464 & 0.839646 & 0.039594 & 0.687428 & 0.857392 & 0.501934 \\
\hline West North Central & 0.818556 & 0.979782 & 0.2213 & 0.02073 & 0.61377 & 0.754532 & 0.457961 \\
\hline South Atlantic & 0.622206 & 0.870386 & 0.6234 & 0.104359 & 0.714314 & 0.822677 & 0.503342 \\
\hline East South Central & 0.604461 & 0.924998 & 0.465837 & 0.084599 & 0.756403 & 0.692815 & 0.496257 \\
\hline West South Central & 0.80976 & 0.943465 & 0.972549 & 0 & 0.777809 & 0.816601 & 0.552062 \\
\hline Mountain North & 0.823532 & 0.914379 & 1 & 0.038056 & 0.870798 & 0.765534 & 0.816463 \\
\hline Mountain South & 0.823532 & 0.914379 & 1 & 0.038056 & 0.870798 & 0.765534 & 0.816463 \\
\hline Pacific North & 0.789113 & 0.935962 & 0.710998 & 0.089078 & 0.871074 & 0.671133 & 0.531521 \\
\hline Pacific South & 0.789113 & 0.935962 & 0.710998 & 0.089078 & 0.871074 & 0.671133 & 0.531521 \\
\hline
\end{tabular}

Table A.21. Fraction of Building Stock With Setback/Setup- Heating Products

\begin{tabular}{|l|l|l|l|l|l|l|l|}
\hline & Assembly & Education & $\begin{array}{c}\text { Food } \\
\text { Service }\end{array}$ & Lodging & \multicolumn{1}{|c|}{ Office } & Retail & Warehouse \\
\hline New England & 0.100362 & 0.04357 & 0 & 1 & 0.198738 & 0.051227 & 0.447844 \\
\hline Middle Atlantic & 0.397417 & 0.113601 & 0 & 0.915039 & 0.363347 & 0.191461 & 0.442684 \\
\hline East North Central & 0.258869 & 0.130536 & 0.160354 & 0.960406 & 0.312572 & 0.142608 & 0.498066 \\
\hline West North Central & 0.181444 & 0.020218 & 0.7787 & 0.97927 & 0.38623 & 0.245468 & 0.542039 \\
\hline South Atlantic & 0.377794 & 0.129614 & 0.3766 & 0.895641 & 0.285686 & 0.177323 & 0.496658 \\
\hline East South Central & 0.395539 & 0.075002 & 0.534163 & 0.915401 & 0.243597 & 0.307185 & 0.503743 \\
\hline West South Central & 0.19024 & 0.056535 & 0.027451 & 1 & 0.222191 & 0.183399 & 0.447938 \\
\hline Mountain North & 0.176468 & 0.085621 & 0 & 0.961944 & 0.129202 & 0.234466 & 0.183537 \\
\hline Mountain South & 0.176468 & 0.085621 & 0 & 0.961944 & 0.129202 & 0.234466 & 0.183537 \\
\hline Pacific North & 0.210887 & 0.064038 & 0.289002 & 0.910922 & 0.128926 & 0.328867 & 0.468479 \\
\hline Pacific South & 0.210887 & 0.064038 & 0.289002 & 0.910922 & 0.128926 & 0.328867 & 0.468479 \\
\hline
\end{tabular}

For the packaged boiler analyses, the FLEOHs were adjusted to account for the standby losses. Standby losses only occur when the boiler is in a hot standby condition. The length of the heating season and building-specific operational requirements dictate the number of days in a year the boiler is in a hot standby condition. For this analysis, the criterion specified in the 1998 ASHRAE Handbook:

Fundamentals was used to decide the number of days the boiler is available or in a hot standby condition (ASHRAE 1998). The number of days the boiler is available and the standby loss correction factors for each climate location and building type are tabulated in Table A.22. The heating FLEOHs are multiplied by these correction factors when analyzing the packaged boiler products. 
Table A.22. Standby Loss Correction Factor for Packaged Boilers

\begin{tabular}{|l|c|c|c|c|c|c|c|c|}
\hline $\begin{array}{c}\text { Climate } \\
\text { Location }\end{array}$ & $\begin{array}{c}\text { Number of } \\
\text { Days Boiler } \\
\text { is Available }\end{array}$ & Assembly & Education & $\begin{array}{c}\text { Food } \\
\text { Service }\end{array}$ & Lodging & Office & Retail & Warehouse \\
\hline Providence & 195 & 1.07 & 1.13 & 1.13 & 1.10 & 1.19 & 1.18 & 1.16 \\
\hline Detroit & 180 & 1.05 & 1.11 & 1.10 & 1.08 & 1.14 & 1.14 & 1.12 \\
\hline Minneapolis & 195 & 1.07 & 1.12 & 1.10 & 1.09 & 1.14 & 1.14 & 1.11 \\
\hline Knoxville & 150 & 1.07 & 1.15 & 1.13 & 1.13 & 1.26 & 1.32 & 1.28 \\
\hline Shreveport & 150 & 1.12 & 1.27 & 1.26 & 1.27 & 1.55 & 2.00 & 2.00 \\
\hline Orlando & 60 & 1.06 & 1.22 & 1.25 & 1.26 & 1.50 & 2.00 & 2.00 \\
\hline Denver & 195 & 1.08 & 1.15 & 1.15 & 1.13 & 1.24 & 1.23 & 1.23 \\
\hline Phoenix & 90 & 1.06 & 1.24 & 1.21 & 1.26 & 1.52 & 2.00 & 2.00 \\
\hline Seattle & 180 & 1.04 & 1.09 & 1.09 & 1.07 & 1.16 & 1.19 & 1.12 \\
\hline Fresno & 180 & 1.06 & 1.18 & 1.16 & 1.18 & 1.41 & 1.84 & 2.00 \\
\hline Los Angeles & 60 & 1.01 & 1.08 & 1.10 & 1.10 & 1.30 & 2.00 & 2.00 \\
\hline
\end{tabular}

\section{A.10 Representative Building Size and Shape}

The building and equipment coil loads for the screening analysis were estimated using the generic building approach similar to the approach used for the Phase-I analysis (Barwig et al. 1996). This appendix provides a brief description of the approach and assumptions.

The coil loads simulated using the BLAST hourly simulation tool (BLAST 1991) are based on a generic 3-story, 15-zone building with specific building characteristics from the seven representative buildings types selected for the screening analysis. The generic building used for the simulation was a $48,000 \mathrm{ft}^{2}, 3$-story building with 5 zones per floor. In addition, the aspect ratio and perimeter depth were assumed to be $1: 1$ and $15 \mathrm{ft}$, respectively.

Several reasons exist to use a generic building approach to estimate loads for the screening analysis. A primary reason is that the EPACT-covered equipment (EPACT, P.L. 102-486) is used in a broad class of buildings (e.g., offices, warehouses, public assembly) rather than in any particular building type. Thus, specifying a highly detailed building geometry (size and shape) to represent one of these classes is unrealistic. However, for this analysis, it was necessary to establish the major characteristics that distinguish one building class from others (e.g., internal load levels, window-to-wall ratio).

Second, properly characterizing large classes of buildings requires eliminating any orientation biases because the actual building stock is oriented more or less randomly. Some analysts have approached this problem by simulating a square prototype with equal glazing area facing each cardinal direction. However, most real buildings are not square and loads based on a square prototype will improperly weight the influences of internal gains and external weather on building loads. Another approach is to simulate a building with a realistic aspect ratio in each of several orientations. This approach, of course, greatly increases the effort to obtain the load estimates. 
Finally, the process of simulating a generic building and transforming the loads to represent a more realistic building not only addresses the previous two issues but minimizes the effort required to obtain load estimates for multiple representative buildings. A single BLAST simulation of a generic building can provide load estimates for many buildings of the same class.

A 3-story, 5 zones-per-floor generic building captures all the important zone types of the relevant building class. The 3-story prototype has a ground level, a roof level, and an intermediate level. Buildings with more than three stories can be represented by multiplying the middle-floor loads of the generic prototype. Further, each floor is represented by a core zone (i.e., a zone that has no exterior walls or windows) and a perimeter zone facing each of the cardinal directions. Buildings with more wall area facing one direction than others (i.e., buildings with nonsquare aspect ratios) can be represented by scaling or weighting the generic building zone loads to emphasize the dominant orientation(s).

A final benefit of this approach is that nonsquare buildings can be represented with a proper balance of internal load and external (weather) drivers without arbitrarily biasing the results toward a particular solar orientation. Because the building stock is more or less randomly oriented, to eliminate any bias from the solar gains, zone load from all perimeters must be equally weighted while perimeter versus core influence is adjusted to match the desired aspect ratio.

To get a realistic estimate of the coil loads for each of the seven representative building types selected for the analysis, the estimated coil loads from the generic building are scaled to represent an "average" or "typical" building size and shape. The scaling is accomplished by using the scaling algorithm developed for the Phase-I analysis (Barwig et al. 1996). The scaling algorithm takes the generic building loads and scales the loads to represent a building that is of a different size and shape given 1) total conditioned area, 2) number of floors, 3) number of zones per floor, 4) aspect ratio, and 5) perimeter depth.

The area, number of floors, and aspect ratio for the seven representative building types were estimated from the CBECS data (EIA 1992, 1995) weighted with the EPACT-covered equipment, while the number of zones per floor were assumed (see Table A.23). The perimeter depth for Assembly, Education, Lodging, and Office building types was assumed to be $15 \mathrm{ft}$, while the perimeter depth for the Food Services, Retail, and Warehouse building types were estimated from the floor area and the aspect ratio.

\section{A.11 Service Water Heater Sizing}

\section{A.11.1 Sizing Curves}

For this analysis, the ASHRAE Handbook of HVAC Applications equipment sizing curves were normalized (ASHRAE 1995). The normalized curves express storage capacity in terms of storage time (defined as the ratio of usable storage capacity to recovery capacity). With the normalized curves, presented in Figures A.1 and A.2, the ratio of a given water heater's peak-load capacity to steady-state capacity in a given application can be obtained directly after computing the water heater's storage time: 
Table A.23. Building Size and Shape Characteristics for the Seven Representative Building Types for the Preliminary Analysis

\begin{tabular}{|c|c|c|c|c|c|c|c|}
\hline \multirow[b]{2}{*}{ Building Type } & \multirow{2}{*}{$\begin{array}{c}\text { Number of } \\
\text { Zones per } \\
\text { Floor }\end{array}$} & \multicolumn{2}{|c|}{ Number of Floors } & \multicolumn{2}{|c|}{ Aspect Ratio } & \multirow[b]{2}{*}{$\begin{array}{c}\text { Total Area } \\
\left(\mathrm{ft}^{2}\right)\end{array}$} & \multirow[b]{2}{*}{$\begin{array}{l}\text { Perimeter } \\
\text { Depth (ft) }\end{array}$} \\
\hline & & CBECS 95(a) & Suggested $^{(\mathbf{b})}$ & $\operatorname{CBECS} 92^{(\mathrm{c})}$ & Suggested $^{(b)}$ & & \\
\hline Assembly & 5 & 1.65 & 2 & 1.93 & \begin{tabular}{|l|}
2 \\
\end{tabular} & 10,751 & 15 \\
\hline Education & 5 & 1.61 & 2 & 2.56 & 3 & 25,594 & 15 \\
\hline Food Service & 4 & 1.37 & 1 & 1.96 & 2 & $5,000^{(d)}$ & 25 \\
\hline Lodging & 5 & 2.45 & 3 & 2.84 & 3 & 25,625 & 15 \\
\hline Office $^{(e)}$ & 5 & 1.80 & 2 & 2.1 & 2 & 11,700 & 15 \\
\hline $\operatorname{Retail}^{(\mathfrak{f})}$ & 4 & 1.49 & 1 & 2.14 & 2 & $13,448^{(\mathrm{b})}$ & 41 \\
\hline Warehouse & 4 & 1.23 & 1 & 2.64 & 3 & $22,188^{(\mathrm{b})}$ & 43 \\
\hline \multicolumn{8}{|c|}{$\begin{array}{l}\text { (a) Actual number from EIA (1995). } \\
\text { (b) Suggested number for the screening analysis. } \\
\text { (c) Actual number from EIA (1992, 1995) did not collect this information. } \\
\text { (d) The area from CBECS was slightly adjusted to yield a nonfractional perimeter depth. } \\
\text { (e) Includes buildings that are classified as Healthcare (outpatient). } \\
\text { (f) Retail buildings including strip malls and enclosed shopping center/malls. }\end{array}$} \\
\hline
\end{tabular}

$$
\text { Storage Time (hours) }=\frac{\text { Storage Volume }(\mathrm{gal})}{\text { Recovery Capacity }(\mathrm{gph})}
$$

The analysis was further simplified by finding the slope and intercept for each sizing curve in the small region (Storage Time $<1$ hour) characteristic of EPACT-covered water-heating equipment. The fitted lines are plotted in Figure A.2 and the slopes and intercepts of these lines are reported in Table 2.4 of this report.

\section{Building Types}

The ASHRAE service water-heating chapter does not provide sizing curves for retail, warehouse, or assembly building types (ASHRAE 1995). Accepted numbers for occupant density and schedules in these building types were reported in previous work (Barwig et al. 1996). The time-distribution of weekday occupancy reported for retail, warehouse, and assembly building types is similar to that reported for the office building type. The office building type also has similar hot water uses (employees' and visitors' bathrooms), to the retail, warehouse, and assembly building types. For this analysis, therefore, the hot water use per occupant hour in the office building type was assumed to apply to these lesscommon building types. 


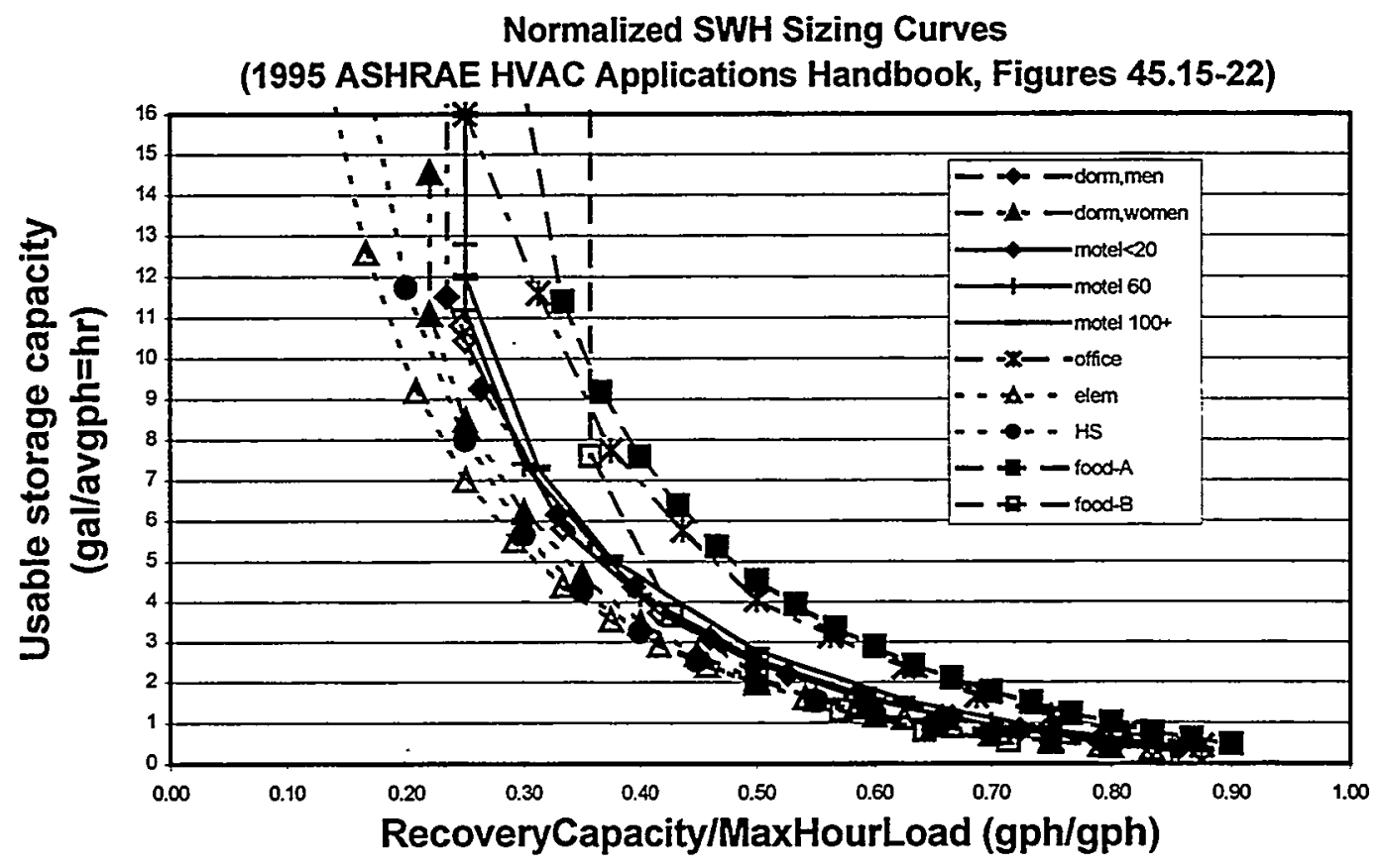

Figure A.1. Normalized Water-Heating Storage-Recovery Capacity Curves

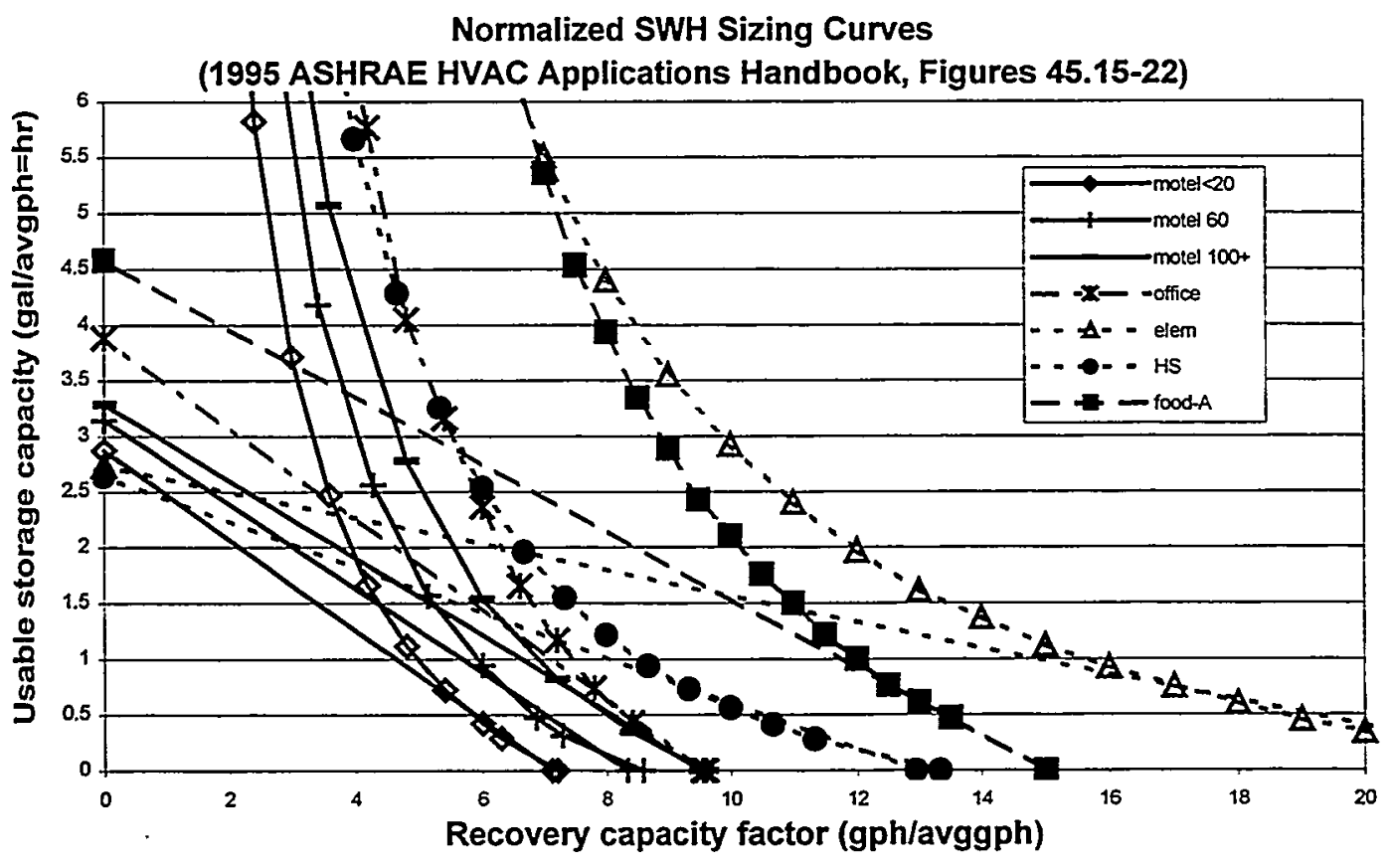

Figure A.2. Interpolation Lines for Storage Time $<1$ Hour 


\section{A.11.2 Service Unit Areal Densities}

The sizing curves are expressed in terms of various service units; e.g., load per student, per occupant, per guestroom, and per peak-hour meal. ${ }^{(a)}$ Occupant densities and schedules for the seven building types were developed for earlier standards development work (Barwig et al. 1996). The relationships between ASHRAE service units and floor area for this analysis are based primarily on the earlier work.

It is important to thoroughly document the occupancy assumptions because the term "occupancy" has different meanings in different contexts. Occupant densities and equivalent occupancy hours by day type are presented in Barwig et al. (1996, Table A.12), which are identical to the occupancy densities and occupancy schedules used in the screening analysis. In this scheme, "occupancy" means the nominal occupant density (people per $\mathrm{ft}^{2}$ ), which corresponds to hours when the Table $\mathrm{A} .12$ occupancy-factor $=$ 1.00. The average hot water loads given in ASHRAE (1995, Table 45.7) are for days or weeks of normal building operation. One condition of normal building operation is that the daily or weekly time-integral of occupancy-factor corresponds approximately to the Table A.12 integral for the building type in question. Most buildings will experience many hours per year when occupancy exceeds the nominal value. A building's maximum hourly hot water load (defined in Table 2.6.2 [and in ASHRAE 1995, Table 45.7]) may correspond to an occupant density significantly larger than the nominal occupant density given in Barwig et al. (1996, Table A.12).

A brief description of the Table 45.7 data and rationale for its application to each building type follows.

Office. The ASHRAE guidance on hot water design loads (ASHRAE 1995, Table 45.7) uses occupants as the service unit for office buildings. The nominal occupant density for offices is 0.0033 people per $\mathrm{ft}^{2}$ (Barwig et al. 1996).

Retail. Hot water uses include employee bathrooms, and break rooms and cleaning use. These uses are very similar to office hot water uses. The corresponding hot water volume demands and demand distribution are assumed to be similar, on a per-occupant basis, to the office. The occupancy profiles of retail buildings are also very similar to those of offices (Barwig et al. 1996). We therefore consider the retail service unit to be the occupant, and use a nominal occupant density of 0.0022 people per $\mathrm{ft}^{2}$ (Barwig et al. 1996).

Warehouse. Hot water uses include employee washroom/breakroom and cleaning use. These uses are very similar to office hot water uses. The corresponding hot water volume demands and demand distribution are assumed to be similar, on a per-occupant basis, to the office. The occupancy profiles of warehouses are also very similar to those of offices (Barwig et al. 1996). We therefore consider the warehouse service unit to be the occupant and use a nominal occupant density of 0.0003 people per $\mathrm{ft}^{2}$ (Barwig et al. 1996).

(a) We assume that meals per hour capacity is equal to the product of seating capacity and table turnover rate. 
Education. The ASHRAE water-heating design guidance (ASHRAE 1995, Table 45.7) uses students as the service unit for schools. Two curves are given: one for elementary schools and the other for junior and senior high schools. ASHRAE recommends, however, that the elementary school curve be used for junior high schools and middle schools in which there is little or no shower use.

The U.S. student population is roughly distributed at $45 \%$ elementary, $10 \%$ middle school, $10 \%$ junior high, $20 \%$ high school, and $15 \%$ post-secondary school. Post-secondary can initially be ignored because it represents the smallest share of hot water use and, probably, the largest use of central plant heating with derivative service water heating. While the daily and hourly demands for high schools are about twice those for elementary schools, the normalized curves for elementary and high schools are almost identical. An average daily load of 1.3 gal per student and an average peak load of 0.8 gph per student can therefore be used with the average normalized sizing curve. A nominal areal density of 0.0107 people per $\mathrm{ft}^{2}$ (Barwig et al. 1996) is assumed. This building type could be readily split into two, or possibly three, categories for future analysis.

Assembly. Hot water uses include employee bathrooms, and breakrooms and cleaning use, which are very similar to office hot water uses. The corresponding hot water volume demands and demand distribution are assumed to be similar, on a per-occupant basis, to the office numbers. The occupancy profiles of the assembly building type are also very similar to those of offices (Barwig et al. 1996). We therefore consider the assembly service unit to be the occupant, and have used a nominal occupant density of 0.016 people per $\mathrm{ft}^{2}$.

Lodging. Normalized curves for the 20-room-or-less and 100-room-or-more motels are very close to the median (60-room motel) normalized curve shown in Figures A.1 and A.2. We have used the median sizing curve (60 units) to represent all lodging. The ASHRAE service unit for lodging is the guestroom. We have estimates of $300 \mathrm{ft}^{2}$ per guestroom from Taylor and Pratt $(1989,1990)$; Taylor (1992); EIA (1992); and Barwig et al. (1990). Service unit density of 0.0033 guestrooms per $\mathrm{ft}^{2}$ was assumed.

Restaurant. The "Type A" (sit-down) restaurant represents most of the existing floor area and hot water use. We have used the "Type $A$ " sizing curve and the corresponding design and average loads (ASHRAE 1995, Table 45.7) of 1.5 and 2.4 gal per meal. Note that the ASHRAE service unit is the meal because the number of meals served is a better predictor of hot water use than the number of occupants because patron residence times are so variable. Because available data are in terms of occupancy, we will consider occupant density to be the sum of staff and patron densities and assume that a given restaurant's patron throughput and meal throughput are equal.

Nominal occupant density is reported Barwig et al. (1996) to be 0.011 people per $\mathrm{ft}^{2}$ (Tables A.12, A.14) and the equivalent (day-type-weighted) occupancy time per average day is 7.76 hours per day (Table A.12). Assuming a patron-hours to staff-hours ratio of $4: 1$ and an average patron throughput of 0.7 hours per meal, the average service unit areal density is 0.048 meals per day per $\mathrm{ft}^{2}$. The average daily hot water load is calculated as 0.115 gpd per $\mathrm{ft}^{2}\left(0.0048\right.$ gph per $\left.\mathrm{ft}^{2}\right)$.

Peak meal throughput per unit area varies widely and a designer generally relies on the restaurant operator for an estimate. In the absence of national data, we can only make ad hoc estimates. If patron 
throughput and patron-to-staff ratio are both somewhat higher-say 2.0 meals per hour and 6 guests per staff during peak hot water load hours, the peak hour service unit areal density is 0.019 meals per hour per $\mathrm{ft}^{2}$. The resulting peak hourly load is 0.0283 gph per $\mathrm{ft}^{2}$.

\section{Temperature Rise Affects Sizing}

The recovery and storage capacities realized in a given application, rcva and stgtime, are related to the rated recovery capacity, $\operatorname{rcvr}(\mathrm{m})$ in gph, and actual storage volume, stgvol(m) in gallons, by:

and

$$
\text { rcva }=\operatorname{rcvr}(m)\left(T_{\text {rg.set }}-T_{\text {rg,main }}\right) /\left(T_{\text {set }}(b)-T_{\text {main }}(r)\right)
$$

$$
\text { stgtime }=f_{u s e} s t g v o l(m) / r c v a
$$

where $\mathrm{T}_{\text {rg,set }}=90^{\circ} \mathrm{F}$ is the temperature rise used for rating water heaters

$\mathrm{T}_{\text {set }}(\mathrm{b})=$ temperature set point in actual use

$\mathrm{T}_{\text {main }}(\mathrm{r})=$ inlet temperature for region $\mathrm{r}$

$f_{u s e}=$ the usable storage capacity factor; $f_{u s e}=0.7$ is a typical value.

The set point is taken to be a function of building type only with values of $140^{\circ} \mathrm{F}-160^{\circ} \mathrm{F}$ for restaurants, $120^{\circ} \mathrm{F}-140^{\circ} \mathrm{F}$ for warehouses and lodging, and $120^{\circ} \mathrm{F}$ for all others (Barwig et al. 1996; ASHRAE 1995). The inlet temperature is taken to be a function of region only, as enumerated in Table A.24.

Table A.24. Average Air and Water Inlet Temperatures

\begin{tabular}{|l|l|c|c|}
\hline $\begin{array}{c}\text { City (selected to } \\
\text { represent region) }\end{array}$ & $\begin{array}{c}\text { Surrogate City } \\
\text { (simple mean of } \\
\text { temperatures) }\end{array}$ & $\begin{array}{c}\text { Normal Year Air } \\
\text { Temperature ( }{ }^{\circ} \text { F) }\end{array}$ & $\begin{array}{c}\text { Assumed Water } \\
\text { Inlet Temperature } \\
\text { (air plus } \mathbf{2}^{\circ} \text { F) }\end{array}$ \\
\hline Providence & New York and Boston & 52.8 & 54.8 \\
\hline Detroit & Chicago & 49.0 & 51.0 \\
\hline Minneapolis & & 44.9 & 46.9 \\
\hline Knoxville & Nashville & 59.1 & 61.1 \\
\hline Shreveport & Lake Charles & 67.8 & 69.8 \\
\hline Orlando & Miami and Jacksonville & 71.9 & 73.9 \\
\hline Denver & & 50.3 & 74.3 \\
\hline Phoenix & & 72.6 & 54.0 \\
\hline Seattle & & 52.0 & 65.3 \\
\hline Fresno & & 63.3 & 65.0 \\
\hline Los Angeles & & 63.0 & 74.6 \\
\hline
\end{tabular}




\section{A.11.3 Water-Heating Energy and Efficiency by Region, Building, and Equipment Type}

The FLEOH calculation for service water-heating equipment differs from that for space-conditioning equipment because sizing is affected by storage, as well as recovery capacity. Another important difference is the need to convert loads from gallons to Btus and to convert the load bases from service units to square feet. It is also necessary to compute water heater standby loss based on the hours when the unit is not firing (assumed to be $8760-\mathrm{FLEOH}$ ). The water heater energy calculation steps are documented below. Note that units are assumed to be sized exactly by the ASHRAE procedures with no additional safety factor or allowance for the fact that equipment is only available in discrete sizes.

Installed Capacity. The continuous recovery capacity (in gallons) in a particular installation differs from the rated capacity by the ratio of the rating temperature rise $\left(90^{\circ} \mathrm{F}\right)$ to the average actual temperature rise. The latter is the difference between set point temperature (Tset), assumed to be a function of building type as listed in Section 2.6.2, Table 2.X, and the mean annual inlet water temperature (Tinlet), assumed to be a function of region as listed in Table A.26. Installation-specific continuous recovery capacity is therefore given by:

$$
\text { Recovery Capacity }=\text { Rated Recovery Capacity } \frac{90^{\circ} \mathrm{F}}{\text { Tset }- \text { Tinlet }}
$$

Storage Time. Storage time is defined in terms of the useable storage volume, assumed to be $70 \%$ of the rated volume, divided by the installation-specific continuous recovery capacity:

$$
\text { Storage Time (hours) }=0.70 \times \frac{\text { Storage Volume }(\mathrm{gal})}{\text { Recovery Capacity }(\mathrm{gph})}
$$

Storage Capacity Factor. A measure of a building type's peak hot water demand character, essential to both the sizing calculation and the FLEOH calculation, must be obtained from the ASHRAE curve for the building type of interest. Because the EPACT-covered water heaters all have storage times $<1$ hour and the curves are nearly linear in this region, we use a slope and intercept for each building type, as reported in Section 2.6.2, Table 2.4, and evaluate the storage capacity factor using the following expression:

$$
\text { Storage } \text { Capacity Factor }=\frac{\text { Intercept }- \text { Storage Time/Slope }}{\text { Intercept }}
$$

Equipment Density. The floor area served by a water heater depends on its recovery capacity and its storage capacity factor for the building type in which it will be installed, as well as on the service unit density. This results in:

$$
\text { Equipment Density (1/sf) }=\text { SUdensity(SU/sf) } \frac{\text { Average Daily Load (gpd/SU)*Storage Capacity Factor }}{24(\mathrm{~h} / \text { day }) * \text { Recovery Capacity (gph) }}
$$


FLEOH. A FLEOH (representing the number of hours of operation needed to serve the water heater load) is calculated for each water heater type in each building and location defined for the analysis. This calculation is necessary because water heaters are sized based on maximum load, and each building type has a different ratio of maximum-to-average load. This value is water heater-specific because storage allows the use of smaller continuous heating capacity to service a given peak load; increasing storage therefore increases FLEOHs. Note all analysis presented assumes that

$$
\text { FLEOH }=\frac{\text { Average Daily Load * Days Per Year }}{\text { Maximum Hourly Load }} \text { Storage Capacity Factor }
$$

This FLEOH is used to generate the annual energy use of the water heater to service the water heater load for each combination of water heater design, building type, and location. The additional energy use due to standby loss is calculated in the aggregation step based on the estimated hourly standby energy use for each design and the hours of standby, calculated as $8760-$ FLEOH.

\section{A.12 References}

American Society of Heating, Refrigerating and Air-Conditioning Engineers, Inc. (ASHRAE). 1989a. ASHRAE/IES Standard 90.1-1989, "Energy Efficient Design of New Buildings Except Low-Rise Residential Buildings." Atlanta, Georgia.

American Society of Heating, Refrigerating and Air-Conditioning Engineers, Inc. (ASHRAE). 1989b. ASHRAE Standard 62-1989, "Ventilation for Acceptable Indoor Air Quality." Atlanta, Georgia.

American Society of Heating, Refrigerating and Air-Conditioning Engineers, Inc. (ASHRAE). 1993. 1993 ASHRAE Handbook: Fundamentals. Atlanta, Georgia.

American Society of Heating, Refrigerating and Air-Conditioning Engineers, Inc. (ASHRAE). 1995. Handbook of HVAC Applications. Atlanta, Georgia.

American Society of Heating, Refrigerating and Air-Conditioning Engineers, Inc. (ASHRAE). 1998. 1998 ASHRAE Handbook: Fundamentals. Atlanta, Georgia.

Barwig, F. E., D. B. Elliott, S. L. Freeman, M. Friedrich, A. Y. Gu, D. L. Hadley, M. A. Halverson, R. E. Jarnagin, S. Katipamula, L. A. Klevgard, J. D. Miller, R. G. Pratt, J. S. Schliesing, S. A. Shankle, S. Somasundaram, G. P. Sullivan, Z. T. Taylor, and D. W. Winiarski. 1996. Preliminary Findings: Analysis of Commercial Space-Conditioning and Storage Water-Heating Equipment Efficiencies. PNNL-1 1191, Pacific Northwest National Laboratory, Richland, Washington.

BLAST Support Office (BLAST). 1991. Volume 1: BLAST User Manual. University of Illinois at Urbana-Champaign, Illinois. 
Energy Information Administration (EIA). 1992. 1992 Commercial Building Energy Consumption and Expenditures (CBECS), Public Use Data, Micro-data files on EIA website:

ftp://ftp.eia.doe.gov/pub/consumption/commercial/micro.data/

Energy Information Administration (EIA). 1995. 1995 Commercial Building Energy Consumption and Expenditures (CBECS), Public Use Data, Micro-data files on EIA website: http://www.eia.doe.gov/emeu/cbecs/microdat.html

Energy Policy Act of 1992 (EPACT). Public Law 102-486, 106 Stat 2776.

Halverson, M. A., J. L. Stoops, J. R. Schmelzer, W. D. Chvala, J. M. Keller, and L. Harris. 1994. "Lighting Retrofit Monitoring for the Federal Sector - Strategies and Results at the DOE Forrestal Building." In Proceedings of the American Council for an Energy Efficient Economy 1994 Summer Study on Energy Efficiency in Buildings, Vol. 2, pp. 2.137-2.144. August 28-September 3, 1994, Pacific Grove, California. American Council for an Energy-Efficient Economy (ACEEE), Washington, D.C.

International Conference of Building Officials (ICBO). 1994. 1994 Uniform Building Code: Volume I, "Administrative, Fire- and Life-Safety, and Field Inspection Provisions." Whittier, California.

Kasmar, J. 1992. End-Use Metering in Commercial Buildings - 1991 Summary Results. Pacific Gas and Electric Company, San Francisco, California.

Taylor, Z. T., and R. G. Pratt. 1989. Description of Electric Energy Use in Commercial Buildings in the Pacific Northwest. DOE/BP-13795-22, prepared by Pacific Northwest Laboratory for the Bonneville Power Administration, Portland, Oregon.

Taylor, Z. T., and R. G. Pratt. 1990. Comparison of ELCAP Data with Lighting and Equipment Load Levels and Profiles Assumed in Regional Models. PNL-7449, Pacific Northwest Laboratory, Richland, Washington.

Taylor, Z. T. 1992. Description of Electric Energy Use in Commercial Buildings in the Pacific Northwest: 1992 Supplement. DOE/BP-1958, prepared by Pacific Northwest Laboratory for the Bonneville Power Administration, Portland, Oregon.

U.S. Department of Commerce (DOC). 1997. Statistical Abstract of the United States, 117th Edition. Bureau of the Census, Washington, D.C. 


\section{Appendix B}

\section{Aggregation Methodology Used to Estimate National Results}




\section{Appendix B}

\section{Aggregation Methodology Used to Estimate National Results}

The engineering simulations described Section 2 are conducted for particular building prototypes in locations chosen to represent distinct climatic regions of the U.S. To extrapolate the results of these simulations to a national level, a method is required to estimate the relative importance of each building in each location. This appendix describes the methodology and data sources by which the aggregation of various results to a national level is achieved.

Specifically, the building level FLEOH from the BLAST simulations are generated for each of 11 geographic locations (cities) and 7 building types. The first step in the aggregation methodology is to map these specific cities to a regional basis; the regions are generally defined in terms of census divisions. Census divisions are used because a variety of statistical data pertaining to human and building populations are available at that level. The combination of census divisions and building types yield distinct market segments for which estimates of their relative importance can be estimated from the available demographic information.

\section{B.1 Disaggregation of Mountain and Pacific Census Divisions}

One of the features of the screening analysis, as discussed in Section 3, is the generation of a distribution of life-cycle cost savings across various market segments-as just defined, in terms of building types and regions. A credible effort to estimate the distribution of economic benefits requires representing the major regional differences in both climate factors and energy prices. The census definitions of the Mountain and Pacific divisions suffer in this respect because they include very wide disparities of climate and electricity prices. Generally, the warmer areas within these regions-California and the desert Southwest-have much higher electricity prices than the northern areas. Thus, the use of only the official nine census divisions will blur the relative economic benefits to these areas resulting from the adoption of equipment efficiency standards.

The prior choice of climate locations in a previous analysis of several commercial products (Barwig et al. 1996) and the development of associated population weights suggested a natural disaggregation of the two western census divisions. The most natural division occurs in the Pacific census division, where a state level disaggregation separates Oregon and Washington from California. In the Mountain division, the break is represented by separation into a "North" region, represented climatically by Denver, and a "South" region represented by Phoenix. ${ }^{\text {(a) }}$

(a) The population weights from the previous analysis (Barwig et al. 1996) indicated a relative weighting of 0.64 for the Mountain-North and 0.36 for the Mountain-South. 
This special disaggregation results in 11 geographic divisions. For the remainder of this section (and throughout much of the report), however, we will continue to refer to these divisions as census divisions. While this step adds some complexity to the analysis and requires gathering some additional information on building population characteristics, the separate identification of the northwest (represented by Seattle) and the desert southwest (represented by Phoenix) can, for some products, provide convenient bounding cases for the life-cycle cost analyses, as discussed in Section 3.

\section{B.2 Translation of Climate Location Results to Census Divisions}

The first step in the overall aggregation process is to translate the building level FLEOH from climate locations to the (modified) census divisions. Demographic information on existing ${ }^{(a)}$ building square footage is available by census division. Therefore, the climate location results must be translated to a census division basis to incorporate demographic data for the various building types in the analysis.

This step essentially answers the question: How should the relative influence of the climate locations be estimated to construct an appropriately weighted measure for each census division? For example, three climate locations-Knoxville, Shreveport, and Tampa-were selected to generally represent the South (census region). What is the relative influence of each of these cities in describing each of the three census divisions-South Atlantic, East South Central, and West South Central-in the south?

In more specific terms, what is the relative representation (e.g., floor area) of commercial buildings for each of the climate locations (or portions of) that fall within the boundaries of a census division? In answering this question, estimates of the relative representation of commercial buildings were calculated from human population data from the USDA Economic Research Services (USDA 1993). ${ }^{\text {(b) }}$ All metropolitan areas within the census division boundaries with a population of over one million were assumed to have significance in the calculation. The geographic distribution of these metro-populations is known by their corresponding central or fringe county populations.

After the modification of the census divisions as described in Section B.1, a weighting matrix is created that maps the 11 climate location results to the 11 (modified) census divisions. This matrix is shown in Table B.1. For example, FLEOH in the West North Central census division is determined by a weighted aggregation of the results from the Detroit and Minneapolis climate locations:

$$
(\mathrm{FLEOH})_{\text {WestNorthCentral }}=0.6^{*}(\mathrm{FLEOH})_{\text {Detroit }}+0.4^{*}(\mathrm{FLEOH})_{\text {Minneapolis }}
$$

(a) The units considered in this analysis can be replacements for existing units or new installations in new buildings. Commercial Building Energy Consumption Survey (CBECS) data representing existing construction was used to represent building demographic data (as opposed to ASHRAE, which used only new construction in its analysis) (EIA 1992, EIA 1995).

(b) Population data must be used in the first aggregation step as a surrogate for floor area because floor area, either total or by building type, is not known at the climate location level. This implies that the weighting procedure at this step is the same for all building types. 
In more general terms, this transformation to a census division basis can be expressed as the dot product of a vector of climate location results with a vector of climate location weights (column 5 in Table B.1 West North Central division):

$$
\mathrm{FLEOH}_{\mathrm{WNC}}=\sum_{\mathrm{m}=\mathrm{I}}^{11} \mathrm{X}_{-} \mathrm{CL}_{\mathrm{m}} \cdot \mathrm{WCL}_{\mathrm{m}, 4}
$$

where $\mathrm{FLEOH}_{\mathrm{WNC}}=$ aggregated FLEOH for the West North Central census division

$\mathrm{X} \mathrm{CL}_{\mathrm{m}}=\mathrm{FLEOH}$ for each of 11 climate locations

$W^{W C L} L_{m, 4}=11$ weights for the climate locations having influence in the West North Central census division (column 5 in Table B.1) (column 4 in Table CA).

The process described in Equation (B.2) above can be repeated for each of the seven building types considered in the analysis. The weighting matrix in Table B.1 is assumed to remain the same for all building types. This further generalization for the building types is shown in the equation below with the addition of a second index on the $\mathrm{X}$ terms.

$$
\mathrm{FLEOH}_{\mathrm{i}, \mathrm{j}}=\sum_{\mathrm{m}=1}^{11} \mathrm{X} \mathrm{CL}_{\mathrm{i}, \mathrm{m}} \cdot \mathrm{WCL} \mathrm{L}_{\mathrm{m}, \mathrm{j}}
$$

where FLEOH $_{i, j}=$ FLEOH for building type $\mathrm{i}$ and census division $\mathbf{j}$

$\mathrm{X} \_\mathrm{CL}_{\mathrm{i}, \mathrm{m}}=\mathrm{FLEOH}$ for building type $\mathrm{i}$ and climate location $\mathrm{m}$

$\bar{W} C L_{m, j}=$ influence or weight of climate location $m$ within census division $\mathrm{j}$.

As an illustration, the results of weighting the climate-location FLEOH pertaining to central cooling equipment are shown in Table B.2.

Table B.1. Aggregation Weights for Census Divisions

\begin{tabular}{|l|l|l|l|l|l|l|l|l|l|l|l|}
\hline & $\begin{array}{c}\text { New } \\
\text { Englan }\end{array}$ & $\begin{array}{c}\text { Mid- } \\
\text { Atlantic }\end{array}$ & $\begin{array}{c}\text { East } \\
\text { North } \\
\text { Central }\end{array}$ & $\begin{array}{c}\text { West } \\
\text { North } \\
\text { Central }\end{array}$ & $\begin{array}{c}\text { South } \\
\text { Atlantic }\end{array}$ & $\begin{array}{c}\text { East } \\
\text { South } \\
\text { Central }\end{array}$ & $\begin{array}{c}\text { West } \\
\text { South } \\
\text { Central }\end{array}$ & $\begin{array}{c}\text { Mountain } \\
\text { South }\end{array}$ & $\begin{array}{c}\text { Mountain } \\
\text { North }\end{array}$ & $\begin{array}{l}\text { Pacific } \\
\text { South }\end{array}$ & $\begin{array}{l}\text { Pacific } \\
\text { North }\end{array}$ \\
\hline Providence & 1.000 & 1.000 & 0 & 0 & 0 & 0 & 0 & 0 & 0 & 0 & 0 \\
\hline Detroit & 0 & 0 & 0.992 & 0.600 & 0 & 0 & 0 & 0 & 0 & 0 & 0 \\
\hline Minneapolis & 0 & 0 & 0.007 & 0.400 & 0 & 0 & 0 & 0 & 0 & 0 & 0 \\
\hline Knoxville & 0 & 0 & 0 & 0 & 0.507 & 0.675 & 0.134 & 0 & 0 & 0 & 0 \\
\hline Shreveport & 0 & 0 & 0 & 0 & 0.177 & 0.326 & 0.806 & 0 & 0 & 0 & 0 \\
\hline Tampa & 0 & 0 & 0 & 0 & 0.316 & 0 & 0.060 & 0 & 0 & 0 & 0 \\
\hline Denver & 0 & 0 & 0 & 0 & 0 & 0 & 0 & 0 & 1.000 & 0.005 & 0.117 \\
\hline Phoenix & 0 & 0 & 0 & 0 & 0 & 0 & 0 & 1.000 & 0 & 0 & 0 \\
\hline Seattle & 0 & 0 & 0 & 0 & 0 & 0 & 0 & 0 & 0 & 0 & 0.884 \\
\hline Fresno & 0 & 0 & 0 & 0 & 0 & 0 & 0 & 0 & 0 & 0.157 & 0 \\
\hline Los Angeles & 0 & 0 & 0 & 0 & 0 & 0 & 0 & 0 & 0 & 0.838 & 0 \\
\hline Sum & 1.000 & 1.000 & 1.000 & 1.000 & 1.000 & 1.000 & 1.000 & 1.000 & 1.000 & 1.000 & 1.000 \\
\hline
\end{tabular}


Table B.2. FLEOH by Census Division for Central Cooling Equipment

\begin{tabular}{|l|c|c|c|c|c|c|c|}
\hline & Assembly & Education & $\begin{array}{c}\text { Food } \\
\text { Service }\end{array}$ & Lodging & Office & Retail & Warehouse \\
\hline New England & 1,059 & 766 & 1,523 & 842 & 1,059 & 1,281 & 880 \\
\hline Middle Atlantic & 986 & 756 & 1,523 & 873 & 1,005 & 1,234 & 775 \\
\hline East North Central & 955 & 664 & 1,368 & 779 & 961 & 1,179 & 775 \\
\hline West North Central & 999 & 708 & 1,157 & 797 & 950 & 1,124 & 769 \\
\hline South Atlantic & 2,235 & 1,510 & 2,820 & 2,192 & 2,017 & 2,321 & 1,738 \\
\hline East South Central & 1,843 & 1,272 & 2,317 & 1,785 & 1,737 & 1,984 & 1,527 \\
\hline West South Central & 2,209 & 1,488 & 2,858 & 2,138 & 1,995 & 2,288 & 1,676 \\
\hline Mountain North & 1,164 & 819 & 1,749 & 974 & 1,295 & 1,385 & 1,207 \\
\hline Mountain South & 2,823 & 1,990 & 3,487 & 2,781 & 2,559 & 2,841 & 2,534 \\
\hline Pacific North & 794 & 562 & 1,361 & 503 & 1,018 & 1,246 & 881 \\
\hline Pacific South & 1,626 & 1,154 & 2,616 & 1,126 & 1,844 & 2,266 & 1,205 \\
\hline
\end{tabular}

\section{B.3 Aggregation across Market Segments}

As described in Section B.1, the 11 (modified) census divisions along with the 7 building types yields 77 partitions that we term "market segments." After translating the engineering results from a location (city) basis to market segments, the next step is to develop an estimate of the number of units of equipment shipped to (and assumed to be installed in) these segments. The approach separates the estimation of the distribution of shipments across these market segments from the projection of total national shipments. Total national shipments information is generally available for each product. The absolute numbers of shipments to the market segments are obtained by multiplying the estimated distribution by total national shipments.

\section{B.3.1 Methodology}

Shipments of any specified category of equipment consist of replacement units in existing buildings and units installed in new buildings (referred to below as simply "new" units). The relative shares of replacement versus new units depend primarily upon the lifetime of the equipment and the rate of growth of the building stock.

For both replacement and new units, the distribution methodology considers potentially three (multiplicative) factors:

1. Square Footage by Building Type and Region. Square footage data by building type and location is available from the Commercial Building Energy Consumption Survey (CBECS) (EIA 1992, 1995). Projections from EIA's Annual Energy Outlook (AEO) [generated by the National Energy Modeling System (NEMS)] provide a means of estimating the distribution of future building stock by region and building type (EIA 1999a). 
2. Equipment Fractions of Floor Space. Equipment is not used in the same manner in all market segments. For example, boilers are primarily used in larger buildings; heat pumps are more prevalent in milder climates. The CBECS data can be used to estimate the percentage of floor space that is served by generic types of equipment for each market segment. These percentages can then be multiplied by the floor space estimates to develop the absolute amount of floor space served by the equipment.

3. Peak Load Intensities. The capacity of the equipment installed for a given amount of floor space will depend, to some degree, upon the peak load that it must serve. This variation is most prevalent in serving heating loads across the country. The peak-heating load that must be served in Minneapolis is significantly greater than it is in Tampa. These intensities are expressed in capacity $(\mathrm{kBtu} / \mathrm{h})$ per square foot (and can be estimated by the building energy simulations). When these intensities are multiplied by floor space served for a specific type of equipment, a measure of the total installed capacity is obtained for each market segment. The distribution of (existing or projected newly) installed capacity is then assumed to represent the distribution of replacement or new shipments across market segments.

For the screening analysis, the third factor--peak load intensities--was not used. For cooling, the results of the BLAST simulations suggested that the variation of cooling intensities did not vary greatly across regions. For heating equipment, the variation was more pronounced, but there remained the question of whether, for the same amount of floor space, more units of a given size were installed in colder regions, or whether the average equipment size was larger. Without some empirical information related to this question, we decided to omit this factor in the screening process.

The combining of the floor space and equipment shares matrices yields estimates of the distributions for both replacement and new equipment shipments. Thus, we have formally

$$
\begin{aligned}
\text { MS[Replacment }]_{i, j} & =\text { FISpcExist }_{i, j} \times \text { EqShr }_{i, j} \text { and } \\
\text { MS[New }]_{i, j} & =\text { FISpcNew }_{i, j} \times \text { EqShr }_{i, j}
\end{aligned}
$$

where MS[Replacement $]_{\mathrm{i}, \mathrm{j}}=$ estimated share of national installed capacity in existing buildings by building type $i$ and census division $j$

$\operatorname{MS}[\mathrm{New}]_{\mathrm{i}, \mathrm{j}}=$ estimated share of national installed capacity in new buildings, by building type $i$ and census division $j$

FlrSpcExist ${ }_{i, j}=$ floor space in existing building type $\mathrm{i}$ and census division $\mathrm{j}$ (normalized)

FirSpcNew $_{i, j}=$ floor space in existing building type and census division $\mathrm{j}$ (normalized)

EqpShr $_{i, j}=$ share of floor space in building type $i$ and census division $j$ served by equipment in analysis

The principal difference between MS[Replacement] and MS[New] stems from the shift in regional construction-i.e., higher proportions of (projected) floor space in new buildings in the south and west as compared to the existing stock. In the future, this will tend to put slightly more emphasis on cooling equipment and less on heating equipment. Differences in the equipment fractions of floor space between 
existing and new buildings were assumed to be small for the screening analysis. Moreover, the CBECS does not contain sufficient numbers of observations to easily characterize equipment usage in new buildings.

Given estimates of the percentage of total national shipments that are replacement units, a final market shares matrix is computed as

$$
\begin{aligned}
\mathrm{MS}_{\mathrm{i}, \mathrm{j}}= & \text { (Replacement Shipments/Total Shipments) } \times \text { MS[Replacement }]_{\mathrm{i}, \mathrm{j}}+ \\
& \text { (New Shipments/Total Shipments) } \times \text { MS[New }]_{\mathrm{i}, \mathrm{j}}
\end{aligned}
$$

The methodology here does not try to develop detailed product-specific estimates of the shares of total shipments that are replacements versus those that are installed in new buildings. Some recent national studies of commercial equipment have used inventory models (using historical shipments data and assumed lifetimes) that could be exploited to split current national shipments into replacement and new equipment installations. ${ }^{\text {(a) }}$

For the screening effort, however, this information was not collected to make this split. Rather, some very simplifying assumptions were made to generate these shares. As a rough approximation, new buildings were assumed to make up about $1.5 \%$ of the building stock for any future years (1\% net growth $+0.5 \%$ for removals). For cooling equipment, with an estimated life of 15 years, approximately $6.5 \%$ of the stock is replaced each year. Thus, the share of new units was assumed to be $1.5 /(1.5+6.5)$ or about $20 \%$. For boilers with a 30 -year life we also assumed 20 to $80 \%$ split, based roughly on a view that boilers are not as prevalent in new buildings as they are in existing buildings. For water heaters, with a much shorter lifetime of 7 years, we assumed a 10 to $90 \%$ split. As will be shown below, the projected differences in the distribution of floor space between existing and new buildings is not so great as to make these assumptions significantly influence the final results.

\section{B.3.2 Numerical Results for Specific Example}

The results for large packaged air conditioning units are shown below to illustrate the aggregation methodology described above.

\section{Floor Space Distributions}

Table B.3 shows a projected distribution of floor space by region and building type for 2004 . The distribution is normalized to sum to $1,000 \mathrm{ft}^{2}$ on a national basis. These values are taken from the commercial building module of the National Energy Modeling System (with the projection consistent with the AEO [EIA 1999a]). This projected distribution for 2004 is assumed to be a reasonable representation of where replacement equipment will be sold over the period 2004 to 2030 .

(a) For example, Arthur D. Little, Inc. (ADL) conducted several studies in the 1990s for DOE that were based on this approach. One such study by ADL is R.F. Patel and A. Phylactopoulos. 1995. Commercial Heating, Ventilation, and Air-conditioning Baseline Energy Use (Draft). 
Table B.3. Projected Distribution of Floor Space (per 1,000 total $\mathrm{ft}^{2}$ ) for Period 2004

\begin{tabular}{|c|c|c|c|c|c|c|c|c|}
\hline Region & Assembly & Education & $\begin{array}{l}\text { Food } \\
\text { Service }\end{array}$ & Lodging & Office & Retail & $\begin{array}{l}\text { Ware- } \\
\text { house }\end{array}$ & Total \\
\hline New England & 3.7 & 11.1 & 0.7 & 2.9 & 10.5 & 15.6 & 6.0 & 50.6 \\
\hline Middle-Atlantic & 8.4 & 25.1 & 2.4 & 3.8 & 31.2 & 38.1 & 22.2 & 131.2 \\
\hline East N. Central & 11.5 & 26.8 & 8.1 & 12.9 & 31.0 & 39.0 & 33.5 & 162.8 \\
\hline West N. Central & 6.4 & 14.0 & 1.1 & 5.3 & 14.7 & 23.6 & 8.2 & 73.3 \\
\hline South Atlantic & 13.3 & 21.0 & 3.7 & 15.2 & 44.3 & 45.2 & 33.8 & 176.4 \\
\hline East S. Central & 5.6 & 7.9 & 2.2 & 7.1 & 12.9 & 27.3 & 22.5 & 85.5 \\
\hline West S. Central & 8.4 & 21.6 & 3.4 & 5.4 & 23.2 & 29.3 & 17.8 & 109.0 \\
\hline Mountain North & 6.0 & 8.0 & 0.9 & 6.1 & 13.0 & 6.7 & 7.7 & 48.4 \\
\hline Mountain South & 3.4 & 4.5 & 0.5 & 3.5 & 7.3 & 3.8 & 4.3 & 27.2 \\
\hline Pacific North & 1.7 & 3.5 & 0.8 & 2.3 & 7.3 & 5.1 & 3.8 & 24.4 \\
\hline Pacific South & 7.9 & 15.8 & 3.5 & 10.5 & 33.2 & 23.1 & 17.3 & 111.2 \\
\hline Total & 76.2 & 159.2 & 27.2 & 75.0 & 228.6 & 256.8 & 177.0 & 1000.0 \\
\hline
\end{tabular}

Table B.4 shows a similar distribution for new construction. The distribution of new construction is represented by the floor space built in each market segment over the period 2010 to 2020 , again taken from the NEMS commercial model. Note, for example, that the percentage of new construction in the Mountain North region is $7.1 \%$ (i.e., $71.1 / 1000$ ), as compared to the $4.8 \%$ in existing (i.e., 2004) buildings.

Several adjustments were made to the projected floor space estimates generated by the NEMS model. First, the floor space for assembly buildings was adjusted downward; the screening analysis considered only public assembly buildings and omitted religious assembly buildings. Second, office floor space was increased to account for out-patient health care (the percentage increases varied by census division, based

Table B.4. Projected Distribution of Floor Space (per 1,000 total $\mathrm{ft}^{2}$ ) for Period 2011-2020

\begin{tabular}{|c|c|c|c|c|c|c|c|c|}
\hline Region & Assembly & Education & $\begin{array}{l}\text { Food } \\
\text { Service }\end{array}$ & Lodging & Office & Retail & $\begin{array}{l}\text { Ware- } \\
\text { house }\end{array}$ & Total \\
\hline New England & 3.2 & 9.6 & 0.3 & 3.3 & 6.3 & 13.3 & 3.7 & 39.8 \\
\hline Middle-Atlantic & $\overline{4.9}$ & 22.0 & 0.9 & 2.8 & 16.2 & 32.3 & 13.8 & 92.9 \\
\hline East N. Central & 8.0 & 30.4 & 6.8 & 10.5 & 19.4 & 38.5 & 28.2 & 141.7 \\
\hline West N. Central & 5.8 & 17.1 & 1.3 & 3.7 & 10.0 & 20.4 & 2.6 & 60.9 \\
\hline South Atlantic & 18.4 & 34.1 & 5.4 & 17.6 & 34.6 & 55.2 & 43.7 & 209.1 \\
\hline East S. Central & 5.3 & 8.2 & 1.7 & 8.4 & 8.7 & 25.0 & 19.4 & $\overline{76.6}$ \\
\hline West S. Central & 8.2 & 29.6 & 3.5 & 7.2 & 19.6 & 32.3 & 20.2 & 120.6 \\
\hline Mountain North & 9.0 & 12.8 & 1.6 & 11.2 & 16.9 & 11.9 & 7.9 & 71.2 \\
\hline Mountain South & 5.1 & 7.2 & 0.9 & 6.3 & 9.5 & 6.7 & 4.4 & $\overline{40.0}$ \\
\hline Pacific North & 1.8 & 4.6 & 0.9 & 2.6 & 6.0 & 6.3 & 4.2 & 26.4 \\
\hline Pacific South & 8.2 & 21.0 & 4.3 & 11.7 & 27.5 & 28.7 & 19.3 & $\overline{120.8}$ \\
\hline Total & 77.9 & 196.4 & 27.6 & 85.3 & 174.7 & 270.5 & 167.5 & 1000.0 \\
\hline
\end{tabular}


upon the 1995 CBECS). Finally, the floor space for the Mountain and Pacific Census divisions needed to be split into the North and South components. Based upon the transformation matrices developed in Barwig et al. (1996), the Mountain North was assigned 64\% of the floor space in Mountain census region, with the remainder going to the Mountain South. Pacific South is defined as California. It was assigned $82 \%$ of the floor space in the Pacific Census region. These shares were used for both existing and new floor space matrices.

The floor space distributions shown in Tables B.3 and B.4 are the same for all products covered by the screening analysis.

\section{Equipment Shares}

The 1995 CBECS data (EIA 1995) are used to estimate the percentage of floor space for each market segment served by each type of equipment. The CBECS collects information on packaged cooling equipment, boilers, furnaces, and water heaters. For each type of equipment, a matrix is constructed such that each element shows the fraction of the floor space served by that type of equipment in each region and building type. Lacking more detailed information, these generic matrices were used for all of the individual products within a product type. Thus, for example, the packaged cooling matrix was used for all of heat pump equipment as well as the air source and water source cooling equipment.

To ensure statistically valid results for the equipment shares, the data from the CBECS were aggregated to four broad regions. The regions were chosen to represent four quadrants of the U.S., as shown in Table B.5. The use of the quadrants was deemed to sufficiently represent the variations in equipment choice that may depend upon temperature differences between north and south regions, as well as differential humidity conditions between the east and the west.

Table B. 6 shows the final equipment shares matrix for packaged cooling equipment. Stemming from the aggregation process above, the shares are repeated for each (modified) census division that is contained within a given quadrant.

Multiplying the floor space matrix for existing buildings (Table B.3) by the equipment shares matrix (Table B.6), and then normalizing the results to add to $100 \%$, yields the distribution matrix for replacement sales. As described in Equation (B.5) above, the same process is followed to construct the distribution by market segment for units installed in new buildings. Here the floor space matrix for new construction (Table B.4) is multiplied by the same equipment shares matrix (Table B.6). The resulting distribution matrices are shown as Table B.7 and Table B.8.

Table B.5. Aggregation of Regions to Quadrants

\begin{tabular}{|l|l|}
\hline \multicolumn{1}{|c|}{ Quadrant } & \multicolumn{1}{|c|}{ Census Division } \\
\hline Northeast & Northeast, Middle-Atlantic \\
\hline Southeast & South Atlantic, East South Central, West South Central \\
\hline Northwest & Mountain North, Pacific-North \\
\hline Southwest & Mountain South, Pacific-South \\
\hline
\end{tabular}


Table B.6. Equipment Shares for Packaged AC Equipment

\begin{tabular}{|l|c|c|c|c|c|c|c|}
\hline \multicolumn{1}{|c|}{ Region } & Assembly & Education & $\begin{array}{c}\text { Food } \\
\text { Service }\end{array}$ & Lodging & Office & Retail & Warehouse \\
\hline New England & 0.36 & 0.35 & 0.53 & 0.37 & 0.53 & 0.48 & 0.44 \\
\hline Middle-Atlantic & 0.36 & 0.35 & 0.53 & 0.37 & 0.53 & 0.48 & 0.44 \\
\hline East N. Central & 0.36 & 0.35 & 0.53 & 0.37 & 0.53 & 0.48 & 0.44 \\
\hline West N. Central & 0.36 & 0.35 & 0.53 & 0.37 & 0.53 & 0.48 & 0.44 \\
\hline South Atlantic & 0.40 & 0.49 & 0.70 & 0.43 & 0.54 & 0.56 & 0.34 \\
\hline East S. Central & 0.40 & 0.49 & 0.70 & 0.43 & 0.54 & 0.56 & 0.34 \\
\hline West S. Central & 0.40 & 0.49 & 0.70 & 0.43 & 0.54 & 0.56 & 0.34 \\
\hline Mountain North & 0.31 & 0.13 & 0.71 & 0.23 & 0.62 & 0.57 & 0.15 \\
\hline Mountain South & 0.62 & 0.42 & 0.58 & 0.32 & 0.57 & 0.64 & 0.60 \\
\hline Pacific North & 0.31 & 0.13 & 0.71 & 0.23 & 0.62 & 0.57 & 0.15 \\
\hline Pacific South & 0.62 & 0.42 & 0.58 & 0.32 & 0.57 & 0.64 & 0.60 \\
\hline Source: CBECS 1995 & & & & & & \\
\hline
\end{tabular}

Table B.7. Estimated Percentage of Distribution of Replacement Shipments for Large AC Equipment

\begin{tabular}{|c|c|c|c|c|c|c|c|c|}
\hline Region & Assembly & Education & $\begin{array}{l}\text { Food } \\
\text { Service }\end{array}$ & Lodging & Office & Retail & $\begin{array}{l}\text { Ware- } \\
\text { house }\end{array}$ & Total \\
\hline New England & 0.3 & 0.8 & 0.1 & 0.2 & 1.2 & 1.6 & 0.6 & 4.8 \\
\hline Middle-Atlantic & 0.6 & 1.9 & 0.3 & 0.3 & 3.5 & 3.9 & 2.1 & 12.6 \\
\hline East N. Central & 0.9 & 2.0 & 0.9 & 1.0 & $\overline{3.5}$ & 4.0 & 3.1 & 15.5 \\
\hline West N. Central & 0.5 & 1.1 & 0.1 & 0.4 & 1.7 & 2.4 & 0.8 & 6.9 \\
\hline South Atlantic & 1.1 & 2.2 & 0.5 & 1.4 & 5.1 & 5.4 & 2.4 & 18.2 \\
\hline East S. Central & $\overline{0.5}$ & 0.8 & $\overline{0.3}$ & 0.7 & 1.5 & 3.3 & $\overline{1.6}$ & 8.7 \\
\hline West S. Central & $\overline{0.7}$ & 2.2 & $\overline{0.5}$ & $\overline{0.5}$ & 2.7 & 3.5 & $\overline{1.3}$ & 11.4 \\
\hline Mountain North & 0.4 & 0.2 & 0.1 & 0.3 & 1.7 & 0.8 & 0.2 & 3.8 \\
\hline Mountain South & $\overline{0.4}$ & $\overline{0.4}$ & 0.1 & 0.2 & 0.9 & 0.5 & 0.5 & 3.1 \\
\hline Pacific North & $\overline{0.1}$ & 0.1 & 0.1 & 0.1 & 1.0 & $\overline{0.6}$ & $\overline{0.1}$ & 2.1 \\
\hline Pacific South & 1.0 & 1.4 & 0.4 & $\overline{0.7}$ & 4.0 & 3.1 & 2.2 & 12.9 \\
\hline Total & 6.6 & 13.1 & 3.5 & 5.9 & 26.8 & 29.1 & 14.9 & 100.0 \\
\hline
\end{tabular}

Corresponding to Equation (B.6), a final distribution matrix is constructed, given the assumption about the percentage of national shipments that are replacement units as compared to new units. As discussed at the end of Section B.3.1, for cooling equipment, the assumption used in the screening analysis was to assign $80 \%$ of shipments to replacement applications and $20 \%$ of shipments to new (post-2003) buildings. Using these weights, the final distribution matrix is shown in Table B.9. Thus, Table B. 9 is constructed by multiplying Table B. 7 by 0.8 and Table B. 8 by 0.2 and then adding the results. 
Table B.8. Estimated Percentage of Distribution of Shipments to New Buildings for Large AC Equipment

\begin{tabular}{|c|c|c|c|c|c|c|c|c|}
\hline Region & Assembly & Education & $\begin{array}{c}\text { Food } \\
\text { Service }\end{array}$ & Lodging & Office & Retail & $\begin{array}{l}\text { Ware- } \\
\text { house }\end{array}$ & Total \\
\hline New England & 0.3 & 0.7 & 0.0 & 0.3 & 0.7 & 1.4 & 0.3 & 3.7 \\
\hline Middle-Atlantic & 0.4 & 1.7 & 0.1 & 0.2 & 1.9 & 3.3 & 1.3 & 8.8 \\
\hline East N. Central & 0.6 & 2.3 & 0.8 & $\overline{0.8}$ & 2.2 & 4.0 & 2.6 & 13.4 \\
\hline West $\mathrm{N}$. Central & 0.4 & 1.3 & 0.1 & 0.3 & 1.2 & 2.1 & 0.2 & 5.7 \\
\hline South Atlantic & 1.6 & 3.6 & 0.8 & 1.6 & 4.0 & 6.7 & 3.2 & 21.5 \\
\hline East S. Central & $\overline{0.5}$ & 0.9 & 0.3 & $\overline{0.8}$ & 1.0 & 3.0 & 1.4 & 7.8 \\
\hline West S. Central & 0.7 & 3.1 & 0.5 & 0.7 & 2.3 & 3.9 & 1.5 & 12.6 \\
\hline Mountain North & $\overline{0.6}$ & $\overline{0.4}$ & 0.2 & $\overline{0.6}$ & 2.2 & 1.5 & $\overline{0.3}$ & 5.7 \\
\hline Mountain South & 0.7 & $\overline{0.6}$ & 0.1 & 0.4 & 1.2 & 0.9 & 0.6 & 4.5 \\
\hline Pacific North & 0.1 & 0.1 & 0.1 & 0.1 & $\overline{0.8}$ & 0.8 & 0.1 & 2.2 \\
\hline Pacific South & 1.1 & 1.9 & 0.5 & 0.8 & 3.3 & 3.9 & 2.5 & 14.1 \\
\hline Total & 6.9 & 16.5 & 3.7 & 6.6 & 20.8 & 31.4 & 14.0 & 100.0 \\
\hline
\end{tabular}

Table B.9. Estimated Percentage of Distribution of All Shipments for Large AC Equipment

\begin{tabular}{|c|c|c|c|c|c|c|c|c|}
\hline Region & Assembly & Education & $\begin{array}{l}\text { Food } \\
\text { Service }\end{array}$ & Lodging & Office & Retail & $\begin{array}{l}\text { Ware- } \\
\text { house }\end{array}$ & Total \\
\hline New England & 0.3 & 0.8 & 0.1 & 0.2 & 1.1 & 1.5 & 0.5 & 4.6 \\
\hline Middle-Atlantic & $\overline{0.6}$ & 1.8 & $\overline{0.2}$ & 0.3 & 3.2 & 3.8 & 1.9 & 11.8 \\
\hline East N. Central & 0.8 & 2.1 & 0.9 & 1.0 & 3.3 & 4.0 & 3.0 & 15.0 \\
\hline West $\mathrm{N}$. Central & 0.5 & 1.1 & 0.1 & $\overline{0.4}$ & 1.6 & $\overline{2.3}$ & 0.7 & 6.7 \\
\hline South Atlantic & 1.2 & 2.4 & $\overline{0.6}$ & 1.4 & 4.9 & 5.7 & 2.6 & 18.8 \\
\hline East S. Central & $\overline{0.5}$ & 0.8 & 0.3 & 0.7 & 1.4 & 3.2 & $\overline{1.6}$ & 8.5 \\
\hline West S. Central & 0.7 & 2.4 & $\overline{0.5}$ & $\overline{0.5}$ & 2.6 & 3.6 & 1.3 & 11.7 \\
\hline Mountain North & $\overline{0.4}$ & $\overline{0.3}$ & 0.2 & 0.4 & 1.8 & 1.0 & 0.2 & 4.2 \\
\hline Mountain South & 0.5 & 0.5 & 0.1 & 0.3 & 0.9 & 0.6 & $\overline{0.6}$ & 3.4 \\
\hline Pacific North & 0.1 & 0.1 & 0.1 & 0.1 & 0.9 & 0.6 & 0.1 & 2.2 \\
\hline Pacific South & 1.1 & 1.5 & 0.5 & 0.7 & 3.9 & $\overline{3.3}$ & 2.3 & 13.2 \\
\hline Total & 6.7 & 13.8 & 3.5 & 6.0 & $\overline{25.6}$ & 29.6 & 14.7 & 100.0 \\
\hline
\end{tabular}

\section{B.3.3 Aggregation to a National Result}

The final step in the aggregation process is to produce a single national result. The national result is an aggregation across the market segments using weights that reflect the estimated shipments of commercial equipment to each market segment. 
Because energy consumption is proportional to the FLEOH in each market segment, the weighting can be applied first to the FLEOH or at the end of the process to the unit energy consumption in each market segment. From an engineering viewpoint, it is perhaps useful to gain some perspective as to what the average operating hours may be for a specific piece of equipment across the U.S. The equation below represents this aggregation process.

$$
\mathrm{FLEOH}_{\mathrm{US}}=\sum_{i=1}^{7} \sum_{\mathrm{j}=1}^{11} \mathrm{MS}_{\mathrm{i}, \mathrm{j}} \bullet \mathrm{FLEOH}_{\mathrm{i}, \mathrm{j}}
$$

where $\mathrm{FLEOH}_{\mathrm{US}}=$ a single FLEOH that represents all building types and the entire United States $\mathrm{MS}_{\mathrm{i}, \mathrm{j}}=$ estimated shipments to each market segment expressed as a fraction of the total shipments in the United States.

In terms of the example for large air conditioners, the process described in Equation (B.7) indicates multiplying the FLEOHs in Table B.2 by the percentages in Table B.9 and adding the results. In this case, the national average FLEOH for large AC equipment is estimated to be 1,537 hours.

\section{B.4 Price Estimates for Subcensus Divisions}

Splitting the Mountain and Pacific census divisions into "north" and "south" regions, as described above, requires estimates of energy prices for these subcensus divisions. Information from the EIA State Energy Price and Expenditure Report (EIA 1998) report for 1995 was used to construct adjustment factors to estimate electricity prices for these breakout regions. As a first step, for both the Mountain and Pacific census divisions, the 1995 state data were aggregated to construct quantity-weighted prices for three groupings of states: 1) north, 2) south, and 3) all. The north region of the Pacific census division consists of Washington and Oregon. The south region is defined as California. For the mountain census division, the price for the south region is represented by the weighted average price of Arizona and Nevada. The remaining states in the Mountain census division were used to construct a price for Mountain North.

For the Pacific region, the published price in the AEO 2000 (EIA 1999b) was nearly 9\% lower than the average price constructed from the state-level data for 1995 . The reduction in the overall price was largely assumed to be the result of electricity deregulation in California. As a way to roughly calibrate to the AEO results, the electricity price for California was reduced by $11 \%$ prior to the averaging process. For 2000 , this method yields a calculated price of $\$ 22.93$ per million Btu ( 7.8 cents per $\mathrm{kWh}$ ) versus the AEO estimate of $\$ 22.79$ for the Pacific census division. This adjustment reduces the relative difference between the Pacific North and Pacific South over the forecast horizon and is qualitatively consistent with trends that may result from further deregulation of electricity markets. (For the Mountain region, the difference between the calculated and published data was not large and no special adjustment was applied.)

The second step was to create an adjustment factor for each subcensus division. Thus, for example, the adjustment factor for Pacific North is 


$$
\frac{P(\text { PacificNorth })}{P(\text { Pacific })}=F(\text { PacificNorth })
$$

where P (Pacific North) and P (Pacific) are based on the 1995 State Energy Price and Expenditure Report (EIA 1998).

The results of these calculations generated the following adjustment factors:

$\begin{array}{ll}\text { Mountain North } & 0.91 \\ \text { Mountain South } & 1.14 \\ \text { Pacific North } & 0.62 \\ \text { Pacific South } & 1.17\end{array}$

For the projection period, the AEO projections are multiplied by the appropriate adjustment factor to generate the projected energy price for each subcensus division. Thus, continuing with the above example, the price for the Pacific North is equal to F (Pacific North) times the AEO projected price for the Pacific census division.

In essence, this procedure holds the relative differences between the subregions and the census divisions constant over the forecast horizon. Although the AEO suggests some narrowing of the electricity price differentials across the nine census divisions by 2020 , the screening analysis does not extend this phenomenon to the subcensus regions in the west.

Differentials among states with respect to natural gas are much smaller than they are for electricity. The screening analysis used the overall census division price for both the north and south subdivisions in the Mountain and Pacific divisions.

\section{B.5 References}

Barwig, F. E., D. B. Elliott, S. L. Freeman, M. Friedrich, A. Y. Gu, D. L. Hadley, M. A. Halverson, R. E. Jarnagin, S. Katipamula, L. A. Klevgard, J. D. Miller, R. G. Pratt, J. S. Schliesing, S. A. Shankle, S. Somasundaram, G. P. Sullivan, Z. T. Taylor, and D. W. Winiarski. 1996. Preliminary Findings: Analysis of Commercial Space-Conditioning and Storage Water-Heating Equipment Efficiencies. PNNL-1 1191, Pacific Northwest National Laboratory, Richland, Washington.

Energy Information Administration (EIA). 1992. 1992 Commercial Building Energy Consumption and Expenditures (CBECS), Public Use Data, Micro-data files on EIA website: $\mathrm{ftp} / / / \mathrm{ftp}$.eia.doe.gov/pub/consumption/commercial/micro.data/

Energy Information Administration (EIA). 1995. 1995 Commercial Building Energy Consumption and Expenditures (CBECS), Public Use Data, Micro-data files on EIA website: http://www.eia.doe.gov/emeu/cbecs/microdat.html 
Energy Information Administration (EIA). 1998. State Energy Price and Expenditure Report, 1995. DOE/EIA-0376(95). U. S. Department of Energy, Washington, D.C.

Energy Information Administration (EIA). 1999a. Annual Energy Outlook 2000. DOE/EIA-0383(2000), U.S. Government Printing Office, Washington, D.C.

Energy Information Administration (EIA). 1999b. Supplement Tables for the Annual Energy Outlook 2000, on EIA website: http://www.eia.doe.gov/oief/aeo/supplement/index.html, Tables 11-20. U.S. Department of Energy, Washington, D.C.

U.S. Department of Agriculture (USDA). 1993. Rural-Urban Continuous Codes, [CD-ROM database]. Available: USDA, Economic Research Service, Washington D.C. 


\section{Appendix C}

Screening Analysis Spreadsheet: User's Guide and Model Documentation 


\section{Appendix C}

\section{Screening Analysis Spreadsheet: User's Guide and Model Documentation}

\section{C.1 Introduction}

The screening analysis spreadsheet has been developed to assist the Department of Energy in assessing the benefits of setting efficiency standards for commercial space conditioning and water heating equipment. The spreadsheet was designed to estimate the energy savings and economic impacts of alternative efficiency levels for approximately 40 commercial space conditioning and water heating products covered by the Energy Policy Act of 1992 (EPACT, P.L. 102-486). The purpose of the analysis was to provide guidance as to which products may provide significant energy savings and economic benefits for efficiency levels that exceed those recently the ASHRAE Standard 90.1-1999 building standard.

\section{C.2 Key Objectives}

The development of screening analysis spreadsheet has been influenced by the following objectives:

1. Transparency. The principal reason for developing a spreadsheet-based methodology was to provide a reasonable level of transparency for estimating the economic and energy savings from a range of equipment efficiency levels. While spreadsheets can become very complex, they provide the best means to disseminate to a wide audience of interested parties the exact assumptions and data that produce a given set of numerical results. In the past several years, DOE has developed spreadsheets as part of the technical documentation of several appliance standards rulemakings.

2. Flexibility. The screening analysis was aimed toward a comparative analysis of products covered by EPACT. This phase of work may be followed by a more detailed analysis of products for which DOE may consider increasing efficiency levels beyond Standard 90.1-1999. A desirable feature of the model is the ability to use the same basic structure for both the screening analysis and subsequent more detailed analyses. To ensure flexibility, the spreadsheet includes features that allow it to automatically calculate savings for groups of products as well as providing the means to make indepth analyses of selected products.

3. User Efficiency. In an era of powerful personal computers, computational efficiency is no longer an issue for analyses of this nature. Even considering the market segmentation approach implemented in screening analysis methodology, the spreadsheet model is basically an elaborate accounting structure with many multiplication and addition instructions. Promotion of user efficiency, however, remains a 
goal of software of this type. Generally, this simply means automating the most common tasks that users may wish to perform. Some automation is included in the spreadsheet as a way of improving user efficiency, while still maintaining transparency.

\section{C.3 General Spreadsheet Structure and User's Guide}

This section covers two major topic areas. The first portion provides a general overview of how the various worksheets in the spreadsheet relate to each other. This will provide some key information to help the user navigate through the various worksheets. The second topic area discusses how the user can change key model parameters and execute the model.

\section{C.3.1 Overview of Data Flow through the Worksheets}

Figure C.1 presents the general linkages and data flow through the 18 worksheets currently making up the spreadsheet model. The direction of data flow is designated with arrows joining the worksheetsin spreadsheet parlance the lines with arrows between worksheets imply that cells in one worksheet refer to cells in another worksheet. Dashed lines denote that data is transferred via Visual Basic (VB) instructions (i.e., "macros") that perform the Copy and Paste Values functions in Excel.

The top two rows show the primary data inputs and assumptions that are used to calculate energy savings and net present value (NPV). In addition to these inputs, the equipment prices for selected discrete efficiency levels are in worksheet ProductData (shown at the right of row 3 ).

The two most important worksheets in the screening analysis spreadsheet are CurrentProduct and Calc_Savings. CurrentProduct assembles all data inputs that are specific to a single product. This includes the equipment capacity, equipment prices and efficiency levels, and total shipments. This worksheet can also be used to modify the matrices that define the distribution of equipment sales by building type and geographic region.

Calc_Savings performs all of the calculations to derive energy savings and NPV for each efficiency level. In broad terms this worksheet consists of three major sections. The section at the extreme left contains the main inputs and outputs, organized in the form of the product summary table. A middle section derives the distribution matrices that are used to weight the unit energy consumption by region and building type. The section at the right contains a series of arrays, with years shown horizontally and panels of values for each building type and region arranged vertically. These arrays are used to calculate unit energy consumption and life-cycle cost (LCC) for each market segment.

The bottom series of worksheets in Figure C.1 represent the key outputs from the model. ProdTable shows the one-page product summary table in the general format that was planned at the beginning of the screening analysis effort, a format that lays out the major input values and resulting energy savings and LCC/NPV measures. Supplemental information is shown below the table-investment performance and other measures as calculated from national average energy prices and unit consumption. ProdTable is created by copying (values only) the product summary table at the left of worksheet CurrentProduct. 


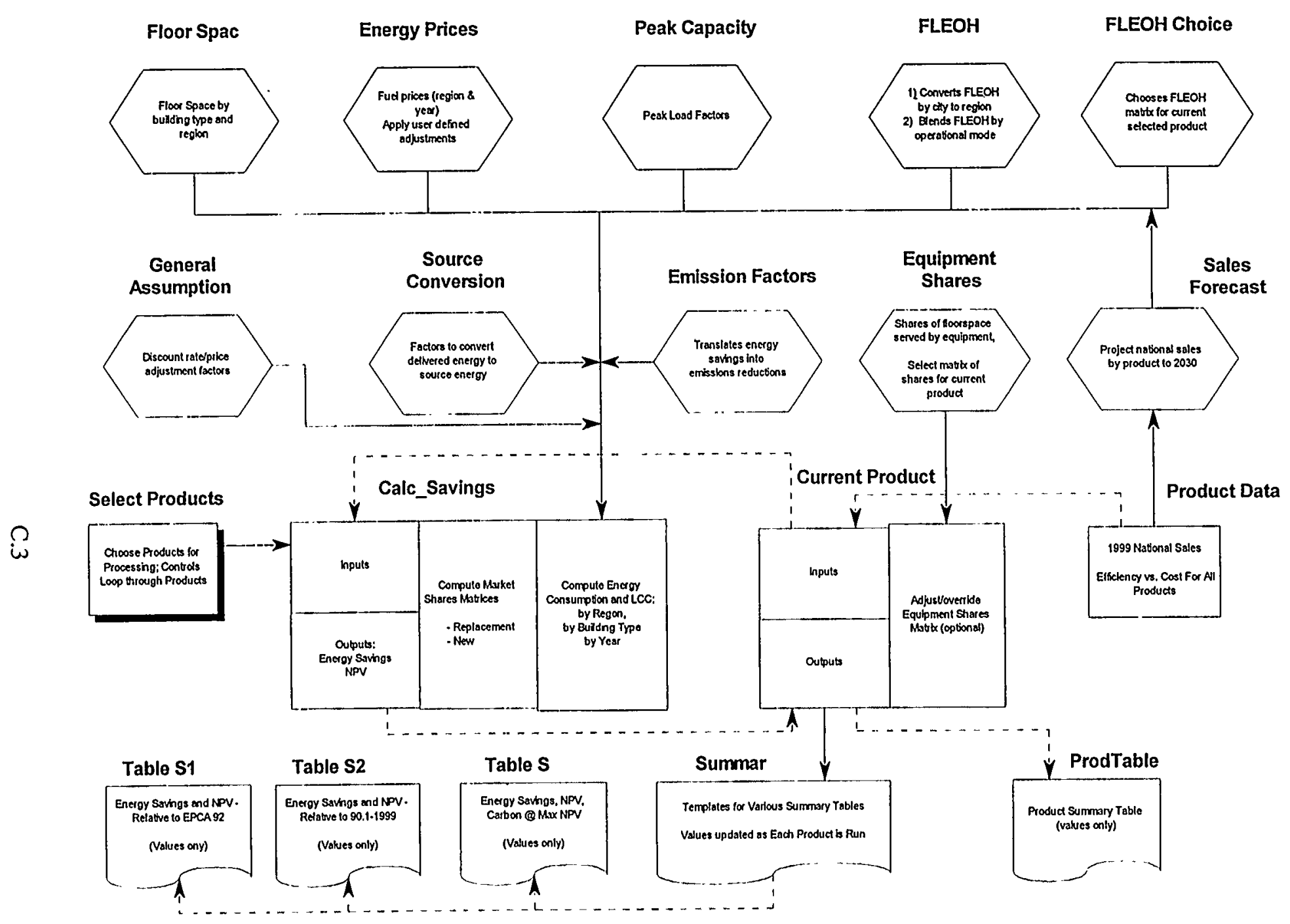

Figure C.1. Linkages and Data Flow Through the Worksheets in the Spreadsheet Model 
Worksheet Summary collects key results that are placed in a single row in several summary tables corresponding to the single product. On the left side of the worksheet, templates are defined for six summary tables.

Table S.1 shows the energy savings and NPV for the Standard 90.1-1999 efficiency level, the efficiency level with highest NPV, and the highest efficiency level with positive NPV (all measured against the levels of equipment cost and efficiency in the Energy Policy and Conservation Act (EPCA, P.L. 94-163). In addition to these particular efficiency levels, Table S.1 shows the estimated number of products shipped in 1999.

Table S.2 shows the efficiency rating, energy savings, and NPV for the ASHRAE Standard 90.1-1999 level and for up to four higher efficiency levels. Equipment cost data were not defined for all four levels for some products. The table nevertheless provides a convenient way to look at the results for all products and all of the efficiency levels considered by the screening analysis. The savings metrics in this table are evaluated with respect to the Standard 90.1-1999 level.

Table S.3 shows the energy savings, NPV, and carbon emissions reductions for the efficiency level with the maximum NPV relative to EPCA 1992 and Standard 90.1-1999. As example of the type of output shown in the summary tables, Table C.1 shows the results for heating equipment from the spreadsheet's generic Table S.3.

Tables S.4 through S.6 provide the basis for several of the tables shown in Section 3. Table S.4 displays national energy savings for all efficiency levels. Table S.5 displays LCC for all efficiency levels. Table S.6 shows the energy savings and carbon emissions for Standard 90.1-1999 and the efficiency levels corresponding to maximum NPV.

Table S.1, Table S.2, and Table S.3 are worksheets that are simply copies of the corresponding tables defined at the left side of the Summary worksheet. These worksheets consist of values only (no formulas) and can be conveniently copied to other spreadsheets for comparative analyses.

\section{C.3.2 Changing Key Parameters and Executing the Spreadsheet Model}

With reference to Figure C. 1 and the information provided in the previous section, the key procedures that the majority of users would likely wish to employ with the spreadsheet can be described. This section shows how to change key macro parameters (e.g., discount rate or equipment price markups) or individual equipment price and efficiency assumptions.

The most important general assumptions are contained in the Gen_Assumptions worksheet. In this worksheet the user can change the discount rate, the markup from contractor cost to installed cost, and other parameters that can be used to adjust energy prices from the Annual Energy Outlook.

The spreadsheet model can be used to process an individual product or a series of products with a single click. As used in the screening analysis, the capability of the model to automatically process a series of products was used extensively. In this mode, the model introduces equipment price and 
Table C.1. Heating Products Energy Savings and NPV for Efficiency Levels with Maximum NPV

\begin{tabular}{|c|c|c|c|c|c|c|c|c|c|c|}
\hline \multirow[b]{3}{*}{ Product } & \multicolumn{2}{|c|}{ EPCA 1992} & \multicolumn{3}{|c|}{ Standard 90.11999} & \multicolumn{5}{|c|}{$\begin{array}{l}\text { Efficiency with Maximum NPV } \\
\text { Relative to } 90.1-1999\end{array}$} \\
\hline & $\begin{array}{c}2004-2030 \\
\text { Baseline } \\
\text { Consumption }\end{array}$ & $\begin{array}{c}\text { Thermal } \\
\text { Efficiency }\end{array}$ & $\begin{array}{l}\text { Thermal } \\
\text { Efficiency }\end{array}$ & $\begin{array}{l}\text { Energy } \\
\text { Savings }\end{array}$ & $\begin{array}{c}\text { Carbon } \\
\text { Reduction }\end{array}$ & $\begin{array}{c}\text { Thermal } \\
\text { Efficiency }\end{array}$ & $\begin{array}{c}\text { Additional } \\
\text { Energy } \\
\text { Savings } \\
\end{array}$ & $\begin{array}{c}\text { Carbon } \\
\text { Reduction }\end{array}$ & NPV & IRR \\
\hline & (TBtu) & $(\%)$ & (\%) & (TBtu) & (MMtons) & $(\%)$ & (TBtu) & (MMtons) & (mill.98S) & $(\%)$ \\
\hline Package Boilers, Gas Fired $400 \mathrm{kBtu} / \mathrm{h}, \mathrm{HW}$ & 684 & 75 & 75 & 0.0 & 0.0 & 78 & 26.3 & 0.3 & $\$ 17.9$ & $13.2 \%$ \\
\hline Package Boilers, Gas Fired $800 \mathrm{kBtu} / \mathrm{h}, \mathrm{HW}$ & 1,493 & 75 & 75 & 0.0 & 0.0 & 78 & 57.4 & 0.8 & $\$ 42.5$ & $14.4 \%$ \\
\hline Package Boilers, Gas Fired $1,500 \mathrm{kBtu} / \mathrm{h}, \mathrm{HW}$ & 491 & 75 & 75 & 0.0 & 0.0 & 88 & 72.6 & 0.9 & $\$ 64.6$ & $17.8 \%$ \\
\hline Package Boilers, Gas Fired 3,000 kBtu/h, HW & 324 & 75 & 75 & 0.0 & 0.0 & 88 & 47.8 & 0.6 & $\$ 55.9$ & $30.0 \%$ \\
\hline Package Boilers, Gas Fired $400 \mathrm{kBtu} / \mathrm{h}$, Stcam & 320 & 72 & 75 & 12.8 & 0.2 & 76 & 4.0 & 0.1 & $\$ 1.6$ & $9.4 \%$ \\
\hline Package Boilers, Gas Fired $800 \mathrm{kBtu} / \mathrm{h}$, Steam & 875 & 72 & 75 & 35.0 & 0.5 & 76 & 11.1 & 0.1 & $\$ 8.9$ & $15.7 \%$ \\
\hline Package Boilers, Gas Fired 1,500 kBtu/h, Steam & 402 & 72 & 75 & 16.1 & 0.2 & 81 & 28.6 & 0.4 & $\$ 10.5$ & $9.0 \%$ \\
\hline Package Boilers, Gas Fired 3,000 kBtu/h, Steam & 256 & 72 & 72 & 0.0 & 0.0 & 82 & 31.2 & 0.4 & $\$ 30.8$ & $20.8 \%$ \\
\hline Warm Air Furnaces, Gas Fired $250 \mathrm{kBtu} / \mathrm{h}$ & 7,392 & 75.1 & 77.5 & 236.5 & 3.4 & 77.5 & 0.0 & 0.0 & $\$ 0.0$ & NA \\
\hline Warm Air Furnaces, Gas Fired $400 \mathrm{kBtu} / \mathrm{h}$ & 7,562 & 75.1 & 77.5 & 241.9 & 3.5 & 77.5 & 0.0 & 0.0 & $\$ 0.0$ & NA \\
\hline
\end{tabular}


efficiency data from the ProductData worksheet as each product is processed. In manual mode, the user can change price and efficiency assumptions or modify the matrices that define the distribution of product sales across market segments.

Automatic Mode. In this mode, the key worksheet is SelectProducts. To set up an analysis run, the user makes selections within the SelectProducts worksheet that will inform the model which equipment should be analyzed and what output is desired. After making the appropriate selections, the user clicks on the Run Selected Products button to initiate the analysis.

- Product Class Selection: At the top left portion of the worksheet, the user has a choice of selecting the class of products that will be analyzed. The choices are: 1) Space Cooling Equipment, 2) Space Heating Equipment, or 3) Water Heating Equipment. The user chooses one class of products by typing an " $x$ " in the appropriate cell to the right of the product class of interest. This will tell the model which equipment to place in the Product Description list. If a product class is not selected, the default class is cooling equipment. Only one product class can be analyzed at a time.

- Product Selection: Below the selection of the product class, the user will select the specific products within the product class that will be processed by placing an " $\mathrm{x}$ " next to the product description in the Product Description list.

- Save Product Tables in an Output File Selection: To the right of the product class selection area is a switch that will allow the user to save the results of the run to an output file. Selecting this option allows the user to save the product summary table as each product is run and then the summary tables after all products have been processed. These saved tables are put into separate worksheets in a new Excel spreadsheet. This option must be used when analyzing more than one product from the product description list if the user wants to review the individual product tables. This is because the ProdTable worksheet containing the information specific to each product is overwritten by each consecutive product in the run. When the user elects to save the results to an output file, the user will be prompted for a file name. The output file is created and the product and summary tables are transferred to the output file automatically.

Manual Mode. In manual mode, the user runs only a single product at a time. Here the user starts in the CurrentProduct worksheet. In the top row of the worksheet, the user can type the product code for the product to be processed in cell C2. Product codes can be found in the SelectProducts worksheet. By clicking on the Load Inputs button to right of the product code, the user can load the default efficiency and equipment price information (as stored in the ProductData worksheet). Because the equipment price and efficiency data are copied via a Visual Basic procedure, the specific data values can be modified without disturbing the default information. Processing for each of the efficiency levels is initiated by clicking the Calc Savings button at the top left comer of the worksheet. 


\section{C.4 Results for Example Product}

As mentioned above, the screening analysis spreadsheet model produces a summary page of results for each product. The top portion of this page is a high-level summary that presents LCC and energy savings, carbon reductions, and NPV for each efficiency level. The lower portion of the page shows supplementary information, with special emphasis on various measures of investment performance. This section explains the various input and output items included on the one-page summary and relates them to the methodology laid out in Sections 3 of the main report.

Figure C.2 shows the main results from the summary page for the high-capacity central airconditioning equipment $(\geq 135 \mathrm{kBtu} / \mathrm{h}$ and $<240 \mathrm{kBtu} / \mathrm{h})$. The top five items are straightforward. The equipment size is represented by output capacity-Btu/h that is transferred to the building space (or water in the case of water heaters). The estimated shipments for 1999 are shown for informational purposes only. The projected annual shipments between 2004 and 2030 drive the energy calculations. The cumulative total shipments are shown under the estimate for 1999.

\section{C.4.1 Inputs by Efficiency Level}

Most of the remainder of Figure C.2 is organized within seven columns, with each column representing a particular efficiency level. The first three columns are always linked to the same group of efficiency levels. Column 1 shows the EPCA 1992 efficiency and estimated equipment price. Column 2, labeled "Market Baseline," can be used to represent a higher average efficiency that may be more appropriate to the composition of shipments currently being installed. For the screening analysis, however, no formal attempt was made to collect such information. Accordingly, this value was set equal to the EPCA 1992 value for all products. The third column represents the efficiency level for Standard 90.1-1999.

The remaining columns show efficiency levels beyond Standard 90.1-1999 and vary by specific product. In only a few cases were sufficient data available to fill in all four efficiency levels beyond Standard 90.1-1999. Where appropriate, the labels on the top line give a rough indication of the source or rationale for the particular efficiency level.

The key inputs by efficiency are shown in the top two rows. The first row shows the efficiency rating (EER for AC/HP equipment, thermal efficiency (\%) for heating and water-heating equipment). The next row shows the standby loss in Btu/h for water-heating equipment. The standby loss is zero for other equipment (boilers have a standby loss, but it is incorporated in the thermal efficiency measure for the screening analysis).

The next two rows show the equipment prices, first excluding and then including the markup from the manufacturer to the final consumer. The equipment price markup percentage is shown in the top left corner of the table. 


\begin{tabular}{|c|c|c|c|c|c|c|c|}
\hline Product: & Central, Air Source A & $>=135,<240$ & & & & & \\
\hline Output Capacity (Btu/hr) & 180,000 & & & Estimated Shi & ments in 1999 & & 65,000 \\
\hline Lifetime (years) & 15 & & & Projected Ship & ments, 2004-2 & & $2,086,082$ \\
\hline Equip. Price Markup & $25 \%$ & & & & & & \\
\hline Efficiency Level $\longrightarrow$ & EPCA 1992 & $\begin{array}{l}\text { Market } \\
\text { Baseline }\end{array}$ & $\begin{array}{l}\text { Standard } \\
90.1-1999\end{array}$ & 90.1R Tier 2 & $\begin{array}{c}\text { ASHRAE } \\
\text { Tier } 1 \\
\text { Analysis }\end{array}$ & $\begin{array}{l}\text { Upgrade } \\
\text { Group }\end{array}$ & MaxTech \\
\hline EER & 8.5 & 8.5 & 9.7 & 10.2 & 10.4 & 10.8 & 11.5 \\
\hline Standby Loss (NA) & 0 & 0 & 0 & 0 & 0 & 0 & 0 \\
\hline Equip. Price (w/o markup) & $\$ 6,798$ & $\$ 6,798$ & $\$ 7,614$ & $\$ 7,886$ & $\$ 8,089$ & & \\
\hline Equip. Price (w/ markup) & $\$ 8,497$ & $\$ 8,497$ & $\$ 9,517$ & $\$ 9,857$ & $\$ 10,112$ & NA & NA \\
\hline Year of Standard & NA & NA & 2004 & 2004 & 2004 & 2004 & 2004 \\
\hline $\begin{array}{l}\text { LIFE CYCLE COST (LCC) } \\
\text { Savings relative to EPCA }\end{array}$ & $\begin{array}{l}\text { AVINGS, for } 2010 \\
92\end{array}$ & & & $1998 \mathrm{DO}$ & llars per Unit & & \\
\hline Weighted Average LCC & avings & & $\$ 1,431$ & $\$ 1,942$ & $\$ 2,005$ & NA & NA \\
\hline Max LCC Savings & & & $\$ 5,163$ & $\$ 6,970$ & $\$ 7,516$ & NA & NA \\
\hline Min LCC Savings & & & $-\$ 491$ & $-\$ 648$ & $-\$ 834$ & NA & NA \\
\hline Percentage of units witt & CC savings $>0$ & & $97.5 \%$ & $97.5 \%$ & $95.4 \%$ & $0.0 \%$ & $0.0 \%$ \\
\hline $\begin{array}{l}\text { NATIONAL ENERGY SAV } \\
\text { Relative to EPCA } 1992\end{array}$ & & & & Trillion & Btu (Primary) & & \\
\hline & & & 20.6 & 27.8 & 30.4 & 35.5 & 43.5 \\
\hline & & & 44.6 & 60.0 & 65.8 & 76.7 & 94.0 \\
\hline & & & 46.6 & 62.8 & 68.9 & 80.3 & 98.4 \\
\hline $2004-2030$ & & & 899.4 & $1,211.7$ & $1,328.2$ & $1,548.3$ & $1,896.6$ \\
\hline Relative to Standard 90. & 999 & & & & & & \\
\hline & & & & 7.2 & 9.8 & 14.9 & 22.8 \\
\hline & & & & 15.5 & 21.2 & 32.2 & 49.4 \\
\hline & & & & 16.2 & 22.2 & 33.7 & 51.7 \\
\hline $2004-2030$ & & & & 312.3 & 428.8 & 648.9 & 997.2 \\
\hline EMISSIONS REDUCTIONS & 2004-2030) & & & Million & Metric Tons & & \\
\hline Relative to EPCA 1992 & & & & & & & \\
\hline Carbon Equivaler & & & 13.2 & 17.8 & 19.5 & 22.8 & 27.9 \\
\hline NOx & & & 0.12 & 0.16 & 0.18 & 0.20 & 0.25 \\
\hline Relative to Standard 90. & 999 & & & & & & \\
\hline Carbon Equivaler & & & & 4.6 & 6.3 & 9.5 & 14.7 \\
\hline NOx & & & & 0.04 & 0.06 & 0.09 & 0.13 \\
\hline NET PRESENT VALUE (NPV & Discount Rate of & $7.0 \%$ & & Million & 1998 Dollars & & \\
\hline Relative to EPCA 1992 & & & $\$ 1,042.2$ & $\$ 1,414.4$ & $\$ 1,460.1$ & NA & NA \\
\hline Relative to Market Basel & & & & $\$ 372.2$ & $\$ 417.9$ & NA & NA \\
\hline $\begin{array}{l}\text { Adjust AEO Fuel Prices: } \\
\text { Report created: }\end{array}$ & $\begin{array}{l}\text { Multiplier: } \\
\text { 3/13/00 8:25 AM }\end{array}$ & 1.05 & Adder & (\$/kWh): & $\$ 0.000$ & & \\
\hline
\end{tabular}

Figure C.2. Product Summary Table (Main Results) for Large Central Air Conditioners

The final input row shows the year in which the standard is assumed to become effective. For the screening analysis, 2004 was chosen for all products and efficiency levels. The user of the spreadsheet model has the ability to modify the dates to reflect the additional time a full rulemaking or alternative approach might delay implementation of a new standard. 


\section{C.4.2 Outputs by Efficiency Level}

The remainder of the table shows the results of the analysis organized by efficiency level. The top four rows pertain to LCC savings on a per unit basis [as derived from Equations (3.8) and (3.10)]. Based upon the estimated distribution of shipments to the 77 market segments, the top row shows the weighted average LCC savings based on the projected energy prices for 2010 and subsequent years [per Equation (3.10)]. All savings are calculated relative to the EPCA 1992 efficiency level. For the example product, the $135-240 \mathrm{kBtu} / \mathrm{h}$ cooling unit, the average LCC savings increases from $\$ 1,431$ per unit to $\$ 2,005$ per unit.

The next two lines indicate the maximum LCC saving and minimum LCC saving across the 77 market segments. The variation in regional energy prices and climate typically lead to LCC savings in some segments that differ significantly from the weighted average. The last line of this section provides a measure of how pervasive the LCC savings are for higher efficiency levels. The "percentage of units with LCC savings $>0$ " is based on the sum of the market shares for segments that show positive savings relative to EPCA 1992. Although this metric was not used in the formal screening analysis, similar distributional measures have been incorporated in prior DOE analyses for residential appliances. For the high-capacity cooling unit, an EER of 10.4 would still yield LCC savings for an estimated $95.4 \%$ of total shipments, based upon energy prices for 2010 and subsequent years.

The next panel of outputs shows the estimates of national energy savings. Energy savings are computed relative to both the EPCA 1992 efficiency level and the Standard 90.1-1999 efficiency level. The results are shown for three specific years: 2010,2020, and 2030-as well as for a cumulative total from 2004 through 2030. The conversion to primary energy units is described in Section 3.2.

The emissions reductions shown in the next panel are related directly to the energy savings. As cited in Section 3.5, the factors to convert energy to emissions are taken from DOE's Office of Energy Efficiency and Renewable Energy (EERE) as part of the Government Performance and Reporting Act (GPRA) metrics program. As above, the emissions savings are shown relative to both EPCA 1992 and Standard 90.1-1999.

The last panel of outputs in this part of the table presents the estimates of national NPV. NPV is calculated as shown in Equation (3.13) in Section 3.2.4 and is calculated relative to both the EPCA 1992 and Standard 90.1-1999 baseline efficiency levels. As shown in the table, the NPV estimates were based upon a $7 \%$ real discount rate.

\section{C.4.3 Supplemental Results}

The supplemental results section of the product summary table, as shown in Figure C.3, is intended to provide more information to help evaluate and crosscheck the detailed results. The top panel of the supplemental results portion of the table relates to measures on a per unit basis. 


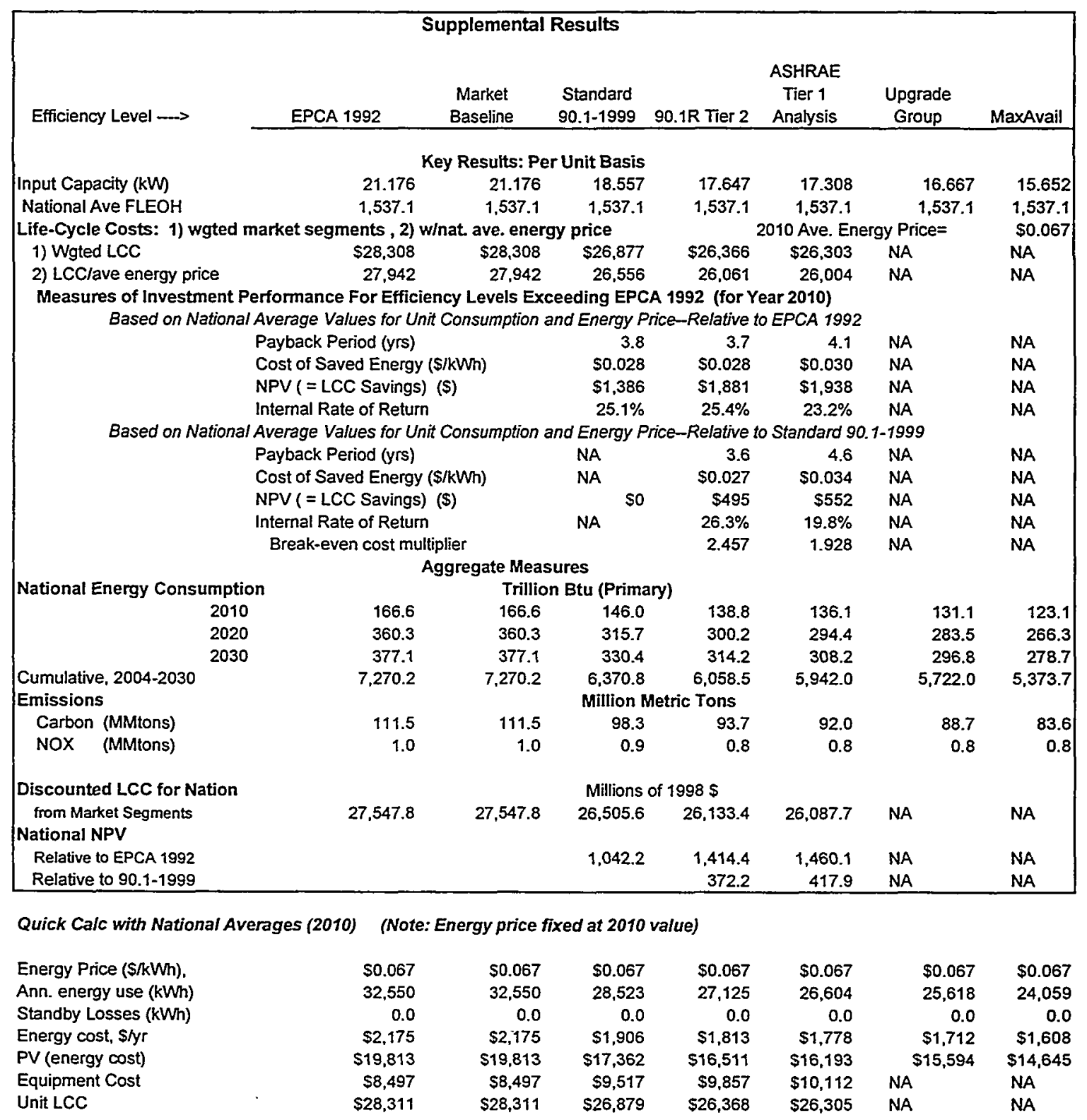

Figure C.3. Product Summary Table (Supplemental Results) for Large Central AC

The first two rows provide the two factors that yield unit energy consumption. The first row translates the output capacity and efficiency rating into the input capacity-expressed in $\mathrm{kW}$ or MMBtu/h. The second row shows the national average full-load equivalent operating hours (FLEOH Us $_{\text {). }}$ The product of these two factors provides an estimate of (national average) annual unit energy consumption. ${ }^{(a)}$

(a) For water heaters, the annual standby loss would need to be added to this result. See Equation (3.3). 
The next section of the table shows key economic variables on a per unit basis, again based upon the energy prices and other inputs for 2010. The national average energy price abutting the right margin of the table is taken from the 2000 Annual Energy Outlook (AEO) (EIA 1999a), but includes any adjustments requested by the user. As discussed in Section 3.2.1, a 5\% multiplier was applied to electricity prices for the screening analysis.

\section{Life-Cycle Cost}

Two sets (rows) of LCCs are displayed in the supplemental results. Both sets of LCC's are assumed to apply to units purchased in 2010 and include the effects of any energy price trends (from the AEO 2000 projection [EIA 1999a]) through the operating lifetime of the equipment. The first LCC ("LCC/wgted market segments") shows the national average LCC, weighted by the projected number of shipments to each market segment. Thus, it employs both FLEOH and energy price at the subcensus division in constructing the national average. The LCC's in the second set ("LCC/ave energy price") are assumed to apply to a single unit purchased in 2010 for which the national average energy price is paid. These two rows correspond to Equations (3.10) and (3.11), respectively, in the main portion of the report.

\section{Measures of Investment Performance}

The next section shows a series of measures of investment performance related to the increase in first cost and lower annual energy costs for each efficiency level. Again, these measures are calculated for the inputs for 2010 and thus include the small energy price trends in the AEO projections beyond that year. Two sets of measures are shown: 1) investment performance measured relative to the EPCA 1992 efficiency levels and related costs, and 2) investment performance relative to the Standard 90.1-1999 efficiency levels and related costs.

As discussed earlier, the NPV value shown in this section is equivalent to LCC savings on a unit basis. The NPV values in the supplemental results section of the table (relative to EPCA 1992) will not exactly match the unit LCC savings estimates shown at top of the table (in Figure C.2). The unit LCC savings at the top of the table are based upon weighting the LCC savings for individual market segments (as shown by Equation 3.10). In the supplemental results section, the NPV estimate is based upon a single unit evaluated with the national average energy price and with the national average FLEOH [as per Equation (3.11)].

As mentioned above, in addition to LCC and NPV, several other measures can be used to evaluate investments in increased energy efficiency of the equipment. The principal measures are 1) payback period, 2) cost of conserved energy, and 3) internal rate of return.

\section{Payback Period}

The simple payback period measures the amount of time required to recover the incremental equipment cost through lower operating costs. By using $\mathrm{k}$ to designate the efficiency level (where $\mathrm{k}=0$ represents the base cost), the equation for payback is 


$$
\operatorname{Payback}(k)=\frac{E q p \operatorname{Cost}(k)-E q p \operatorname{Cost}(0)}{O p \operatorname{Cost}(k)-O p \operatorname{Cost}(0)}
$$

Payback periods are expressed in years. Thus, a payback period of five years indicates that it takes five years of operating (energy cost) savings to equal the additional purchase cost of the equipment. The simple payback does not consider the foregone interest yield on the money used to pay the additional purchase cost. If the payback period is longer than the life of the product, the purchase price is never recovered in reduced operating expenses.

\section{Cost of Conserved Energy}

The cost of conserved energy (CCE) is the hypothetical price of energy that would make the LCC savings (or NPV) of the investment equal to zero. Based on Equation (3.7), CCE is calculated as the PFUEL that satisfies the equation:

$$
\mathrm{EQPCOST}+\sum_{\mathrm{t}=1}^{N} \frac{\text { Rated Capacity } \times \text { FLEOH } \times \text { PFUEL }}{(1+r)^{t} \times \text { Rated Efficiency } \mathrm{k}_{\mathrm{k}}}=0
$$

Based on an LCC criterion, an investment is cost effective if the CCE is less than the purchase price of energy. Thus, for example, an investment for which the CCE for electricity is less than 2 cents per $\mathrm{kWh}$ would be cost effective in nearly all regions of the United States. CCE is most often used in utility planning to compare the marginal cost of energy associated with building new generation capacity with that of investing in energy conservation measures.

\section{Internal Rate of Return}

The internal rate of return (IRR) approach measures the percentage yield on an investment. It uses the same cost elements as the LCC method, but differs in two ways: 1) in its unit of measure, a percentage rather than dollars, and 2) in the way the discounting is performed. The IRR approach solves the value of the discount rate that will equate discounted total benefits (reductions in operating costs) to the cost of the investment. This rate can be compared against a discount rate that represents the consumer's minimum acceptable rate of return. In the context here, the investment in increased efficiency is deemed cost effective if the IRR exceeds a prescribed discount rate.

The computation of the IRR is conceptually similar to the computation of the CCE. Again, beginning from Equation (3.7), the IRR is calculated as the discount rate $r$ that satisfies the following equation:

$$
\text { EQPCOST }+\sum_{t=1}^{N} \frac{\text { Rated Capacity } \times \text { FLEOH } \times \text { PFUEL } t}{(1+r)^{t} \times \text { Rated Efficiency } y_{k}}=0
$$

While all these measures have been used in various analyses of efficiency standards and other energy conservation programs, they have particular strengths and weakness with respect to comparing diverse 
types of energy-using equipment. Payback is appropriate to comparing alternative efficiency levels for a single product, but it fails to account for different equipment lifetimes between products. The payback measure sometimes does not reflect the comparative benefits of higher efficiencies for longer-lived equipment (e.g., boilers). The cost of conserved energy must be normalized to satisfactorily compare equipment using different fuels. For simple investments in which all investment cost is incurred at the outset (as is the case with the installation of higher efficiency equipment), the IRR provides a neutral measure that can be used to compare the relative value of alternative investments.

\section{Investment Performance for Example Product}

For the large air-conditioning equipment shown in Figure C.3, the simple payback at the maximum NPV level (efficiency level 4)-relative to the Standard 90.1-1999 level--is 4.6 years. The cost of conserved energy (electricity) is 3.4 cents, just over half the 2010 national average price of 6.7 cents. The IRR is computed to be $19.8 \%$.

\section{National Results}

The bottom of the supplemental results section shows the aggregate absolute values for energy consumption, emissions, and NPV. The various national energy and emissions savings measures are computed from these values.

The energy consumption numbers need to be carefully interpreted. They are based only on sales of equipment from 2004 and later. As such, the energy consumption estimate for 2010 is not an estimate based upon the total stock of equipment in place in that year. For most cooling equipment and water heaters, with lifetimes less than or equal to 15 years, the 2020 number may provide a reasonable estimate of national energy consumption. By 2020, all existing equipment would have been replaced and the entire stock would reflect the efficiency level shown at the top of that column in the table. With assumed lives of 30 years for boilers, even the 2030 value would fall somewhat short of yielding an appropriate measure of consumption for the stock of this equipment. The lack of incomplete turnover, however, is not an issue for selecting optimal efficiency levels because the screening analysis is only concerned with the differences in consumption levels for products shipped in 2004 and later years.

The second to last two rows ("Total LCC for Nation") provide a further diagnostic for the LCC calculations. In the row labeled "from market segments," total (discounted) LCC is computed as first summing the total LCC (unit LCC times units shipped) over the 77 market segments and then discounting the total back to the year 2000 .

The last two rows present the national NPV as calculated from two baselines-EPCA 1992 and Standard 90.1-1999. As described in Section 3.4.2, the national NPV is based upon the discounted LCC values aggregated from the market segments (as shown in the preceding line). Thus, for example, the NPV for efficiency level 4 relative to Standard $90.1-1999$ is equal to $\$ 26,088-\$ 25,506$ or $\$ 418$ million.

Below the boxed area for the supplemental is a short section entitled "Quick Calc.". This section illustrates the energy and first cost components that go into estimates of LCC. The LCC estimates here 
use the national average FLEOH and a constant 2010 price of energy. The second and third rows in this section show the annual unit energy consumption for the hours in which the unit is operating and for the hours the unit is idle (i.e., standby loss). The sum of the these entries times the (2010) energy price in row one yields the annual cost of energy, as shown in the fourth row. The next row shows the present value (PV) of the energy cost, computed by discounting the energy costs over the expected lifetime of the equipment. The sum of the present value of the energy cost and the (first) cost of the equipment is the LCC, as shown in the final row of the table. The LCC estimates developed in this section will differ slightly from those described in the supplemental results section because they employ a constant (2010) price of energy.

\section{C.5 Technical Documentation}

This section provides more detailed documentation of the screening analysis spreadsheet that may be useful to those who wish to change some of the other data inputs that influence the energy savings and NPV estimates. It is also designed to facilitate future efforts to incorporate additional features in the spreadsheet.

\section{C.5.1 Common Programming Methods}

Current Data. Many of the data inputs vary by the key attributes of the product. For example, heating product FLEOH are different from cooling product FLEOH. Fuel prices vary by product as well as the vectors used to convert site-based energy consumption into source or primary energy.

Variable names are used throughout the model to select the appropriate data inputs. Key variables that control the selection of data inputs are:

$$
\begin{array}{ll}
\text { product_code } & \text { abbreviated name for each product } \\
\text { product_class_code } & \text { cooling (1), heating (2), and water heating (3) } \\
\text { fuel_code } & \text { electricity (1), gas (2), fuel oil (3) }
\end{array}
$$

For most worksheets containing input data, the various data arrays are arranged vertically. For example, in the worksheet EnergyPrices, the arrays for electricity, natural gas, and fuel oil prices are arranged on top of each other, beginning at row 20. Depending upon the fuel code, the appropriate energy price data for the product being processed is moved to the top of the worksheet. This translation is accomplished using Excel's OFFSET function.

This same procedure is used in a number of worksheets. In general, the specific data that is related to the current product is moved to the top of the worksheet. In most cases, this area is labeled the "current" data set. This approach fixes the locations of cells from which the links between worksheets are built. It also makes it easy for the user to move between the various input worksheets and check the data being requested for a specific product.

Conditional Updating. Early in the development of the spreadsheet model, it became clear that storing all of the intermediate results for each efficiency level would yield an unmanageably large 
spreadsheet. Accordingly, the spreadsheet model extensively uses a programming method that might be termed "conditional updating." Essentially, it means that the spreadsheet cells holding final results are updated only when certain conditions are met. To illustrate, the product summary table in worksheet Calc_Savings has a column associated with each efficiency level. Most of the cells in this part of the worksheet have a formula similar to the following example:

$$
=\text { If(eff_level }=\mathrm{j}, \mathrm{d} 89=\mathrm{a} 89, \mathrm{~d} 89)
$$

This formula is placed in cell $\mathrm{d} 89$. A final value, which has been calculated elsewhere in the spreadsheet, resides in cell a89. If the efficiency level is equal to " $\mathrm{j}$ ", then cell d89 is replaced by the value in cell a89. Otherwise the value is not changed-i.e., the value in cell $\mathrm{d} 89$ is set equal to itself. This method makes it possible to build up a table of results in a step-wise fashion. The spreadsheet model updates cells using conditional updating for both the results table in Calc_Savings and the summary results in the Summary worksheet.

By using the conditional updating method, Excel thinks the model is making circular references and will periodically issue a warning to that effect. This warning can be easily removed by setting the model to an iterative calculation mode and specifying 10 iterations for its solution. This step can be performed manually by going into the ToolsiOptionslCalculation menu. The spreadsheet is set to this mode automatically when one or more products from the SelectProducts worksheet are analyzed for the first time.

\section{C.5.2 Worksheet Descriptions}

This section describes each of the worksheets in the spreadsheet model, in the order in which they are organized in the spreadsheet. Special Excel functions are identified and briefly explained.

\section{a) Gen_Assumptions}

This worksheet contains common assumptions applicable to all products, including discount rate, equipment price markup, and fuel price adjustments.

\section{b) SelectProducts}

This worksheet provides a list of products for which default input data are defined. It permits the savings calculation to be made for multiple products at a time, with the option of savings the results to a separate file. The worksheet is described in greater detail in Section C.3.2.

\section{c) Summary}

This worksheet generates three summary tables that list energy savings and NPV for all defined products. Columns $B$ through $A R$ contain the results of the conditional updates and the selection of maximum NPV that is performed in columns AS through CT. The worksheet is described in greater detail in section C.3.1. 


\section{d) CurrentProduct}

This worksheet defines the working area-accepting both input and output values-for a specific product. In automatic mode, the inputs required to generate energy savings and LCC/NPV are copied via Visual Basic code from worksheet ProductData. In manual mode, this same data can be copied by clicking the "Load Default Data" at the top of the worksheet. At this point, the user can edit any of the input values.

This worksheet also accepts inputs from EquipShares and Calc_Savings in columns $\mathrm{N}$ through $\mathrm{X}$. The user can either modify or override the matrix that defines the distribution of shipments by market segment. The user can override the default inputs by placing a "Y" in cell AR48 and supplying distribution inputs for calculations in columns $Z$ through AX. Distributions can be separately adjusted or chosen for replacement units in existing buildings or for new units.

After calculation of the energy savings and LCC/NPV results in worksheet Calc_Savings, the results are copied to the product summary table in this worksheet (via Visual Basic code). Thus, both the inputs and outputs for the product summary table are copied in from other parts of the spreadsheet. In automatic mode, the entire product summary table is copied to worksheet ProdTable before processing is started for the next product.

\section{e) Calc_Savings}

Calc_Savings contains the logic to calculate energy and LCC savings by market segment and then to aggregate the resuits to a national basis.

Table C. 4 shows the basic organization of worksheet Calc_Savings. Columns $C$ through $J$ contain a formatted product summary table, with equipment price and efficiency values at the top of the table and the resulting energy savings, LCC, and NPV metrics below. The equipment price and efficiency (input) assumptions are transferred into this worksheet via a copy values macro from worksheet CurrentProduct.

The spreadsheet processes seven different efficiency levels-the value of the efficiency level counter is shown in cell Al1. Looping through the efficiency level is controlled by a VB procedure (although the

Figure C.4. Data Organization in Worksheet Calc_Savings

\begin{tabular}{|c|c|c|c|}
\hline Column A & Columns C:J & Columns M: $\overline{\mathrm{BK}}$ & Columns BL:CQ \\
\hline \multirow{4}{*}{$\begin{array}{l}\text { Temporary } \\
\text { Results }\end{array}$} & $\begin{array}{l}\text { Product Summary } \\
\text { Table }\end{array}$ & $\begin{array}{l}\text { Data arrays to estimate } \\
\text { distribution matrix to weight } \\
\text { market segments }\end{array}$ & $\begin{array}{l}\text { Product shipments by year } \\
\text { FLEOH (weighted for } \\
\text { replacement } \& \text { new) }\end{array}$ \\
\hline & $\begin{array}{l}\text { Inputs (from } \\
\text { CurrentProduct) }\end{array}$ & & $\begin{array}{l}\text { Units installed by market segment } \\
\text { National Energy Consumption }\end{array}$ \\
\hline & $\begin{array}{l}\text { Outputs (transferred to } \\
\text { CurrentProduct) }\end{array}$ & & Unit Energy Consumption \\
\hline & $\begin{array}{l}\text { Change in life-cycle } \\
\text { cost by market segment }\end{array}$ & & $\begin{array}{l}\text { Life-cycle cost by market segment } \\
\text { Investment performance, re: } 2010\end{array}$ \\
\hline
\end{tabular}


user can actually change the value in cell Al1 and observe all of the intermediate results for that efficiency level). For each efficiency level, the hourly unit energy consumption is placed in a cell in column A (cell A59). This value is transferred to the rightmost section of the table to calculate annual unit energy consumption for each year. Annual consumption depends upon the number of FLEOH for that product. The FLEOH are linked to worksheet FLEOHChoice.

The rightmost section of the table aggregates the energy consumption by market segment to the national level and cumulates the energy consumption to the 2004-2030 time frame. The resulting values are transferred back to column A. Using the conditional updating method described in Section B.5.1 above, these values are then placed into the appropriate column associated with the chosen efficiency level.

The middle portion of Calc_Savings (columns $\mathrm{M}: \mathrm{BK}$ ) is almost entirely devoted to constructing matrices that are used to weight the annual consumption for each market segment. Separate matrices are constructed for both replacement and new portions of national shipments. More detailed documentation of the various arrays is contained in the upper left portion of this part of the worksheet. This part of worksheet does not vary as the model loops through the efficiency levels.

After efficiency level 7 has been processed, another VB procedure copies the results section of the product summary table in Calc_Savings back to the corresponding section of the product summary table in worksheet CurrentProduct. Thus, for a casual user, there is no need to examine the results in Calc_Savings.

\section{f) ProductData}

This worksheet stores default efficiency and cost data by product. Based upon the choice of product via the variable product_code, the appropriate input data for that product (capacity, lifetime, efficiency ratings, and equipment prices) are copied to a data input section within the worksheet, identical to the form shown of the top of the product summary table. In auto mode, VB code then copies these inputs from the top of ProductData worksheet to the top of the CurrentProduct worksheet.

The default product data are stored by rows starting in column AY. The leftmost portion of each row consists of the following entries: 1) product code name, product description (i.e., a more complete name), fuel type ( $E, G$, or O), equipment (output) capacity in Btu/hour, product lifetime, and 1999 estimated shipments. To the right of these values are six sets of four values. In each set the following entries are shown: 1) efficiency level name, 2) efficiency (EER or thermal efficiency), standby loss (Btu/h), and 4) contractor cost. The six sets are arranged in a consistent order beginning with EPCA 1992, Standard 90.1-1999, and then followed by four levels of increasing efficiency. (The "market baseline" efficiency shown in the product summary table was not specified as part of the default data.)

In the same manner as many of the worksheets, the data associated with the current product or set of products is moved to the top of the spreadsheet. For the ProductData worksheet, all data associated with the current product class (i.e., cooling equipment, heating equipment, or water heating equipment) is moved as an array beginning in row 8 (and column AY). This choice is controlled by the named variable 
product_class_code. This variable is changed by means of the user putting an " $x$ " for the desired set of products in worksheet SelectProducts (the variable itself is contained in cell N4 of that worksheet). As stated earlier in Section C.5.1, the product class codes are simply: cooling products $=1$, heating products $=2$, and water heating products $=3$. The available data sets in ProductData are identified in terms of product class codes that appear in column AW. A MATCH function in cell AW3 indicates the starting row in the overall named array (product_data_input-contains data for all of the default data sets) for which the requested data reside. Several alternative default sets of data are included in the named array product_data_input, but they will not be used unless the first row (in column AW) is changed to 1, 2, or 3 .

The currently selected matrix of input data for the chosen product class is translated to a location to the left-the upper left entry in cell AY8 is linked to cell O16. Using a VLOOKUP function, the information for the specific product is then transferred to row 10. Thus, the data for the current product ends up in a row vector, O10:AJ10.

\section{g) SalesForecasts}

This worksheet extrapolates estimates of national shipments for all products, including estimated share that are replacement vs. new. The model applies simple growth rates to the estimates of 1999 shipments from worksheet ProductData.

The base year (1999) shipments from ProductData are highlighted in dark green in column G, beginning in row 13. To the right are the extrapolated values for 2000, 2005, 2010, 2020, and 2020. At the top of this section are the user-defined growth rates between each pair of the these years. The growth rates are in the vector defined in range H8:G8.

To the right of this section are the values for all years 2000 through 2030 (columns $\mathrm{N}$ through AS). The values for the "non-even" years (i.e., 2013) are obtained by simple linear interpolation. At the top of this section are three rows (4,5, and 6$)$ that give total shipments, replacement shipments, and shipments to new buildings for the product currently being analyzed.

The split between replacement and new shipments is based upon a user-specified value for each product. These values are placed in column $\mathrm{F}$ and are highlighted in light green to denote their nature as user-specified assumptions.

\section{h) FloorSpace}

This worksheet computes the distributions of commercial building floor space by (modified) census division and building type. Two arrays at the top of the spreadsheet are highlighted in green to denote input values. In the array G7:M18 are the AEO 1999 projections of floor space (in millions of square feet) by (modified) census division for 2004. In the array to the right (cells T7:Z17) are the projections of floor space additions, summed over the period 2011-2020. The initial source of these values was a special run of the National Energy Modeling System (NEMS) that modified the commercial module to output the commercial floor space stock and additions for all years. These values were subsequently adjusted for several building types as described in Appendix B. 
Distributions showing the percentage of floor space by region for each building type are shown in the rows immediately below the two input arrays. These arrays help to show the extent of regional shifts in construction, suggested by the differences between the 2004 stock values and the values associated with projected construction between 2011 and 2020.

The final set of rows (41 through 52) show the distributions normalized such that the sum of all entries equals 1000 (square feet). These arrays are used in the Calc_Savings worksheet as in input to the estimated distribution of national shipments for each product.

\section{i) EquipShares}

Worksheet EquipShares contains logic to select the appropriate equipment shares matrix for the product that the spreadsheet is currently processing. The elements of the equipment shares matrices are estimates of the fractions of floor space served by a particular type of equipment.

The structure of EquipShares is very similar to the structure of worksheet FLEOH_choice. Column B contains a list of products (code names) covered in the screening analysis. To the right of each entry in column $\mathrm{B}$ is the name of the FLEOH matrix that is to be used in the analysis for that product. Generic matrices are used for the cooling and heating products, primarily based upon information from the 1995 CBECS. For water heating products, a separate FLEOH matrix was developed for each product.

The equipment shares matrices are organized in a stacked fashion in columns $\mathrm{H}$ through $\mathrm{Q}$. The matrix associated with the current product is brought to the top of the spreadsheet (in the same columns), using the logic described in the first part of Section C.4.1. The current product code is shown in cell B6 while the name of the selected equipment shares matrix is shown is cell $\mathrm{C} 6$. The names of the available matrices are in column $\mathrm{F}$, aligned with the first row of each equipment shares matrix.

The general source of the equipment shares matrices in this worksheet is from the 1995 CBECS (EIA 1995). These matrices are developed in a separate worksheet (cbecsequip.xls). There are no other externally supplied data to the worksheet.

The user has the ability to alter the selection of the equipment shares associated with any specific product by simply altering the name of the matrix in column B. Currently, the named arrays would have to be modified to permit additional choices of equipment shares arrays. The user, however, can modify the selected equipment shares matrix within worksheet CurrentProduct.

\section{j) FLEOH}

Worksheet FLEOH contains the FLEOH for particular types of load (cooling, heating, water heating). The worksheet starts with city by building type FLEOH from the BLAST building energy simulations for cooling and heating; these values are placed in columns $\mathrm{C}$ through $\mathrm{M}$. They are then multiplied by aggregated weights for climate regions (from Barwig et al. 1996) which are located in the columns immediately to the right. The resulting matrix products are shown in columns AC through AM. 
In columns AP through AW normalizing multipliers for economizer and setback use from 1995 CBECS are shown, which are applied to the cooling and heating FLEOH in columns AZ through BG. The sum of the normalized cooling, boiler, and furnace FLEOH appear in columns BJ through BR. For cooling and heating products, with the exception of boilers, the final FLEOH appear in teal colored matrices in columns BJ through BR. A final multiplier to adjust for boiler standby loss is applied o the boiler FLEOH with the resulting matrix a teal colored table in the array CD69:CL84. The final teal colored matrices are linked (as inputs to) worksheet FLEOH_Choice.

\section{k) FLEOH_Choice}

Worksheet FLEOH_Choice contains logic to select the appropriate FLEOH matrix for the product that the spreadsheet is currently processing. Column B contains a list of products (code names) covered in the screening analysis. To the right of each entry in column $B$ is the name of the FLEOH matrix that is to be used in the analysis for that product. Generic matrices are used for the cooling and heating products. For water heating products, a separate FLEOH matrix was developed for each product.

The FLEOH matrices are organized in a stacked fashion in columns $\mathrm{H}$ through $\mathrm{Q}$. The matrix associated with the current product is brought to the top of the spreadsheet (in the same columns), using the logic described in the first part of Section C.4.1. The current product code is shown in cell B6 while the name of the selected FLEOH matrix is shown is cell C6. The names of the available matrices are in column $F$, aligned with the first row of each FLEOH matrix.

The source of the FLEOH matrices in this worksheet is from the worksheet FLEOH. There is no other externally supplied data to the worksheet.

The user has the ability to alter the selection of the FLEOH associated with any specific product by simply altering the name of the matrix in column B. Currently, the named arrays would have to be modified to permit additional choices of FLEOH arrays.

\section{l) Peak_Cap}

Peak Load Intensities $\left(\mathrm{kBtu} / \mathrm{h}-\mathrm{ft}^{2}\right)$ that influence the number of sales in each market segment. [These values were not used in the screening analysis-in this worksheet they are all set equal to 1.0.]

\section{m) EnergyPrices}

The EnergyPrices worksheet selects an array of either electricity or gas prices depending upon the product. The energy price arrays from this worksheet are organized by (modified) census division and for years 2000 through 2060 . The years 2031 through 2060 are needed to compute LCC for boilers, whose lifetimes are set at 30 years. 
Energy prices by census division from 2000 through 2020 are taken directly from the Annual Energy Outlook 2000 (EIA 1999b). The prices from the AEO are expressed in $98 \$$ per million Btu and are highlighted in green.

Above each set of prices (electricity, gas, distillate) from the AEO is an array that converts the prices to more natural units (cents/kWh for electricity) as well as making estimates of prices for the break-out north and south regions of the Mountain and Pacific census regions. Moreover, any user-requested multiplicative or additive adjustment factor is applied.

The named variable fuel_prices, set at the top of worksheet CurrentProduct, is used to select the appropriate array of fuel prices and move them to the top of worksheet EnergyPrices. The moving of the requested array is accomplished by means of an OFFSET function in each cell in the current set of energy prices.

\section{n) SourceConversion}

The SourceConversion worksheet selects the appropriate vector of factors to convert delivered energy to primary energy for each fuel. The worksheet is adapted from a similar one used in the National Energy Savings spreadsheet for residential water heater standards. For electricity, conversion factors are calculated from the projections of delivered and primary energy in the AEO 2000-for years 1998, 2005, 2010,2015 , and 2020 (EIA 1999a). The projected energy consumption values from the AEO are highlighted in green in columns $\mathrm{D}$ and $\mathrm{E}$ in the upper left hand portion of the table. In column $\mathrm{C}$, the values are interpolated for intervening years.

The conversion factors are transposed to rows to the right of the spreadsheet. The selection of which row is actually used in the calculation is made with a CHOOSE function in row 6.

\section{o) Emissions Factors}

This worksheet translates energy consumption by fuel into estimates in environmental emissions. The primary input data is a set of projected emissions conversion factors by year (MMtons per trillion Btu of delivered energy) taken from an access database used in the Building Energy Savings Estimation Tool (BESET) developed by PNNL for the Office of Building Technologies, State and Community Programs as part of the GPRA metrics program. These values were originally provided by the Office of Energy Efficiency and Renewable Energy (EERE) of the U.S. Department of Energy (see Section 3.3.4 for further details [DOE 1999]). These input values are shown in bright green to denote they come from an external source.

In worksheet EmissionsFactors, the emissions for factors for carbon and $\mathrm{NO}_{\mathrm{x}}$, for three fuelselectricity, natural gas, and oil-are transposed to rows beginning in column $X$. These six rows of data are shown in rows 15 through 20 in this portion of the worksheet. In rows 8 through 13, a multiplicative adjustment is made to the emissions factors for natural gas and oil. This adjustment ensures that the total emissions savings are appropriate to the total (primary) energy savings for these fuels (as calculated in Calc_Savings). Following the same procedure as the energy conversion factors, a CHOOSE function is 
used to select the pair of emissions factors (carbon, $\mathrm{NO}_{\mathrm{x}}$ ) corresponding to the fuel for the current product. The selected pair of rows is copied to rows 4 and 5 at the top of the worksheet.

\section{p) ProdTable}

ProdTable contains a copy of the product summary table that is generated in sheet CurrentProduct. This worksheet can be copied to a user file for storage of results either manually, or by selecting the "Save product tables in an output file?" option in the SelectProducts worksheet prior to initiating the analysis.

\section{C.6 References}

Barwig, F. E., D. B. Elliott, S. L. Freeman, M. Friedrich, A. Y. Gu, D. L. Hadley, M. A. Halverson, R. E. Jarnagin, S. Katipamula, L. A. Klevgard, J. D. Miller, R. G. Pratt, J. S. Schliesing, S. A. Shankle, S. Somasundaram, G. P. Sullivan, Z. T. Taylor, and D. W. Winiarski. 1996. Preliminary Findings: Analysis of Commercial Space-Conditioning and Storage Water-Heating Equipment Efficiencies. PNNL-11191, Pacific Northwest National Laboratory, Richland, Washington.

Energy Information Administration (EIA). 1995. 1995 Commercial Building Energy Consumption and Expenditures (CBECS), Public Use Data, Micro-data files on EIA website: http://www.eia.doe.gov/emeu/cbecs/microdat.html

Energy Information Administration (EIA). 1999a. Annual Energy Outlook 2000. DOE/EIA-0383(2000), U.S. Government Printing Office, Washington, D.C.

Energy Information Administration (EIA). 1999b. Supplement Tables for the Annual Energy Outlook 2000, on EIA website: http:/www.eia.doe.gov/oief/aeo/supplement/index.html, Tables 11-20. U.S. Department of Energy, Washington, D.C.

Energy Policy Act of 1992 (EPACT). Public Law 102-486, 1096 Stat 2776.

Energy Policy and Conservation Act (EPCA). 42 USC 62901, et seq.

U.S. Department of Energy (DOE). 1999. GPRA Data Call, Fiscal Year 2001. U.S. Government Printing Office, Washington, D.C. 
Appendix D

Summary Results for all Products Analyzed 
Appendix D

D Summary Results for all Products Analyzed 


\section{Product Description}

3-Phase Single Package, Air Source AC, $<65 \mathrm{kBtu} / \mathrm{h}$ 3-Phase Single Package, Air Source HP, $<65 \mathrm{kBtu} / \mathrm{h}$ 3-Phase Split, Air Source AC, $<65 \mathrm{kBtu} / \mathrm{h}$ 3-Phase Split, Air Source HP, $<65 \mathrm{kBtu} / \mathrm{h}$ Central, Air Source AC, $>=65,<135 \mathrm{kBtu} / \mathrm{h}$ Central, Air Source HP, > $=65,<135 \mathrm{kBtu} / \mathrm{h}$ Central, Water Cooled AC, $<65 \mathrm{kBtu} / \mathrm{h}$ Central, Water Source HP, $<17 \mathrm{kBtu} / \mathrm{h}$ Central, Water Source HP, $>17,<65 \mathrm{kBtu} / \mathrm{h}$ Central, Water Cooled AC, $>=65,<135 \mathrm{kBtu} / \mathrm{h}$ Central, Water Source HP, $>=65,<135 \mathrm{kBtu} / \mathrm{h}$ Central, Air Source AC, $>=135,<240 \mathrm{kBtu} / \mathrm{h}$ Central, Air Source HP, $>=135,<240 \mathrm{kBtu} / \mathrm{h}$ Central, Water Cooled AC, $>=135,<240 \mathrm{kBtu} / \mathrm{h}$ Packaged Terminal AC, $<7 \mathrm{kBtu} / \mathrm{h}$ Packaged Terminal AC, 7-10 kBtu/h Packaged Terminal AC, 10-13 kBtu/h Packaged Terminal AC, $>13 \mathrm{kBtu} / \mathrm{h}$ Packaged Terminal HP, $<7 \mathrm{kBtu} / \mathrm{h}$ Packaged Terminal HP, 7-10 kBtu/h Packaged Terminal HP, 10-13 kBtu/h Packaged Terminal HP, $>13 \mathrm{kBtu} / \mathrm{h}$ Pkg'd Boilers, Gas, $400 \mathrm{kBtu} / \mathrm{h}, \mathrm{HW}$ Pkg'd Boilers, Gas, 800 kBtu/h, HW Pkg'd Boilers, Gas, 1500 kBtu/h, HW Pkg'd Boilers, Gas, 3000 kBtu/h, HW Pkg'd Boilers, Gas, $400 \mathrm{kBtu} / \mathrm{h}$, Steam Pkg'd Boilers, Gas, 800 kBtu/h, Steam Pkg'd Boilers, Gas, 1500 kBtu/h, Steam Pkg'd Boilers, Gas, 3000 kBtu/h, Steam Warm Air Furnaces, Gas, $250 \mathrm{kBtu} / \mathrm{h}$ Warm Air Furnaces, Gas, $400 \mathrm{kBtu} / \mathrm{h}$ Storage Water Heater, Gas, $120 \mathrm{kBtu} / \mathrm{h}$ Storage Water Heater, Gas, $199 \mathrm{kBtu} / \mathrm{h}$ Storage Water Heater, Gas, $360 \mathrm{kBtu} / \mathrm{h}$ Instantaneous Water Heater, Gas, $400 \mathrm{kBtu} / \mathrm{h}$ Instantaneous Water Heater, Gas, $1000 \mathrm{kBtu} / \mathrm{h}$ Instantaneous Tank Type Wtr Htr, Gas, 500 kBtu/h Electric (120 gal)

\section{Page Number}
$D-3 \& D-4$
$D-5 \& D-6$
$D-7 \& D-8$
D-9 \& D-10
$D-11 \& D-12$
$D-13 \& D-14$
$D-15 \& D-16$
$\mathrm{D}-17 \& \mathrm{D}-18$
$D-19 \& D-20$
$D-21 \& D-22$
$D-23 \& D-24$
D-25 \& D-26
$\mathrm{D}-27 \& \mathrm{D}-28$
D-29 \& D-30
$D-31 \& D-32$
D-33 \& D-34
D-35 \& D-36
D-37 \& D-38
D-39 \& D-40
$D-41 \& D-42$
$D-43 \& D-44$
$D-45$ \& D-46
$D-47 \& D-48$
D-49 \& D-50
$D-51$ \& D-52
D-53 \& D-54
D-55 \& D-56
D-57 \& D-58
D-59 \& D-60
D-61 \& D-62
D-63 \& D-64
D-65 \& D-66
D-67 \& D-68
D-69 \& D-70
D-71 \& D-72
D-73 \& D-74
D-75 \& D-76
D-77 \& D-78
D-79 \& D-80 


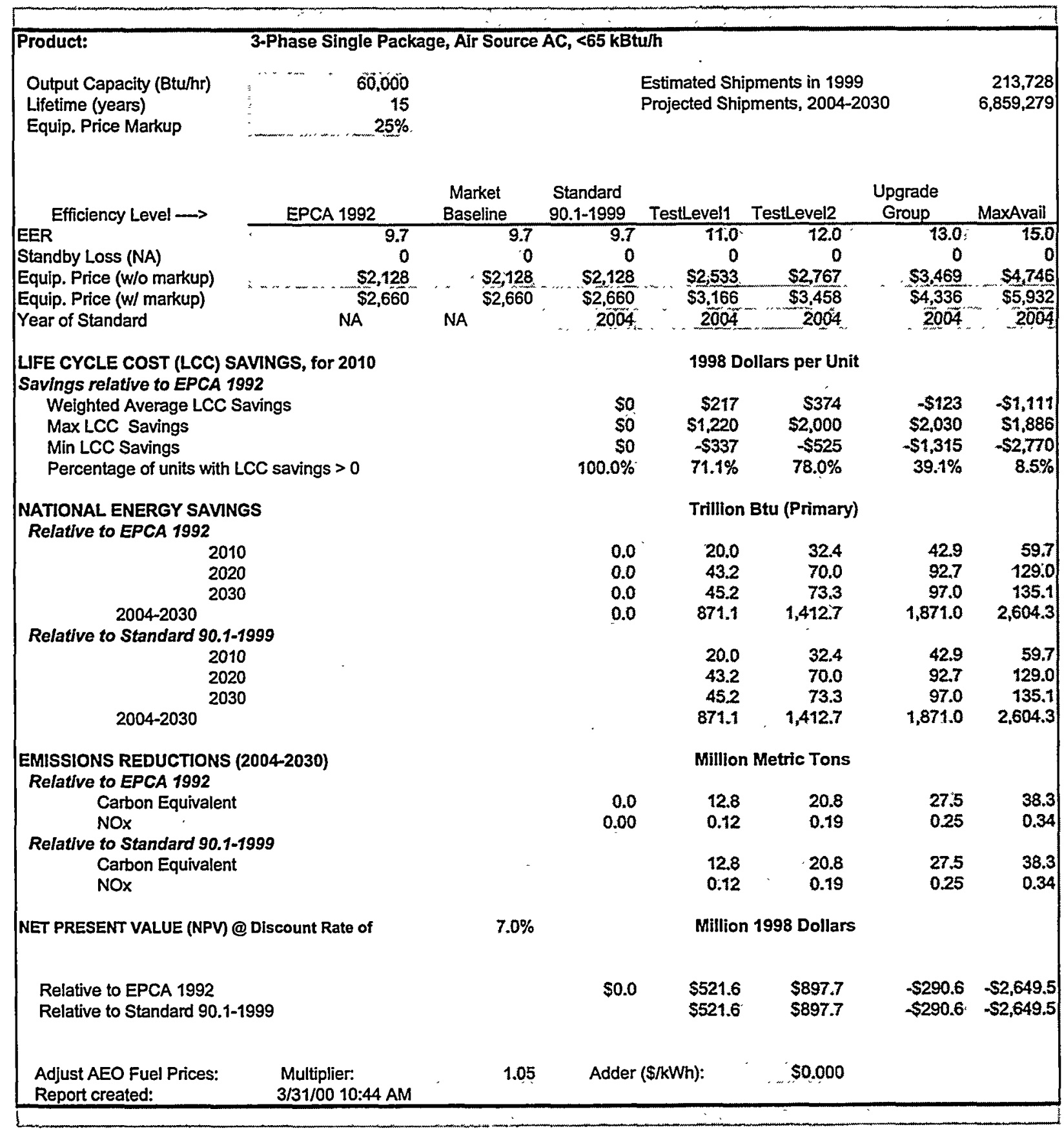




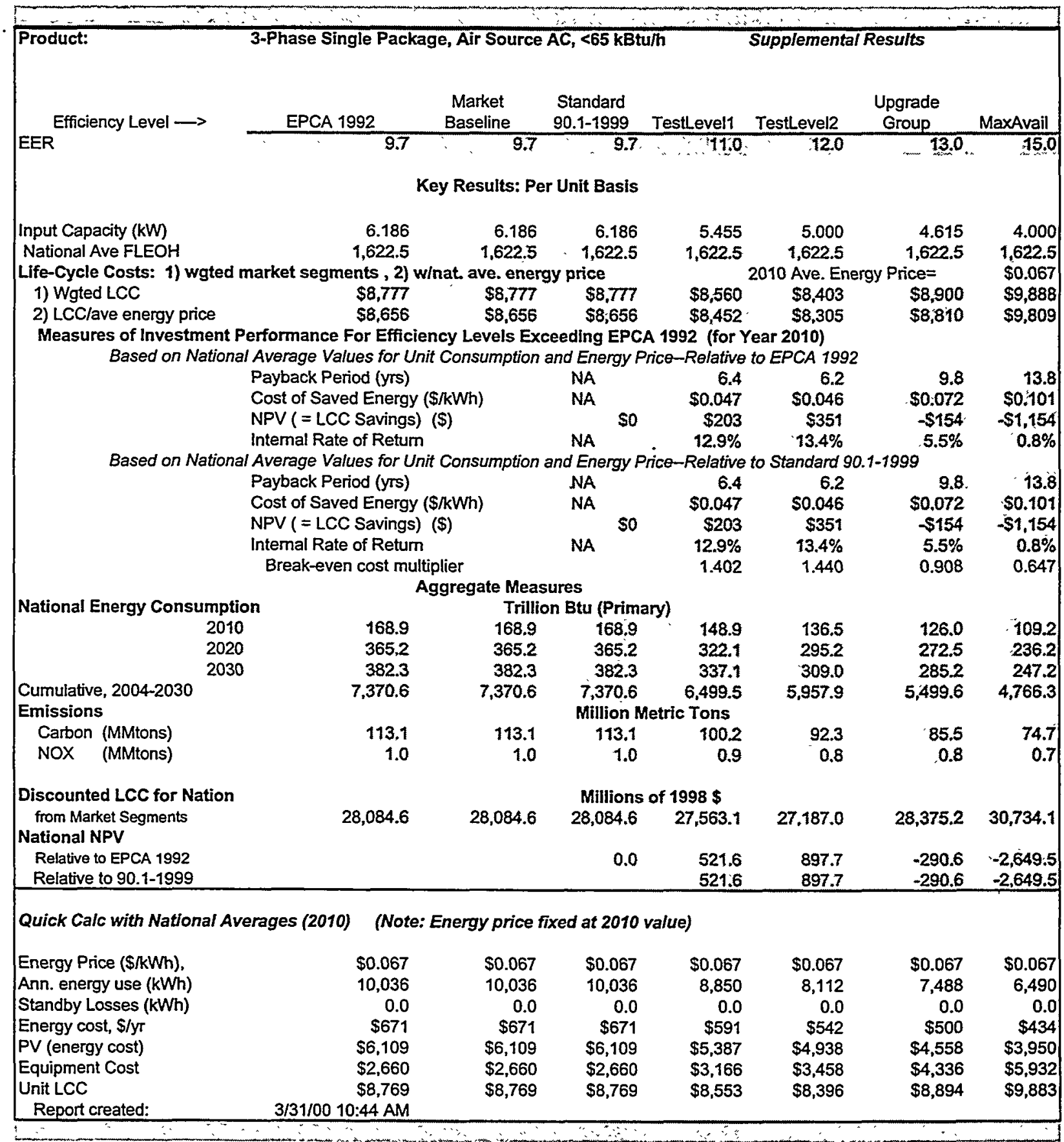




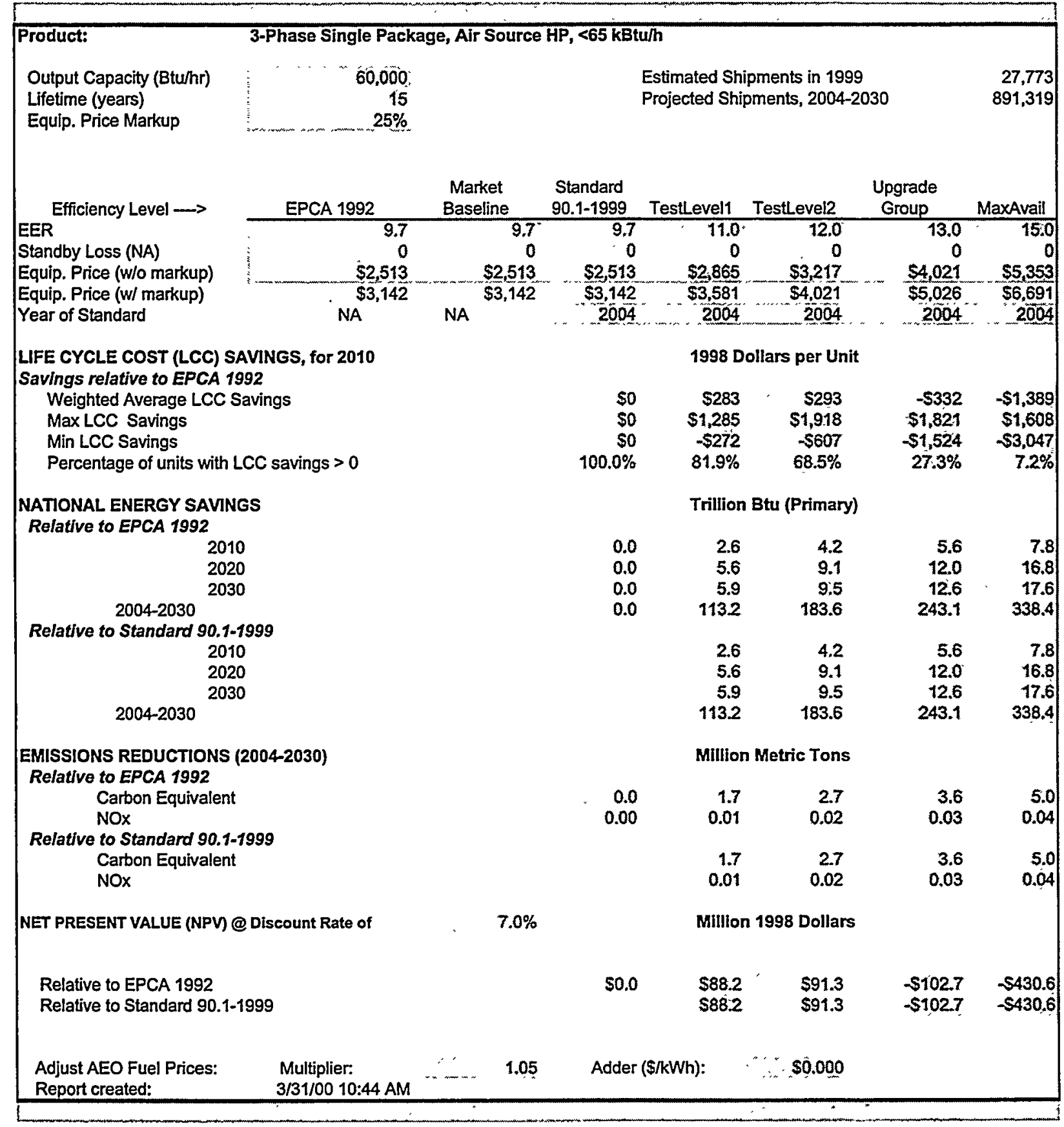




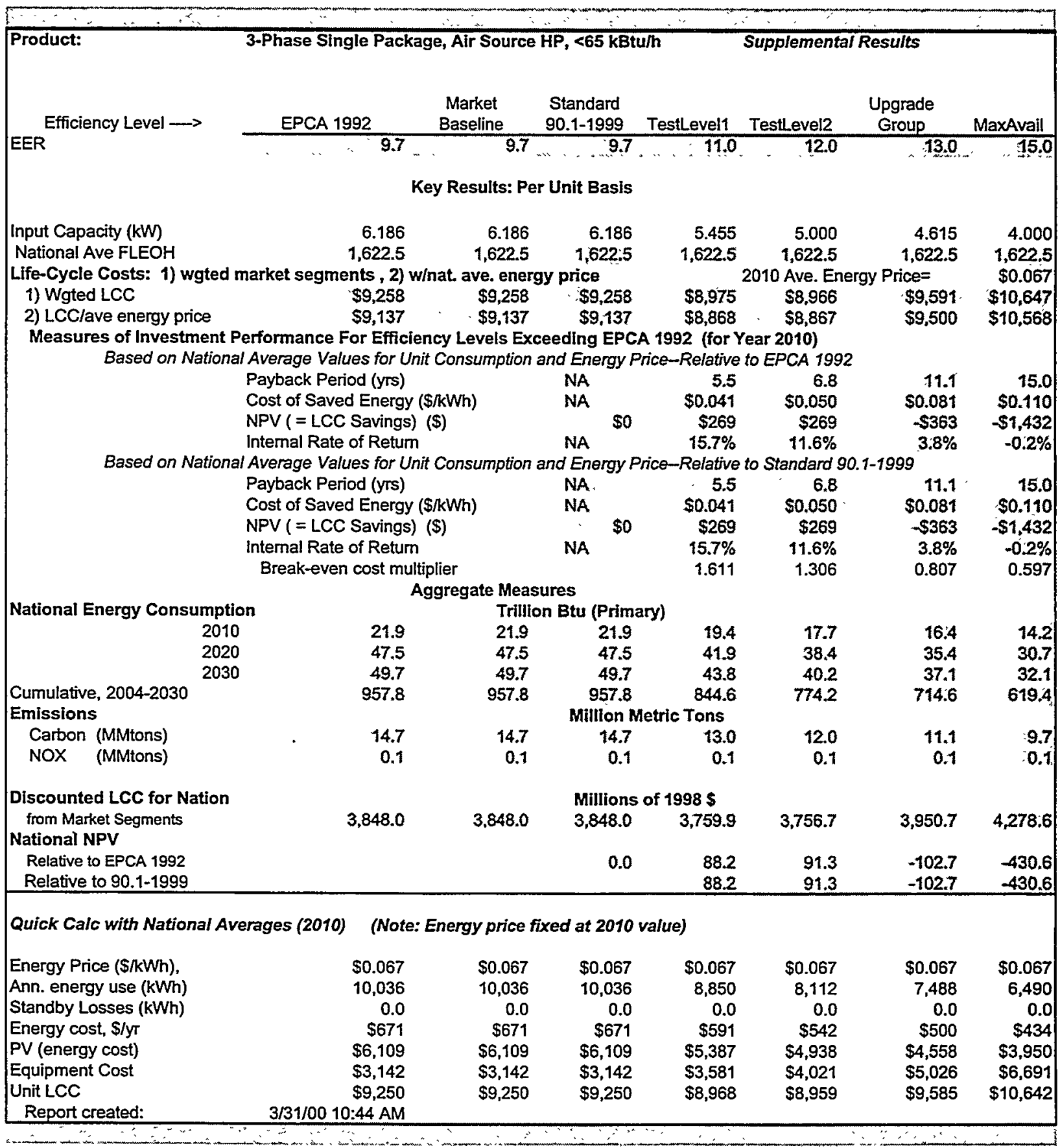




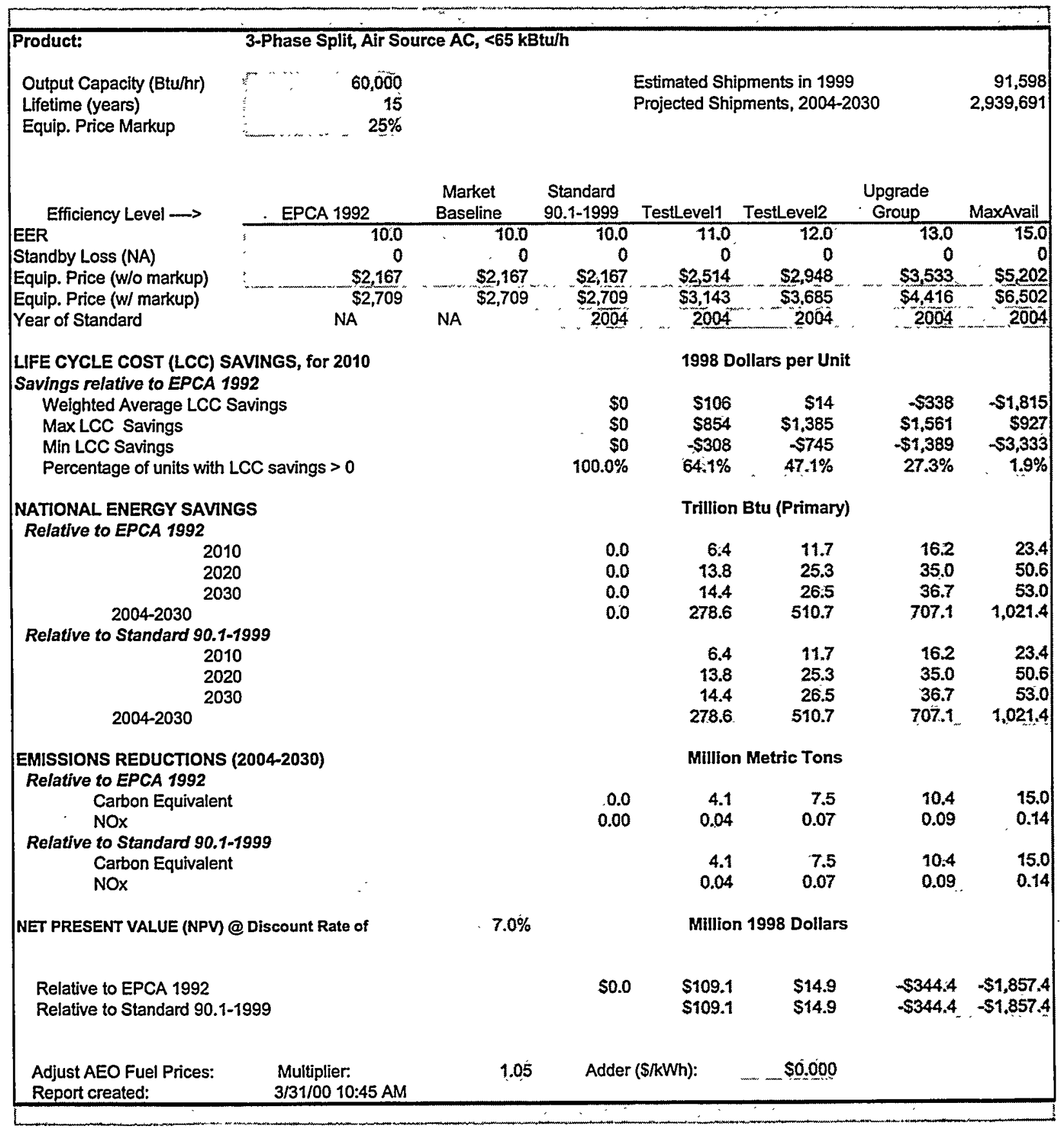




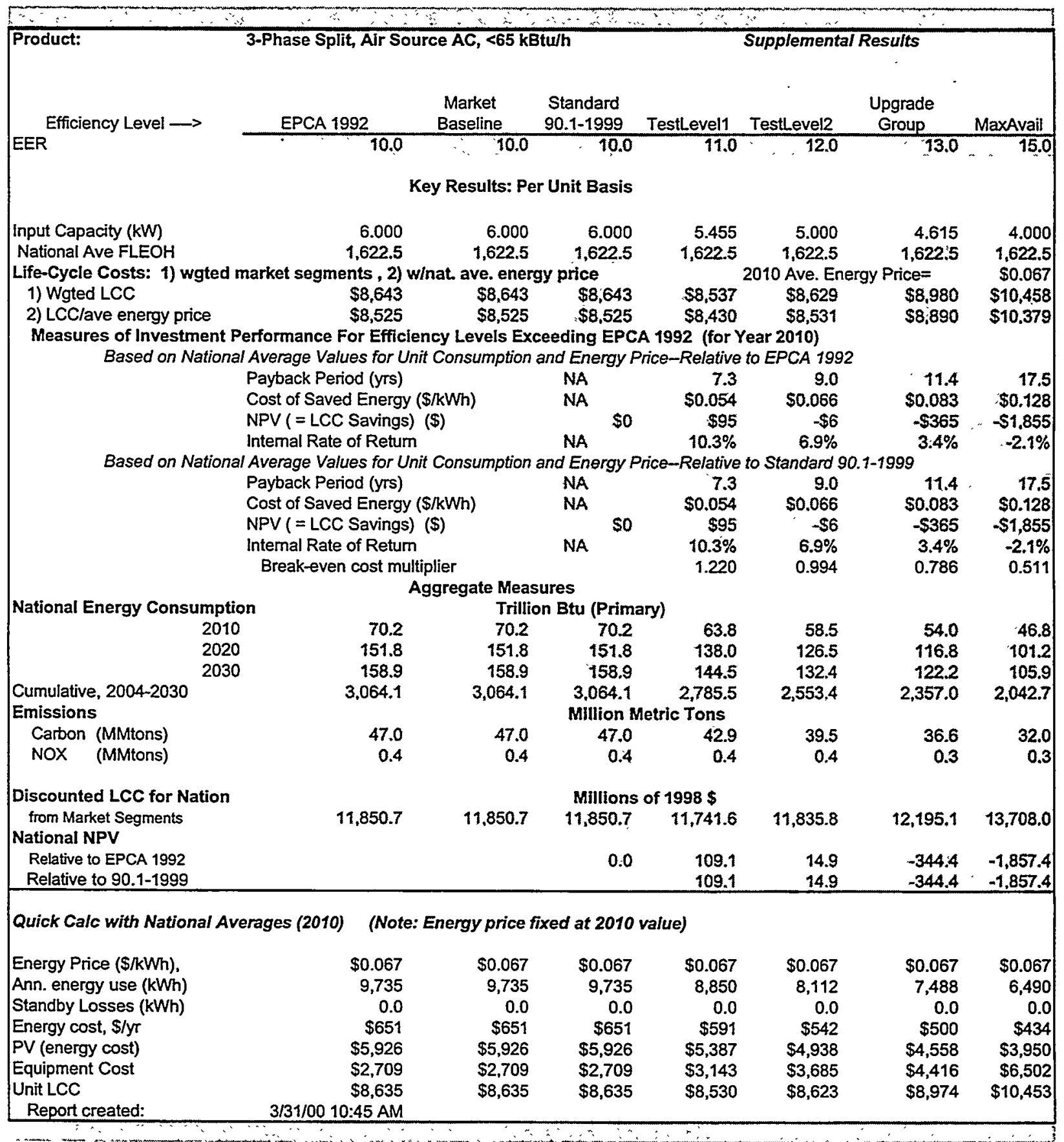




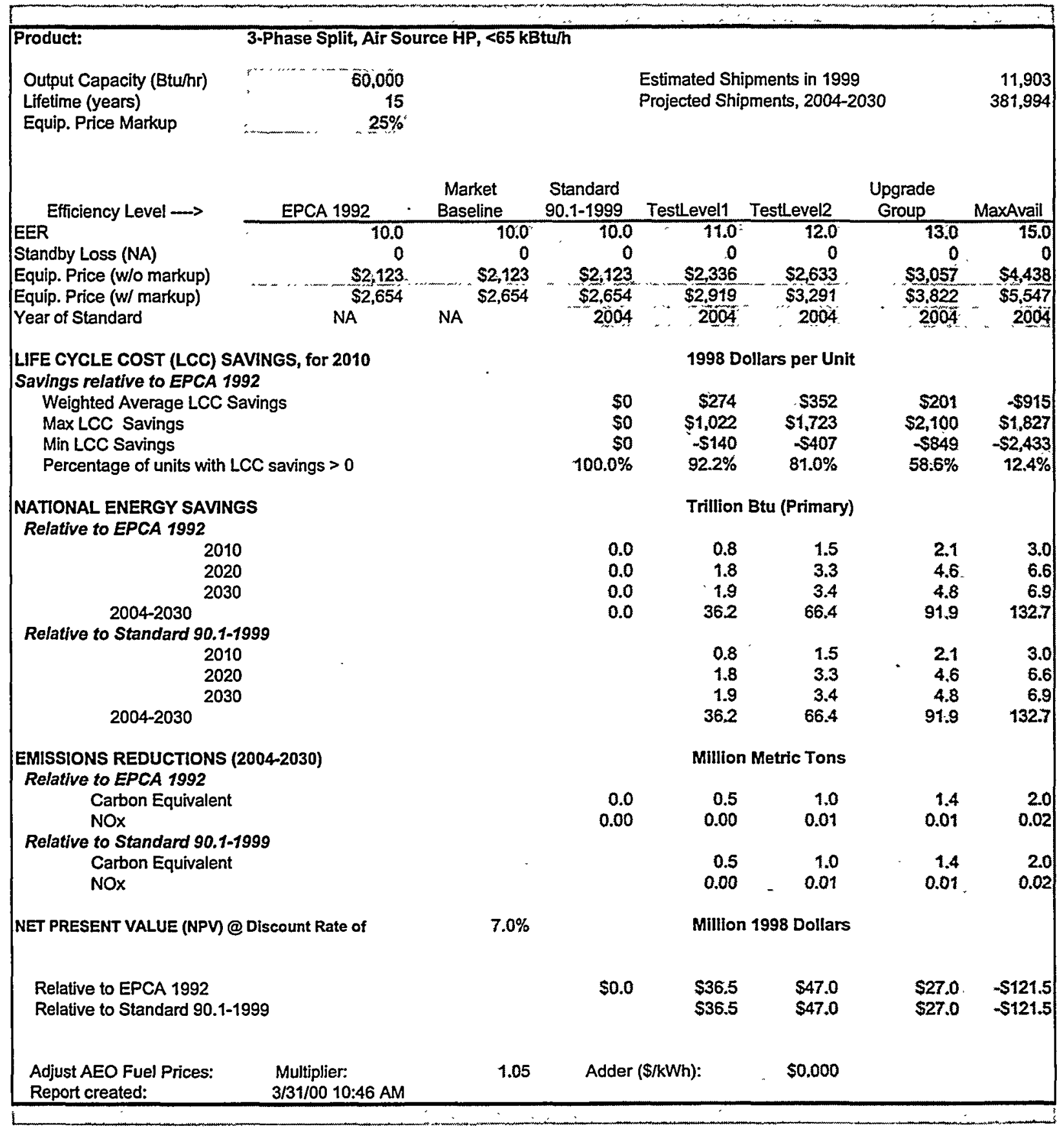




\begin{tabular}{|c|c|c|c|c|c|c|c|}
\hline Product: & \multicolumn{4}{|c|}{ 3-Phase Split, Alr Source HP, $<65 \mathrm{kBtu} / \mathrm{h}$} & \multicolumn{3}{|c|}{ Supplemental Results } \\
\hline Efficiency Level $\rightarrow$ & EPCA 1992 & $\begin{array}{c}\text { Market } \\
\text { Baseline }\end{array}$ & $\begin{array}{l}\text { Standard } \\
90.1-1999\end{array}$ & Testlevel1 & TestLevel2 & $\begin{array}{l}\text { Upgrade } \\
\text { Group }\end{array}$ & MaxAvail \\
\hline EER & $\quad 10.0$ & 10.0 & 10.0 & 11.0 & 12.0 & 13.0 & 15.0 \\
\hline \multicolumn{8}{|c|}{ Key Results: Per Unit Basis } \\
\hline $\begin{array}{l}\text { Input Capacity (kW) } \\
\text { National Ave FLEOH }\end{array}$ & $\begin{array}{r}6.000 \\
1.622 .5\end{array}$ & $\begin{array}{r}6.000 \\
16225\end{array}$ & 6.000 & 5.455 & 5.000 & 4.615 & $\begin{array}{r}4.000 \\
16225\end{array}$ \\
\hline \multicolumn{4}{|c|}{ Life-Cycle Costs: 1) wgted market segments, 2) w/nat. ave. energy price } & $1,0<2.0$ & \multicolumn{2}{|c|}{2010 Ave. Energy Price= } & $\begin{array}{l}1,022.0 \\
\$ 0.067\end{array}$ \\
\hline 1) Wgted LCC & $\$ 8,587$ & $\$ 8,587$ & $\$ 8,587$ & $\$ 8,313$ & $\$ 8,236$ & $\$ 8,386$ & $\$ 9.503$ \\
\hline 2) LCC/ave energy price & $\$ 8,469$ & $\$ 8,469$ & $\$ 8,469$ & $\$ 8,206$ & $\$ 8,137$ & $\$ 8,295$ & $\$ 9,424$ \\
\hline \multicolumn{8}{|c|}{$\begin{array}{l}\text { Measures of Investment Performance For Efficiency Levels Exceeding EPCA } 1992 \text { (for Year 2010) } \\
\text { Based on National Average Values for Unit Consumption and Energy Price-Relative to EPCA } 1992\end{array}$} \\
\hline & Payback Period (yrs) & & NA & 4.5 & 5.9 & 7.8 & 13.3 \\
\hline & Cost of Saved Energy & (kWh) & NA & $\$ 0.033$ & $\$ 0.043$ & $\$ 0.057$ & \$0.098 \\
\hline & NPV ( = LCC Savings) & & so & $\$ 263$ & $\$ 332$ & $\$ 174$ & $-\$ 954$ \\
\hline & Intemal Rate of Retum & & NA & $20.6 \%$ & $14.6 \%$ & $9.3 \%$ & $1.2 \%$ \\
\hline \multicolumn{8}{|c|}{ Based on National Average Values for Unit Consumption and Energy Price-Relative to Standard 90.1-1999 } \\
\hline & Payback Period (yrs) & & NA & 4.5 & 5.9 & 7.8 & 13.3 \\
\hline & Cost of Saved Energy & (kWh) & NA & S0:033 & $\$ 0.043$ & \$0.057 & $\$ 0.098$ \\
\hline & NPV ( = LCC Savings) & & so & $\$ 263$ & $\$ 332$ & $\$ 174$ & $\$ 954$ \\
\hline & Intemal Rate of Retum & & NA & $20.6 \%$ & $14.6 \%$ & $9.3 \%$ & $1.2 \%$ \\
\hline & Break-even cost mul & & & 1.992 & 1.522 & 1.149 & 0.670 \\
\hline \multicolumn{8}{|c|}{ gregate Measures } \\
\hline National Energy Consumptio & & Trillic & In Btu (Prima & Iry) & & & \\
\hline 2010 & 9.1 & 9.1 & 9.1 & 8.3 & 7.6 & 7.0 & 6.1 \\
\hline 2020 & 19.7 & 19.7 & 19.7 & 17.9 & 16.4 & 15.2 & 13.2 \\
\hline 2030 & 20.6 & 20.6 & 20.6 & 18.8 & 17.2 & 15.9 & 13.8 \\
\hline Cumulative, 2004-2030 & 398.2 & 398.2 & 398.2 & 362.0 & 331.8 & 306.3 & 265.4 \\
\hline Emissions & \multicolumn{7}{|c|}{ Million Metric Tons } \\
\hline Carbon (MMtons) & 6.1 & 6.1 & 6.1 & 5.6 & 5.1 & 4.8 & 4.2 \\
\hline NOX (MMtons) & 0.1 & 0.1 & 0.1 & 0.1 & 0.0 & 0.0 & 0.0 \\
\hline Discounted LCC for Nation & \multicolumn{7}{|c|}{ Millions of 1998 \$ } \\
\hline $\begin{array}{l}\text { from Market Segments } \\
\text { National NPV }\end{array}$ & $1,530.1$ & $1,530.1$ & $1,530.1$ & $1,493.6$ & 1.483 .2 & 1.503 .1 & $1,651.7$ \\
\hline Relative to EPCA 1992 & & & 0.0 & 36.5 & 47.0 & 27.0 & -121.5 \\
\hline Relative to 90.1-1999 & & & & 36.5 & 47.0 & 27.0 & -121.5 \\
\hline \multicolumn{8}{|c|}{ Quick Calc with National Averages (2010) (Note: Energy price fixed at 2010 value) } \\
\hline Energy Price $(\$ / \mathrm{kWh})$, & $\$ 0.067$ & $\$ 0.067$ & $\$ 0.067$ & $\$ 0.067$ & $\$ 0.067$ & $\$ 0.067$ & $\$ 0.067$ \\
\hline Ann. energy use (kWh) & 9,735 & 9,735 & 9,735 & 8,850 & 8,112 & 7,488 & 6.490 \\
\hline Standby Losses (kWh) & 0.0 & 0.0 & 0.0 & 0.0 & 0.0 & 0.0 & 0.0 \\
\hline Energy cost, S/yr & $\$ 651$ & $\$ 651$ & $\$ 651$ & $\$ 591$ & $\$ 542$ & $\$ 500$ & $\$ 434$ \\
\hline PV (energy cost) & $\$ 5,926$ & $\$ 5,926$ & $\$ 5,926$ & $\$ 5,387$ & $\$ 4,938$ & $\$ 4,558$ & $\$ 3,950$ \\
\hline Equipment Cost & $\$ 2,654$ & $\$ 2,654$ & $\$ 2,654$ & $\$ 2,919$ & $\$ 3,291$ & $\$ 3,822$ & $\$ 5,547$ \\
\hline Unit LCC & $\$ 8,580$ & $\$ 8,580$ & $\$ 8,580$ & $\$ 8,306$ & $\$ 8,229$ & $\$ 8,380$ & $\$ 9,497$ \\
\hline Report created: & 3/31/00 10:46 AM & & & & & & \\
\hline
\end{tabular}




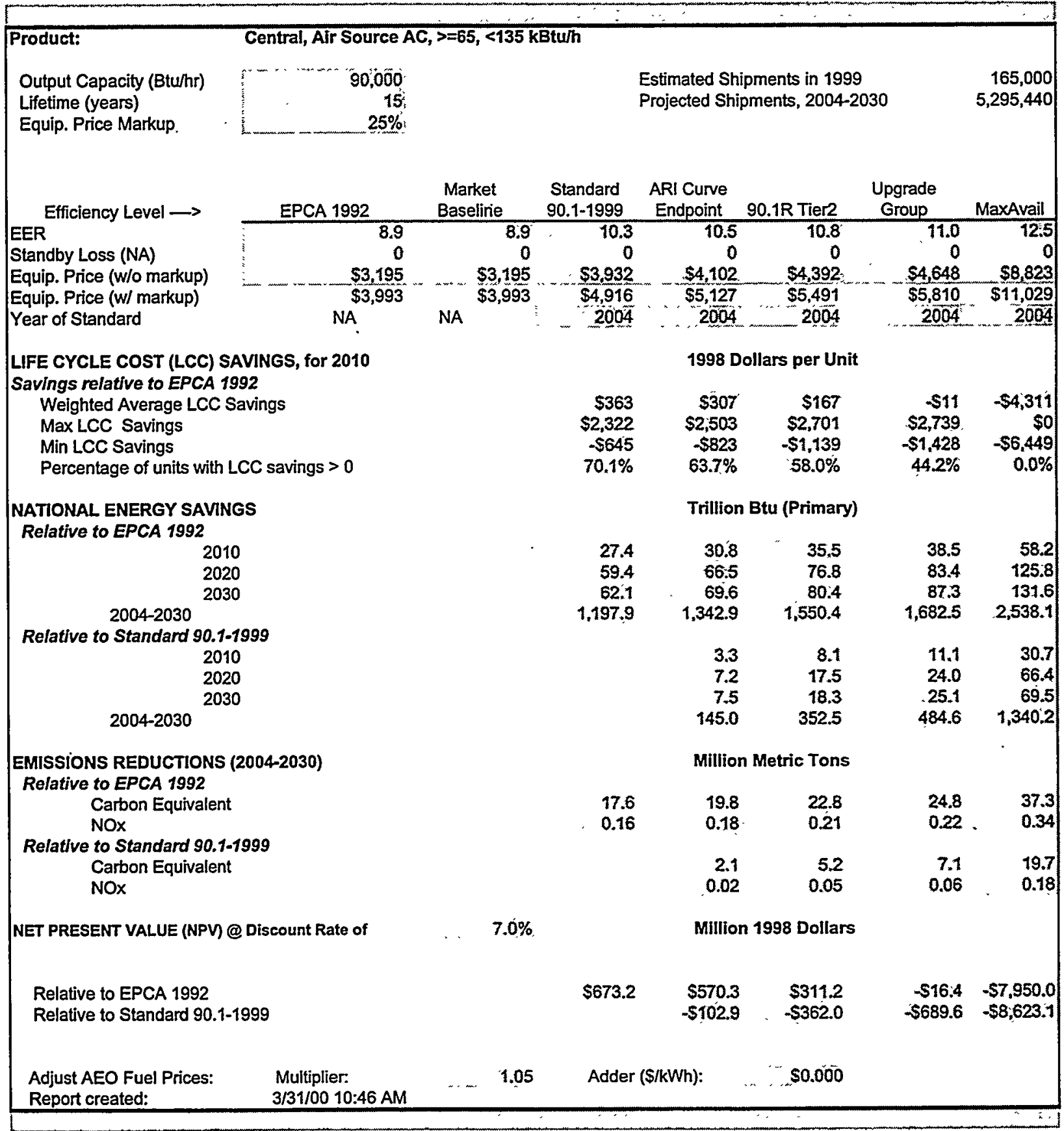




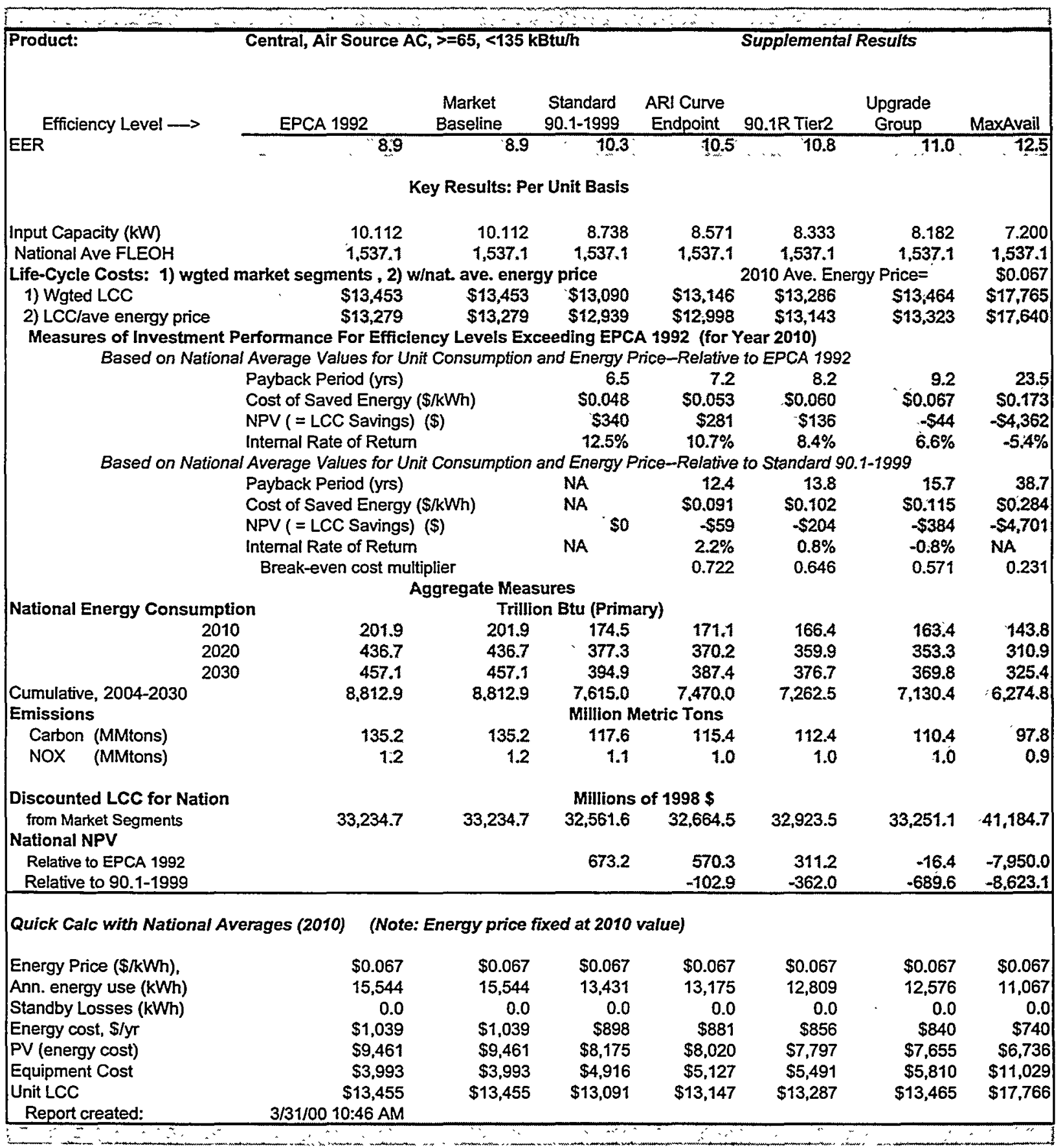




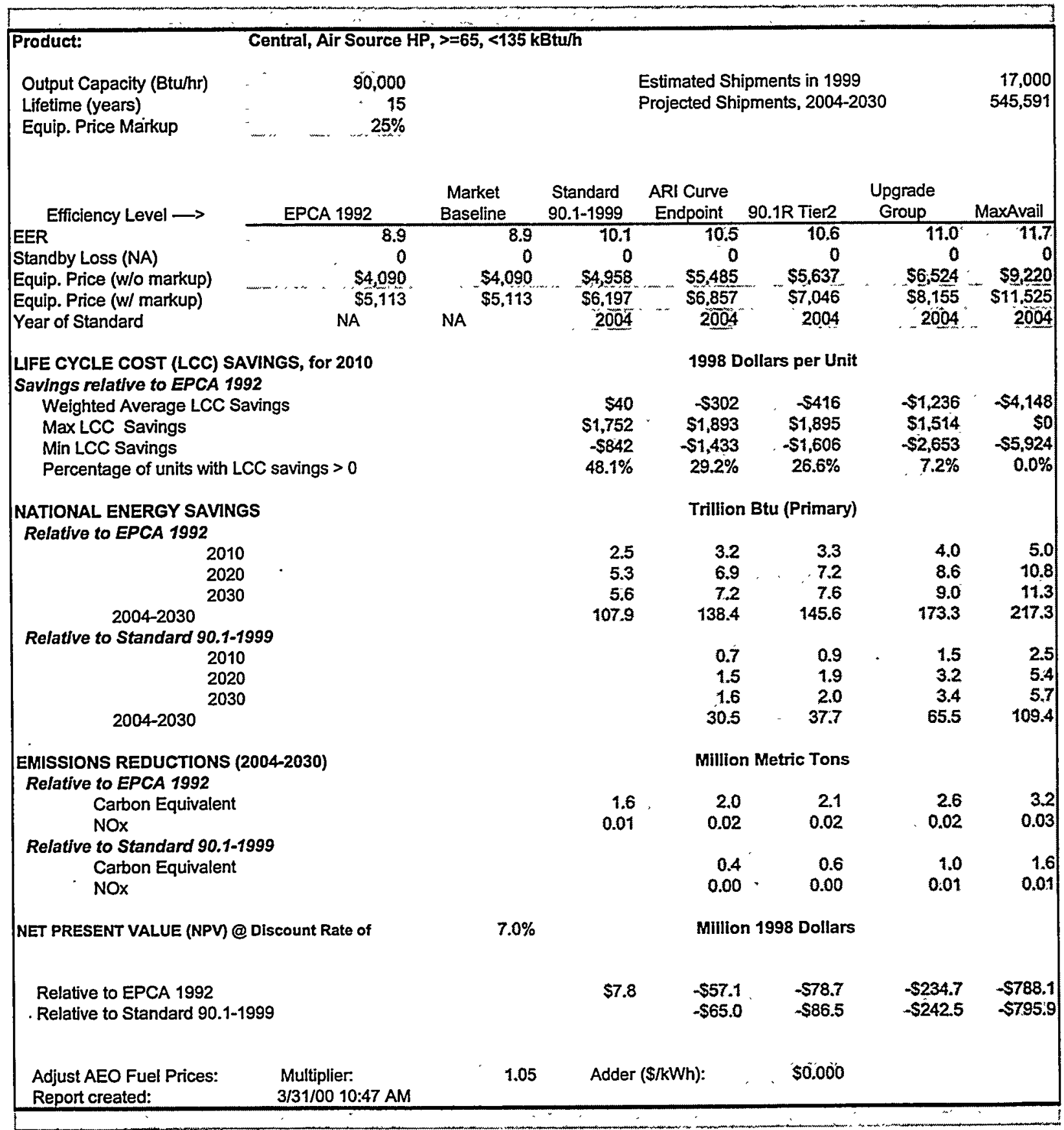




\begin{tabular}{|c|c|c|c|c|c|c|c|}
\hline \multirow{3}{*}{$\begin{array}{l}\text { Product: } \\
\text { EEfficiency Level } \rightarrow \\
\text { EER }\end{array}$} & \multicolumn{4}{|c|}{ Central, Air Source HP, $>=65,<135 \mathrm{kBtu} / \mathrm{h}$} & \multicolumn{3}{|c|}{ Supplemental Results } \\
\hline & EPCA 1992 & $\begin{array}{l}\text { Market } \\
\text { Baseline }\end{array}$ & $\begin{array}{c}\text { Standard } \\
90.1-1999\end{array}$ & $\begin{array}{l}\text { ARI Curve } \\
\text { Endpoint }\end{array}$ & 90.1R Tier2 & $\begin{array}{l}\text { Upgrade } \\
\text { Group }\end{array}$ & MaxAvail \\
\hline & 8.9 & 8.9 & $\therefore 10.1$ & 10.5 & $m: 10.6$ & $: 11.0$ & $\mathbf{1 1 . 7}$ \\
\hline \multicolumn{8}{|c|}{ Key Results: Per Unit Basis } \\
\hline Input Capacity (kW) & 10.112 & 10.112 & 8.911 & 8.571 & 8.491 & 8.182 & 7.692 \\
\hline National Ave FLEOH & $1,537.1$ & $1,537.1$ & $1,537.1$ & $1,537.1$ & $1,537,1$ & $1,537.1$ & $1,537.1$ \\
\hline \multicolumn{5}{|c|}{ Life-Cycle Costs: 1) wgted market segments , 2) w/nat. ave. energy price } & \multicolumn{2}{|c|}{2010 Ave. Energy Price $=$} & $\$ 0.067$ \\
\hline 1) Wgted LCC & $\$ 14,573$ & $\$ 14,573$ & $\$ 14,533$ & $\$ 14,875$ & $\$ 14,989$ & $\$ 15,809$ & $\$ 18,721$ \\
\hline 2) LCC/ave energy price & $\$ 14,399$ & $\$ 14,399$ & $\$ 14,379$ & $\$ 14,727$ & $\$ 14,842$ & $\$ 15,668$ & $\$ 18,588$ \\
\hline \multicolumn{8}{|c|}{$\begin{array}{l}\text { Measures of Investment Performance For Efficiency Levels Exceeding EPCA } 1992 \text { (for Year 2010) } \\
\text { Based on National Average Values for Unit Consumption and Energy Price-Relative to EPCA } 1992\end{array}$} \\
\hline 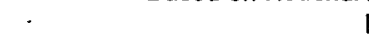 & Payback Period (yrs) & & 8.8 & 11.0 & 11.6 & 15.3 & 25.8 \\
\hline & Cost of Saved Energy ( & (kWh) & $\$ 0.064$ & 50.081 & $\$ 0.085$ & $\$ 0.113$ & S0.189 \\
\hline & NPV ( = LCC Savings) & & $\$ 19$ & $-\$ 329$ & $-\$ 444$ & $-\$ 1,270$ & $-\$ 4,190$ \\
\hline & Internal Rate of Retum & & $7.3 \%$ & $3.9 \%$ & $3.1 \%$ & $-0.5 \%$ & $-6.3 \%$ \\
\hline \multicolumn{8}{|c|}{ Based on National Average Values for Unit Consumption and Energy Price-Relative to Standard 90.1-1999 } \\
\hline & Payback Period (yrs) & & NA & 18.9 & $\quad 19.7$ & 26.1 & 42.6 \\
\hline & Cost of Saved Energy ( & (kWh) & NA & S0.139 & $\$ 0.144$ & \$0.192 & so.312 \\
\hline & NPV ( = LCC Savings) & & so & $-\$ 348$ & $\$ 463$ & $-\$ 1,289$ & $-\$ 4,209$ \\
\hline & Internal Rate of Return & & NA & $-3.0 \%$ & $-3.4 \%$ & $-6.5 \%$ & NA \\
\hline & Break-even cost mult & lier & & 0.473 & 0.455 & 0.342 & 0.210 \\
\hline \multicolumn{8}{|c|}{ Aggregate Measures } \\
\hline National Energy Consumptio & & Trilli & on Btu (Prim & & & & \\
\hline 2010 & 20.8 & 20.8 & 18.3 & 17.6 & 17.5 & 16.8 . & 15.8 \\
\hline 2020 & 45.0 & 45.0 & 39.6 & 38.1 & 37.8 & 36.4 & 34.2 \\
\hline 2030 & 47.1 & 47.1 & 41.5 & 39.9 & 39.5 & 38.1 & 35.8 \\
\hline Cumulative, 2004-2030 & 908.0 & 908.0 & 800.1 & 769.6 & 762.4 & 734.7 & 690.7 \\
\hline Emissions & \multicolumn{7}{|c|}{ Million Metric Tons } \\
\hline Caron (MMtons) & 13.9 & 13.9 & 12.3 & 11.9 & 11.8 & 11.4 & 10.7 \\
\hline NOX (MMtons) & 0.1 & 0.1 & 0.1 & 0.1 & 0.1 & 0.1 & 0.1 \\
\hline Discounted LCC for Nation & \multicolumn{7}{|c|}{ Millions of $1998 \$$} \\
\hline from Market Segments & $3,707.1$ & $3,707.1$ & $3,699.3$ & $3,764.2$ & 3.785 .8 & $3,941.7$ & $4,495.2$ \\
\hline \multicolumn{8}{|l|}{ National NPV } \\
\hline Relative to EPCA 1992 & & & 7.8 & -57.1 & -78.7 & -234.7 & -788.1 \\
\hline Relative to 90.1-1999 & & & & -65.0 & -86.5 & -242.5 & -795.9 \\
\hline \multicolumn{8}{|c|}{ Quick Calc with National Averages (2010) (Note: Energy price fixed at 2010 value) } \\
\hline Energy Price (\$/kWh), & $\$ 0.067$ & $\$ 0.067$ & $\$ 0.067$ & $\$ 0.067$ & \$0.067 & $\$ 0.067$ & $\$ 0.067$ \\
\hline Ann. energy use ( $k W h)$ & 15,544 & 15,544 & 13,697 & 13,175 & 13,051 & 12,576 & 11,824 \\
\hline Standby Losses (kWh) & 0.0 & 0.0 & 0.0 & 0.0 & 0.0 & 0.0 & 0.0 \\
\hline Energy cost, $\$ / y T$ & $\$ 1,039$ & $\$ 1,039$ & $\$ 915$ & $\$ 881$ & $\$ 872$ & $\$ 840$ & $\$ 790$ \\
\hline PV (energy cost) & $\$ 9,461$ & $\$ 9,461$ & $\$ 8,337$ & $\$ 8,020$ & $\$ 7,944$ & $\$ 7,655$ & $\$ 7,197$ \\
\hline Equipment Cost & $\$ 5,113$ & $\$ 5,113$ & $\$ 6,197$ & $\$ 6,857$ & $\$ 7,046$ & $\$ 8,155$ & $\$ 11,525$ \\
\hline $\begin{array}{l}\text { Unit LCC } \\
\text { Report created: }\end{array}$ & $\begin{array}{r}\$ 14,574 \\
3 / 31 / 0010: 47 \text { AM }\end{array}$ & $\$ 14,574$ & $\$ 14,534$ & $\$ 14,876$ & $\$ 14,990$ & $\$ 15,810$ & $\$ 18,722$ \\
\hline
\end{tabular}




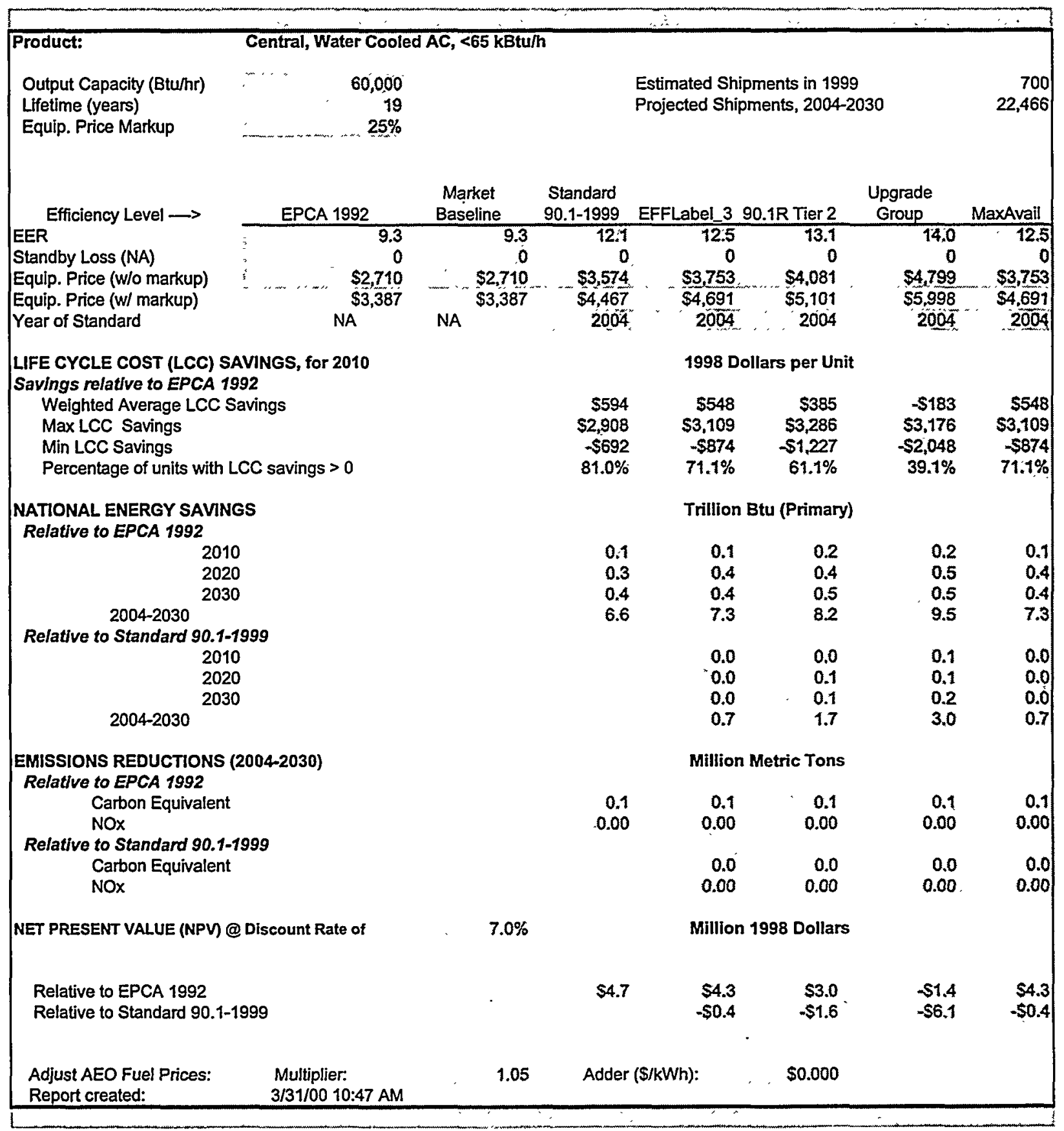




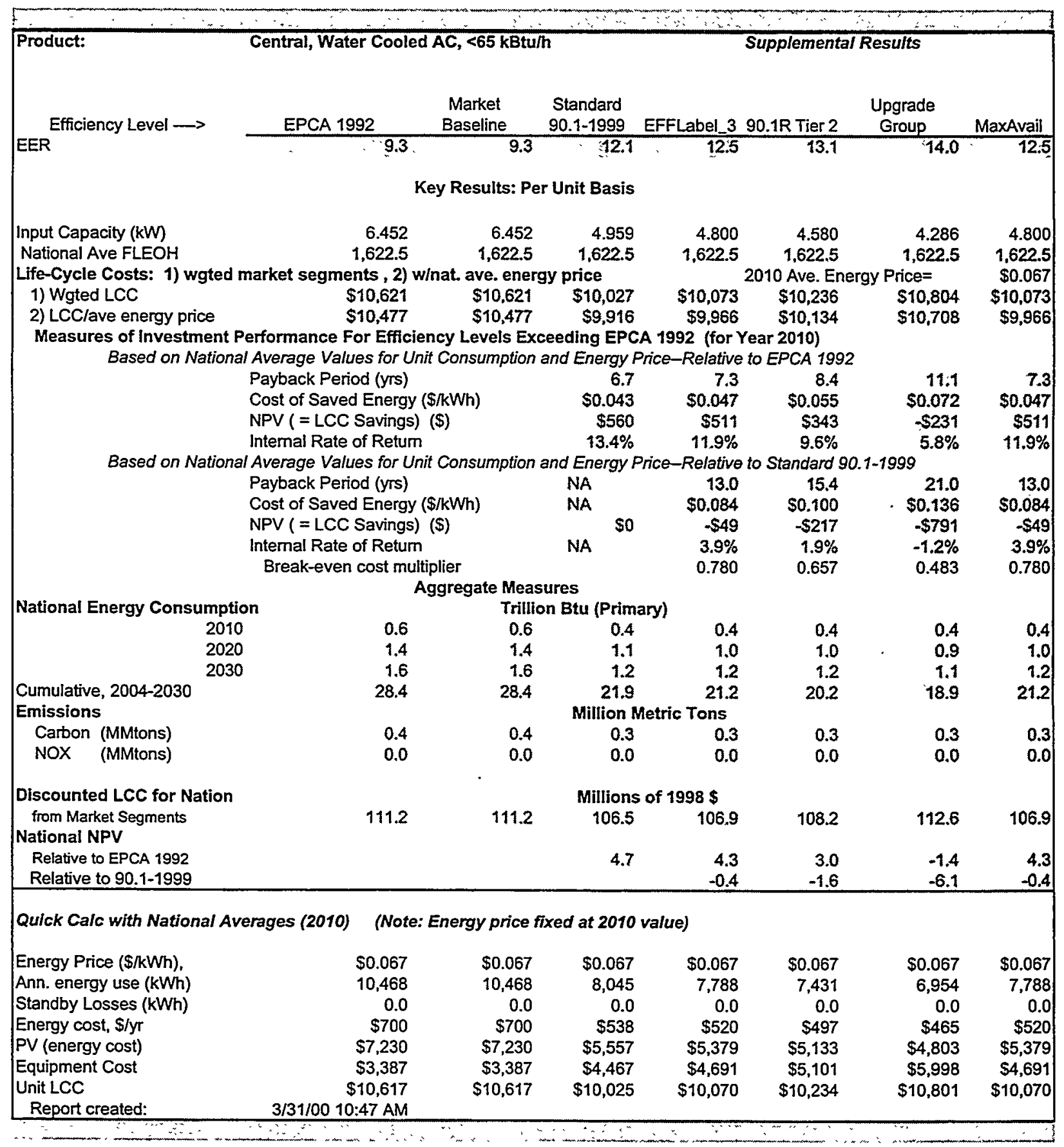




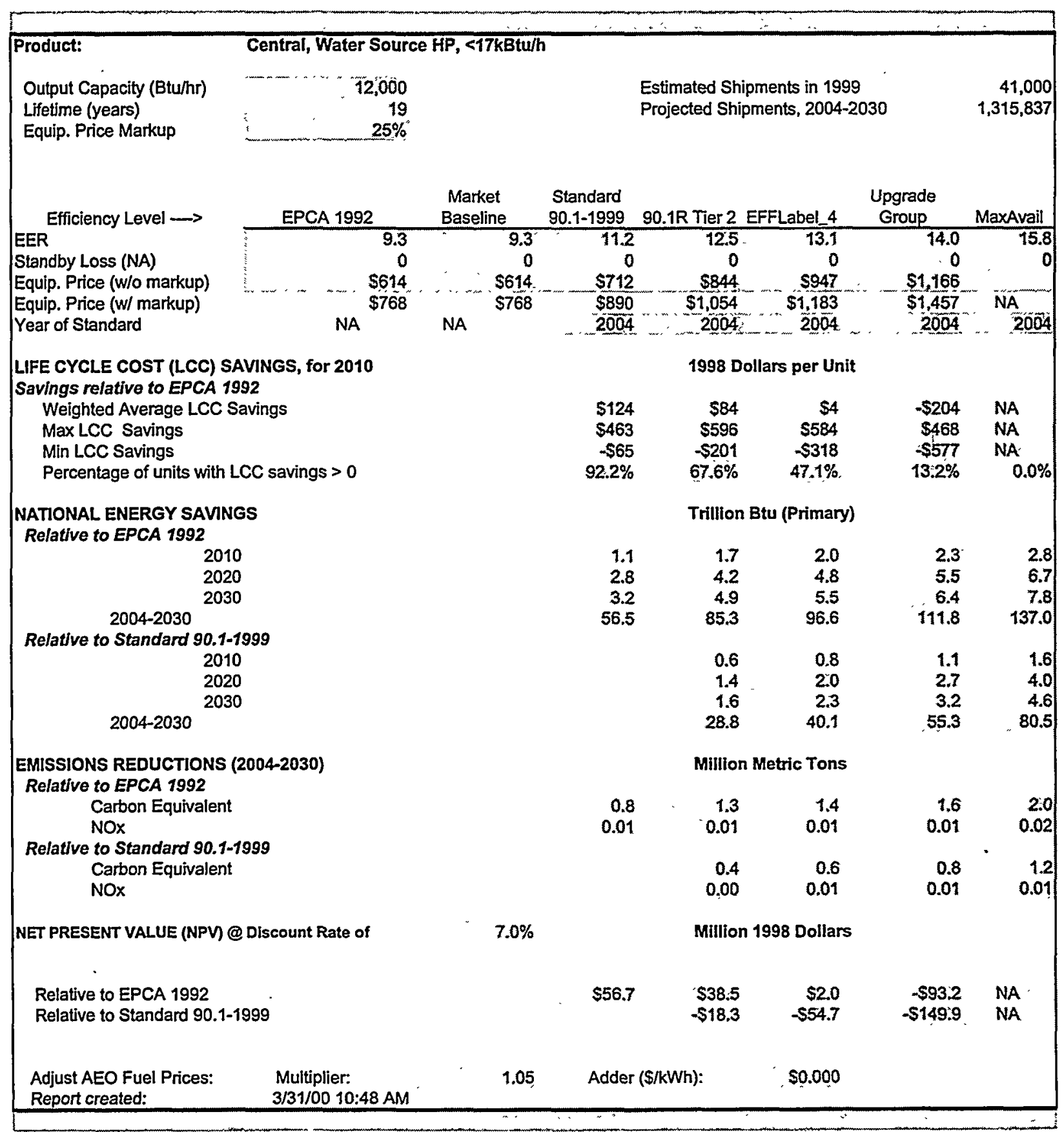




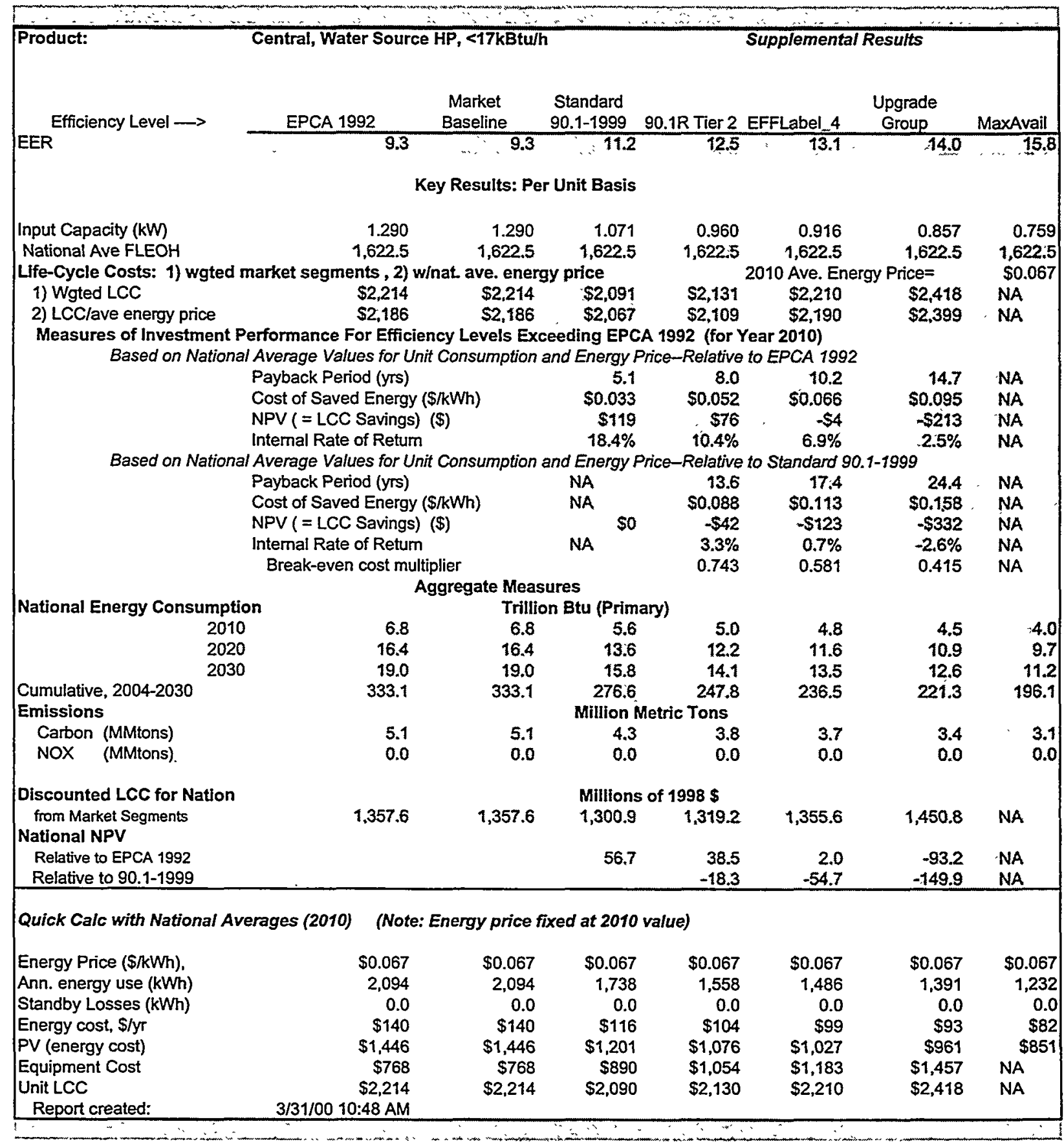




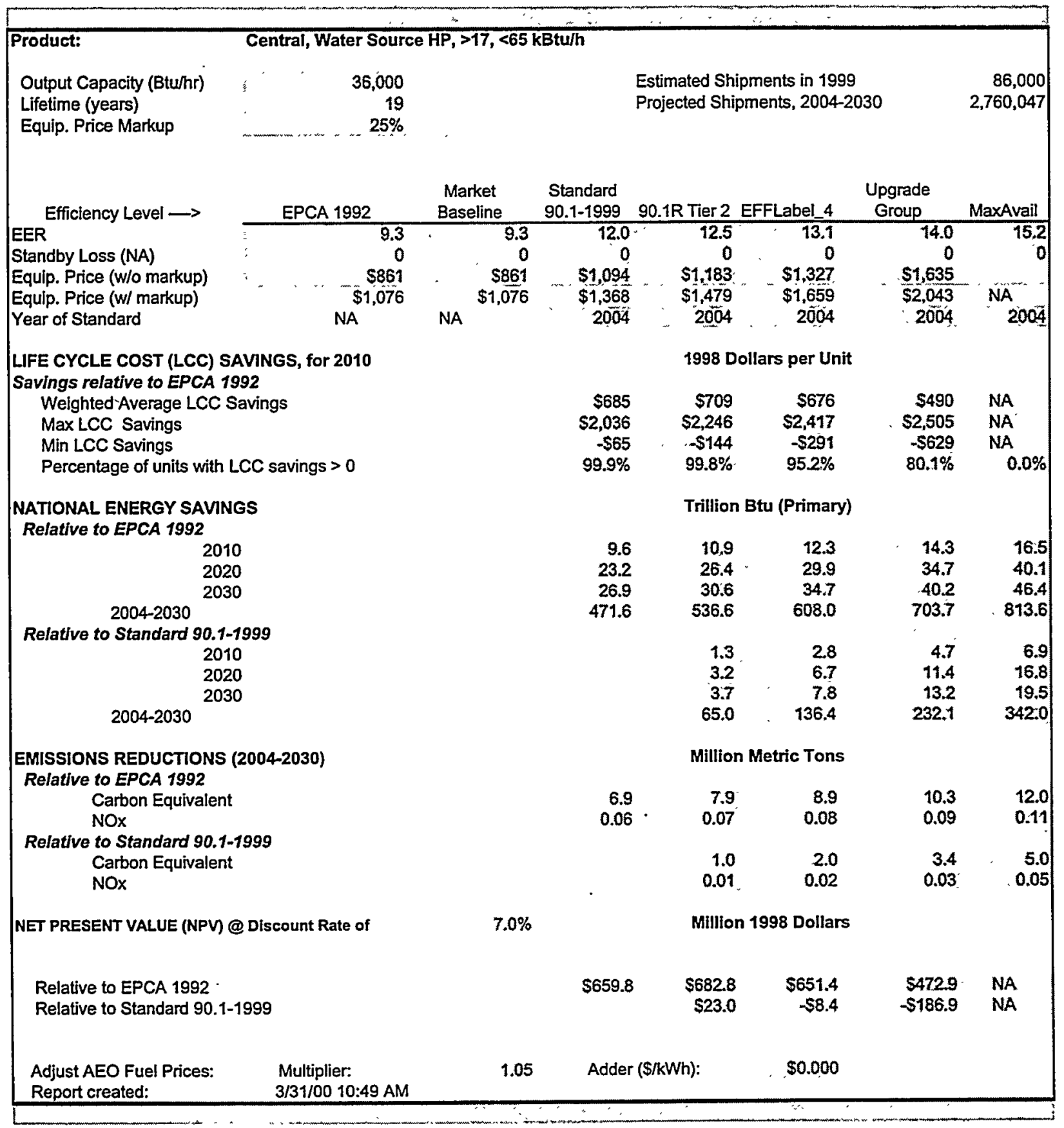




\begin{tabular}{|c|c|c|c|c|c|c|c|}
\hline \multicolumn{8}{|l|}{ 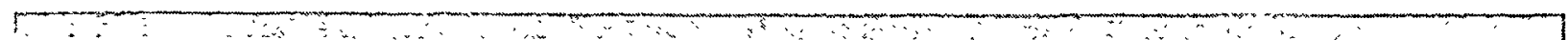 } \\
\hline \multirow{3}{*}{$\begin{array}{l}\text { Product: } \\
\text { Efficiency Level } \longrightarrow \\
\text { EER }\end{array}$} & \multicolumn{4}{|c|}{ Central, Water Source HP, >17, $<65 \mathrm{kBtu} / \mathrm{h}$} & \multicolumn{3}{|c|}{ Supplemental Results } \\
\hline & EPCA 1992 & $\begin{array}{l}\text { Market } \\
\text { Baseline }\end{array}$ & $\begin{array}{l}\text { Standard } \\
90.1-1999\end{array}$ & $90.1 R$ Tier 2 & EFFLabel 4 & $\begin{array}{l}\text { Upgrade } \\
\text { Group }\end{array}$ & MaxAvail \\
\hline & 9.3 & 9.3 & 12.0 & 12.5 & 13.1 & 14.0 & 15.2 \\
\hline \multicolumn{8}{|c|}{ Key Results: Per Unit Basis } \\
\hline Input Capacity (kW) & 3.871 & 3.871 & 3.000 & 2.880 & 2.748 & 2.571 & 2.368 \\
\hline National Ave FLEOH & $1,622,5$ & $1,622.5$ & $1,622.5$ & $1,622.5$ & $1,622.5$ & $1,622.5$ & $1,622.5$ \\
\hline \multicolumn{5}{|c|}{ Life-Cycle Costs: 1) wgted market segments , 2) winat. ave. energy price } & \multicolumn{2}{|c|}{2010 Ave. Energy Price= } & $\$ 0.067$ \\
\hline 1) Wgted LCC & $\$ 5,417$ & $\$ 5,417$ & $\$ 4,732$ & $\$ 4,708$ & $\$ 4,741$ & $\$ 4.926$ & NA \\
\hline 2) LCClave energy price & $\$ 5,330$ & - $\$ 5,330$ & $\$ 4,665$ & $\$ 4,643$ & $\$ 4,679$ & $\$ 4,869$ & NA \\
\hline \multicolumn{8}{|c|}{$\begin{array}{l}\text { Measures of Investment Performance For Efficlency Levels Exceeding EPCA } 1992 \text { (for Year 2010) } \\
\text { Based on National Average Values for Unit Consumption and Energy Price-Relative to EPCA } 1992\end{array}$} \\
\hline & Payback Period (yrs) & & 3.1 & 3.7 & 4.8 & 6.9 & NA \\
\hline & Cost of Saved Energy & (kWh) & 50.020 & 50.024 & $\$ 0.031$ & 50.044 & NA \\
\hline & NPV $(=$ LCC Savings) & & $\$ 666$ & S687 & $\$ 651^{\prime}$ & $\$ 461$ & NA \\
\hline & Internal Rate of Return & & $31.8 \%$ & $26.0 \%$ & $19.9 \%$ & $12.9 \%$ & NA \\
\hline \multicolumn{8}{|c|}{ Based on National Average Values for Unit Consumption and Energy Price-Relative to Standard 90.1-1999 } \\
\hline & Payback Period (yrs) & & NA & 8.5 & 10.7 & 14.5 & NA \\
\hline & Cost of Saved Energy & (kWh) & NA & $\$ 0.055$ & $\$ 0.069$ & $\$ 0.094$ & NA \\
\hline & NPV ( = LCC Savings) & & \$o & $\$ 21$ & $-\$ 15$ & $-\$ 204$ & NA \\
\hline & Internal Rate of Return & & NA & $9.5 \%$ & $6.3 \%$ & $2.6 \%$ & NA \\
\hline & $\mathrm{n}$ cost mul & lier & & 1.191 & 0.950 & 0.697 & NA \\
\hline \multicolumn{8}{|c|}{ Aggregate Measures } \\
\hline \multicolumn{5}{|l|}{ National Energy Consumption } & & & \\
\hline 2010 & 42.5 & 42.5 & 33.0 & 31.6 & 30.2 & 28.2 & 26.0 \\
\hline 2020 & 103.2 & 103.2 & 80.0 & 76.8 & 73.3 & 68.6 & 63.2 \\
\hline 2030 & 119.6 & 119.6 & 92.7 & 89.0 & 84.9 & 79.4 & 73.2 \\
\hline Cumulative, 2004-2030 & $2,096.0$ & $2,096.0$ & $1,624.4$ & $1,559.4$ & $1,488.0$ & $1,392.3$ & $1,282.4$ \\
\hline Emissions & \multicolumn{7}{|c|}{ Million Metric Tons } \\
\hline Carbon (MMtons) & 32.0 & 32.0 & 25.1 & 24.1 & 23.0 & .21 .6 & 20.0 \\
\hline NOX (MMtons) & 0.3 & 0.3 & 0.2 & 0.2 & 0.2 & 0.2 & 0.2 \\
\hline \multicolumn{3}{|l|}{ Discounted LCC for Nation } & \multicolumn{2}{|c|}{ Millions of $1998 \$$} & & & \\
\hline $\begin{array}{l}\text { from Market Segments } \\
\text { National NPV }\end{array}$ & 6.975 .8 & $6,975.8$ & $6,316.0$ & $6,293.0$ & $6,324.3$ & $6,502.9$ & NA \\
\hline Relative to EPCA 1992 & & & 659.8 & 682.8 & 651.4 & 472.9 & NA \\
\hline Relative to $90.1-1999$ & & & & 23.0 & -8.4 & -186.9 & NA \\
\hline \multicolumn{8}{|c|}{ Quick Calc with National Averages (2010) (Note: Energy price fixed at 2010 value) } \\
\hline Energy Price $(\$ / k W h)$, & $\$ 0.067$ & $\$ 0.067$ & $\$ 0.067$ & $\$ 0.067$ & $\$ 0.067$ & $\$ 0.067$ & $\$ 0.067$ \\
\hline Ann. energy use (kWh) & 6,281 & 6,281 & 4,867 & 4,673 & 4,459 & 4,172 & 3,843 \\
\hline Standby Losses (kWh) & 0.0 & 0.0 & 0.0 & 0.0 & 0.0 & 0.0 & 0.0 \\
\hline Energy cost, \$/yr & $\$ 420$ & $\$ 420$ & $\$ 325$ & $\$ 312$ & $\$ 298$ & $\$ 279$ & $\$ 257$ \\
\hline PV (energy cost) & $\$ 4,338$ & $\$ 4,338$ & $\$ 3,362$ & $\$ 3,228$ & $\$ 3,080$ & $\$ 2,882$ & $\$ 2,654$ \\
\hline Equipment Cost & $\$ 1,076$ & $\$ 1,076$ & $\$ 1,368$ & $\$ 1,479$ & $\$ 1,659$ & $\$ 2,043$ & NA \\
\hline $\begin{array}{l}\text { Unit LCC } \\
\text { Report created: }\end{array}$ & $\begin{array}{r}\$ 5,415 \\
3 / 31 / 00 \text { 10:49 AM }\end{array}$ & $\$ 5,415$ & $\$ 4,730$ & $\$ 4,706$ & $\$ 4,739$ & $\$ 4,925$ & NA \\
\hline
\end{tabular}




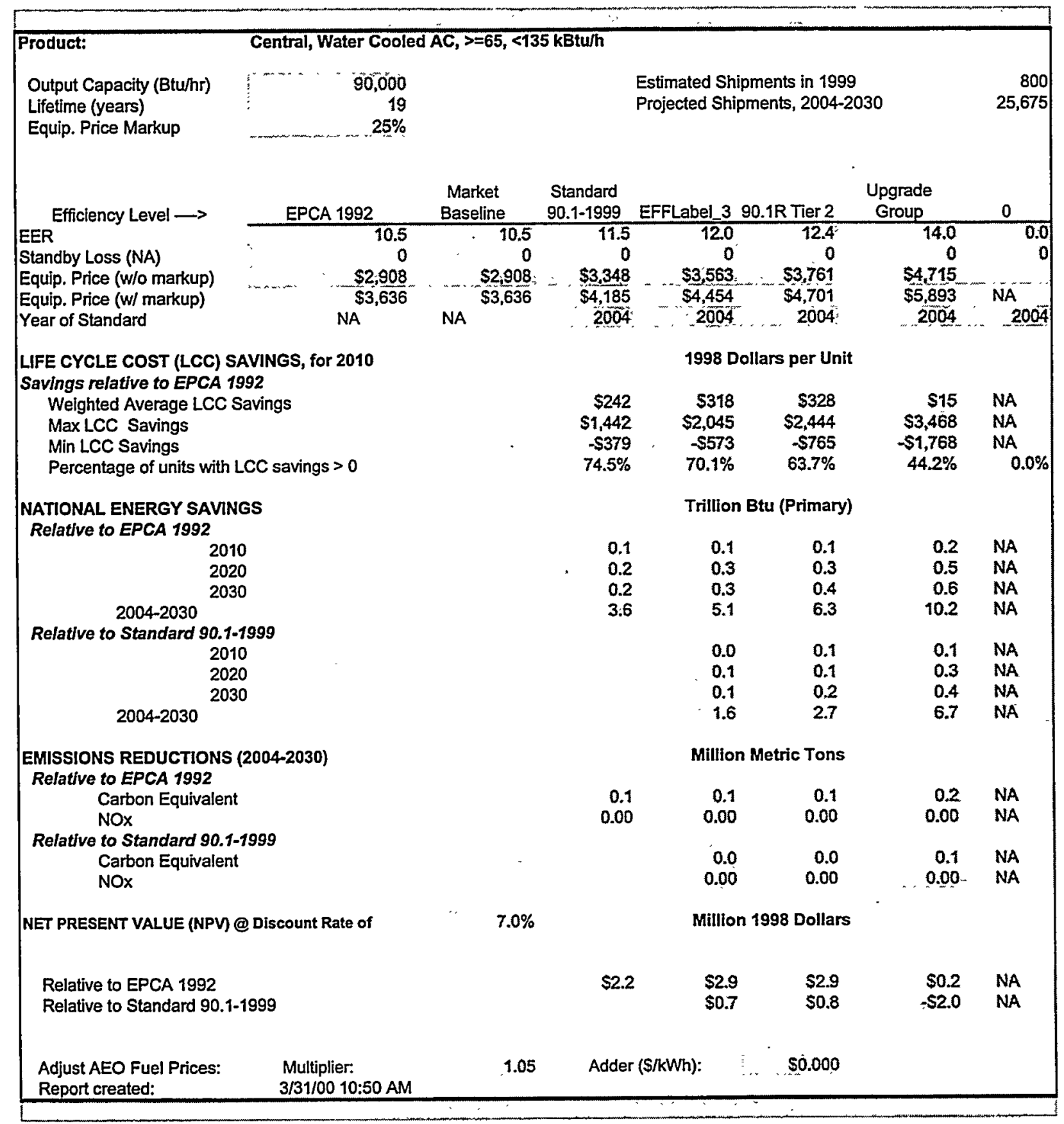




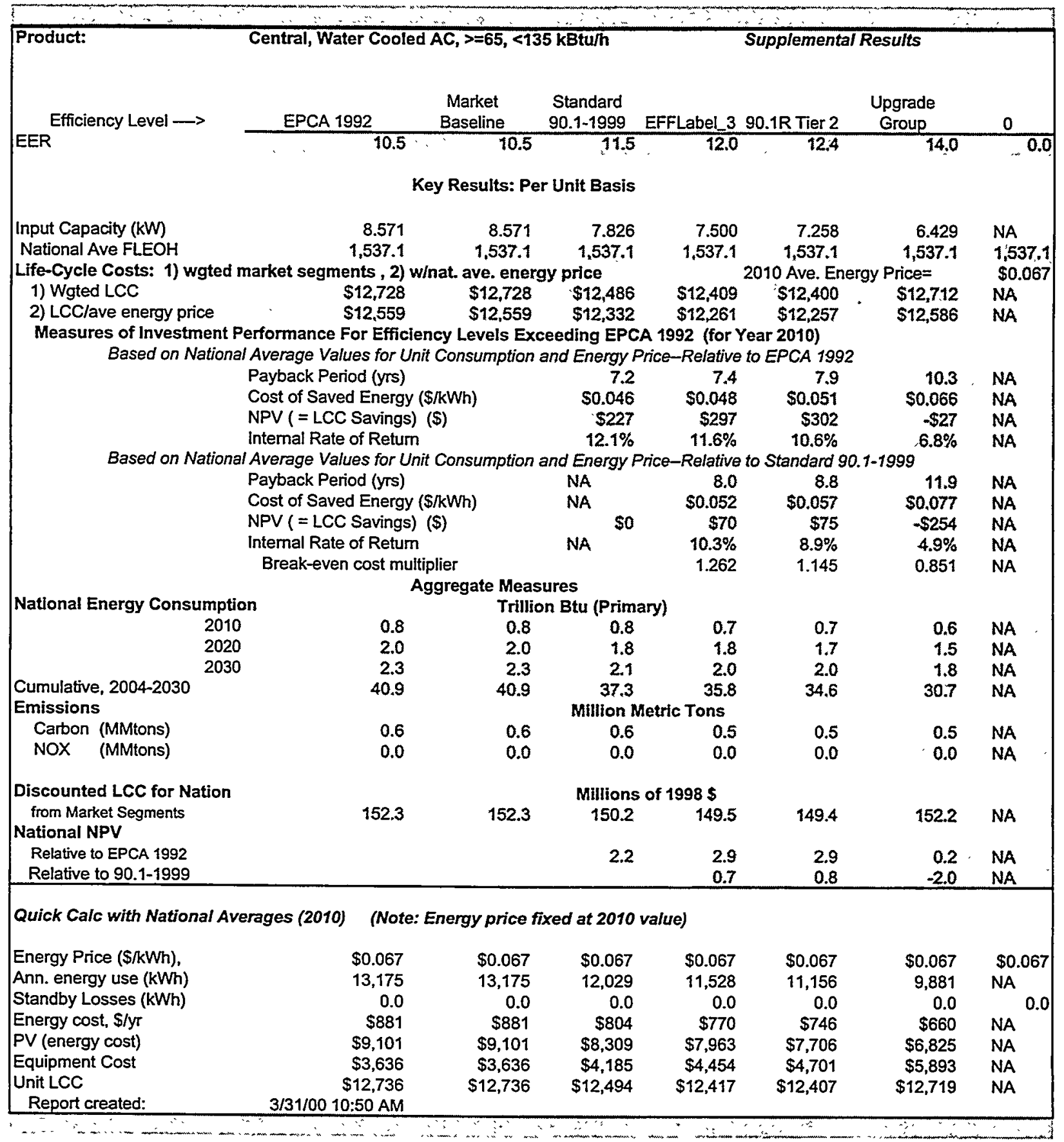




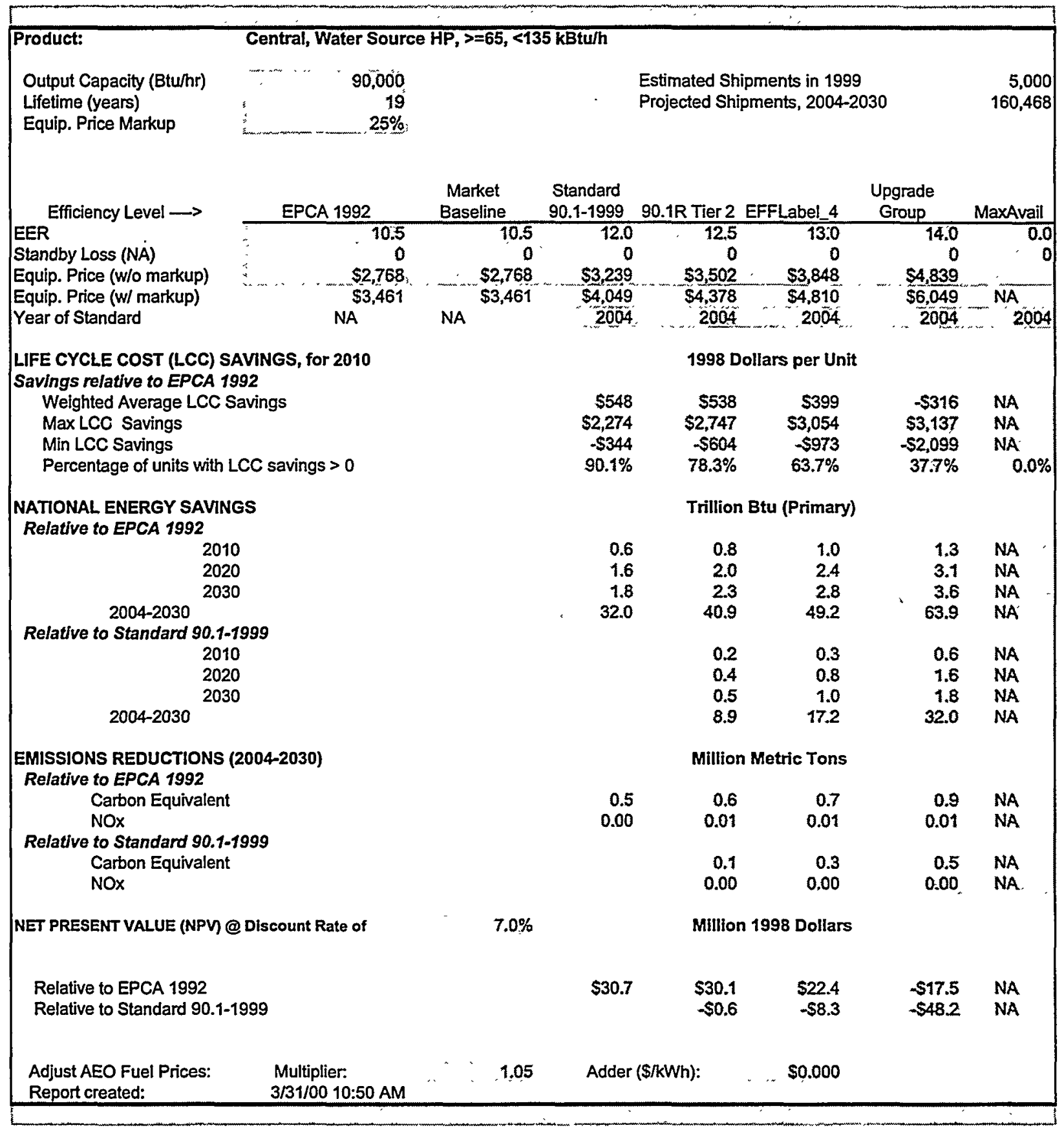




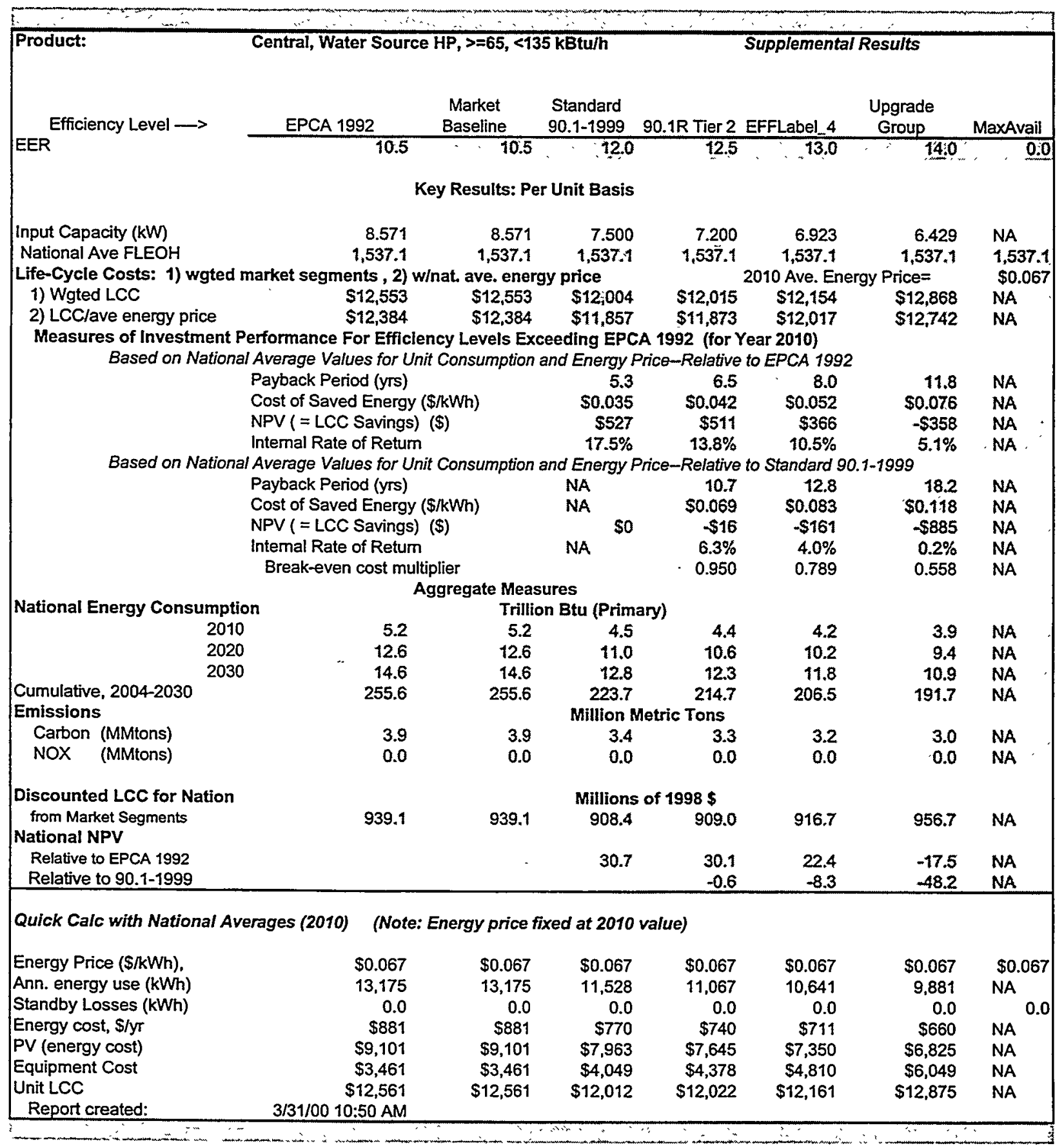




\begin{tabular}{|c|c|c|c|c|c|c|c|}
\hline \multirow{3}{*}{$\begin{array}{l}\text { Product: } \\
\text { Output Capacity (Btu/hr) } \\
\text { Lifetime (years) } \\
\text { Equip. Price Markup }\end{array}$} & \multicolumn{7}{|c|}{ Central, Air Source AC, $>=135,<240 \mathrm{kBtu} / \mathrm{h}$} \\
\hline & \multirow{2}{*}{$\begin{array}{rr}180,000 \\
15 \\
25 \%\end{array}$} & \multirow{2}{*}{\multicolumn{5}{|c|}{$\begin{array}{l}\text { Estimated Shipments in } 1999 \\
\text { Projected Shipments, 2004-2030 }\end{array}$}} & \multirow{2}{*}{$\begin{array}{r}65,000 \\
2,086,082\end{array}$} \\
\hline & & & & & & & \\
\hline Efficiency Level $\longrightarrow$ & EPCA 1992 & $\begin{array}{c}\text { Market } \\
\text { Baseline }\end{array}$ & $\begin{array}{l}\text { Standard } \\
90.1-1999\end{array}$ & 90.1R Tier 2 & $\begin{array}{c}\text { Tier } 1 \\
\text { Analysis }\end{array}$ & $\begin{array}{l}\text { Upgrade } \\
\text { Group }\end{array}$ & MaxAvail \\
\hline EER & 8.5 & 8.5 & 9.7 & 10.2 & 10.4 & 10.8 & 11.5 \\
\hline Standby Loss (NA) & 0 & & 0 & 0 & 0 & 0 & 0 \\
\hline Equip. Price (w/o markup) & 56,798 & $\$ 6,798$ & $\$ 7,614$ & $\$ 7,886$ & $\$ 8,089$ & & \\
\hline Equip. Price (w/ markup) & $\$ 8,497$ & $\$ 8,497$ & $\$ 9,517$ & $\$ 9,857$ & $\$ 10,112$ & NA & NA \\
\hline Year of Standard & NA & NA & 2004 & 2004 & 2004 & 2004 & 2004 \\
\hline \multirow{2}{*}{\multicolumn{2}{|c|}{$\begin{array}{l}\text { LIFE CYCLE COST (LCC) SAVINGS, for } 2010 \\
\text { Savings relative to EPCA } 1992\end{array}$}} & \multirow{2}{*}{\multicolumn{6}{|c|}{1998 Dollars per Unit }} \\
\hline & & & & & & & \\
\hline Weighted Average LCC & avings & & $\$ 1,431$ & $\$ 1,942$ & $\$ 2,005$ & NA & NA \\
\hline Max LCC Savings & & & $\$ 5,163$ & $\$ 6,970$ & $\$ 7,516$ & NA & NA \\
\hline Min LCC Savings & & & $-\$ 491$ & $-\$ 648$ & $\$ 834$ & NA & NA \\
\hline Percentage of units with & $C C$ savings $>0$ & & $97.5 \%$ & $97.5 \%$ & $95.4 \%$ & $0.0 \%$ & $0.0 \%$ \\
\hline \multirow{2}{*}{\multicolumn{2}{|c|}{$\begin{array}{l}\text { NATIONAL ENERGY SAVINGS } \\
\text { Relative to EPCA } 1992\end{array}$}} & \multicolumn{6}{|c|}{ Trillion Btu (Primary) } \\
\hline & & \\
\hline & & 20.6 & 27.8 & 30.4 & 35.5 & 43.5 \\
\hline \multicolumn{2}{|c|}{2020} & & 44.6 & 60.0 & 65.8 & 76.7 & 94.0 \\
\hline \multirow{2}{*}{\multicolumn{2}{|c|}{2030}} & & 46.6 & 62.8 & 68.9 & 80.3 & 98.4 \\
\hline & & & 899.4 & $1,211.7$ & 1.328 .2 & $1,548.3$ & $1,896.6$ \\
\hline \multicolumn{2}{|c|}{ Relative to Standard 90.1-1999 } & & & & & & \\
\hline \multicolumn{2}{|c|}{2010} & & & 7.2 & 9.8 & 14,9 & 22.8 \\
\hline \multirow{2}{*}{\multicolumn{2}{|c|}{$\begin{array}{l}2020 \\
2030\end{array}$}} & & & 15.5 & $21: 2$ & 32.2 & 49.4 \\
\hline & & & & 16.2 & 22.2 & 33.7 & 51.7 \\
\hline \multicolumn{2}{|c|}{$2004-2030^{2030}$} & & & 312.3 & 428.6 & 648.9 & 997.2 \\
\hline \multicolumn{2}{|c|}{ EMISSIONS REDUCTIONS (2004-2030) } & \multicolumn{6}{|c|}{ Million Metric Tons } \\
\hline \multicolumn{2}{|c|}{ Relative to EPCA 1992} & & & & & & \\
\hline Carbon Equivaler & & & 13.2 & 17.8 & $19: 5$ & 22.8 & 27.9 \\
\hline NOx & & & 0.12 & 0.16 & 0.18 & 0.20 & 0.25 \\
\hline \multicolumn{2}{|c|}{ Relative to Standard 90.1-1999 } & \multirow{2}{*}{\multicolumn{3}{|c|}{$\begin{array}{r}4.6 \\
0.04\end{array}$}} & & \multirow{3}{*}{$\begin{array}{r}9.5 \\
0.09\end{array}$} & \\
\hline \multicolumn{2}{|c|}{$\begin{array}{l}\text { Carbon Equivalent } \\
\text { NOx }\end{array}$} & & & & $\begin{array}{r}6.3 \\
0.06\end{array}$ & & $\begin{array}{l}14.7 \\
0.13\end{array}$ \\
\hline \multicolumn{2}{|c|}{ NET PRESENT VALUE (NPV) @ Discount Rate of } & $7.0 \%$ & & Million & 1998 Dollars & & \\
\hline $\begin{array}{l}\text { Relative to EPCA } 1992 \\
\text { Relative to Standard } 90 .\end{array}$ & 1999 & & $\$ 1,042.2$ & $\begin{array}{r}\$ 1,414.4 \\
\$ 372.2\end{array}$ & $\begin{array}{r}\$ 1,460.1 \\
\$ 417.9\end{array}$ & $\begin{array}{l}\text { NA } \\
\text { NA }\end{array}$ & $\begin{array}{l}\text { NA } \\
\text { NA }\end{array}$ \\
\hline $\begin{array}{l}\text { Adjust AEO Fuel Prices: } \\
\text { Report created: }\end{array}$ & $\begin{array}{l}\text { Multiplier: } \\
\text { 3/31/00 10:51 AM }\end{array}$ & 1.05 & Adder & $(\$ / \mathbf{k W h})$ & $\$ 0.000$ & & \\
\hline
\end{tabular}




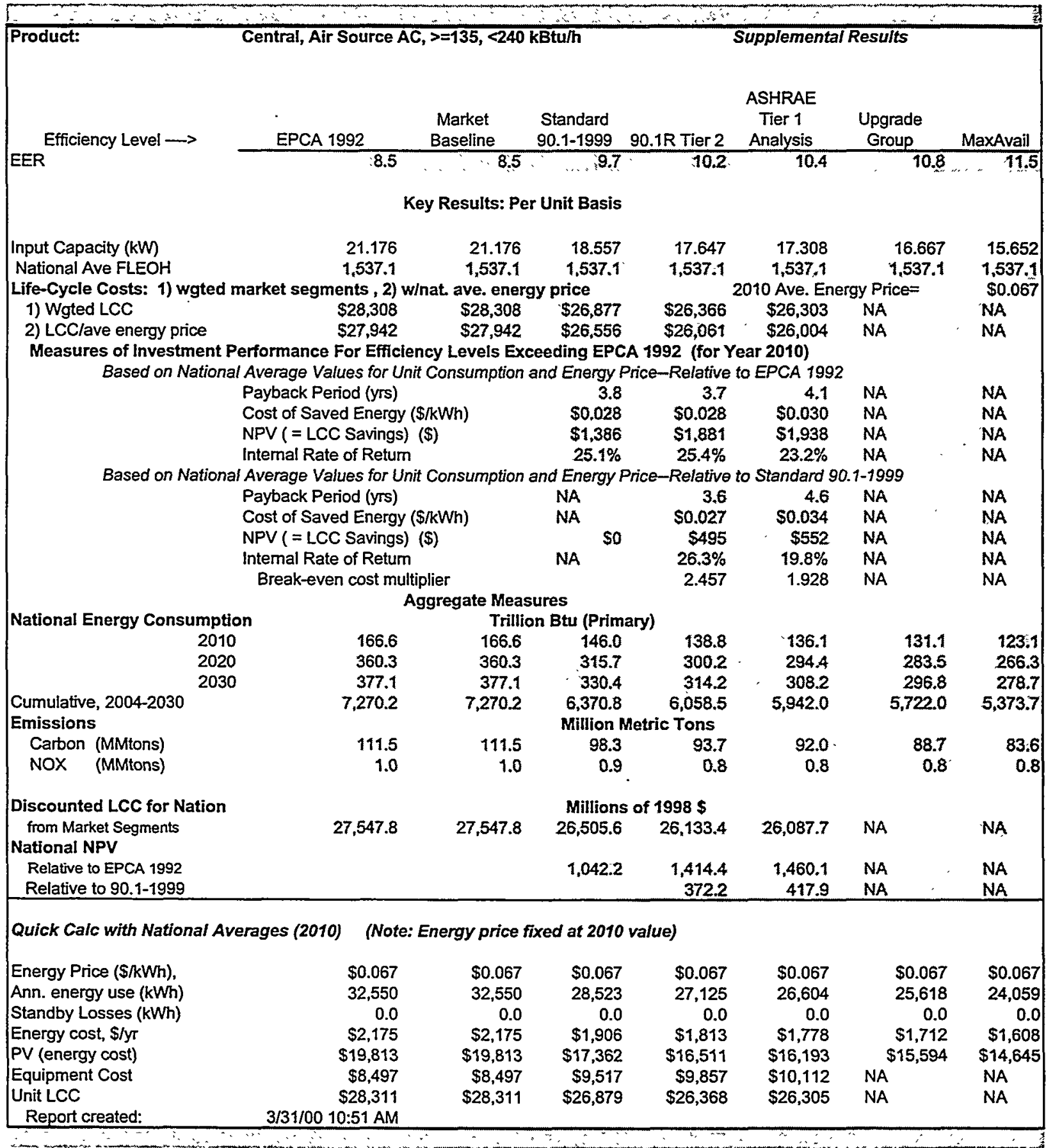




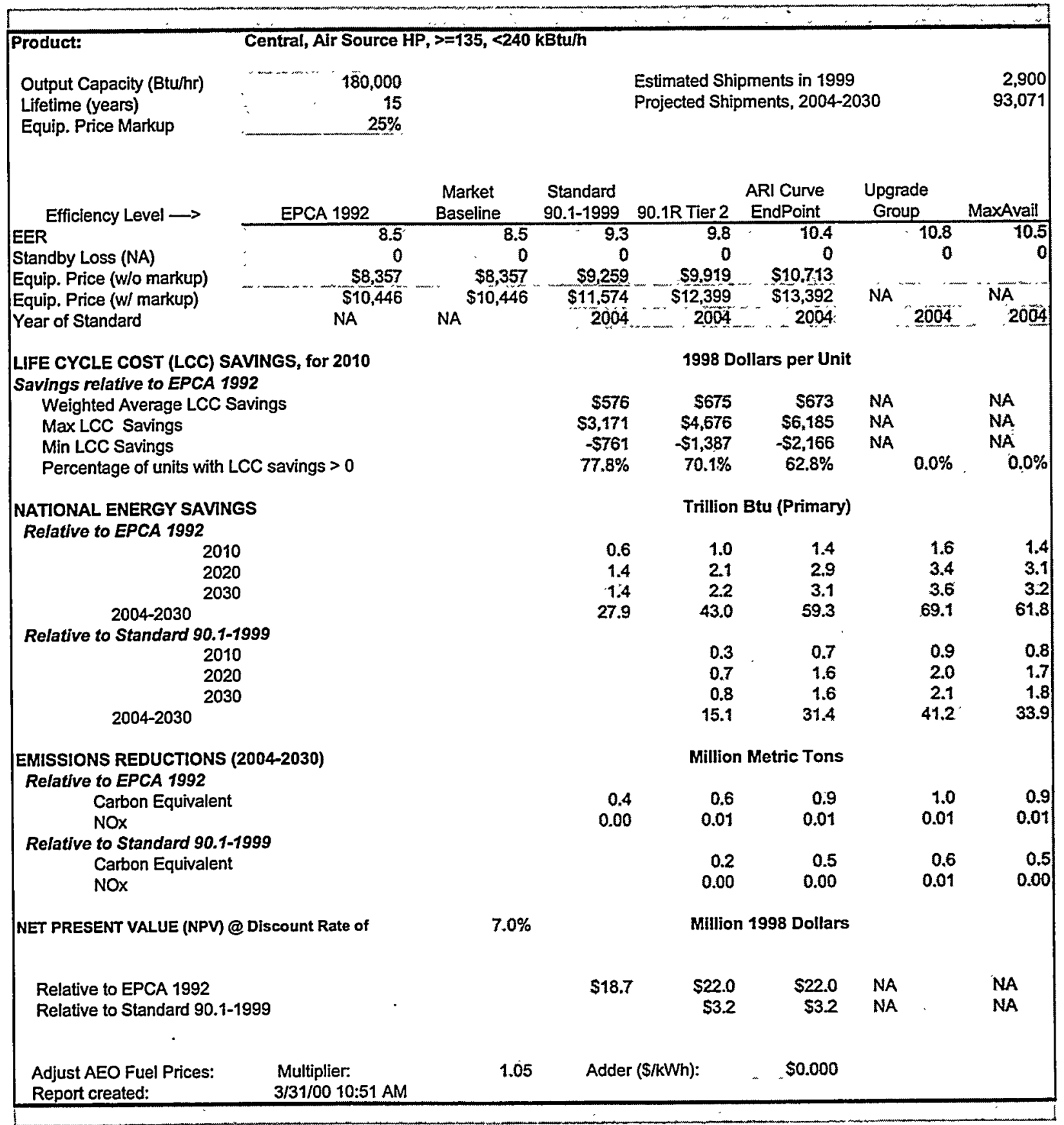




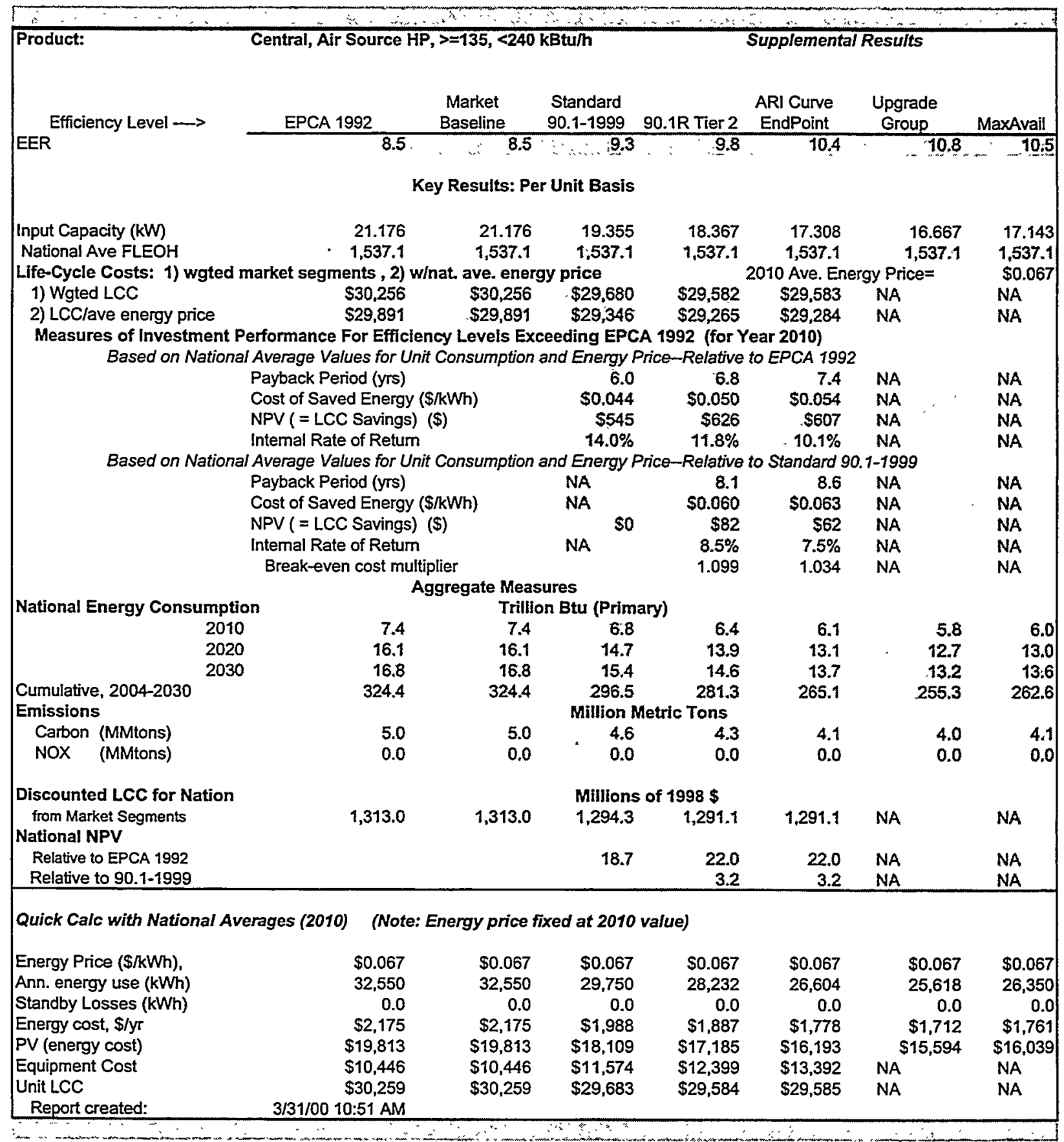




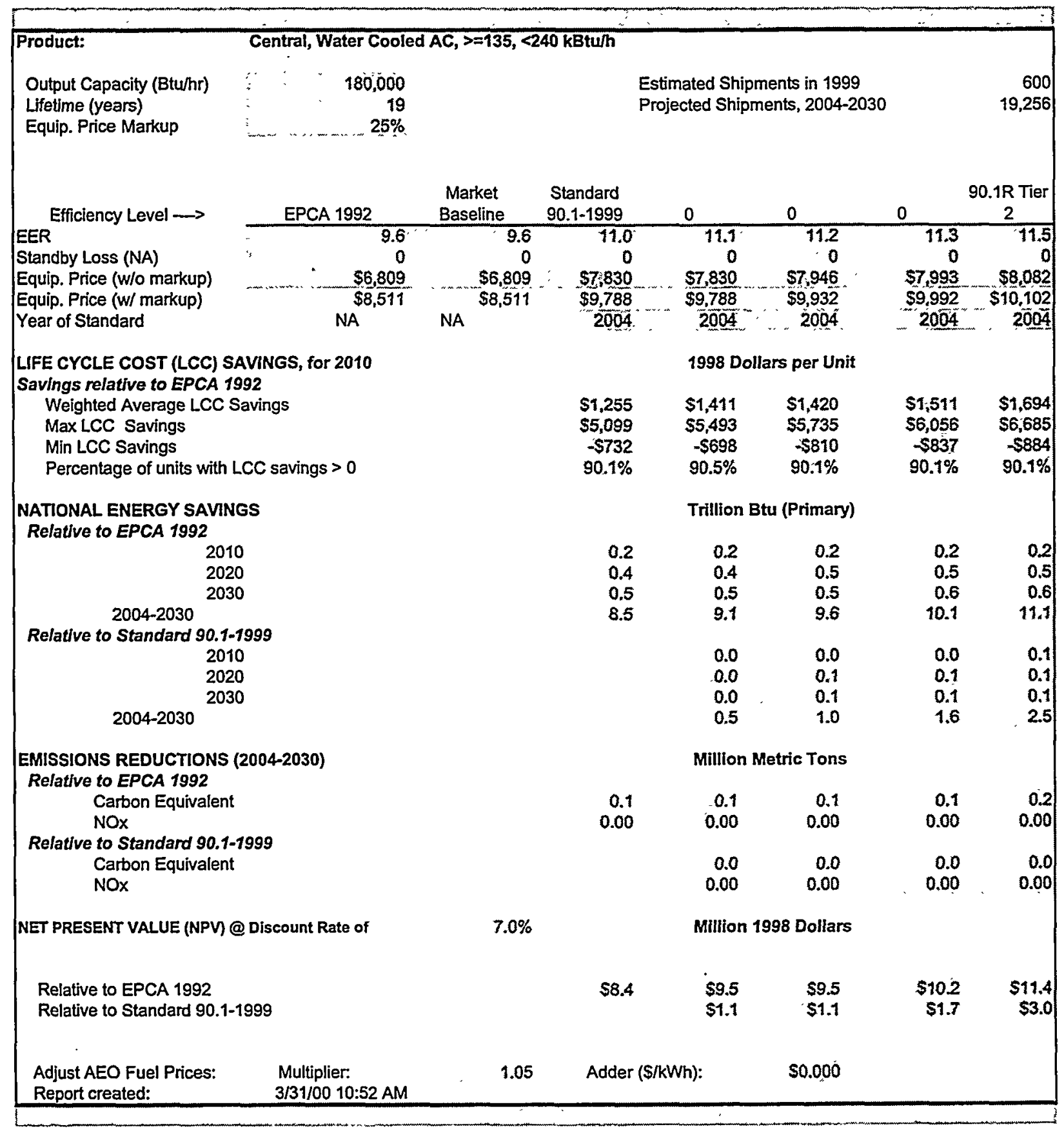




\begin{tabular}{|c|c|c|c|c|c|c|c|}
\hline \multirow{2}{*}{$\begin{array}{l}\text { Product: } \\
\text { Efficiency Level } \longrightarrow\end{array}$} & \multicolumn{3}{|c|}{ Central, Water Cooled AC, $>=135,<240 \mathrm{kBtu} / \mathrm{h}$} & \multicolumn{3}{|c|}{ Supplemental Results } & \multirow[b]{2}{*}{$\begin{array}{l}\text { 90.1R Tier } \\
\quad 2\end{array}$} \\
\hline & EPCA 1992 & $\begin{array}{l}\text { Market } \\
\text { Baseline }\end{array}$ & $\begin{array}{l}\text { Standard } \\
90.1-1999\end{array}$ & 0 & 0 & 0 & \\
\hline EER & 9.6 & 9.6 & 11.0 & 11.1 & 11.2 & 11.3 & 11.5 \\
\hline \multicolumn{8}{|c|}{ Key Results: Per Unit Basis } \\
\hline Input Capacity (kW) & 18.750 & 18.750 & 16.364 & 16.216 & 16.071 & 15.929 & 15.652 \\
\hline National Ave FLEOH & $1,537.1$ & $1,537.1$ & $1,537.1$ & $1,537.1$ & $1,537.1$ & $1,537.1$ & $1,537.1$ \\
\hline \multicolumn{5}{|c|}{ Life-Cycle Costs: 1) wgted market segments, 2) w/nat ave. energy price } & \multicolumn{2}{|c|}{2010 Ave. Energy Price $=$} & $\$ 0.067$ \\
\hline 1) Wgted LCC & $\$ 28,399$ & $\$ 28,399$ & $\$ 27,145$ & $\$ 26,988$ & $\$ 26,980$ & $\$ 26,888$ & $\$ 26,705$ \\
\hline 2) LCC/ave energy price & $\$ 28,031$ & $\$ 28,031$ & $\$ 26,823$ & $\$ 26,669$ & $\$ 26,663$ & $\$ 26,575$ & $\$ 26,397$ \\
\hline \multicolumn{8}{|c|}{$\begin{array}{l}\text { Measures of Investment Performance For Efficiency Levels Exceeding EPCA } 1992 \text { (for Year 2010) } \\
\text { Based on National Average Values for Unit Consumption and Energy Price-Relative to EPCA } 1992\end{array}$} \\
\hline & Payback Period (yrs) & & 5.2 & 4.9 & 5.2 & 5.1 & 5.0 \\
\hline & Cost of Saved Energy & kWh) & $\$ 0.034$ & $\$ 0.032$ & $\$ 0.033$ & $\$ 0.033$ & $\$ 0.032$ \\
\hline & NPV ( = LCC Savings & & $\$ 1,208$ & $\$ 1,361$ & $\$ 1,367$ & $\$ 1,456$ & $\$ 1,633$ \\
\hline & Internal Rate of Return & & $18.1 \%$ & $19.4 \%$ & $18.3 \%$ & $18.5 \%$ & $18.9 \%$ \\
\hline \multicolumn{8}{|c|}{ Based on National Average Values for Unit Consumption and Energy Price-Relative to Standard 90.1-1999 } \\
\hline & Payback Period (yrs) & & NA . & 0.0 & 4.8 & 4.6 & 4.3 \\
\hline & Cost of Saved Energy & (kWh) & NA & $\$ 0.000$ & $\$ 0.031$ & $\$ 0.030$ & $\$ 0.028$ \\
\hline & NPV ( = LCC Savings & & $\$ 0$ & $\$ 153$ & $\$ 160$ & $\$ 248$ & $\$ 426$ \\
\hline & Internal Rate of Retur & & NA & NA & $19.7 \%$ & $20.9 \%$ & $22.3 \%$ \\
\hline & Break-even cost mu & & & NA & 2.103 & 2.214 & 2.352 \\
\hline \multicolumn{8}{|c|}{$\begin{array}{ll}\text { Aggregate Measures }\end{array}$} \\
\hline \multicolumn{5}{|c|}{ National Energy Consumption } & & & \\
\hline & 1.4 & 1.4 & 1.2 & 1.2 & 1.2 & 1.2 & 1.1 \\
\hline & 3.3 & 3.3 & 2.9 & 2.9 & 2.8 & 2.8 & 2.8 \\
\hline & 3.8 & 3.8 & 3.3 & 3.3 & 3.3 & 3.3 & 3.2 \\
\hline Cumulative, $2004-2030$ & 67.1 & 67.1 & 58.6 & 58.0 & 57.5 & 57.0 & 56.0 \\
\hline Emissions & \multicolumn{7}{|c|}{ Million Metric Tons } \\
\hline Carbon (MMtons) & 1.0 & 1.0 & 0.9 & 0.9 & 0.9 & 0.9 & 0.9 \\
\hline NOX (MMtons) & 0.0 & 0.0 & 0.0 & 0.0 & 0.0 & 0.0 & 0.0 \\
\hline \multicolumn{3}{|l|}{ Discounted LCC for Nation } & \multicolumn{2}{|c|}{ Millions of 1998 \$ } & & & \\
\hline \multicolumn{7}{|l|}{ National NPV } & 243.5 \\
\hline Relative to EPCA 1992 & & & 8.4 & 9.5 & 9.5 & 10.2 & 11.4 \\
\hline Relative to $90.1-1999$ & & & & 1.1 & 1.1 & 1.7 & 3.0 \\
\hline \multicolumn{8}{|c|}{ Quick Calc with National Averages (2010) (Note: Energy price fixed at 2010 value) } \\
\hline Energy Price (\$/kWh), & $\$ 0.067$ & $\$ 0.067$ & \$0.067 & $\$ 0.067$ & $\$ 0.067$ & $\$ 0.067$ & $\$ 0.067$ \\
\hline Ann. energy use ( $k W h)$ & 28,821 & 28,821 & 25,153 & 24,926 & 24,703 & 24,485 & 24,059 \\
\hline Standby Losses (kWh) & 0.0 & 0.0 & 0.0 & 0.0 & 0.0 & 0.0 & 0.0 \\
\hline Energy cost, \$/yr & $\$ 1,926$ & $\$ 1,926$ & $\$ 1,681$ & $\$ 1,666$ & $\$ 1,651$ & $\$ 1,636$ & $\$ 1,608$ \\
\hline PV (energy cost) & $\$ 19,908$ & $\$ 19,908$ & $\$ 17,374$ & $\$ 17,217$ & $\$ 17,064$ & $\$ 16,913$ & $\$ 16,619$ \\
\hline Equipment Cost & $\$ 8,511$ & $\$ 8,511$ & $\$ 9,788$ & $\$ 9,788$ & $\$ 9,932$ & $\$ 9,992$ & $\$ 10,102$ \\
\hline $\begin{array}{l}\text { Unit LCC } \\
\text { Report created: }\end{array}$ & $\begin{array}{r}\$ 28,418 \\
3 / 31 / 00 \text { 10:52 AM }\end{array}$ & $\$ 28,418$ & $\$ 27,161$ & $\$ 27,005$ & $\$ 26,996$ & $\$ 26,904$ & $\$ 26,721$ \\
\hline
\end{tabular}




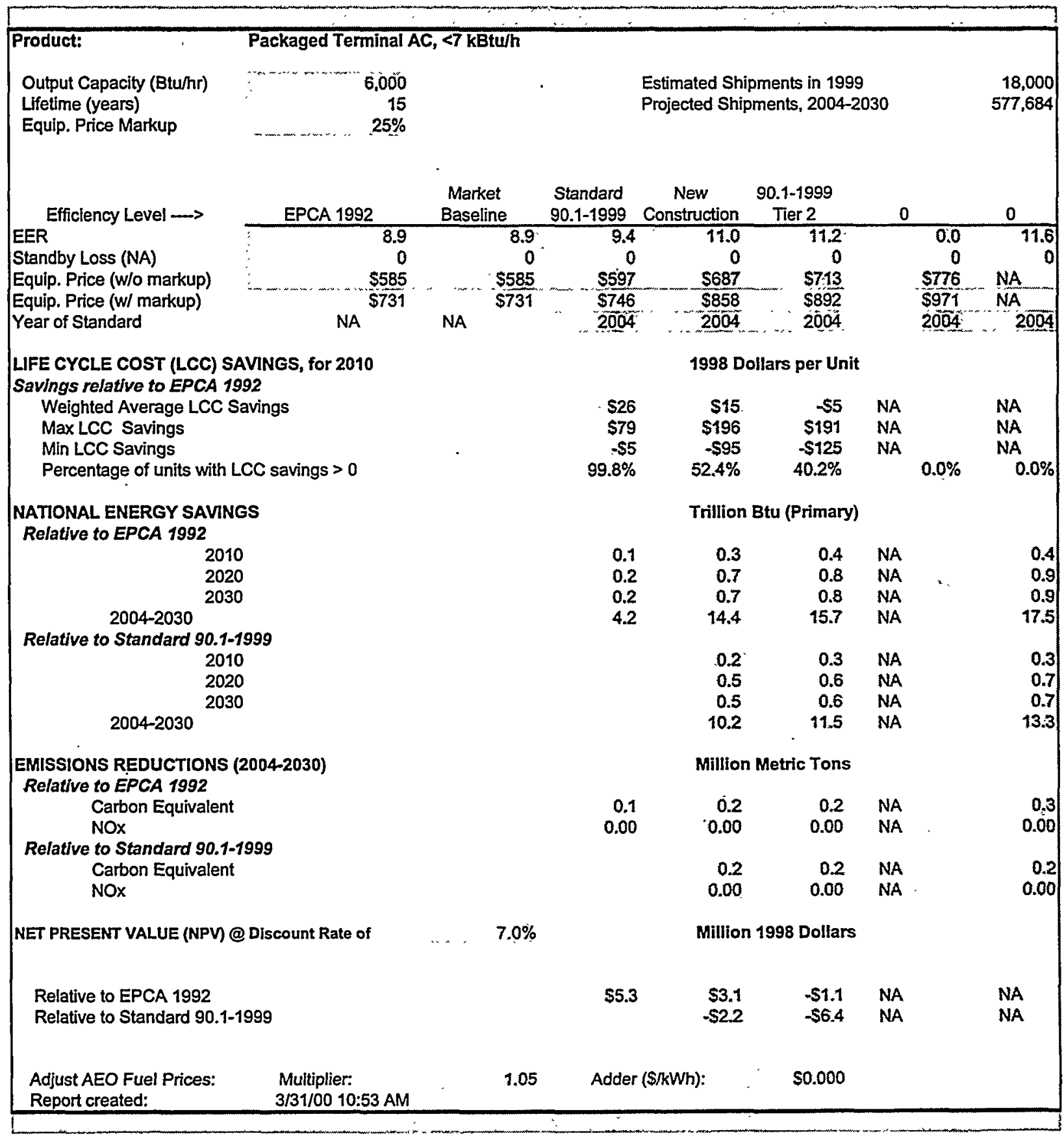




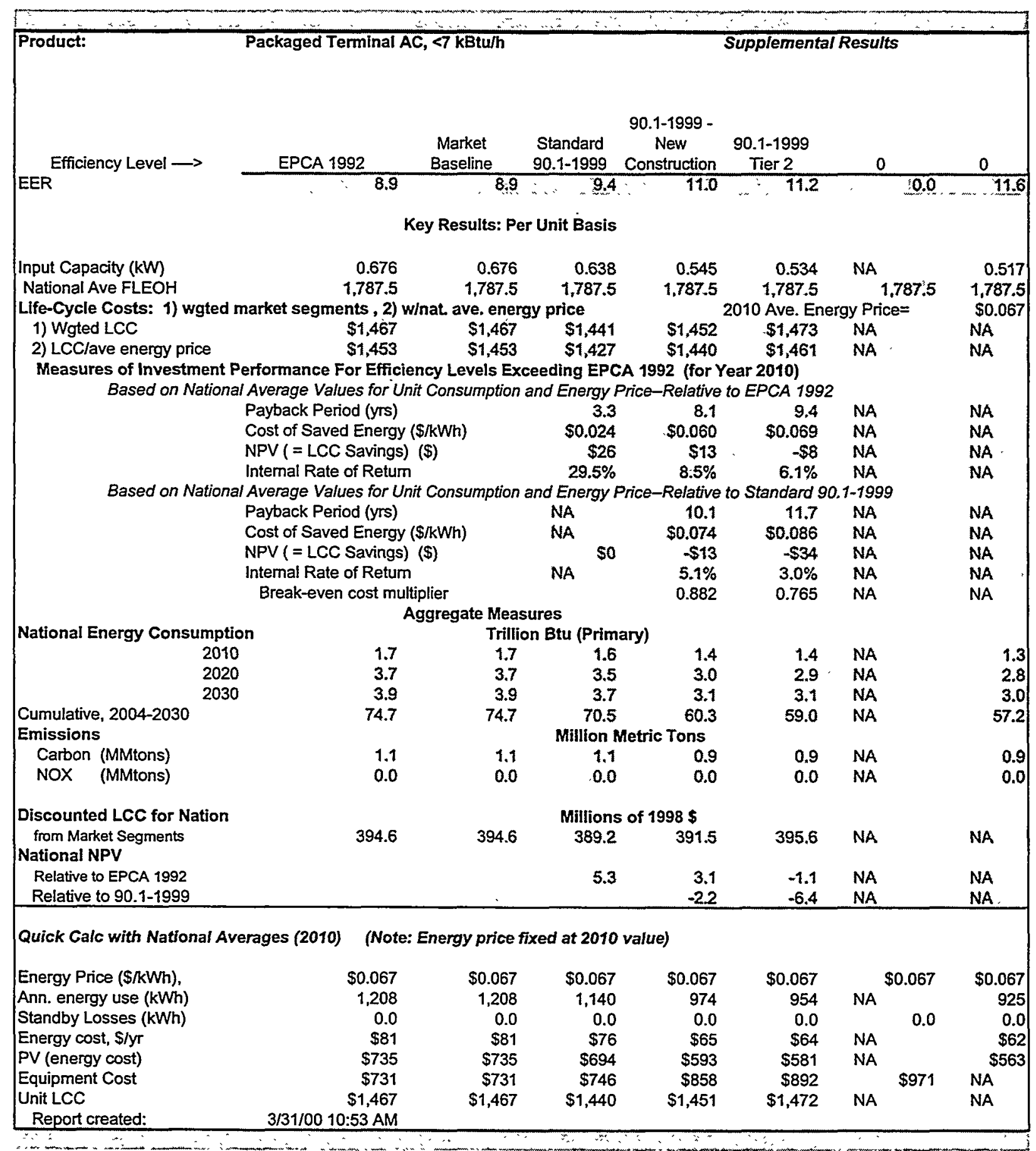




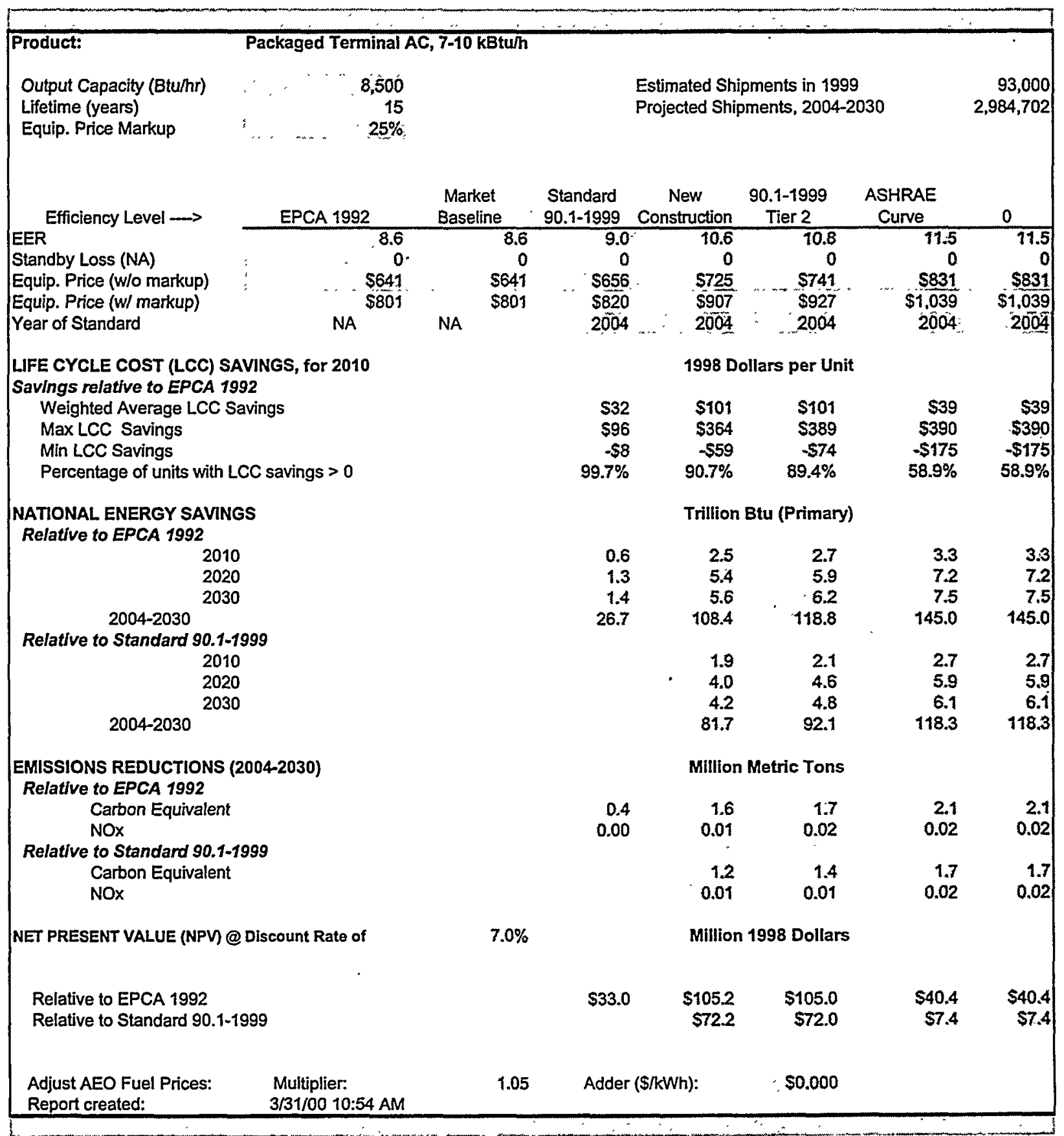




\begin{tabular}{|c|c|c|c|c|c|c|c|}
\hline \multirow[t]{2}{*}{ Product: } & \multicolumn{2}{|c|}{ Packaged Terminal AC, 7-10 kBtu/h } & \multicolumn{5}{|c|}{ Supplemental Results } \\
\hline & EPCA 1992 & $\begin{array}{l}\text { Market } \\
\text { Baseline }\end{array}$ & $\begin{array}{c}\text { Standard } \\
90.1-1999\end{array}$ & $\begin{array}{c}90.1-1999 \text { - } \\
\text { New } \\
\text { Construction }\end{array}$ & $\begin{array}{c}90.1-1999 \\
\text { Tier } 2\end{array}$ & $\begin{array}{l}\text { EndPoint } \\
\text { ASHRAE } \\
\text { Curve }\end{array}$ & 0 \\
\hline EER & 1. & 8.6 & 9.0 & 10.6 & 10.8 & 11.5 & 11.5 \\
\hline \multicolumn{8}{|c|}{ Key Results: Per Unit Basis } \\
\hline Input Capacity (kW) & 0.993 & 0.993 & 0.946 & 0.803 & 0.785 & 0.739 & 0.739 \\
\hline National Ave FLEOH & $1,787.5$ & 1.787 .5 & $1,787,5$ & $1,787.5$ & $1,787.5$ & $1,787.5$ & $1,787.5$ \\
\hline \multicolumn{7}{|c|}{ Life-Cycle Costs: 1) wgted market segments, 2) w/nat. ave. energy price } & $\$ 0.067$ \\
\hline 1) Wgted LCC & $\$ 1,882$ & $\$ 1,882$ & $\$ 1,851$ & $\$ 1.782$ & $\$ 1,782$ & $\$ 1,844$ & $\$ 1,844$ \\
\hline 2) LCClave energy price & W1861 & $\$ 1,861$ & $\$ 1,831$ & $\$ 1,764$ & $\$ 1,765$ & $\$ 1,828$ & $\$ 1,828$ \\
\hline \multicolumn{8}{|c|}{$\begin{array}{l}\text { Measures of Investment Performance For Efficiency Levels Exceeding EPCA } 1992 \text { (for Year 2010) } \\
\text { Based on National Average Values for Unit Consumption and Energy Price-Relative to EPCA } 1992\end{array}$} \\
\hline & Payback Period (yrs) & & 3.4 & 47 & 5.1 & & 7.8 \\
\hline & Cost of Saved Energy & (kWh) & 80.025 & $\$ 0.034$ & $\$ 0.037$ & $\$ 0.058$ & $\$ 0.058$ \\
\hline & NPV ( = LCC Savings & & $\$ 31$ & $\$ 97$ & $\$ 96$ & $\$ 33$ & $\$ 33$ \\
\hline & Internal Rate of Retur & & $27.9 \%$ & $19.7 \%$ & $17.8 \%$ & $0.1 \%$ & $9.1 \%$ \\
\hline \multicolumn{8}{|c|}{ Based on National Average Values for Unit Consumption and Energy Price-Relative to Standard 90.1-18999 } \\
\hline & Payback Period (yrs) & & NA & 5.1 & 5.5 & 8.8 & 8.8 \\
\hline & Cost of Saved Energy & (kWh) & NA & $\$ 0.037$ & $\$ 0.041$ & $\$ 0.065$ & $\$ 0.065$ \\
\hline & NPV ( = LCC Savings & & $\$ 0$ & $\$ 66$ & $\$ 66$ & $\$ 2$ & $\$ 2$ \\
\hline & Internal Rate of Retur & & NA & $17.8 \%$ & $15.8 \%$ & $7.2 \%$ & $7.2 \%$ \\
\hline & Break-even cost mu & & & 1.766 & 1.616 & 1.011 & 1.011 \\
\hline \multicolumn{8}{|c|}{ Aggregate Measures } \\
\hline \multicolumn{5}{|c|}{ National Energy Consumption } & & & \\
\hline 20 & 13.0 & 13.0 & 12.4 & 10.5 & 10.3 & 9.7 & 9.7 \\
\hline 20 & 28.1 & 28.1 & 26.8 & 22.7 & 22.2 & 20.9 & 20.9 \\
\hline 20 & 29.4 & 29.4 & 28.0 & 23.8 & 23.3 & 21.9 & 21.9 \\
\hline Cumulative, 2004-2030 & 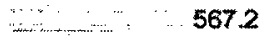 & 567.2 & 540.5 & 4588 & 448.4 & 422.2 & 422,2 \\
\hline Emissions & \multicolumn{6}{|c|}{ Million Metric Tons } & \\
\hline Carbon (MMtons) & $\therefore \quad \cdots+\cdots$ & 8.7 & 8.3 & 7.1 & 7.0 & 6.6 & 6.6 \\
\hline NOX (MMtons) & $\alpha_{n}$ & 0.1 & 0.1 & 0.1 & 0.1 & 0.1 & 0.1 \\
\hline \multicolumn{3}{|l|}{ Discounted LCC for Nation } & \multicolumn{2}{|c|}{ Millions of 1998} & & & \\
\hline $\begin{array}{l}\text { from Market Segments } \\
\text { National NPV }\end{array}$ & $2,617.6$ & $2,617,6$ & $2,584.6$ & $2,512,4$ & $2,512.6$ & $2,577.2$ & $2,577.2$ \\
\hline \multicolumn{2}{|l|}{$\begin{array}{l}\text { Relative to EPCA } 1992 \\
\text { Relative to } 90.1-1999\end{array}$} & & -33.0 & $\begin{array}{r}105.2 \\
72.2\end{array}$ & $\begin{array}{r}105.0 \\
72.0\end{array}$ & $\begin{array}{r}40.4 \\
7.4\end{array}$ & $\begin{array}{r}40.4 \\
7.4\end{array}$ \\
\hline \multicolumn{8}{|c|}{ Quick Calc with National Averages (2010) (Note: Energy price fixed at 2010 value) } \\
\hline Energy Price (\$/kWh), & $\$ 0.067$ & $\$ 0.067$ & $\$ 0.067$ & $\$ 0.067$ & $\$ 0.067$ & $\$ 0.067$ & $\$ 0.067$ \\
\hline Ann. energy use (kWh) & 1,775 & 1,775 & 1,691 & 1,436 & 1,403 & 1,321 & 1,321 \\
\hline Standby Losses (kWh) & 0.0 & 0.0 & 0.0 & 0.0 & 0.0 & 0.0 & 0.0 \\
\hline Energy cost, \$/yr & $\$ 119$ & $\$ 119$ & $\$ 113$ & $\$ 96$ & $\$ 94$ & $\$ 88$ & $\$ 88$ \\
\hline PV (energy cost) & $\$ 1,080$ & $\$ 1,080$ & $\$ 1,030$ & $\$ 874$ & $\$ 854$ & $\$ 804$ & $\$ 804$ \\
\hline Equipment Cost & $\$ 801$ & $\$ 801$ & $\$ 820$ & $\$ 907$ & $\$ 927$ & $\$ 1,039$ & $\$ 1,039$ \\
\hline Unit LCC & $\$ 1,882$ & $\$ 1,882$ & $\$ 1,850$ & $\$ 1,781$ & $\$ 1,781$ & $\$ 1,843$ & $\$ 1,843$ \\
\hline Report created: & $3 / 31 / 00$ 10:54 AM & & & & & & \\
\hline
\end{tabular}




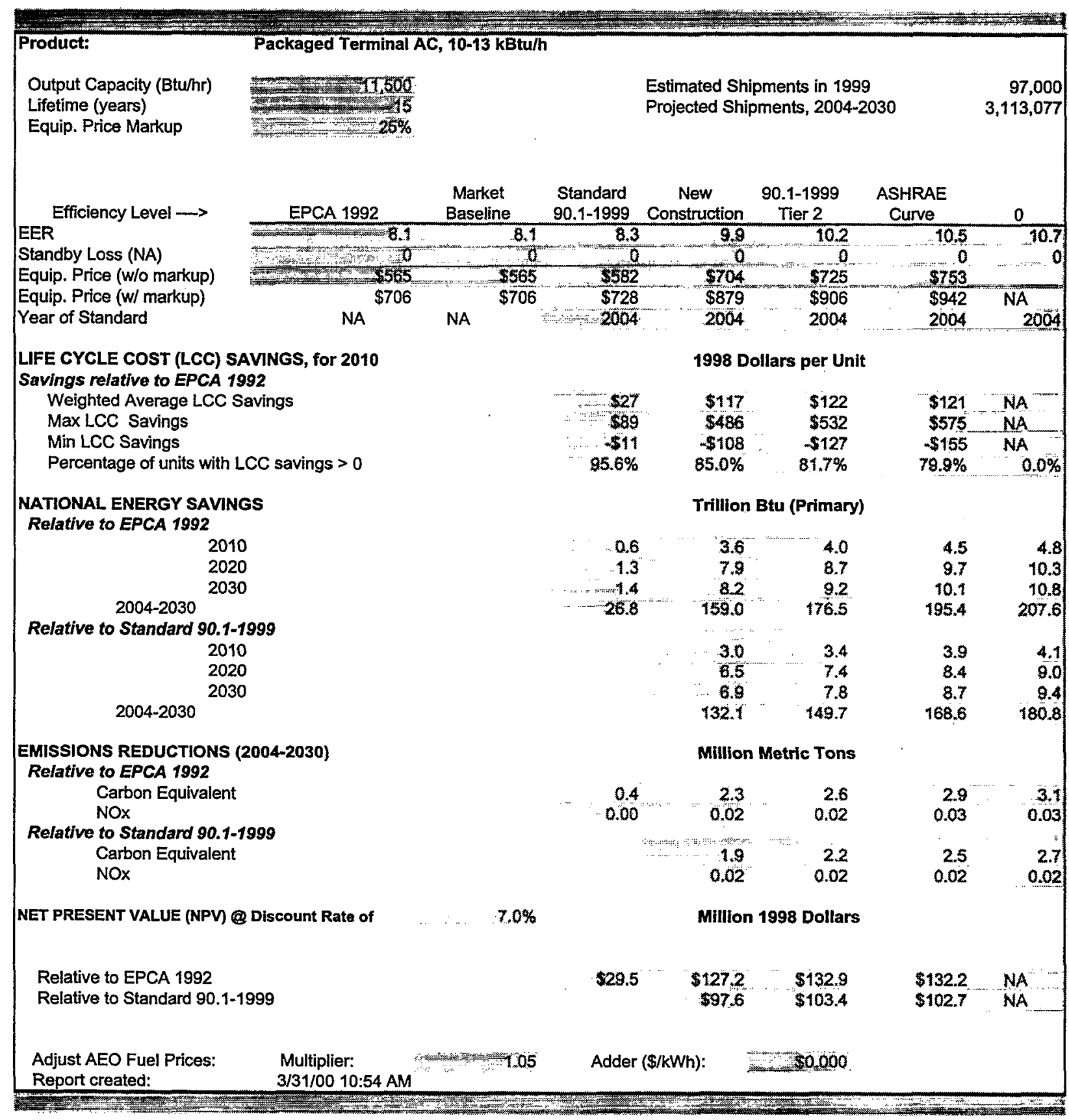




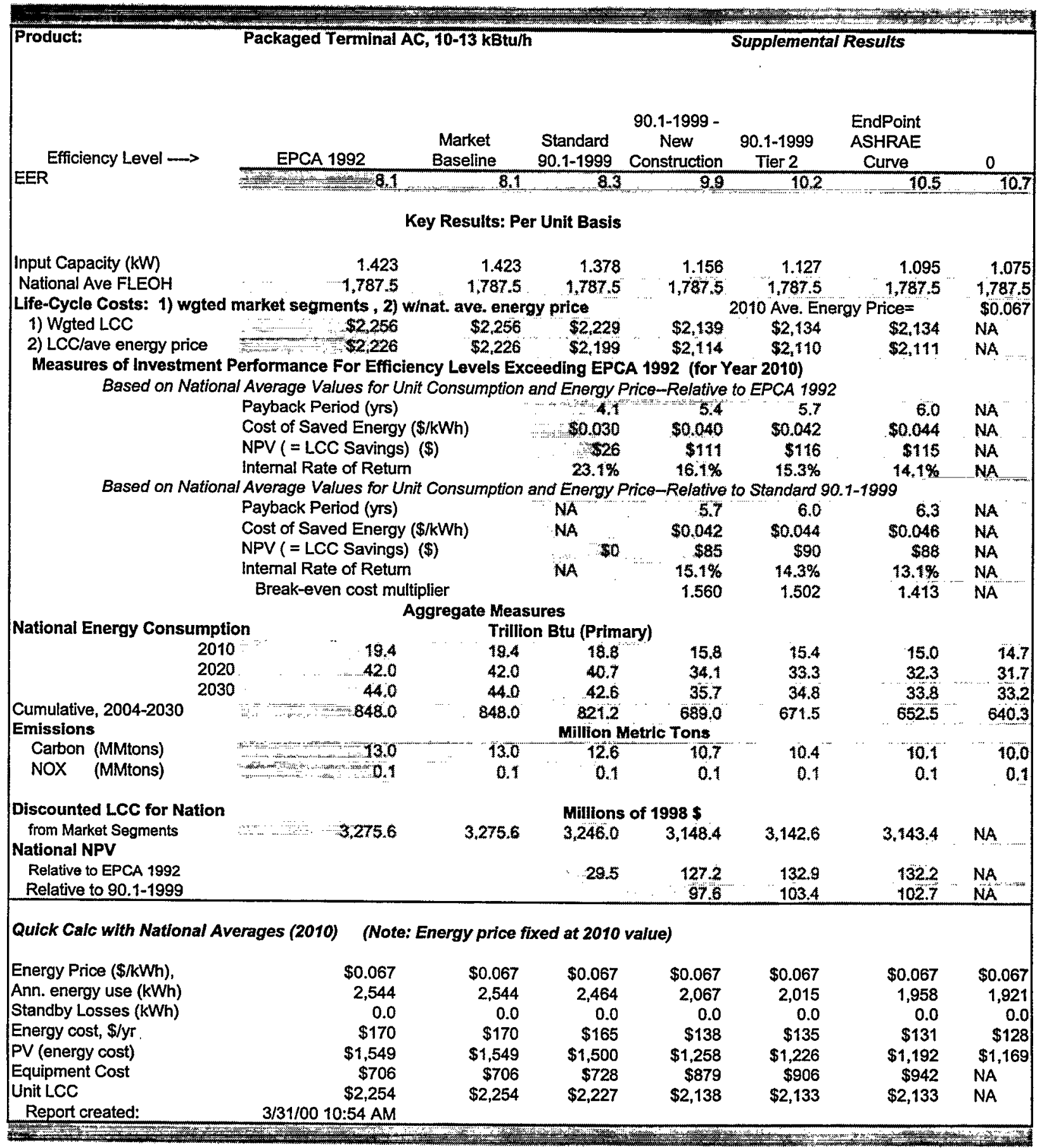




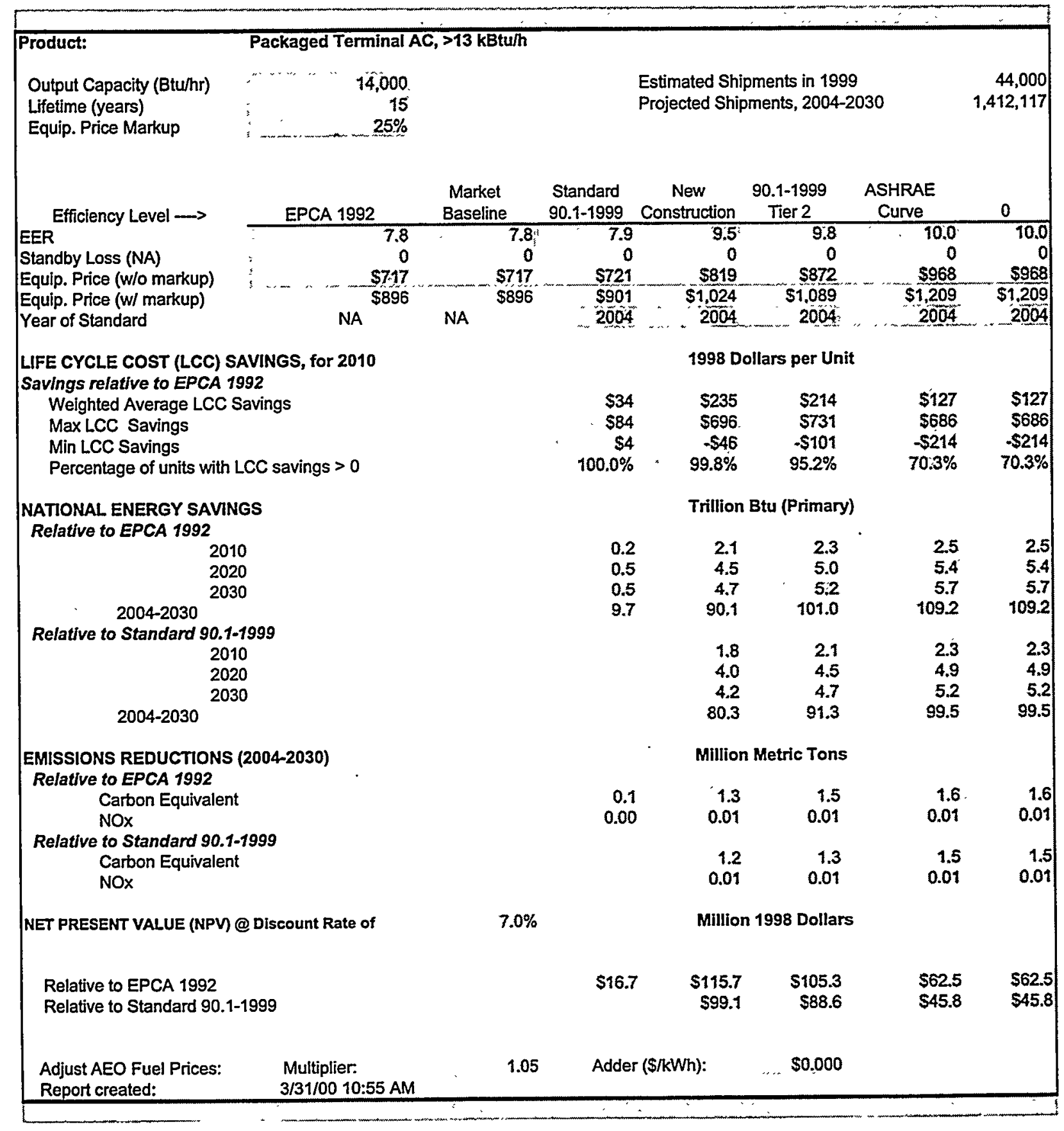




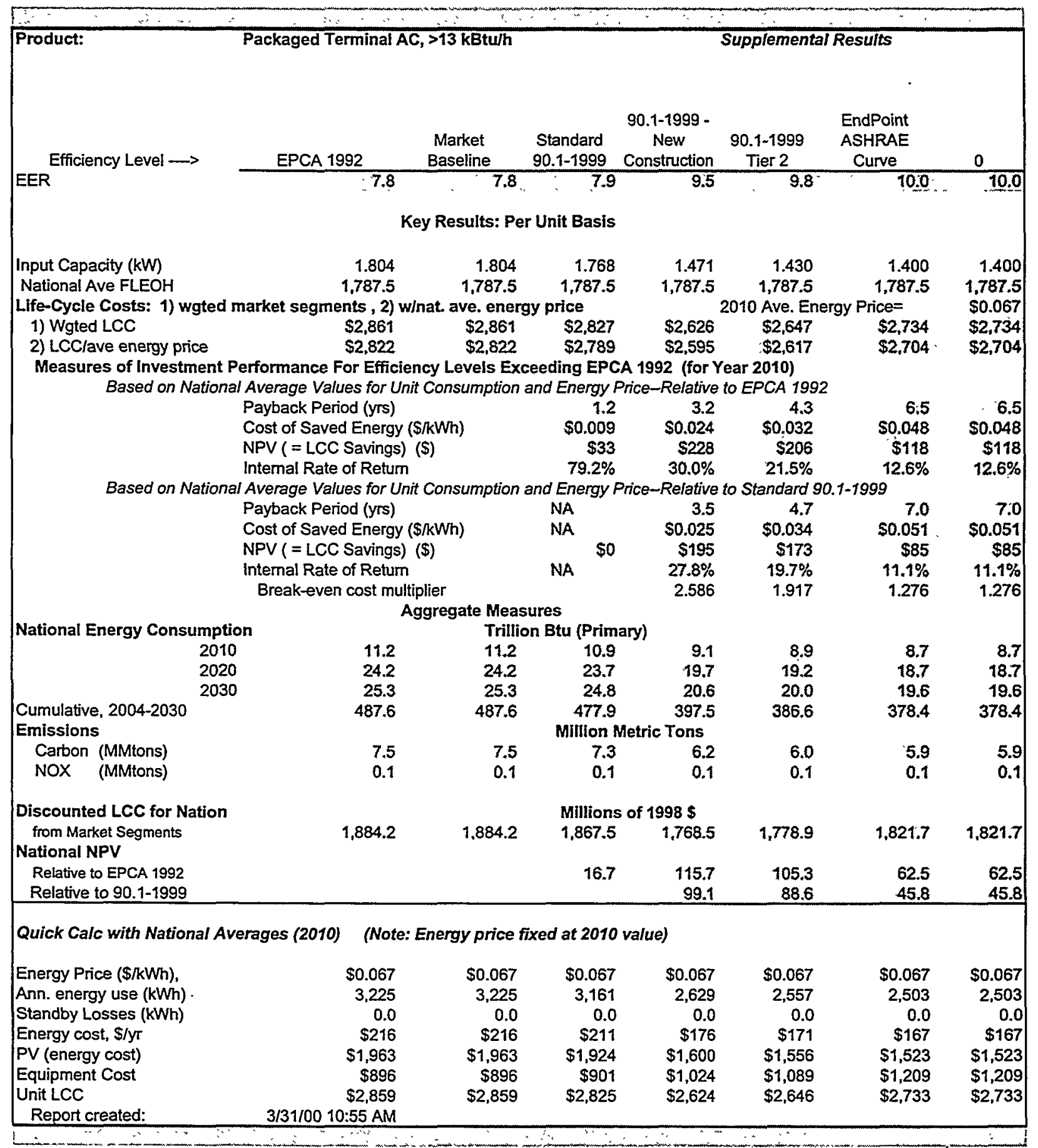




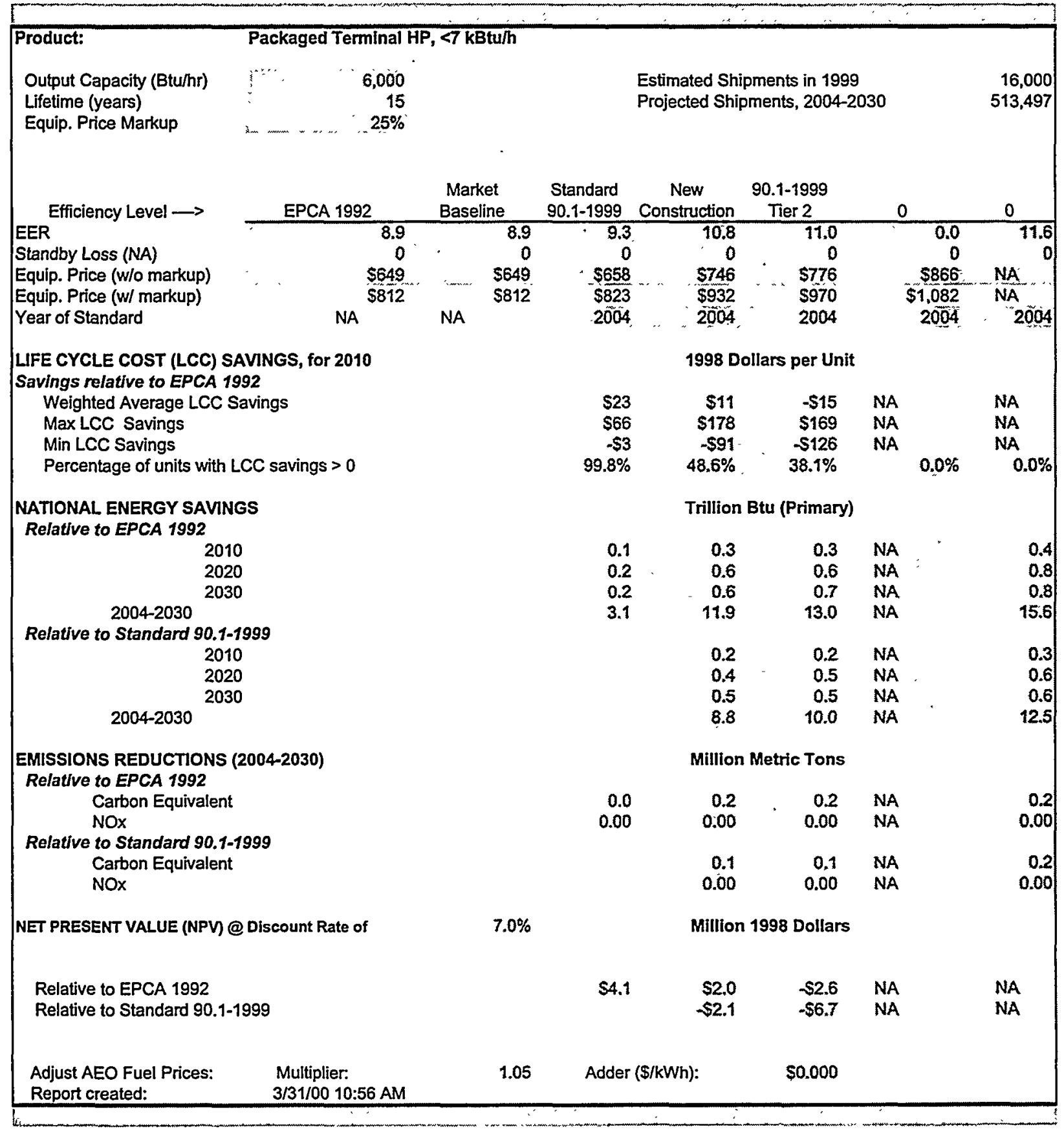




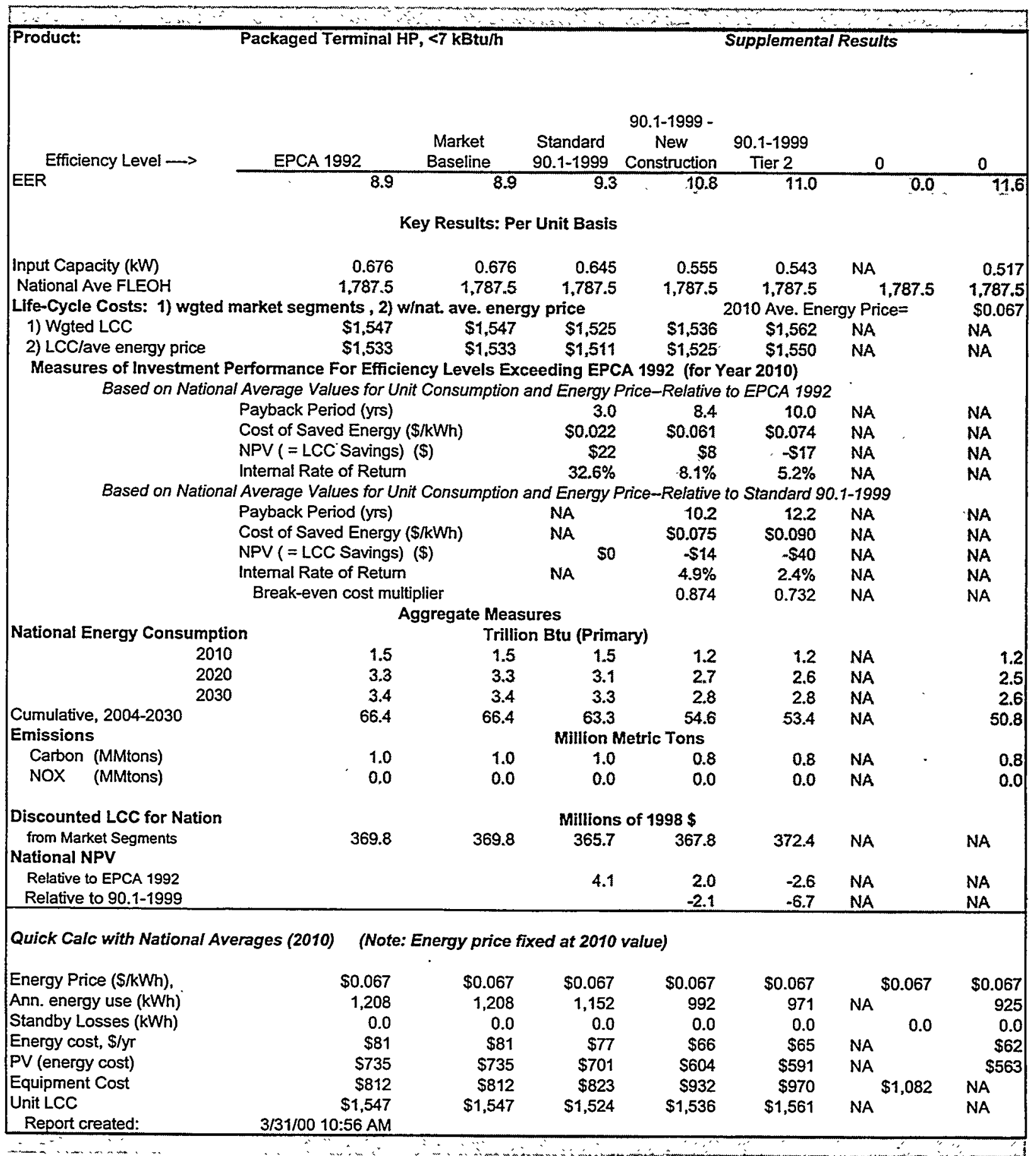




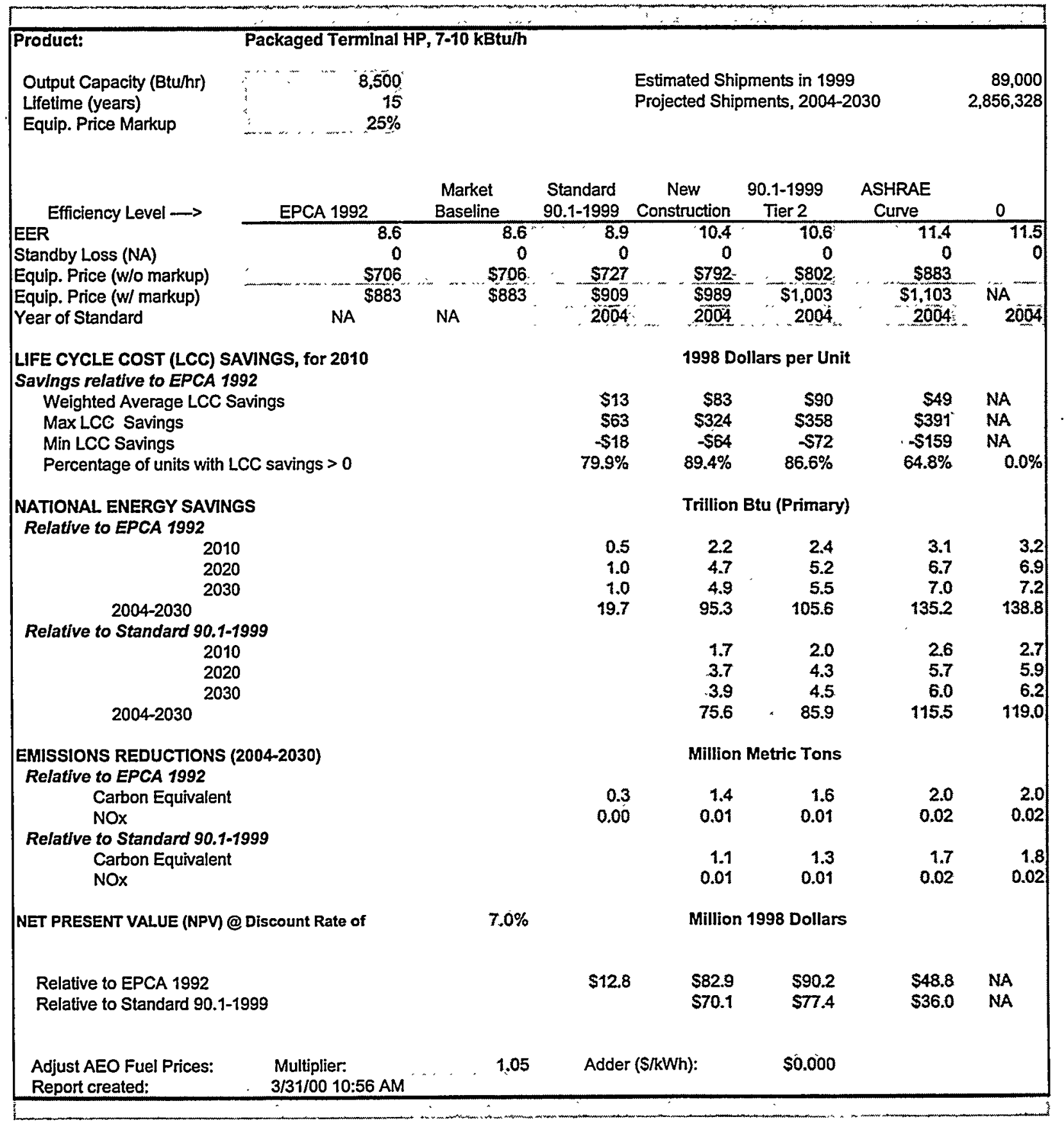




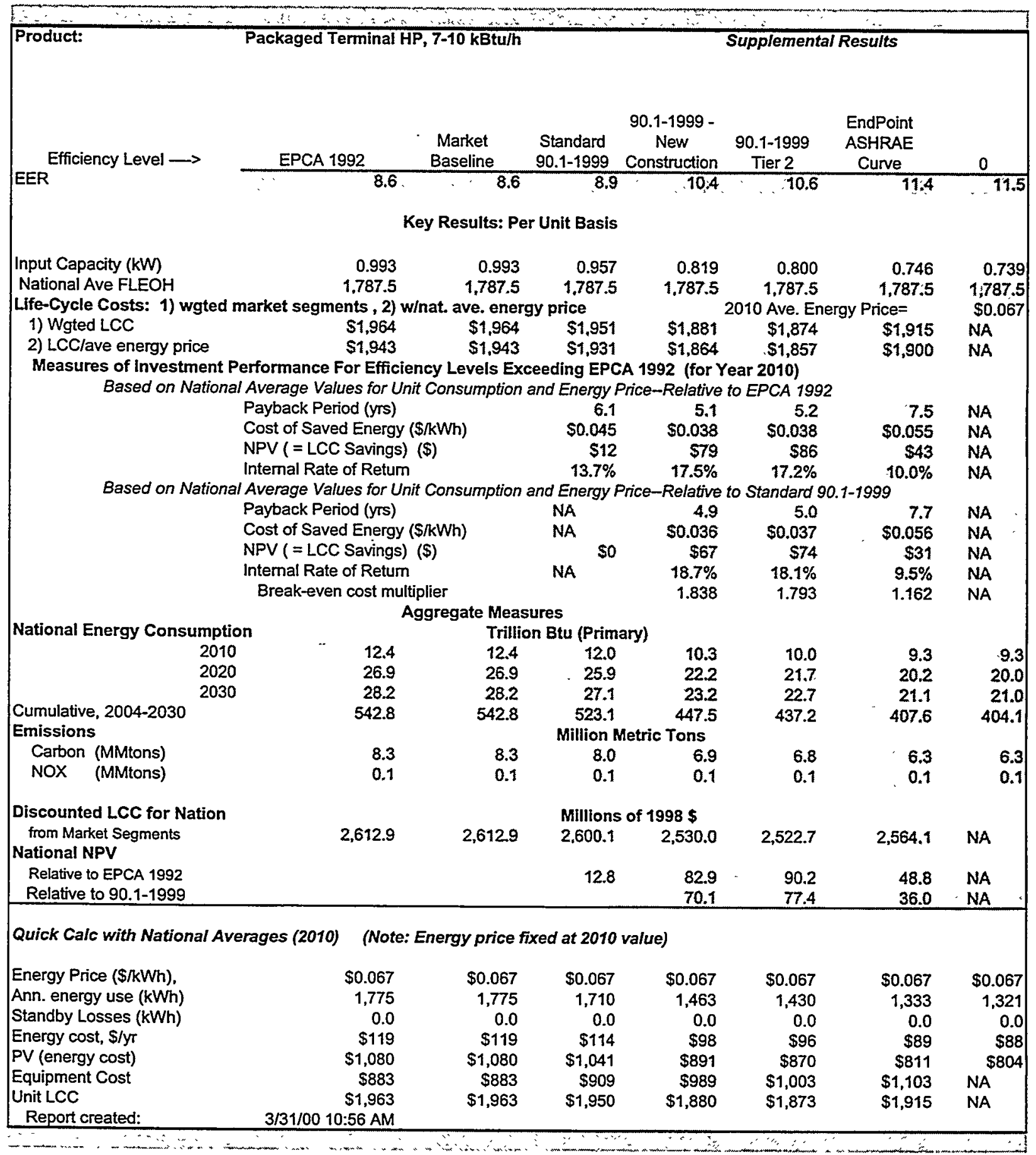




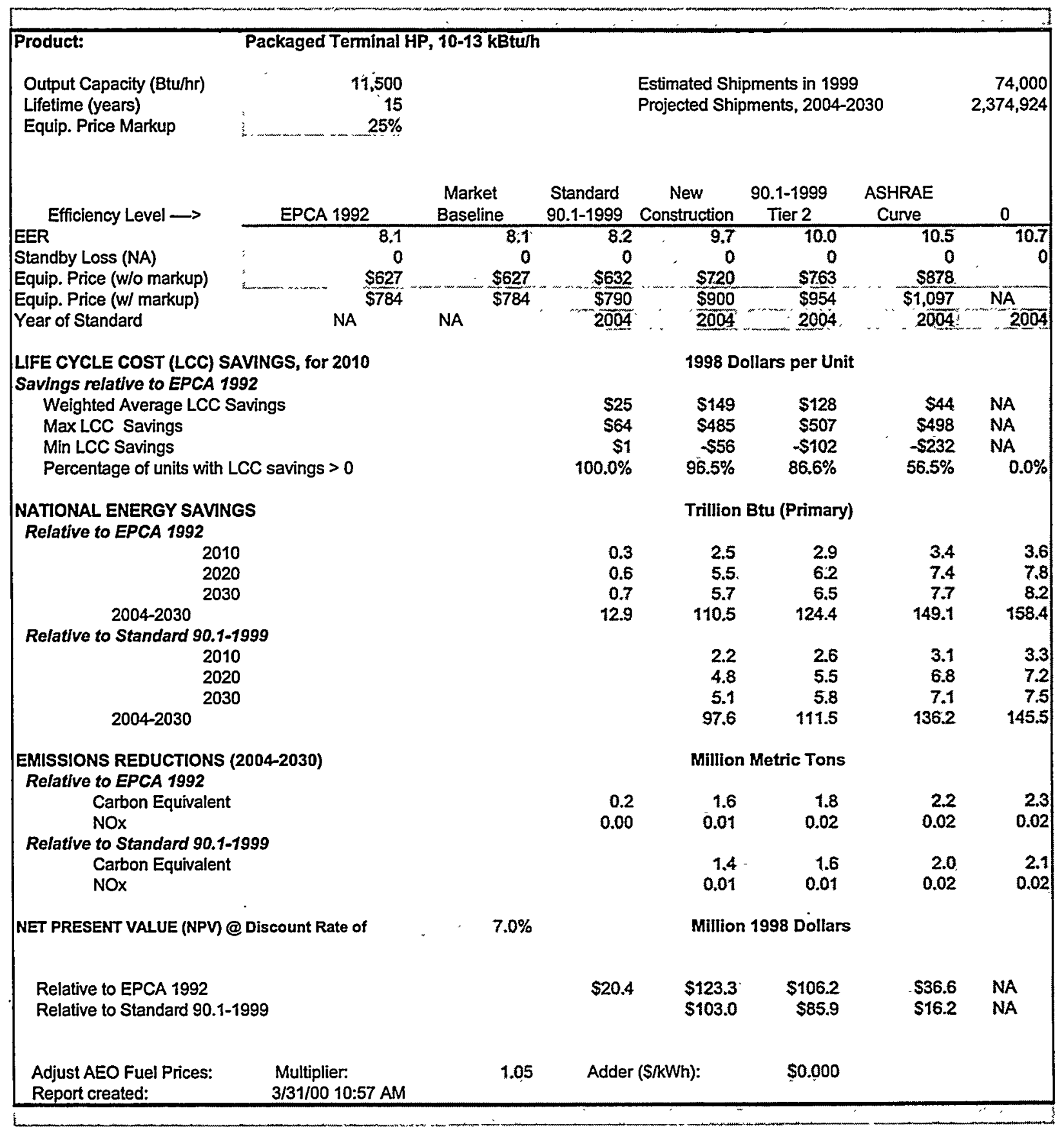




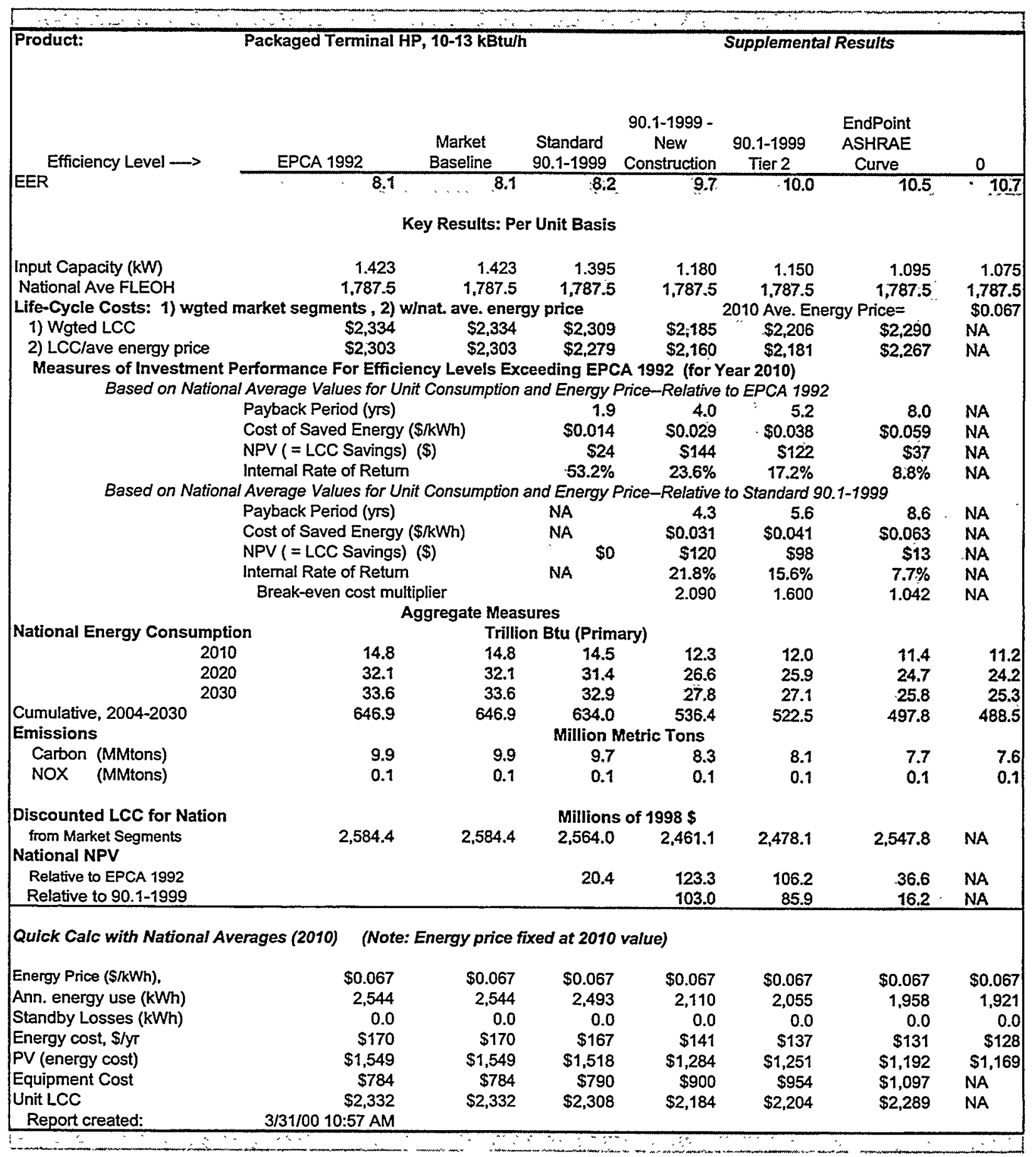




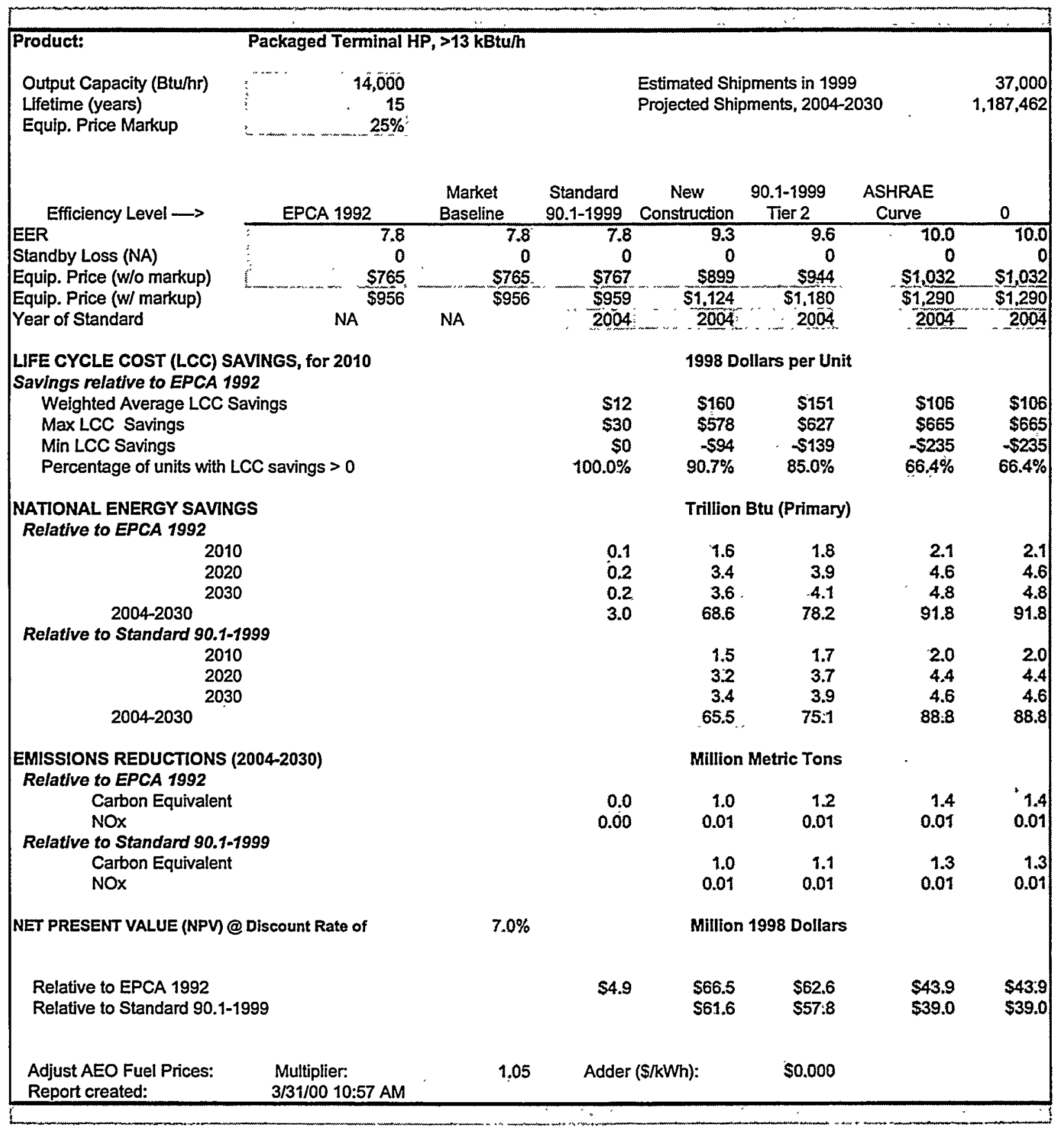




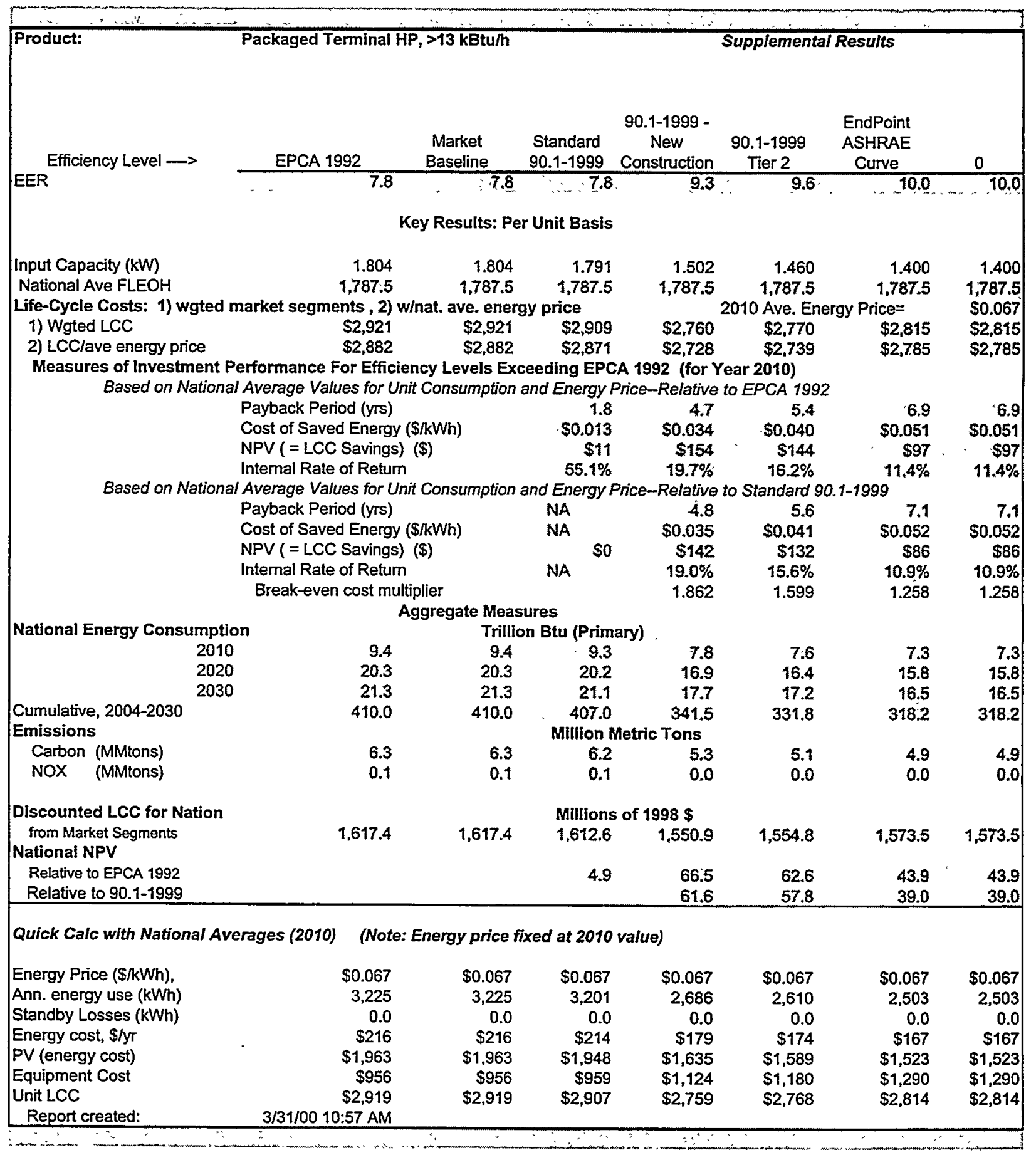




\begin{tabular}{|c|c|c|c|c|c|c|c|c|}
\hline Product: & Pkg'd Bollers, Gas, 4 & $\mathbf{k B}$ & ah, HW & & & & & \\
\hline Output Capacity (Btu/hr) & $\vdots \quad \sim \quad 400,000$ & & & & Estimated Sh & pments in 199 & & 2,821 \\
\hline Lifetime (years) & $\quad 30$ & & & & Projected Sh & Pments, 2004 & 2030 & 90,536 \\
\hline Efficiency Level $\longrightarrow$ & EPCA 1992 & $\begin{array}{l}\text { Ma } \\
\text { Bas }\end{array}$ & $\begin{array}{l}\text { rket } \\
\text { eline }\end{array}$ & $\begin{array}{c}\text { Standard } \\
90.1-1999\end{array}$ & Testlevel1 & TestLevel2 & Testlevel3 & MaxAvail \\
\hline Thermal Efficiency (\%) & 75.0 & & 75.0 & 75.0 & 78.0 & 79.0 & 81.0 & 88.0 \\
\hline Standby Loss (NA) & 0 & & & 0 & 0 & 0 & 0 & 0 \\
\hline Equip. Price (w/o markup) & $\$ 3,972$ & & $\$ 3,972$ & $\$ 3,972$ & $\$ 4,585$ & $\$ 5,262$ & $\$ 8,291$ & $\$ 12,636$ \\
\hline Equip. Price (w/ markup) & $\$ 4,966$ & & $\$ 4,966$ & $\$ 4,966$ & $\$ 5.732$ & $\$ 6,578$ & $\$ 10,364$ & $\$ 15,795$ \\
\hline Year of Standard & NA & NA & & $\therefore 2004$ & 2004 & 2004 & 2004 & 2004 \\
\hline LIFE CYCLE COST (LCC) & VINGS, for 2010 & & & & $1998 \mathrm{D}$ & ollars per-Uni & & \\
\hline Savings relative to EPCA & & & & & & & & \\
\hline Weighted Average LCC & avings & & & So &.$\$ 566$ & $\$ 141$ & $-\$ 2,834$ & $\$ 5,715$ \\
\hline Max LCC Savings & & & & \$o & $\$ 3,122$ & $\$ 3,506$ & $\$ 2,089$ & $\$ 4,104$ \\
\hline Min LCC Savings & & & & $50^{\circ}$ & $-\$ 718$ & $-\$ 1,549$ & $-\$ 5,306$ & $-\$ 10,645$ \\
\hline Percentage of units witl & CC savings $>0$ & & & $100.0 \%$ & $81.3 \%$ & $58.5 \%$ & $4.6 \%$ & $4.6 \%$ \\
\hline NATIONAL ENERGY SAV & & & & & Trillior & Btu (Primary & & \\
\hline Rerauve to LPCA 7994 & & & & 0 & 05 & 06 & na & 18 \\
\hline & & & & 0.0 & 1.2 & 1.5 & 2.3 & $\begin{array}{l}1.8 \\
4.5\end{array}$ \\
\hline & & & & 0.0 & 2.0 & 2.6 & 3.8 & 7.5 \\
\hline $2004-2030$ & & & & 0.0 & 26.3 & 34.7 & 50.7 & 101.1 \\
\hline Relative to Standard 90. & 999 & & & & & & & \\
\hline & & & & & 0.5 & 0.6 & 0.9 & 1.8 \\
\hline & & & & & 1.2 & 1.5 & 2.3 & 4.5 \\
\hline & & & & & 20 & 2.6 & 3.8 & 7.5 \\
\hline 2004-2030 & & & & & 26.3 & 34.7 & 50.7 & 101.1 \\
\hline EMISSIONS REDUCTION & 2004-2030) & & & & Millior & Metric Tons & & \\
\hline Relative to EPCA 1992 & & & & & & & & \\
\hline Carbon Equivale & & & & 0.0 & 0.4 & 0.5 & 0.7 & 1.5 \\
\hline $\begin{array}{c}\text { NOx } \\
\text { Relative to Standard } 90 .\end{array}$ & 999 & & & 0.00 & 0.00 & 0.00 & 0.01 & 0.01 \\
\hline $\begin{array}{l}\text { Carbon Equivale } \\
\text { NOx }\end{array}$ & & & - & & $\begin{array}{r}0.4 \\
0.00\end{array}$ & $\begin{array}{r}0.5 \\
0.00\end{array}$ & $\begin{array}{r}0.7 \\
0.01\end{array}$ & $\begin{array}{r}1.5 \\
0.01\end{array}$ \\
\hline NET PRESENT VALUE (NPV & Discount Rate of & & $7.0 \%$ & & Millior & 1998 Dollars & & \\
\hline $\begin{array}{l}\text { Relative to EPCA } 1992 \\
\text { Relative to Standard } 90 .\end{array}$ & 999 & & & \$0.0 & $\begin{array}{r}\$ 17.9 \\
-\$ 17.9\end{array}$ & $\begin{array}{l}\$ 4.5 \\
\$ 4.5\end{array}$ & $\begin{array}{l}-\$ 89.4 \\
\$ 89.4\end{array}$ & $\begin{array}{l}\$ 180.2 \\
-\$ 180.2\end{array}$ \\
\hline $\begin{array}{l}\text { Adjust AEO Fuel Prices: } \\
\text { Report created: }\end{array}$ & $\begin{array}{l}\text { Multiplier: } \\
\text { 3/31/00 11:01 AM }\end{array}$ & 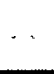 & 1.00 & Adder $(\$ / M$ & AMBtu): & $\$ 0.000$ & & \\
\hline
\end{tabular}




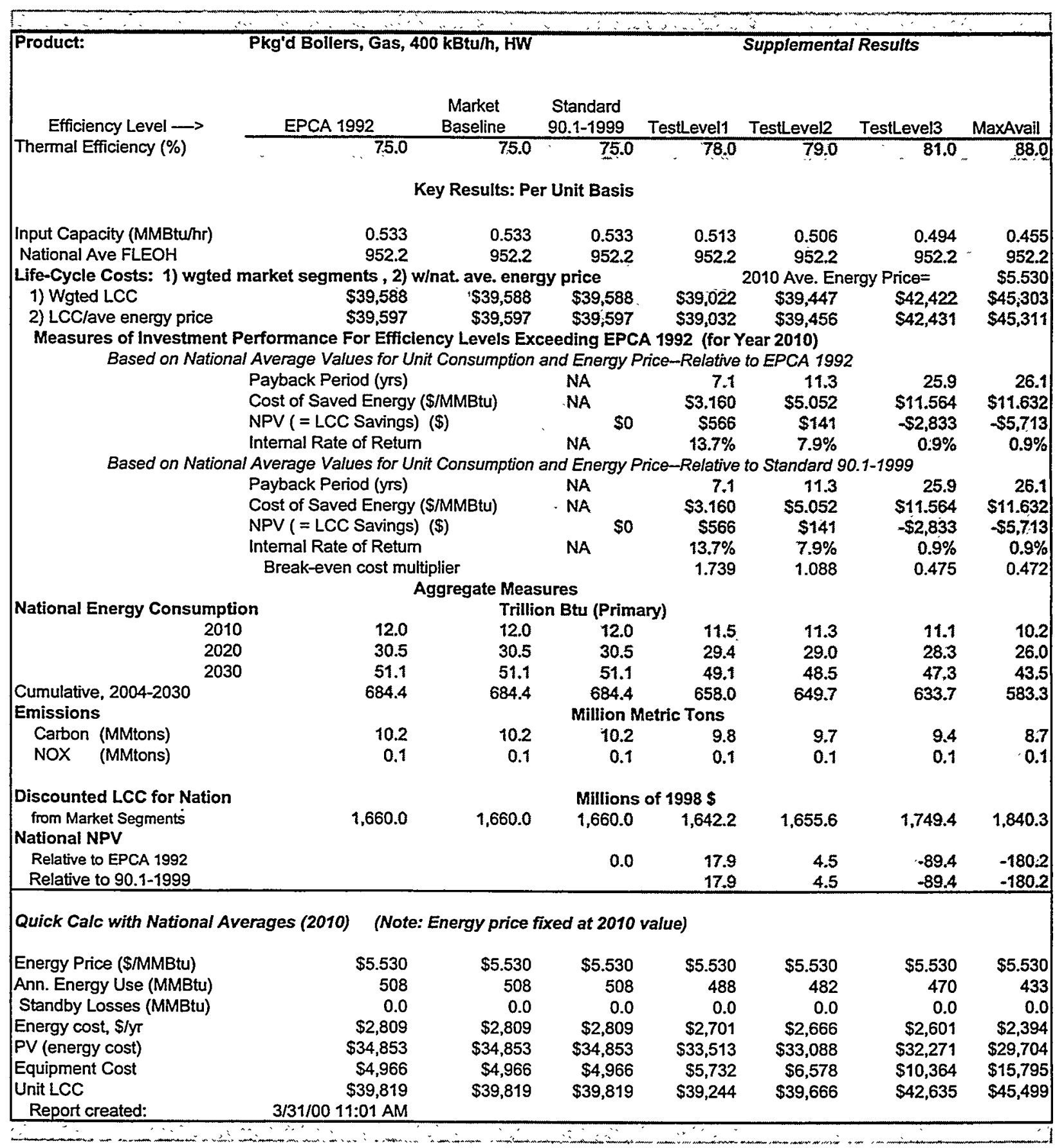




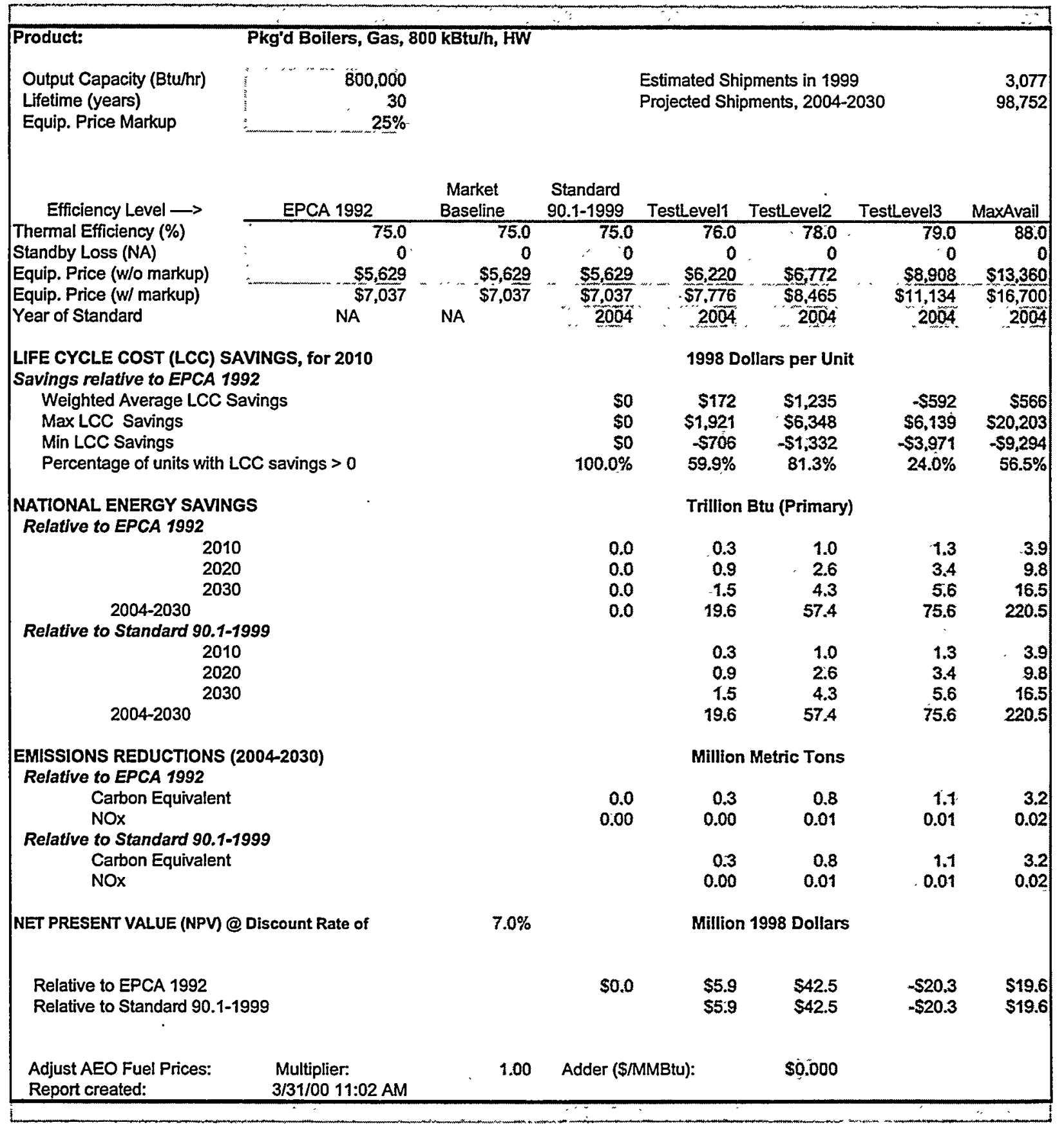




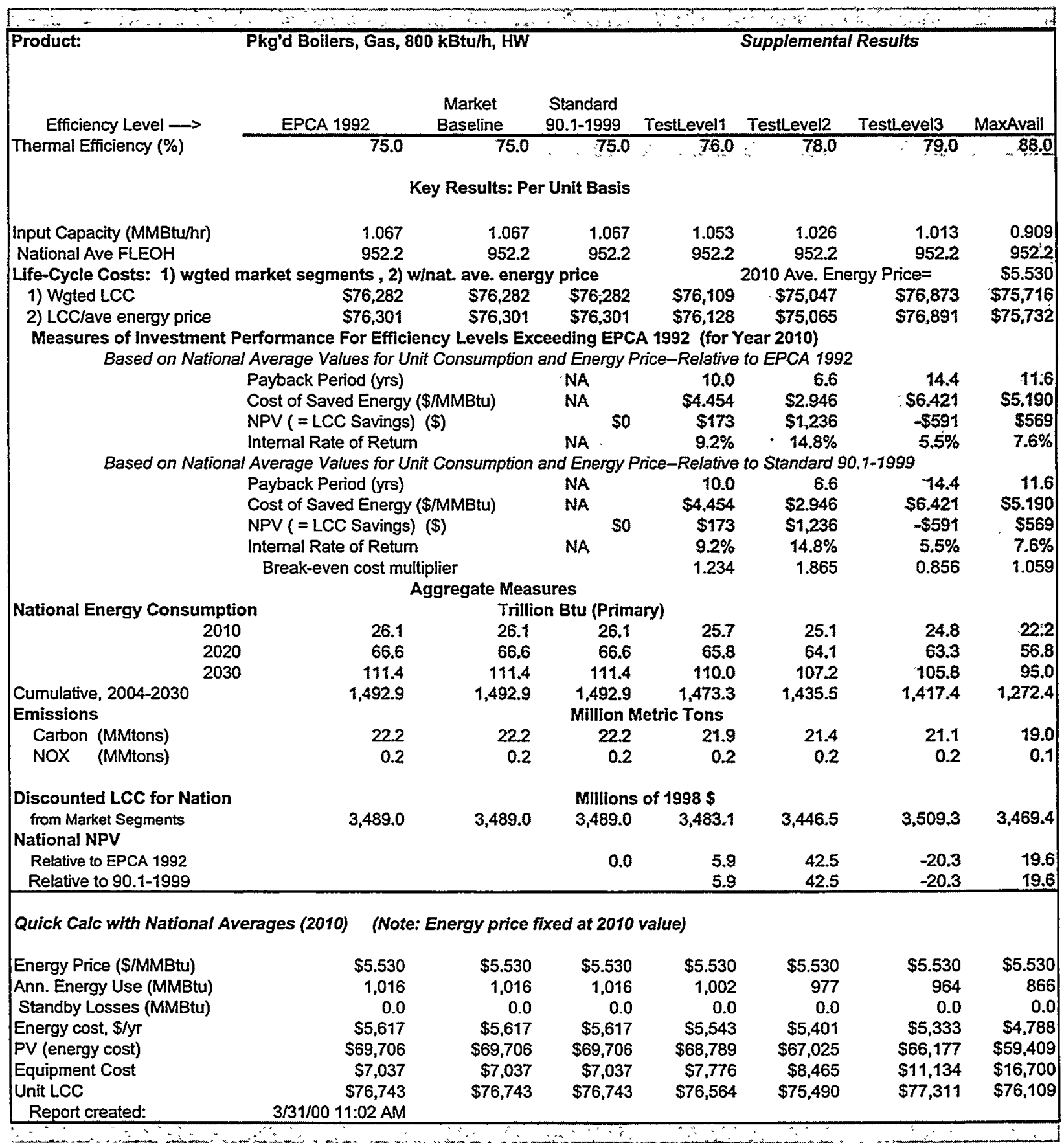




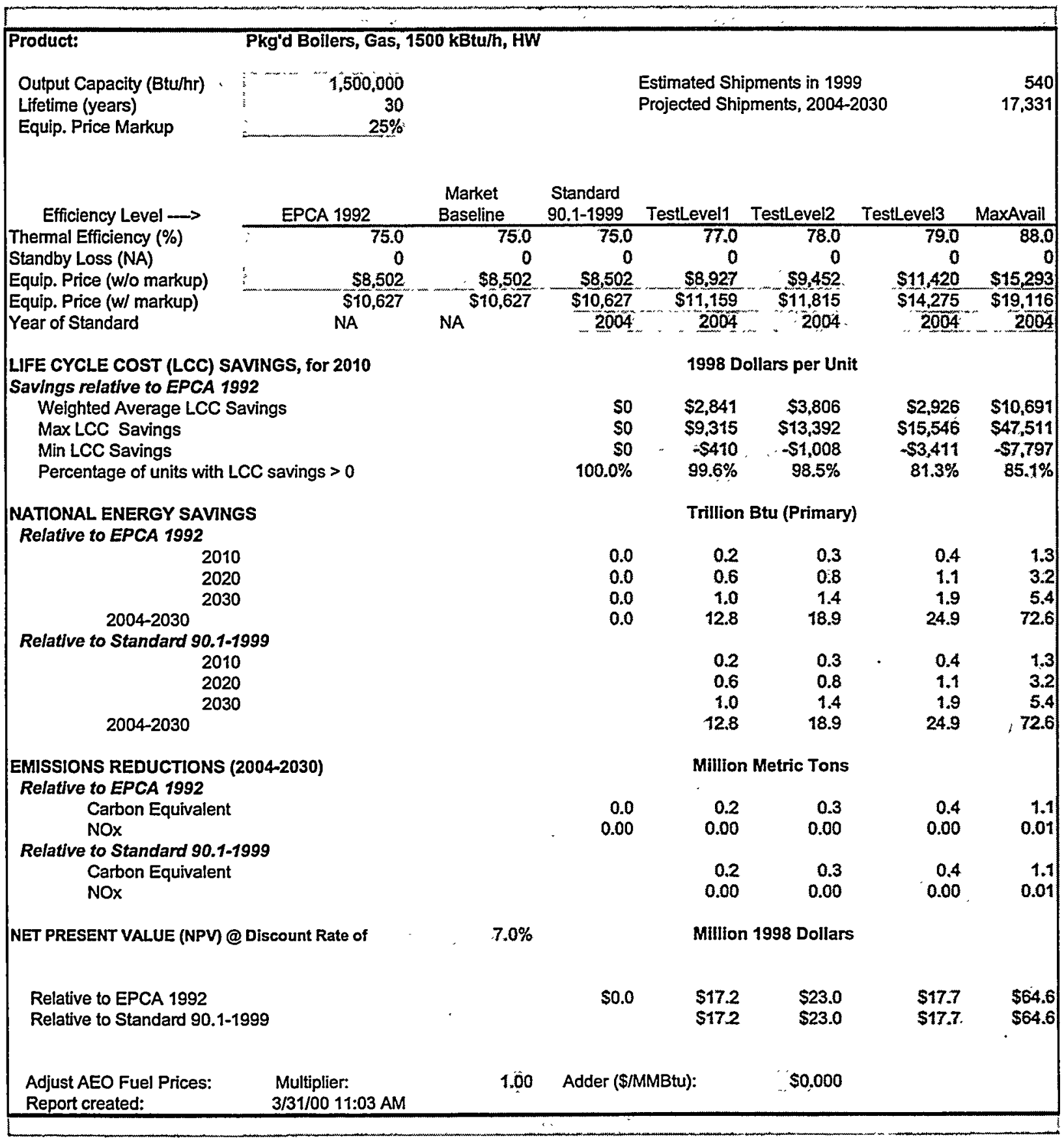




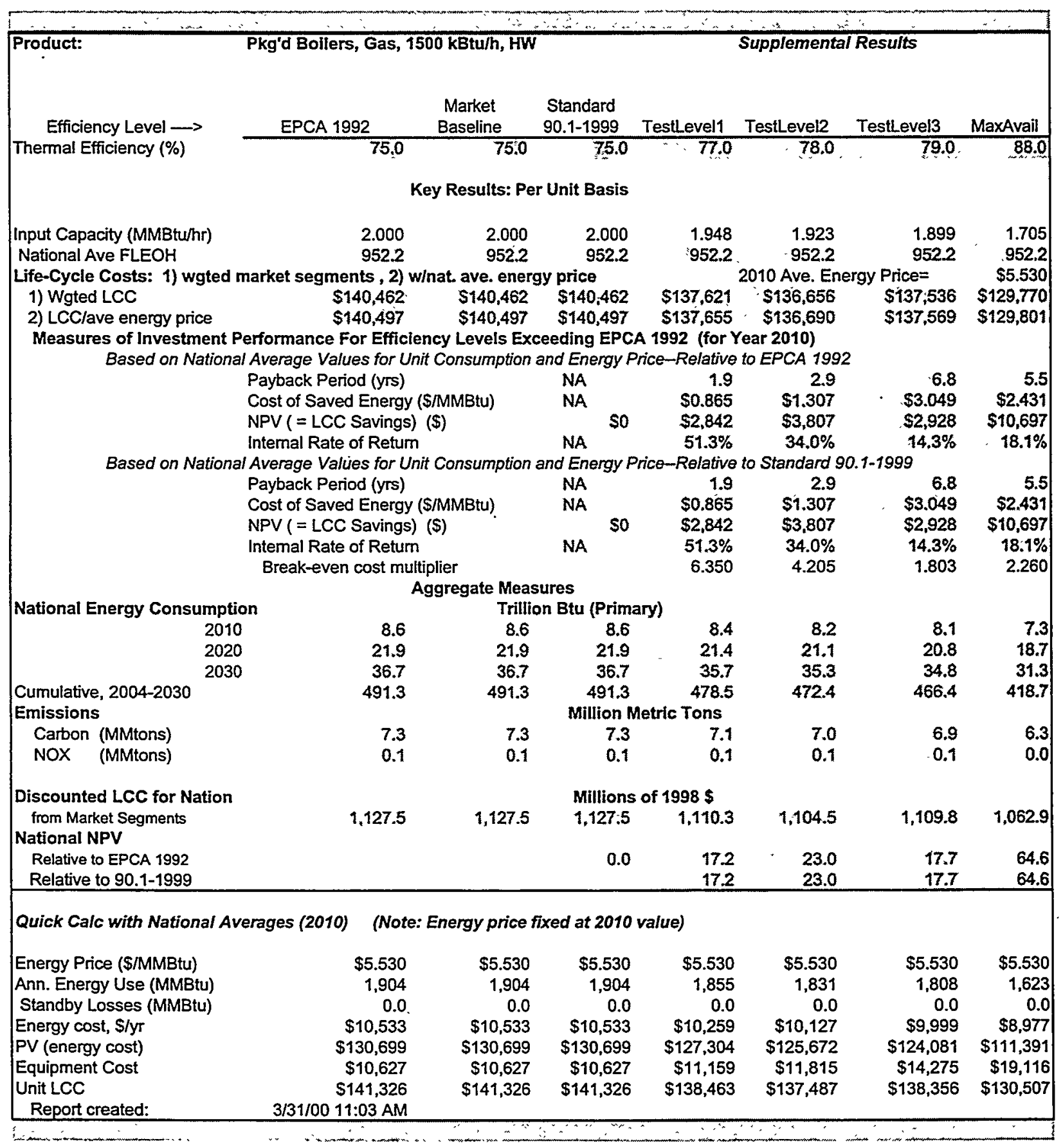




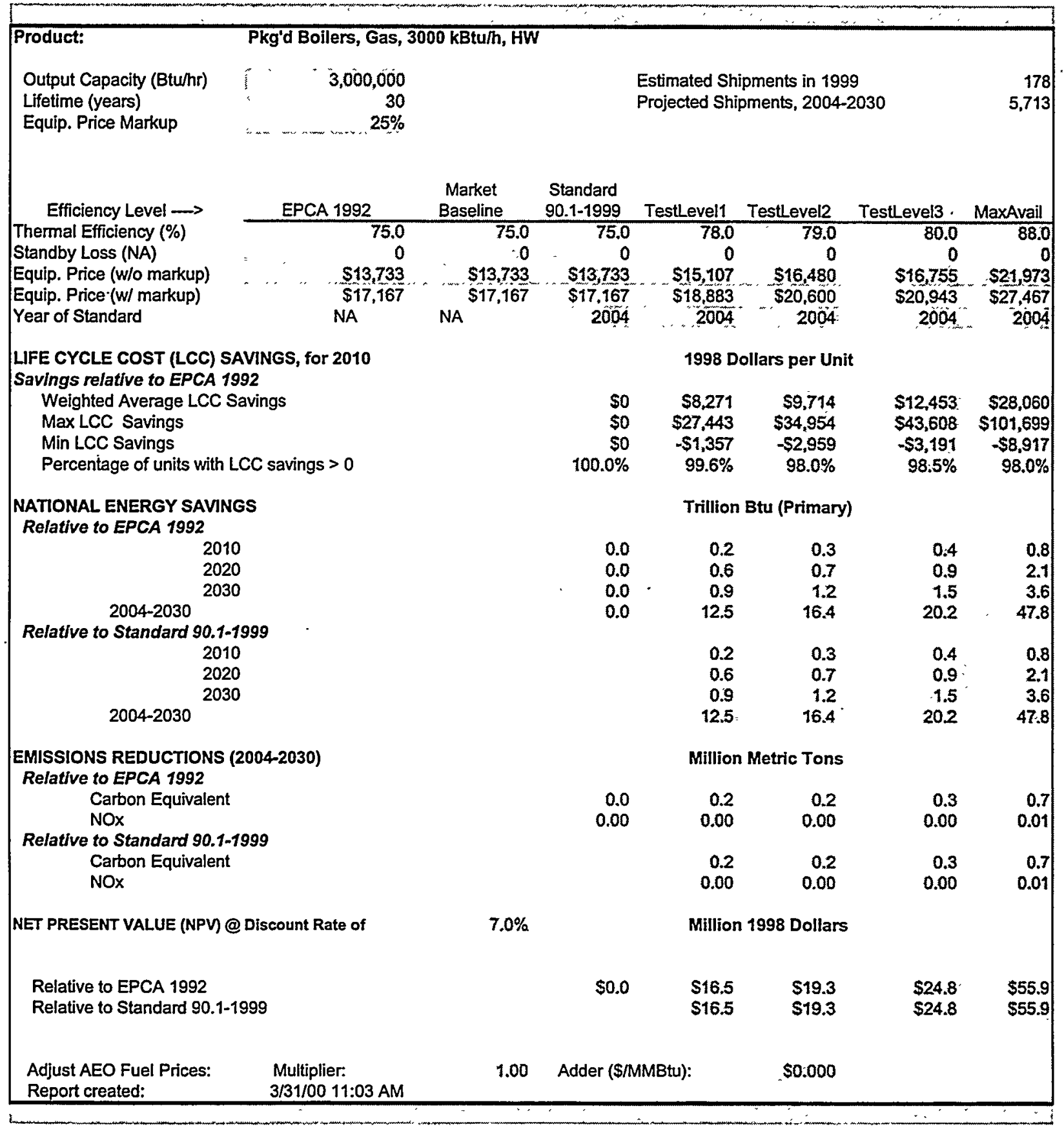




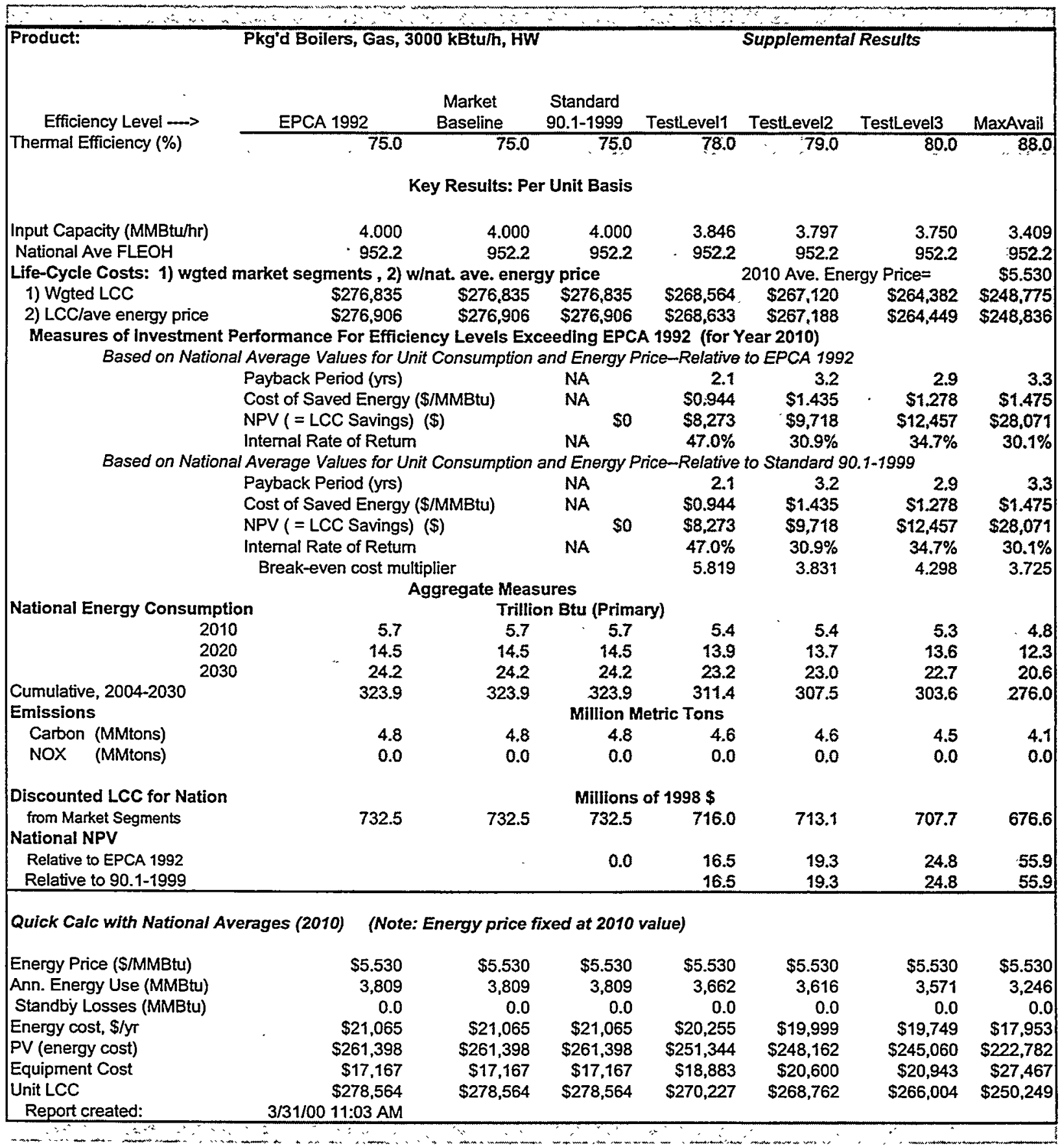




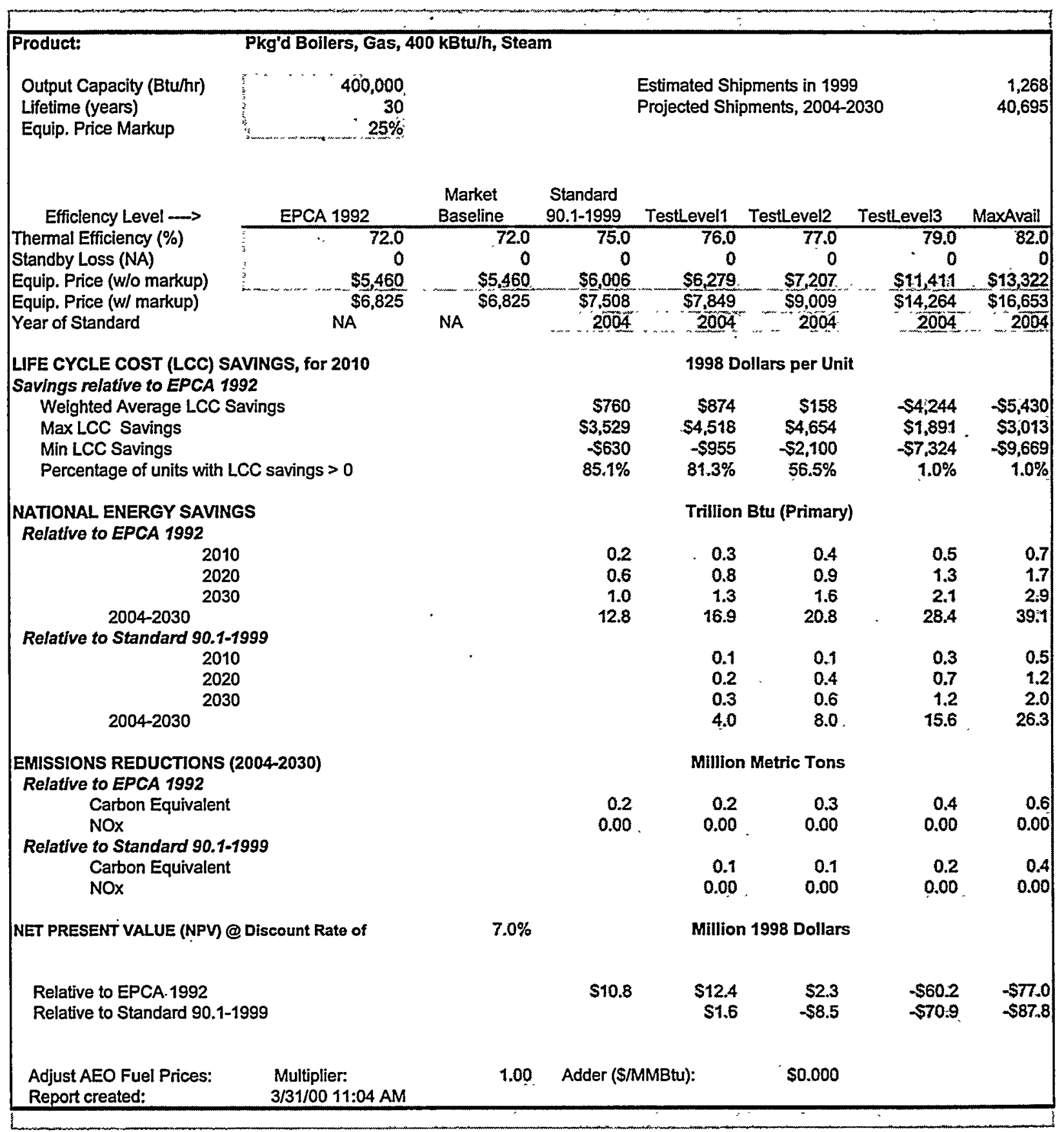




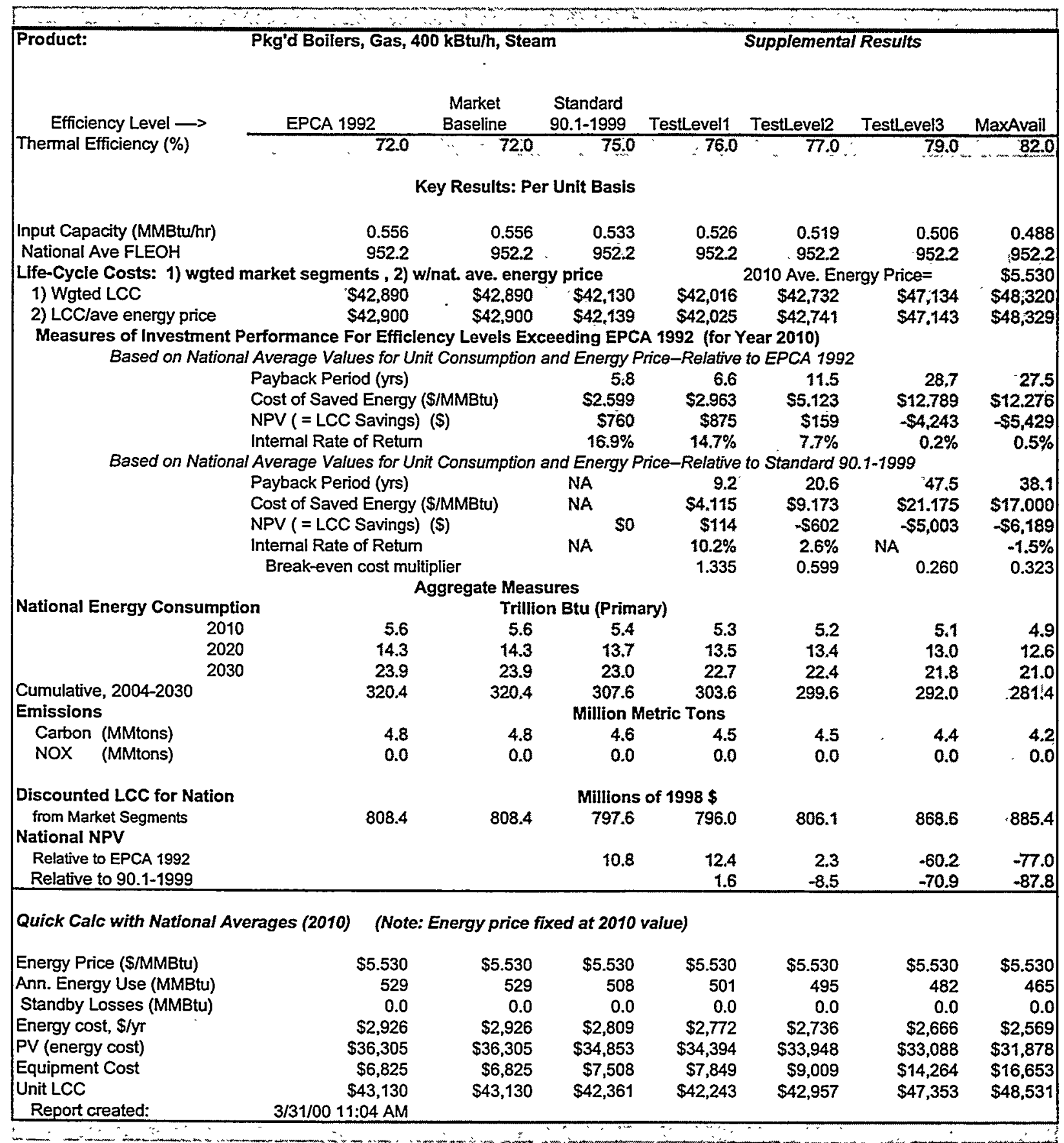




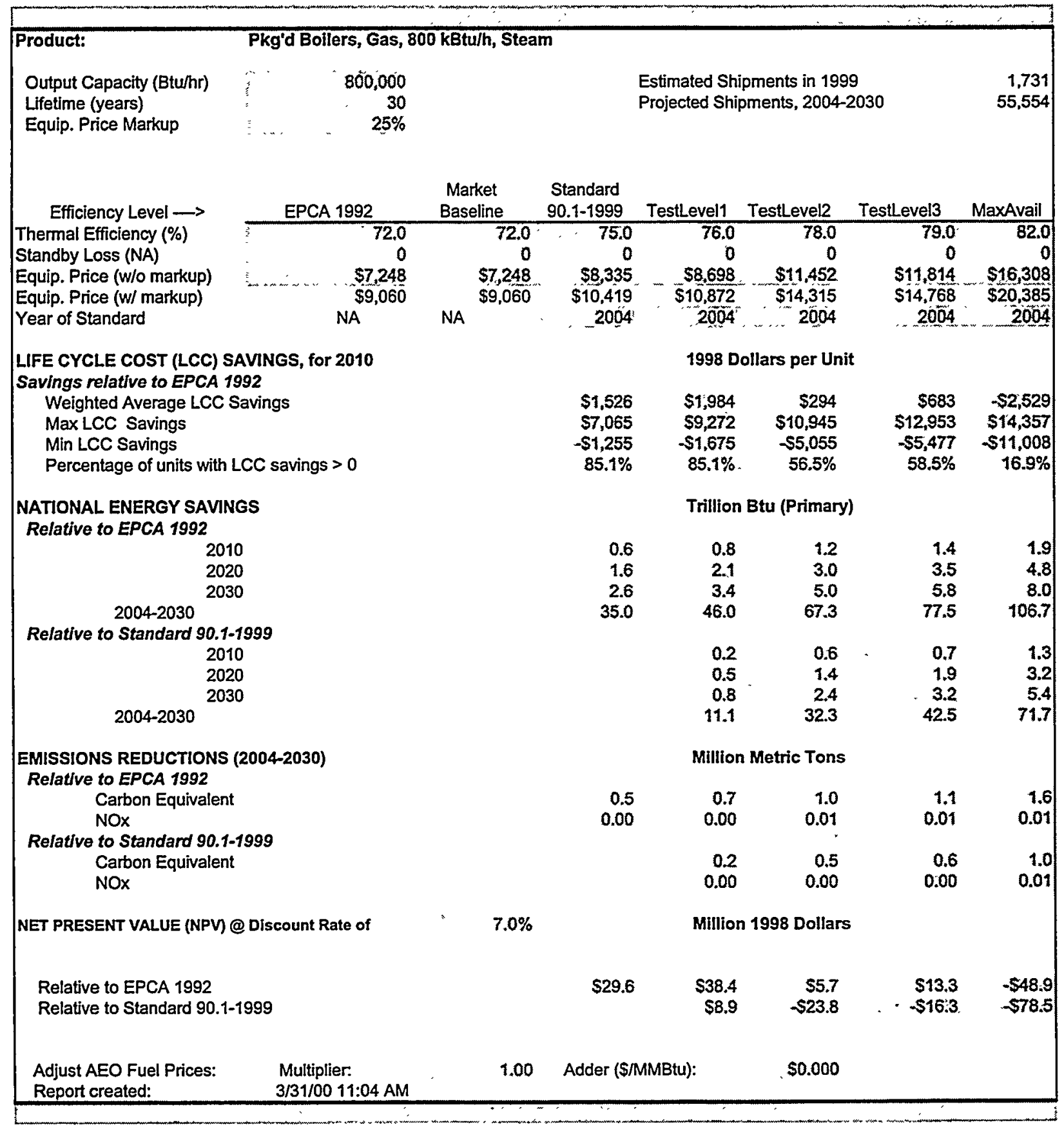




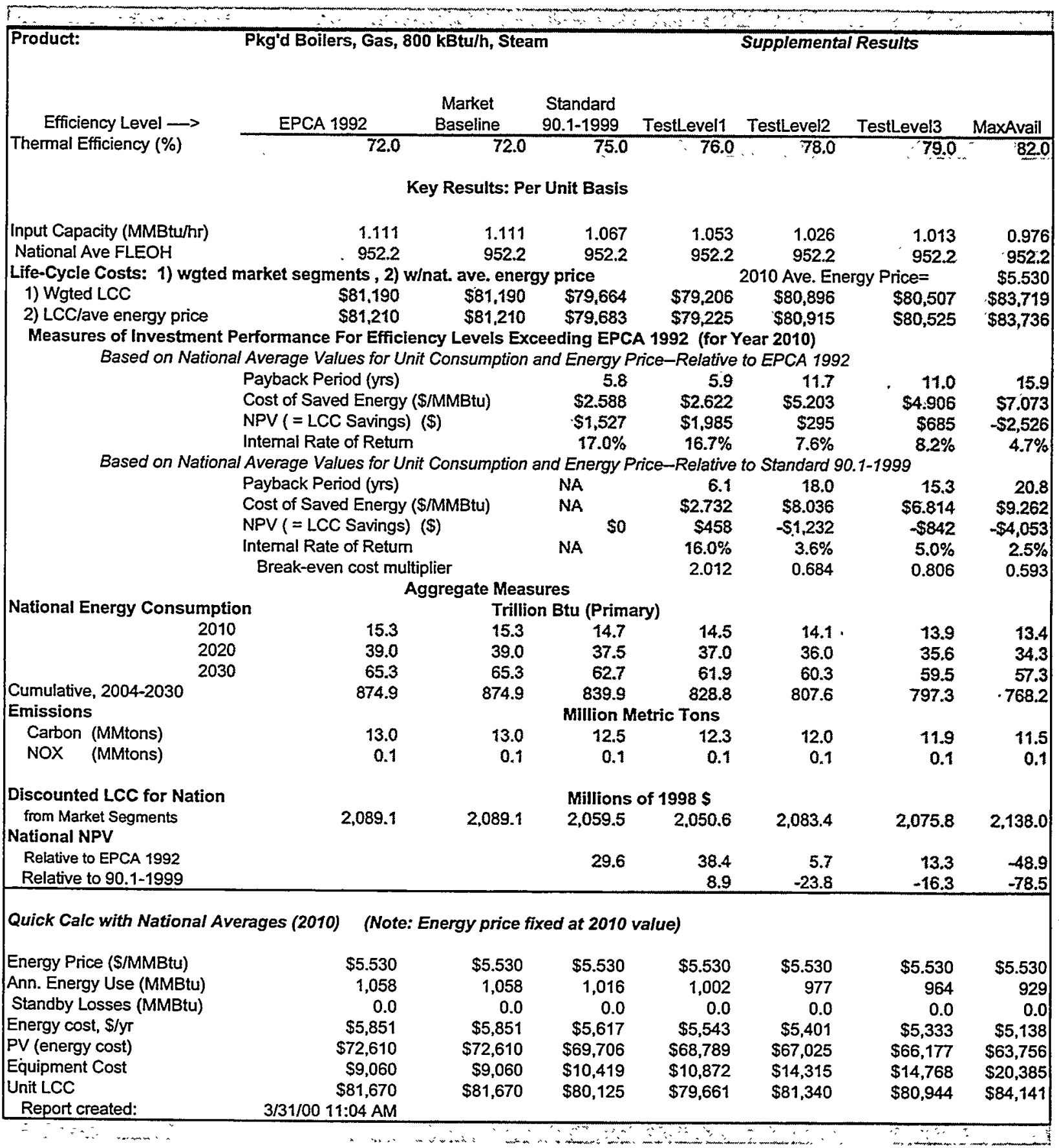




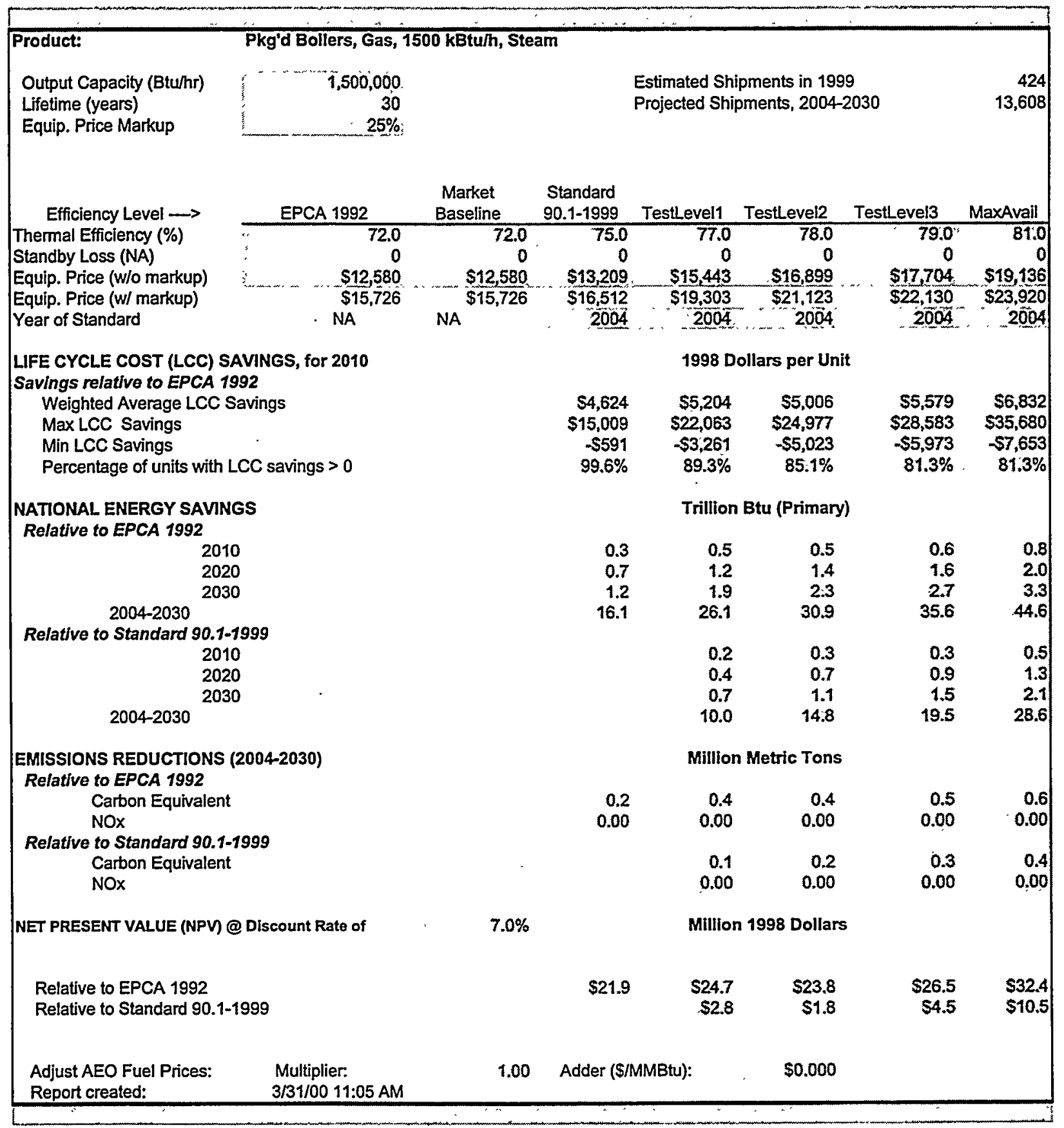




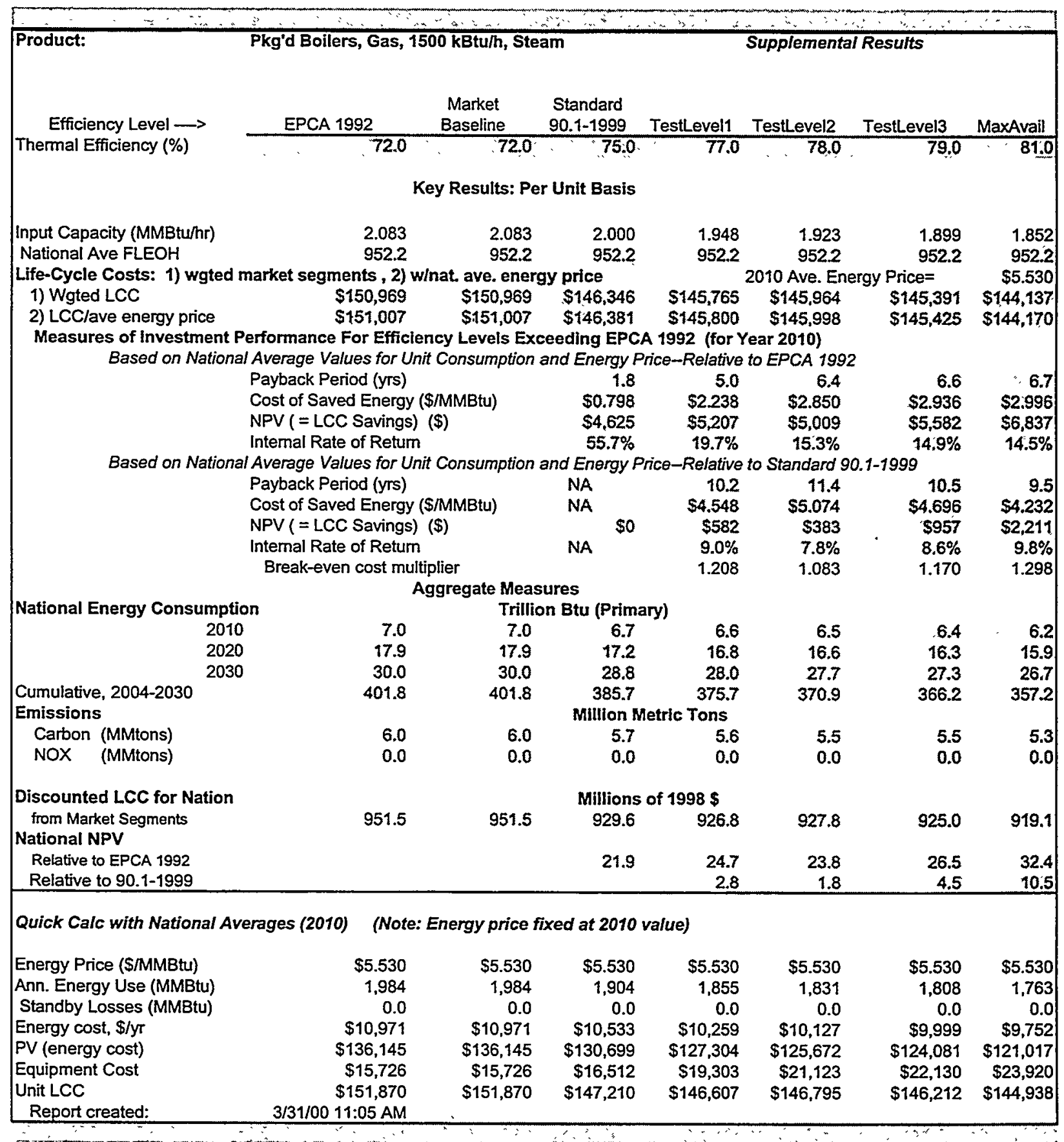




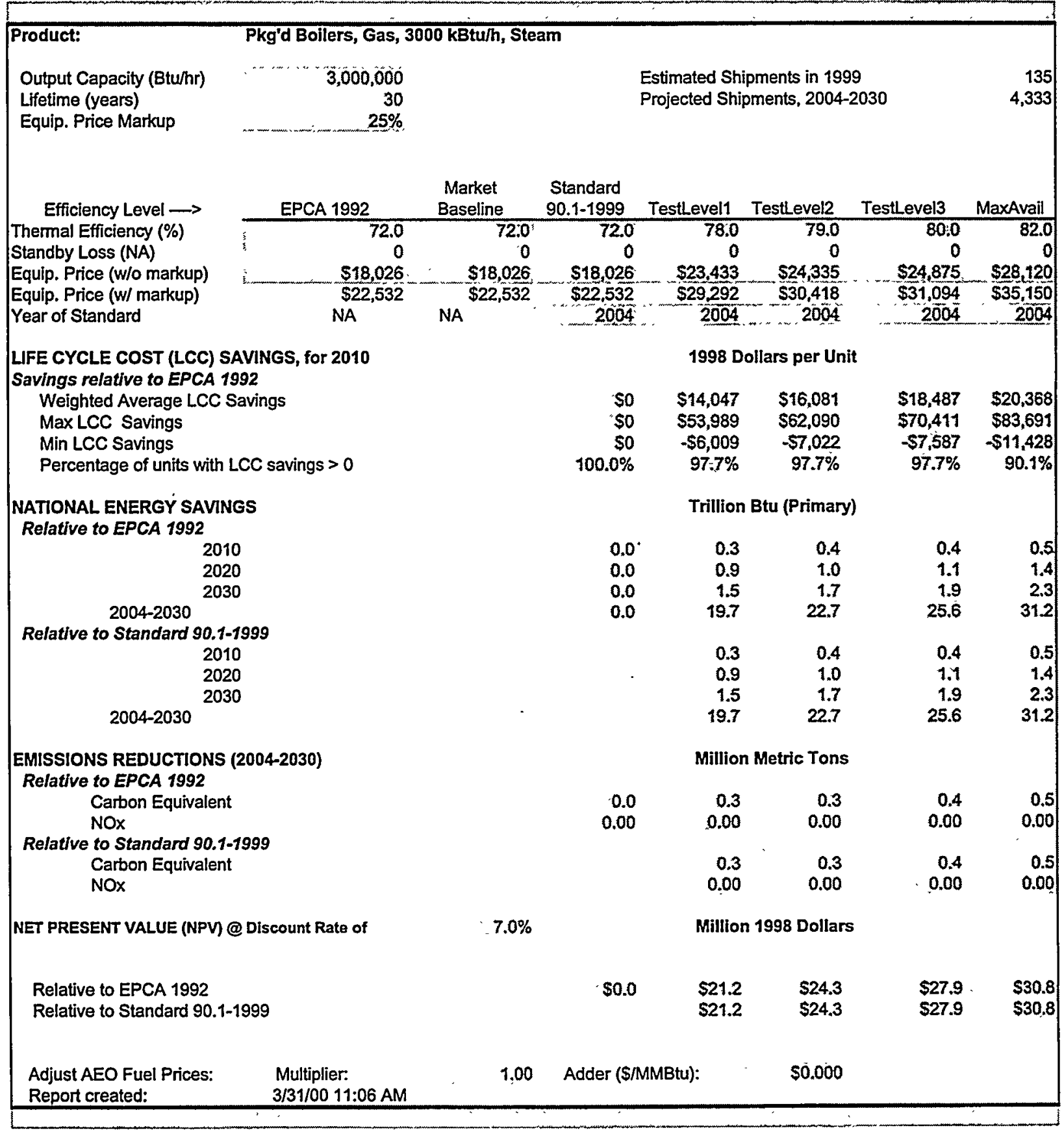




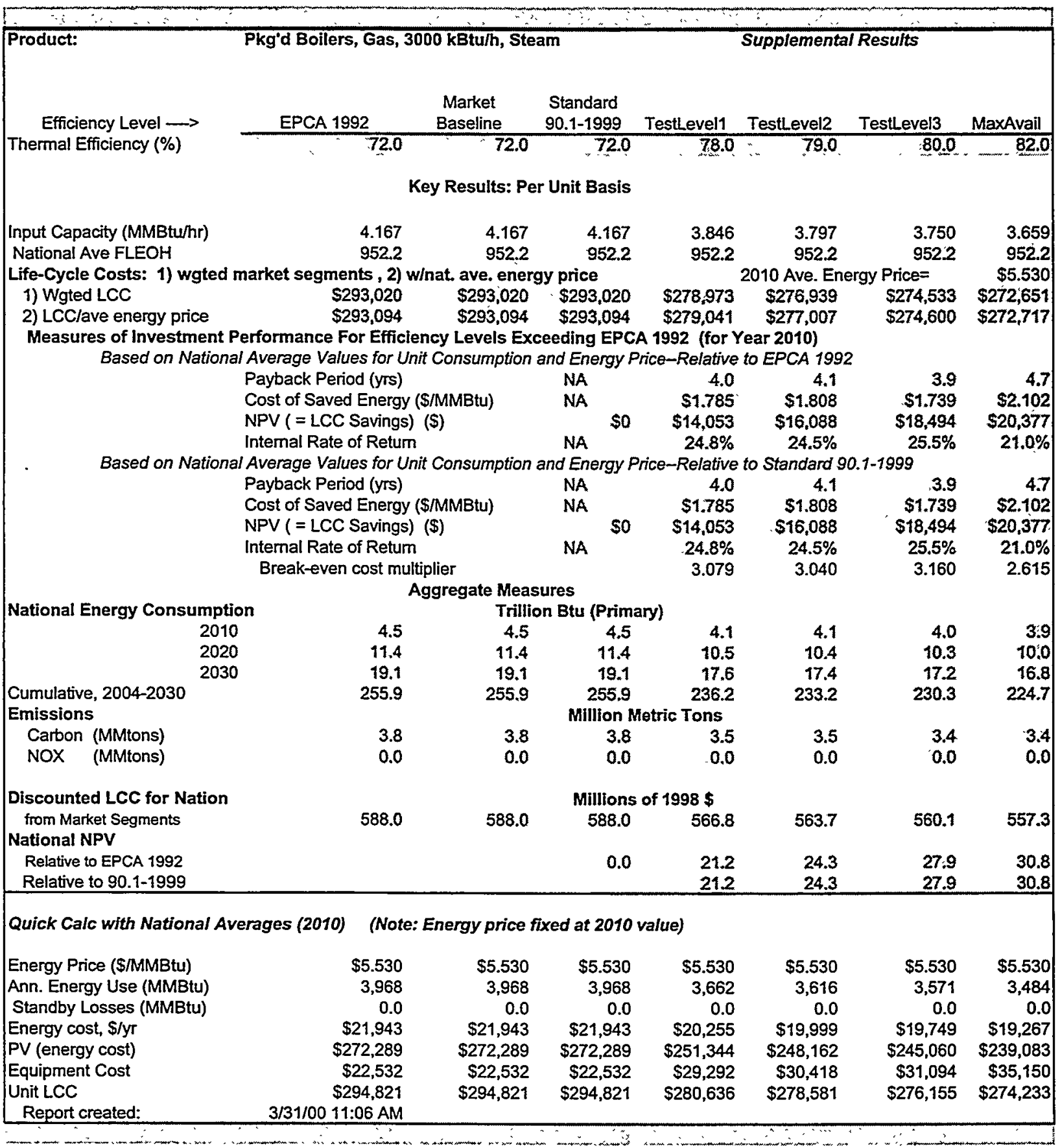




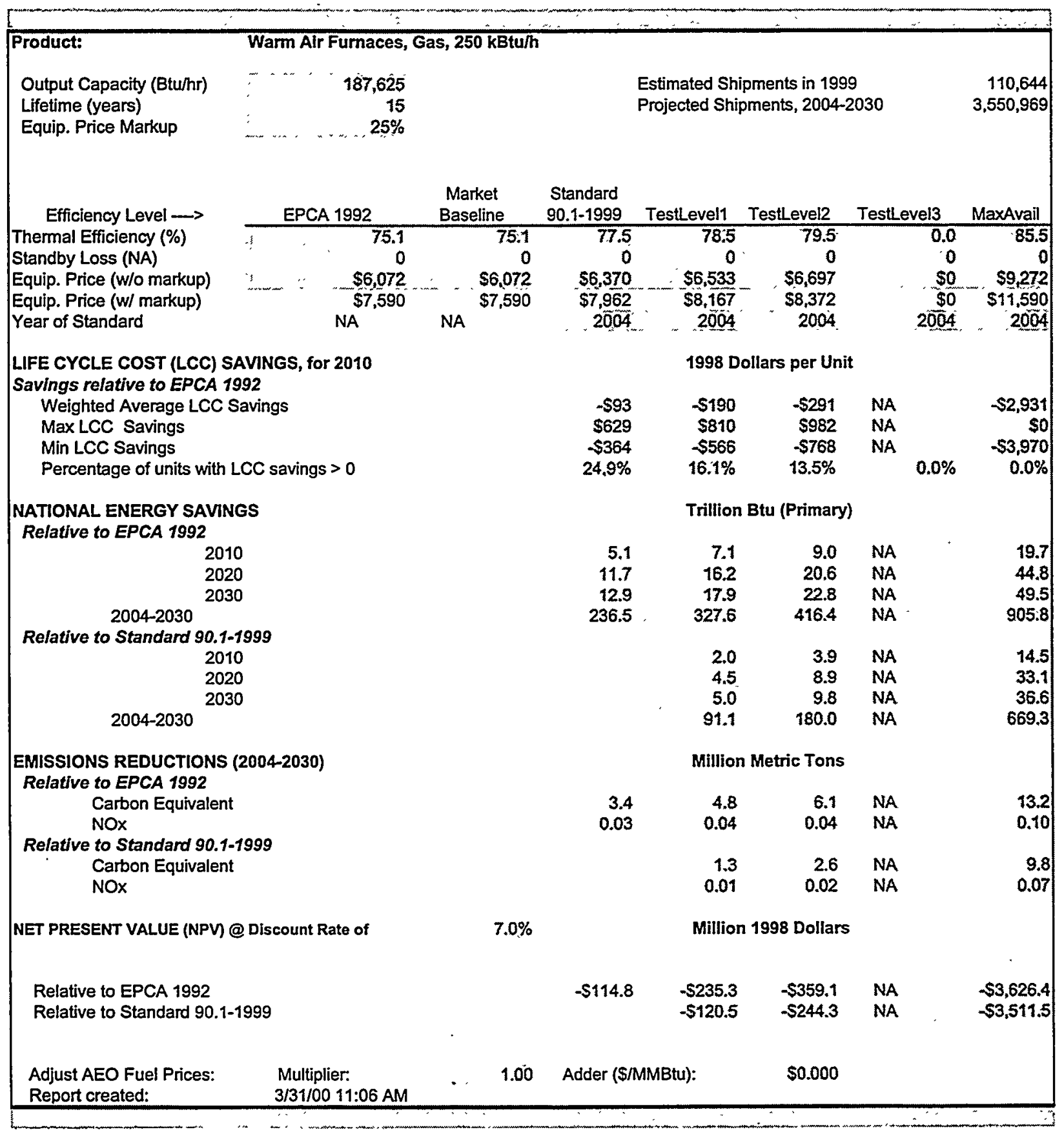




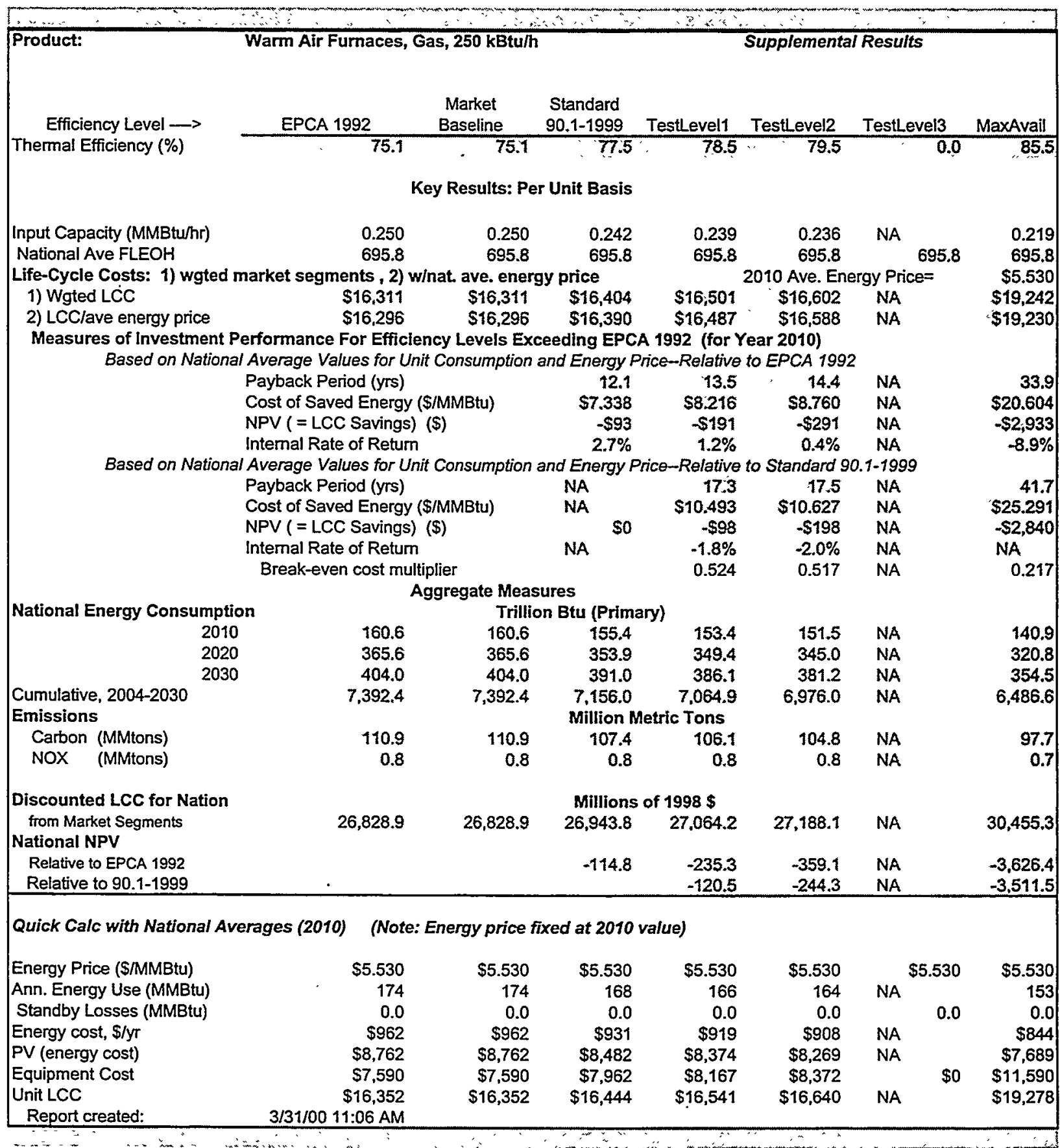




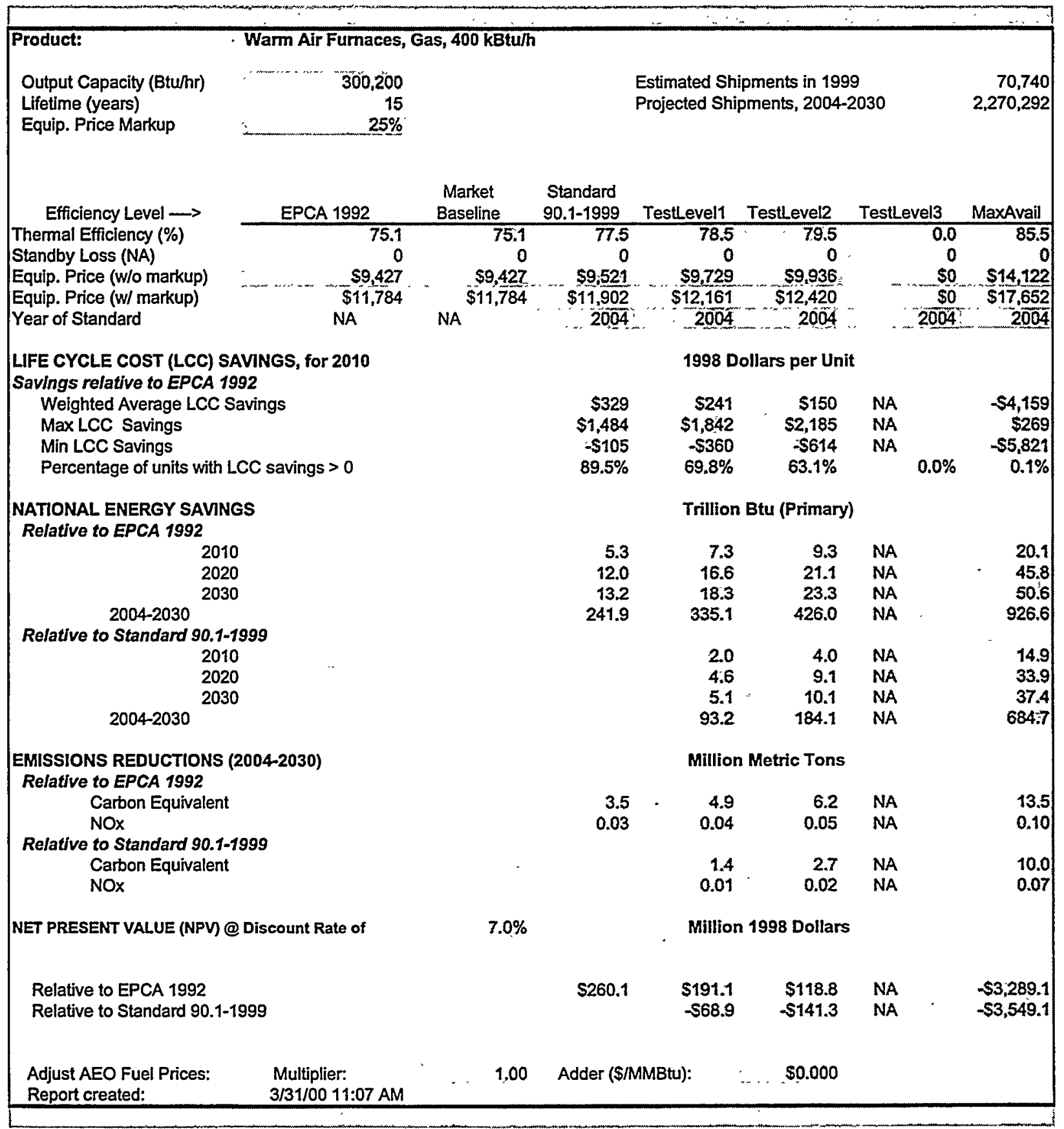




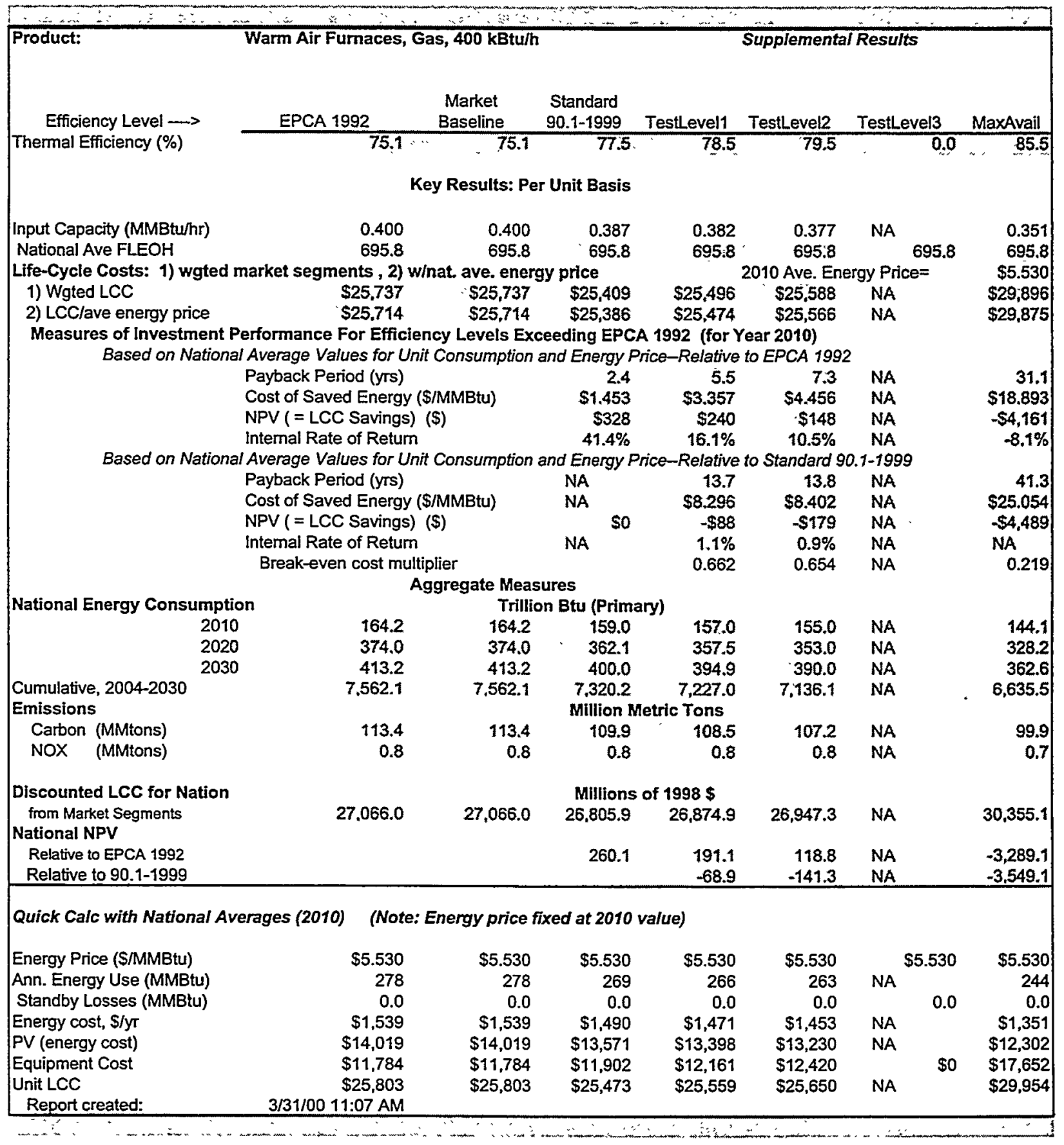




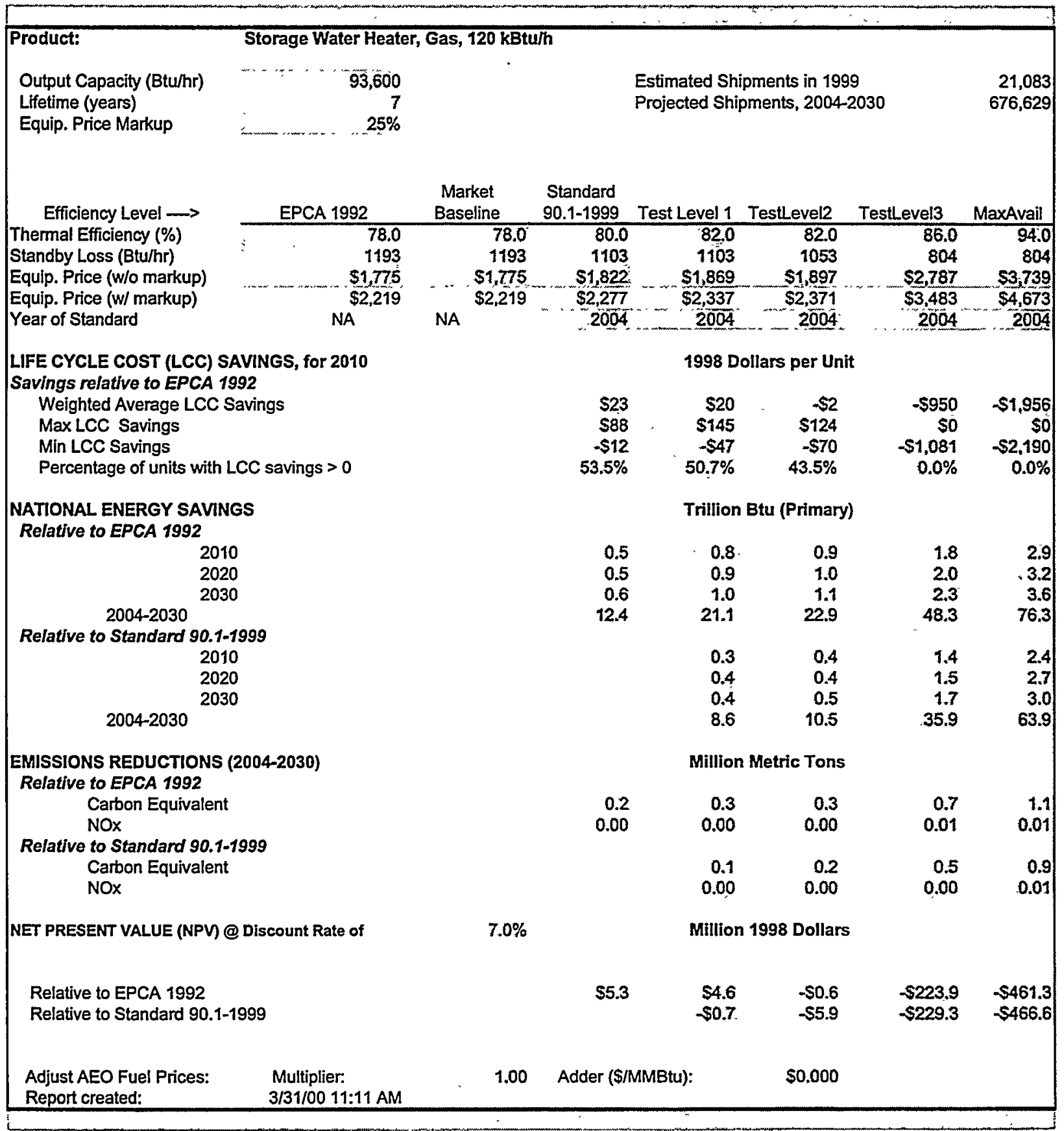




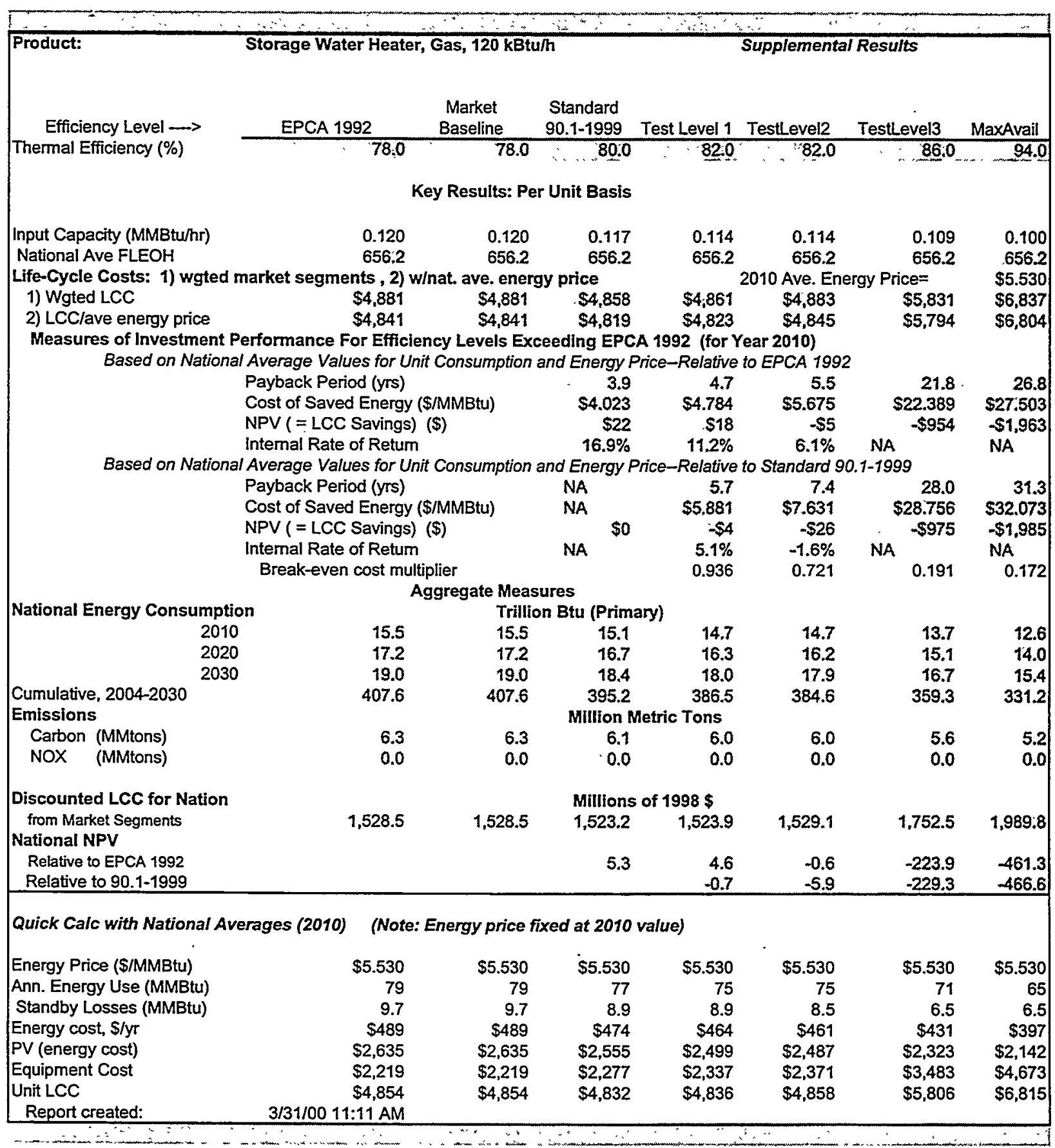




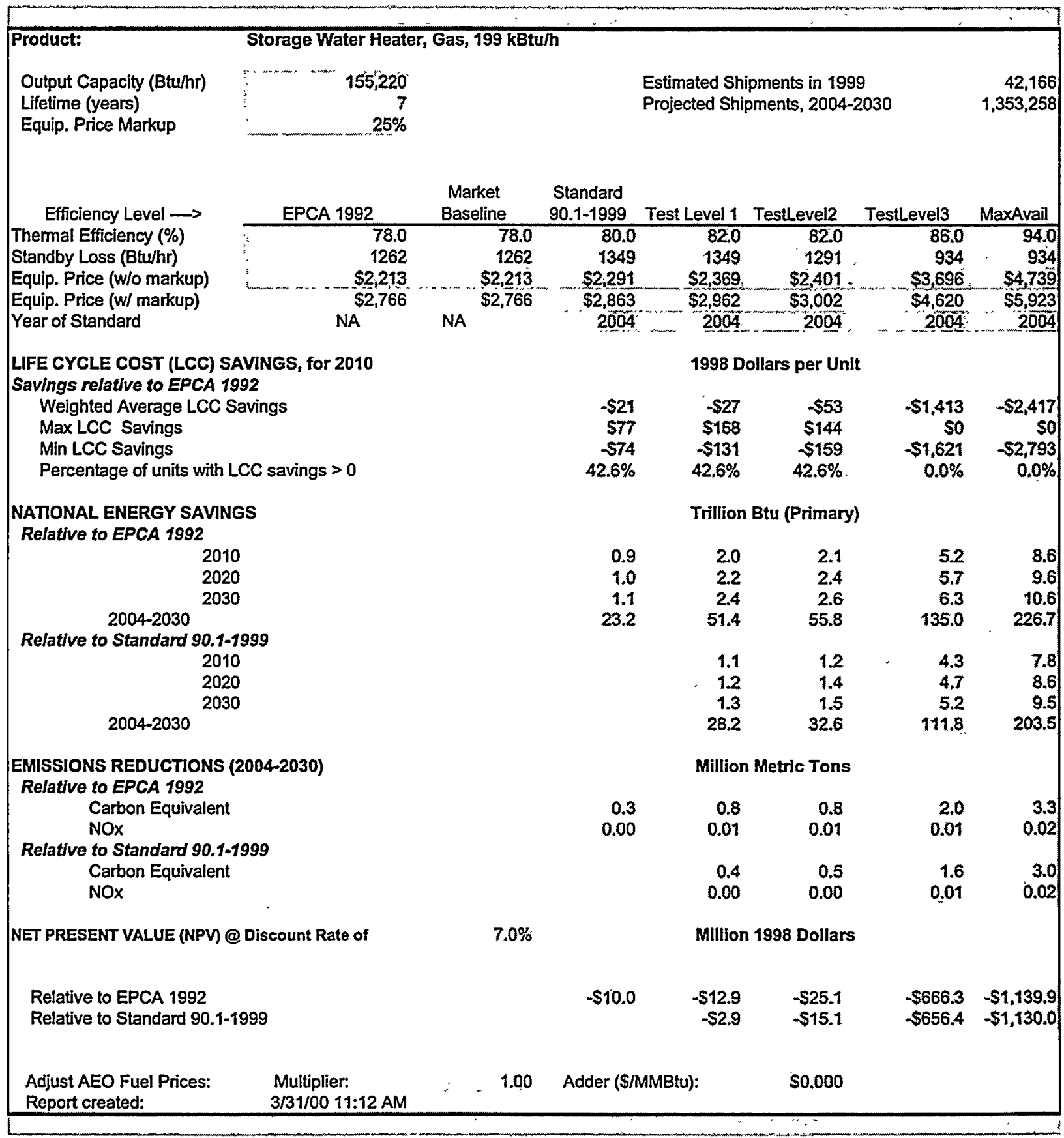




\begin{tabular}{|c|c|c|c|c|c|c|c|}
\hline \multirow{3}{*}{$\begin{array}{l}\text { Product: } \\
\text { Efficiency Level } \longrightarrow \\
\text { Thermal Efficiency }(\%)\end{array}$} & \multicolumn{4}{|c|}{ Storage Water Heater, Gas, 199 kBtu/h } & \multicolumn{3}{|c|}{ Supplemental Results } \\
\hline & EPCA 1992 & $\begin{array}{c}\text { Market } \\
\text { Baseline }\end{array}$ & $\begin{array}{l}\text { Standard } \\
90.1-1999\end{array}$ & Test Level 1 & Testlevel2 & TestLevel3 & MaxAvail \\
\hline & $\because \quad \quad \quad 78.0$ & $\therefore 78.0$ & $: 80.0$ & 82.0 & $\therefore \quad 82: 0$ & 886.0 & 94.0 \\
\hline \multicolumn{8}{|c|}{ Key Results: Per Unit Basis } \\
\hline Input Capacity (MMBtu/hr) & 0.199 & 0.199 & 0.194 & 0.189 & 0.189 & 0.180 & 0.165 \\
\hline National Ave FLEOH & 647.2 & 647.2 & 647.2 & 647.2 & 647.2 & .647 .2 & 647.2 \\
\hline \multicolumn{7}{|c|}{ Life-Cycle Costs: 1) wgted market segments , 2) winat. ave. energy price } & $\$ 5.530$ \\
\hline 1) Wgted LCC & $\$ 6,954$ & $\$ 6,954$ & $\$ 6,975$ & $\$ 6.981$ & $\$ 7,007$ & $\$ 8,366$ & $\$ 9,370$ \\
\hline 2) LCC/ave energy price & $\$ 6,889$ & $\$ 6,889$ & $\$ 6,911$ & $\$ 6,919$ & $\$ 6,945$ & $\$ 8,308$ & $\$ 9,317$ \\
\hline \multicolumn{8}{|c|}{$\begin{array}{l}\text { Measures of Investment Performance For Efficlency Levels Exceeding EPCA } 1992 \text { (for Year 2010) } \\
\text { Based on National Average Values for Unit Consumption and Energy Price-Relative to EPCA } 1992\end{array}$} \\
\hline & Payback Period (yrs) & & 7.0 & 6.3 & 7.0 & 22.9 & 23.2 \\
\hline & Cost of Saved Energy & /MMBtu) & $\$ 7.161$ & $\$ 6.503$ & $\$ 7.223$ & $\$ 23.485$ & $\$ 23,829$ \\
\hline & NPV ( = LCC Savings & & $-\$ 22$ & $-\$ 30$ & $-\$ 56$ & $-\$ 1,419$ & $\$ 2,428$ \\
\hline & Internal Rate of Retun & & $-0.1 \%$ & $2.4 \%$ & $-0.3 \%$ & NA & NA \\
\hline \multicolumn{8}{|c|}{ Based on National Average Values for Unit Consumption and Energy Price-Relative to Standard 90.1-1999 } \\
\hline & Payback Period (yrs) & & NA & 5.8 & 7.1 & 26.2 & 25.1 \\
\hline & Cost of Saved Energy & ;MMBtu) & NA & $\$ 5.962$ & $\$ 7.268$ & $\$ 26.869$ & $\$ 25.727$ \\
\hline & NPV ( = LCC Savings & & $\$ 0$ & $-\$ B$ & $-\$ 34$ & $-\$ 1,397$ & $-\$ 2,406$ \\
\hline & Internal Rate of Retun & & NA & $4.7 \%$ & $-0.4 \%$ & NA & NA \\
\hline & Break-even cost mu & olier & & 0.923 & 0.757 & 0.205 & 0.214 \\
\hline \multicolumn{8}{|c|}{ Aggregate Measures } \\
\hline \multicolumn{5}{|l|}{ National Energy Consumption } & & & \\
\hline 2010 & 48.9 & 48.9 & 48.0 & 46.9 & 46.8 & 43.8 & 40.3 \\
\hline 2020 & 54.1 & 54.1 & 53.1 & 51.9 & 51.7 & 48.4 & 44.5 \\
\hline 2030 & 59.7 & 59.7 & 58.6 & 57.3 & 57.1 & 53.4 & 49.2 \\
\hline Cumulative, 2004-2030 & $1,281.8$ & $1,281.8$ & $1,258.7$ & $1,230.4$ & $1,226.1$ & $1,146.8$ & $1,055.2$ \\
\hline Emissions & & & Million $\mathbf{M}$ & letric Tons & & & \\
\hline Carbon (MMtons) & 19.8 & 19.8 & 19.5 & 19.1 & 19.0 & 17.8 & 16.5 \\
\hline NOX (MMtons) & 0.1 & 0.1 & 0.1 & 0.1 & 0.1 & 0.1 & 0.1 \\
\hline \multicolumn{3}{|l|}{ Discounted LCC for Nation } & \multicolumn{2}{|c|}{ Millions of 1998 \$ } & & & \\
\hline $\begin{array}{l}\text { from Market Segments } \\
\text { National NPV }\end{array}$ & $4,355.0$ & $4,355.0$ & $4,364.9$ & $4,367.9$ & $4,380.1$ & $5,021: 3$ & $5,494.9$ \\
\hline Relative to EPCA 1992 & & & -10.0 & -12.9 & -25.1 & $-666,3$ & -1.139 .9 \\
\hline Relative to $90.1-1999$ & & & & -2.9 & -15.1 & -656.4 & -1.130 .0 \\
\hline \multicolumn{8}{|c|}{ Quick Calc with National Averages (2010) (Note: Energy price fixed at 2010 value) } \\
\hline Energy Price (\$/MMBtu) & $\$ 5.530$ & $\$ 5.530$ & $\$ 5.530$ & $\$ 5.530$ & $\$ 5.530$ & $\$ 5.530$ & $\$ 5.530$ \\
\hline Ann. Energy Use (MMBtu) & 129 & 129 & 126 & 123 & 123 & 117 & 107 \\
\hline Standby Losses (MMBtu) & 10.2 & 10.2 & 10.9 & 10.9 & 10.5 & 7.6 & 7.6 \\
\hline Energy cost, \$/yr & $\$ 769$ & $\$ 769$ & $\$ 755$ & $\$ 738$ & $\$ 735$ & $\$ 688$ & $\$ 633$ \\
\hline PV (energy cost) & $\$ 4,144$ & $\$ 4,144$ & $\$ 4,069$ & $\$ 3,977$ & $\$ 3,963$ & $\$ 3,707$ & $\$ 3,411$ \\
\hline Equipment Cost & $\$ 2,766$ & $\$ 2,766$ & $\$ 2,863$ & $\$ 2,962$ & $\$ 3,002$ & $\$ 4,620$ & $\$ 5,923$ \\
\hline $\begin{array}{l}\text { Unit LCC } \\
\text { Report created: }\end{array}$ & $\begin{array}{r}\$ 6,910 \\
3 / 31 / 0011: 12 \text { AM }\end{array}$ & $\$ 6,910$ & $\$ 6,932$ & $\$ 6,939$ & $\$ 6,965$ & $\$ 8,327$ & $\$ 9,334$ \\
\hline
\end{tabular}




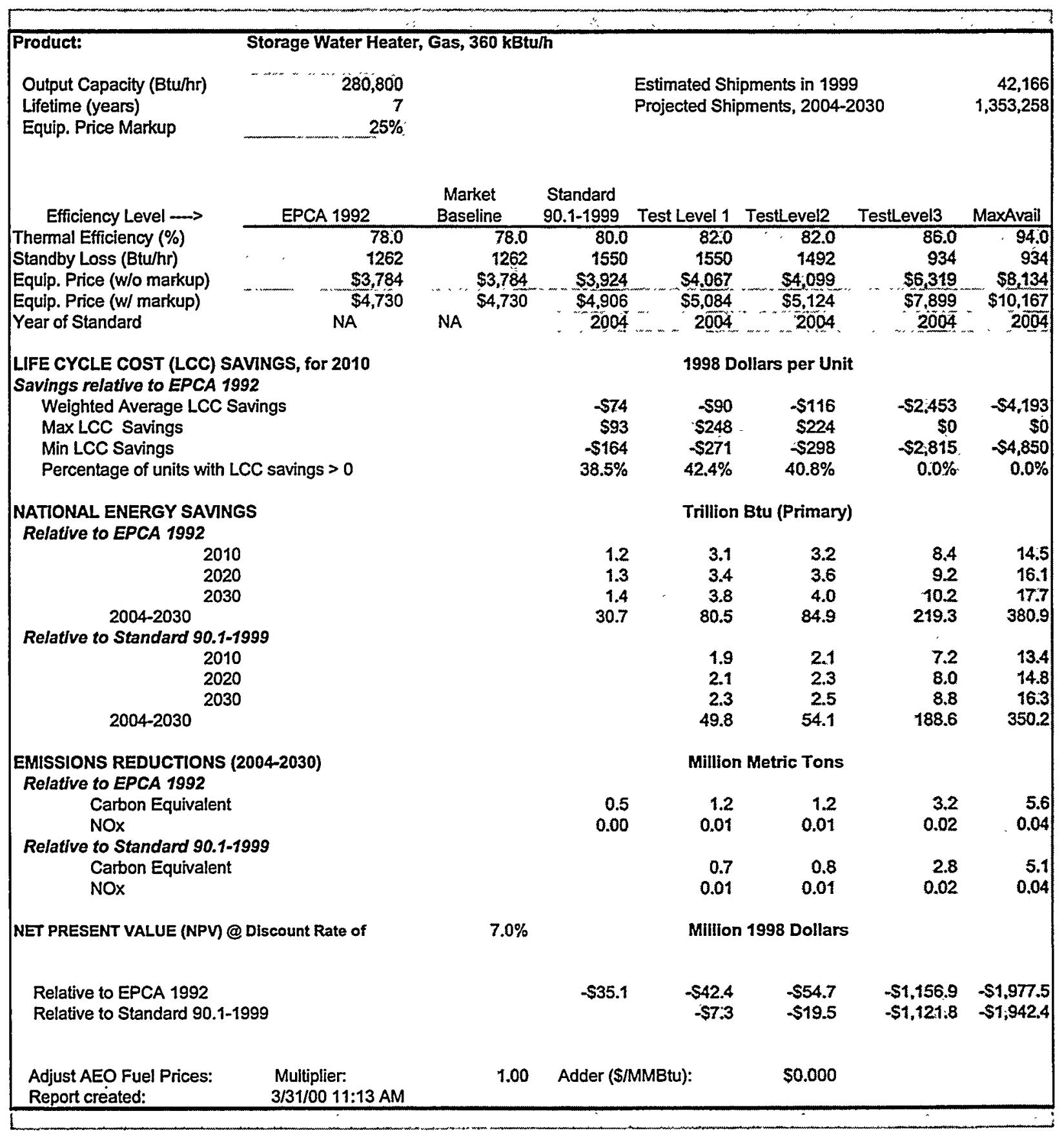




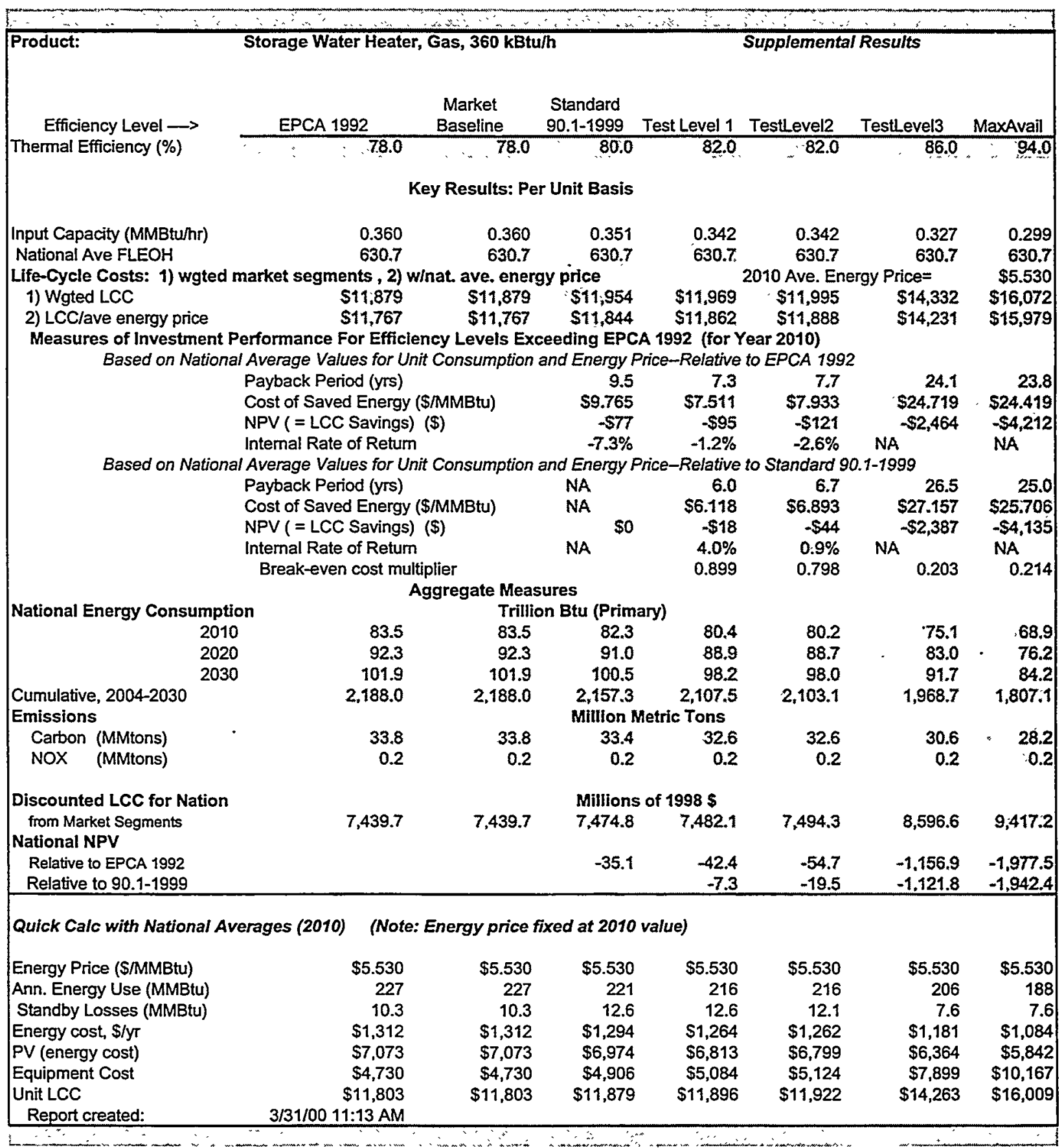




\begin{tabular}{|c|c|c|c|c|c|c|c|}
\hline \multirow{2}{*}{$\begin{array}{l}\text { Product: } \\
\text { Output Capacity (Btu/hr) } \\
\text { Lifetime (years) } \\
\text { Equip. Price Markup }\end{array}$} & \multicolumn{7}{|c|}{ Instantaneous Water Heater, Gas, 400 kBtu/h } \\
\hline & $\begin{array}{r}320,000 \\
15 \\
25 \%\end{array}$ & \multicolumn{5}{|c|}{$\begin{array}{l}\text { Estimated Shipments in } 1999 \\
\text { Projected Shipments, 2004-2030 }\end{array}$} & \multirow{2}{*}{$\begin{array}{r}30,199 \\
969,194 \\
\text { MaxAvail }\end{array}$} \\
\hline Efficiency Level $\longrightarrow$ & EPCA 1992 & $\begin{array}{l}\text { Market } \\
\text { Baseline }\end{array}$ & $\begin{array}{l}\text { Standard } \\
90.1-1999\end{array}$ & Test Level 1 & TestLevel2 & Testlevel3 & \\
\hline Thermal Efficiency (\%) & 80.0 & 80.0 & 80.0 & 83.0 & NA & 86.0 & 94.0 \\
\hline Standby Loss (Btu/hr) & & & 0 & 0 & 0 & 0 & 0 \\
\hline Equip. Price (w/o markup) & $\$ 2,794$ & $\$ 2 ; 794$ & $\$ 2,794$ & $\$ 3,420$ & so. & $\$ 4,991$ & $\$ 6,839$ \\
\hline Equip. Price (w/ markup) & $\$ 3,492$ & $\$ 3,492$ & $\$ 3,492$ & $\$ 4,274$ & SO & $\$ 6,238$ & $\$ 8,549$ \\
\hline Year of Standard & NA & NA & 2004 & 2004 & 2004 & 2004 & 2004 \\
\hline \multicolumn{4}{|c|}{$\begin{array}{l}\text { LIFE CYCLE COST (LCC) SAVINGS, for } 2010 \\
\text { Savings relative to EPCA } 1992\end{array}$} & \multirow{2}{*}{\multicolumn{3}{|c|}{1998 Dollars per Unit }} & \\
\hline \multicolumn{3}{|c|}{ Weighted Average LCC Savings } & 80 & & & & S32015 \\
\hline \multicolumn{2}{|c|}{ Max LCC Savings } & & so & $\begin{array}{r}-\$ 335 \\
\$ 131\end{array}$ & $\begin{array}{l}\text { NA } \\
\text { NA }\end{array}$ & $-\$ 1,883$ & $\begin{aligned}-\$ 3,215 \\
50\end{aligned}$ \\
\hline \multicolumn{2}{|c|}{ Min LCC Savings } & & so & $\$ 582$ & NA & $-\$ 2,360$ & $-\$ 4,232$ \\
\hline \multicolumn{2}{|c|}{ Percentage of units with LCC savings $>0$} & & $100.0 \%$ & $11.1 \%$ & $0.0 \%$ & $0.0 \%$ & $0.0 \%$ \\
\hline \multicolumn{2}{|c|}{$\begin{array}{l}\text { NATIONAL ENERGY SAVINGS } \\
\text { Relative to EPCA } 1992\end{array}$} & \multicolumn{6}{|c|}{ Trillion Btu (Primary) } \\
\hline \multicolumn{2}{|c|}{2010} & & 0.0 & 2.2 & NA & 4,3 & 9.1 \\
\hline \multirow{2}{*}{\multicolumn{2}{|c|}{$\begin{array}{l}2020 \\
2030\end{array}$}} & & 0.0 & 5.0 & NA & 9.7 & 20.8 \\
\hline & & & 0.0 & 5.6 & NA & 10.8 & 23.0 \\
\hline $2004-2030$ & 2030 & & 0.0 & 102.0 & NA & 196.9 & 420.4 \\
\hline \multicolumn{8}{|c|}{ Relative to Standard 90.1-1999 } \\
\hline \multicolumn{2}{|c|}{2010} & & & 2.2 & NA & 4.3 & 9.1 \\
\hline \multicolumn{2}{|c|}{2020} & & & 5.0 & NA & 9.7 & 20.8 \\
\hline \multicolumn{2}{|c|}{2030} & & & 5.6 & NA & 10.8 & 23.0 \\
\hline \multicolumn{2}{|c|}{$2004-2030$} & & & 102.0 & NA & 196.9 & 420.4 \\
\hline \multicolumn{3}{|c|}{ EMISSIONS REDUCTIONS (2004-2030) } & \multicolumn{5}{|c|}{ Million Metric Tons } \\
\hline \multirow{2}{*}{\multicolumn{2}{|c|}{$\begin{array}{l}\text { Relative to EPCA } 1992 \\
\text { Carbon Equivalent }\end{array}$}} & & & & & & \\
\hline & & & 0.0 & 1.5 & NA & 2.9 & 6.1 \\
\hline \multicolumn{2}{|c|}{$\begin{array}{c}\text { NOx } \\
\text { Relative to Standard 90.1-1999 }\end{array}$} & & 0.00 & 0.01 & NA & 0.02 & 0.05 \\
\hline \multirow{2}{*}{\multicolumn{2}{|c|}{$\begin{array}{l}\text { Carbon Equivalent } \\
\text { NOx }\end{array}$}} & & & 15 & NA & 29 & 6.1 \\
\hline & & & & 0.01 & NA & 0.02 & 0.05 \\
\hline \multicolumn{2}{|c|}{ NET PRESENT VALUE (NPV) @ Discount Rate of } & $7.0 \%$ & & Million & 1998 Dollar & & \\
\hline Relative to EPCA 1992 & & & $\$ 0.0$ & $-\$ 113.2$ & NA & $-\$ 636.0$ & $-\$ 1,085.7$ \\
\hline Relative to Standard 90. & 999 & & & $-\$ 113.2$ & NA & $-\$ 636.0$ & $-\$ 1,085.7$ \\
\hline $\begin{array}{l}\text { Adjust AEO Fuel Prices: } \\
\text { Report created: }\end{array}$ & $\begin{array}{l}\text { Multiplier: } \\
\text { 3/31/00 11:13 AM }\end{array}$ & 1.00 & Adder $(\$ / \mathrm{A}$ & MMBtu): & $\$ 0.000$ & & \\
\hline
\end{tabular}




\begin{tabular}{|c|c|c|c|c|c|c|c|}
\hline \multirow{2}{*}{ Product: } & \multirow{2}{*}{\multicolumn{4}{|c|}{ Instantaneous Water Heater, Gas, $400 \mathrm{kBtu} / \mathrm{h}$}} & $\because \because \quad \therefore-\cdots$ & & $\therefore \therefore$ \\
\hline & & & & & \multicolumn{3}{|c|}{ Supplemental Results } \\
\hline Efficiency Level $\longrightarrow$ & EPCA 1992 & $\begin{array}{c}\text { Market } \\
\text { Baseline }\end{array}$ & $\begin{array}{l}\text { Standard } \\
90.1-1999\end{array}$ & Test Level 1 & TestLevel2 & TestLevel3 & MaxAvail \\
\hline Thermal Efficiency (\%) & 80.0 & 80.0 & 80.0 & $.83: 0$ & $\mathrm{NA}$ & 86.0 & 94.0 \\
\hline \multicolumn{8}{|c|}{ Key Results: Per Unit Basis } \\
\hline Input Capacity (MMBtu/hr) & 0.400 & 0.400 & 0.400 & 0.386 & NA & 0.372 & 0.340 \\
\hline National Ave FLEOH & 608.3 & 608.3 & 608.3 & 608.3 & 608.3 & 608.3 & 608.3 \\
\hline \multicolumn{5}{|c|}{ Life-Cycle Costs: 1) wgted market segments , 2) w/nat. ave. energy price } & \multicolumn{2}{|c|}{2010 Ave. Energy Price= } & $\$ 5.530$ \\
\hline $\begin{array}{l}\text { 1) Wgted LCC } \\
\text { 2) LCC/ave energy price }\end{array}$ & $\begin{array}{l}\$ 15,857 \\
\$ 15,671\end{array}$ & $\begin{array}{l}\$ 15,857 \\
\$ 15,671\end{array}$ & $\begin{array}{l}\$ 15,857 \\
\$ 15,671\end{array}$ & $\begin{array}{l}\$ 16,192 \\
\$ 16,013\end{array}$ & $\begin{array}{l}\text { NA } \\
\text { NA }\end{array}$ & $\begin{array}{l}\$ 17,741 \\
\$ 17,567\end{array}$ & $\begin{array}{l}\$ 19,072 \\
\$ 18,914\end{array}$ \\
\hline \multicolumn{8}{|c|}{$\begin{array}{l}\text { Measures of Investment Performance For Efficiency Levels Exceeding EPCA } 1992 \text { (for Year 2010) } \\
\text { Based on National Average Values for Unit Consumption and Energy Price-Relative to EPCA } 1992\end{array}$} \\
\hline & Payback Period (yrs) & & NA & 16.1 & NA & 29.2 & 25.2 \\
\hline & Cost of Saved Energy & (5/MMBtu) & NA & $\$ 9.762$ & NA & $\$ 17,759$ & $\$ 15.319$ \\
\hline & NPV ( = LCC Savings & & so & $\$ 342$ & NA & $-\$ 1,896$ & $-\$ 3,243$ \\
\hline & Interna! Rate of Retun & & NA & $-0.9 \%$ & NA & $-7.5 \%$ & $-6.0 \%$ \\
\hline \multicolumn{8}{|c|}{ Based on National Average Values for Unit Consumption and Energy Price-Relative to Standard 90.1-1999 } \\
\hline & Payback Period (yrs) & & NA & 16.1 & NA & 29.2 & 25.2 \\
\hline & Cost of Saved Energy & b/MMBtu) & NA & $\$ 9.762$ & NA & $\$ 17.759$ & $\$ 15.319$ \\
\hline & NPV ( = LCC Savings & & so & $-\$ 342$ & NA & $-\$ 1,896$ & $-\$ 3,243$ \\
\hline & Intemal Rate of Retun & & NA & $-0.9 \%$ & NA & $-7.5 \%$ & $-6.0 \%$ \\
\hline & Break-even cost mu & plier & & 0.563 & NA & 0.309 & 0.359 \\
\hline \multicolumn{8}{|c|}{ Aggregate Measures } \\
\hline \multicolumn{5}{|c|}{ National Energy Consumption } & & & \\
\hline 201 & 61.3 & 61.3 & 61.3 & 59.1 & NA & 57.0 & 52.2 \\
\hline 202 & 139.6 & 139.6 & 139.6 & 134.6 & NA & 129.9 & 118.8 \\
\hline 203 & 154.2 & 154.2 & 154.2 & 148.7 & NA & 143.5 & 131.3 \\
\hline Cumulative, 2004-2030 & $2,822.4$ & $2,822.4$ & $2,822.4$ & $2,720.4$ & NA & $2,625.5$ & $2,402.0$ \\
\hline Emissions & \multicolumn{7}{|c|}{ Million Metric Tons } \\
\hline Carbon (MMtons) & 42.3 & 42.3 & 42.3 & 40.8 & NA & 39.5 & 36.2 \\
\hline NOX (MMtons) & 0.3 & 0.3 & 0.3 & 0.3 & NA & 0.3 & 0.3 \\
\hline Discounted LCC for Nation & \multicolumn{7}{|c|}{ Millions of $1998 \$$} \\
\hline $\begin{array}{l}\text { from Market Segments } \\
\text { National NPV }\end{array}$ & $7,120.5$ & 7.120 .5 & $7,120.5$ & $7,233.6$ & NA & $7,756.4$ & $8,206.2$ \\
\hline Relative to EPCA 1992 & & & 0.0 & -113.2 & NA & -636.0 & $-1,085.7$ \\
\hline Relative to $90.1-1999$ & & & & -113.2 & NA & -636.0 & -1.085 .7 \\
\hline \multicolumn{8}{|c|}{ Quick Calc with National Averages (2010) (Note: Energy price fixed at 2010 value) } \\
\hline Energy Price (\$/MMBtu) & $\$ 5.530$ & $\$ 5.530$ & $\$ 5.530$ & $\$ 5.530$ & $\$ 5.530$ & $\$ 5.530$ & $\$ 5.530$ \\
\hline Ann. Energy Use (MMBtu) & 243 & 243 & 243 & 235 & NA & 226 & 207 \\
\hline Standby Losses (MMBtu) & 0.0 & 0.0 & 0.0 & 0.0 & 0.0 & 0.0 & 0.0 \\
\hline Energy cost, \$/yr & $\$ 1,346$ & $\$ 1,346$ & $\$ 1,346$ & $\$ 1,297$ & NA & $\$ 1,252$ & $\$ 1,145$ \\
\hline PV (energy cost) & $\$ 12,257$ & $\$ 12,257$ & $\$ 12,257$ & $\$ 11,814$ & NA & $\$ 11,402$ & $\$ 10,431$ \\
\hline Equipment Cost & $\$ 3,492$ & $\$ 3,492$ & $\$ 3,492$ & $\$ 4,274$ & \$0 & $\$ 6,238$ & $\$ 8,549$ \\
\hline Unit LCC & $\$ 15,749$ & $\$ 15,749$ & $\$ 15,749$ & $\$ 16,088$ & NA & $\$ 17,640$ & $\$ 18,980$ \\
\hline Report created: & $3 / 31 / 0011: 13$ AM & & & & & & \\
\hline
\end{tabular}




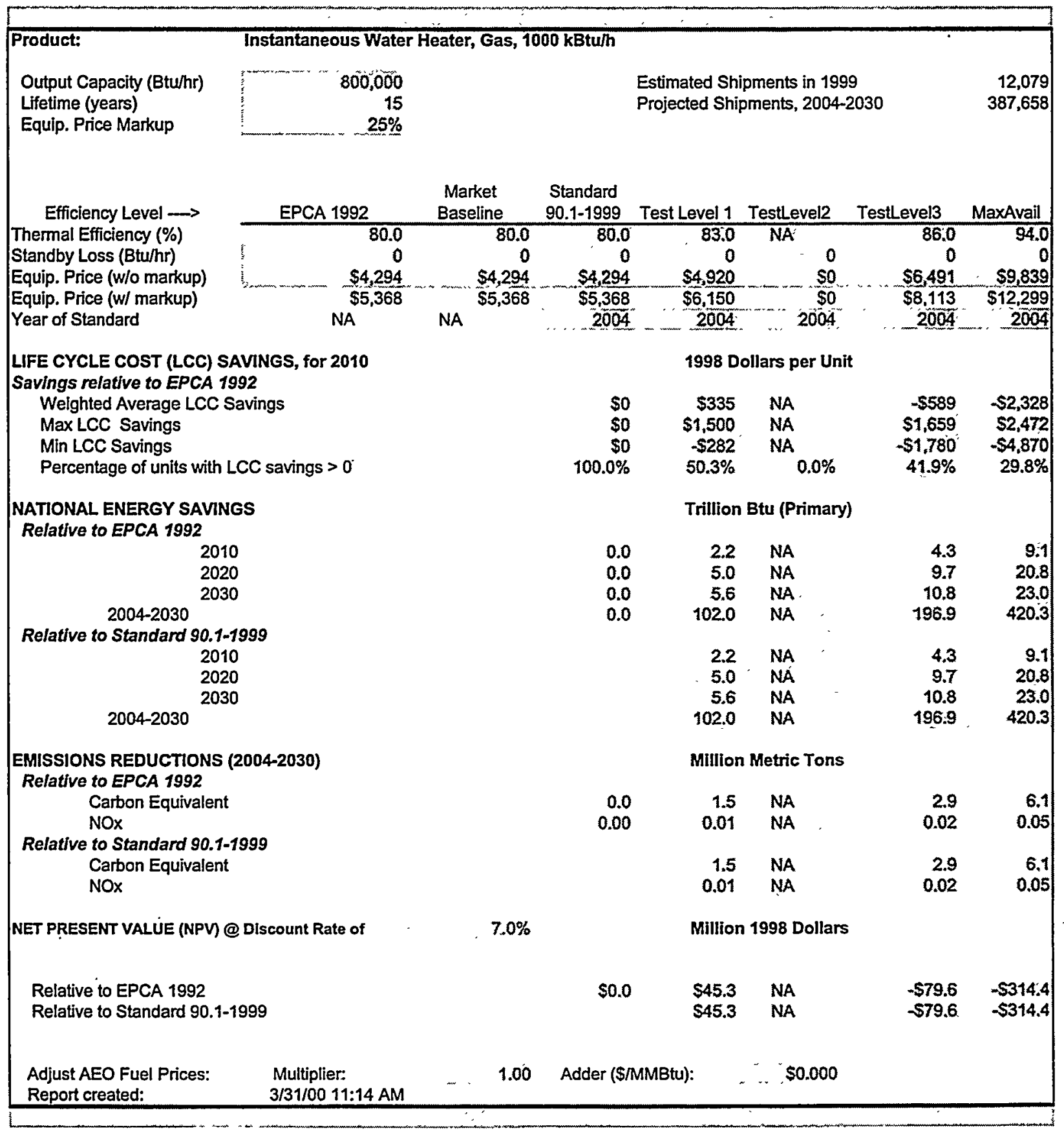




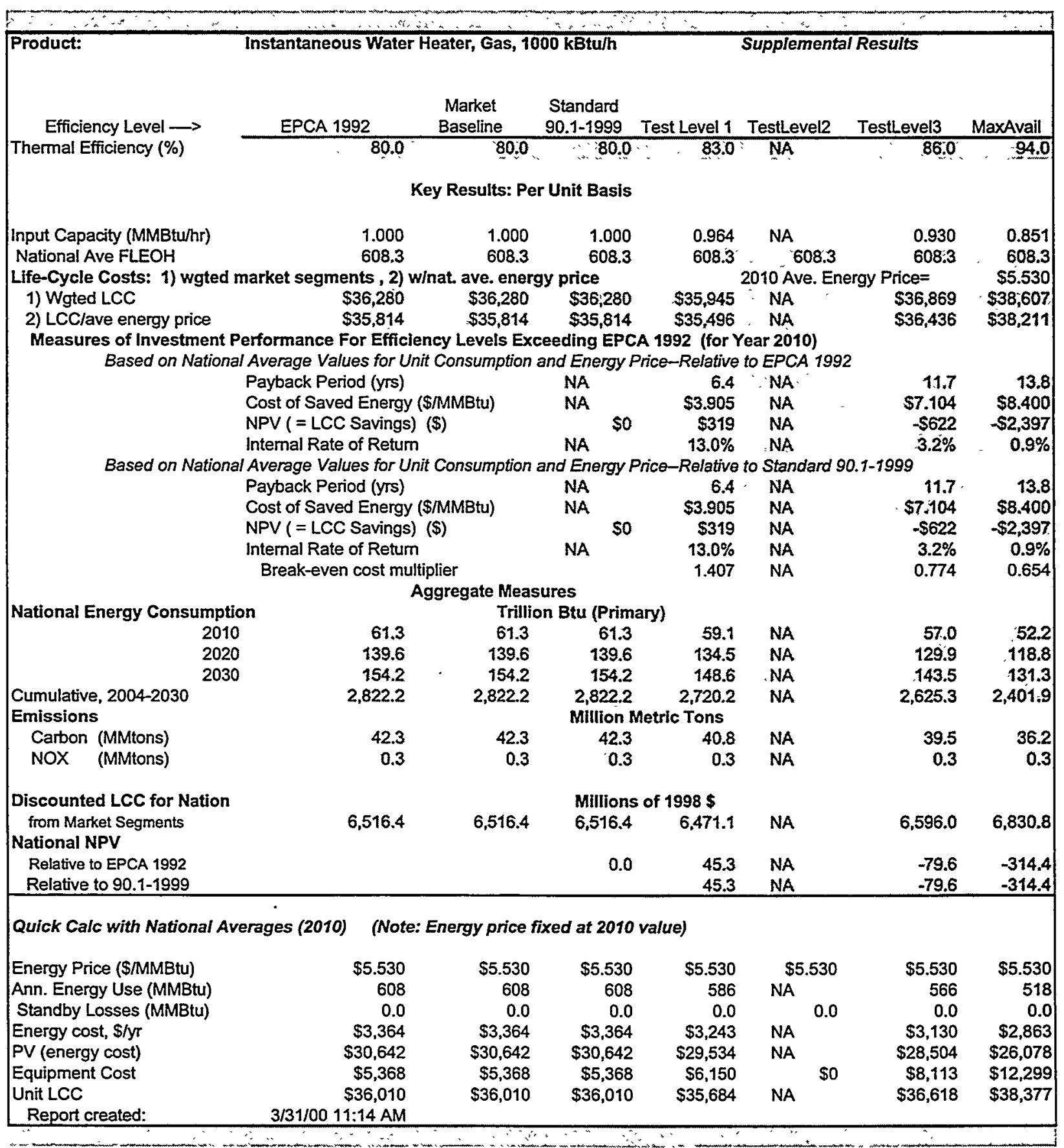




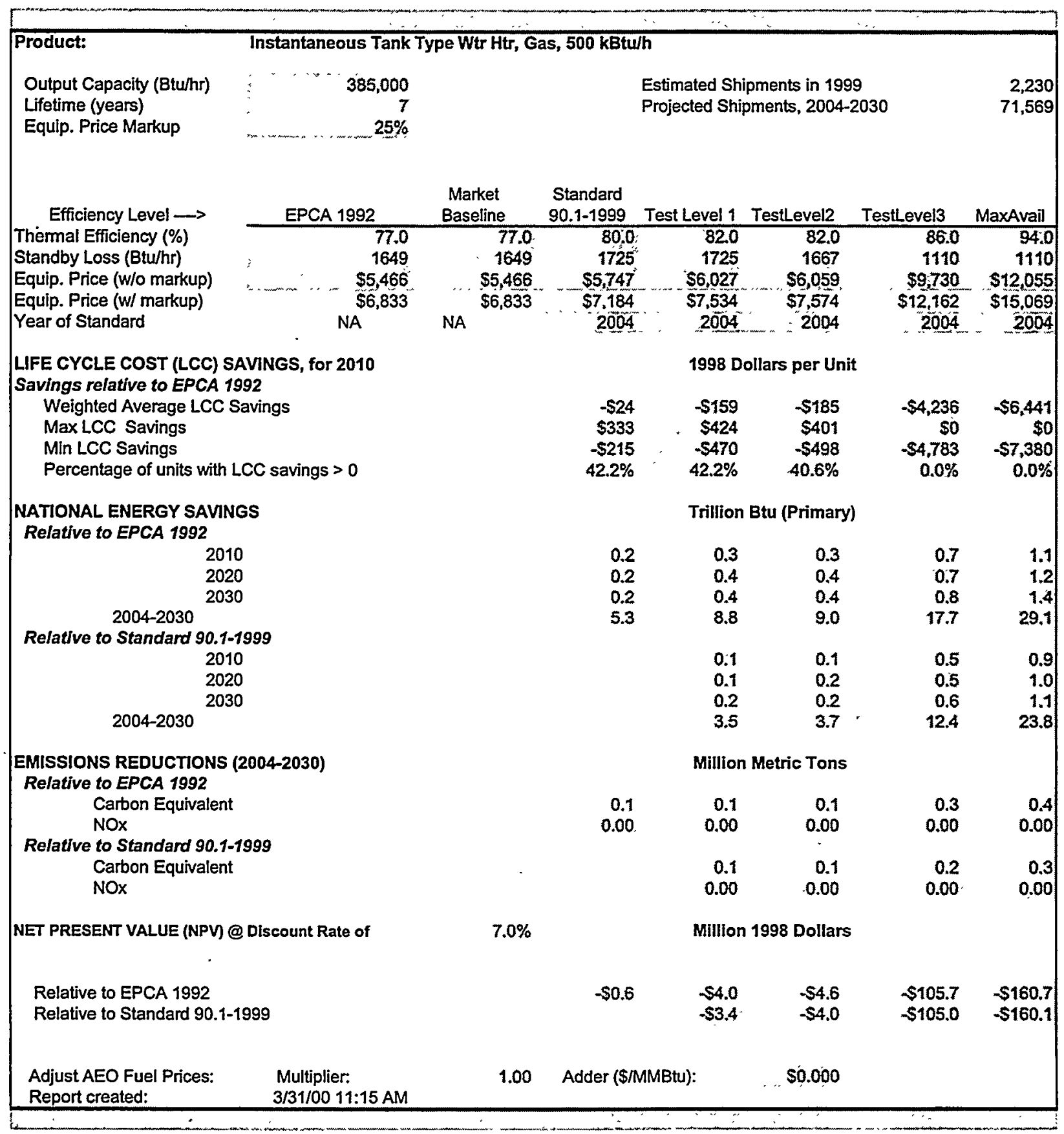




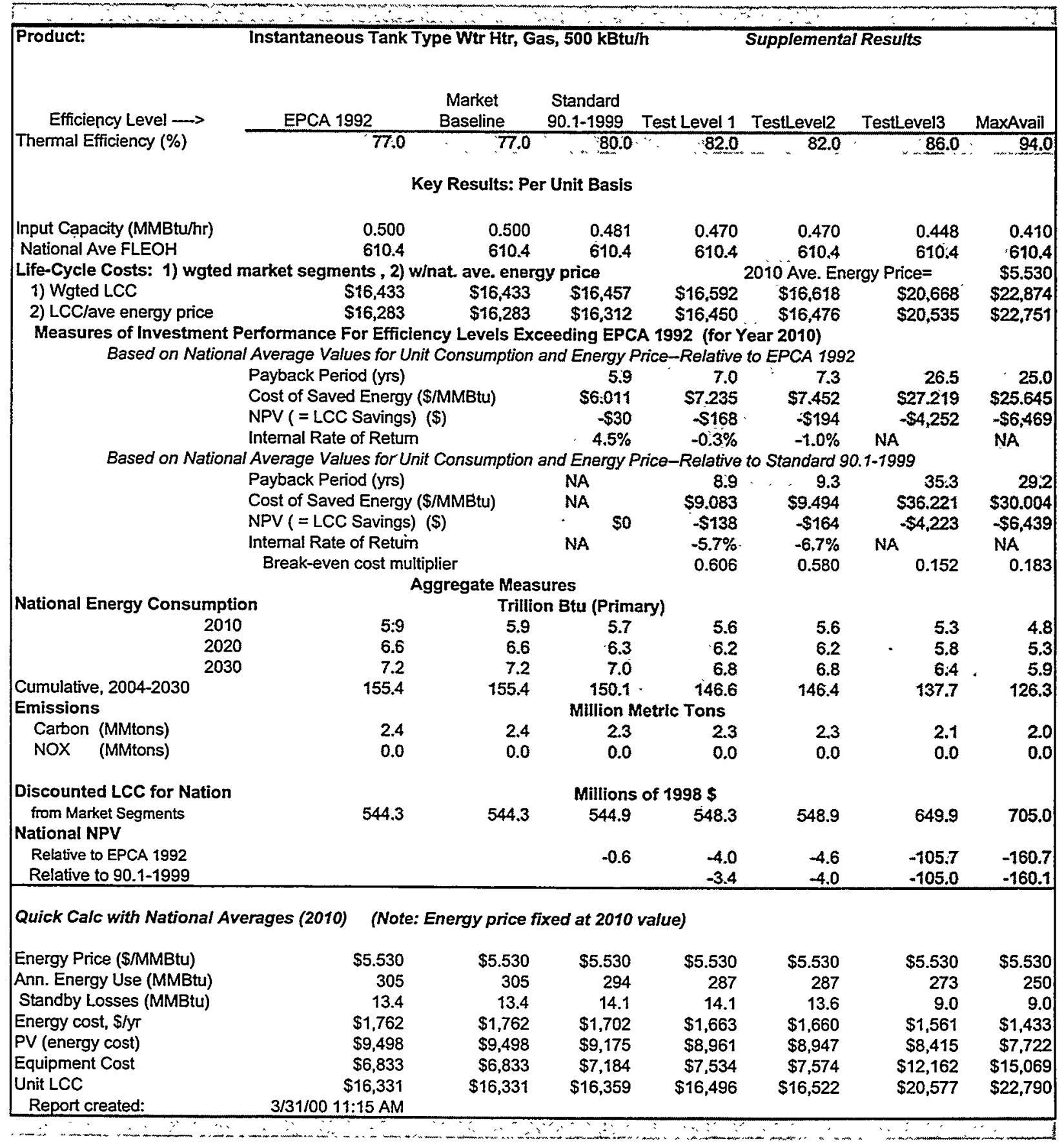




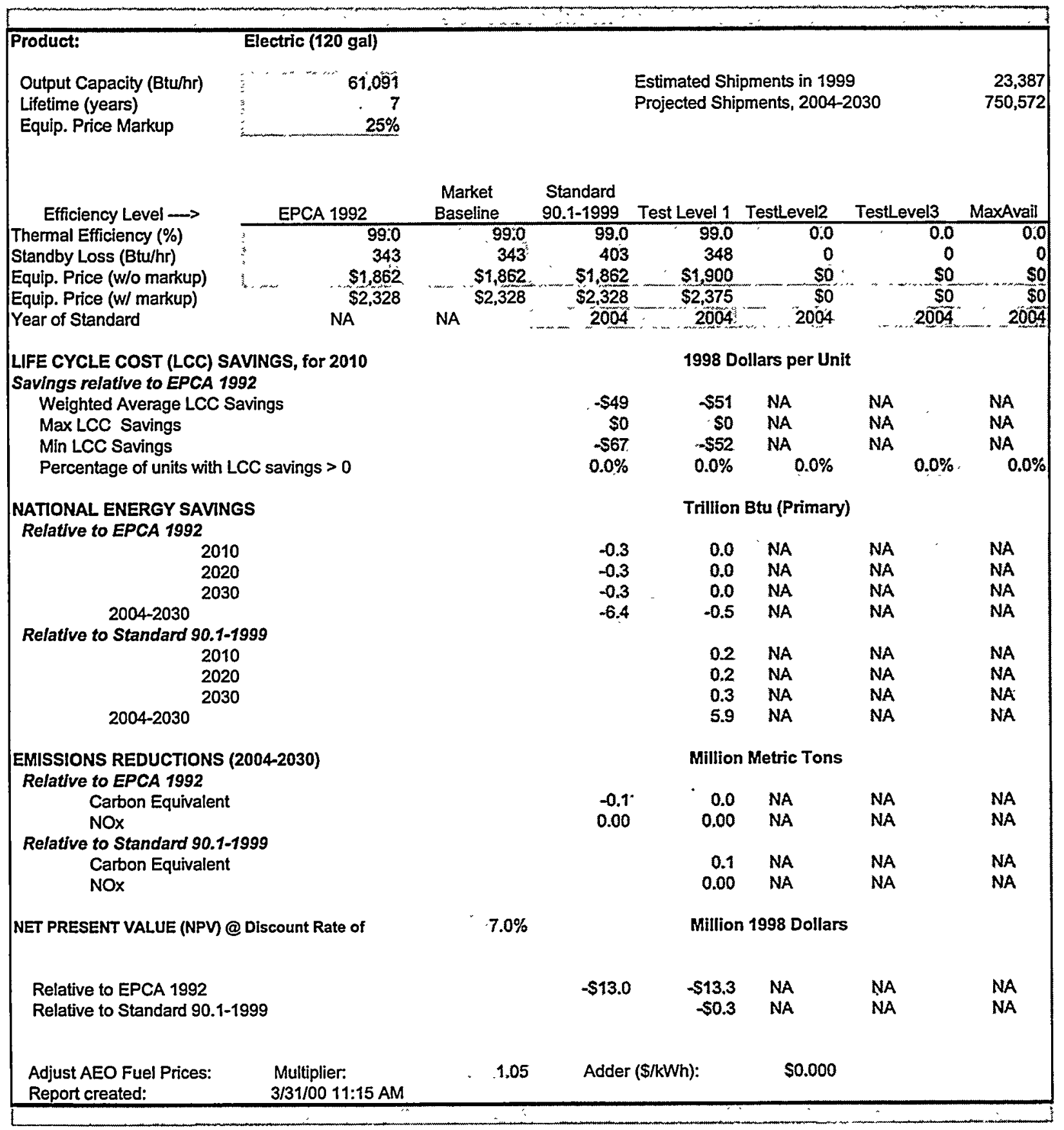




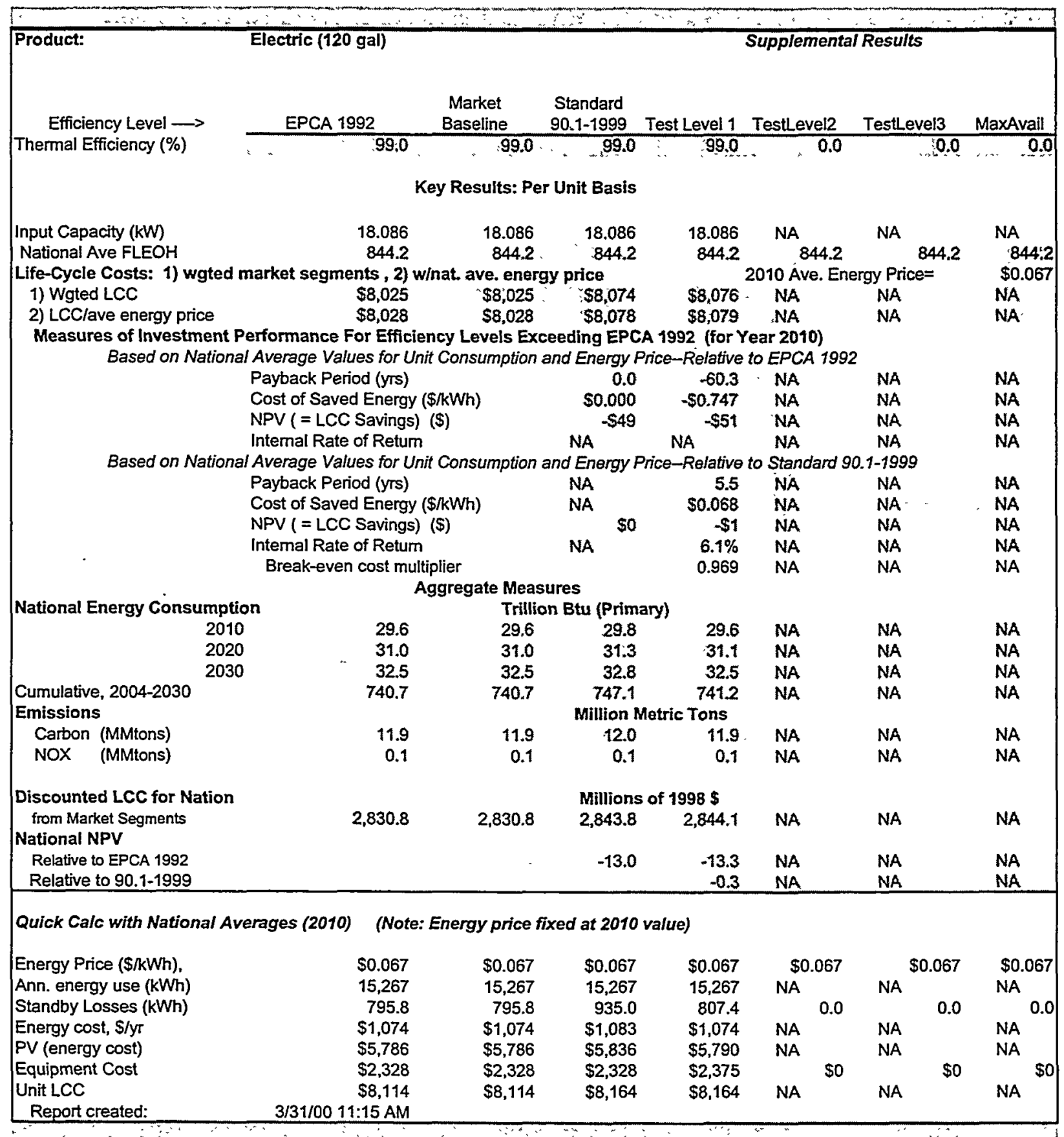




\section{Distribution}

No. of

Copies

\section{OFFSITE}

J. R. Brodrick

D\&R International

1300 Spring Street, Suite 500

Silver Spring, MD 20910

S. Katipamula

Enron Energy Services

1400 Smith Street, EB626B

Houston, TX 77002

Q. B. Laughlin

U.S. Department of Energy, Headquarters Forrestal Building

Mail Stop 6A-116

1000 Independence Avenue, S.W.

Washington, DC 20585

M. J. Mc Cabe

U.S. Department of Energy, Headquarters

Forrestal Building

Mail Stop 6A-116

1000 Independence Avenue, S.W.

Washington, DC 20585

J. E. McMahon

Lawrence Berkeley National Laboratory

1 Cyclotron Road, Mail Stop 90-4000

Berkeley, CA 94720

K. H. Nasseri

U.S. Department of Energy, Headquarters

Forrestal Building

Mail Stop 6A-116

1000 Independence Avenue, S.W.

Washington, DC 20585
No. of

Copies

E. O. Pollock, Jr.

U.S. Department of Energy, Headquarters

Forrestal Building

Mail Stop 6A-116

1000 Independence Avenue, S.W.

Washington, DC 20585

M. Rivest

Arthur D. Little, Inc.

2111 Wilson Blvd.

Suite 1000

Arlington, VA 22201

\section{ONSTTE}

32 Pacific Northwest National Laboratory

P. R. Armstrong

K5-20

D. B. Belzer

K8-17

S. C. Gaines

K5-16

D. L. Hadley

K5-16

J. B. Holloman

BWO

R. E. Jarnagin

K5-16

D. P. McConnell

K7-73

S. C. McDonald

BWO

R. J. Neese

K8-07

A. K. Nichols

BWO

B. F. Saffell

K5-02

D. L. Shankle

K8-07

S. A. Shankle

K5-16

D. L. Smith

K8-17

S. Somasundaram (10) K5-20

D. W. Winiarski

K5-08

Information Release Office (7)

Distr.1 
